\title{
VIAJE y EXTRANJERÍA EN LA OBRA DE JUAN JOSÉ SAER
}

Universidad Nacional de La Plata Facultad de Humanidades y Ciencias de la Educación

Tesis para optar por el grado de Doctora en Letras Prof. y Licenciada: Carolina Maranguello Tutora: Dra. Laura Juárez Fecha: Julio de 2018 


\section{VIAJE Y EXTRANJERÍA EN \\ LA OBRA DE JUAN JOSÉ SAER}

\section{Índice}

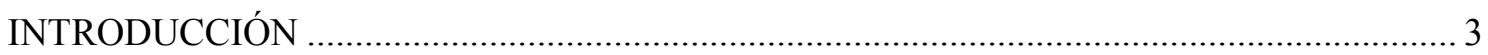

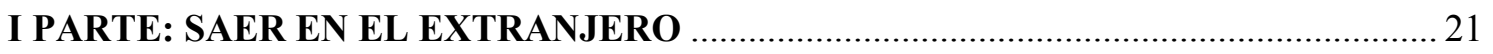

1. MÁSCARAS VIAJERAS PARA UN ESCRITOR SIN IMAGEN …................................ 26

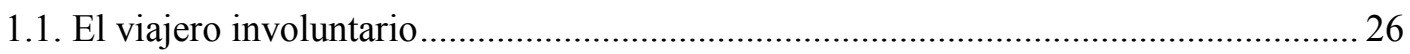

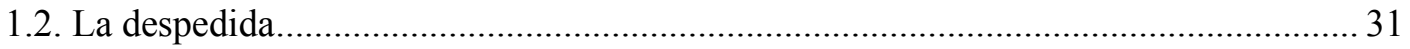

1.3. Un modernista camina las calles de Mayo del ' 68 ….................................................. 34

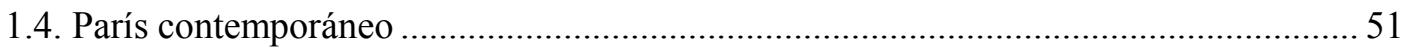

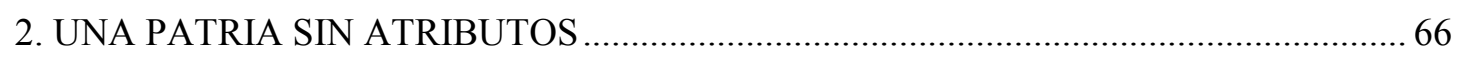

2.1. Del inmigrante al exiliado: biblioteca y filiaciones literarias....................................... 69

2.2. Aprender de la inmadurez: distorsión y ceguera en Witold Gombrowicz ..................... 78

2.3. Una vocación temporal: versiones de la patria según Saer ........................................... 89

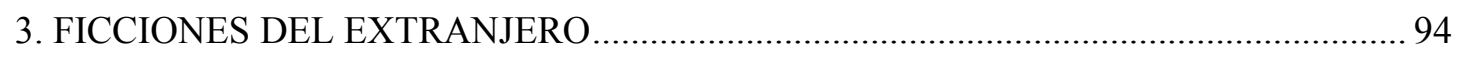

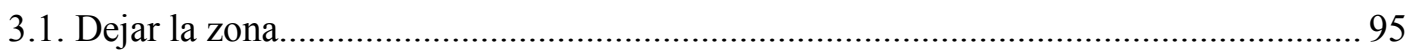

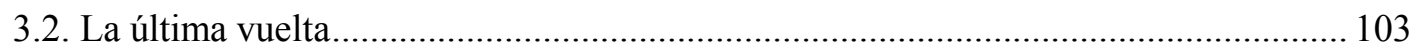

4. “NOTICIAS SECRETAS” DE UN VIAJE IMPOSIBLE ................................................. 107

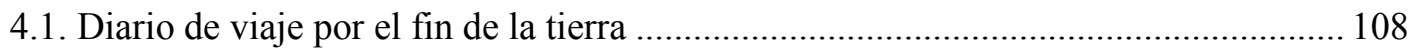

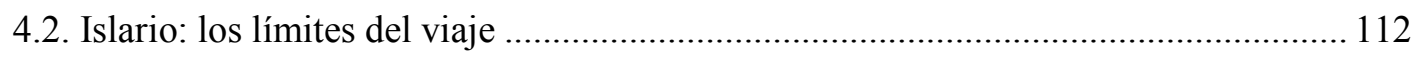

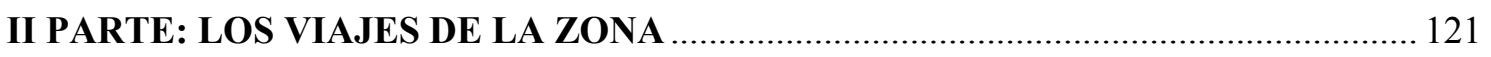

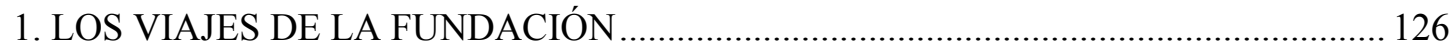

1.1. El mar: puntuación y extravío de la historia............................................................... 128

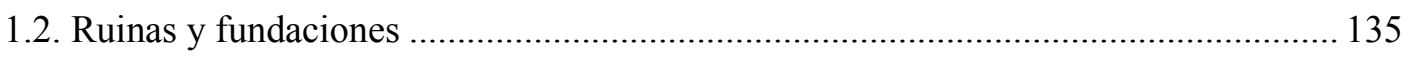

1.3. El paisaje saltado: primeras imágenes para el desierto ………………………............ 139

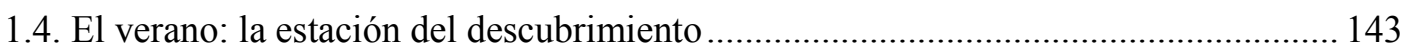

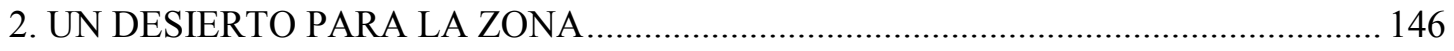




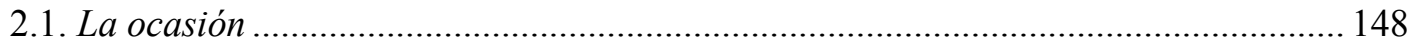

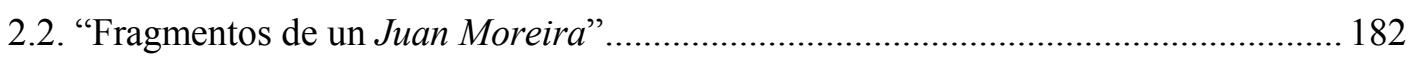

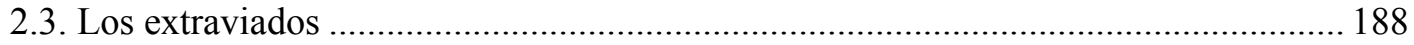

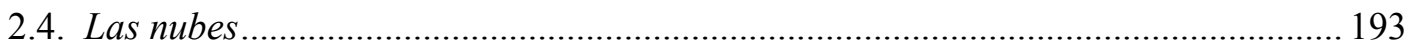

3. MANCHAR EL MAPA URBANO: DESPLAZAMIENTOS EN LA CIUDAD DE LOS

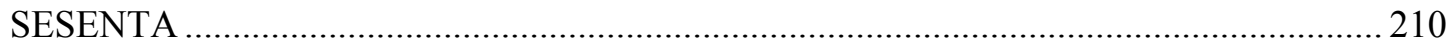

3. 1. Santa Fe en los sesenta: la Atenas de Sudamérica ...................................................... 213

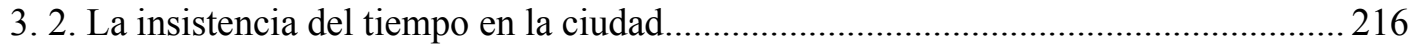

3. 3. La grilla se incendia: desplazamiento alucinado por la costra reseca ....................... 218

3. 4. La ciudad suspendida: condensación y apertura vegetal americana...........................2223

3. 5. Fiebre y geometría: dripping sobre la retícula hipodámica ...................................... 226

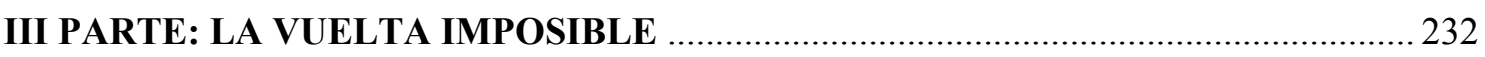

1. LA ISLA PORTÁTIL: VARIACIONES SOBRE LA ESCRITURA FLUVIAL .............. 240

1.1. Ulises carapachayo: un regreso irreverente a los orígenes de la tradición fluvial......242

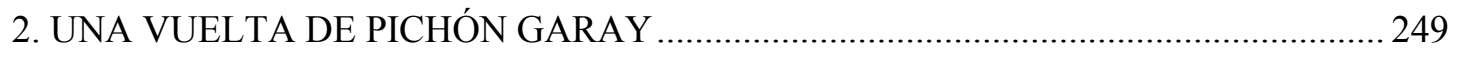

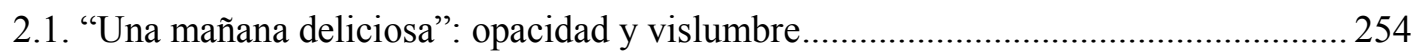

2.2. Washington Noriega en Baker Street: policial, amistad y dictadura .......................... 259

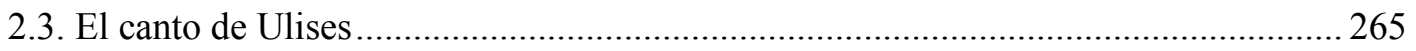

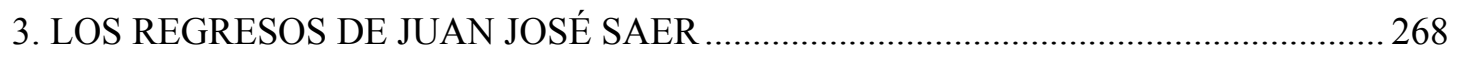

3.1. Las libretas de viaje y El río sin orillas: apuntes para una memoria del lugar .......... 271

4. LA GRANDE: REGRESO ORIENTAL Y TIEMPO ESCÉNICO …............................... 305

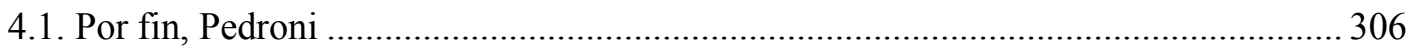

4.2. Actuar el regreso: la zona mítica sobre las tablas ...................................................... 316

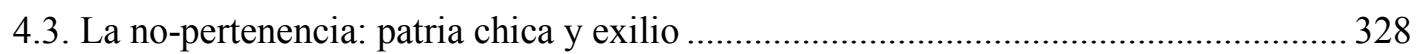

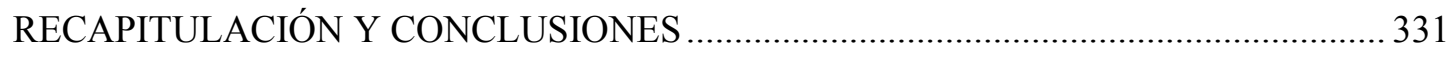

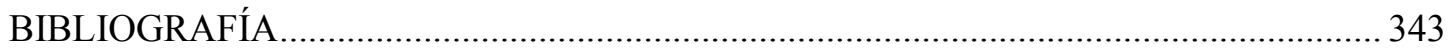




\section{INTRODUCCIÓN}

Ah, de qué modo soy viajero, en qué medida mudo, y cuánto me han gastado el musgo de oro de las paredes, las noches naturales y carnales y los significados. [...] Apenas una lectura fugaz, en idioma extranjero, de esto que relumbra delante de mí. Un desierto es por definición al mismo tiempo el todo y la nada, y está plagado de ciudades, de fornicaciones, de violencias y de gritos.

(Saer, "Pequeños poemas en prosa I", Poemas, 109)

- Qui aimes-tu le mieux, homme énigmatique, dis? ton père, ta mère, ta soeur ou ton frère? - Je n'ai ni père, ni mère, ni soeur, ni frère.

- J'ignore sous quelle latitude elle est située.

- Eh! qu'aimes-tu donc, extraordinaire étranger? - J'aime les nuages... les nuages qui passent... là-bas... là-bas... les merveilleux nuages!

(Baudelaire, "L'Étranger", Le spleen de Paris)

Desde 1982 hasta el año 2000 Saer viaja acompañado de unas pequeñas libretas en las que se mezclan anotaciones sobre el paisaje, instrucciones de escritura, citas, borradores de poemas y de cartas y rápidos bocetos del natural. El "descubrimiento" de estas libretas y su adscripción problemática al género del "viaje" materializaron una pregunta ¿podría ser Saer, el escritor del "lugar”, un escritor-viajero? ${ }^{1}$, y en ese caso ¿de qué tipo de viajero se trataba?

¿Qué hacían en sus libretas los nombres de otros viajeros, como Sarmiento, Hudson o Gombrowicz?, ¿de qué distancias y proximidades hablaba esa escritura sostenida e íntima a la que el escritor volvía a la hora de proyectar sus ficciones y ensayos pero también en sus sucesivos retornos? La fecha de la primera de las libretas, 1982, coincide con el primer regreso de Saer a la Argentina luego de seis años de

\footnotetext{
${ }^{1}$ Es difícil encasillar la escritura fragmentaria y heterogénea de estas libretas, como se verá en la tercera parte de la tesis, no son propiamente "diarios de viaje" y varias de las notas volcadas allí también aparecen en otros cuadernos del escritor. De estas libretas, publicadas en el II tomo de los Papeles de trabajo, se conocían las "Notas en vivo (sep-oct. 1982)" que Saer extrajo de la libreta negra y utilizó como material preparatorio para Glosa, incorporadas en la edición crítica de El entenado-Glosa coordinada por Julio Premat. El resto de los cuadernos fueron publicados como material inédito en los Borradores. En lo personal, "descubrí" estas libretas de viaje a propósito del trabajo final de un seminario impartido por Adriana Amante, "Estilografías visuales para la literatura" que cursé en 2015 en la Facultad de Filosofía y Letras de la Universidad de Buenos Aires. Las lecturas y discusiones allí compartidas fueron muy estimulantes y me permitieron reformular en parte la presente investigación.

Según Beatriz Colombi, la escritura producida por la figura del "escritor-viajero": "incluye la mención de notas y diarios personales, libros y documentos, así como las acciones de escritura y de lectura durante el viaje" ("De la práctica al género" 9).
} 
ausencia. Durante ese viaje se hospedó en Buenos Aires con sus amigos María Teresa Gramuglio y Juan Pablo Renzi, y los tres compartieron sus impresiones sobre la novela Bajo el volcán de Malcolm Lowry. Es Gramuglio quien recuerda esos días en que los tres hablaban sobre "el aura mítica que adquiría la figura ruinosa del cónsul inglés en el escenario mexicano dominado por los volcanes" (Gramuglio, "El cónsul”, El lugar de Saer 74). La novela los impresiona vivamente: Renzi pinta algunos cuadros a partir de las imágenes que le despertó su lectura y Saer escribe un breve texto a propósito de Lowry y de Renzi que luego se incorporó al catálogo de la serie La guerra de los pájaros, en las que se incluyeron esos y otros cuadros. "A Renzi” es a la vez una condensada glosa de la novela y un tributo a la visualidad de los cuadros expresionistas que su amigo había vuelto a pintar por aquellos días, pero es sobre todo un brevísimo tratado sobre la extranjería que trasciende las referencias particulares de su producción y permite pensar, hacia atrás y hacia adelante, toda la obra de Saer:

Todo hombre es como el cónsul de alguna patria que lo ha olvidado. Sabe, confusamente, que se espera de él alguna tarea, pero su conocimiento imperfecto lo inmoviliza. Sus actos se vuelven gestos vacíos; sus viajes, errabundeo. [...] El cónsul busca su patria en las formas que, indiferente por los simples cambios que derivan de su crecimiento, el día deja entrever (Saer, citado en Gramuglio "El cónsul", El lugar de Saer 75).

El cónsul condensa dos figuras fundamentales: la del viajero que ha quedado exiliado de su patria y la del artista, cuya indagación semiciega deviene "errabundeo", 2 pero también "jungla de manchas y de sonidos" más o menos familiares pero incomprensibles.

Como se sabe, Saer viajó a Francia en 1968 con una beca del gobierno francés para estudiar el Nouveau roman y lo que iba a ser una estadía de seis meses se prolongó por el resto de su vida. El dato ha sido consignado innumerables veces, y suele iniciar casi todas las presentaciones del escritor que ensayaron sus principales entrevistadores y críticos. Sin embargo, la extranjería en la que Saer desarrolla más de la mitad de su prolífica obra suele quedar soslayada como un dato biográfico que parece no afectar demasiado su producción. Esta relativa indiferencia es en realidad el efecto que busca

\footnotetext{
${ }^{2}$ El sujeto, que busca desesperadamente esa patria, comprende que el sentido se le escapa y que es indiferente llamar a lo que ve "percepciones o visiones", porque "toda forma, por otra parte, bien mirada, es mancha, todo objeto compacto y nítido torbellino [...] siempre le está soplando en la cara, sin darle casi tiempo a parpadear, el viento de lo visible" (Saer, citado en Gramuglio "El cónsul" El lugar de Saer 76). La figura del "semiciego" puede rastrearse no solo en cuentos, como "Carta a la vidente", sino también en varios de sus ensayos críticos. En "Narrathon", por ejemplo, la función ética del artista se define por la posibilidad de comunicar esa ceguera y desmitificar lo que el mundo ha dado como "visible".
} 
producir y produce efectivamente Saer: que sus lectores se aferren a lo que Miguel Dalmaroni llamó "las pregnancias del territorio" y a la suerte de la sociedad de personajes que habita la mítica "zona", mientras la figura de autor permanece en un relativo anonimato. No obstante, Saer vivió treinta y siete años en Francia, apuntó sus viajes por algunas regiones de Europa y de América Latina y fundamentalmente sus regresos al país en unas pequeñas libretas de viaje; escribió poesías sobre su arribo a París; leyó con deleite a innumerables viajeros; y reflexionó sobre el exilio, las migraciones, los viajes y la patria en su producción ficcional y ensayística. Todo su proyecto literario, desde En la zona hasta La grande asume la figura de un viaje: Willy Gutiérrez es el personaje que se va y regresa a la zona después de que buena parte de sus ficciones haya multiplicado los derroteros de muchísimos de sus personajes. ${ }^{3}$

Esta tesis busca reponer el viaje y la extranjería como instancias fundamentales de la obra de Saer. Ya Julio Premat había advertido en la "Introducción general" a los Papeles de trabajo que el traslado a Francia había contribuido a modificar los modos de escribir de Saer y su lugar en el campo literario nacional. En "El largo camino del silencio al consenso" Miguel Dalmaroni indagó los efectos de su distanciamiento y señaló que su figura se "asordinó" después de haberse mudado al extranjero. Interesará pensar de qué maneras Saer vuelve ese alejamiento y ese progresivo borramiento una instancia productiva no sólo para los modos inéditos en que armó su figura de escritor sino también, y sobre todo, para la configuración de su proyecto escritural. De esta manera, el viaje (en tanto experiencia biográfica real y en tanto preocupación filosófica, estética y política) y la extranjería (en tanto condición permanente del sujeto saeriano) ${ }^{4}$ son fundamentales por tres aspectos: contribuyen a complejizar la modulación de su figura de escritor, impactan sustancialmente en su escritura $y$, de manera

\footnotetext{
${ }^{3}$ En este sentido puede constatarse a primera vista la presencia del "viaje" como un tópico que se reitera y se diversifica a lo largo de sus ficciones y que permite encontrar una variedad de "viajeros" y de viajes: la llegada de los conquistadores en El entenado, "El intérprete" y "Paramnesia"; el "viaje utilitario" de La ocasión y "El viajero"; el avance atormentado de la caravana de locos en Las nubes; el viaje a Europa de artistas y escritores de las distintas generaciones vanguardistas de la zona, como Higinio Gómez y Héctor, por nombrar solo algunos.

${ }^{4}$ Esa condición extranjera, que Rafael Arce subraya en La felicidad de la novela: "El presentimiento del hombre saeriano [...] es el de su no pertenencia. [...] El presentimiento de esta extrañeza original, que es la relación del hombre con el mundo" (116-7), es constitutiva de los personajes de Saer y de las propias figuraciones del escritor, es previa a su traslado efectivo a Francia pero se agudiza a partir de allí. Como se verá, la extranjería declina por las diferentes variantes saerianas del desplazamiento y la diáspora (su particular concepción del exilio, su problemática adscripción como inmigrante y su intermitente figuración como viajero $\mathrm{y}$ retornante).
} 
complementaria, permite que haya una "zona" que sólo podría explicarse en función de los disímiles desplazamientos, exploraciones, refundaciones, exilios y regresos que hacen posible su (contingente) permanencia.

En primer lugar, la escritura de Saer se modifica en relación a su experiencia del extranjero y a la copiosa y heteróclita "biblioteca viajera" que el escritor lee desde sus inicios: ${ }^{5}$ Charles Darwin, Alfred Ebelot, Domingo F. Sarmiento, Roger Caillois, Cristóbal Colón, Alexander von Humboldt, Francis Bon Head, entre muchos otros. De esta manera, una buena parte de su producción poética, ensayística y ficcional se trama sobre la relectura y la reescritura crítica de varios de estos textos. Sus cuentos y novelas tomarán de la retórica del viaje formas de conceptualizar el paisaje y la ciudad, y ensayarán un repertorio de imágenes que recupera y a la vez subvierte su imaginario visual y lingüístico. Pero además, como podrá observarse a partir del análisis de algunos textos específicos (las dos versiones de "A medio borrar" y las tres instancias de escritura de "La ocasión") el extranjero produce una modificación singular en los modos de reescribir y continuar borradores que Saer había empezado a escribir en Santa Fe y que termina de concretar en Francia.

En segundo lugar, Saer modula su imagen de escritor en el extranjero apelando fundamentalmente a figuras -provisorias y anacrónicas- de viajeros y escritoresviajeros a partir de los cuales puede resistir formas contemporáneas y legitimadas de “ser escritor". Así por ejemplo, se identificará con Rubén Darío apenas llegue a Francia porque su estética ácrata y su desarticulación pesimista de la parisiana le proveerán un modelo de resistencia a las prerrogativas políticas y estéticas de la ciudad luz en los sesenta; o se identificará, más tarde, con Witold Gombrowicz o W. H. Hudson cuando a partir de la década del ochenta retome sus viajes de visita al país y deba inventarse una distancia justa, una perspectiva exterior acorde para observarlo, explorarlo y reconstruirlo en sus novelas y ensayos.

Por último, el viaje modifica la modulación de la "zona". Como se sabe, éste es uno de los aspectos más revisitados por la crítica, desde las primeras lecturas que

\footnotetext{
${ }^{5}$ Beatriz Colombi explica que en la "biblioteca viajera" los relatos de viaje se influyen unos a otros y configuran una larga cadena, "un circuito de deudas, memorias, palabras robadas, metáforas establecidas, fórmulas aceptadas. La biblioteca viajera irrumpe a cada momento, con la cita de los escritores que lo precedieron en esos mismos parajes y pasajes" (Cosmópolis 19). En este mismo sentido se apelará a la conocida idea de Edward Said sobre la "actitud textual" que algunos viajeros mantienen con respecto a los espacios que visitan y que le permite al sujeto "entra[r] en contacto con algo relativamente desconocido y amenazante, que hasta entonces, había estado lejos de él” (Said, Orientalismo 135).
} 
denostaban al joven Saer y lo adscribían a un regionalismo más o menos tradicional y retardatario, a las lecturas que a partir de Punto de Vista y la crítica universitaria apuntaban a señalar su radical modernidad. A contrapelo de las primeras interpretaciones, enfatizaban el tratamiento distorsivo que Saer ensayaba sobre el espacio, una desintegración que encuentra como ápice negativista el negro tipográfico de El limonero real o la disolución puntillista de la experiencia del bañero en Glosa. Como ha señalado Dalmaroni, ${ }^{6}$ la obra saeriana convocaba a una lectura que privilegiaba lo autorreferencial y la intertextualidad, y en ese marco, la recurrencia de una zona y de un grupo de personajes reconocibles se explicaban en tanto reescrituras de otras geografías imaginarias, las de Faulkner y Onetti. Fue Gramuglio en "El lugar de Juan José Saer" quien sentó las nuevas coordenadas de interpretación y releyó la obra clásica de Saer desde sus inicios para señalar la importancia de la "zona" y del "lugar". Interesa particularmente su perspectiva porque Gramuglio da un paso más y analiza la proposición de Barco en "Algo se aproxima" ("Yo escribiría la historia de una ciudad. No de un país ni de una provincia; de una región a lo sumo" 517) no sólo en relación al proyecto de escritura que efectivamente cumplió Saer sino en relación con un aspecto que será muy importante en la presente tesis: la historia de la "frágil" tradición americana, asentada sobre textos que problematizan las relaciones entre Europa y América y recodifican el tópico de la ciudad como un desierto sin tradición. ${ }^{7}$

En el marco de ese reposicionamiento de la crítica, ${ }^{8}$ interesa aquí incorporar la perspectiva del viaje como tensión que dialectiza y complejiza la conformación de ese espacio. En primer lugar, el mismo escritor declara en algunas entrevistas que la "zona" no es un territorio estable sino un espacio conformado a partir de los múltiples desplazamientos de sus personajes (exilios, dispersiones, viajes, exploraciones, fundaciones y refundaciones, paseos urbanos, pérdidas de rumbo, navegaciones y regresos); en segundo lugar, la permanencia de la "zona" se afirma sobre un delicado

\footnotetext{
${ }^{6}$ Cfr. Dalmaroni, Miguel. "El largo camino del 'silencio' al 'consenso'. La recepción de Saer en la Argentina (1964-1987)".

${ }^{7}$ En efecto, el viaje se asume como un dispositivo ensayístico que le permite reflexionar sobre temas y preocupaciones que se reiteran en su obra: la pregunta por lo extranjero y la "región"; la condición exiliar del sujeto y del escritor particularmente; las relaciones entre la literatura nacional y la cultura europea.

${ }^{8}$ En "Las ruinas y el fragmento. Experiencia y narración en El entenado y Glosa", Garramuño también explicará este desplazamiento: desde una lectura intraliteraria que privilegia la imposibilidad de la representación a una indagación de la experiencia como lo irrepresentable y como trauma, cambio que se confirma a partir de la publicación-escandalosa- de El entenado y de Glosa.
} 
equilibrio: entre la documentación obsesiva de su fauna, de su clima y de sus usos lingüísticos y la proliferación intertextual que le permite reescribirla y redescubrir sus costados más singulares.

De esta manera, el entrañable paisaje de la zona es, muchas veces, un paisaje leído en textos de viajeros que Saer reescribe. Abrir la zona a esta nueva serie de filiaciones permite además observar que muchas de las operaciones distorsivas sobre el paisaje que podían entenderse como ensayos experimentales de Saer, ${ }^{9}$ ya aparecían en precursores textos de viajeros de siglos pasados que también disponían el paisaje para mancharlo, borrarlo o abrirlo a fantásticas visiones, aun cuando su preocupación fuera, sin embargo, capturar "lo real" para medirlo, clasificarlo y conjurar sus extrañezas. Por último, incorporar la dimensión de la extranjería supone resituar la zona en un contexto mayor que la contiene y la excede: un continuum geográfico que le permite a Saer vivir "entre ciudades", entre Santa Fe y París, entre el litoral y la ciudad europea, sin convertirse, por eso, en un escritor cosmopolita; y una apertura temporal que retrotrae la zona a sus orígenes cósmicos y geológicos o la empuja vertiginosamente hacia su destrucción escatológica.

Si lo que efectivamente busca indagar esta tesis es la sedimentación retórica, imaginaria y visual que el viaje como experiencia real y como sustrato de lecturas fue operando sobre el proyecto literario de Saer y sobre su configuración de escritor, así como sobre sus reposicionamientos en el campo literario nacional, será necesario leer transversalmente la obra del escritor a partir de esta preocupación. De esta manera, como perspectiva no solamente espacial sino también temporal, el viaje permite observar de qué maneras el modo Saer tiñe y redefine las principales ideas vinculadas al viaje: patria, extranjería, extravío, regreso y nostalgia en relación a momentos específicos de la vida del escritor, y del acontecer social y político del país y del mundo.

Teniendo en cuenta la coherencia del proyecto escritural de Saer y la dinámica de corte y continuidad que entablan sus textos, esta tesis se propone leer su obra desde la perspectiva del viaje. En ese sentido, si bien se tendrán en cuenta los libros de relatos y novelas que escribió antes de su partida a Europa, se privilegiarán aquellos textos

\footnotetext{
${ }^{9}$ La vertiente formalista de la crítica había enfatizado estas operaciones de desintegración de lo real. Por supuesto, también es posible comprender esas desarticulaciones a partir de la adscripción pictoricista que Saer aprendió fundamentalmente en las poéticas de la abstracción geométrica y sensible. Cfr. al respecto los trabajos de Miguel Dalmaroni: "Pintura y poética de lo real en Juan José Saer: a partir de La mayor", "El empaste y el grumo. Narración y pintura en Juan José Saer", "Notas de un profano en pintura" y "La vuelta incompleta (una pintura)".
} 
producidos en el exterior en los que la tensión entre la zona y lo extranjero quede subrayada, y aquellos en los que la biblioteca viajera intervenga de un modo activo reconfigurando las formas de reescribir la "zona". Como se verá, muchas de las operaciones que Saer realizó en el extranjero -modelización de figuras de escritor, intervención crítica en debates sobre el compromiso, relaciones con otros escritores e intelectuales, decisiones de publicación o postergación de proyectos, reescritura de textos que había comenzado a escribir en Santa Fe y Rosario- pueden leerse en el material de archivo publicado en los cuatro tomos de borradores inéditos.

De esta manera, muchas de las novelas, poesías, narraciones y ensayos publicados por Saer se leerán en relación con esa filigrana heterogénea y fragmentaria de textos no publicados. Como se verá, el volumen La mayor así como una serie de poesías incorporadas en El arte de narrar y en Poemas serán fundamentales para revisar los diferentes modos en que se actualiza la problemática del viaje en su obra. Se leerá además con especial atención su novela La ocasión porque aglutina una serie de representaciones sobre el viaje, los viajeros y el desierto que permiten revisar, retrospectivamente, la primera versión de esta novela (el relato homónimo "La ocasión"), pero también El entenado; y prospectivamente, Las nubes. La grande, a su vez, será la ficción en la que convergen las diferentes preocupaciones del regreso que Saer comienza a desarrollar desde la década del ochenta en una variedad de textos ensayísticos y narrativos, y articulará la pesquisa documental que abren sus libretas de viaje, los desplazamientos de Pichón Garay y la vuelta de los personajes que habían aparecido en sus ficciones tempranas (En la zona, pero también La vuelta completa y Cicatrices).

Es importante señalar que no existe ningún estudio crítico que haya explorado exhaustivamente el tema del viaje en la totalidad de la obra saeriana. Sin embargo, es posible mencionar una serie de aproximaciones que analizan obras particulares en las que el viaje se vuelve un tópico insoslayable (El entenado, La ocasión, Las nubes y El río sin orillas) y también una serie de estudios que exploran temas ya clásicos de su crítica -el paisaje, las tensiones en torno a lo regional o la particular lectura que Saer hace de la historia- ${ }^{10}$ pero que, abordados desde la perspectiva del viaje, adquieren nuevas resonancias.

\footnotetext{
${ }^{10}$ Sobre los debates en torno al regionalismo y la importancia del paisaje, cfr. entre otros: Delgado, Sergio. "Realismo y Región. Narrativas de Juan Carlos Dávalos, Justo P. Sáenz, Amaro Villanueva y Mateo Booz"; Foffani, Enrique y Adriana Mancini. "Más allá del
} 
Uno de los primeros análisis sobre el tema fue el libro de Nancy Fernández quien en Narraciones viajeras. César Aira y Juan José Saer estudia fundamentalmente El entenado y contempla el viaje no solo como un tópico literario sino como un dispositivo escriturario. Resultaron particularmente sugerentes las consideraciones realizadas por Rafael Arce en su reciente libro Juan José Saer: la felicidad de la novela porque allí se advierte que los dos modos fundamentales del viaje son el exilio y el arribo y que ambos subrayan la condición de "no pertenencia" de los sujetos con respecto a un mundo que se revela como extraño. Por ese motivo se señala que "todos los viajes de la saga son una inversión del viaje épico en tanto que más que permitir conocer lo extranjero vuelven extraño lo propio, familiar" (118).

Atendiendo precisamente a esa dinámica que permea toda la obra de Saer entre partida y recuperación de la zona, David Oubiña realiza un interesante aporte en $E l$ silencio y sus bordes y reflexiona sobre el carácter móvil de la "región": "La estructura del viaje, que habilita para el escritor el punto de vista un poco exterior del que regresa, es la clave en la que se cifra esa mirada singular. [...] Es posible ser fiel a una región; solo que, para eso, es preciso traicionarla, abandonarla, partir. [...] La célebre zona saeriana, entonces, es un sitio transportable" (120). Es preciso mencionar, también en relación a ese movimiento de exilios y arribos, el reciente libro de Luigi Patruno, Relatos de regreso. Ensayos sobre la obra de Juan José Saer, que revisa la vuelta como principio constructivo en la obra saeriana y retoma diversos tipos de regreso (el de los personajes de la zona; el de la vuelta a la narración y el del propio Saer a la Argentina). Según Patruno, los regresos -usualmente diferidos y fracasados-, no generan relatos de "recuperación" sino de "reflexión" a partir de los cuales Saer diseña una imagen de intelectual cosmopolita que opera sobre el territorio como si fuera un extranjero y no un sujeto que retorna a su hogar. Esta tesis discrepa parcialmente con esta última afirmación porque si bien es cierto que Saer regresa como un viajero, no lo hace como un cosmopolita. Precisamente, si el escritor cosmopolita habla varias lenguas y adopta cualquier patria como si fuera la propia, Saer, aún partiendo de un vínculo igualitario entre lo local y lo universal, subraya que es la "región" la estructura que elige para

regionalismo: la transformación del paisaje"; Gramuglio, María Teresa. "El lugar de Saer"; Premat, Julio. "Saer: un escritor del lugar"; Prieto, Martín. "Escrituras de la 'zona' " y Sarlo, Beatriz. "La duda y el pentimento", este último está dedicado a Juan L. Ortiz, pero muchas de sus apreciaciones sobre la poética orticiana pueden pensarse también para el caso de Saer. 
procesar el universo entero, ${ }^{11}$ y aunque hable y traduzca varias lenguas, escribe toda su obra en español.

También Sergio Delgado retoma el viaje como una clave de lectura, esta vez para leer la poesía de Saer. En "Paisaje desde el andén" analiza una serie de poemas incorporados en $\mathrm{El}$ arte de narrar que son el resultado o el registro de un viaje y se centra particularmente en el conocido poema de Saer "Rubén en Santiago" en el que el escritor yuxtapone diferentes viajes -el de Rubén Darío en Santiago de Chile y el de Pichón Garay entre París y Bretaña-. ${ }^{12}$ Según Delgado, la poesía de Saer, pensada desde el tema del viaje, se inscribe en la tradición americana fundada principalmente por los escritores modernistas y puntualizada por Lezama Lima en La expresión americana a partir de la figura de la "ausencia posible" que implica como condición de lo americano la ausencia del escritor de su territorio. Resulta muy sugerente el modo en el que Delgado lee las interferencias culturales y biográficas que se cruzan productivamente en el tratamiento que la poesía de Saer hace del tópico del viaje.

Por otro lado, es interesante mencionar una serie de estudios críticos que incorporan algunas de las ficciones de Saer -en un corpus literario y cultural muchísimo más extenso y heterogéneo- para reflexionar sobre la construcción de las fábulas genealógicas de las identidades nacionales, ${ }^{13}$ las modulaciones del paisaje nacional y del desierto en particular, ${ }^{14}$ y sobre las alternativas políticas y estéticas que estuvieron en la base de los destinos nacionales de la patria (Gamerro 2015). Así Florencia Garramuño retomará El entenado junto a otras ficciones latinoamericanas producidas entre las décadas del ochenta y del noventa que reescriben textos fundacionales, -ya sea de las

\footnotetext{
${ }^{11}$ En la entrevista que le realizó María Teresa Gramuglio, publicada en el número 3 de la revista Pluma \& Pincel de mayo de 1976, la crítica le pregunta a Saer por la adscripción de su obra al regionalismo, y el escritor afirma: "yo creo que una región es fundamentalmente una estructura. Pienso que mi generación tiene una mentalidad fenomenológica, y que una región es un modo de recortar el universo entero para tratar de procesarlo desde esa región. [...] En cualquier fragmento de la realidad podemos intuir la totalidad, y me parece que es una buena manera de trabajar en literatura, [...] plantearlo concretamente como relaciones estructurales en el interior de un ámbito geográfico, o espacial, mejor dicho, reducido, que plantearlo como formas abstractas que pertenecen al planeta entero" (Saer citado en Prieto y Constantin, Catálogo Conexión Saer 21).

${ }^{12}$ Sobre este poema y las relaciones entre Saer y Rubén Darío también habría que anotar los trabajos de Martín Prieto, el prólogo "El canto de las estrellas" que le dedica a El arte de narrar y la "Introducción. En el aura del sauce en el centro de la historia de la poesía argentina" que escribe para la Obra completa de Juan L. Ortiz.

${ }^{13}$ Cfr. Genealogías culturales. Argentina, Brasil y Uruguay en la novela contemporánea (19811991) de Florencia Garramuño.

${ }^{14}$ Cfr. El lugar común: Una historia de las figuras de paisaje en el Río de la Plata de Graciela Silvestri, y Un desierto para la nación. La escritura del vacio de Fermín Rodríguez.
} 
crónicas de la conquista como de los discursos nacionales de la formación del estadoen los que se construye y define una cultura. Según su hipótesis, estas novelas desplazan y tergiversan ese espacio de construcción de identidades y fábulas de fundación. Por su parte, Fermín Rodríguez analiza en Un desierto para la nación cómo las sucesivas intervenciones de los viajeros que llegaron al continente contribuyeron a configurar el "desierto" como un dispositivo discursivo pero también visual. A lo largo de su valioso libro escandirá las diversas ficciones viajeras que fundaron el desierto para la expansión de la nación, muchas de las cuales Saer reelabora en su particular mirada sobre el paisaje. $^{15}$

También Graciela Silvestri en El lugar común se interrogará por la configuración de "la identidad de la nación argentina, privilegiando las imágenes [...] que representan el territorio físico que asumimos como propio" (17) a partir de una lectura que considera el viaje como uno de los principales móviles de esas diversas configuraciones. Su libro propone una historización a partir del gusto pero busca incorporar además la dimensión material a partir de la cual se vehiculizaron transformaciones sobre el paisaje, y por ese motivo incorpora una serie heterogénea de representaciones -mapas, paisajes, maquetas militares, postales turísticas, reconstrucciones paleontológicas y proyectos arquitectónicos- ${ }^{-}$. Recurre en su libro a tres figuras retóricas que ilustran las distintas formas de la sensibilidad: lo bello, lo pintoresco y lo sublime. Esta última resulta particularmente importante para pensar el tipo de operaciones literarias y plásticas que Saer le imprime al paisaje de la llanura, como Silvestri alcanza a esbozar hacia el final de su libro.

Finalmente Gamerro traza una hipotética historia de la literatura argentina actualizando una hipótesis de Borges - y de Oscar Wilde- sobre la relación constitutiva y casi mágica entre "el” libro nacional y el destino de una nación, Facundo o Martín Fierro. Así, observará los modos en que algunas novelas de Saer reescriben la dicotomía sarmientina entre civilización y barbarie, retomando además los textos clásicos de Hernández y Echeverría; y analizará también el particular tratamiento que

\footnotetext{
15 Entre ellas pueden mencionarse: ficciones de origen durante la conquista; ficciones románticas y científicas inauguradas por Humboldt; ficciones paleontológicas y geológicas a partir del viaje de Darwin; ficciones nostálgicas de un naturalista a través de los escritos de Hudson; ficciones mercantiles escritas por los viajeros ingleses y finalmente aquellas ficciones nacionales que eclosionaron hacia fines del siglo XIX a partir de proyectos políticos y militares que buscaron avanzar definitivamente sobre el desierto -la zanja de Alsina y la "solución final" de Julio Argentino Roca- .
} 
Saer hace de la dictadura, a partir de un desplazamiento genérico, de la serie policial a la serie política.

Como se puede observar, la bibliografía crítica sobre Saer presenta interesantes avances parciales sobre el tema del viaje y ha centrado su atención en algunas obras particulares. Sin embargo, ninguno de estos estudios ha tomado la totalidad de sus textos. En este sentido, esta tesis se propone retomar estos aportes para leer las diversas preocupaciones críticas que el viaje permite replantear, y profundizar algunos aspectos abordados por los antecedentes críticos pero no trabajados en toda su significación -el carácter extranjerizante de la mirada viajera de Saer, a partir de figuras señeras como Darwin o los conquistadores españoles, por ejemplo-. Además, como se dijo, este estudio busca considerar un conjunto de textos que hasta hace unos años no estaba disponible para la mayor parte de los investigadores: los borradores inéditos recogidos en la serie de Papeles de trabajo.

En relación al eje del viaje que estructura la tesis es necesario realizar algunos deslindes y precisiones teóricas. Tal como ha señalado Beatriz Colombi en varios de sus artículos, resulta muy complejo definir el "viaje" como práctica porque alude a una multiplicidad de significados y deseos - conquista, conocimiento, alteridad, exotismo, ocio- así como circunscribir el "relato de viaje" a un género definido. Colombi lo considera una "formación anfibia" que aloja elementos que tienen un correlato externo con otros que no tienen ningún anclaje en lo verídico, y pese al "efecto de verdad" (Barthes) que pretende lograr, se constituye como una verdadera "ficción de viaje" (Said). El estatuto indefinido del relato de viaje y su solapamiento con otros géneros será fundamental para pensar la obra saeriana, porque Saer satura y desarticula los formatos tradicionales, cuestionando muchas veces sus pretensiones de verdad y desarmando el entramado ideológico/institucional que sustentaron algunas de sus construcciones discursivas; ${ }^{16}$ pero además porque varias de sus ficciones se escriben en el filo genérico que se produce entre el viaje y la escritura íntima. En este sentido, en "El viaje, de la práctica al género", Colombi prefiere hablar de una "solidaridad" entre el autor, el narrador y el personaje y afirma que el relato de viaje se ha vinculado a los géneros íntimos (diarios, cartas, memorias) pero que no habría que pensar en identidades autobiográficas estables sino en intensidades de la subjetividad que los diferentes viajeros han impreso en sus escritos, desde el egotismo sarmientino hasta

\footnotetext{
${ }^{16} \mathrm{Cfr}$. Foucault, Michel. Las palabras y las cosas. Una arqueología de las ciencias humanas y Penhos, Marta. Ver, dominar, conocer. Imágenes de Sudamérica a fines del siglo XVIII.
} 
formas más renuentes que eluden o velan lo autobiográfico y producen una enunciación sin rastros de subjetividad, apelando a un "narrador discreto" que se enajena de su propia identidad y de su pasado para convertirse en un "ojo" entregado al ejercicio de la percepción, matices que serán fundamentales a la hora de observar los velados procesos de autofiguración que Saer opera como viajero.

En "El viaje y su relato" César Aira sostiene que la estructura de todo viaje es intrínsecamente narrativa, sin embargo, el viaje en Saer desarticula la elegancia formal de este presupuesto y relativiza tanto las expectativas vinculadas a la partida como la ética del retorno. Para pensar precisamente en los anómalos regresos de Saer se retomará la idea de oikos que desarrolla Georges Van Den Abeele en un estudio ya clásico, Travel as metaphor, porque allí la casa, punto de partida originario, no coincide con el punto de llegada y la vuelta al hogar se vuelve imposible. Será Sylvia Molloy quien permita pensar a Saer dentro de un corpus más extendido en la historia de la literatura argentina, como parte de las "narrativas de regreso", que para ella siempre ostentan, a la vez, una curiosa mezcla de esplendor y de "miseria fantasmagórica". La dislocación y la disrupción de lo familiar que provoca la idea del retorno solo puede conjurarse a través del "simulacro del hogar o de la nación" que el viajante lleva consigo en sus viajes, una estimulante solución, como se verá, para reflexionar sobre las libretas de viaje del escritor.

Uno de los tópicos más asociados a la temática del regreso es la nostalgia. A partir de las reflexiones de Svetlana Boym y de Bárbara Cassim se intentará repensar de qué formas Saer elabora la "nostalgia" por la zona. ${ }^{17}$ En la perspectiva de Boym, la nostalgia tensiona casa y extranjero, expresa su deseo de otra forma del tiempo y además permite vincular la biografía de un sujeto a la historia de una nación, aspecto que interesará pensar en El río sin orillas. La nostalgia posee además un carácter paradojal porque se trata de la repetición de lo irrepetible y de la materialización de lo inmaterial, y devela un asombroso poder para evocar percepciones sensoriales, elemento fundamental de la poética de Saer que se reformula en sus textos del retorno. Por su parte, Bárbara Cassim resalta el carácter "ficcional" de la nostalgia e interroga las relaciones entre patria, exilio y lengua materna.

\footnotetext{
${ }^{17}$ Cfr. The future of Nostalgia de Svetlana Boym y La nostalgia. ¿Cuándo es que, por fin, uno está en su hogar? Ulises, Eneas, Arendt de Barbara Cassim.
} 
Finalmente, atendiendo a la diversidad de viajes y viajeros que aparecen en la literatura de Saer, ${ }^{18}$ se retomarán aquellos estudios que presenten una historización crítica de los diferentes viajeros que arribaron a América, desde los primeros viajes de exploración y conquista, ${ }^{19}$ los viajes de exploración científico-naturalista, hasta el afán de expansión económica que caracterizó la ola de viajeros ingleses y el asentamiento de los colonos. ${ }^{20}$

Las sucesivas desarticulaciones y reescrituras paródicas, apóstatas y críticas que Saer ensaya sobre los múltiples desplazamientos que se han realizado a lo largo de la historia parecen por momentos indicar que "viajar" se ha vuelto imposible, ${ }^{21}$ porque ya no quedan espacios verdaderamente capaces de diferenciarse del magma de lo indiferenciado ni "lugares" a los que se pueda realmente "regresar". Sin embargo, de principio a fin, el paisaje natal insiste en la obra de Saer, reúne a los personajes y logra conjurar por un momento la retracción del espacio provocada por los viajes de exploración, explotación económica, fuga exotista y paseo turístico. Las tres partes que componen este trabajo se sostienen sobre esa imposible, impensable, inútil y azarosa posibilidad del viaje e imaginan un hipotético relato de traslado ("I. Saer en el extranjero), exploración ("II. Los viajes de la zona”) y regreso ("III. La vuelta imposible"). Una indagación que no es sólo temporal sino también espacial. En Atlas de la novela europea Franco Moretti asegura que la geografía es un aspecto decisivo del desarrollo y de la invención literaria. En este sentido, la tesis señala en los distintos capítulos, como en un mapa intensivo puntos de intensidad geográfica y afectiva: ${ }^{22}$

\footnotetext{
${ }^{18}$ En el curso de los capítulos se incorporará y ampliará la bibliografía teórica y el estado de la cuestión sobre el viaje.

${ }^{19}$ Cfr. Adorno, Rolena. "El sujeto colonial y la construcción cultural de la alteridad"; Todorov, Tzvetan. La Conquista de América. El problema del otro; Walter Mignolo. "Cartas, crónicas y relaciones del descubrimiento y la conquista"; Subirats, Eduardo. El continente vacío. La conquista del Nuevo Mundo y la conciencia moderna; Añón Valeria y Vanina Teglia. "Prólogo" en Colón, Cristóbal. Diario, cartas y relaciones y otros textos. Antología Esencial.

${ }^{20}$ Véase Pratt, Mary Louise. Ojos imperiales. Literatura de viajes y transculturación; Prieto, Adolfo. Los viajeros ingleses y la emergencia de la literatura argentina; Rodríguez, Fermín. Un desierto para la nación. La escritura del vacio; Silvestri, Graciela. El lugar común: Una historia de las figuras de paisaje en el Río de la Plata.

${ }^{21}$ Cfr. El viaje imposible. El turismo y sus imágenes de Marc Augé.

${ }^{22}$ Cfr. el ensayo de Giles Deleuze "Lo que dicen los niños" en Crítica y clínica. Allí Deleuze distingue los "mapas de extensión" en los que se representan los trayectos del espacio, de los "mapas de intensidad" o de densidad afectiva en los que se produce el devenir de los personajes: "El devenir es lo que convierte el trayecto más mínimo, o incluso una inmovilidad sin desplazamiento, en un viaje; y el trayecto es lo que convierte lo imaginario en un devenir. Los dos mapas, el de los trayectos y el de los afectos, remiten el uno al otro" (94).
} 
París, la Bretaña francesa, Finisterre; la ciudad de Santa Fe, el camino de la costa, el campo, el mar, las islas y el río.

En la primera parte de la tesis se indagará qué imagen de viajero construye Saer en el extranjero y cómo va modelando esa distancia a través del tiempo. Si como se dijo anteriormente, al irse se "asordina" y se borra en el anonimato, el objetivo será pensar de qué voces e imágenes se alimenta, paradójicamente, su figura de escritor sustraído, silencioso y "sin imagen". Como se verá, Saer apela a ciertos poetas -fundamentalmente Rubén Darío- para sentar su propia experiencia de viaje y su definitivo traslado a la capital francesa. La versión iconoclasta, desinteresada y crítica del viaje a París, que retoma en este sentido el desencanto modernista, le permite a Saer desarticular y oponerse al París de los sesenta y resistir otras imágenes cristalizadas del escritor-viajero contemporáneo: los asimilados a la vida cultural y al idioma francés -Héctor Biancotti-, los "comprometidos" -Cortázar y Vargas Llosa- e incluso los amigos, como Paco Urondo, cuya versión radicalizada del intelectual guerrillero es problematizada por Saer. Sin embargo, ese efecto de sustracción y de resistencia a la agenda política del momento puede mitigarse a partir de dos operaciones: la construcción de un París rebelde que se retrotrae a los tiempos de la Comuna de París y el trabajo sobre ensayos marcadamente "políticos" que Saer escribió en esa época, pero no publicó.

En un segundo momento se observará de qué maneras Saer comenzó a desarticular conceptos fundamentales en torno a lo nacional, la patria y el exilio. Si hasta principios de la década del setenta, la forma privilegiada para pensar su situación como residente francés había sido la poesía y la prosa poética, comienza a predominar, ahora, el ensayo en las diferentes variantes que probó Saer: artículos ensayísticos pero también borradores de entrevistas. ${ }^{23}$ Paulatinamente el escritor se pensará como un tipo especial de "exiliado" y asumirá su pasado como hijo de inmigrantes sirios. Sin embargo, frente a ese linaje familiar de inmigrantes, construirá un linaje alternativo de escritores exiliados. Se explorará aquí la relación entre Saer y Gombrowicz, un "inmaduro" escritor y viajero disidente que, como veremos, le permite consolidar su posicionamiento sobre la tradición literaria nacional y europea y reafirmar, contra la determinación familiar, una estirpe alternativa.

\footnotetext{
${ }^{23}$ Según ha advertido Premat en la Introducción a Ensayos. Borradores inéditos 4, Saer acostumbraba a pedir con antelación las entrevistas, las organizaba y deformaba a gusto y escribía "mini-ensayos" como respuestas.
} 
En tercer lugar se observará que Saer no sólo conjura la partida del espacio natal y la llegada a Francia a partir de una serie de poesías que invierten la "parisiana" entusiasta del viajero sino también a partir de los "argumentos" que formarán La mayor. Pichón Garay será el personaje clave que intercepte poemas y prosas y a partir del cual Saer pueda imaginar otras proyecciones de escritores o reflexionar sobre lo que significa dejar la zona. La geografía del extranjero se ampliará, cruzada por nuevas preocupaciones políticas, en Lugar.

Por último, se analizarán las poesías que se integran en El arte de narrar bajo el subtítulo "Noticias secretas", que expanden la geografía europea explorada por Saer, así como la nómina de viajeros. Allí se leerá por un lado un conjunto de poemas que configuran un breve diario de viaje poético por Finisterre y radicalizan ese efecto de “enajenación” biográfica señalado por Colombi. Saer será un ojo que apenas roza el paisaje, más preocupado en capturar lo "informe" común al mundo que la singularidad de los escenarios franceses. Por otro lado, varias de las poesías allí reunidas reescribirán poéticamente los desplazamientos de famosos viajeros y artistas -Colón, Gauguin, Rimbaud- para incorporar una intensa reflexión sobre las posibilidades y los límites del viaje.

En la segunda parte de la tesis interesará revisar de qué desplazamientos está hecha la zona saeriana atendiendo a tres momentos y escenarios fundamentales. En primer lugar, los viajes de la conquista abren las orillas barrosas del paisaje americano a las indeterminaciones del océano y fijan los contactos entre españoles y nativos. Se prestará especial atención al espacio marítimo por su condición paradojal de puntuar "históricamente" las sucesivas exploraciones de la zona a pesar de la delirante indeterminación que acucia a los viajeros cada vez que se lanzan a las aguas. El mar, como ocurrirá posteriormente con la llanura, oscila entre las pretensiones racionales de conocimiento y progreso económico, y los efectos distorsivos que produce sobre aquellos que se atreven a surcarlo. Esta primera parte atenderá al carácter inestable del paisaje local, hecho y deshecho a partir de las frágiles fundaciones españolas y los asaltos, abandonos e incendios que reducen esas construcciones a sus ruinas. A su vez, el espacio oscilará entre el imaginario humanista español y la lengua antiesencialista y experimental colastiné, que se revelará como la única capaz de transmitir la intermitencia constante del paisaje de la zona.

En segundo lugar, las ficciones de Saer revisan, yuxtaponen y reescriben las alternativas políticas, espaciales y estéticas del desierto del siglo XIX: los pajonales 
acribillados de pozos, la extensa llanura de explotación ganadera, el campo en vías de modernización agrícola, el residual fantasma de los malones indios, la llanura cósmica y darwiniana, la naturaleza febril y sublime de Hudson, la extensión a la vez amenazante y atractiva que cruzaban las carretas de Francis Bon Head y de Alfred Ebelot y la frontera díscola de Mansilla. En su fragmentada reescritura del siglo XIX Saer distingue a los viajeros extraviados de aquellos que, con aires de baqueano, pueden manipular el espacio a medias conquistado, sin embargo, el resto resistente e ilegible del desierto los mantendrá, a todos por igual, en la intemperie del exilio. Cada vez que una novela, una poesía o un relato declinan por el imaginario del desierto reescriben las violencias políticas que formaron parte de la genealogía cultural de la nación pero también las preocupaciones estéticas, filosóficas y políticas contemporáneas al momento de escritura.

Por último, la indagación sobre la zona pasa "más al centro", para revisar el espacio privilegiado de la ciudad. Como se ha dicho muchas veces, la urbe se hace a partir de los recorridos, caminatas y encuentros azarosos entre los personajes que forman la comunidad afectiva de la zona. La "parisiana" crítica que configura Saer cuando llega a Francia y la reiteración de postales-diatribas de las distintas ciudades europeas que recorren sus personajes contrastan con la persistente atención con la que el escritor arma y desarma "su" ciudad. La zona recoge en esta última configuración espacial los vestigios arcaicos de su fundación y traza una memoria del lugar a partir de las diversas generaciones que la atraviesan. El mapa real de Santa Fe y Rosario se abre, como se verá, a las “incongruencias” literarias, y la ciudad encuentra su representación visual en la obra pictórica de los artistas de vanguardia.

La tercera y última parte de la tesis está dedicada a los regresos. Se analizará en primer término El limonero real como una novela que se escribe alrededor de las posibilidades e imposibilidades de la vuelta y que reescribe principalmente el relato de retorno por excelencia, la Odisea. Planeada durante diez años, entre la "zona” y Francia, será ésta la obra que le posibilite a Saer "regresar" al paisaje isleño, y como veremos, a la tradición de viajeros y políticos que lo exploraron y sentaron sus características más sobresalientes. En segundo lugar se considerará de qué modos Saer fue tramando progresivamente su propia experiencia de la distancia y anudando el regreso a su autobiografía. Entre los ochenta y el año 2000 llevará adelante tres proyectos que problematizan, por diferentes vías, las vueltas del escritor a su patria: la escritura íntima de sus libretas de viaje; la escritura ensayística de El río sin orillas y la escritura 
ficcional de La pesquisa y La grande, la novela póstuma que recoge los hilos de las narraciones previas. Como se verá, la década del ochenta será clave para comprender los regresos del escritor en un momento de progresiva afirmación de su literatura y de su figura autoral. Saer no sólo viajará para encontrarse con sus viejos amigos y con su familia sino también por motivos profesionales que lo llevan a participar de presentaciones de libros, charlas y encuentros. Sin embargo, lejos de cristalizarse bajo una imagen de escritor sólida y cosmopolita, apelará en las Libretas y en El río sin orillas a ciertas figuras que insisten en su extranjería y revelan un anacronismo productivo: el "inmigrante", el "topógrafo", el "naturalista", "el recolector de curiosidades lingüísticas", formas disidentes de volver no como el cabal conocedor de lo propio sino como un viajero dispuesto a interrogar, observar, tomar notas, corregir viejas percepciones y confirmar otras.

Finalmente, se explorarán las dos versiones más directamente ficcionales del regreso. Un primer corpus se aglutinará alrededor de Pichón Garay, cuya vuelta a la zona dispara, como veremos, una espiral de relatos policiales y mitológicos que permite revisar la historia afectiva de la sociedad de personajes y la historia política argentina a partir de un quiebre que las atraviesa a ambas: la dictadura militar. Intentaremos dilucidar aquí qué relaciones se establecen entre policial, dictadura y regreso y qué interferencias, cruces y solapamientos hay entre el paisaje opaco de la región y Pichón Garay. Por último, veremos cómo La grande no sólo dibuja el regreso de Willy Gutiérrez sino también la incorporación del universo familiar de inmigrantes sirios del que Saer había renegado y al que comienza a volver ya en El río sin orillas, dedicándoles el libro, significativamente, a sus padres. La novela revisa la tradición de vanguardias literarias locales que el joven Saer había conocido en su juventud e inscribe una forma particular del retorno: el homenaje al poeta de la inmigración, José Pedroni, bajo la representación del almacén de ramos generales que su padre tenía en Serodino y sobre el que el poeta le había pedido que escribiera alguna vez. Como se verá, el "retorno" de Willy Gutiérrez convertirá el "tiempo mítico" de la zona en tiempo reconstituido, fundamentalmente "teatral".

Como se dijo al inicio, el año 1982 pliega dos escrituras de la extranjería relativamente poco conocidas: la libreta negra que Saer trae durante su primer regreso a la Argentina y el breve texto "El cónsul" que firma en París. Ambos son periféricos en el proyecto literario de Saer, inéditos en el caso de las libretas, poco conocidos en el caso del segundo, pero ambos se aglutinan sobre la singular definición ampliada que 
Saer le dio a la palabra "exilio": no sólo el político o el social, sino el exilio ontológico: "constitutivo del hombre, en quien la certidumbre confusa, y difícil de probar, de no estar reducido a la pura materialidad, lo hace girar en círculos y a ciegas, sin poder modificar su condición, del nacimiento a la muerte. Estamos hechos de esa encrucijada de destierros, de esa caja china de exilios y de carencias que desembocan en lo negro" (Saer, Ensayos 149). Sin embargo hacia el final, cuando el cónsul ya es viejo y "abandona su día" distraído e indiferente, algunos creen adivinar "por fin, los ecos del viejo llamado" (76). Las libretas de viaje y "El cónsul" muestran cómo el exilio se transforma en asilo, es decir, según Nancy, el exilio como una dimensión de lo propio. ${ }^{24}$ Viajero sin estado, aventurero fluvial, explorador urbano, naturalista amateur, pintor de paisajes, escritor exiliado, hijo de inmigrantes en la pampa criolla y en París, dichoso retornante al Paraná. Cada forma del viaje en Saer convoca otras escrituras, abre filiaciones inesperadas en la historia de la literatura argentina, reescribe tramos conflictivos o ignorados de la historia nacional y transforma la "zona" en un espacio más indeterminado, una patria sin atributos, o mejor, "un asilo" de cónsules.

\footnotetext{
${ }^{24}$ Cfr. Nancy, Jean-Luc. "La existencia exiliada".
} 


\section{PARTE: SAER EN EL EXTRANJERO}

Escucho a veces/ hablar a hombres que llaman río a un hilo de agua/ estragada, yo, que he visto un río de oro/ cayendo abierto como un tigre y manchando/ largamente el agua pura del mar. Envejezco,/ solitaria. ¿Pasarán, a estas horas, todavía,/ los lagartos del bañado al palmar, y los monos/ qué se dirán, de un árbol a otro,/ gesticulando/ en las mañanas deslumbrantes?/ Del extranjero/ aprendí, sin embargo, la irrisión del recuerdo mismo/ en estos años de confusión.

(Saer, "Una palmera en Bretaña", Poemas 174)

El deseo, ante un hombre como usted, es rehacer su vida paso a paso desde el nacimiento hasta la muerte para encontrar - dónde-

la semilla que germinó toda su claridad. (Saer, fragmento de “A Rubén Darío", Poemas 155)

"Ser un escritor (del lugar) mientras se vive en el extranjero" parece haber sido la paradójica consigna que siguió Saer desde su traslado a Francia en 1968. En relación con ella se intentará aquí responder a dos interrogantes fundamentales: qué máscaras viajeras adoptó Saer y qué transformaciones operó la distancia sobre su producción literaria y ensayística. Desde el prólogo que abre En la zona pueden seguirse las coordenadas programáticas del proyecto saeriano que, como ya se ha dicho muchas veces, establece un primer movimiento de pasaje del campo a la ciudad; y de los personajes orilleros, jugadores, estafadores y prostitutas al grupo de amigos vagamente intelectuales y escritores de "Algo se aproxima". Sin embargo, "la zona" no termina de configurarse como tal hasta que no se advierte su desgarradura, el hiato del extranjero que paulatinamente se instala en la casa natal y la transforma. ${ }^{25}$

¿Qué hay además de anonimato y refracción en esa operación sustractiva que Saer perfecciona, yéndose de Santa Fe y Rosario para siempre? Nathalie Heinich advierte en Ser escritor. Creación e identidad que lejos de ser estable, la identidad de los escritores está marcada por una radical inestabilidad. "Ser escritor" es el resultado de pasar de una actividad (escribir) a un ser ("soy escritor"). Esta operación vertiginosa se

\footnotetext{
${ }^{25}$ Por supuesto, la tensión de lo "extranjero" no es el resultado inmediato del viaje real de Saer en 1968. Mucho antes, ya en La vuelta completa o en Cicatrices la "zona" adquiere su perfil deformante y es ganada por la indeterminación del sentido. Sin embargo, el traslado a Francia agudiza y abre esa indeterminación a una experiencia real de distancia, a partir de la cual se modifican, a la vez, la figura de Saer y su concepción del espacio.
} 
ve acuciada por una serie de imperativos contradictorios (entre la afirmación de una singularidad y la pertenencia a un grupo; entre la reivindicación de una filiación y la fábula de un autoengendramiento; entre la marginalidad y la integración; entre el aislamiento y el compromiso político). Estas tensiones le van dando forma a las diversas figuras de autor (imágenes) y a las variadas ficciones de autor (relatos) que irá probando el escritor, siempre en relación con los "valores" construidos en la colectividad en la que se aloja e imagina esta profesión tan singular. ${ }^{26}$

Los grandes lectores de Saer han indagado y desentrañado gran parte de estos movimientos a partir de los cuales el escritor se "hace un lugar" en la literatura argentina y se construye, negativamente, como autor. Desde el artículo fundante de María Teresa Gramuglio en "El lugar de Saer" (1986) en el que, como advierte Dalmaroni, la lectura fuertemente autorreferencial e intertextual de la crítica anterior cede a las pregnancias del territorio, Saer comienza a ser un escritor que indaga y construye ficcionalmente una “zona”. Gramuglio señala que la dispersión de César Rey y Pancho Expósito en su obra temprana clausura la etapa de formación del escritor, ¿qué otros desplazamientos y viajes de los personajes permitirían atisbar algunas de las transformaciones de su poética? En "Saer: un escritor del lugar", Julio Premat presenta

\footnotetext{
${ }^{26}$ Según cuentan sus allegados, Saer demora en concebirse a sí mismo como "escritor" aunque va configurando, a lo largo de los años, una ética implacable sobre los rigores de la escritura. A partir de algunas entrevistas realizadas a Laurence Guéguen y a Clara Saer se pueden reconstruir las tensiones entre su actividad como profesor en la Universidad de Rennes, profesión que Saer sí asumía, y su incesante actividad de escritor, que sin embargo, le costaba reconocer. Clara Saer recuerda: "-Yo siempre lo vi escribir. La escritura era parte de nuestra vida cotidiana. Él no era una persona que se presentara como "escritor", y menos todavía ante su familia. [...] En 25 años nunca lo oí referirse a sí mismo como escritor. Le parecía totalmente ridículo. Pero de muy joven yo sabía que él era mucho más escritor que profesor" ( $\mathrm{s} / \mathrm{p})$. Cfr. "Saer, el persistente. La vigencia del escritor que creó su propio paisaje", disponible en http://www.lanacion.com.ar/1911857-pagina-3pensamiento-libros-arte A su vez, Laurence Guéguen evoca el momento en que vivieron en Rennes como un período de gran concentración literaria pero también de aislación con respecto a sus pares. Cfr. la entrevista de Luisa Corradini, "Argentino de mate y asado", disponible en http://www.lanacion.com.ar/968402-argentino-demate-y-asado

Quién más, quien menos, todos escriben en sus ficciones: Higinio Gómez, Adelina Flores y Cuello; César Rey, Willy Gutiérrez y Sergio Escalante; los jóvenes Tomatis, Barco y Pichón Garay; los recién llegados Nula, Soldi y Gabriela, e incluso el detestable líder del precisionismo, Mario Brando; pero también Bianco, el entenado y el doctor Real, y por supuesto Washington Noriega. La actividad escritural declina por las variantes generacionales, estéticas, filosóficas y políticas de cada uno de estos personajes, algunos de los cuales estarán más cerca de las búsquedas estéticas del propio Saer, y otros, en cambio, en sus antípodas, "autorretratos desautorizados y falsos, modos soñados de ser escritor que funcionan como imágenes de una posibilidad: todos son y ninguno es, mientras la escritura sí 'está siendo' " (Premat, "Saer: un escritor del lugar" 178).
} 
a Saer como "un escritor borrado, sin imagen ni biografía, que delimita una presencia fuerte a través de la construcción ambivalente de un lugar y de una compleja gama de personajes de escritor" (29) y estudia algunos de esos contradictorios imperativos mencionados por Heinich. En sus ficciones Saer escribe la vida intelectual de la ciudad y construye una fábula de pertenencia a un grupo, pero sus ensayos afirman, en cambio, su individualidad. El gesto importante es aquí el de la construcción de una filiación (Washington Noriega/ Juan L. Ortiz/ Macedonio Fernández) que lo coloca en una tradición de poetas y experimentadores y disloca el centro del canon argentino al margen del Litoral. Cuando Saer se va a Francia, se borra, y París se configura como un margen donde es posible escribir "no estando".

Miguel Dalmaroni también abordó las oscilaciones que sufre la figura de autor en "El largo camino del silencio al consenso" a partir de una doble perspectiva que a la vez focaliza sobre las operaciones de figuración de Saer como sobre las mutaciones en su valoración y recepción en Argentina. Ese pasaje que estudia Dalmaroni desde el "silencio" al "consenso" más o menos generalizado sobre el valor de su obra permite atisbar una serie de movimientos en su figura. Saer es, alrededor de 1964, un "iracundo a medio borrar", un joven que polemiza en encuentros y charlas de escritores y produce un módico revuelo en la vida literaria que llega hasta Buenos Aires. Sin embargo, cuando viaja a París, su figura se "asordina", se sustrae de la esfera pública y de las demandas políticas del compromiso a las que sí respondía la nueva literatura latinoamericana. Saer será durante muchos años el "escritor casi secreto", "silencioso", "ilegible", y también será, de acuerdo a las primeras críticas que recibieron sus textos, "mal leído", no interpretado. ${ }^{27}$

Por su parte, en "El canto de las estrellas", Martín Prieto comienza a indagar de qué maneras la poesía de Saer procesa esos desplazamientos de su obra y de su figura de autor. En "Rubén en Santiago", un poema clave de El arte de narrar, Saer se mide con Rubén Darío a partir de un juego de proyecciones entre el poeta, Pichón Garay y Saer, cuyos viajes en Francia y en Chile se yuxtaponen y abren una interrogación sobre los

\footnotetext{
${ }^{27}$ Es precisamente un efecto de corrección y de reposicionamiento el que efectuará Punto de $V i s t a$, en relación con nuevas morales de lectura y valoración estética. A partir de los ochenta Saer ganará progresivamente una mayor visibilidad y con la publicación de Glosa se profesionalizará en tanto escritor que tiene un editor estable, participa de charlas, encuentros y entrevistas, y es traducido y comentado por un círculo cada vez menos restringido de lectores. Un consenso, sin embargo, que nunca deja de establecerse sobre una obra "resistente", una poética que no cede a las presiones externas y una figura pública que no comercia con su vida privada y se mantiene en el estricto ámbito de la literatura.
} 
espejismos e inclemencias del medio literario al que es arrojado el poeta, y sobre la intemperie en cambio, productiva, en la que todavía puede oírse "el canto de las estrellas".

Interesa entonces retener esos enunciados sobre lo que sucede cuando Saer se traslada a Francia: "se asordina", "se vuelve un escritor sin imagen", "se sustrae de la esfera pública", "puede ser un escritor sin serlo", porque el de Saer parece ser un silencio lleno de ruidos y estridencias, y su ausencia, un vértigo voraz de representaciones y enigmas alrededor de su figura que, desde la otra orilla, no dejan de interrogar sus amigos y allegados. ¿Qué hubo entonces en el extranjero?, ¿cómo Saer se “asordinó”?, ¿apelando a qué imágenes veló la suya propia?, ¿cómo puede ser un escritor sin serlo? Se indagará, en esta primera parte de la tesis, de qué voces e imágenes se alimenta, paradójicamente, su figura de escritor sustraído, silencioso y "sin imagen”.

En Viaje intelectual Beatriz Colombi advierte: "El desplazamiento coloca a prueba la autofiguración del sujeto así como su pertenencia a una cultura periférica, por eso la escritura desterritorializada fue un vector de numerosas metáforas culturales [...] formuladas como narraciones de autoafirmación, emancipación o descolonización cultural" (15). El desplazamiento de Saer, entonces, vuelve a indicar una oscilación en su "identidad de escritor" (Heinich) pero a su vez, como se verá, vehiculiza nuevas representaciones sobre la cultura periférica de la que proviene y sobre el espacio natal que dejó, que se irán radicalizando a medida que se consolide la distancia.

¿Qué queda del viaje a Francia entre los papeles de Saer?, ¿qué huellas deja la vida en el extranjero en sus poesías, en sus ensayos y en su prosa ficcional?, ¿hay, propiamente un relato de viaje? Saer es, como se verá, un viajero raro que desarticula las expectativas culturales vinculadas al viaje a Europa y construye negativamente el espacio parisino. No encontramos entre sus borradores y papeles sueltos ningún "libro de viaje", ningún diario sobre su llegada a París, apenas unas impresiones viajeras de otros recorridos por Europa y algunas breves notas sobre la capital francesa. Sin embargo, el escritor reformula los modos en que se tocan el viaje, la (auto)biografía y la ficción reescribiendo a una serie de escritores viajeros que le ofrecen las formas de resistencia política y estética en el extranjero: fundamentalmente Rubén Darío y Witold Gombrowicz. ¿Cuál es, podríamos preguntarnos junto a Heinich y Premat, la pertenencia fabulada que abre el viaje?, ¿qué filiación del exilio y del desplazamiento? Vallejo, Akinari, Dante, por nombrar solo algunos. Una "solidaridad" que excede la relación entre viajero/narrador/personaje para abrirse a una serie proliferante de 
máscaras viajeras. Se intentará pensar en esta primera parte de la tesis cómo, por ejemplo, se radicaliza la afirmación de una individualidad a partir de un rechazo de los contemporáneos (los asimilados a la vida cultural y al idioma francés, pero también los "comprometidos" con la agenda política) y la configuración, por otro lado, de un París anacrónico. Para ello se revisarán las poesías -en su mayor parte inéditas hasta la publicación de los Borradores- que Saer escribió durante sus primeros años en Francia. En segundo lugar se leerán algunos de los ensayos y entrevistas en los que Saer reflexionó a propósito de la vida en el extranjero y en los que modeló su particular definición de patria y exilio. Se analizarán relatos de La mayor y de Lugar, y finalmente algunos poemas de El arte de narrar en los que se expande la geografía europea así como las referencias a grandes viajeros reales y ficcionales que le permiten a Saer discurrir sobre los límites del viaje. 


\section{MÁSCARAS VIAJERAS PARA UN ESCRITOR SIN IMAGEN}

\subsection{El viajero involuntario}

Yo no tenía intención de ir a ningún lado. Un amigo que quería ir a Francia me pidió ayuda para elaborar un trabajo a presentar en la Alianza Francesa, en 1968. Hicimos el estudio y el director de la Alianza nos propuso que lo presentáramos para una beca. Nos presentamos los dos y la beca para viajar a Francia me la dieron a mí y no a mi amigo. Yo propuse cambiar, pero como esa beca venía de un ministerio no se podía hacer nada. Fui, obligado, por seis meses, y hace 26 años que estoy (Saer, "Los que se van" 6, las cursivas me pertenecen). ${ }^{28}$

En 1968, un mes y medio después del Mayo francés, Saer viaja a París con una beca del gobierno de Francia para estudiar el nouveau roman y lo que iba a ser una estadía de seis meses se prolonga por el resto de su vida. En "El viaje, de la práctica al género", Beatriz Colombi advierte que lo que distingue al viaje de otra clase de desplazamientos como la migración, el exilio, la expatriación y la diáspora es su carácter más o menos voluntario. El testimonio de Saer sobre su traslado a Francia empieza precisamente cuestionando ese deseo. ${ }^{29}$ A diferencia de la larga tradición de escritores nacionales consignada por Viñas en el ya clásico texto "La mirada a Europa: del viaje colonial al viaje estético", que voluntariamente fueron al viejo mundo para encontrar allí un espacio de aprendizaje, una forma de distinción social y una oportunidad para consagrarse como escritores, el viaje de Saer parece más bien obra de otros y no intención propia: ${ }^{30}$ el amigo que sí quería viajar, la sugerencia del director de

\footnotetext{
${ }^{28}$ Saer, Juan José. s/t en AAVV. "Los que se van". Página/12. Domingo 8 de septiembre de 1996. Testimonio de Saer sobre su vida en París, p. 6.

${ }^{29}$ En una entrevista realizada por Miguel Russo, Saer evoca y amplía las circunstancias de su viaje y cuenta que después de la muerte de André Bretón en 1966, su amigo Jorge Cohen le pidió ayuda para realizar un audiovisual sobre su vida, con la intención de ganar una beca y viajar a París. Saer aceptó y armaron el trabajo a partir de una suerte de montaje de textos, objetos y diapositivas. Al director de la Alianza Francesa le gustó y los invitó a presentarse a una beca con el gobierno francés, a propósito de lo cual Saer comenta: "Yo no quería saber nada, pero él había preparado todos los formularios. Ahí firmamos, medio mamados, y al poco tiempo me mandaron una carta confirmando la beca, pero sólo para mí. Yo no tenía ni cinco de ganas de viajar, traté de protestar, de cambiar la beca a favor de Cohen, pero no lo aceptaron y me fui" (Saer en Russo s/p).

${ }^{30}$ En la entrevista realizada por Ana Inés Larre Borges, "El arte de narrar", para la revista Brecha en 1997, la entrevistadora presenta a Saer de la siguiente manera: "Lleva casi 30 años viviendo en Francia. Vino por seis meses en 1968. Se quedó, pero piensa que vivir en París fue circunstancial. Descree de la predestinación de los lugares" (Una forma más real 112).
} 
la Alianza Francesa y el mismo gobierno Francés. Viaja entonces, sin intención y obligado, pero su estadía se prolonga por causas que sí puede reconocer:

Otras de las razones involuntarias para permanecer allá fueron la degradación de la situación política de la Argentina, los cambios de mi situación familiar y el nacimiento de mis hijos. Por supuesto que me gustaría vivir en Argentina, pero no podría dejar París por mucho tiempo; y como las condiciones de trabajo son mejores allá que acá, me parece mucho más fácil quedarme (Saer, "Los que se van" 6, las cursivas me pertenecen).

Entre las múltiples razones "involuntarias" que enumera Saer, ${ }^{31}$ no se encuentra, sin embargo, "el" motivo principal por el cual muchos escritores latinoamericanos abandonaron el continente para viajar a Europa. Saer no viaja como un escritor latinoamericano agobiado por la "abulia intelectual" del medio provinciano en el que se mueve, ni busca al parecer promover su figura legitimándola en la metrópolis parisina. Cuando abandona el país ya tiene escrita una parte importante de su obra: cuatro libros de cuentos: En la zona (1960), Esquina de febrero ${ }^{32}$ (escritos entre 1964-5), Palo y hueso (1965) y Unidad de lugar (1967); y cuatro novelas, La vuelta completa (1966), Responso (1964), Cicatrices (escrita en 1967) y el comienzo de El limonero real (que empezó a desarrollar desde 1964). Además, ya contaba con varios de los poemas que integrarían El arte de narrar y algunos ensayos.

Tampoco viaja, como señala Sarlo en Zona Saer, para convertirse en un lector cosmopolita, porque previamente en Santa Fe ya había leído a Joyce, Faulkner, Proust y Virginia Woolf. Sus amigos Roberto Maurer y Raúl Beceyro evocan con afecto el entusiasmo que Saer les transmitía por sus recientes lecturas y descubrimientos, tanto en materia literaria cuanto filosófica -Saer lee tempranamente los ensayos de Adorno y Benjamin cuando nadie los leía-. Dice Sarlo: "[Saer] sabe algo de modo definitivo, pero eso que sabe no concierne a los avatares de su biografía como viajero o profesor en

\footnotetext{
${ }^{31}$ Una de las cartas que Saer les envía a su madre y a su hermana (fechada el 9 de septiembre de 1969) revela las tensiones entre los compromisos laborales del escritor -repartidos entre su escritura, su relación con las editoriales y sus traducciones- y sus deseos de volver al país: "Nosotros estamos muy bien y trabajamos mucho. [...] Yo tengo que ponerme a terminar la otra novela que le vendí a Sudamericana, porque, según me manda decir Beceyro, ya figura en el catálogo y todavía no está ni siquiera terminada. Yo ya estoy un poco cansado de Francia. Tengo ganas de volver a la Argentina, aunque parece que por allá las cosas se están poniendo vidriosas, a juzgar por lo que leo en los diarios" (citada en Prieto y Constantin, Catálogo Conexión Saer 30).

${ }^{32}$ Relatos descubiertos por Saer en el año 2000 y publicados en los Cuentos completos.
} 
Rennes sino a la biografía literaria de hombre del sur, argentino, santafecino" (Sarlo, Zona Saer 19).

En numerosas entrevistas Saer reconstruye los años de formación en la zona y da cuenta del auge cultural del período, caracterizado por fuertes intercambios entre artistas e intelectuales de Santa Fe, Rosario y Buenos Aires. Señala que para él Santa Fe representaba la creación literaria y Rosario el pensamiento filosófico, la sociología y el psicoanálisis. Dos líneas de la actividad y del pensamiento que terminaron por converger en su obra. En la conversación que mantiene con Edgardo Dobry a propósito de Aldo Oliva, Saer reconstruye retrospectivamente el campo literario de la época a partir de una perspectiva generacional sumamente positiva y encomiosa: "Creo que Aldo se inscribe en lo que podríamos llamar la generación del '50, junto con Padeletti, y también con Giribaldi [...]. Creo que como movimiento poético [...] es el más importante después de Boedo y Florida, incluso diría después del modernismo" (AA.VV., Una forma más real 173). El intercambio, intenso y frecuente, hecho de fuertes lazos afectivos e intelectuales y no exento de discusiones y polémicas se figuraba en una serie de operaciones culturales. Por un lado, Saer comenta que era común que entre los poetas amigos se leyeran y comentaran sus escritos y menciona en ese grupo a Jorge Conti, el ‘negro’ Ielpi, Rubén Sevlever, Hugo Gola y Aldo Oliva, así como las míticas visitas a la casa de Juan L. Ortiz en Paraná. Señala también que los poetas de Rosario y Santa Fe se visitaban mutuamente y que si bien ese fuerte lazo intelectual no estaba institucionalizado sí había cristalizado en algunas revistas, como $\mathrm{El}$ arremangado brazo (1963-1964), dirigida por Rafael Ielpi, Romeo Medina y Aldo Oliva, o Setecientosmonos (1964-1967). ${ }^{33}$ Algunos lugares, como la Biblioteca Vigil en Rosario o el Instituto de Cine de Santa Fe funcionaron además como puntos de

\footnotetext{
${ }^{33}$ En "Setecientosmonos y la modernización de la crítica literaria argentina", Judith Podlubne afirma que Setecientosmonos fue un factor de modernización de la crítica literaria argentina a partir de la llegada de Nicolás Rosa. Interesa subrayar que parte de esa modernización se debió a la incorporación de textos de teóricos franceses contemporáneos, traducidos por el propio Rosa (Merleau-Ponty, Barthes, Sartre). Pero además, en paralelo a ese episodio de su formación, la revista permite reconstruir las relaciones intelectuales de las que también formaba parte Saer, porque Rosa invitó a Adolfo Prieto y a su grupo de investigación a participar. En este marco, Nora Desinano publicó “J. J. Saer: después de la vuelta completa", un texto crítico sobre la narrativa de Saer y sobre las discusiones que se venían generando a su alrededor, una crítica precursora de la recepción argentina del escritor. Saer colaboró -continúa explicando Podlubne- en el último número de la revista con una traducción del cuento "La playa" de Alain Robbe Grillet y con una selección de poemas que luego formarían parte de El arte de narrar. También habían colaborado previamente Juan L. Ortiz y Hugo Gola, poetas que formaban parte de ese grupo cultural junto a Saer y los críticos universitarios antes mencionados.
} 
encuentro muy significativos: "Todo eso creó una mouvance que para mí fue muy importante [...] ahí se creó un movimiento de pensamiento literario, político, filosófico, pictórico, musical muy singular, como hubo también en Córdoba" (167).

Pero además, el movimiento excedió el límite provincial. Saer refiere que establecieron relaciones con los poetas de Poesía Buenos Aires a través de Hugo Gola, que oficiaba como nexo. Así conocieron a Rodolfo Alonso, Raúl Gustavo Aguirre, Edgard Bayley y 'Coco' Madariaga. Estos poetas y artistas viajaban a Santa Fe, entre ellos, Paco Urondo, que también estaba en Poesía Buenos Aires, y Juan Gelmán, que militaba en el PC con Hugo Gola. El relato de Saer no reproduce la lógica de marginalidad intelectual del interior con respecto a Buenos Aires. Por el contrario, contribuye a posicionar a los escritores y artistas de Rosario y Santa Fe en fuertes polémicas de la época y los figura como una avanzada ideológica y estética. Saer le recuerda a Dobry que fueron ellos los primeros desde la izquierda en reivindicar a Borges como un gran escritor, a diferencia de Contorno que lo consideraba un escritor evasivo y evoca una gran discusión que él y Hugo Gola mantuvieron con algunos miembros de Contorno, entre ellos, Paco Urondo, a propósito de Borges. ${ }^{34}$

Como se verá también más adelante, cada vez que Saer es interrogado sobre sus años de aprendizaje literario y sus influencias, refiere que casi toda su formación la adquirió durante su juventud en Argentina. Destaca además la facilidad con que era posible acceder a la literatura de vanguardia y a "las cosas más importantes de la literatura mundial" -Freud, Faulkner, Joyce- en las mesas de saldo de las librerías de Santa Fe. En conversación con Graciela Speranza señala por ejemplo que a pesar de que París es donde se puede ver más cine en el mundo, su formación cinematográfica la hizo en su ciudad natal, donde llegaba lo que llegaba: "Me pregunto si no es mejor que el azar determine los gustos" (Speranza, Una forma más real 102). Es decir, cuando Saer abandona la "zona" ha escrito y publicado bastante y forma parte de un entramado cultural, afectivo y estético de gran calidad artística y rigurosidad intelectual. Esto resulta importante a la hora de pensar sus primeros años en Francia, que como se verá, distan bastante de este período de fuertes intercambios y apogeo cultural.

\footnotetext{
${ }^{34}$ Noé Jitrik testimonia esta polémica en la semblanza personal y literaria de Saer que escribió para la apertura del Coloquio Internacional Juan José Saer (realizado en Santa Fe en mayo de 2017) y lo evoca: "vociferando contra Contorno, reivindicando a Borges, cuestionándome vigorosamente por no sostener a Borges, pobrecita víctima de la despiadada furia de los Viñas. Lo recuerdo sudoroso, gesticulando, movido por una pasión que en ese momento consideré seguidista pero que muy pronto cambiaría su signo sin por eso perder su espesor" (citado en Prieto, Catálogo Zona Saer 9).
} 
Si la obra editada no ofrece en primera instancia una gran cantidad de textos que permitan reconstruir las impresiones viajeras de Saer, quien, como estudia Premat, perfecciona su borramiento como figura autoral y rechaza la efusión intimista, es posible hallar algunas de estas autofiguraciones en textos que habían permanecido sin editar y que fueron publicados recientemente en la serie de los Papeles de trabajo; ${ }^{35} \mathrm{o}$ bien volver a leer, desde la clave del viaje, textos ya conocidos. Por ese motivo, el corpus que se explorará a continuación es heterogéneo. El escritor inscribió su experiencia de traslado en una variada serie de géneros: poesías, ensayos, borradores de entrevistas, reflexiones de carácter autobiográfico, citas y escenas teatrales. Sin embargo, resulta sugerente el orden en el que va desplegando estas variantes de escritura. Los primeros años concentran en primer lugar una gran cantidad de poesías cuyo tema es el viaje y lo extranjero. Un solo texto en prosa, "El paraíso recuperado", escrito en 1969, interrumpe esta primer constelación poemática del viaje, que se continúa hasta 1971 aproximadamente. Como se intentará demostrar, esta primera configuración de su imagen como viajero abre una serie de interrogantes sobre el lugar del artista y del intelectual que Saer ocupó en un momento de gran agitación política como fue el de los sucesos alrededor de mayo del ' 68 . En este sentido, se leerá también una serie de ensayos que escribió en esos mismos años a propósito de los debates alrededor del "compromiso" del escritor.

\footnotetext{
${ }^{35}$ Los Papeles de trabajo del escritor permiten observar las modificaciones que atraviesa su escritura una vez que se traslada a París así como atisbar las nuevas autofiguraciones que ensaya, vinculadas como veremos a una serie de otros escritores viajeros. En la "Introducción general" que escribe para los dos primeros tomos de Papeles de trabajo, Premat tomará el viaje como parteaguas a la hora de ordenar los borradores inéditos del escritor y distinguirá un "Saer argentino" de un Saer ya instalado en Francia. La primera parte de esta producción incluye trabajos que van desde fines de los cincuenta a fines de los sesenta: una multiplicidad de inicios de cuentos, pero también un sorprendente conjunto de ensayos y poesías que permite registrar un desfasaje entre lo editado en esa etapa temprana y lo efectivamente escrito por Saer. Su producción ensayística, por otra parte, revela esa dimensión polémica que caracterizó su participación en la escena literaria nacional, a través de "enfrentamientos intelectuales, inserción en grupos, los debates y tensiones del campo literario argentino y santafesino" (Premat, "Introducción", Papeles de trabajo 19). Cuando Saer llega a Francia "el cambio de su obra se confirma" (Premat 19) porque domina la escritura de ficción, escenas, aforismos y poesía. Se trata de un período de creatividad y de proyectos truncos así como de esbozos de la obra posterior. Una segunda etapa mostraría una profesionalización de la escritura, observable en la reducción de tanteos previos pero también en la incorporación de un género nuevo: las libretas de viaje que Saer utilizará particularmente en sus regresos a Argentina.
} 


\subsection{La despedida}

Como se ha analizado muchas veces, los textos que ficcionalmente exhiben la partida son fundamentalmente "Discusiones sobre el término zona" y "A medio borrar", ambos relatos de La mayor que Saer comenzó a escribir en $1969,{ }^{36}$ cuando ya estaba instalado en Francia. Entre la fidelidad y la imposibilidad de serle fiel a una región; entre la partida de Pichón Garay y la permanencia fantasmática de su hermano el Gato, estos textos inauguran esa posición "entre dos aguas" que asume su literatura, como advertirá más adelante Saer. Sin embargo, interesa ahora observar una serie de poesías, algunas publicadas y otras inéditas hasta la aparición de Poemas. Borradores inéditos 3 que se concentran en el umbral de la partida y tematizan la despedida del viajero. En 1968 Saer escribió dos poemas -no incluidos en El arte de narrar-que condensan ese momento bisagra en el que el sujeto está por dejar su tierra natal.

En primer lugar, "A una persona en el extranjero" realiza una curiosa condensación del tiempo y del espacio: "Meses enteros no duran más/ que los tensos relámpagos que anteceden,/ en esta noche, a una lluvia imprecisa. [...] Nuestra/ pasión está ahora en la sala de espera de la estación,/ nuestra mirada fija sobre el reloj detenido" (Saer, Poemas 114). ${ }^{37}$ El poema se concentra en esa hora central en la que se cruzan el que llega y el que se va, mientras que, frente a ese momento decisivo, meses y años enteros no duran más que "relámpagos", "explosiones", "ráfagas" y "destellos". Curiosamente el "viaje" se inaugura a partir de una detención espacial y temporal. El poema contrapone el locus estático e interior de la sala de espera de la estación a la imagen de un tren en movimiento que metaforiza el paso del tiempo: "el tiempo corre para atrás/ y hacia lo hondo, como los árboles/ que entrevemos, veloces,/ desde la caja de los trenes" (114). Sin embargo, el sujeto poético no es aquí propiamente el viajero sino aquel que fija su mirada en un reloj detenido.

El segundo poema, "Perspectivas de un viaje", promete romper esa tensión del poema anterior: "La misma liberación/ lo asaltará en Orly,/ la misma [...]/ liberación, de esa ansiedad,/ de ese pavor,/ de esa melancolía con que prepara,/ en medio de los viajes,/ la Partida" (Saer, Poemas 124). Orly es una pequeña comuna ubicada en Isla de

\footnotetext{
${ }^{36}$ Estos relatos se analizarán en el capítulo 3 de la I parte de la tesis, "Ficciones del extranjero".

37 "A una persona en el extranjero" es un poema inédito publicado en Poemas. Borradores inéditos 3 y en Papeles de trabajo I. Los editores comentan que se trata de un texto del que hay varias versiones dactilografiadas que presentan pocas variantes entre sí, entre ellas, en el verso 8 , "la caja de los trenes" por "las ventanillas", y "explosiones" por "ráfagas-destellos-visiones".
} 
Francia, a 14 kilómetros del sur de París y allí se encuentra el aeropuerto de París-Orly. Posiblemente a este espacio esté dedicado el poema, que de alguna manera actúa como umbral profético porque el sujeto lírico parece saber que en el "-viaje dentro de un viaje,/ y dentro todavía,/ como una caja china de viajes- [se prepara] en medio de los viajes,/ la Partida" (124).

En "La infancia en la ciudad de la memoria", el texto introductorio preparado para Infancia en Berlín hacia 1900 de Walter Benjamin, Jorge Monteleone advierte que el viaje que Benjamin hizo hacia Ibiza buscando una mayor estabilidad económica coincidió con las celebraciones de inauguración del Tercer Reich, y que por las cartas que le enviaba a su amigo Gershom Scholem, Benjamin "comenzaba a intuir que en ese viaje turístico se dibujaba una incipiente experiencia del exilio" (Monteleone 7). Interesa destacar aquí ese carácter mutante del viaje, que encierra y depara para el viajero una condición inesperada: el viaje "turístico" de Benjamin deviene exilio forzado. Salvando las enormes distancias, el viaje al principio "involuntario", "obligado" y "acotado" que prometía la beca de Saer se convierte posteriormente en un "traslado" permanente que irá perfeccionándose bajo las singulares características que asume la figura del exilio para el escritor.

De las poesías publicadas en la primera sección de El arte de narrar (19601975), podrían a su vez destacarse dos que asumen poéticamente el tópico de la partida: "A Böhlendorff" y "Despedida". La primera, inspirada en las cartas de Hölderlin a su amigo, el escritor, poeta e historiador Casimir Ulrich Böhlendorff (1775-1825) incorpora una reflexión sobre lo nacional que, como se verá, Saer reiterará en varias ocasiones:

\author{
Lo nacional \\ equidista sabiamente \\ de la sangre y de las banderas \\ y se da, para la lengua, en el rigor. La infancia \\ es el solo país, como una lluvia primera \\ de la que nunca, enteramente, nos secamos. Y aunque \\ yo viaje, ahora, al mediodía, toda \\ esta niebla, común, perdurará \\ (Saer, “A Böhlendorff”, El arte de narrar 10).
}

Esta reflexión se ubica en el centro del poema y viene precedida de una estrofa en la que, por un lado, se apela a la amistad a partir de una metáfora bélica, como línea 
de fuego en la que los amigos cantan "contra toda aspereza" acompañando al que ha avanzado; y por otro lado reconoce el esfuerzo creador de Böhlendorff, cuyo Fernando lo muestra "en la ocasión de estar dándolo todo de sí" (10). La última estrofa posiblemente cite palabras de este escritor y anuncia el oscuro futuro al que deberá enfrentarse, aunque ese horror sea, en comparación "a los fantasmas que dicen serme/ contemporáneos,/ la salud más grande" (10 cursivas en el original). El sujeto que viaja al mediodía, alejándose del centro afectivo que lo acompañaba, sabe que lo nacional seguirá reverberando en el rigor del idioma, que la infancia es una fatalidad y que esa "niebla común” (¿la que compartía con sus amigos?) perdurará, y sabe también que ingresará en un territorio en el que no hay amigos sino fantasmas con los que es imposible cualquier diálogo porque no comparten, aun en el mismo espacio, una misma temporalidad, y no podrían alinearse, como los amigos, en "la primera línea de fuego" (10). Aunque no tenemos acceso a la fecha en la que se escribe este poema, la experiencia de Saer resuena aquí una vez más y parece condensar los principales núcleos de la partida: el alejamiento de la zona -intelectual y afectiva- en la que poetas, pintores, filósofos y cineastas participaban de la misma línea de fuego, acompañándose en las estocadas que sus obras producían en el campo artístico regional y en las polémicas intelectuales de las que participaban; "A Böhlendorff” vuelve a plantear el problema de la patria y de la lengua y termina anunciando un pasaje desolador que evocará, como veremos, los primeros años de Saer en París.

El segundo poema, "Despedida", recoge los tópicos asociados a la partida: la invocación al mar que impone una distancia entre las dos orillas y separa a los viajeros de los que se quedan: "Hoy nos separas, profundo, y alguien/ recorrerá ese millón de pasos que se acunan,/ [...] sentimos nuestros ojos arder entre unos gestos/ delicados, en esta orilla/ solitaria, en plena tarde/ y en un octubre extremo" (82). Como se vio, en ninguno de los casos analizados Saer inscribe su partida de modo directo, como una experiencia autobiográfica. El distanciamiento y el anonimato que consumará su permanencia en Francia ya opera en este momento transicional. La experiencia de la despedida, incluso con su carga de angustia e incertidumbre, se manifiesta de modos oblicuos: se escribe "a una persona", innominada, en el extranjero; se coloca en el lugar del viajero a uno de los personajes ficcionales de la saga (una de las versiones de "Perspectivas de un viaje" aparecía con su título tachado y cambiado por "Tomatis al extranjero"); la partida se traduce como reflexión en un poema dedicado a otro escritor (“A Böhlendorff”) o se diluye en un nosotros indeterminado (“Despedida"). 


\subsection{Un modernista camina las calles de Mayo del '68}

Cuando estaba en París, los domingos, arduos, me despertaba a mediodía la luz frágil que entraba por la ventana. Mis ojos turbios chocaban contra un cielo liso, y los últimos rastros del sueño se borraban de mi mente. ¡Qué tristeza! Salía a caminar por calles pulidas por el uso, y llegaba hasta el Sena verde. Pasaban remolcadores lentos. Pensaba, fumando, apoyado en la baranda de un puente antiguo, que había en el mundo una casa que era la mía [...]. Ahora que he vuelto, la pesadilla de París, ciudad que pertenece a otros, se ha borrado (Saer, "El paraíso recuperado", Papeles II 28).

En "El paraíso recuperado" Saer evoca sus primeros días parisinos y sus caminatas y detenciones por una ciudad pesadillesca que no le pertenece, demasiado caminada -y escrita- por otros, cuya luz frágil contrastará con "el sol obseno" y “el mar de blancura deslumbrante" (28) que lo despierta los domingos al mediodía en Santa Fe. Apenas unas breves reflexiones autobiográficas, acotaciones en entrevistas y un puñado de poesías permiten recomponer fragmentariamente los recorridos de Saer -o mejor, cabría decir, las proyecciones subjetivas de sus poemas- por París. El escritor camina por las principales arterias de la ciudad y visita lugares conocidos: pasea por Versalles y el Louvre, los Campos Elíseos y el Boulevard Auguste Blanqui, pasa por el Café de la Paz y por el Mercado de la calle Moufetard. Desde un puente antiguo mira el Sena verde y lee el trazado urbanístico de la ciudad cuya racionalidad organiza en vértices perfectos los monumentos de la cultura y de la historia. Visita también la tumba de Sartre en el cementerio de Montparnasse y el "Muro de los Federados" en el Cementerio del Père-Lachaise. Al poco tiempo de vivir en París le ofrecen un trabajo como profesor de Literatura Latinoamericana en la Universidad de Rennes y así, su vida entre Rennes y París lo hará atravesar en tren el paisaje de Bretaña. Mucho después, en La pesquisa (1994), París aparecerá como el escenario policial y fantasmático de los recorridos de Morvan y Lautret.

Unos meses después de su llegada, en 1969, Saer visita otras partes de Europa y parece sucumbir al mismo enamoramiento que Stendhal experimentó en Italia. Una nota suelta lo atestigua:

[...] Bologna, una ciudad mucho más bella que todo lo que uno pueda imaginar, más bella incluso que lo que uno pueda desear, porque para el deseo una ciudad como Bologna puede parecer extravagancia y locura. He visto Pisa, Lucca, Pistoia. Mañana voy a Siena y dentro de unos días a Roma. En Italia uno siente que en París no ha hecho más que perder el tiempo (Saer, Papeles de trabajo II 29). 
El fragmento interesa no tanto por el pasajero síndrome stendhaliano de Saer sino por la aversión hacia París, una ciudad en la que al parecer no hay demasiado para ver y por la que aparenta no sentir ningún deseo.

París es, además, una de las ciudades más sobrescritas: en crónicas, cartas, poemas, pinturas y textos de viaje, cientos de artistas e intelectuales cubrieron con su testimonio su experiencia de París, contribuyeron a armar su mitología y fraguaron las principales representaciones de la "parisiana". ${ }^{38}$ Proyectando su figura de escritor en una variedad de personajes escritores - reales y ficcionales- Saer se posiciona en la línea del "desencanto" de París -inaugurada por Sarmiento y desarrollada posteriormente por muchos escritores modernistas-. La versión iconoclasta, desinteresada y crítica del viaje a París, que apela en este sentido al desencanto modernista, le permite a Saer desarticular y oponerse al París de los sesenta.

Se indagará, en primer lugar, de qué manera Saer apela a la figura de Rubén Darío, no sólo para definirse como viajero y residente en París sino también para construir las principales coordenadas de su poesía y establecer su propia y melancólica flânerie por la ciudad. Pero además, se observarán los puntos de contacto y de distancia entre el viaje modernista y religador de Darío y el traslado desinteresado e individual de Saer en relación a las clásicas operaciones de legitimación y reconocimiento por parte de otros escritores. En segundo lugar, se intentará reconstruir el París de fines de los sesenta y principios de los setenta que conoce Saer. Para ello, se buscará leer, principalmente en una serie de ensayos que permanecieron inéditos, las polémicas y diferencias que entabló con sus contemporáneos en relación a los vínculos entre literatura y política.

\section{La lección dariana: una forma refractaria del viaje a París}

\footnotetext{
38 En "Parisiana. Viaje y neurosis", Beatriz Colombi advierte que los escritores hispanoamericanos generaron un relato estereotipado sobre París al que ella denomina "parisiana" en honor a uno de los libros de Darío. La "parisiana" modernista incluye la bohemia, los estudiantes, las aventuras amorosas, la lectura de viejos libros a orillas del Sena, el café, la garçonnière; y además se focaliza en algunos puntos de la geografía urbana: Montmartre, el Barrio Latino, el bulevar.
} 
El año de su llegada a París, Saer le dedica tres poemas a Rubén Darío: "A Rubén Darío", una poesía sin título vinculada a la anterior y "Martes nublado". ${ }^{40}$ En el primer poema el sujeto lírico confiesa haber soñado con Darío:

Cuando me desperté, usted ya había muerto.

Pero en el sueño estaba vivo, borracho, del brazo de Verlaine, desnudo. Nevaba. Copulaban los dos en la rue Vaugirard.

Rubén: si he soñado esta noche con usted, es porque en la memoria de todos usted baila, solitario, como un cometa que ya es ceniza en el momento mismo de arder (Saer, Poemas 155).

El segundo poema retoma algunos versos del "Soneto Autumnal al Marqués de Bradomín”, que Darío le dedica a su amigo Ramón del Valle Inclán, uno de los mayores representantes del modernismo español que escribió las Sonatas: Memorias del

\footnotetext{
${ }^{39}$ Algunos de los vínculos entre Saer y el modernismo fueron abordados por la crítica, que se ha centrado particularmente en el aspecto musical del movimiento y ha estudiado la poesía "Rubén en Santiago". En "El canto de las estrellas", el prólogo que Martín Prieto le dedica a El arte de narrar, el crítico reflexiona sobre estos vínculos y se detiene sobre todo en este poema, una reescritura de la biografía de Rubén Darío hecha en poesía en la que Saer proyecta algunos de los rasgos de su figura a través del personaje de Pichón Garay, quien a su vez se encuentra identificado en el poema con la figura del joven Darío que llega a Chile. En la Introducción que escribe para la Obra completa de Juan L. Ortiz, Prieto continúa deslindando esos vínculos y señala que Darío está en la base del pensamiento poético de Saer, pero procesado por Ortiz. Saer retomará de su maestro Juan L. Ortiz el aprovechamiento de los signos de puntuación y, como se ha dicho ya muchas veces, su escritura ensayará productivos intercambios entre la prosa y la lírica, particularmente entre los procedimientos de distribución y condensación que las caracterizan respectivamente: "Si Darío, para devolver la musicalidad al verso y al poema trabajó sobre formas fijas [....], Ortiz aprovechó toda la experiencia modernista agregándole la utilización de un instrumento [...]: los signos de puntuación" (Prieto, "Introducción", Obra completa de Juan L. Ortiz, 123). Pero además Prieto explica que a diferencia del rechazo que postuló la vanguardia hacia el aspecto musical del lenguaje, "lo que en la década del '60 quería seguir siendo vanguardia [...] empezaba a entender que sólo era posible escribir una obra enteramente nueva no desechando los principios modernistas, sino incorporándolos" (123). Miguel Dalmaroni, en "El grafismo visible de la voz de lo real. La lección del poema en Juan José Saer", también problematiza los diálogos entre Saer y el modernismo, deteniéndose esta vez en una certidumbre que comparten ambas poéticas: "Saer construyó sus relatos porque creía que lo poético era el punto donde el arte literario hace un real" (81), una convicción modernista que permite observar cómo en su obra se articulan la prosa narrativa y el ritmo y cómo también la narración se distancia de la función vicaria de representar para habitar un territorio propio.

${ }^{40}$ Estos tres poemas permanecerán inéditos hasta la publicación de los Borradores inéditos. El primero se titula, como se dijo, "A Rubén Darío" y el segundo no tiene título ni fecha. Sergio Delgado explica que tomaron como criterio de edición publicar juntos ambos poemas porque su escritura está relacionada. En el primer poema está escrito y tachado el primer verso del segundo poema: "Cuando nevó en París yo estaba lo más bien", como si se tratara de una idea que Saer dejara en suspenso para explorarla más tarde en un segundo texto. "Martes nublado" fue escrito en una hoja suelta y fechado por Saer en 1968. Fue incluido en Papeles de trabajo II.
} 
Marqués de Bradomín. En el poema dariano, el poeta saluda al Marqués a su regreso de un "Versalles doliente", le confiesa haber pensado en él y advierte la decadencia de la ciudad, que ya no canta con la música de Verlaine: "Había mucho frío y erraba vulgar gente./ El chorro de agua de Verlaine estaba mudo [...] Versalles otoñal; una paloma; un lindo/ mármol; un vulgo errante, municipal y espeso;/ anteriores lecturas de tus sutiles prosas" (Darío, Cantos de vida y esperanza 121). ${ }^{41}$ Saer no sólo toma dos versos de Darío ("había mucho frío y erraba vulgar gente" y "El chorro de agua de Verlaine estaba mudo") sino la situación misma del poema, en el que un poeta camina por París evocando "las sutiles prosas" de otro escritor. Será aquí el yo lírico el que piense en Darío al regresar del Louvre: "Iba hacia el Louvre y al cruzar un puente,/ pensé en usted. Me entristecí, Rubén" (Saer, Poemas 156). Constata: "Estaba mudo el chorro de Verlaine/ Ninguna música en ninguna fuente" (156). Sin embargo, si el París de Darío está atravesado de un vulgo espeso y municipal, el de Saer parece ser un espacio vacío, el sujeto está solo. En distintos tiempos y en distintos planos, Saer y Darío se cruzan por París, van y vienen hacia los lugares prestigiosos de la cultura -Versalles y el Louvre--, pero el recorrido urbano no se traduce en una flânerie entusiasta por el espacio sino en un repliegue que los lleva a invocar a otras figuras literarias y a constatar un relativo silencio poético, figurado en el silencio de Verlaine, representante de la musicalidad de la poesía ("la musique avant toute chose") que Darío había traducido al español como "harmonía verbal". 42

"Martes nublado", un poema que también escribe el año en que llega a Francia, reitera elementos anteriores: por un lado y a modo de epígrafe, se retoma el verso de Darío: "El chorro de agua de Verlaine estaba mudo", y se despliega, ahora de un modo más extendido, la cartografía urbana de París. La percepción auditiva del sujeto lírico registra el silencio de los Campos Elíseos, el del Café de la Paz, el rumor del Metropolitano y el golpe de los cuchillos en el mercado de la calle Moufetard. Más

\footnotetext{
${ }^{41}$ Rubén Darío publica Cantos de vida y esperanza en 1905. Colombi señala que el poemario puede leerse en relación a la reconciliación con las raíces culturales hispánicas, nueva orientación que asumen algunos escritores modernistas tras la guerra de Cuba y la política panamericanista de los Estados Unidos. Para este momento, el desencanto de París estaba consumado para Darío, quien se había mudado a Madrid en 1899 y había conocido ese mismo año a Ramón del Valle Inclán.

${ }^{42}$ En la "Introducción" a la Obra completa de Juan L. Ortiz, Martín Prieto apunta precisamente que los vanguardistas latinoamericanos habían rechazado ese precepto verlainiano encarnado en la figura de Darío y los modernistas. Como se dijo, su hipótesis es que Juan L. Ortiz y Saer recuperan esa musicalidad. En este sentido, entonces, será importante pensar en la dimensión del "canto" que reaparece con frecuencia como una de las preocupaciones de su poesía.
} 
adelante, el mismo sujeto adopta la mirada en altura para recortar paisajes típicos de la ciudad: "Uno ve el Sena verde relumbrar desde el elevado; [...] paseando por los jardines del Louvre/ se puede ver, desde el arco de Napoleón/ que el obelisco de la Plaza de la Concordia viene a dar justo en la mitad del Arco del Triunfo" (Saer, Papeles II 19). Sin embargo, ese escenario escandido por los monumentos de la cultura y organizado racionalmente emerge silencioso y el poema lo somete a un proceso de borramiento y desencanto: "Locura:/ han preparado un mundo en el que no suena una sola voz. Cuando se hace de noche, la niebla borra/ los árboles, empasta las luces,/ y me paseo por las calles desiertas cantando/ en voz alta [...]/ la ilusión de los años dorados hecha polvo color de <planeta>" (Saer, Papeles II 19-20). El silencio que se anuncia desde el epígrafe y se reitera sucesivas veces termina cediendo a la voz del sujeto que puede entonar un canto en la ciudad desierta y nocturna.

Resulta interesante, en este sentido, contraponer a este fragmentario testimonio poético de Saer sobre París, el comentario que otros artistas argentinos realizaron sobre su experiencia en la ciudad de la época. Entre fines de los cincuenta y principios de los setenta, una gran cantidad de pintores, músicos, escritores y cineastas vivieron en la Ciudad Luz. Jorge Fondebrider recopila algunos de estos testimonios -diseminados en cartas, libros y fragmentos literarios- en La París de los argentinos. Frente a la ciudad desierta y silenciosa que Saer dice recorrer, muchos de estos comentarios expresan su agitada vida artística y cosmopolita, llena de turistas, estudiantes y artistas, rebozante de experiencias culturales y espectáculos. Alejandra Pizarnik, por ejemplo, que vivió en París desde 1960 a 1964, le confiesa en una carta al poeta Antonio Requeni su fascinación parisina: “¿Qué puedo decirte de París que ya no sepas? Estoy enamorada de esta ciudad y de las callecitas que dicen, que cantan. No hago más que caminar y ver y aprender a ver; he conocido a algunos jóvenes poetas y pintores franceses" (Pizarnik en Fondebrider 256, las cursivas me pertenecen). Unos años más tarde, en 1966, llega el mítico editor José Luis Mangieri, creador de La Rosa blindada y Libros de Tierra Firme, quien señala: "París ya en ese entonces, era una ciudad inmensamente rica. Estaba llena de estudiantes de todas partes y había muchos hippies" (267). Las calles que cantan y le hablan a Pizarnik, inmensamente ricas y pobladas de atractivos, contrastan con el paisaje urbano desierto "en el que no canta una sola voz" del poema de Saer.

Los tres poemas dedicados a Darío coinciden en la misma representación de París: aunque el sujeto poético visite las principales atracciones turísticas y cumpla con 
los paseos del recién llegado, reconoce que se desplaza por una ciudad desierta y silenciosa que se repliega en lo onírico o se descompone en las ciudades literarias que se forjan entre Verlaine, Darío y Valle Inclán. París es, en todo caso, un laberinto en el que se sigue la huella de un poeta muerto. En “A Rubén Darío” el sujeto lírico le confiesa a Darío: "El deseo, ante un hombre como usted,/ es rehacer su vida paso a paso/ desde el nacimiento hasta la muerte/ para encontrar - dónde- la semilla que germinó toda su claridad" (155); y también, en el segundo poema, un par de versos que luego Saer decidió tachar: "No había nadie. Estaba solo y quise/ saber quién es usted, quién había sido" (156). La pregunta, dos veces formulada, es una interrogación que excede -pero incluye- lo biográfico y apunta hacia el misterio de la escritura poética. ${ }^{43}$ Como se verá más adelante, otros poemas posteriores comenzarán a responder a estos interrogantes.

Rubén Darío visitó por primera vez París en 1893 y conoció allí a Verlaine. Luego, entre 1899 y 1905 viajó por diferentes ciudades europeas como cronista corresponsal del diario La Nación. En 1900 cubrió la Exposición Universal, a propósito de la cual escribió numerosas crónicas publicadas luego en Peregrinaciones. Su segunda estancia parisina se prolongará, interrumpida por numerosos viajes y temporales residencias en otras partes de Europa y América, hasta 1914. París forma parte de los sueños de su infancia y profesa hacia la ciudad un arrobamiento religioso: "París era para mí como un paraíso en donde se respirase la esencia de la felicidad sobre la tierra. Era la Ciudad del Arte, de la Belleza y de la Gloria; y, sobre todo, era la capital del Amor, el reino del Ensueño" (Darío, Autobiografía 40).

Colombi señala que París es la "meca literaria" a la que se desplazan masivamente, entre 1900 y la Primera Guerra Mundial, artistas y escritores hispanoamericanos. ${ }^{44}$ Constituirá para muchos una ocasión de formación y notoriedad en el campo cultural de origen y un espacio privilegiado para consolidar o transformar la imagen de escritor. Sin embargo, será también un espacio de simulacros y

${ }^{43}$ En Zona Saer, Sarlo apunta que estos poemas inéditos dedicados a Darío constituyen otra elección "marginal" de Saer. La primera había sido la predilección local por un poeta desconocido como Juan L. Ortiz, resistente a la poética coloquialista de los sesenta. La admiración profesada por Darío, cuando a excepción de los profesores, nadie hablaba de él, y el modernismo era un tema ausente, una reminiscencia en tránsito de ser olvidada en Buenos Aires, era inusual, "[no] parecía posible que un escritor de treinta años, como Saer, lo evocara de manera intensamente subjetiva (sincera, si la palabra fuera menos insólita cuando hablamos de literatura)" (50). Interesa particularmente esta idea de Sarlo porque enfatiza el doble carácter de esta reescritura de Saer, subjetiva y marginal, es decir, los modos en que dos vidas y dos trayectorias de escritura dialogan desde una posición voluntariamente excéntrica y a la vez, central, en la literatura latinoamericana.

${ }^{44}$ Cfr. Colombi, Beatriz. "Camino a la meca: escritores hispanoamericanos (1900-1920)". 
espejismos, que deparará para otros el anonimato, el fracaso, la locura y el suicidio. En "Parisiana. Viaje y neurosis", Colombi analizará de qué manera la experiencia gozosa de la ciudad y la "parisiana", esa representación estereotipada de París que habían fraguado los escritores hispanoamericanos, se irán descomponiendo en versiones más perturbadoras y más pesimistas de la vida en la urbe. El viaje de Sarmiento señalaría el comienzo de ese desencanto del viajero, que será continuado por varios escritores hispanoamericanos que sufrirán en varias ocasiones la sensación de ser permanentes extranjeros y desconocidos en París. ${ }^{45}$ Darío interpondrá la distancia y registrará, junto a otros intelectuales, el progresivo deterioro de la ciudad, socavando su prestigio estético que ahora encuentran subsumido en un mundo aburguesado y de creciente mercantilización en el que el arte se vuelve complaciente. París deja de ser el bosque de secretas analogías y aparece como una atracción malsana, como una patología: "fiebre cerebral", "neurosis", "vicio", "locura" y "embriaguez". Entre el rotundo fracaso de París (representado en Julián del Casal, Augusto de Armas y Horacio Quiroga) y la asimilación de Gómez Carrillo, "se encuentran los refractarios como Darío" (Colombi, Viaje intelectual 189). Saer se incorpora en esa serie de escritores que reescriben la "parisiana" y advierten sobre la desilusión y el anonimato que les depara la gran ciudad. Darío responde a ese desencanto a través de una representación de la ciudad articulada en la desilusión o bien replegándose sobre su yo (Cfr. "Epístola a la señora de Lugones”). Saer recupera esa vía refractaria y la extrema: allí donde Darío podía

${ }^{45}$ En su Viaje a Francia Sarmiento escribe: "Las costas de Francia se diseñaron al fin en el lejano horizonte. Saludábanlas todos con alborozo, las saludaba también yo, sintiéndome apocado y medroso [...]. Saltábame el corazón al acercarnos a tierra, y mis manos recorrían sin meditación los botones del vestido, $[\ldots]$ como cuando el enamorado novel va a presentarse ante las damas" (27) y cuando la embarcación atraca por fin en los canales, "una turba de criados" los asalta para ofrecerles alojamiento: “ $E$ Eh! ¡la Europa! ¡triste mezcla de grandeza y de abyección, de saber y de embrutecimiento [...] opulencia y vida salvaje!” (27). El vapor luego irá desde El Havre a Ruán. El primer encuentro entre Sarmiento y Francia se construye a partir de una doble retórica religiosa y amorosa (que pasa del embelesamiento a cierta desilusión) y el escritor recomienda ingresar a la capital haciendo este recorrido, porque allí puede reconstruirse la historia del país: "los señores normandos y los ingleses, las tradiciones y las batallas, la Edad Media con sus conventos, sus agujas y sus castillos" (38). Sin embargo, una vez en Ruán, se desespera por llegar a París: "Quiero despedirme de Ruán, tengo tomado asiento en el ferrocarril y me estoy comiendo por verme lanzado en aquel torbellino de fuego, de humo y de ruedas que se traga las leguas en un santiamén" (46). En París Sarmiento aprende las artes de la flânerie, reconoce la benevolencia parisina hacia los extranjeros, se siente "dueño" de museos, galerías, palacios y monumentos, visita grandes personajes y asiste a espectáculos populares en los bailes y el hipódromo. Sin embargo, como advierte Colombi, París será fundamentalmente un enigma que Sarmiento intentará conjurar de varias maneras aunque su viaje termine inaugurando el "desencanto del viajero", un tópico romántico a partir del cual el intelectual leerá una doble restauración política, de la monarquía en Francia y del despotismo rosista en América. 
refugiarse, encontrar reconocimiento y cumplir funciones religadoras dentro de la colonia de artistas y escritores hispanoamericanos que formaban una especie de ghetto contra el anonimato y la indiferencia de París, ${ }^{46}$ Saer se autofigura, casi sin excepciones, como un escritor que está solo. ${ }^{47}$

Una red de poemas que escribe entre 1968 y 1971 comienzan a responder a ese deseo inicial de "conocer" a Darío y le dan forma a las primeras reflexiones e inquietudes del escritor en el extranjero, desarticulando, de paso, los tópicos del intelectual y del poeta de provincia que busca reactualizar su propia parisiana. "Rubén en Santiago" es la punta visible -el texto que Saer elige publicar en El arte de narrarde esa red. Una trama poética que podría componerse en principio de los tres poemas analizados anteriormente e incorporar además las siguientes poesías no publicadas en vida de Saer: "Primera estación” (1969), "Elegía Pichón Garay" y "Elegía Michel

46 Retomo aquí las reflexiones de Zanetti y Colombi, desarrolladas por extenso en dos iluminadores artículos que condensan gran parte de las problemáticas de los escritores modernistas en París y contribuyen a pensar la figuración de Darío. Cfr. Zanetti, Susana. "El modernismo y el intelectual como artista: Rubén Darío" y Colombi, Beatriz. "Camino a la meca: escritores hispanoamericanos en París (1900-1920)" ambos en Altamirano, Carlos (dir.). Historia de los intelectuales en América Latina.

${ }^{47}$ Vale aclarar que Saer sí mantuvo vínculo con poetas rioplatenses, como César Fernández Moreno, al que conoció hacia 1968 o 1969. En un soneto sin título incluido en Poemas. Borradores 3, se puede leer una pequeña escena de correspondencia poética entre ambos escritores, que a través de dos sonetos pactan una cena con sus respectivas mujeres. A través de Fernández Moreno, como se verá más adelante, Saer también conoce al escritor Roger Caillois, de quien hablará en El río sin orillas. También coincidió con Noé Jitrik, quien recuerda en la semblanza dedicada a Saer sus encuentros en Francia: "un par de años después apareció en Besançon, donde había desembarcado con una beca para estudiar francés y resulta que nosotros estábamos instalados allí, gracias a las benéficas medidas tomados por el efímero general Onganía. En ese momento empezaron a tomar forma nuestras relaciones, salidas de descubrimientos, conversaciones, viajes y, sobre todo, la aproximación a lo que iba siendo su obra" (citado en Prieto y Constantin, Catálogo Conexión Saer 10).

En Zona Saer, Sarlo señala que Saer no se incorpora a la colonia de escritores latinoamericanos consagrados. Podría argumentarse que lo que sí intenta hacer es favorecer el desplazamiento de su propia comunidad intelectual y afectiva que había dejado en la zona. Según señala Sarlo, su amigo Adolfo Prieto se mudó junto a su familia durante un año, desde octubre de 1970 a octubre de 1971 para trabajar un tiempo como profesor de la universidad en Besançon y al menos tres veces visitaron París. Saer intentó interceder vía César F. Moreno para que prolongaran su estadía un año más, pero los Prieto regresaron finalmente a Rosario. También Raúl Beceyro y Marilyn Contardi, santafesinos profesores en Rennes, fueron parte de su grupo de amigos. Incluso cuando Saer ya esté asentado como profesor y escritor, seguirá afirmando esta relativa soledad. En una entrevista realizada por Carlos Dámaso Martínez en 1981, ante la pregunta "¿Cuál es su inserción durante estos últimos diez años en la cultura francesa?", declara: "Sigo muy poco la vida literaria aquí, casi no tengo contactos, no conozco a ningún escritor francés. Mi integración se da en el plano laboral, pues doy clases de literatura en la Universidad de Rennes, pero eso no tiene nada que ver con mi trabajo de escritor. Mantengo, eso sí, relaciones con mi editor. Aquí se traducen a muchos escritores latinoamericanos" (AA.VV., Una forma más real 20). 
Barón” (ambos de 1971). Como se verá, esta última establece algunas relaciones con “Akinari Monogatari”, texto que sí fue publicado en El arte de narrar.

Seguimos en varias de estas poesías las aventuras europeas de Pichón Garay, ${ }^{48}$ el personaje que abandona la zona en "A medio borrar" y cuyas peripecias dibujan espectralmente algunos de los desplazamientos, regresos, reflexiones y actividades del propio Saer (entre los Borradores inéditos encontramos, por ejemplo, a Pichón Garay en Princeton). Las expectativas, miedos, ansiedades y recorridos de este personaje resultan significativos porque contribuyen a diseñar un tipo de escritor y profesor universitario que exhibe las marcas de su desarraigo y la inestabilidad de su configuración sobre la base de ciertas elecciones, rechazos y principalmente proyecciones en otros escritores -un cuentista japonés, Ueda Akinari; un dramaturgo francés, Michel Baron-, entre los que resaltará, como se anticipó, la figura de Darío.

Efectivamente, las elegías despliegan la historia de un sujeto exiliado de su infancia, de su casa y de su lengua que atraviesa un período de incertidumbre y perplejidad: "Desprovisto, ya, de su infancia, sucio después de tantos viajes,/ ninguna palabra le servía, se le atascaban en la garganta" (Saer, "Elegía Pichón Garay", Poemas 175). La inestabilidad de ese sujeto, que no termina de acomodarse al funcionamiento de la urbe moderna ("Tentado como estaba/ por las ciudades modernas, los grandes temas de conversación"), se exacerba en la reiterada mutación de la voz enunciadora: "Empezando,/ canto, en tercera persona, para venir a terminar, gritando, como esas otras ramas del mismo árbol de oro creciente/ [e inmortal/ a las que llamo/ con desdén/ mis enemigos literarios" (176)

En ambas, los dilemas del escritor y la interrogación por la poesía se responden a partir de metáforas alimenticias que ofrecen la lengua poética como resto o residuo. En "Elegía Pichón Garay" leemos: "qué es, me pregunto, la poesía, sino este trago de cognac/ que el perro del recuerdo, después de habernos buscadomucho, nos da a tomar en medio de una noche polar, el vómito/ que nos devuelve la salud después de la borrachera?" (176); y así también en "Elegía Michel Baron": "La poesía consiste en devorar el amor, el tiempo, encontrarse, de golpe/ [una mañana,/ la vida y la muerte tirados sobre la mesa/ como los restos de una comida que nadie, después de una noche/ [larga, levantó” (134).

\footnotetext{
${ }^{48}$ Llamado explícitamente "Pichón Garay" en "Elegía Pichón Garay" y en "Rubén en Santiago" y no nombrado en "Elegía Michel Barón" pero cuya figuración es bastante cercana a la que Saer imagina para este personaje en París, como profesor universitario y escritor.
} 
En febrero de 1969 Saer escribe "Primera estación", un poema narrativo que condensa la vida de Pichón Garay en París:

He eliminado muchos peligros, el peligro de ahogarme en el Sena

el de recibir una piedra en plena cara en el Luxemburgo,

el de escuchar la voz del demonio, a media noche, en la rue

[Vaugirard.

Me he vuelto un hombre intachable que vuelve a su país a la

[edad de Cristo.[...]

y he aquí un hombre formal, que fuma en pipa,

tiene una amante en París y escribe ensayos literarios (165).

Pichón Garay se está despidiendo de su amante parisina, Virginia, un personaje desconocido que no volverá a aparecer. El poema menciona el cuadro de Van Gogh que cuelga en el cuarto de Tomatis en "La mayor": “"El campo del trigo de los cuervos', mancha azul y amarilla./ Hay por lo menos otra pared en este mundo que divide ese [cuadro./ ¿Hay, por lo menos, otra pared en este mundo que divide ese [cuadro?” (Saer, Poemas 164). Todo parece despertar referencias literarias y pictóricas: el hecho de que Pichón fume pipa y que mencione la rue Vaugirard (en la que se soñó a Darío con Verlaine), la referencia de un ahogado en el Sena (que podría aludir irónicamente a la ambigua desaparición de la Maga en Rayuela) y la atmósfera bohemia que evoca Van Gogh, no sólo por la mención de uno de sus cuadros, sino también porque Pichón fuma pipa, y el cuarto vagamente recuerda la pintura "El dormitorio de Arlés": "Por la ventana alta y angosta se ven las luces de la ciudad,/ [cuando Pichón se levanta./ Los dos cuerpos desnudos están parados junto a la silla de paja" (Saer, Poemas 165). De este modo, el poema se constituye como una alusión paródica del viaje de escritor latinoamericano. ${ }^{49}$ La no publicación de "Primera estación" retendrá a Pichón en Francia y postergará para siempre el regreso definitivo del personaje a la zona.

\footnotetext{
${ }^{49}$ Los aprendizajes, fracasos y desvíos del viaje literario de Pichón Garay ya pueden rastrearse en otro personaje, el misterioso escritor Higinio Gómez, que ha partido en 1933 a París y Londres y ha regresado antes del estallido de la Segunda Guerra Mundial a Buenos Aires, y finalmente alrededor de los años sesenta ha vuelto a la ciudad, para suicidarse en una pieza de hotel unos años más tarde. Resulta significativo que los dos textos que trazan las principales coordenadas de su vida y de su trayectoria intelectual "Biografía de Higinio Gómez" y "Fin de Higinio Gómez" se incorporen en obras que también giran alrededor de los primeros años de Saer en París: los Argumentos de La mayor (escritos entre 1969 y 1976) y los primeros poemas de El arte de narrar (de 1960 a 1975). El resultado de su pasaje por el extranjero desarticula el éxito asociado al viaje. Por el relato que hace Tomatis de los papeles del escritor ya muerto sabemos que ha dejado poemas narrativos, unos aforismos escritos en lápiz; y como traductor, fragmentos y esbozos de traducciones sin terminar, y que casi nadie lo conoce en el ámbito local. Como ha advertido Mirta Stern en "El espacio intertextual en la narrativa de Juan José
} 


\section{"Rápidas visiones para ojos de poeta": el viaje en tren}

La ecuación para todo relato de viaje, advierte Colombi en "El viaje: de la práctica al género", sería "el que viaja es el que narra", pacto que Saer reescribe en varias de estas poesías: "el que viaja es el que lee, recuerda y compone”. Efectivamente, después del errabundeo solitario por las calles de París y la dificultad para hallar la escritura poética, los derroteros de Pichón Garay se abren hacia Bretaña, Oslo y fundamentalmente hacia otros viajes literarios.

"Rubén en Santiago" yuxtapone, como ha señalado la crítica, los viajes de Pichón Garay en Francia y de Rubén Darío desde Valparaíso a Santiago de Chile. El viaje, como en los poemas anteriores, comienza una vez que se ha cerrado "la flor de la infancia”. El poema glosa poéticamente algunos fragmentos de la autobiografía de Rubén Darío e intercala reflexiones sobre el viaje que, podemos suponer, no son privativas de Darío y que Saer reformulará más tarde en ensayos y entrevistas sobre su propia experiencia: el viaje permite atisbar el verdadero tamaño del mundo; se percibe así el ritmo con el que se abre y cierra "la prisión de la ciudades"; el viaje supone, por último, perderlo todo en el fondo del mar y empezar de cero, metáfora que Saer retomará más adelante. El poema intenta responder a ese interrogante abierto en 1969 sobre la vida de Darío y despliega una serie de imágenes sobre su figura: la del genio, la de la puta decrépita que pasean de país en país, la del chico engreído, la del poeta trabajador encarnizado, la del amanuense. Saer se pregunta qué le hacen el viaje y el medio literario de las grandes capitales a la lengua, al cuerpo y a la escritura de Darío. Sin embargo, "eso" que Saer quería indagar -“dónde la semilla que germinó toda su claridad" (“A Rubén Darío", Poemas 155)- no puede responderse por la vía biográfica y lo que emerge es la alternativa refractaria que Saer le impone siempre al intimismo, un repliegue, como veremos, muy witoldiano: lo que él (¿Darío/Saer/Pichón Garay?)

Saer: instancia productiva, referente y campo de teorización de la escritura", la figura de Higinio Gómez "sirve para recrear, indirectamente, una variante nacional de cierto tipo de escritor, así como el sistema de relaciones sociales y literarias que lo definen -la lección del padre, que le enseña a montar 'para que se haga hombre'; el viaje a Europa, rito de iniciación obligatorio; el bautismo intelectual, consumado en Francia, a través de las discusiones con 'Breton y los tipos de su gavilla' o de 'las clases de Paul Valery en el College de France' " (978). Stern identifica por un lado la presencia de Cesare Pavese en la escena de suicidio que se narra en el poema "El fin de Higinio Gómez", pero también la soterrada referencia a Güiraldes y su Don Segundo Sombra, una "bifocalidad" que suele presidir siempre en la intertextualidad saeriana. 
quería, "ningún/ deseo, ningún equilibrio, ninguna predestinación/ y únicamente la mano decrépita,/ deslizándose de izquierda a derecha y sembrando/ [...] unos signos incomprensibles/ en los que otros dicen oír/ el canto de las estrellas" (Saer, El arte de narrar 72).

El tren es el dispositivo que permite el intercambio de sujetos viajeros y da a ver un paisaje que se pierde a la distancia. De la Gare de Montparnasse a la Bretaña se desliza en altura y rápidamente por un escenario borrado por la lluvia. En Autobiografía, Darío señala sobre el viaje en tren a Santiago: "Por el camino no fueron sino rápidas visiones para ojos de poeta, y he aquí la capital chilena" (50). De esta manera transmite el poeta su experiencia de viaje, elidiendo los paisajes que vio a través de la ventanilla. En cambio, privilegia la agitación sonora que produce la llegada del tren a la estación, que será también el modo en el que Saer reescriba este fragmento de su biografía: "algún ruido metálico lleno de ecos o el chirriar de las ruedas/ pulidas de alguna vagoneta de carga/ sobre el andén atravesado de pasos" (Saer, "Rubén en Santiago", El arte de narrar 69).

"Pichón Garay viaja leyendo una autobiografía de Rubén Darío" iba a ser el nombre original que figura en el manuscrito del poema, fechado en 1970. La lectura tiene un efecto performativo sobre el viajar y transforma el paisaje efectivamente recorrido fundiéndolo con las visiones del paisaje leído. Así ocurre también en "Elegía Michel Barón”, donde el paisaje de la Bretaña que el personaje mira por la ventanilla del tren se transforma en el paisaje oriental del imaginario que despierta Ueda Akinari, un escritor japonés al que Saer le dedicará un poema en El arte de narrar: "50 "Las cosas, mom vié, están todas hechas de piedra: permanecen./ Y esta tarde, volviendo en el tren (Akinari Monogatari)/ me descubrí pensando: si yo estuviera muerto/ seguirían corriendo para atrás, de hierro, los ciruelos, desde la/ [ventanilla” (134).

Pero además, el viaje en tren guardará una relación productiva con la escritura y ofrecerá la oportunidad de capturar una imagen que pueda convertirse en materia poética: "y había visto, sin embargo, desde el tren,/ dos niños jugando en la nieve, vestidos de azul, dándose vuelta/ cuando su madre, desde una ventana de la casa, [...]

\footnotetext{
${ }^{50}$ Por su parte, el poema "Akinari Monogatari" publicado en El arte de narrar es uno de los pliegues que se abre a partir de "Elegía Michel Barón" y que vuelve a proyectar a un sujeto escritor, profesor y viajero. El poema, dividido en dos partes, "El deshielo" y "El invierno" retoma los viajes y las enseñanzas de Akinari, un literato de mediana edad que "viajaba entre dos ciudades/para enseñar/ la doctrina del imperio/ a unos jóvenes/ [...] Y de regreso/ $\mathrm{Y}$ era en el mes del deshielo/ de una ciudad a la otra/ iban los ojos de Akinari/ fijos en el camino/ y no veían sin embargo golpear la lluvia contra los grandes/ [árboles" (74).
} 
los llamaba" ("Elegía Pichón Garay" 175). La voz del poema sugiere que esa imagen quedará grabada como una cicatriz junto a otros recuerdos que conformarán "la experiencia" del sujeto y a partir de la cual podrá escribir, una tarea nada sencilla: “También a mí me saldrán esas odas que cantan como soles en/ [el aire de nuestros años./ No tengo más que recuperar mi simplicidad'. Echar por la borda/ lecturas y tics, temores" (176).

Saer parece retomar la lección dariana: "rápidas visiones para ojos de poeta". El tren será mucho más que un medio de desplazamiento entre dos ciudades y mucho más también que un dispositivo óptico que revela un paisaje: se constituye como un espacio de lectura -Pichón Garay lee la biografía de Rubén Darío y evoca la lectura de Akinari-, y de futura escritura, pero también proyecta la subjetividad del sujeto lírico -las vías del tren son como la infancia; él es como un tren en movimiento que se desplaza entre dos continentes llevando a cuesta a sus muertos- ${ }^{-}$. El tren es un espacio privilegiado del intercambio entre paisaje, literatura y subjetividad, ${ }^{51}$ y le permite al viajero multiplicarse en una gran red de otros sujetos escritores viajeros. ${ }^{52}$

\section{Una correspondencia diferida: "Vecindades de Char"}

De las múltiples relaciones que Saer estableció con el modernismo y particularmente con la figura de Rubén Darío, retomando tanto la lección musical de su poesía como parte del imaginario visual y pictoricista del movimiento ${ }^{53}$ interesa indagar ahora en ciertas operaciones de autofiguración y repliegue que Saer parece compartir con Darío en dos momentos particularmente álgidos y polémicos para la construcción de la figura del artista y del intelectual como fueron el modernismo y los sesenta.

\footnotetext{
${ }^{51}$ Esta posibilidad del intercambio también funciona para la experiencia biográfica del viaje en tren que Saer evoca en El río sin orillas. Allí se narra que al menos una vez por semana el escritor atravesaba la llanura de la Beauce para ir a trabajar a Rennes. Aquí la experiencia es la de un sujeto que interrumpe su lectura cuando se aproxima al paisaje de la llanura, para capturar con atención la mayor cantidad de sus detalles y advertir que su inclinación a este paisaje se debe a la ilusión de identidad casi perfecta que guarda con la llanura argentina.

${ }^{52}$ Como señala Berg en "Juan José Saer: una música imborrable", en El arte de narrar se despliega un sujeto de enunciación itinerante que se dispersa y se desplaza en una pluralidad de figuras, voces y roles: narrador o cuasi historiador, coleccionista o viajero. Lo mismo podría afirmarse de estos poemas que constituyen el gran borrador del poemario.

${ }^{53}$ Estos vínculos fueron abordados en " 'Paisaje pensativo' y 'paisaje intolerable' en Nadie nada nunca de Juan José Saer", ponencia presentada en el III Encuentro de jóvenes investigadores en arte. Saer no solo pareciera recuperar el aspecto musical del movimiento sino también algunas de sus preferencias visuales y sus materiales privilegiados -el bronce, el acero, la plata-. En Nadie nada nunca, Saer retoma la 'transposición de arte' practicada por el modernismo, principalmente los contactos entre la pintura, la escultura, la música y la literatura.
} 
Por un lado, en "Rubén Darío y las reglas del arte americano", Mónica Bernabé analiza cómo Darío piensa en las nuevas figuras de artista a través de su idea de "raro": "La conciencia del escritor moderno se expresa, [...] a través de la progresiva formulación de una imagen de artista diferente a la del letrado. En este sentido, la serie de retratos de artistas que Darío comienza a publicar en la década del 90 en La Nación viene a aportar a esa nueva comunidad" (41). Se trata, como explica Rama en "El poeta frente a la modernidad", de un momento de inminencia donde las viejas prácticas letradas conviven con lo nuevo, y donde la profesionalización exige de los escritores un alto grado de conciencia y de percepción sobre los rumbos que tomaría la cultura, una pregunta que resuena en los reiterados intentos de Saer por comprender los caminos de la evolución narrativa que desarrolla en muchos de sus ensayos.

En términos de trayectorias vitales y literarias, Saer parece seguir algunos de los pasos de Darío: como él, es un poeta-niño que muy tempranamente empieza a escribir o mejor, como el poeta nicaragüense, es un "intérprete" que imita todas las músicas poéticas que tiene a su alcance. En el caso de Saer, imita precisamente a Rubén Darío y a cuanto escritor en lengua castellana se le cruzara entre los 13 y los 15 años, ${ }^{54}$ como él mismo lo indica en una entrevista, "sin conciencia poética", como algo gestual. Cuando ambos dejan su patria siendo aún relativamente jóvenes -a la edad de 19 años en el caso de Darío, a los 31 años en el caso de Saer- se despiden también de su infancia y juventud y del primer aprendizaje poético - central para el caso de Saer-. Como señala Bernabé: "Aristocracia del talento y falta de dinero van de la mano en la conformación de la imagen del intelectual que sobrevuela en el libro [Los raros]" (43), una dupla que resuena en la autofiguración que construye Saer sobre los años que rondaron su partida a Europa. En la entrevista realizada por Alberto Perrone en 1976 Saer señala que se fue del país también por causas económicas:

Me desprendí de una realidad que me afectaba negativamente. Por razones económicas estaba literalmente aplastado. Cuando trabajaba como profesor universitario ganaba 68 mil pesos viejos. Debía ayudarme con otras cosas. Vendí libros de una editorial española. [...]. Pero, como ves, no tenía ánimo para escribir y al mismo tiempo sentir la incertidumbre de no cubrir las necesidades mínimas

\footnotetext{
${ }^{54}$ En la entrevista con Graciela Esperanza, Saer distingue tipos de escritores: aquellos que nos gusta leer y aquellos que incitan a escribir: "Probablemente incitan a escribir porque esos mundos propios se incorporan a la imaginación de determinados lectores y producen un fuerte en su vida emocional. Son aquellos escritores a los cuales uno adhiere hasta en sus defectos. Faulkner, Borges, Joyce, Neruda, Vallejo y tantos otros. Darío cuando yo tenía trece años o Fernández Moreno cuando tenía quince" (Una forma más real 96).
} 
para subsistir. También llegué a trabajar como periodista en El Litoral de Santa $\mathrm{Fe}$, de donde tuve que irme por un cuento que se consideró non sancto. (Perrone, Una forma más real 12).

Pero además, Saer y Darío se asemejan en las formas refractarias con que se acercan a los escritores "faro" del momento en que arriban a París. En 1988, el escritor evoca su llegada a Francia en un breve texto compuesto a propósito de la muerte del poeta francés René Char, "Vecindades de Char", que no es sólo un homenaje a su poesía sino una rememoración de los primeros días de Saer en París. Allí cuenta que al llegar traía consigo una carta en la que Raúl Gustavo Aguirre, el traductor argentino de Char, saludaba al gran poeta. Saer, no obstante la oportunidad que tenía para conocerlo, nunca entregó la misiva: "ese saludo era al mismo tiempo una generosa carta de presentación, por timidez o discreción me abstuve de hacerle llegar a René Char ese saludo, que podía pasar como un pretexto para infiltrarme en sus inmediaciones" (Saer, Ensayos 134). Lo que sí hace Saer apenas arriba es comprarse Fureur et mystère, una antología que reúne una parte importante de los poemas de Char escritos entre 1938 y 1947 y advierte que su primera experiencia en Francia es inseparable de su poesía. Saer, como antes haría Darío, se niega a usar la carta como pase de presentación al círculo prestigioso de poetas e intelectuales de los que se rodeaba el poeta. ${ }^{55}$ En Zona Saer, Sarlo advierte que durante esos primeros años en París el escritor "no tenía agente literario ni una editorial que se preocupara por su obra, ni críticos reconocidos que escribieran sobre ella; no formaba parte activa de un campo ideológico-político internacional, ni hizo rápidamente nuevos amigos notables o famosos. [...] Saer renuncia a esa práctica de la sociabilidad literaria” (Sarlo, Zona Saer 18).

Saer, como también haría Darío, ${ }^{56}$ posterga el encuentro con el poeta consagrado aunque reconoce haber llevado durante años la carta en su bolsillo hasta perderla

\footnotetext{
${ }^{55}$ Efectivamente, como advierte Saer, la carta-saludo enviada por Raúl Gustavo Aguirre era un pretexto para que él pudiera insertarse en el medio literario francés. Aguirre y Char mantuvieron una fluida comunicación epistolar que podía prescindir absolutamente de Saer y a través de la cual Aguirre manifestó su constante admiración e identificación con los poemas del escritor francés, con quien estrechó una intensa amistad. Para el momento en el que Saer llega a Francia René Char era un escritor altamente reconocido, que había formado parte del prestigioso grupo surrealista -Breton, René Crevel, Louis Aragón-. Pero además, como señala Mario Ortiz, el poeta había participado activamente de la Resistencia contra la ocupación nazi junto a su amigo Albert Camus, lo que aumentaba aún más su legitimidad en la Francia de posguerra. Cfr. Ortiz, Mario. "El don valioso de sus poemas. Acerca de la correspondencia René Char / Raúl Gustavo Aguirre".

${ }^{56}$ En Viaje intelectual, Beatriz Colombi señala la recurrencia de algunos sitios de encuentros de los escritores hispanoamericanos durante el siglo XIX, textualizados en
} 
definitivamente. Sin embargo, la demora saeriana, a diferencia de la de Darío, se vuelve permanente y se "salda" poéticamente recién veinte años después. El texto homenaje "Vecindades de Char" deviene una conversación que Saer entabla con los muertos -Aguirre había fallecido unos años antes en 1983-: "Yo me permito transmitir hoy a René Char su saludo" (135). El Saer ya consagrado de fines de los ochenta puede, ahora sí, ser el intermediario entre el traductor y Char, aunque esa mediación ya no redunde en beneficios reales en términos de visibilidad y consagración en la escena literaria francesa. ${ }^{57}$

Susana Zanetti y Marcela Zanín advierten sobre la compleja figuración de artista que construye Darío, una autofiguración ambivalente que oscila entre la afirmación de una estética ácrata, que no reconoce antecedentes y rivaliza con sus pares contemporáneos, y una poética que encuentra a sus precursores en la antigua poesía indígena y también en algunos "padres" literarios que el propio Darío construye como tales, pero a partir de ciertas inversiones. Ambas autoras señalan la importancia de la figura de Verlaine y establecen las coordenadas de esa filiación. ${ }^{58}$

Como sostiene Zanetti en "Rubén Darío y el legado posible", en el cuento "Historia de un sobretodo", retomado en el poema de Saer "Rubén en Santiago", Darío cruza dos historias de iniciación literaria, la suya y la de Gómez Carrillo, quien ya ha

'cronotopos': el café, algunos bailes, la casa de prestigiosos editores. Advierte que uno de los protocolos de sociabilidad era el encuentro con los grandes escritores, algunos instalados en el café, como Verlaine. Sin embargo, no todos cumplieron inmediatamente ese mandato. Colombi explica que entre la asimilación parisina de Enrique Gómez Carrillo y el fracaso del 'poeta suicida' Augusto de Armas, Darío fue siempre un "refractario" que siguió considerándose un extranjero en París y no siguió al pie de la letra los protocolos de sociabilidad literaria, tuvo poco contacto con escritores franceses y solo después de cinco años de residencia entrevistó a Remy de Gourmont, el escritor faro del momento al cual todo cronista hispanoamericano debía conocer.

${ }^{57}$ Una operación similar registra Sarlo sobre el vínculo entre Saer y Borges. Su hipótesis es que tempranamente Saer debía "matar a Borges" para convertirse en escritor (y defender, sí, a Juan L. Ortiz y a Di Benedetto, que no ocupaban un lugar central en la literatura argentina) y para ello "lo olvida" desde muy joven, lo lee pero incorporándolo en un sistema de referencias no borgeanas, lo desplaza y escribe el margen desde otro "ethos". Recién hacia el final de su carrera puede enjuiciarlo políticamente, homenajearlo y "escribir como él". Así lo hace, señala Sarlo, en textos tardíos, como "La conferencia", (Lugar, 2000) en que se evoca "La flor de Coleridge" de los ensayos borgianos: "A los sesenta años Saer ya no necesita demostrar su independencia estética y formal. Puede, finalmente, escribir lo mismo porque ya ha establecido su diferencia respecto a Borges" (Sarlo, Zona Saer 38).

${ }^{58}$ En "El don de Verlaine", Marcela Zanín se interroga por los vínculos entre Darío y el poeta francés y señala que "la figura de Paul Verlaine es el emblema de la renovación poética contemporánea, es uno de los 'representantes' de la poesía del fin del siglo XIX. Una figura faro que con sus rasgos ilumina la vida de artista que Darío se imagina, para sí y para los otros. Una figura, en suma, transformada en precursora por la ficción dariana" (Zanín 41). 
triunfado en París como cronista y poeta. Ambas historias se desarrollan a partir del periplo de un ulster que Darío paga con la mitad de su salario para abrigarse en el invierno de Valparaíso. El sobretodo pasa luego a manos de Gómez Carrillo y finalmente termina abrigando a Paul Verlaine. Invirtiendo el padrinazgo literario, el joven y pobre escritor americano abriga paternalmente al excéntrico poeta faro del simbolismo. Zanín, en el artículo mencionado, entiende los vínculos entre Darío y Verlaine en términos de "don", cuando el sobretodo y la palabra poética son intercambiados por ambos poetas. Sin embargo, y aquí interesa detenerse para analizar el caso de Saer, Darío escribe dos textos en relación con la muerte de Verlaine, el retrato que se incluye en Los Raros y el poema "Responso", de Prosas profanas. En un principio Darío escribirá "Vayan, pues estas líneas, como ofrenda del momento" (48), como si se tratara de una carta que Verlaine pudiera responder. En el poema "Responso" efectivamente evoca al muerto. Zanin explica cómo el poema hace salir a Verlaine de la muerte, convirtiéndolo en fantasma, en aparición, en imagen. Bajo el tono menor del "responso" Darío le rinde homenaje a Verlaine, y al hacerlo, sin desdecir al padre, se reapropia de su voz.

En "Rubén en Santiago", Saer retoma la biografía de Darío y dice “[...] (Un ligero/ deseo de no haber salido nunca de su casa, los bolsillos/ 1lenos de cartas de presentación). [...]" (69). Como explica Prieto y comentábamos más arriba, el poema pone en escena una yuxtaposición de viajes, el de Pichón Garay que va de París a Bretaña y el de Darío en Chile. Saer asume en este poema el desafío de medirse con Darío a través de una sutil red que se despliega entre sus biografías. Establece entonces sus primeros contactos con París proyectando su imagen sobre los grandes poetas del modernismo y de las vanguardias, ${ }^{59}$ y se ubica refractariamente en la ciudad de las luces. Como Darío, rehusará utilizar la posibilidad que le ofrece la carta de Aguirre pero aprovechará en cambio la poesía de Char. Como pudo observarse, la cartografía parisina que bosqueja Saer no responde tanto a una flânerie entusiasta y su experiencia de la ciudad se desprende de las lecturas poéticas que hace de sus precursores, también habitantes de París, y del entramado de linajes y reapropiaciones que traza Saer y que

\footnotetext{
${ }^{59}$ Por otro lado, Saer le escribe un poema a César Vallejo, "Gloria de Vallejo" (1968), en el que contrapone dos espacios, el espacio de la muerte en el que Vallejo puede vivir ahora "completo, múltiple", del espacio real "piedra envejecida", un mundo en el que reconoce que se ha golpeado ciegamente al poeta. En "Fernando Espino", la semblanza que le dedica al pintor, Saer se referirá a Vallejo como "un cholo peruano, que llamaba Bizancio a la casi aldea de Lima, y que terminó muriendo en París de hambre y de apatía, [...] uno de los más grandes poetas del idioma español" (Ensayos 195).
} 
pueden mejor comprenderse a la luz de las operaciones estratégicas que realizó Rubén Darío en relación a la tradición.

\subsection{París contemporáneo}

Como se anticipó, Saer arriba a París unos pocos meses después de los sucesos de Mayo del 68, un momento particularmente significativo que comenzaba a marcar el fin de las expectativas políticas de cambio inminente que habían signado el período anterior. Como ha señalado Gilman, 1968 es un año partido en dos para los intelectuales latinoamericanos, y particularmente para Cuba. La primera mitad se caracteriza por la eufórica alianza entre los intelectuales y la revolución. La segunda mitad por la disolución de esos lazos. Durante los sesenta y los setenta la política constituyó el parámetro de la legitimidad de la producción textual y el escritor autorizó su voz interviniendo en el espacio público. Decir "intelectual progresista" ya era una redundancia porque el sólo hecho de llamar a alguien "intelectual" lo filiaba con un pensamiento de izquierda. Los intelectuales de derecha habían quedado en una posición marginal, como lo prueba John King en su trabajo sobre la revista Sur y "también hubo casos de escritores que no ocuparon la posición intelectual, aunque parezca objetable: es el caso de García Márquez, a lo largo de la época, aunque mucho más claramente el de Bioy Casares, Manuel Puig o Lezama Lima, para dar algunos ejemplos muy diversos de escritores que se mostraron reticentes a convertirse en intelectuales" (Gilman 58). Más allá del carácter arbitrario y discutible de la lista, Saer podría haber formado parte de ella. Su ausencia viene a mostrar más claramente todavía el exitoso efecto de borramiento que ensayó en Francia, aun cuando, como intentará demostrarse, incorporará en su escritura ensayística algunos de los debates de la coyuntura política internacional y latinoamericana. ${ }^{60}$

\footnotetext{
${ }^{60}$ Efectivamente, como apunta Dalmaroni en "El largo camino del silencio al consenso", pocos críticos de la primera hora pudieron leer el tipo de tratamiento que Saer le dispensaba a la política. La reseña que hizo Altamirano en 1965 sobre Responso en Hoy en la cultura, una publicación bastante cercana al PC, se destaca en este sentido porque allí Altamirano pudo leer el efecto crítico que buscaba la representación sórdida de los militantes sindicales de la novela. Señala Dalmaroni que, leída retrospectivamente, esta reseña permite "notar toda la distancia que separaba a Saer y su poética de las morales del intelectual predominantes en los años sesenta. Por una parte, los momentos políticos de las historias narradas en sus libros parecían oponerse diametralmente a cualquier imperativo histórico edificante, a cualquier forma de optimismo político o revolucionario [...]. Por otra parte, también las actitudes públicas de Saer parecían completamente ajenas a la creciente demanda de una función política del escritor cada vez más
} 
La hipótesis que guía este segundo apartado es que Saer, descomponiendo su autofiguración en un haz de escritores viajeros heterogéneos, reales y ficcionales, resiste a ciertas cristalizaciones y exigencias del escritor latinoamericano que se habían consolidado ya para mitad de los sesenta: la del intelectual comprometido y político de la revolución (Cortázar- Vargas Llosa); la versión radicalizada del intelectual guerrillero (Paco Urondo) pero también la versión oficial del letrado "exitoso" pero asimilado (Biancotti). Apelando a la experiencia de la Comuna de París y a la experiencia refractaria de Darío, Saer establece una relación diferida y anacrónica con respecto a la política y a la estética contemporánea. Sin embargo, la política no está ausente de sus preocupaciones y opera de dos maneras: por un lado, Saer se detiene en un punto del mapa político francés y lee en las ruinas de la ciudad la pervivencia de los comuneros de París, referencia clave que, como veremos, también se retomó en los sesenta. Pero además, escribe ensayos y participa de algunas polémicas de la época aunque elija no publicar dichas intervenciones o aplazar significativamente su publicación. No ser un "intelectual" no significará, por supuesto, plegarse a la asimilación y esta resistencia no sólo lo mantiene voluntariamente marginado del mundo literario francés sino también a resguardo alerta de los influjos de su idioma.

\section{Breve paseo por el París rebelde}

Mientras recorre una ciudad vacía, mira el Sena desde un puente y piensa en Darío al volver del Louvre, el sujeto poético de los poemas de Saer recuerda al comunista "Ogust Blanquí" cuando intenta atravesar el boulevard que lleva su nombre una mañana de octubre, ${ }^{61}$ y pasea entre las tumbas del cementerio más grande de París.

directa y más vinculada con la participación activa en la lucha revolucionaria, [...] es indudable que, a diferencia de lo que se iba generalizando a fines de los sesenta en el campo intelectual, ni su escritura ni su figura pública adquirían sentido ni legitimidad en la política ni por la política" (631).

${ }^{61}$ Se trata de "Balada Bulevar Blanquí", un poema de 1969 no publicado en El arte de narrar en el que un sujeto intenta atravesar el boulevard Blanquí en dirección a la Estación Glacière. El texto suspende el recorrido fluido del personaje a partir de espacios en blanco que parecen interrumpir, a la vez, la caminata y el poema. En un juego típicamente saeriano que comparte la misma cadencia de "La mayor", el poema enuncia los trazos reconocibles de una cartografía urbana para erosionar en el mismo momento las referencias espacio-temporales y los hechos que refiere: "Atravesaba o sea estaba en medio del bulevar atravesándolo cuando de golpe creo un pensamiento en la mitad de la calle estuvo a punto de asaltarme [...] una mañana creo en el mes de octubre en la vil de París" ("Balada Bulevar Blanquí', Poemas 161), y despliega 
"En la pared de los federados" recupera un espacio marcado por la historia política, punto fundamental del mapa del París rebelde. El poema está incluido en la primera sección de El arte de narrar, que Saer escribió desde 1960 a 1975, y evoca los acontecimientos políticos que se dieron junto al muro del Cementerio del Père-Lachaise, el fusilamiento de 147 federados combatientes de la Comuna de Paris, que fueron muertos y echados a una fosa abierta al pie del muro el 28 de mayo de 1871. El sujeto deambula por el espacio, camina entre las tumbas y advierte las diferencias entre el pasado y un presente vacío: "Ya no se escuchan ni el dolor ni el sabor/ de la pólvora ni de la sangre. Estamos más muertos que vivos" (28), y pronuncia una advertencia que suena al menos inusual en la poética de Saer: “porque nada, porque nada/ -ni pájaro, ni rama, ni río, ni tormenta, ni flor-/ tendrá una voz para cantar/ si no viene de la pared manchada de sangre/ que se levanta todavía del otro lado de esas tumbas" (Saer, "En la pared de los federados", El arte de narrar 28). Una advertencia que podría leerse como otro "Arte poética": el pájaro, la rama, el río, la tormenta y la flor son los materiales predilectos de buena parte de su obra y un nuevo homenaje a la poética de Juan L. Ortiz que sólo podrían cantar, benjaminianamente, si su voz se levantara desde las ruinas no redimidas de la historia.

En "París, capital del siglo XIX" Benjamin muestra que la particularidad histórica de la ciudad es la singular combinación de libertad política e invención de una modernidad literaria, dualidad representada en "la pareja maldita" compuesta por Baudelaire y Blanqui. Como señala Benjamin, tanto uno como el otro se oponían al progreso y experimentaban la historia como catástrofe: "Lo que les era común alcanza más hondo que la diversidad de ambos; cala hondo la obstinación y la impaciencia, la fuerza para indignarse y para odiar; y también cala hondo la impotencia que fue cuota de los dos [...]. La acción de Blanqui ha sido hermana del sueño de Baudelaire. Ambos están entrelazados” (Benjamin, Iluminaciones II 120).

una especie de guía para entender la ciudad: "ya se sabe el que ha estado en París conoce todo dividido en arrondisesmants para facilitar la comprensión de la vil una mañana decía nublada en el mes de octubre atravesaba la calle el bulevar en dirección a la estación de metro abreviatura de metropolitano tren que se eleva sobre el bulevar rodando sobre andamios de fierro y después baja" (Saer Poemas 160, se respetan los espacios en blanco del original). Resulta interesante además la castellanización de la ortografía de ciertas palabras francesas: (arrondismant por arrondissement, por ejemplo). 
Esa dualidad de París señalada por Walter Benjamin como espacio de reivindicaciones políticas y recinto de modernidad literaria, visible en la pareja Baudelaire/Blanqui, parece constituirse como una característica que se reactiva fuertemente durante la década de los sesenta. Como señala Claudia Gilman, tanto en el período de emancipación, como durante el torbellino modernista y, ${ }^{62}$ finalmente durante los sesenta los intelectuales latinoamericanos asumen un fuerte compromiso de pertenencia con respecto al continente y buscan unir las preocupaciones culturales y políticas en un proyecto superador de las fronteras nacionales. El latinoamericanismo y la solidaridad tercermundista serán las divisas ostentadas por la familia intelectual latinoamericana, que encontrará en la Revolución Cubana la confirmación de las expectativas emancipatorias, y en las políticas culturales de Casa de las Américas un enclave apropiado para expandir sus preocupaciones literarias y políticas.

Como explica Isabel Plante en Argentinos en París, los sesenta serán un período signado por una modernización acelerada a ambos lados del océano (crecimiento de mercado y del público del arte), por la crisis de mayo de 1968, el auge del tercermundismo y del antiamericanismo. En ese marco, hacia fines de la década, París se politiza y reconfigura un perfil "revolucionario", es decir, "su lugar como capital de la República de las artes y núcleo de una resistencia política -que tenía en la Comuna de París de 1871 uno de los antecedentes más radicales- se modeló durante los años sesenta en relación con una nueva imagen del Tercer Mundo y un antiamericanismo renovado al calor de la Guerra de Vietnam" (Plante 19).

Si durante el modernismo la autonomización de la esfera artística exige nuevas figuraciones de escritores y artistas, durante la década del sesenta -momento de crisis

\footnotetext{
${ }^{62}$ Como explica Zanetti en "Modernidad y religación: una perspectiva continental (1880-1916)" la coyuntura epocal en la que se desarrolla el modernismo hispanoamericano resulta clave para observar las nuevas reparticiones de la sensibilidad intelectual, política y artística. En dicho contexto, el viaje y fundamentalmente el viaje a París fue una de las experiencias religadoras fundamentales. París era sentido por muchos de los intelectuales y artistas como una posibilidad de abrir el horizonte cultural de sus literaturas locales, un derecho a la búsqueda de una originalidad que trascendiera los límites de lo temático y se abriera a resonancias universales y específicamente literarias. Además, la ciudad encarnó también en esos años el lugar conflictivo del artista en la sociedad moderna: por un lado, representó la salida del mundo estrecho de las ciudades centrales hispanoamericanas; por el otro, enfrentó al escritor a las manipulaciones del mercado con una intensidad mayor que la vivida en América Latina, algo sobre lo que Gómez Carrillo y Darío reflexionaron en muchísimos textos. Por un lado, los escritores-artistas y los intelectuales comenzaron a configurar una esfera diferenciada que paulatinamente se desvinculó de la esfera política a la que estaba asociada. El planteo de la autonomía del arte y del lugar del artista llevó a los escritores a probar diferentes soluciones, algunos optaron por marginarse en el Ideal del Arte y buscar la evasión en el grupo selecto mientras que otros buscaron formar un lector abierto a una nueva percepción, empresa que asumen fuertemente Martí y Darío.
} 
de la modernidad- se produjeron nuevas recolocaciones de las figuras del artista y del intelectual. Además, la creciente internacionalización de la cultura hizo reaparecer la cuestión de lo nacional y de lo regional como un problema para artistas e intelectuales latinoamericanos. El año 1968 es clave en esta reconfiguración de roles. Gilman señala que hasta mediados de la década la conversión del escritor en intelectual era un proceso consumado y bajo la amplia noción de "compromiso" se aglutinaban los diferentes atributos del intelectual (el ideólogo, el buen escritor, el militante). Sin embargo, hacia 1966-68 se discutió la legitimidad del "intelectual", porque comenzó a emerger una nueva figura, radicalizada, de "intelectual-revolucionario".

Diversos testimonios contribuyen a reconstruir la experiencia de Mayo del '68 para los intelectuales y artistas argentinos que estaban viviendo en París en ese momento y resulta sugerente comprobar la disparidad de los mismos. Nicolás Casullo, por ejemplo, relata la progresiva fuerza que fue cobrando la insurrección, desde la asamblea en la Universidad de Nanterres, donde surgió el Movimiento 22 de Marzo liderado por Cohn-Bendit, hasta la toma de la Sorbona, las ocupaciones de fábricas, los piquetes estudiantiles y la huelga que abarcó la totalidad de las fuerzas de trabajo. Casullo refiere que "Francia estaba paralizada. Los partidos de izquierda radicalizados y los comités de jóvenes obreros conjeturaban o discretamente llamaban a la toma del poder” (en Fondebrider 244). Tomás Abraham, que había llegado a París en 1966, señala: "Mayo del '68 fue algo extraordinario, un despertar. Cuando yo llegué a Francia, París era una ciudad gris, depresiva. [...] Francia era un país patriarcal y burocrático. [...] Y entonces vino Mayo de 1968 y la gente se puso de fiesta" (en Fondebrider 284).

Sin embargo, otros intelectuales, sin desconocer la importancia de lo sucedido, revelan una versión más pesimista y crítica de sus efectos posteriores. En "París, Mayo 1968", César Fernández Moreno desenmascara la faceta "revolucionaria” de los hechos y denuncia que a pesar de las barricadas y la represión policial, los movimientos de rebeldía y las huelgas no terminaron de desarticular la "racionalidad" de París ni llegaron a modificar los hábitos de los ciudadanos. París continuó funcionando como una ciudad atenta al turismo, al espectáculo y al consumo: "los disciplinados obreros y empleados hacen sus huelgas sin perjudicar más de lo necesario al gran público" (Fernández Moreno en Fondebrider 279).

El escritor desmonta además el mito de París, al que compara con una capital latinoamericana por el mediocre funcionamiento de algunos de sus servicios, pero carente de la profundidad y la tragicidad política del continente: "no hay contexto 
revolucionario en Francia, como sí lo hay en América Latina” (Fernández Moreno en Fondebrider 276). Registra, sin embargo, el desorden urbano que ha causado la movilización, atentando contra una de las costumbres más preciadas de los viajeros: en tiempos de agitación política es preciso utilizar improvisados medios para llegar al trabajo. Ahora la caminata morosa que se permitía dar vueltas por callecitas escondidas o detenerse ante cada vidriera ha mutado en la caminata utilitaria y en línea recta. Frente a la retórica del "descubrimiento" que permea buena parte de los testimonios entusiastas de París, el escritor señala que lo que verdaderamente devela el "parisién latinoamericano" es que París no es tan diferente a la ciudad latinoamericana de la que proviene: "La ciudad se ha ido secando como una flor: su aparente perfección, se asombrará este latinoamericano, era sólo fachada; hurgando un poco se descubren pústulas más graves (por más antiguas y complejas), que las de su lejano país. Y se asombrará más aún, pues una situación así habría dado margen ya, en su América Latina, a golpes militares y explosiones guerrilleras. Pero en esta ciudad, oh, no es así" (280). Por último, Fernández Moreno muestra el desencantado escenario que queda después de Mayo del '68: "Ya es 14 de Julio y la gente vuelve a bailar en las calles, pero como autómatas a quienes nuevamente se hubiera aceitado y dado un poco de cuerda. [...] Las ardientes barricadas se recuerdan ahora como juegos" (en Fondebrider 281).

A ese mundo, entonces, llega Saer. Fernando García, en una entrevista para la Revista $\tilde{N}$, le pregunta cómo encontró la universidad francesa ese año de su llegada a Francia. La respuesta de Saer, como se verá, constata el diagnóstico realizado por Fernández Moreno sobre la rápida e higiénica normativización de la sociedad francesa:

-Cuando yo llegué, encontré mucha efervescencia de lo que había pasado dos meses antes. Los años que siguieron marcaron el retroceso de ese espíritu. Una involución muy tensa y mortífera, ¿no? que yo veía continuamente. Una retirada constante, día a día, año tras año. Yo lo veía en la Universidad, donde todas las medidas que se disponían iban contradiciendo el espíritu de mayo del 68 y, más bien, trayendo de regreso el régimen anterior (García, Una forma más real 192).

¿Cómo responde Saer a esa demanda de "intelectualidad" y compromiso signada por la época? A la par de la intensa actividad poética desplegada por el escritor durante las décadas del sesenta y del setenta, Saer escribió desde sus inicios una gran profusión de ensayos cuya publicación debía acompañar la salida de su primera gran novela, $L a$ vuelta completa. Sin embargo, como se sabe, muchos de esos textos fueron publicados 
tardíamente en El concepto de ficción. ${ }^{63}$ A continuación se leerá un corpus de artículos ensayísticos y notas menos conocido en los que despuntan las tensiones de la contingencia política en la escritura de Saer. ${ }^{64}$

Desvíos del compromiso: ensayo de una demora I'm nobody! Who are you?
Are you nobody, too?

Then there's a pair of us-don't tell! They'd banish us, you know

How dreary to be somebody! How public, like a frog To tell your name the livelong day To an admiring bog! ${ }^{65}$

\footnotetext{
${ }^{63}$ En primer lugar cabría aclarar, teniendo en cuenta la profusa bibliografía sobre el género, que lo que algunos críticos denominan "ensayos" es un grupo heterogéneo de textos que Saer escribió a lo largo de toda su carrera - prólogos, conferencias, notas de lectura, apuntes sobre la propia obra, artículos periodísticos-. En general la crítica que ha estudiado estos textos comienza apuntando una incomodidad a la hora de abordarlos y subraya la distancia -pocas veces salvada- entre la radicalidad de su prosa ficcional y la "debilidad" de sus ensayos. Cfr. Gramuglio en "Una imagen obstinada del mundo"; Catelli en "Desplazamientos necesarios"; Giordano en "Saer como problema", entre otros. Advierten que estos suelen presentarse como los trabajos de un profesor universitario cuya fuerza persuasiva a menudo decae por algunas simplificaciones, ideas previsibles y peticiones de principio no demasiado fundadas. Giordano apunta las "maniobras justificatorias" que prueba Saer en los prólogos al apelar a una "ética" del ejercicio crítico que debería oponerse a la mercantilización de la literatura, una tesis, podría decirse, anacrónica, que sigue sosteniéndose sobre el valor de la marginalidad de las vanguardias. Por supuesto, estos textos de Saer también han sido valorados: Gramuglio señala que funcionan como un laboratorio para la formulación de una idea de la prosa que los relatos ponen a prueba; Giordano celebra aquellos momentos en que irrumpe un recuerdo de lectura que emocionó al escritor porque allí se abre un espacio de indeterminación y ambigüedad en medio de la exquisita y rigurosísima exigencia del gusto estético que Saer no deja de exponer.

${ }^{64}$ Premat señala en la introducción a los Ensayos que los borradores muestran aspectos que Saer aparentemente quiso luego matizar u ocultar y que es posible leer en ellos elementos menos habituales de su escritura ensayística, como fuertes tomas de posición en polémicas del momento, particularmente en textos sobre literatura y compromiso que resultan muy significativos para observar la serie de tanteos que ensayó Saer en sus estrategias por integrar lo político-social a sus novelas.

${ }^{65}$ Poema n. ${ }^{\circ} 288$ de Emily Dickinson. El editor de Ensayos. Borradores inéditos 4 señala que esta versión de Saer difiere mucho de la incluida en la edición de Thomas H. Johnson, The poems of Emily Dickinson, Cambridge: The Belknap Press of Harvard University Presse, 1955. La edición de Johnson es reconocida entre los lectores de Dickinson por ser la que mejor respeta el inusual uso de mayúsculas y de guiones practicado por la escritora. La versión de Saer normaliza su ortografía.
} 
En 1969 Saer escribe un bellísimo ensayo sobre Emily Dickinson que no formó parte de la publicación tardía de El concepto de ficción. El texto, que incorpora poemas de la escritora, es ante todo un intento por definir la función de la poesía y podría leerse como una respuesta crítica a los pronunciamientos, manifiestos y tentativas de los escritores contemporáneos que, por otras vías, habían intentado dilucidar el mismo interrogante en el contexto de la inminente revolución latinoamericana. Parafraseando a Saer, la función de la poesía sería rescatar la palabra de las presiones de la "sociabilidad", resguardar la relación de los hombres con el mundo; borrar la falsa historicidad y la "conspiración de lo abstracto" y ofrecerle al poeta, exiliado y suspendido de la historia, la posibilidad de recuperar la familiaridad con lo real: "El reconocimiento póstumo de un poeta testifica de su verdad. La asunción de la oscuridad literaria es una elección crítica" (Saer, Ensayos 58).

Desafiando a quienes leen en la reticencia y el aislamiento de los poetas un acto moral, señala que cabría entender allí una función estética que permite afirmar la función absolutamente necesaria de la poesía, que se afirma de este modo como una "crítica del gusto" y crítica de la historia: "Gloria, entonces, al silencio lúcido y a la oscuridad, plena de responsabilidades, de Emily Dickinson" (60). Por supuesto, hablar de las responsabilidades y de la función de la poesía a través de Emily Dickinson en 1969 es una provocación a partir de la cual Saer define su propia posición, y así continuará haciéndolo en muchísimos ensayos que escriba para la misma época. En "El libro por venir", por ejemplo, una especie de "autorretrato indirecto", como lo llama Premat, atenta contra la escritura imperfecta de sus contemporáneos, que pecan voluntariamente de dos males: el prejuicio de la política y el prejuicio de la modernidad. En un ensayo sobre John Dos Passos (1966) vuelve a cargar contra la condición irreductible, pretensiosa y abstracta de la moral que se le exige a los "escritores comprometidos".

Sin embargo, esta extensa reflexión sobre las preocupaciones de la época no sólo se vehiculiza a partir de sus artículos y apuntes sobre escritores de literatura. Un recorrido por sus ensayos muestra que estaba muy atento a las noticias políticas nacionales e internacionales y seguía de cerca los debates y polémicas que se alzaban en relación a ciertas figuras y acontecimientos políticos puntuales, como el encarcelamiento de Paco Urondo o el secuestro del empresario italiano Oberdán Salustro. A principios de los setenta, Saer estaba preparando la edición de un conjunto de ensayos titulado Serie Negra que finalmente no se realizó. Algunos de esos textos 
fueron retomados en un proyecto posterior. En el copete a esta nueva serie, Saer señala: "Estas Noticias de policía, ${ }^{66}$ escritas en años agitados, formaban una serie de comentarios sobre acontecimientos políticos y sociales de Europa y de América Latina. La violencia, en cualquiera de sus formas [...] era el común denominador de esos textos" (Saer, Ensayos 15). En estos y otros ensayos el escritor discute las cristalizaciones sobre el "compromiso", interpela las figuras de "intelectual de izquierda" y de "intelectual revolucionario" y polemiza fuertemente con escritores como Cortázar y Vargas Llosa. ${ }^{67}$ Como explica la nota aclaratoria anterior, muchos de estos textos nacen al calor de acontecimientos políticos del momento, ${ }^{68}$ se escriben en respuesta a noticias periodísticas que Saer recortaba y guardaba entre sus papeles ${ }^{69} \mathrm{o}$ bien se constituyen como una extensa respuesta crítica a debates intelectuales. ${ }^{70} \mathrm{Sin}$ embargo, la urgencia de la escritura, a tono con los imperativos de la época que demandaban del intelectual una intervención social y un pronunciamiento directo sobre los acontecimientos, se desvanece en la demora o directamente en la ausencia de publicación.

En "La muerte de Oberdán Salustro" Saer escribe a propósito de las repercusiones que tuvo en la prensa mundial el secuestro y ajusticiamiento de este empresario de la FIAT a manos de militantes del ERP. El ensayo es significativo por varias razones, en primer lugar, no intenta sumarse al coro de polémicas (en las que intervinieron el PC y el Papa) sino evaluar los efectos del acontecimiento y desentrañar las asunciones filosóficas que justifican el juicio casi unánime al ERP. Lo que vino a desestabilizar la muerte de Salustro, señala Saer, no es un privilegio de clase o una coyuntura epocal determinada sino los fundamentos abstractos, de estirpe renacentista, que le dan coherencia a la ideología burguesa: el individuo, la civilización, el humanismo, la compasión, la muerte como última forma de la serenidad. Bajo este orden de cosas: “en la zona negra, o 'desde', más bien, anónimo, amorfo, confuso,

\footnotetext{
${ }^{66}$ Esos tres textos eran "La perversión institucionalizada" (1969), "Los intelectuales y la CIA" (1969) y "Los travestis y el público" (s/f), aunque el conjunto quizás incluyera otros ensayos, como "Un poeta en la cárcel", sobre Paco Urondo, publicado finalmente en Diario de Poesía en 1999.

${ }^{67}$ Advierte Gilman que Vargas Llosa y Cortázar politizan sus exilios en un sentido progresista e insisten en caracterizar el heroísmo inherente al escritor e intelectual (por el solo hecho de serlo).

${ }^{68}$ Cfr. "La muerte de Oberdan Salustro" (1972) incluido en Ensayos. Borradores inéditos 4.

${ }^{69}$ Cfr. "La perversión institucionalizada" (1969) incluido en Ensayos. Borradores inéditos 4.

${ }^{70}$ Cfr. "¿Es Papa el amo?” y "Los intelectuales y la CIA” (1969) incluidos en incluido en Ensayos. Borradores inéditos 4.
} 
turbador, el ERP golpea, ciego, irracional, prehistórico y preburgués" (Saer, Ensayos 86), y registra un cambio significativo del nuevo orden político, aquel en el que ya no hay individuos sino "cuerpos": "En la mesa de tortura, en la onda expansiva del napalm, en el hambre, ya no hay más individuo sino el órgano que se martiriza, la carne que vuela en mil pedazos, el vientre que se deforma, las pústulas que roen la piel, el equilibrio y la identidad" (86).

Un texto como "Un poeta en la cárcel”, por ejemplo, ensayado a propósito de la polémica que levantó el encarcelamiento de Paco Urondo en $1972,{ }^{71}$ fue escrito por Saer en 1974 y publicado más de veinte años después, en 1999 en Diario de Poesía. Saer rechaza en este texto las "causas psicologicistas" que muchos de los colegas de Urondo esgrimieron para explicar su encarcelamiento: "imaginación desenfrenada, cierta indiscreción, vanidad literaria, e incapacidad para emitir ninguna clase de juicio político" (Saer, Ensayos 161-2) porque suponen negar la significación política e histórica del comportamiento de Urondo y además porque es precisamente ese el capital simbólico con el que cuenta para hacer la revolución: "lo que el poeta ha sabido conquistar no con las armas, sino con el arrojo y la energía de su imaginación creadora" (Saer, Ensayos 163). Antes, en "Los intelectuales y la CIA", de 1969, ${ }^{72}$ Saer había dicho abiertamente: "me declaro partidario de la revolución socialista en América Latina, y me comprometo a colaborar con ella por todos los medios que estén a mi alcance" (Saer, Ensayos 90) como aclaración "a posibles protestas y acusaciones" (90). ${ }^{73}$ Como en otros textos, intentará aquí desmontar las cristalizaciones alrededor de la figura del

\footnotetext{
${ }^{71}$ La figura de Paco Urondo es muy significativa para Saer. En varias oportunidades evoca su vieja amistad pero también sus diferencias políticas. En "Saer en la ruta del adiós a su geografía literaria", la entrevista con Fernando García, recuerda: "Lo quería mucho a Paco, pero nunca entendí su evolución, su muerte me dolió muchísimo. La muerte de Leto [...] está un poco inspirada en la de Urondo. Yo me entendía muy bien con él, en una de sus últimas declaraciones que hizo habló generosamente de mí. Pero bueno, yo no entendía su elección" (Una forma más real 194). En El río sin orillas Paco Urondo aparece como "el amigo guerrillero" que todos tenían en los setenta. Saer apela aquí a una imagen previa de Urondo (previa a su incorporación a Montoneros y su pase a la clandestinidad, aunque, aclara, hayan seguido siendo amigos después de eso) en la que se recupera la dimensión poética, afectiva e intelectual de sus intercambios, al margen de sus elecciones políticas y de las cristalizaciones que la política hizo de Urondo: "conociéndolo desde mediados de los años cincuenta, de la época en que, tomando un vino jovial, discutíamos sobre Char, sobre Juan L. Ortiz, Apollinaire o Drummond de Andrade, en las orillas del río Paraná" (186) y confiesa que quince años después de su muerte no puede comprender "sus posibilidades de dialogar con esa masa obtusa de instinto de muerte, oportunismo y de megalomanía que eran los dirigentes Montoneros" (El río 186).

${ }^{72}$ Ensayo explícitamente excluido del proyecto de libro de ensayos de los noventa.

${ }^{73}$ Saer formaba parte de la juventud de izquierda de Santa Fe y tanto él como Hugo Gola y José Pedroni formaban parte del PC.
} 
“intelectual de izquierda", cuyo "desprecio por el pensamiento", dice, coincide con el ejercitado por la CIA, órgano que supuestamente estaba sustentando económicamente ciertas publicaciones de izquierda, lo que generó el debate entre los intelectuales de América Latina y el resto del mundo, y terminó dividiendo las aguas entre “colaboracionistas" y "honestos revolucionarios". El problema sin embargo no radica en que algunos escritores revolucionarios hayan colaborado en las publicaciones de la CIA, sino "que la mayoría de esos escritores se hayan plegado a la ideología típicamente burguesa que ellos atribuyen a la CIA, [...] consistente en exaltar la praxis política en detrimento del pensamiento" (91). El mismo argumento que Saer utilizará unos años más tarde para el caso de Urondo y que se sostiene sobre la clásica disyuntiva entre las armas o las letras.

La dimensión polémica de estos ensayos puede también leerse en “¿Es papa el amo?", donde Saer comenta muy críticamente la intervención de Cortázar en un encuentro que se desarrolló en París en 1970 sobre política y literatura -al que Saer asistió- y el texto que la editorial Rayuela de Buenos Aires publicó ese mismo año titulado "Viaje alrededor de una mesa". Saer analiza con rigurosidad e ironía las intervenciones de Cortázar, desmontando tanto sus procedimientos argumentativos - consistentes por lo general en descalificar a sus oponentes para desechar sus opiniones- como sus argumentos y señala que la supuesta polémica arte por el artecompromiso que Cortázar resume a partir de todos los lugares comunes imaginables es en realidad una disyuntiva falsa para los grandes escritores como Pavese, Brecht, Peter Weiss, Dos Passos, Vallejo, Breton y Borges, que han intentado expresar una "visión totalizante del mundo" (Ensayos 101), aunque no lo hagan, señala Saer irónicamente, con los recursos que Cortázar busca promover: el erotismo, el sentimiento lúdico y el humor. Cortázar "resuelve" la cuestión de la responsabilidad de los intelectuales latinoamericanos a partir de una suerte de desdoblamiento: los escritores deberían observar una conducta humana y política responsable sin dejar de hacer obras que gocen de toda la libertad creadora posible, aunque eso implique un desajuste con su tiempo. Ante los gritos y vociferaciones del público que pecaba, según Cortázar, de falta de entendimiento, posibilidad de diálogo, maoísmo y folklorismo, él mismo se coloca "en otro tiempo y dimensión". 74

${ }^{74}$ Dice Cortázar: "Por momentos, frente a esas ráfagas de elocuencia demasiado fácil, a esa
repetición mecánica de términos manejados sin la menor dialéctica, me había sentido como 
En otro ensayo inédito, "Función actual de la poesía: una modesta proposición", Saer ensaya un diagnóstico de la poesía argentina y señala sobre Cortázar que reúne "a nivel declarativo" los dos prejuicios que sustentan la mala literatura, vanguardia y compromiso, "lloran la muerte de Ernesto Guevara en malos versos que Guevara hubiera deplorado, reciben premios en Casa de las Américas [...] y después vuelven a su casa a hacer una vida que no difiere en nada [...] de la de Lugones" (Ensayos 123-4). El escritor rechaza la opción del compromiso: "los sentimientos, sin duda edificantes, que mueven a ciertos escritores a pronunciarse por el compromiso, a veces no pasan de ser un pretexto para ocultar la falta de coraje necesario que hace que un escritor decida a ir en apariencia a contrapelo de la historia y de sus contemporáneos" (123). Como se verá, muchas de las figuras de viajeros que selecciona para desplegar su propio proyecto creador son las de aquellos que van a contrapelo de la historia y sufren el escarnio o la indiferencia de muchos de sus contemporáneos.

Al parecer, entonces, Saer no se sustrae por completo de ciertas polémicas sobre literatura y compromiso y atiende además a los acontecimientos políticos que estaban sucediendo en esos años, pero lo hace anteponiendo una valoración estética. En el mencionado ensayo sobre Cortázar lo expone claramente: "Yo no me ocuparía de los chatos textos políticos de Cortázar si no pensara que detrás de ellos se oculta una chata literatura" (98). También en el caso de Urondo, Saer reivindica sus atributos como escritor: "Podemos muy bien no compartir la política concreta de Urondo [...], es sin embargo su imaginación [...] lo que su posición tiene de más indestructible" (163), y finalmente también para el caso paradigmático de Sartre. En "A propósito de las relaciones de Sartre con la literatura", luego de complejizar la noción de "compromiso" que tanto los entusiastas como los antagonistas del filósofo se han ocupado en banalizar y fetichizar, Saer puntualiza su propia versión: "El escritor no es un tenor que vocaliza generalidades humanistas en un escenario bien iluminado, sino un hombre semiciego que trata de ver claro en la negrura de la historia" (117). Reivindica su labor crítica y lo llama un "filósofo poeta". Señala que su pensamiento es inclasificable y que todos sus textos nacen de la misma obsesión: "asir al hombre en situación [...] para reunir los pedazos de una totalidad desgarrada por múltiples contradicciones" (119), y en esto se acerca a los grandes escritores de nuestro tiempo.

relegado en otro tiempo y en otra dimensión, cambiando inútilmente señales con gentes que a su vez pertenecían a otro tiempo y a otra dimensión" (Cortázar, "Alrededor de una mesa", s/p). 


\section{Perder el alma: de la provincia de Córdoba a la Academia francesa}

En octubre de 1998 Saer participa de una ronda de preguntas en el Centro Cultural Parque de España y responde sobre variados temas que van desde la estructuración de sus novelas y la crisis del cuento a la situación financiera y el sistema de créditos y subsidios del Instituto de Cine. ${ }^{75}$ Después de haber evocado a sus escritores predilectos de la zona (José Pedroni, Evaristo Carriego, Fernández Moreno, entre otros) recuerda el caso de Héctor Bianciotti, un escritor cordobés que abandonó la provincia de Córdoba y aterrizó en la Academia Francesa. Según relata Saer, Bianciotti escribió una crítica elogiosa sobre El Entenado en Le Monde y ambos mantenían una relación cordial aunque distante. Saer reconoce su buen gusto literario pero advierte que su literatura no le gusta, y tampoco que escriba en francés, y mucho menos que haya terminado en la Academia francesa, "un lugar muy poco recomendable", señala. Todos los grandes maestros de la literatura francesa han elegido el camino opuesto a Bianciotti, han hecho su carrera afuera de los círculos académicos: "Es como si Héctor hubiera perdido su alma en esta especie de viaje de la provincia de Córdoba a la Academia Francesa. [...] Esa trayectoria no presenta un gran interés para mí. Él lo sabe, lo intuye, nos vemos poco". Saer recuerda que siempre lo insta a regresar al país, y que Bianciotti aplaza el regreso por temor de llegar como un desconocido, actitud que Saer juzga de infantil. Evoca, por último, una escena interesante: el año anterior Saer había encontrado una traducción al español del primer tomo de la Divina Comedia que tenía un sello de la familia Bianciotti: “Andrés Rafael Bianciotti” y comenta que pese a que quería quedarse con el ejemplar, decide llamar al escritor para regalarle el libro, porque a él mismo le gustaría tener uno en el que figurara el nombre de algún familiar suyo. Sin embargo, cuando lo llama, nota que Bianciotti lo toma a mal, como "si yo estuviera recordándole sus raíces” y a pesar de comprometerse para buscar el libro, nunca lo hace. Irónico, Saer concluye que fue mejor así, porque pudo quedarse con el ejemplar.

En "Exilio y extraterritorialidad: Wilcock y Bianciotti", Podlubne y Giordano retoman la hipótesis de Steiner sobre la "extraterritorialidad" que caracteriza a buena parte de la literatura moderna y que supone que descentramiento cultural $y$ extraterritorialidad lingüística son los parámetros que definen la orientación de la

\footnotetext{
${ }^{75}$ En el blog Sonidos de Rosario se aloja una grabación del intercambio entre Saer y personas del público bajo la entrada "En cassettes, Juan José Saer" y puede escucharse en: http://www.sonidosderosario.com.ar/audio/en-cassettes-juan-jose-saer/ Las citas a continuación son transcripciones de esta grabación.
} 
literatura contemporánea en general. Advierten que en la literatura argentina hay varios casos de escritores que presentan la condición del exiliado y la de la extraterritorialidad lingüística, como Manuel Puig y Copi, y más particularmente Rodolfo Wilcock y Hector Biancotti, quienes en un momento de sus vidas abandonaron por completo la escritura en español.

El caso de Biancotti es bastante singular para contraponer al caso saeriano. El escritor arribó a Francia en 1961 y después de veinte años de residencia parisina, en la década del ochenta, comenzó a escribir en francés. Como señalan los críticos, la decisión de cambiar de lengua literaria obedeció en él a un proceso de integración. Publicó toda su obra en París, sus libros se publicaron en francés antes que en español y a pesar de haber sido casi un desconocido en Argentina, se convirtió en un autor consagrado en Francia, medio en el que cumplió un activo rol como agente cultural, crítico y cronista literario. ${ }^{76}$

Resulta interesante observar los itinerarios que llevaron a Saer y a Biancotti a la misma ciudad y distinguir la diversa figuración que produjeron en sus relatos autobiográficos. En el caso de Biancotti, anotan los críticos: "de la llanura a la ciudad de Córdoba, de Córdoba a Buenos Aires y de Buenos Aires a Europa; ya en Europa, de Nápoles a Roma y de Roma a París [...] un itinerario cultural ascendente: el que va desde la más rigurosa barbarie hasta la cumbre de civilización" (Podlubne y Giordano 395). El periplo saeriano no es tan diferente, a grandes rasgos reitera el pasaje del campo a la ciudad cosmopolita, pero incorpora además un derrotero que insiste en la "zona" y se saltea el paso por Buenos Aires: de Serodino a Santa Fe, luego a Rosario y de regreso a Santa Fe, realiza viajes por el norte de la provincia, vive un tiempo en el campo, en Colastiné, y finalmente viaja a Francia. Según analizan Podlubne y Giordano, la llanura es percibida por Bianciotti de acuerdo a una matriz sarmientina que lo hace considerar el campo como una fuerza negativa que embrutece e inhibe los

\footnotetext{
${ }^{76}$ Las distancias entre Saer y Bianciotti se agudizan cuando se observan las operaciones de autofiguración que realizaron. A diferencia de la voluntad sustractiva de Saer, Bianciotti escribe una extensa autobiografía en tres volúmenes (Lo que la noche le cuenta al día, El paso tan lento del amor y Como la huella un pájaro en el aire). En "Héctor Bianciotti: la autobiografía del escritor público", Alberto Giordano advierte que allí Biancotti cuenta su exitoso "transplante" francés y se autorepresenta como un "escritor clásico", continuador de la tradición humanista de las letras francesas y "gran civilizado". Lo que en Saer resiste como afirmación de una zona y de una lengua, en Bianciotti se asimila: "El joven que dejó Argentina creyendo que "no partía para el Viejo Mundo, sino que regresaba a él', comprueba en su primer paseo por Nápoles que "la sensación de volver a casa se transformó en evidencia'" (Giordano, "Héctor Bianciotti", Una posibilidad de vida 179).
} 
sentimientos y las manifestaciones estéticas y que debe ser opuesta a la ciudad. Bianciotti encarna el ideal de aprendizaje de nuestra mitología nacional, "la de la superioridad espiritual y estética de la cultura francesa. [...] Como Ocampo, Bianciotti cree en la superioridad del idioma francés tanto en el dominio literario como en el intelectual” (396-7) y además se piensa a sí mismo un "europeo en el exilio", por el cual el viaje a Europa no es otra cosa que el retorno a los orígenes.

A diferencia de Puig, Copi, Wilcock y Bianciotti, Saer no asume la extraterritorialidad lingüística y desafía la hipótesis de Steiner. Se puede ser un escritor plenamente moderno, estar a la hora de las vanguardias, ${ }^{77} \sin$ abandonar la casa de la lengua natal. Por el contrario, como se verá más adelante, Saer reivindica la lengua como uno de los baluartes más importantes de su escritura y realiza una serie de interesantes operaciones de "regreso" lingüístico. Saer es además un viajero raro por el uso que hace del francés. En "Elegía Michel Barón”, por ejemplo, los editores anotan que algunos versos estaban escritos en una primera versión en francés correcto y "corregidos" luego con tinta violeta en una escritura fonética "a la española". Saer elige mostrar la permanencia de su lengua materna en el nuevo idioma y Sarlo advierte al respecto que Saer hablaba "un francés impecable léxica y sintácticamente pero con una tozuda fonética santafesina" (Zona Saer 53).

\footnotetext{
${ }^{77}$ En Las tres vanguardias, Piglia señala que a partir de las poéticas de Borges, Macedonio Fernández, Bioy Casares, Marechal y Cortázar, "por fin, la literatura nacional no está en una relación asincrónica o de desajuste respecto del estado de la narrativa en cualquier otra lengua" (14). Las "vanguardias" protagonizadas por Walsh, Puig y Saer se harán en relación con esta productiva actualización y "puesta en hora" del escenario del arte local y "discutir hoy la poética de Saer o de Puig es lo mismo que discutir la de Thomas Pynchon o la de Peter Handke" (16).
} 


\section{UNA PATRIA SIN ATRIBUTOS}

Un día, con luna nueva, usté venga, venga a ver mi rastro, como huella de jaguar, eh, ¡soy jaguar! Hum, ¿usté no me cree? [...] El jaguareté mi tío, hermano de mi madre, tutira... ¡Mis parientes! ¡Mis parientes! (Guimarães Rosa 435-6)

A fines de la década del setenta Saer comienza a configurar de otro modo su experiencia en el extranjero. Ya no escribirá poesías para conjurar su llegada a Francia sino textos en los que predomina un tono reflexivo sobre el viaje, el exilio y la patria que culminarán, hacia los noventa, en El río sin orillas y en la conferencia "Entre dos aguas" que escribe explícitamente para una jornada sobre literatura y multilingüismo. ${ }^{78}$ Sin embargo, varias de estas reflexiones ya pueden leerse en las entrevistas, los pequeños ensayos y los artículos que escribe fundamentalmente a partir de los ochenta, una década, como veremos, decisiva en relación a la confirmación de su obra, la ampliación del círculo de lectores y la progresiva visibilización de su figura autoral. Como se intentó mostrar, las poesías que Saer compuso durante los primeros años de su llegada a París permitían observar las múltiples proyecciones que asumió como residente francés, a partir de un juego de homenajes y referencias a una variada serie de poetas y escritores -Rubén Darío, César Vallejo, René Char, Ueda Akinari- con quienes el sujeto lírico trazaba correspondencias y diálogos, o contra quienes "se medía". Pero además, como se vio, estos poemas desarticulaban las expectativas usualmente asociadas a la vida literaria parisina y al viaje exitoso del escritor sudamericano.

Si la matriz genérica utilizada para reflexionar sobre el viaje que se privilegiaba hasta principios de la década del setenta era la poesía o la prosa poética, predominará en esta segunda etapa el ensayo, ${ }^{79}$ no sólo en aquellos textos que se efectúan explícitamente como tales, sino también con respecto a las entrevistas y borradores de

\footnotetext{
${ }^{78}$ En 1974 escribe por ejemplo un texto anómalo para el proyecto saeriano. "El café" es una pieza teatral inconclusa en la que se problematizan el exilio y las imágenes del desierto a partir de un contrapunto dialógico entre un viejo nativo del lugar y un viajero joven. Más tarde, en 1977, Saer escribe otro texto anómalo, "Las instrucciones del letrado Koei", que, como se verá más adelante, resulta fundamental para reflexionar sobre su particular idea de "patria".

${ }^{79}$ Esto no significa que Saer haya dejado de escribir poesías (lo hizo hasta 1987) o que su producción ensayística emerja en los setenta, sino que su reflexión sobre la vida en el extranjero comienza a vehiculizarse, predominantemente, a través de la matriz reflexiva que le permiten el "ensayo" y la entrevista.
} 
entrevistas. Esta transición de la poesía al ensayo produce una serie de efectos y reposicionamientos en su figura de escritor porque ${ }^{80}$ como ha analizado Nicolás Lucero, ${ }^{81}$ el ensayo como "forma" (adorniana) le ofrece a Saer un programa filosófico y formal, crítico y negativo, capaz de desarticular las abstracciones perturbadoras de la patria y de lo nacional, conceptos que se volvieron especialmente sospechosos durante la dictadura militar y la Guerra de Malvinas. ${ }^{82}$

Según advierte Premat en el "Liminar" a Ensayos, Saer comenzó a escribir textos ensayísticos desde los primeros años de su producción, pero como se dijo, escritura y publicación están disociadas: El concepto de ficción reúne textos que van desde 1965 a 1996; muchísimos otros ensayos escritos durante esos años no se

${ }^{80}$ Cabe aclarar que más allá de este pasaje genérico se puede verificar, por otro lado, una indagación permanente sobre la prosa de ficción que abarca varios años y coincide con la escritura de poesías y ensayos. Desde 1969 a 1975 Saer escribirá los argumentos de La mayor, que, como se verá en el capítulo a él dedicado, será el libro de ficción en el que problematiza la partida y la vida en el extranjero.

${ }^{81}$ En el esclarecedor artículo "El ensayo como forma en El río sin orillas" Nicolás Lucero advierte que la práctica crítica y ensayística de Saer es deudora de la de Adorno, no sólo por su recelo hacia las formas de la industria cultural y su confianza en la función crítica de las vanguardias, sino fundamentalmente por su adscripción a una concepción negativa de la forma: "La estética de Saer se vincula con la negatividad adorniana por la tenacidad con que revela los antagonismos que encubren las formulaciones identitarias" (Lucero 682). Interesa rescatar algunas de estas coincidencias entre Saer y Adorno indagadas por Lucero porque permiten considerar de qué maneras, a través del ensayo, Saer aborda y desarticula las nociones cristalizadas sobre "patria" y "exilio". En primer lugar Adorno postula que el ensayo debe ser un cuestionamiento radical de los orígenes y debe tomar el origen como objeto de reflexión y como algo negativo. Leemos en "El ensayo como forma": "El ensayo abandona la ruta militar que busca los orígenes y que en realidad no lleva sino a lo más derivado, al ser, a la ideología duplicadora" (Adorno 21). A falta de "creación original", continua argumentando Lucero, el ensayo se asume en cambio como un texto intersticial que se escribe "entre" otros textos. Ese cuestionamiento del origen, que por supuesto Saer ejercita largamente en El río sin orillas, también permea sus ensayos más breves y se encarniza, como veremos, contra ciertas ideas abstractas de "identidad nacional". En segundo lugar, y en relación con lo anterior, para Adorno el ensayo es la forma crítica de la ideología por excelencia. Advierte Lucero: " "El ensayo como forma' circunscribe la posición crítica del intelectual a la práctica de escritura del ensayista. En ese lugar, que tradicionalmente ha ocupado la figura del pensador, Saer pone al viajero, al narrador, a quien inventa su propio método para lidiar con el error y nombrar las reiteraciones de lo mismo" (Lucero 688). El ensayo será, como veremos, el dispositivo de pasaje en el que Saer puede intervenir sin ser un "intelectual comprometido" y en el que ingresarán, en cambio, esas figuras díscolas que incorpora a su particular reflexión sobre los viajes y la patria.

${ }^{82} \mathrm{La}$ apuesta política y estética que Saer deposita en el género podría leerse además en correlato con esa emergente preocupación por el ensayo que Giordano advierte en el campo intelectual argentino en su libro El discurso sobre el ensayo. En "La crítica: entre la literatura y el ensayo" Sarlo advierte que hasta la década del cuarenta las discusiones importantes sobre la literatura y la política nacional discurrían bajo la forma del ensayo - desde el Facundo a Martínez Estradapero que esta forma comenzó a decaer hacia los años sesenta, cuando en la universidad argentina se impuso una mayor especialización disciplinaria, una especificidad conceptual más estricta y una fuerte matriz teórica estructuralista. 
publican. ${ }^{83}$ Este desfasaje, que podría vincularse con lo que Giordano llama "neutralización del contexto agonístico" ("Saer como problema" 249) se "salda" con la publicación de El río sin orillas, un encargo que Saer tuerce para escribir un texto anómalo, un "des-ensayo" que responde, ${ }^{84}$ involuntariamente quizás, a esa demanda de la crítica identificada por Giordano. No todos los textos y entrevistas que se revisarán en este apartado conforman verdaderos "ensayos" aunque compartan algunos de sus modos, ${ }^{85}$ pero apuntalan ciertas ideas sobre patria y exilio que El río sin orillas retoma y satura en un pensamiento discontinuado sobre la nación.

Como se verá, entonces, frente a la pluralidad de sujetos que en las poesías refractaban al sujeto lírico saeriano, en los ensayos se prodiga una mayor densidad autobiográfica y crítica. Pero además, las referencias se organizan y se amplían, porque Saer, sin dejar de referirse a su propia experiencia, se distancia y aborda el problema con una mayor perspectiva. Aparecen, como se verá, nuevos viajeros y escritores a partir de los cuales el escritor va a tramar no sólo su permanencia en Francia sino

${ }^{83}$ Los textos que forman La narración-objeto y los artículos periodísticos de Trabajos sí alcanzan, en cambio, una relativa contemporaneidad entre escritura y publicación.

${ }^{84}$ En "Lo incalculable. Saer en la escuela argentina" Dalmaroni lo caracteriza como el "desensayo" del no-ser nacional. Más adelante se abordará con mayor detenimiento el análisis de $E l$ rio sin orillas.

${ }^{85}$ Los diferentes críticos que han teorizado sobre el ensayo recogen en sus textos las prevenciones y prejuicios que ha suscitado el género como una forma discursiva que se sustrae tanto de las prerrogativas conceptuales de la ciencia como de las formas artísticas. En "El ensayo como forma", Adorno advierte sobre su carácter fragmentario, su predilección por lo parcial ante la totalidad, su conciencia de la "no identidad" y su resistencia a las formas tradicionales de la verdad y a la ética abstracta de la filosofía. En "¿Es posible definir el ensayo?" Jean Starovinsky revisa las características del género a través de su lectura de los Ensayos de Montaigne e identifica dos vertientes (una subjetiva y otra objetiva) para observar que el ensayista debe por un lado ensayarse a sí mismo y evaluar su propia capacidad de observación, pero además, desplegar una curiosidad infinita por todo lo exterior, por la proliferación de lo real y su contradictoria actualización discursiva. Starobinsky subraya la libertad del ensayo y su carácter de insubordinación, personalidad e imprevisión que aloja y potencia las incertidumbres (la lección de Montaigne: "voy inquiriendo e ignorando"). Dentro de la crítica literaria argentina, Alberto Giordano ha particularizado los modos ensayísticos de escritores argentinos como Borges, Cortázar, Bioy Casares y Bianco, entre otros, y ha indagado particularmente el "ensayo literario", que lo es no por el tema abordado sino porque asume la "legalidad propia de la literatura, un modo de 'conocer' literario" (Modos del ensayo 225). Una de las vías de esa lectura (que Giordano ejemplifica en Benjamin y en Borges) es leer a contrapelo de las lecturas canonizadas y alegóricas a partir de "detalles" potentes que exceden las interpretaciones tradicionales. Según Giordano apunta en "Saer como problema" a propósito de los textos críticos de Saer, sólo algunos "momentos" de sus escritos alcanzan a ser verdaderos ensayos. Interesa, sin embargo, retener las particularidades del género para leer transversalmente algunas de estas intervenciones en las que Saer ensaya sobre los conceptos de exilio, viaje y nación y también sobre su descentrada posición de escritor. 
también sus regresos a Argentina, que a partir de la década del ochenta hará de manera sostenida.

\subsection{Del inmigrante al exiliado: biblioteca y filiaciones literarias}

En "En líneas generales puede decirse que...", un borrador de entrevista fechado en 1981, emerge una figura particular del viajero que Saer no había puntualizado con esa claridad en ocasiones anteriores: ${ }^{86}$ el escritor se reconoce como un "inmigrante" y se incorpora en una tradición familiar de inmigrantes de larga data. La primera serie, entonces, es la del viaje familiar. Saer dice en la respuesta 14: "Mis padres eran inmigrantes sirios" (Saer, Ensayos 140) y señala que todos sus tíos que vivían en Argentina se casaron con otros sirios, pero además,

estaban esos vagos personajes de generaciones anteriores a los que había que llamar tíos y otros vagos primos de nuestra generación. Eran todos sirios e hijos de sirios. Ese microcosmos de inmigrantes tenía sus leyes propias; era un mundo bastante cerrado y yo lo vivía subjetivamente como en conflicto con el medio ambiente que no era avaro [...] en manifestaciones de racismo ordinario (Saer, Ensayos 140).

Hasta 1968 dice haberse alejado paulatinamente del microcosmos familiar y reconoce haber tenido una relación muy tumultuosa con su padre, pero fue a partir de su llegada a Francia que comenzó a revisar su propia experiencia:

mi situación, en cierto sentido, era idéntica a la de mi padre. Como él yo era un inmigrante, como mis dos hijos nacidos en Francia yo era un hijo de inmigrantes, con los mismos conflictos de lengua, de cultura, de nostalgia y de incomunicabilidad [...], durante cuatro generaciones entonces el exilio ha sido nuestro destino común. Habría que ser ciego para no percibir la importancia central de esa situación (Saer, Ensayos 141). ${ }^{87}$

${ }^{86}$ Tapuscrito que en su versión manuscrita llevaba como título "Respuestas a Slimane Zeghidour".

${ }^{87}$ En ¿Quién de nosotros escribirá el Facundo? José Luis de Diego repasa los distintos tópicos que retomaron los escritores e intelectuales en sus testimonios sobre el exilio. En el caso argentino, la referencia al Génesis es frecuente, así como las menciones a los destierros de la Antigüedad; otros escritores, como Gelman, incorporan la tradición mística y cabalística por su "visión exiliar del mundo" o asocian la diáspora con la metáfora del judío errante. "De entre esas variantes, una recurrente es la que se remite a una historia más cercana: los exiliados argentinos están desandando el camino de sus abuelos, como si formaran parte de una historia mayor de itinerancia que los engloba" (de Diego 167). Los exiliados comienzan a reconocerse como partes de un vasto proceso de migraciones y arman sus propias genealogías exiliares. Algunas remiten a los proscriptos del rosismo, porque en ellos identifican no solo el comienzo 
La advertencia del propio Saer sobre la importancia del linaje, en este caso, un linaje de inmigrantes y de "vagos personajes" permite repensar las tensiones entre sus orígenes y la tradición cultural argentina de la que forma parte y a la cual contribuye a modificar. No sorprende, porque es parte fundante de nuestra historia cultural, que un hijo de inmigrantes nacido en un pueblo de provincias se haya convertido en uno de los escritores más significativos de la literatura argentina del siglo $\mathrm{XX}$, pero interesa pensar de qué manera ese origen, rechazado en sus comienzos y recuperado en su obra posterior, dibuja un funcionamiento singular entre su familia y la(s) biblioteca(s) a la(s) que accede desde su juventud y que lo acompañan en su traslado europeo. El linaje extranjero de Saer puede además ser leído a contraluz del caso paradigmático de la literatura argentina: el "doble linaje" de Borges ${ }^{88}$ no porque Saer ostente, como Borges,

de la literatura nacional sino también el inicio de la historia nacional. Otros, como Viñas y Adellach apelan en cambio a los desterrados "internos" de la nación, a los caudillos que no gozaron del amparo de aristocracias extranjeras; a los habitantes de la frontera; a los excluidos que no participan de la modernidad. Estas distintas series, advierte de Diego, están polemizando sobre el presente: "Viñas y Adellach -aun habiendo sido exiliados- parecen rechazar los supuestos privilegios de una tradición ilustre y el reclamo de un reconocimiento social acorde con ella, para cambiar el foco de atención sobre las otras, silenciosas e innominadas, víctimas de la dictadura" (171). Cabe aclarar que el nombre de Saer no aparece en el listado de exiliados políticos que reúne el autor, aunque sí se menciona su partida como un "exilio voluntario" y se lo incluye entre quienes "no regresaron o lo hicieron de modo esporádico", junto a Gelman, Cozarinsky, Goloboff y Matamoro. Sin embargo, algunos de los tópicos, preguntas y genealogías del exilio retomadas por de Diego permiten pensar el traslado de Saer a Francia, su propia colocación como inmigrante y su vínculo con los exiliados políticos que fueron llegando al país.

${ }^{88}$ Repasemos lo que Piglia llama el "doble linaje". El lado materno lo constituye a Borges como descendiente de fundadores y de conquistadores (Borges dice ser descendiente de los primeros españoles, Juan de Garay e Irala) y lo provee de "los mayores", una estirpe de guerreros heroicos que lucharon en las batallas que contribuyeron a la formación de la nación. Esta ficción familiar es una interpretación de la cultura argentina y una cifra de las contradicciones siempre presentes en su historia: entre las armas y las letras, entre lo criollo y lo europeo, entre el coraje y la cultura, en suma, entre barbarie y civilización. A partir de la tradición oral que relataba las hazañas bélicas de Isidoro Suárez, Isidoro Acevedo y el coronel Francisco Borges, la familia se apropia de la historia argentina. La leyenda épica se completa a partir de los bienes materiales de los antepasados, en general, soldados y estancieros. Por otro lado, la ficción familiar paterna ligada a la tradición intelectual y a la cultura inglesa lo convierte en el descendiente espiritual de otra serie, la de los antepasados literarios (Wells, Chesterton, De Quincey, Conrad, Wilde, Stevenson, Kipling) ${ }^{88}$ Pero a su vez, el doble linaje borgeano abre un hiato lingüístico en su hogar, entre el español criollo y el inglés, que aprende de su padre. La literatura de Borges se funda como un destino y también como el saldo de una deuda que Borges contrae con la figura paterna: "Mi padre siempre había deseado ser un hombre de letras y lo fue de manera parcial. Y como mi padre había querido ser un escritor, quedó más o menos sobreentendido que yo debía cumplir ese destino" (Borges, citado en Piglia "Ideología y ficción en Borges" 5). Esta doble herencia no sólo define ideológicamente el proyecto borgeano sino también sus selecciones formales, proveyendo al escritor de distintos sistemas de relatos. 
un doble linaje de antepasados honorables sino precisamente porque a pesar de no tener ninguno apela a similares operaciones de reapropiación y reescritura filogenética/autobiográfica de la historia nacional. ${ }^{89}$

En primer lugar y a diferencia de Borges, Saer funda su lugar en la literatura argentina distanciándose del microcosmos familiar sirio y fundamentalmente sustrayéndose del deseo paterno que lo reclamaba para el mundo del trabajo y soñaba para él un futuro como abogado. Saer efectivamente empieza a estudiar abogacía y luego filosofía, y reconoce: "terminé no siendo nada. Eso generó muchos conflictos con mi padre. Y lamentablemente murió demasiado joven como para remediarlos" (Saer en Russo s/p). Roberto Maurer recuerda que algunos amigos y conocidos lo llamaban "turco" aunque ese apelativo no terminara de constituir un nombre afectivo para Saer. En la entrevista con Miguel Russo recompone el éxodo del que proviene su familia: "Mis padres pertenecían a la minoría católica apostólica romana de Damasco, en Siria. Las persecuciones religiosas de los musulmanes a los cristianos, plena época del imperio Otomano, fueron un factor determinante para mucha inmigración" (Saer en Russo s/p). Como se verá en la tercera parte de este trabajo, será en sus libros tardíos cuando Saer comience a reconciliarse con su estirpe árabe. En 1991 les dedicará El río sin orillas a sus padres, José Saer y María Anoch, e incluirá en La grande la historia de la familia de Nula, conformada por inmigrantes sirios. Como advierte Sarlo en Zona Saer, será aquí donde finalmente se le haga un lugar a esa forma de la violencia política que sufrían los sirio-libaneses en el país.

A diferencia de Borges, que podía reconocer los nombres de esos gloriosos antepasados que habían luchado en las guerras de la patria, Saer habla por el contrario de esos "vagos personajes", tíos y primos innominados. Si el núcleo familiar le daba a Borges la historia argentina y la biblioteca inglesa, Saer compone su propia estirpe a medida que se aleja del cosmos familiar y se vincula, afectiva e intelectualmente con el

\footnotetext{
${ }^{89}$ La crítica que se ha ocupado de este aspecto de la ideología borgeana coincide en señalar que Borges elabora una relación imaginaria con sus antepasados a partir de la cual convierte la historia argentina en una historia familiar. Fundamentalmente cfr. Piglia en "Ideología y ficción en Borges" y Rafael Olea Franco en El otro Borges. El primer Borges. Saer, que carece de esos antepasados familiares gloriosos que sí tiene Borges, los construye en sus cuentos y novelas a partir de la estirpe de la familia Garay, que como se ha dicho muchas veces, permite retrotraer la historia de la familia hasta el conquistador español. No obstante, a diferencia de la posesión de tierras y bienes que ostentaban los antepasados ricos de Borges, en el presente literario de Saer los mellizos Garay sólo acumulan chatarras y tambores viejos en el patio de la casa de Rincón.
} 
grupo de poetas y plásticos rosarinos y santafesinos, y fundamentalmente "crea" un padre en la figura tutelar de Juan L. Ortiz.

Biblioteca y familia serán dos series que se irán paulatinamente distanciando en la formación intelectual de Saer. En la entrevista que le realiza Miguel Russo, el escritor reconoce irónicamente que su padre era un gran lector: "Leía todo el tiempo y cualquier cosa. En mi casa había dos o tres libros en árabe dando vueltas. Pero mi padre era un gran lector. Creía en la cultura, y se había suscripto a Selecciones del Readers Digest. Un día nos hizo una bibliotequita para mi hermano y para mí, y allí guardábamos las revistas y los libritos de Selecciones que devorábamos" (Saer en Russo s/p). Sin embargo será en el seno familiar "árabe" y a partir de objetos heterogéneos donde el escritor tenga su primer acercamiento al libro símbolo de la literatura nacional. En "Libros argentinos", un artículo literario y memoria autobiográfica de sus lecturas, Saer cuenta que conoció los versos del Martín Fierro por haberlos escuchado en la radio familiar, pero también porque varias de sus escenas habían sido ilustradas en los almanaques de Alpargatas que colgaban del almacén de ramos generales de su padre, e incluso porque leyó esos versos pintados en un extraño vestido de su hermana: "un vestido de seda, de un rosa pálido, en el que venían impresos, ejecutados con algo que parecía tina china, unos diminutos temas criollistas (algún ranchito con su ombú liliputense, o un nido de hornero pegado a un tronco y cosas así) y versos del Martín Fierro" (Saer "Libros argentinos", Trabajos 189).

Sin embargo, esa historia cambia cuando se mudan en 1948 a Santa Fe, ciudad que le permite ampliar la exigua biblioteca familiar. Allí Saer conoce a Lugones, a Carriego y a Almafuerte; lee y copia muchísima poesía argentina y, como dirá en varias ocasiones, su propia evolución es muy semejante a la que siguió la poesía misma: modernismo, posmodernismo, sencillismo, coloquialismo, vanguardia. Sin embargo, será recién en 1955 cuando Saer tenga su propia biblioteca en el pequeño cuarto de la terraza de la casa a la que se mudan en esa época, espacio que expandirá virtualmente a partir de otras tres bibliotecas populares y de las librerías de viejo en las que canjeaba libros: “Antes de haber tenido mi 'cuarto propio', aunque leía enormemente, tenía pocos libros. Tres bibliotecas me los suministraban: la Pedagógica [...] y dos bibliotecas muy frecuentadas, la Emilio Zolá y la Cosmopolita, fundadas por grupos anarquistas [...] El otro recurso para la lectura era una librería de viejo, la librería Sarmiento [...] en la que, más que comprar, canjeaba muchísimos libros" ("Libros argentinos”, Trabajos 191). Acceso artliano y un tanto plebeyo a las bibliotecas populares y a las antologías 
publicadas por editoriales de amplia circulación como Espalsa Calpe y Losada. Durante los sesenta Saer se interesará además por la colección El pasado argentino, de Gregorio Weimberg y, una vez en Rennes, le hará comprar a la Universidad la Colección entera en dos tomos. A pesar de los dos o tres libros en árabe que circulaban en su casa paterna, la biblioteca personal de Saer se forma a partir de una serie de exclusiones: ni la literatura de consumo del Readers Digest, ni los libros que pertenecen al mundo cultural sirio de su familia. Una biblioteca, en cambio, criolla y universal (pero no "borgeana" ni porteña) y viajera. Saer puede leer en la Universidad de Rennes los mismos libros que leía antes de partir en la terraza de su casa: una colección de "auténticos clásicos argentinos" - aunque sus autores hayan sido en gran medida extranjeros-, particularmente ingleses y franceses: William H. Hudson y Alfred Ebelot entre los predilectos.

Distanciado de la serie familiar de sus vagos ancestros sirios, Saer apela a una pertenencia distinta y se inventa una nueva serie de antepasados. En "Los tíos narradores", un ensayo de Trabajos, Saer postula precisamente esa deriva a propósito de Meu tio iauaretê de Guimarães Rosa. El narrador del extraordinario relato es un cazador de jaguares mestizo, hijo de un padre blanco y una madre india toupira. A medida que se interna en la selva, va entrando en el aura de sus víctimas y comienza a mutar, "se jaguariza”. Recupera, explica Saer, su filiación matrilineal: “un retorno a sus orígenes, pero no en un retroceso biológico, sino más bien en un orden cultural, porque su padre biológico es justamente un blanco, y el jaguar pertenece al ámbito cultural de su madre india" (Saer, "Los tíos narradores" 74). Una elección del narrador que Saer festeja y traspola a la que hacen los escritores, porque "los momentos más fecundos de la cultura son aquellos en los que, separándose de una fatalidad biológica o de una tradición demasiado rígida [...] ciertos grupos o individuos reivindican una filiación novedosa [como] hizo Dostoievsky [cuyos] tíos narradores se llamaban Gogol, Balzac, Cervantes, Shakespeare, Homero" (76-77).

Esa otra serie de filiaciones literarias tiene larga data en la literatura argentina y permite examinar los vínculos entre el escritor argentino y la tradición, como bautizó Borges a la polémica que Saer retoma en múltiples oportunidades. ${ }^{90}$ Como hijo de

90 En la quinta respuesta a la entrevista "En líneas generales..." desnaturaliza la falsa contradicción entre tradición local, nacional y planetaria para afirmar que en un nivel antropológico esas contradicciones se resuelven por sí solas: "si lo que trata un escritor no es válido para todo tiempo y lugar no puede serlo tampoco para un lugar concreto y separado" (Saer, Ensayos 138). 
inmigrantes sirios y joven escritor sudamericano Saer apelará a este linaje literario universal a partir de su reelaboración de la idea de exilio. ${ }^{91}$ En primer lugar diferencia tres clases de exilio: el exilio circunstancial, aquel por el cual los sujetos se ven obligados a vivir en el extranjero por no compartir las ideas de los gobiernos que rigen sus países natales; el exilio de tipo estructural que le hace al hombre sentir los rigores de vivir en una sociedad alienada, incluso en su propia patria, ${ }^{92}$ y finalmente un exilio ontológico que es constitutivo del individuo y lo acompaña del nacimiento a la muerte. Concluye afirmando: "estamos hechos de esa encrucijada de destierros, de esa caja china de exilios y de carencias que desembocan en lo negro" (Saer, Ensayos 149) y particulariza la situación del exilio en la obra de un escritor, para quien supone un “alejamiento, una privación, una explosión [...] una especie de intemperie [...] que tiene al menos una ventaja: permitirnos ver desde afuera el conjunto que nos ha expelido" (Saer, Ensayos 149). Saer ensancha la definición de exilio y la lleva del plano político al plano ontológico. Esto le permite definir cualquier "situación de exterioridad" o intemperie, y multiplicar sus formas:

la enfermedad, física o mental, la pobreza, la sexualidad, etc.... Entre los escritores de nuestro tiempo, hay exiliados voluntarios como Joyce, Beckett, Pound, Eliot, exiliados forzosos como Brecht, Benjamin, Gombrowicz, Vallejo, hay exiliados en su propia patria como Macedonio Fernández, Juan L. Ortiz, Svevo o Faulkner [...] y hay quienes se hallan fuera [...] por otras razones, como la enfermedad [Proust o Kafka], o en el ghetto de la locura, como Artaud (Saer, Ensayos 150)

Ampliando la categoría de exilio Saer termina respondiendo, oblicuamente, a esa fatalidad biológica que signa a su familia y convierte a sus "tíos literarios" en exiliados

\footnotetext{
${ }^{91}$ Estas formulaciones pueden encontrarse en varias entrevistas y ensayos. Se retoma aquí "Una de las propuestas principales de Nadie nada nunca...", borrador de entrevista incluido en el cuarto tomo de sus borradores inéditos, Ensayos.

${ }^{92}$ Algunas circunstancias históricas agudizan esa sensación de exilio estructural. La narrativa de Saer explora fundamentalmente dos, la caída del peronismo y la instauración de la Revolución libertadora (cuyo resultado son las subjetividades fracturadas de Alfredo Barrios, Sergio Escalante y Luis Fiore) y la dictadura militar. Las circunstancias de Tomatis en Lo imborrable podrían aludir a ese exilio estructural que separa al hombre de la sociedad de sus contemporáneos: "Cuando pienso que después de meses de ostracismo y de penuria mental emerjo de nuevo al mundo [...] 'yo' o lo que quedaba de 'yo', que, vengo diciéndomelo desde hace varias semanas, me zambullí sin vacilar en la demencia autodestructiva tratando de escapar a la esquizofrenia general" (18-9). Más tarde Tomatis soñará su "regreso" a la ciudad a partir, una vez más, de una experiencia de extrañamiento: "Ahora salgo a la calle en un día gris, desierto, de bordes un poco carcomidos, semejante a una fotografía vieja descubierta por casualidad en el fondo de un cajón, extraña y familiar al mismo tiempo" (Lo imborrable 224).
} 
de toda clase. En varios ensayos abordará particularmente la cuestión del exilio para los escritores y analizará sus ventajas y desventajas.

Un caso clave en este sentido será "Exilio y literatura", publicado originalmente en el número especial que Les Temps Modernes le dedicó a la situación política en Argentina (“Argentine entre populisme et militarisme”, n. ${ }^{\circ} 420-421$. París, Juillet-Août, 1981). ${ }^{93}$ El texto, incorporado en esta publicación, exhibe ciertas tensiones, porque si bien Saer no puede dejar de aludir al exilio político de intelectuales y escritores argentinos durante la dictadura, apuesta a ampliar su definición y a universalizarla. En primer lugar sostendrá, retomando operaciones de otros exiliados, que el exilio en la literatura argentina es una tradición, verificable en Sarmiento y en Hernández, y en toda la escritura del siglo XIX. Pero además, afirmará que hay muchos tipos de exilio y que el exilio político no es privativo del escritor, es una forma circunstancial, acaso más aguda, de un conflicto constante entre el escritor y la sociedad. Saer vuelve a cargar aquí contra la alianza estatal-mercantil de la ideología liberal -y en este caso, totalitaria- que aparecerá refutada en Lo imborrable y en La grande a propósito de Walter Bueno y Mario Brando, al afirmar que la cultura oficial no puede ni siquiera atisbar la "literatura viviente". Por ese motivo, afirma, el confinamiento no pesa solo sobre aquellos escritores abiertamente opositores al régimen sino sobre cualquiera cuya visión del hombre y del mundo no coincida con los valores del optimismo ansioso y pragmático del Estado, como en los casos de Juan L. Ortiz y Macedonio Fernández. Todo gran escritor es un exiliado aun si jamás salió de su lugar natal: "deberíamos arrancar al exilio de su contingencia, es decir de su coyuntura y su inmediatez histórica para poder condenar de manera más justa y exacta a la sociedad que lo produce" (Saer, “Exilio y literatura”, El concepto de ficción 271).

En "Caminaba un poco encorvado", un ensayo de 1985 sobre Dante Alighieri incorporado a El concepto de ficción, señalará que estar en el exilio le permite al escritor relativizar su propia experiencia y le provee un nuevo principio de realidad. El extranjero se convierte así en "una especie de limbo, y una suerte de observatorio" (Saer, "Caminaba un poco encorvado" 76) desde el cual puede hacer dos cosas: advertir

93 En ¿Quién de nosotros escribirá el Facundo?, José Luis de Diego advierte sobre la importancia de esta publicación. El número fue preparado por César Fernández Moreno y David Viñas y contó con artículos de Juan Carlos Portantiero, León Rozitchner, Julio Cortázar, Noé Jitrik, Juan José Saer y Beatriz Sarlo. Algunos textos se escribieron como denuncias, otros como análisis políticos, otros como ensayos de mayor aliento y otros como breves ensayo de opinión (serie en la que de Diego coloca el texto de Saer, "Exil et littérature", recopilado después en $E l$ concepto de ficción). 
lo injustificado de las pretensiones nacionalistas y desmitificar la supuesta infalibilidad europea. Sin embargo, como no todo es provecho intelectual, el exilio también acarrea una serie de pérdidas: "tiempo, espacio, carne, memoria, experiencia, muerte: todo esto, que es materia común a todos, en la situación del exilio cobra un sabor particular" (Saer, "Caminaba un poco encorvado" 76). La experiencia de otros escritores exiliados le provee además los principios a partir de los cuales construye su imagen de escritor en Francia: "para el joven Joyce, las tres armas del escritor perdido en la penumbra del extranjero, debían ser 'el silencio, el exilio y la astucia'. Ese programa nos da una idea de enfrentamiento, de soledad y de separación" (Saer, "Caminaba un poco encorvado" 76).

Será este tipo de "exilio ontológico" el que defina su condición y aquel a partir del cual Saer se posicione tanto en relación al espacio francés como al espacio natal, al que regresará, como se observará más tarde, sustrayéndose de las identificaciones nacionales. Se trata de una versión del "exilio" que en buena medida coincide con aquella que propone Jean-Luc Nancy en "La existencia exiliada". Aquí Nancy procura releer el tópico de la existencia como un exilio, de raíces greco-judeo-cristianas, en el marco de la enorme cantidad de éxodos, desplazamientos, deportaciones y migraciones a nivel mundial, donde el exilio ha dejado de simbolizar un "pasaje con retorno" para transformarse en una experiencia definitiva sin regreso: "Parece, pues, como si hubiera una especie de exilio constitutivo de la existencia moderna, y que el concepto constitutivo de esta existencia fuera él mismo el concepto de un exilio fundamental: un 'estar fuera de', un 'haber salido de' " (Nancy 36). Sin embargo, Nancy busca desarticular la idea del exilio como la salida de lo propio y como algo transitorio, dialectizable en los términos de ida y retorno. Por el contrario, apuesta por un exilio no dialectizable, "una negatividad pura y simple, la dureza y la desgracia del exilio que no conduce a nada, no se reconvierte en nada" (37), por un exilio que sea él mismo lo propio: "Se trata entonces de pensar el exilio, no como algo que sobreviene a lo propio, ni en relación con lo propio - como un alejamiento con vistas a un regreso o sobre el fondo de un regreso imposible-, sino como la dimensión misma de lo propio" (Nancy $38)$.

Interesa esta reflexión de Nancy porque también desarticula las formas usualmente cristalizadas de "lo propio" contra las cuales Saer escribe: "no necesariamente una propiedad, ni una nación, ni una familia, etc. (quizá no dejen de ser formas alienadas de lo propio: alienaciones del exilio, por decirlo de algún modo)" 
(Nancy 38). Contrapone la idea de "patria", en tanto algo originario, a la idea de "asilo": "Pensar el exilio como asilo [...] es justamente pensar el exilio como constituyendo por sí mismo la propiedad de lo propio" (Nancy 38).

Ese "asilo" estará para Saer ubicado en el intermedio que se dibuja, como él mismo lo señala, "Entre dos aguas". ${ }^{94}$ En este texto Saer reconstruye su experiencia apelando a ciertas figuras comunes de la prosa del exiliado, señala que su lugar no es ni Francia ni Argentina, sino ese espacio intersticial, "entre" dos países, dos culturas y dos idiomas. Se diferencia de otros exiliados que no pudieron adaptarse al nuevo medio aunque reconoce que en todo exiliado siempre permanece "un residuo irreductible al cambio, un nudo íntimo de extrañeza y de distancia que lo obliga a menudo a traducir los datos del presente a un código que subsiste del pasado y que le permite entenderlos a su manera" (Saer, Ensayos 200). Advierte sobre la conocida tensión entre la imagen ideal que el viajero se ha construido del país al que viaja, por haberlo leído e imaginado a partir de un repertorio filosófico, estético y político, y el país empírico al que se enfrenta. Señala además que cuando la adaptación finalmente ocurre da como resultado una especie de "cultura mixta" en la que lo nuevo convive con lo arcaico y el comportamiento se vuelve vagamente excéntrico en los dos lados. Como había señalado en varias oportunidades, Saer confiesa que el viaje le permitió reconfigurar, a la vez, la mirada que tenía sobre Argentina y sobre Europa y puntualiza los problemas específicos a los que se enfrenta un escritor en el extranjero: a saber, el idioma y la vida dislocada. Reconoce por último que durante varios años percibió el mundo como un abismo caótico y destructor, aunque luego adquiriera una actitud más serena o resignada: "de ese hormigueante caos, de esos fragmentos en dispersión, sin embargo, terminó nutriéndose una buena parte de mi literatura" (Saer, Ensayos 202).

Como se verá a continuación, Saer encontrará en la figura del escritor polaco Witold Gombrowicz una forma de procesar, a la vez, su experiencia del extranjero y sus regresos al país y comenzará a darle forma a esa "perspectiva exterior" que elogia de escritores y viajeros como la distancia justa entre el sujeto y el paisaje natal.

\footnotetext{
${ }^{94}$ El texto que Saer escribe para un encuentro sobre literatura y multilingüismo organizado por la MEET (casa de escritores y traductores extranjeros) de Saint-Nazaire, Francia, del 18 al 21 de noviembre de 2004 y publicado por esa misma institución.
} 


\subsection{Aprender de la inmadurez: distorsión y ceguera en Witold Gombrowicz}

Ahora nos toca a nosotros mirarnos en Gombrowicz (García 12). ${ }^{95}$

Hacia 1990 la figura de Witold Gombrowicz insiste en las reflexiones de Saer sobre el viaje. En el conocido ensayo "La perspectiva exterior: Gombrowicz en Argentina" y en El río sin orillas el escritor traza su retrato y revisa parte de su obra a partir de una serie de preocupaciones que ya había tematizado muchas veces: el complejo vínculo entre la literatura nacional y la tradición universal y la paradojal figuración de un escritor exiliado. Como señala Pablo Gasparini en El exilio procaz: Gombrowicz en la Argentina, Ricardo Piglia y Saer recuperan al escritor polaco asimilándolo -o disculpándolo- a través de parámetros borgeanos. Como se intentará demostrar, la figura de Witold Gombrowicz asume para Saer una doble funcionalidad. Por un lado le permite condensar y consolidar su teoría sobre los vínculos entre tradición literaria nacional y tradición europea, reescribiendo witoldianamente el ensayo de Borges. Por otro lado, mediante la figura de Gombrowicz puede continuar diseñando su propio linaje de viajeros -excéntricos algunos, olvidados, estrafalarios y ridículamente heroicos otros- a través de los cuales desarrolla no sólo su proyecto escritural sino también su figuración como escritor exiliado. Si Rubén Darío es el poeta joven que le posibilita a Saer ir hacia París, indagar el silencio de sus calles y preguntarse por el secreto de la poesía, Gombrowicz es el viajero que imaginariamente le ofrece un modo de volver al país y rechazar la adscripción nacionalista en favor de ese "linaje del exilio" bajo el que Saer teje su escritura.

Atraído por la juventud radical y demoníaca de Retiro, crítico despiadado del espíritu racional de Occidente y lúcido observador de los paisajes, la composición social y la literatura de Argentina, Gombrowicz despliega en su Diario argentino una gran variedad de autofiguraciones y desdoblamientos. Es por momentos: “Witoldo', acriollado ya, aunque de vez en cuando aún [se] presenta[ra] como 'escritor polaco', [...] uno de tantos expatriados que hospedaba esta pampa, despojado hasta de la nostalgia por el pasado" (55) y también "un polaco, desconocido en París, autor de

\footnotetext{
${ }^{95}$ Así cierra el homenaje que Germán García le dedica a Gombrowicz a propósito de su muerte en "Leer a Gombrowicz" en la revista Los libros de agosto de 1969. Una frase profética que se alza como un mandato generacional en relación con las nuevas maneras de hacerse un lugar en la política cultural argentina y que rescata fundamentalmente la épica traducción colectiva en la que se aventuró Gombrowicz con su novela Ferdydurke, que realizó con sus amigos y camaradas del café Rex.
} 
cierta obra, con gustos literarios demasiado paradójicos, sospechoso y excéntrico" (9) que se siente un extranjero exótico, ajeno de sí mismo en Goya, un pueblito de Corrientes, pero también un "Aristócrata en Tandil" (160) que a la vez desdeña y es atraído por la intelectualidad de provincias; será más tarde, cuando esté en camino de regresar a Europa, un "elemento ciego" (248) enamorado de Argentina; un viejo fantasma que se pasea en la cubierta del barco para encontrarse en el mar con su fantasma de la juventud, exactamente igual a él, a bordo del Chobry, el vapor que lo llevó hacia la Argentina 24 años atrás, y finalmente un escritor "débil, disperso, disuelto" (261) que entra a París un poco enfermo y sabiendo que "como literato debía aislar[se] de París", ser su enemigo. Las últimas páginas del Diario lo encuentran pensando: "Ningún animal, batracio, crustáceo, ningún monstruo imaginario, ninguna galaxia me son tan inaccesibles y ajenos como yo. [...] Te has esforzado durante años en ser alguien, ¿y qué has llegado a ser? Un río de acontecimientos en el presente [...] el abismo, he ahí lo único tuyo" (262).

La primera lección que Saer aprende de Gombrowicz es a no ser nadie: "Ser polaco. Ser francés. Ser argentino. Aparte de la elección del idioma, ¿en qué otro sentido se le puede pedir semejante autodefinición a un escritor? [...] A priori, el escritor no es nada, nadie" (Saer, "La perspectiva exterior", El concepto de ficción 17). El escritor debe preservarse, dice Saer, de las cristalizaciones sociales que lo individualizan y lo enlazan a categorizaciones abstractas. Y cita a Gombrowicz: "Aunque tenga conciencia, como todo en mí, es más bien una semiconciencia y una cuasiconciencia. Soy semiciego. Soy casquivano. Soy de cualquier manera" (Gombrowicz citado en Saer 18). Al igual que Saer, Gombrowicz también está hecho de una "encrucijada de destierros" porque es quizás uno de los escritores que mejor encarnan esa triple posibilidad del sujeto exiliado: como polaco que llega a Argentina por casualidad pero es sorprendido por la Segunda Guerra Mundial, la invasión nazi (y luego soviética) de Polonia y decide quedarse en el país; como sujeto exiliado de la sociedad y de los valores de la "cultura", a los que Gombrowicz le opondrá el carácter disruptor e indeterminado de la inmadurez, y finalmente acuciado por un exilio ontológico, aquel que lo deja continuamente sin patria y lo separa de sí mismo, aún durante su infancia en Maloszyce, cuando el entonces escolar polaco "hacía todo lo posible para no marchar al ritmo de la orquesta militar", como advierte Gasparini para 
señalar que Gombrowicz inscribe allí, en ese momento de su infancia, el exilio como posibilidad y la Argentina como destino. ${ }^{96}$

Pero a su vez, Saer incorpora a Gombrowicz en dos series de viajeros, que aunque corran paralelas y se toquen en algunos puntos, tienen efectos diferentes. Por un lado, la serie anacrónica o intemporal reúne a Gombrowicz con una gran y heterogénea tradición de viajeros, marineros, científicos, comerciantes y exploradores -Pigafetta, Schmidel, Félix de Azara, Millau, Mac Cann, Woodbine Hinchliff, Alfred Ebelot, Albert Londres y W.H. Hudson- que recorrieron el territorio argentino, formalizaron las primeras imágenes del paisaje del Río de la Plata y fueron capaces de "iluminar y nombrar cosas que antes de su paso se confundían en un magma indiferenciado" (Saer, El río 105). Por otro lado, una serie histórica que devuelve a Gombrowicz a su contemporaneidad y a los azares que lo trajeron primero a Argentina y lo llevaron luego a Europa. En esta serie, el escritor polaco es cruzado por Saer con Ortega y Gasset, Roger Caillois, Borges y la constelación de escritores de Sur.

La primera serie de viajeros, intemporal y heterogénea, le permite a Saer definir la singular mirada del escritor polaco, a quien, entre esa gran variedad de viajeros, le tocó distinguir y sacar del magma indiferenciado la juventud baja de Retiro, "los adolescentes pobres y un poco venales que frecuentaba Gombrowicz" (Saer, El río 105) pero a quien también le cupo observar de un modo novedoso el paisaje nacional. El Diario de Gombrowicz no sólo registra los desplazamientos efectivos del escritor polaco por las diferentes ciudades y regiones del país sino también los cambios sutiles que sufre el ojo del viajero cuando se mueve y observa. Saer destacará: "Y está también su percepción clara de la luz de Santiago, del aire transparente y feliz de Tandil, de la peculiaridad del espacio americano en Necochea, una impresión planetaria, cósmica, la sensación de un presente sin memoria prolongándose a su alrededor hacia el infinito" (Saer, "La perspectiva exterior", El concepto de ficción 22). A continuación, el ensayo de Saer cita un fragmento del diario de Gombrowicz en el que el escritor polaco traspasa los límites visuales de la playa de Necochea para imaginar un espacio ilimitado que se extiende "Vacío y arena, oleaje...estruendo que se ahoga y adormece. Espacio, distancias sin fin. Frente a mí y hasta Australia sólo esta agua surcada de melenas

\footnotetext{
${ }^{96}$ Esta es la cita completa que retoma el libro de Gasparini: “[...] pero la Argentina, desde mi infancia, ¿no estaba ya inscripta en mis destinos, cuando aún escolar, en Polonia, durante los desfiles, hacía todo lo posible para no marchar al ritmo de la orquesta militar?" (citado en Gasparini 30).
} 
brillantes, al sur las islas Falkland y las Orcadas y el Polo. Tras de mí, el interior: Río Negro, la pampa..." (Gombrowicz en Saer 22).

Gombrowicz es el ojo meridiano del paisaje, su cuerpo y su mirada son la bisagra que une y separa tierra y agua; el campo y las islas. Sin embargo, Gombrowicz se aleja de ese punto material del mapa que produjo el paisaje hasta que "su recuerdo llega a desaparecer, y no queda sino el mero hecho de alejarse, incesante, eterno, como un secreto que llevara conmigo" (Gombrowicz en Saer 22). Saer capta a Gombrowicz en el momento en el que se despega del paisaje, tomado, como dice más arriba, por una "impresión material, cósmica". Primer punto de contacto: el ojo de Saer y el ojo de Gombrowicz producen a menudo estas derivas, prendidos de lo más inmediato: la melena brillante del mar, la arena, el color del río, derivan en ocasiones hacia un sublime cósmico. ${ }^{97}$ Pero además, en varios momentos del Diario Gombrowicz reflexiona sobre las imposibilidades, carencias y dificultades de su visión, que por lo tanto dará muchas veces paisajes distorsionados y difusos que no distan demasiado de la imaginería visual que ensaya Saer en algunos de sus textos más experimentales.

En varios oportunidades, como decíamos, la mirada de Gombrowicz se extraña: “Usé la expresión 'me pareció ver' porque no creo que aquello fuera posible. Además estoy dudando, y el sombrero, el resplandor y los matorrales limitaban el campo de visión" (Gombrowicz 30); "No sé nada, quizá miro el paisaje al revés, pero no logro ver sino mosquitos, franjas, puntos, temblor de atmósfera, zumbido bañado en resplandor [...] y el sudor lo inundaba todo y todo se borra" (30-31). Más adelante, bajo un apartado titulado "Geografía” reconoce: "el mundo tangible de los árboles, la tierra, las hojas, este único mundo amistoso y fidedigno, se esfuma en una especie de no-visión, no-existencia... se borra" (107). Es decir, a diferencia de varios de esos viajeros enumerados por Saer cuya pretensión era precisamente conocer el territorio, determinar la productividad de sus tierras y de sus yacimientos mineros o establecer puntos estratégicos para el avance militar, una mirada pragmática y efectiva que implementaba instrumentos de observación y medición, la mirada distorsiva de Gombrowicz, como también será la de Saer, borra y mancha el paisaje.

\footnotetext{
${ }^{97}$ En la entrevista que le realiza Fernando García y que evoca en "Saer en la ruta del adiós a su geografía literaria" (2015) Saer explicará la importancia de lo cósmico en su obra. Cuando se le pregunta por la presencia de la barbarie en su literatura, el escritor explica que lo arcaico tiene una gran importancia y que se verifica en distintos planos, lo subconsciente, lo biológico y sexual, pero también "lo cósmico": "hay una presencia constante. Cuando se habla de lo ígneo, lo gaseoso. La referencia a la materia dispersa del universo que dio lugar al sistema solar" (Una forma más real 191).
} 
La segunda serie de viajeros en la que Saer incorpora a Gombrowicz, fundamentalmente en el largo retrato que traza en El río sin orillas, devuelve al escritor a su historicidad y al campo de rivalidades literarias en el que se desarrolló su particular escritura. Esta reubicación instala una sutil distancia histórica entre Saer y el escritor polaco, quienes coincidieron en París el año del arribo de Saer (luego Gombrowicz murió en 1969) y resuelve esa diferencia en términos generacionales: "Para la gente de mi generación, en 1960, Sur en tanto que revista no era más que un soplo del pasado, [...] pero cuando Caillois y Gombrowicz llegaron al Río de la Plata, los escritores de Sur dominaban la escena cultural" (Saer, El río 153). Como se sabe, en 1960 y posteriormente, Saer librará sus propias batallas, ${ }^{98}$ resulta interesante sin embargo que a pesar de esta leve diacronía, no sean tan distintas a las que da el mismo Gombrowicz cuando se refiere al panorama de la literatura nacional. Saer comparará en El río sin orillas a Gombrowicz con Roger Caillois. Ambos arribaron al país el mismo año de 1939 pero sus derroteros intelectuales fueron prácticamente opuestos, sin embargo, coinciden en algunos puntos: llegaron circunstancialmente pero debieron quedarse por el estallido de la guerra y la ocupación de sus respectivos países y se transformaron, como lo haría el mismo Saer en Francia, de ocasionales viajeros en "huéspedes". 99

\footnotetext{
98 Como señala Miguel Dalmaroni en "El largo camino del 'silencio' al 'consenso'. La recepción de Saer en la Argentina (1964-1987)", Saer se distancia y es en un comienzo ilegible "para casi todos: la nueva izquierda comprometida, los intelectuales revolucionarios, los entusiastas de la 'nueva novela latinoamericana' o del Boom, los partidarios de Julio Cortázar o de Gabriel García Márquez, los detractores de Borges" (613). También Premat en "Saer: un escritor del lugar" repasa estos desacuerdos: "contra los imperativos del regionalismo o del realismo en los años sesenta; como oposición al Boom, al realismo mágico, al exilio y el sufrimiento como pathos del escritor rioplatense (en los setenta), la puesta en duda del culto a Borges, pero también el rechazo hacia operaciones literarias que integran literatura y comercio (propuesta de Umberto Eco). Crea entonces una filiación paralela, leyendo en otros los propios principios o leyendo lo que en los otros vendría a justificar la propia obra" (194). Pero además, Saer refuta y refunda el regionalismo de los cincuenta a partir de una fuerte experimentación literaria que pictorializa el paisaje y se permite incluso criticar el excesivo dogmatismo teórico de la corriente europea en boga a la que supuestamente adscribe, el objetivismo francés. Para revisar esto último cfr. Maranguello, Carolina (2017). "Una geografía pintada: paisaje y abstracción en ficciones y ensayos de Juan José Saer". Anclajes. Revista del Instituto de investigaciones Literarias y Discursivas vol. XXI, n. ${ }^{\circ}$, Universidad Nacional de La Pampa, La Pampa, enero-abril 2017, pp. 43-58. Como se verá, las variadas disputas que mantenga Saer a partir de la década del "60 no son otra cosa que el ajuste histórico y la "evolución" de las alternativas intelectuales y artísticas que cuestiona Gombrowicz unas décadas antes.

${ }^{99}$ La perspectiva del "huésped extranjero" instala, como advierte Joaquín Manzi en "1939 y después: el largo invierno austral de Gombrowicz y Caillois", una relación asimétrica entre la intelectualidad argentina y la europea pero también los lazos de reciprocidad y obligaciones mutuas que exige toda relación de hospitalidad, una constante en la literatura argentina.
} 
Roger Caillois, escritor a quien Saer efectivamente conoció en París a través de César Fernández Moreno, fue invitado por Victoria Ocampo e integrado al grupo de escritores de Sur, y funcionó, dice Saer, como un embajador de la Francia Libre. Editó además la Revista de Letras Francesas financiada por Ocampo en la que escribieron muchos de los intelectuales y escritores franceses censurados durante la ocupación y exiliados en distintas partes del mundo. Gombrowicz, en cambio, llegó sin ser invitado por nadie y desde un país marginal y si bien intentó, como advierte Gasparini, tejer algunas relaciones con la revista Sur y publicar allí la traducción al español de Ferdydurke (1947), el encuentro entre Silvina Ocampo, Borges y Bioy Casares organizado por Mastronardi no tuvo efectos posteriores y en términos generales Gombrowicz vivió en "un hundimiento progresivo y penoso en la pobreza, en la impotencia y en el anonimato" (Saer, El río 155). Sin embargo Saer procede con su retrato como hiciera antes con el de Darío, y como hará también con otros padres o mejor "tíos" artísticos de juventud, como Juan L. Ortiz y Fernando Espino. ${ }^{100}$ Como el Darío al que pasean como una "puta decrépita, de país en país, medio borracho", justo es reconocer, argumenta Saer "que en ese falso conde polaco, siempre al borde del desmoronamiento, roído por la miseria, el desaliento y la mala salud, había algo de inquebrantable y de heroico" (Saer, El río 156).

Saer reconoce en esta figura los atributos de una resistencia ética que va a contrapelo de las expectativas culturales y políticas de la época, otra forma de la refracción ética que el mismo Saer asumiría en 1968 y posteriormente. Según argumenta Gasparini, a diferencia de Caillois, que llevó adelante una tarea de diálogo cultural entre los valores de su patria y los de la nación anfitriona, Gombrowicz se negó a cumplir esta tarea, no actuó como el portavoz de Polonia porque su manera de pensar la nación se lo impedía, aun sabiendo que hubiera sido amparado por la institución literaria si se hubiera asimilado al resto de los conferencistas polacos que clamaban por

\footnotetext{
${ }^{100}$ En 1991, y a propósito de la muerte de Fernando Espino, Saer escribe una semblanza en su homenaje en la que reconoce "una deuda en el tiempo" con el pintor que encarnó "el arquetipo ideal del artista, en conflicto constante con el conformismo de su época y con sus propias tendencias autodestructivas" (Saer, "El pintor Fernando Espino", Ensayos 193) y que reúne todos los atributos que Saer entenderá como necesarios en un verdadero artista: iconoclastia, independencia artística, carácter salvaje y bohemio, divergente y polémico con respecto a los pintores oficiales. Como en el caso de Gombrowicz, Saer convierte los exabruptos, la borrachera y la impertinencia en los atributos del héroe e invierte positivamente los signos: "aunque la mayor parte del tiempo su conversación se limitaba a gruñidos, a sarcasmos musitados y a ironías desdeñosas y críticas [...] nunca puse en duda ni su gusto ni su fineza, ni su inteligencia crítica, de los cuales su propia pintura era la prueba irrefutable" (Saer, "El pintor Fernando Espino", Ensayos 194).
} 
la liberación de su país y escribían textos comprometidos. En este sentido, Gombrowicz es el representante de una "ética de la resistencia", como apunta Czeslaw Milosz, ${ }^{101}$ el escritor y amigo de Gombrowicz en París, que se perfecciona en el apuntalamiento de su 'inmadura' individualidad y en la desarticulación de los valores nacionales de su patria. Efectivamente, para Gombrowicz, Polonia, como también Argentina, y su institución literaria estaban demasiado llenas de "cierta arrolladora moralidad nacional" (citado en Gasparini 69) y por lo tanto su aporte consistía en liberar a la literatura polaca de su culto a la Nación. A diferencia de la Francia de Caillois, "la patria que imagina [Gombrowicz] desde su exilio parece erigirse desde lo usualmente deshonroso o descartado" (Gasparini 70), una patria definida con los signos de la minoridad, una terreno accidentado y un lugar de transición en que el Este y Occidente comenzarían a fallar: "Argentina y Polonia son propuestas de este modo como los guarangos confines que podrían llegar a no reconocer los Sublimes Valores al parecer instaurados en la Absoluta Europa" (Gasparini 71). Como continúa explicando Gasparini, Argentina y Polonia son dos naciones menores, culturalmente heterogéneas, marginales y aún no "formadas", inmaduras y por eso mismo potenciales apuntaladoras de sujetos individuales capaces de desmontar la "madurez europea" y los valores abstractos y totalizantes de la cultura y de la razón.

Será precisamente esta la "perspectiva exterior" de Gombrowicz con respecto a Polonia, pero fundamentalmente con respecto a la cultura occidental, que celebra Saer en su ensayo y retoma para la cultura argentina. Gombrowicz es así el más atípico de los exiliados, el menos integrado, el más singular y esquivo a las clasificaciones y fosilizaciones nacionales y políticas. Como se verá más adelante, Saer compartirá una idea de patria similar y desmontará, como el escritor polaco, todos los lugares comunes asociados a ella: territorio, afectividad e infancia. Pero además, ser Gombrowicz y no Caillois, ni Ortega y Gasset ni otro emigrado polaco, le permite extender sobre el arte la misma tarea destructora que pretende con respecto al culto de lo nacional. En su Diario argentino Gombrowicz abjurará de las abstracciones y de los grandes "valores" de la cultura. El arte debe destruir la realidad, descomponerla en elementos y construir con ellos nuevos mundos absurdos. Gombrowicz disputa con quienes le exigen al arte una claridad "clásica" y postula en cambio un arte de la nocturnidad y la ceguera:

\footnotetext{
${ }^{101}$ Gasparini cita las palabras de Milosz: "En tal situación, ¿cuánta convicción en el valor de lo que se hace será necesaria no sólo para no decaer, sino también para negarse a escribir por dinero o, al menos, por los aplausos?" (en Gasparini 65).
} 
Su claridad [la del arte] es nocturna, no la del día. Su claridad es precisamente igual a la de una linterna que extrae de las tinieblas un objeto, sumergiendo el resto en la oscuridad más insondable. Debe ser -fuera de los límites de la luzoscura como la sentencia de una pitonisa de rostro velado, no dicha sino hasta el final, tornasolada por multitud de significados y más amplia que la razón. [...] Hay que ir en pleno mediodía a contemplar la Venus más clásica para encontrar en ella la noche más oscura (Diario 93).

En "Narrathon" (1973), uno de los textos claves para considerar las ideas sobre novela y narración en el proyecto literario saereano, el escritor utilizará una imagen similar para pensar la tarea de la narración: "Pero la modestia reside en hablar, en tanto que ciego, a los demás, para que vean, no la realidad, o una realidad, sino más bien la ceguera de que sufren y de la que, en la mayoría de los casos, no son conscientes más que a medias" (Saer, El concepto de ficción142). Los escritores, filósofos y poetas forman: "Un círculo de miradas semienceguecidas, alrededor de una catástrofe común" (142).

La crítica artística y literaria de Gombrowicz, fundada desde la intemperie, le permitirá exigirle a la literatura argentina que abandone su "condición escolar" y relativizar, como lo hará Saer, la infalibilidad europea. En el Diario argentino parodia las distintas causas que los intelectuales de Latinoamérica ensayan a la hora de explicar la ausencia de una "gran literatura" (y las alternativas que da van desde "romper con Europa, volver a encontrar al indio de hace cuatrocientos años", volver "a la Patria España y a la Madre Iglesia Católica", "estudiar a Marx" o apelar al más fino cosmopolitismo. Las opciones son, consecuentemente, las que dan los nacionalistas, conservadores, izquierdistas e internacionalistas de Sur). "El problema principal para estos artistas no es expresar su pasión y construir un mundo, sino escribir una novela de 'nivel europeo' para que Argentina, para que América del Sur, logre al fin su papel representativo" (Gombrowicz 123). Esta oposición crítica al papel legitimador de Europa se expresará también cuando él asuma su regreso. Enfermo y débil ingresa a París, ciudad a la que no iba desde 1928, en que la dejó siendo un estudiante insignificante y desconocido, y se autoimpone una consigna "como literato debía aislarme de París" (Gombrowicz 265), debe ser su enemigo porque París representa esa madurez de la que quería escapar: "Conocía desde tiempo atrás las fuentes ocultas de mi fobia parisina, sabía que esta ciudad tocaba mi parte más sensible, la edad, el problema de la edad, y es cierto que si estaba en riña con París era debido a que se trataba de una ciudad 'que pasaba de los cuarenta' " (264). Como señala la crítica, a pesar de esta actitud, Gombrowicz terminará consagrándose en Europa como escritor. Interesa sin 
embargo retener esa actitud refractaria a la ciudad luz, que en Saer era al comienzo "indiferencia", destino involuntario, y más tarde, voluntaria separación "provinciana".

Si durante su vida y su carrera literaria en Santa Fe y Rosario Saer desarticula las tajantes oposiciones entre capital e interior, afirma en cambio su "provincialismo" en París:

Nunca fui muy afrancesado y nunca quise conocer los lugares de los escritores. [...] Respecto a las tramas literarias, en París también existe un enjambre infernal pero yo no tengo nada que ver con eso. Cuando leo a los escritores franceses es como si todavía estuviera leyéndolos en Santa Fe. [...] Se supone que los que viven en París tienen que estar todo el tiempo haciendo una vida literaria pero París es una ciudad como Buenos Aires. Uno puede vivir en un barrio alejado y no conocer a nadie (Speranza, Una forma más real 102).

Porque, como dirá en otra oportunidad, las "capitales" no son los lugares de los escritores sino de los escribas:

París es sin duda una gran capital, y los escribas contemporáneos buscan, como por instinto, las capitales. [...] Para un escritor, en cambio, nada mejor que el aislamiento, la independencia, el anonimato. Eso lo sumerge en la zona oscura de la historia que es donde la escasa realidad de este mundo conserva todavía sus últimos estremecimientos (Saer, Ensayos 153-154).

Como decíamos, Gombrowicz le provee a Saer la imagen de un viajero que escribe y funda desde la intemperie más absoluta una literatura y una lengua que, como postulará desafiantemente Piglia, ${ }^{102}$ modifica el español rioplatense y las redes de la tradición de la novela argentina. Colocado en la serie de escritores contemporáneos, Gombrowicz es vinculado a Borges. En el ensayo ya mencionado, Saer reescribe a ambos y reexamina la conocida conferencia borgeana "El escritor argentino y la tradición". La reescritura que practica Saer trasciende "La perspectiva exterior: Gombrowicz en Argentina" y se extiende a un puñado de ensayos y opiniones en las que sigue debatiendo con el texto de Borges. ${ }^{103}$ En primer lugar y según la formulación de Saer, Borges y Gombrowicz reactualizan un debate siempre presente en la cultura argentina y ponen en primer plano el conflicto que se establece entre un nacionalismo excesivo, de tipo reactivo, y un deslumbramiento, también excesivo, por la literatura europea. Saer reconstruye una serie de escenas - reales y ficcionales- en las que Gombrowicz y Borges aparecen como los duelistas de Transatlántico o como los escritores invitados a una cena catastrófica que reescribe en clave nacional la también

${ }^{102}$ Cfr. Piglia, Ricardo. “Existe la novela argentina?” en Crítica y ficción.

${ }^{103}$ Debate que puede seguirse en El río sin orillas y también, como se verá, en "El escritor argentino en su tradición" (2000), un artículo incluido en Trabajos. 
frustrada cena entre Joyce y Proust. De esos desencuentros -en los que se mezclan la indiferencia borgeana y los mordaces comentarios de Gombrowicz hacia Borges--, Saer es el mediador, el juez que, avalado por su posición en la historia de las generaciones, puede juzgar ecuánimemente los testimonios y comportamientos de ambos duelistas. ${ }^{104}$ A partir de este dístico en el que Saer traza las similitudes y diferencias entre ambos, concluye que resuelven de la misma manera el problema de la tradición y dialogan "desde esas orillas remotas, con la cultura occidental" (Saer, "La perspectiva exterior" 28). ${ }^{105}$

Pero además, resulta interesante leer este ensayo en relación a un texto anterior, también incluido en El concepto de ficción, "Sobre la cultura europea" (1988) porque si en el ensayo recién mencionado Saer se concentraba en desandar el atormentado nacionalismo del país, aquí desarticula el otro núcleo del conflicto ("el deslumbramiento, secreto o confesado, por la literatura europea") a partir, como se verá, de esa valiosa figura ampliada del "exilio", del que Gombrowicz es ejemplo por antonomasia. En este ensayo, como decíamos, Saer desmonta algunos de los principales

\footnotetext{
${ }^{104}$ Saer señala que Gombrowicz se equivocaba al imputarle a Borges el sentido de europeizante, porque ese término supone una adscripción acrítica a todo lo que proviene de Europa y Borges solo es europeizante, sintiéndose a la vez dentro y fuera, de la misma manera en que lo fue Gombrowicz. En realidad, pareciera que aquí Saer "defiende" a Borges de las acusaciones de Gombrowicz matizándolas a partir de sus propios comportamientos. Por ejemplo, en relación al pretendido snobismo de los orígenes militares e ingleses de Borges, ya que Gombrowicz decía de sí mismo que era conde.

${ }^{105}$ En "Besos bárbaros: pretensión y privación cultural" Pastormerlo repasa, los textos críticos de Borges y fundamentalmente "Pierre Menard, autor del Quijote". Advierte que Borges distinguirá al lector "supersticioso" (el que reitera apreciaciones ajenas y cristalizadas porque en realidad no puede ejercer autónomamente el gusto, signo de una privación cultural que señala su falta de familiaridad con la literatura y huella del anacronismo literario desde el que 'venera' los textos clásicos y los 'textos originales') del "lector ingenuo" (capaz de leer sin supersticiones y cuya 'privación' y desconocimiento de las interpretaciones canonizadas se experimenta como un modo feliz de ejercer una lectura nueva y productiva). La figura del "supersticioso" apunta a señalar la declinación de la ideología romántica como una religión de la que ya no es posible participar. En contraposición, Borges postulará la figura del "irreverente reverenciado" (Menard), aquel que mantiene una relación profana y sacrílega con la literatura. Según explica Pastormerlo, Borges aprende de Groussac el término "superstición", quien también desestimaba la devoción y la credulidad literaria: "La actitud de Groussac, el inquisidor de veneraciones supersticiosas que hace casi una militancia de la irreverencia a la literatura reverenciada, se deja explicar, quizá, por su condición de francés en un país que reverenciaba la cultura francesa" (Pastormerlo 5). Interesa la emergencia histórica de la figura del "supersticioso", que Pastormerlo asocia con la declinación de la ideología romántica de la veneración (Rubén Darío y Lugones) y el pasaje a la ideología literaria "profana", que se produce entre finales del siglo XIX y principios del siglo XX en Europa, y algo más tardíamente en la literatura argentina alrededor de la generación de Borges y Arlt. Borges, entonces, hereda la fórmula de la "superstición" de Groussac, un extranjero que no dejaba de ser un "irreverente reverenciado"; Saer participa de esa herencia cultural irreverente pero "su" extranjero, Gombrowicz, es un irreverente no reverenciado que atenta contra la venerabilidad de la cultura europea.
} 
presupuestos ligados a la idea de tradición occidental: Europa no puede seguir sosteniéndose sobre la utopía de los valores humanistas, porque su unidad en realidad se basa, señala Saer, en la voluntad de poder y de competencia mercantil y tecnológica y la barbarie se vuelve el modelo de sus aspiraciones. En segundo lugar, retomando a Adorno y Horckheimer, Saer desarticula la idea de "razón occidental", porque como ya fue demostrado, la razón fue el principal instrumento de servidumbre. Se pregunta entonces si el concepto mismo de tradición universal, "como concepción de la historia, no es una superstición" (86) y reconociendo irónicamente la "riqueza artística, científica y filosófica del continente europeo" (86) afirma que los tan mentados "escritores europeos" no son sino escritores exiliados de esa tradición, que escriben en su contra. Vuelve a mencionar las alternativas que le opusieron a Europa, alternativas, como se recordará, que antes habían formado parte de la noción ampliada de exilio: "A esa adversidad respondieron con el silencio desdeñoso (Beckett), el insulto (Baudelaire), la fuga (Rimbaud), la locura (Nietzche), el enclaustramiento (Proust y Kafka), el suicidio (Pavese o Celan)" (Saer, "Sobre la cultura europea" 87).

Sin embargo, en al menos dos intervenciones posteriores Saer debate con el ensayo borgeano. En "El escritor argentino en su tradición" (2000) y en una entrevista realizada por Mariano Dupont, "La lección del maestro", Saer advierte: "La idea central de Borges es que nosotros pertenecemos a la tradición de Occidente. En eso estoy totalmente de acuerdo. Pero lo que a mi juicio Borges no señala lo suficiente es que esa tradición es modificada por nuestras prácticas. Sarmiento, Borges mismo, Macedonio, son muy buenos ejemplos de ese trabajo de modificación de la tradición de Occidente" (138- 139). Lo que Borges "parece ignorar [son] las transformaciones que el elemento propiamente local le impone a las influencias que recibe" (Saer, Trabajos 66). Resulta al menos extraña esta reconversión al ensayo borgeano, puesto que, como el mismo Saer advierte, Borges reescribe críticamente la tradición occidental en su literatura y ya en la conferencia de 1953 hablaba del derecho de manejar todos los temas europeos "sin supersticiones" e irreverentemente. ${ }^{106}$ Y quizás ese contrapunto, agudizado como se ve

\footnotetext{
106 Así lo entiende Piglia en “¿Existe la novela argentina?”: "En este punto Borges y Gombrowicz se acercan", en relación a cómo escribir desde una cultura secundaria y en una lengua marginal, y señala además una afinidad de estrategias en este uso irreverente de la tradición, estrategias que Saer también había puntualizado entre ambos en "La perspectiva exterior", pero que parece luego haber "olvidado". Dice entonces Piglia: "Para Borges (como para Gombrowicz) este lugar incierto permite un uso específico de la herencia cultural: los mecanismos de falsificación, la tentación del robo, la traducción como plagio, la mezcla, la combinación de registros, el entrevero de filiaciones" (51).
} 
en sus textos tardíos, pueda leerse como el intento de Saer por despegarse de la sombra borgeana. ${ }^{107}$ En la entrevista anteriormente mencionada, "La lección del maestro", muy abocada en un principio a revelar el influjo de Borges en los ensayos de La narraciónobjeto, se adivina cierta incomodidad por parte de Saer, quien sin dejar de reconocer esa presencia, la abre a disímiles referencias internacionales. ${ }^{108}$

\subsection{Una vocación temporal: versiones de la patria según Saer}

¿Qué sería entonces "lo local” en la formulación de Saer?, ¿qué es eso que Borges no termina de particularizar? Como se verá, a lo largo de sus ensayos y de sus textos ficcionales Saer definirá, con ciertas oscilaciones, su particular idea de patria. Volviendo entonces al inicio del ensayo "La perspectiva exterior: Gombrowicz en Argentina", las tres alternativas nacionales del comienzo que Saer da en infinitivo: "ser" polaco, argentino o francés, le permiten relativizar y suspender las adscripciones nacionales y avanzar, en los años en los que escribe el ensayo, hacia una definición de "lugar" que se juega en la suspensión del territorio y en la imaginación de un continuum que enlaza ciudades geográficamente distanciadas: 109 "Mi proyecto desde hace años es

${ }^{107}$ Como se mencionó anteriormente, en Zona Saer Sarlo advierte que Saer debió "matar" a Borges para convertirse en escritor, por ello lo "olvida" desde muy joven y lo lee en medio de otras referencias no borgeanas: "[Saer] lee a Faulkner, mucho, a Pavese. [...] Borges, a quien por supuesto admira, entra a mezclarse con un sistema de autores no borgeano" (36).

${ }^{108}$ Dupont lee un gesto borgeano en La narración-objeto en la lectura a contrapelo que se hace del Quijote, de las letras de tango y de los textos del mismo Borges. Saer señala entonces la necesidad de "salir de Borges": "Podríamos hablar de críticos tan o más importantes que Borges, y a los cuales Borges les debe mucho. Críticos como William Hazlitt o Marcel Schwob, o los primeros críticos de este siglo. Y después, críticos a los cuáles Borges no les debe nada, pero que para mí son tan importantes como él. Michel Butor, por ejemplo, o Eliot..." (Una forma más real 134). Luego Saer se ufana de haber confrontado con la figura de Borges en el Congreso celebrado en su honor en Londres y por haber escandalizado a un público demasiado encandilado por la figura del "ciego maestro de la Biblioteca Nacional" (139).

${ }^{109}$ En las "Notas críticas" a Glosa, Premat explica claramente esta idea a propósito de las dos caminatas que especularmente se proyectan en la novela. La caminata de Leto y el Matemático se repite en París, entre el Matemático y Pichón Garay. Los dos personajes de la zona se encuentran años más tarde y caminan por el Boulevard Saint Germain junto a un grupo de exiliados que va a pedirle al bloque de diputados socialistas que intercedan por las víctimas del terrorismo de estado en Argentina. Entre una y otra caminata, afirma Premat, la ficción pasa de la comedia a la tragedia política, sin embargo, ambas se tejen sobre el continuum espacial que Saer fragua bajo su singular concepción de 'Lugar': "esta indeterminación geográfica, en donde cualquier lugar del planeta refleja o repite lo que sucede en la zona (el lugar saeriano) por excelencia, tiende a convertir al término 'Lugar' en un concepto personal, que sería el espacio de la experiencia humana, fuera de toda coordenada geográfica" ("Notas críticas", Glosa-El Entenado196). 
poder vivir en los dos lados al mismo tiempo. De todas maneras, siempre viví entre Rosario y Santa Fe, entre Rennes y París, de modo que podría vivir perfectamente entre París y Santa Fe" (Tamborena, Mónica y Sergio Racuzzi, Una forma más real 37). ${ }^{110}$ En varias entrevistas Saer explica su concepción del espacio, que también usa para sus ficciones, especialmente para Glosa.

Creo que esto tiene que ver con que el espacio se va creando con el desplazamiento mismo de los personajes. Y al mismo tiempo, todos los espacios quedan relacionados. El hecho de ir y venir, por ejemplo, produce cierta continuidad de diferentes espacios puramente imaginarios. En Glosa, la idea de que todos estamos en el mismo espacio y en el mismo tiempo es uno de los temas principales del libro (Saavedra, Una forma más real 64-5).

Desde el exilio Saer imagina para sí un lugar móvil "entre" ciudades, y progresivamente desarticula la idea de "patria". En un texto temprano, escrito pocos años después de su llegada a Francia, "Lo que es mejor a orillas del Paraná que en París" (1971) comienza a ensayar su versión libre y privada de la patria y enumera, bajo ese título, una serie abigarrada de sensaciones, afectos y elementos ligados a la naturaleza:

El pan casero, el aire en invierno, los caballos, el jacarandá florecido, el amarillo y el moncholo, los aromos florecidos, el sol de enero y de febrero, los ríos espesos y entrecruzados [...] los detritus, las ocasiones, los juegos, la esperanza, el sonido, la madera, el destierro [...] los papeles, las lágrimas, los nombres (Saer, Papeles II, 55-56).

Una especie de aleph santafesino que apresa por un momento la materia huidiza del recuerdo pero que no habría que leer en términos de nostalgia sino de construcción, privada e íntima, profundamente literaria, de la patria. ${ }^{111}$

\footnotetext{
${ }^{110}$ En la misma entrevista de Miguel Russo Saer explicita este continuum espacial: "Estoy en París, pero estoy en Santa Fe. Camino por Francia, miro cómo nieva por la ventana de mi departamento, pero también me sigo sentado en los patios cerveceros de mi provincia, y veo el río y paso tardes maravillosas en los bares de Colastiné".

111 También Gombrowicz, cuando evoca la seducción que sobre él representaron las pampas argentinas, ensaya una definición -caótica y poética- del país: “¿Vieja? Sí. ¿Triangular? También cuadrada, azul, ácida en el eje, amarga desde luego, sí, pero también inferior y un poco parecida al brillo del calzado, a un topo, a un postre o a la puerta, también del género de las tortugas, fatigada, embadurnada, hinchada como un árbol hueco o una vasija, parecida a un chimpancé, consumida por el orín, perversa, sofisticada, simiesca, parecida también a un sándwich y a un empaste dental... Oh, escribo lo que me sale de la pluma, porque todo, cualquier cosa que diga puede aplicarse a la Argentina" (246).
} 
La patria, señala Saer en el borrador de la entrevista "Una de las propuestas principales de Nadie nada nunca..." (1981) es la palabra del diccionario de la que más sospecha, de todas "las abstracciones que nos oprimen, es una de las más sangrientas". Y distingue esa abstracción usada por los "carniceros" de su definición material, íntima y temporal de la patria:

Para mí la patria es ese lugar en su sentido más estricto y material. Lo nacional es la infancia, y es por lo tanto regional, e incluso local. La materialidad de la patria se confunde con mis experiencias y está constituida por la existencia precisa de paisajes, caras, nombres, experiencias comunes. [...] Por eso a veces me sé decir que todo regreso es imposible, ya que esa patria que nos parece persistir en el espacio no es otra cosa que una experiencia intensa vivida en un pasado irrecuperable. El regreso podría ser, en ese caso, una nueva forma del exilio (Saer, Ensayos 150).

En "Razones" Saer profundiza esta misma idea, ${ }^{112}$ la patria es una abstracción que nos presentan como absoluto y en realidad es contingente, "no hay ningún lugar ni acontecimiento predestinados: nuestro nacimiento es pura casualidad. Que de esa casualidad se deduzca un aluvión de deberes me parece perfectamente absurdo" (10). ${ }^{113}$ Como se verá, uno de los textos incluidos en esta antología, "Instrucciones familiares del letrado Koei”, desarticula justamente esos deberes del sujeto con su patria. Pero además, como ya había formulado antes, la patria en Saer no sólo es íntima y privada sino también móvil: "Lengua, sensación, afecto, emociones, pulsiones, sexualidad: de

112 "Razones" es el texto mediante el cual Saer responde a la entrevista que Gramuglio le envió en 1984, publicado en Juan José Saer por Juan José Saer.

${ }^{113}$ En "Política del exilio" Giorgio Agamben desmonta precisamente la ficción implícita de la relación entre el simple nacimiento, la vida desnuda, y la adscripción a una nación, fundamento de la vocación "nacional" y biopolítica del estado moderno (siglo XIX y XX). Los refugiados, señala, ponen en crisis esta ficción originaria y permiten cuestionar esa continuidad entre hombre y ciudadano. Agamben sigue los avatares históricos de esta relación y advierte que después de la Primera Guerra Mundial ese vínculo nacimiento-nación ya no podía seguir ejerciendo sus funciones legitimadoras. Por eso, propone pensar a "refugiados" y "exiliados" por lo que verdaderamente son: "un concepto límite que pone en crisis radical las categorías fundamentales de la Nación-Estado, desde el nexo nacimiento-nación hasta el de hombreciudadano" (Agamben, "Política del exilio" 46-7). La propuesta de Agamben es resituar la figura del exilio para dejar de pensarla como una figura política marginal y comenzar a pensarla - como se hacía en la filosofía clásica- como un concepto filosófico-político fundamental que permite desarmar "la espesa trama de la tradición política todavía hoy vigente" (52). Como puede observarse en sus ensayos y se verá en su prosa ficcional, Saer cuestiona precisamente ese vínculo entre nacimiento y deberes "patrióticos" de un sujeto y comparte esa deriva del exilio desde sus contingencias políticas hasta su condición ontológica como la única esfera posible en la que los artistas pueden sustraerse de los condicionamiento sociales y volver artísticamente productiva su separación. 
eso está hecha la patria de los hombres, a la que quieren volver continuamente y a la que llevan consigo donde quiera que vayan" (Saer, "Razones"10).

"Las instrucciones familiares del letrado Koei" es un texto raro, extraño al proyecto saeriano e incluido precisamente en la sección llamada "Márgenes" de Juan José Saer por Juan José Saer. El relato, en un gesto bastante borgeano, es presentado como una traducción de diferentes versiones francesas y recoge el único fragmento que quedó de la obra del escritor chino Koei, las "instrucciones familiares" que era costumbre que los jefes familiares dejaran a sus descendientes antes de morir. Sin embargo, la escritura de Koei arremete contra el género de las "instrucciones" y ofrece en cambio una "descarada" confesión de los "pecados" del letrado, una mezcla de autobiografía infame y de memoria escrita por un anciano escritor que examina su decisión de abandonar sus funciones en la corte del imperio de China cuando este fue invadido y dominado por los mongoles.

El relato se dedica a desarticular dos ideas: la primera, que la vejez sea sinónimo de sabiduría o de haber alcanzado una personalidad coherente, sólida, nítida y reconocible. La segunda, la concepción de que exista, efectivamente, una patria a la cual el individuo está unido por una serie de deberes cuyo cumplimiento lo volverían ese anciano venerado por los jóvenes. Por el contrario, afirma Koei, cuando él se alejó de la corte imperial no lo hizo por amor a la patria, en primer lugar porque no conocía gran parte de esa extensa geografía ni tampoco le gustaban algunas de las regiones que sí había transitado. Tampoco había tomado esa decisión en favor de su "patria" personal -su familia, su trabajo, algunos amigos- puesto que verdaderamente no peligraban con el cambio de administración, que, como reconoce Koei, no distaba casi en nada del imperio nacional y se volvía difícil diferenciar entre extranjeros y autóctonos.

La patria, continúa afirmando el escritor, tampoco podía definirse por el territorio o el idioma, precisamente porque la lógica del imperio estaba hecha de continuos desmembramientos y anexiones, y en él convivían múltiples lenguas y dialectos. La patria, por otro lado, tampoco podía circunscribirse a la casa, la infancia y los recuerdos, porque la naturaleza misma de la infancia es refractaria a los cambios de gobierno y el lugar de nacimiento es contingente, producto de la casualidad. La infancia es más un producto de la idealización del pasado que realiza nuestra memoria que un cúmulo de experiencias verificable. Koei, es, antes que autor de comedias dramáticas o escritor errante, un filósofo nihilista que niega que los actos obedezcan a algún tipo de justificación y se opone a esas grandes "abstracciones" de las que renegara también 
Gombrowicz - la patria y la sabiduría de los ancianos- porque lo único que puede dejarle a sus descendientes, al final de su vida, es "incertidumbres y porvenir" (55).

La patria de Saer es, entonces, tiempo antes que espacio; movilidad antes que fijación; viaje antes que morada; intimidad antes que identidad compartida; algo que se conoce poco, se olvida y se reconstruye antes que una certidumbre; porvenir antes que pasado. "Las instrucciones del letrado Koei" condensan y radicalizan la desarticulación que el escritor ensaya en entrevistas y ensayos y proyecta, anacrónicamente, en un letrado chino del siglo XIII, las incertezas y escepticidades de un escritor, mezcla de filósofo y poeta, profundamente exiliado, del siglo XX. 


\section{FICCIONES DEL EXTRANJERO}

¿Qué marcas deja la partida en las ficciones que se escriben alrededor del traslado a Francia?, ¿qué le hace el extranjero a esa unidad de lugar que Saer había configurado hasta 1968? La mayor es el libro que Saer comienza a escribir apenas llega a París, entre 1969 y 1975. Como ha señalado la crítica, el libro condensa una de las vertientes más radicales del proyecto saeriano, el momento negativista que rechaza con más fuerza la ilusión ontológica del lenguaje, desarticula la identidad del sujeto y la homogeneidad de la narración, en pos de un mundo contingente hecho de fragmentos que a la vez nos cobija y nos expulsa, y que, sin embargo, puede cantar o resplandecer en el vaivén de los recuerdos o en el "don" del presente. Conformado por dos extensos relatos -"La mayor" y "A medio borrar- y por una serie de 28 "argumentos", como advierte Dalmaroni en "Los aros de la sortija", la prosa se imanta y descalabra al contacto con los lenguajes de la poesía y de la pintura, dos formas de la detención y de la condensación a partir de las cuales Saer ensaya una serie de variadas experimentaciones.

Interesa leer aquí "las innumerables conexiones que este libro expande de un modo radial y radicular hacia el resto de la obra saeriana" (Dalmaroni, "Los aros de la sortija", Zona de prólogos 85) en relación con dos aspectos en particular: el viaje y el extranjero, y el modo en que se narran las partidas de los personajes. Efectivamente, $L a$ mayor puede leerse como un catálogo minucioso aunque no exhaustivo de las diferentes formas del desplazamiento, que a la vez permite recuperar viajes que tuvieron lugar en ficciones anteriores y abrir otros que desarrollarán posteriormente algunas de las novelas. Para mencionar sólo algunas de estas ocurrencias: en "Biografía de Higinio Gómez" Saer dibuja en pocos trazos el viaje de artista del poeta Higinio Gómez, uno de los "viejos" del elenco de personajes de la zona, que escribía extensos poemas narrativos y que solía comentar entre sus amigos que "el extranjero lo mareaba". ${ }^{114}$ Pero además, "El intérprete" se retrotrae al viaje de la conquista que expandirá, como se sabe, El entenado. "Manos y planetas" abre la imaginación al viaje de exploración

\footnotetext{
${ }^{114}$ El viaje de Higinio Gómez se inscribe en ese momento de agotamiento de las vanguardias europeas y de radical transformación del escenario europeo que abriría la Segunda Guerra Mundial. Su relación con el surrealismo no es azarosa, en más de una oportunidad Saer disputará con los principios estéticos del movimiento y con su idea del artista como visionario. Cfr. Dalmaroni, Miguel. "Los aros de la sortija”, en Ricci, Paulo. Zona de prólogos.
} 
espacial que reescribirá, muchísimos años después, "Ligustros en flor"; "Cambio de domicilio" retoma el relato del exilio político -en este caso, un exilio interno, desde Buenos Aires al interior- para reflexionar sobre las imposibilidades de modificar verdaderamente el "pantano" que caracteriza siempre la turbulenta subjetividad de los personajes de Saer. "El viajero" inscribe el atormentado errabundeo circular de un viajero inglés por la llanura e inaugura el ciclo de ficciones sobre otros viajeros del siglo XIX que Saer retomará en La ocasión y Las nubes. Como se puede observar a partir de esta somera enumeración, la tensión extranjero-zona modula gran parte de la primera producción saeriana en París. Interesa pensar entonces de qué desplazamientos, partidas y regresos truncos está hecha esa zona y considerar qué reflexiones sobre el exilio, la dispersión y lo natal vehiculizan estas ficciones, en relación, por supuesto, a las que también aparecían en sus poesías y ensayos de la misma época y que se explicitarán en las décadas del ochenta y del noventa.

Para esos primeros años de su residencia en el extranjero, Saer desafía la clásica pareja viajar/contar y la reemplaza por su negativo: viajar/borrar. El sujeto que viaja es aquel que borra y se borra de un espacio, aquel que solo puede ofrecer, como imagen de su viaje, lo que está quedando de ese lugar al que ya no pertenece, pero que difícilmente puede decir algo sobre el lugar al que arriba. Como haría el mismo Saer con respecto a las esquivas imágenes de París, el personaje saeriano que viaja, fija sus ojos en lo que deja. Y aunque no es, por supuesto, solo el traslado real de 1968 el que dispara las ficciones de viaje, interrogaremos qué marcas deja el extranjero en la fícción.

\subsection{Dejar la zona}

Saer escribe, por decirlo de algún modo, dos veces el mismo cuento. "A medio borrar", redactado en 1971, ya había sido escrito en 1966, bajo el título "Fragmentos",

como él mismo señala en una entrevista a propósito de la recurrencia insistente y a veces involuntaria de ciertos temas en su obra:

cuando volví a la Argentina años después de haberlo escrito e incluso publicado, encontré, entre los papeles que mi hermana había podido salvar de una inundación y de otros cataclismos, un cuaderno y una carpeta; [...] descubrí que ese cuento, "A medio borrar", ya lo había escrito antes. Y me había olvidado por completo de 
que lo había escrito. Estaba inconcluso, pero era la misma historia (Una forma más real 201).

El relato publicado en el que finalmente Pichón Garay abandona la ciudad en medio de una gran inundación para viajar a París se vuelve fundamental porque abre definitivamente un hiato en la zona, pero a su vez porque tiende una serie de lazos con algunos de los argumentos de La mayor -fundamentalmente con "Discusión sobre el término zona", "Me llamo Pichón Garay" y "En el extranjero"- y con las poesías inéditas que tienen a Pichón Garay como personaje. A su vez, permite releer el otro gran abandono del espacio natal: la partida de Willy Gutiérrez.

"Fragmentos" (1966) y “A medio borrar" (1971) tienen algunos puntos en común: ${ }^{115}$ en ambos relatos la ciudad está amenazada por una inundación que no parece detenerse. Dos personajes, uno pintor y el otro escritor, recorren las zonas afectadas de la ciudad y comprueban los derrumbes causados por las explosiones que ha hecho el ejército para evitar que el agua se llevara el puente colgante. En ambos, además, hay un personaje que está próximo a abandonar la ciudad para ir a Francia. De "Fragmentos" al relato editado, sin embargo, se ha estabilizado el "elenco estable" de los personajes, como le gusta decir a Saer, y quienes en el cuento de 1966 eran sujetos desconocidos u ostentaban nombres estruendosamente literarios: Víctor Hugo, Miguel (el pintor), Clotilde, Cielo y un narrador sin nombre, pasan a ser Pichón y el Gato Garay, Héctor, Elisa, Washington Noriega, Wenceslao y Tomatis en "A medio borrar".

Pero además, lo que se modifica también es la relación que los sujetos mantienen con el viaje a París. Repasemos: en "Fragmentos", quien está por viajar a Francia para exponer en una muestra inaugurada por Malraux es el pintor, Miguel, que dice no tener demasiados deseos de regresar, y añade que sólo lo haría para volver a probar la sopa de cebollas que hacen los franceses. Clotilde, su esposa, agrega que Francia es una antigüedad. Como señala Litvan, la atmósfera del relato está explícitamente atravesada por referencias literarias, pictóricas y filosóficas -el narrador quiere releer Las palmeras salvajes de Faulkner a propósito de la inundación, los personajes se demoran en charlas vagamente filosóficas, citan a Pascal, hablan de Klee

\footnotetext{
${ }^{115}$ En ““A medio borrar' en el origen: de Saer a Saer" Valentina Litvan compara ambos relatos para observar cómo opera en Saer una poética del desplazamiento, una escritura que tiene su origen en una posición distanciada. Cfr. también, a propósito del imaginario fluvial de "Fragmentos", el artículo " 'En un lugar arcaico y sin orillas'. Imágenes del río en la obra de Juan José Saer" de Graciela Villanueva.
} 
y de Proust-. De todos modos, el viaje está en un horizonte aún distante y lo que impera son las vueltas por la ciudad, los encuentros con los amigos y los triángulos amorosos, como si el relato prolongara el movimiento y el tono de La vuelta completa, publicada ese mismo año de 1966 pero escrita entre 1961 y 1963. En “A medio borrar”, en cambio, la relación con el viaje se complejiza. Por un lado, Héctor, el pintor vanguardista, ya ha viajado y expuesto en Francia, pero es el viaje de Pichón Garay el que está próximo a cumplirse y cuya inminencia agudiza la progresiva borradura del paisaje. Ambos cuentos están escandidos por una pregunta que se reitera: “¿Oíste las explosiones?" Las dos historias son una prolongada respuesta a esa pregunta, que acumula no sólo la evocación del lugar en el que estuvieron los personajes cuando oyeron las explosiones, sino también la evidencia visual de la destrucción. Sin embargo, de "Fragmentos" a "A medio borrar" interviene más fuertemente la "perspectiva exterior" del viajero, en este caso, la mirada artística de Héctor. El paisaje de "Fragmentos" es:

[un] amontonamiento de caños de desagüe que chorreaban agua manchada de óxido, y las pilas de escombros rescatados del murallón carcomido por el agua. [...] Desde el puente el panorama era más amplio; el agua se confundía con el cielo, a los dos lados. [...] De trecho en trecho se divisaba en esa planicie lisa y resplandeciente el manchón verdoso de la copa de algún árbol o el techo de paja de algún rancho semiderruido (Saer, Papeles 135).

Similar a este paisaje, se presenta el de "A medio borrar", sólo que éste viene precedido por el recuerdo europeo de Héctor, que emerge "como un chorro [...] pulido y perfecto por la continua repetición" (149) y que reitera su permanencia en París durante tres años, sus veraneos en Italia, sus exposiciones en Londres, en Amsterdam y en Copenhague; el contacto con artistas surrealistas -como Roberto Matta, el pintor chileno-, las frecuentes visitas a la casa de Breton y la traducción de textos surrealistas que Edgard Bayley trató de hacer publicar en una revista que dejó de salir justo en ese momento. Así, el paisaje inundado que acumula "un desorden inacabable de objetos: camas, roperos, retratos, sillas, ollas, carros, colchones, animales, hombres" (150) le evoca los mercados de objetos usados que hay en París, el del Marché Aux Puces y el del Hôtel Druot, altamente surrealistas. Sin embargo, él ha renegado de dicha vanguardia (y ahora responde a la vanguardia del justicialismo, dice en modo de chanza) porque demasiado amor por los objetos perturba la reflexión metafísica. La conversación entre Pichón Garay y Héctor, bordeando siempre el comentario irónico e ingenioso, permite atisbar qué elecciones visuales y artísticas admite o desecha el 
paisaje inundado de la zona. El relato exhibe su reemplazo, el paisaje derruido no puede entenderse a partir del montaje surrealista ni del gregarismo misterioso de los objetos en los mercados parisinos, sino a partir de una desaparición progresiva de lo visible que encuentra su correspondencia visual en el cuadro suprematista de Héctor y en las continuas apariciones del blanco. ${ }^{116}$

Pero además, y a diferencia de "Fragmentos", el cuento diseña una imagen de viajero que, como se verá en los capítulos siguientes, se reitera en la obra saeriana. Pichón Garay, como señala Premat, niega la carga afectiva de su partida. No demuestra expectativas por su viaje ni siente tampoco nada por el espacio natal que está a punto de abandonar en medio del cataclismo: ni asombro, ni miedo ni piedad por los que el agua barría. Cuando emergen en su mente imágenes de su hermano -el doble que sí permanece en la zona y a quien no puede encontrar para despedirse- y de sus amigos: "no es, [...] ni el amor, ni la nostalgia, ni ninguna raíz elemental lo que convoca, brillantes, estas imágenes, sino el misterio del tiempo, del espacio, sus operaciones inertes, densas, sólidas, más puras y más nítidas, más reales que nuestra adhesión, [...] y así de espesa" (Saer, "A medio borrar", La mayor 172). Washington Noriega le advierte: "viajar, ya lo veré, es pasar de lo particular a lo universal, y a medida que uno va viajando, lo particular va volviéndose universal y lo universal, particular; no hacen,

${ }^{116}$ Cuando Pichón Garay visita el taller de Héctor, contempla un cuadro terminado: "Es un rectángulo blanco, árido, que no difiere en nada de las paredes del taller" (Saer, "A medio borrar", La mayor 153). Si bien el relato incorpora otras imágenes también significativas, es ésta la que aparece bajo diversas modulaciones: el paisaje fluvial de la inundación también es uniforme y monocromático; el cuadro blanco es, a lo lejos, "como una ventana desde la que se estuviese viendo el amanecer" (156) y también es blanco el bloque de la municipalidad, que hundido en el cielo relumbra al sol; y finalmente el mismo personaje: "Soy, por así decir, el centro, la pared blanca, donde ondulan, como banderas, imágenes" (170). La insistencia con que se reitera esta imagen es más que un homenaje al Cuadrado blanco sobre fondo blanco (1918) de Malévich, el pintor suprematista por el que Héctor, pero también Saer y Renzi sentían una gran predilección. Se trata de una apropiación regional de la pintura vanguardista y de las morales de contemplación que exige, que, trasladadas al clima de catástrofe y desorden mítico que campea todo el relato, adquieren una densidad política. El mismo Héctor explica la significación de su obra, ejemplificándola con lo que ocurre cuando se echa un terrón de azúcar en un vaso de agua: "la durée objetiva [...]. Para que sea objetiva, dice Héctor, hay que medirla, hay que estar. Su cuadro, dice, es un fragmento ampliado de la durée objetiva" (157). Frente a la instantaneidad plana de la imagen televisiva que parpadea durante todo el relato, la obra y particularmente su contemplación se ralentizan y densifican. Esa durée explica también la comprensión diferida de la violencia del paisaje inundado y aquí es cuando un modo estético de la contemplación adquiere una inusitada carga política: "No he tenido, en meses, del agua, ninguna impresión de violencia, sino más bien, y más todavía cuando el hábito de la creciente se instaló entre nosotros, de discreción, de placidez, de silencio, y ha sido necesario ver a los hombres en la Boca del Tigre, en Colastiné, en campamentos, [...], comentando las explosiones, los informativos, para percibir, como en ráfagas, con quien llega a zonas, las atraviesa y por fin las deja atrás, estable, la violencia" (Saer, "A medio borrar" 162). 
dice, más que cambiar de lugar" (166). Una equivalencia, como se vio, que Saer sostendrá para el resto de sus obras -el continuum espacio-temporal de Glosa- pero también para su propia posición de lector y escritor -su tendencia a leer todo como si lo hiciera desde Santa Fe o a vivir en los márgenes silenciosos de París-. Esta indeterminación del paisaje, agudizada por el borrado que ha operado el agua, asume además el carácter de espacio originario de sabor geológico: "la sensación, más que de estar frente a un pueblo abandonado, de llegar, por primera vez y sobre todo los primeros, a un lugar virgen, sin vida animal, sumergido en un agua ciega en la que todavía no se ha formado la vida" (162).

Además, de "Fragmentos" a "A medio borrar" se ha ensanchado el alcance del exilio. En la primera versión inédita, el protagonista-narrador ha quedado imposibilitado de regresar a su casa porque ésta se ubica del otro lado del camino ahora cubierto de escombros, fragmentos de asfalto y tierra producto de las explosiones. Debe permanecer entonces en la casa de su madre. Es, como otros personajes de Saer, escritor y jugador, y sus amigos, y en particular Miguel, le advierten: "Te estás volviendo demasiado duro" (Saer, Papeles 137). Esa dureza y el progresivo aislamiento del personaje parecen radicalizarse en la figura de Pichón Garay. En el vértice de ambos relatos puede leerse "La dispersión", uno de los breves argumentos de La mayor en el que precisamente se distinguen diferentes clases de exilios: "La gente de mi generación se dispersa, en exilio. [...] La muerte, la política, el matrimonio, los viajes, han ido separándonos con silencio, cárceles, posesiones, océanos" (206), e incorpora una veta de distancia generacional que adquiere visos utópicos:

Años atrás, al comienzo, nos reuníamos en patios florecidos y charlábamos hasta el amanecer. Recorríamos la ciudad a paso lento, de las calles iluminadas del centro al río oscuro [...] bajo los paraísos de la casa natal. De esa vida pasada no nos quedan hoy más que noticias o recuerdos. [Para los que no se han separado] el exilio es más grande. Cada uno ha ido hundiéndose en su propio mar de lava endurecida. Todo el mundo tiene los ojos vueltos hacia adentro, pero esos ojos no miran más que un mar mineral, liso y grisáceo, refractario a toda determinación (Saer, "La dispersión", La mayor 206).

Lo que sugiere el tránsito de "Fragmentos" a "A medio borrar" es que ese joven narrador escéptico escindido de su hogar, ha terminado de endurecerse y de aislarse y que ahora sí, próximo a partir, mira indolente ese paisaje familiar, acuático o pétreo, refractario a toda emoción. Pichón Garay queda afuera, como señala Giordano en "El efecto de irreal", de todo lo que al parecer le es más propio e inalienable: el recuerdo 
que lo asalta de golpe; el sueño que se cierra "como el interior de un cajón, abierto apenas", cuando él se inclina para ver qué hay dentro; y la foto de la infancia en la que están con su hermano mellizo, indiferenciables ahora que Pichón permanece afuera de la fotografía. Queda además fuera de la ciudad y de los afectos y se define a partir de todos los lugares en que ya no está: "ya no estoy en el cuarto con los dos escritorios, en el dormitorio con las dos camas, ni interceptando con mi cuerpo la pantalla..." (152), a partir de lo cual saca la siguiente conclusión: "De este mundo, yo soy lo menos real. Basta que me mueva un poco para borrarme" (152).

Si La mayor no ofrece, como hubiera podido quizás esperarse, casi nada del paisaje parisino ni se constituye como el libro del "arribo" al extranjero, multiplica, por el contrario, las escenas de despedida y hace de la partida algo interminable, infinito. El muy comentado argumento "Discusión sobre el término zona" es otra escenificación de la partida. Allí, unos meses antes de que Pichón abandone la ciudad, se juntan a almorzar Lalo Lescano y Pichón Garay. Como sugiere Saer en una entrevista, el relato funciona a partir de una paradójica inversión: quien puede ostentar un origen noble como descendiente del fundador de la ciudad, Juan de Garay, y afirmar que extrañará es quien dejará la ciudad; Lalo Lescano, su antagonista, de origen humilde y oscuro es quien borra, por el contrario, los límites internos del mapa para afirmar que es imposible extrañar una región si no hay regiones, porque no hay manera de delimitar dónde empieza la costa o dónde termina la pampa gringa, ni tampoco definir dónde empieza el centro y dónde los arrabales de una ciudad. Sin embargo, la operación de borrado que hace Lalo Lescano es consustancial a la definición de viaje de Washington Noriega: para pasar de lo particular a lo universal y universalizar luego lo particular es necesario partir con un mapa cuyas fronteras difusas y orillas cabrilleantes permitan ese intercambio.

Además del viaje de Pichón Garay, varios personajes del elenco saeriano abandonan momentánea o definitivamente la zona. Pancho Expósito entra y sale de la ciudad cada vez que debe internarse en un hospital psiquiátrico de Buenos Aires, hasta que se traslada allí para no volver; César Rey anuncia en La vuelta completa que también se irá a la ciudad porteña y nos enteramos en La Grande que allí se suicida muchos años después. Sin embargo, de las diferentes imágenes de partida que despliega la literatura de Saer, dos probablemente son las más recordadas por sus lectores, la de Pichón Garay en "A medio borrar" recién comentada y la de Willy Gutiérrez en "Tango del viudo". Como se sabe, este último relato integra la segunda parte de En la zona y es, 
junto a los otros tres relatos que lo acompañan, una narración que se reescribirá en obras posteriores. La crítica ha señalado el carácter programático de esos cuatros relatos y ha enfatizado especialmente la continuidad que "Tango del viudo" teje con La grande ${ }^{117}$ advirtiendo además que el personaje ingresa en la serie de escritores de la zona, cuyo alejamiento supone no sólo conjurar un abandono amoroso sino también desechar sus tanteos literarios previos, ${ }^{118}$ "deslindar [las] impurezas, terminar con aquellos borradores que ahora no servían para nada, olvidar la técnica" (Saer, "Tango del viudo", La mayor 494) para conquistar por fin su madurez literaria, incendiando toda la producción de juventud. Y podría agregarse, además, que el relato provee las formas de la partida que luego “A medio borrar" precisará y expandirá. El primer libro de Saer ensaya de este modo dos de los movimientos básicos que se reiterarán después: los pasajes y movimientos en la zona, (en este caso, del arrabal al "centro" urbano) pero también las partidas hacia el extranjero.

Irse es abandonar o desmantelar una casa y detenerse por última vez en los objetos en los que se sedimentan experiencias compartidas -el colchón en el que se encontraban Gutiérrez con su amante; la serie de manuscritos, artículos y cartas que echa en la hoguera; la foto de los mellizos Garay, el escritorio de trabajo-. Pero además, partir significa dejar la ciudad y cumplir una serie de rituales sin patetismo -ir a cenar al bar de siempre; compartir una tarde con Washington Noriega-. Irse implica borrarse, sustraer el cuerpo y la voz de un espacio, por eso Pichón sabe que nada de él quedará en

\footnotetext{
${ }^{117}$ Cfr. "Estando empezando" de Julio Premat, La felicidad de la novela, de Rafael Arce y "El lugar de Saer" de Gramuglio.

${ }^{118}$ Como ha señalado Premat en "Estando empezando", el título del relato evoca el poema de Neruda "Tango del viudo", de Residencia en la tierra. Es decir, la partida de Gutiérrez es doblemente literaria, no sólo porque allí quema los manuscritos previos para afrontar de cero la escritura, sino también porque evoca un episodio poético de partida y abandono amoroso. En el poema, Neruda se despide de su amante birmana, llamada ficcionalmente Josie Bliss. Se trata de una poesía testimonial que escribe cuando su barco atravesaba el Golfo de Bengala rumbo a Colombo. Según Edmundo Olivares Briones, el poema asume y a la vez quiebra deliberadamente el dramatismo allí presente, filiándose con el género poético del "tango" a pesar de tratarse de un género que otros poetas, ansiosos de modernidad, hubieran podido juzgar como pasado de moda o cursi. Se trata en Neruda, como él mismo escribe en sus memorias, de un "trágico trozo de mi poesía destinado a la mujer que perdí y me perdió porque en su sangre crepitaba sin descanso el volcán de la cólera" (Neruda, citado Olivares Briones 162). El poema funciona, continúa señalando el crítico, como una posdata lírica de la carta de despedida que le deja el poeta antes de partir. Gutiérrez se verá tentado por esa expresión dramática que reverbera desde el poema de Neruda e imagina un desenlace novelesco para su aventura, se ve a él mismo escribiéndoles una carta a su amante y a su marido, el doctor Calcagno, en el que les reprocha el sentido burgués y utilitario de sus relaciones, pero deshecha la idea: para conquistar su independencia deberá irse solo y sin aviso, sin estridencias, respondiendo a la ética de impasibilidad que caracterizará la partida de todos los personajes de la zona.
} 
la ciudad, anegada además por la inundación, y por eso "Tango del viudo" es la glosa de un incendio en el que Gutiérrez quema sus manuscritos. Mientras crepita la hoguera, el personaje salva momentáneamente del fuego una poesía que -puesta en abismo mediante- también habla de una despedida apelando al imaginario marino. En ambos relatos, además, la partida se da en medio de un clima opresivo que acumula imágenes de muerte y destrucción. ${ }^{119}$

Los que parten del espacio natal se van solos, de noche y en colectivo, y no sienten, como se vio recién, ni nostalgia ni tristeza. Gutiérrez amarra las últimas imágenes de la zona a partir de un montaje bajo el que "aquel árbol [se une] con extrañas sensaciones estomacales, con jadeos y vómitos, aquella gruesa gota acerada y transparente con un acto sexual oscuro y asqueante" (497). Como se recordará, también Pichón Garay mira las últimas imágenes de un espacio en ruinas: el basural, las carpas mudas, las fogatas y las pilas de objetos desordenados. Sin embargo no hay imágenes ni recuerdos que vengan a plegarse a éstas, porque el que se va ya no es alguien sino "algo que ve" y se borra, gradualmente, de la ciudad. Los restos de subjetividad y de dramatismo que aún subsisten en "Tango del viudo", parodiados y censurados por el mismo Gutiérrez, ${ }^{120}$ desaparecen en la impasibilidad y la exterioridad que caracterizan a Pichón Garay.

Una vez en el extranjero, sin embargo, lo que los relatos muestran es el progreso disolvente de esa borradura que comenzaba a materializarse en "A medio borrar". "Me llamo Pichón Garay”, por ejemplo, un brevísimo argumento, termina relativizando la identidad del personaje "Me llamo, digo, Pichón Garay. Es un decir" (199) luego de que éste haya recibido la visita de su amigo Tomatis y haya quedado inmerso en una atmósfera de recuerdos "medio podridos, medio renacidos, medio muertos" (199). "En el extranjero", será Tomatis quien evoque las reflexiones que Pichón le envía por carta: una especie de epistolario negativista sobre la experiencia del extranjero, en sentencias vagamente aforísticas: "La nada no ocupa mi pensamiento sino mi vida", o "El

119 "Tango del viudo" evoca un posible imaginario quevediano en relación con el fin de la relación amorosa que Gutiérrez mantenía con Leonor Calcagno: "No ha quedado nada, no hemos dejado señal de nada vivo" (495) y mientras recorre el dormitorio oye "risas de polvo, voces de ceniza" y el aire tiene una "consistencia de cosa vieja, pútrida". El imaginario de la muerte se extiende al espacio urbano donde "los árboles, sin fronda, eran complicados esqueletos cernidos sobre su desvalida cabeza" (Saer, "Tango del viudo", En la zona 496).

120 "Caminó unos pasos y estiró un brazo apoyándose en la pared, como un personaje de tragedia que sostiene físicamente el peso de su sufrimiento. 'Vamos -se dijo- confesate de que toda la cuestión es porque ella no va a estar más en esa cama.' Movió la cabeza" (Saer, "Tango del viudo", En la zona 497). 
extranjero no deja rastro, sino recuerdos" (205). El argumento podría leerse como otra versión de la teoría de la memoria que incorpora "Recuerdos" porque lo que hace es distinguir dos experiencias disímiles: a diferencia de los recuerdos "[que] nos son a menudo exteriores: una película en colores de la que somos la pantalla" (205), los "rastros", "vienen de más lejos, son el signo que nos acompaña, que nos deforma y que moldea nuestra cara, como el puñetazo la nariz del boxeador" (205). El extranjero es concebido por Pichón Garay como una maquinaria inútil, como un rodeo que aleja del sujeto "ajo y verano", dos rastros que lo acompañan desde siempre y, podríamos decir, constituyen su versión íntima, material y experiencial de la patria. Sin embargo, aunque “irreal" - porque Pichón Garay puede reencontrar ajo y verano-, el extranjero termina constituyendo una amenaza: "De tanto viajar las huellas se entrecruzan, los rastros se sumergen o se aniquilan y si se vuelve alguna vez, no va que viene con uno, inasible, el extranjero, y se instala en la casa natal" (206).

\subsection{La última vuelta}

En Lugar (2000), el último libro de cuentos publicado por Saer, vuelven a problematizarse los conceptos de lo extranjero y lo natal a partir de dos operaciones concomitantes: la ampliación de lo topográfico (aspecto que ha sido por supuesto subrayado por la crítica), ${ }^{121}$ y la apelación a una temporalidad interesada en repasar los principales acontecimientos históricos del siglo XX. ${ }^{122}$ Este apartado no pretende analizar Lugar en su totalidad, por un lado porque varios de sus relatos serán retomados

\footnotetext{
${ }^{121}$ En relación con la crítica consultada, cfr. Gramuglio, María Teresa. "La expansión de los límites"; Mondragón, Juan Carlos. "A propósito de Lugar"; Premat, Julio. "Saer fin de siglo y el concepto de lugar" y Arce, Rafael. "Un enigma familiar: los últimos relatos de Juan José Saer". En la entrevista realizada por Margarita Merbilhaá a propósito de Lugar, Saer explicita esa voluntad de integración de espacios: "Nunca estuve en Egipto ni en los países del Este. Pero la extrañeza está en todo, son como inflexiones del mismo lugar. Pero el lugar está pensado, visto a partir del lugar donde transcurren todas mis ficciones" (4).

${ }^{122}$ Los cuentos de Lugar ficcionalizan acontecimientos históricos fundamentales: la experiencia de los campos de concentración y la caída del Muro de Berlín; la explosión de Chernóbil y la caída del régimen de Ceaucescu. Sin embargo, como en otros relatos de Saer, el elemento arcaico revela el fondo oscuro y pulsional de la historia, y sirve en este caso para desarticular imágenes estereotipadas del turismo. En "Las pirámides", por ejemplo: "Una imagen empieza a obsesionarlo: los tres muchachos diminutos, indefensos, al lado de la mole aplastante de una pirámide, cuyas piedras arcaicas, carcomidas por la erosión del desierto, flotan en el presente como evidencias enigmáticas de un pasado que creemos familiar, porque nos lo representamos siempre con las mismas imágenes simplificadas, pero que en realidad nos es desconocido y remoto" (Lugar 48).
} 
en otras zonas de la tesis y además porque la crítica ya ha señalado varios puntos de interés con los que aquí se dialogará, sin embargo resulta significativo incorporarlo en la parábola de las ficciones que se encargan de tematizar lo extranjero, desde la llegada de Saer a Francia hasta la consagración de su literatura, porque permite observar qué nuevas preocupaciones estéticas y políticas acucian la producción saeriana y comprobar la incorporación tardía del escenario europeo.

En relación al primer aspecto, la ampliación del referente espacial, la crítica advierte que en esta obra tardía Saer vuelve a probar un giro en su poética -en esa dinámica de corte y continuidad que signa sus experimentaciones literarias- a partir de la redefinición del concepto de "lugar" que se vuelve ahora programa narrativo, zona de pasaje entre geografías disímiles y espacio asimilable al de la ficción. De los veintiún relatos que forman el volumen, solo seis se sitúan en "la zona" o en un espacio intersticial (entre la zona y el extranjero) y los otros quince transcurren en diversas ciudades: Berlín, Viena, Buenos Aires, El Cairo, París, Figueras, Chernobyl, Rumania, entre otros. Resulta sugerente cómo ese espacio sustraído de la representación apenas se traslada a Francia, comienza a proliferar en su obra tardía vinculado a problemáticas políticas específicas. Como ha advertido Rafael Arce, Saer cuestiona la idea de Europa como cima de la civilización occidental y devela, benjaminianamente, su violencia y su "barbarie". Esta "desmesura" espacial es tributaria, en algunos casos, de los nuevos "desplazamientos" de los que se ocupa en estas ficciones, que Saer nuevamente matiza a partir de ciertas sutilezas: las caminatas ociosas del matrimonio italiano que pasea por Viena buscan esquivar la "dictadura de las guías turísticas"; el viaje de comercio de la pareja de vendedores de libros de "Bien común" redobla la apuesta del voyeurismo; la versión pesimista y crítica del viaje de exploración espacial, ${ }^{123}$ sirve de contrapunto al repliegue espacial de "El hombre no cultural"; ${ }^{124}$ y la migración de sujetos que provienen de las ex colonias francesas devela las contradicciones de Europa. Así, la racionalidad turística, arquitectónica y financiera de las grandes ciudades aloja un revés atormentado que puede entreverse cuando algo inesperado acontece, como en "Nieve de primavera"; a través de los desórdenes psíquicos de sus habitantes ("Copión"; "Deseos

\footnotetext{
${ }^{123}$ En "Ligustros en flor" se homologa la conquista espacial a la conquista de América y África, otra muestra de la mentada superioridad occidental y aplicación brutal de la racionalidad pragmática que no posee interés científico ni filosófico alguno, sólo un interés militar y comercial.

${ }^{124}$ El descenso especulativo que el tío de Tomatis realiza en busca de "algo más arcaico, demorado entre los límites entre vida y materia que debían subsistir en alguna parte, en el fondo de cada uno de nosotros" (Saer, "El hombre no cultural", Lugar 13).
} 
múltiples") y sobre todo a partir de la incorporación de la otredad -en general árabe- ${ }^{125}$ que abre el trazado de una cartografía marginal y clandestina. ${ }^{126}$

Como se recordará, en "Traoré" se cuenta la legendaria historia de los griots, antiguos juglares que cantaban alabanzas a los reyes y cuyos cantos hacían vacilar la realidad misma. Dos barrenderos inmigrantes, un musulmán y un africano conversan en la Place Vendôme, rodeada de ministerios y joyerías. ${ }^{127}$ El relato tensiona la representación de ambos personajes, porque, aunque uniformados e igualados mediante el color verde a los elementos de limpieza que utilizan, detentan cada uno su propia fe. El musulmán escucha con una mezcla de atracción y repulsión los fantásticos relatos que cada día le ofrece el otro barrendero, que se presenta a sí mismo como Finá Kamara, descendiente de los griots. La historia que le depara ese día es, como se recordará, la versión fabulada de un caso policial muy difundido a propósito de Traoré, un descomunal asesino y violador de origen africano, a la vez cristiano y musulmán, que pasó de ser considerado un "elegido" en su aldea natal a ser "un hijo del diablo". De ahí en más, la violencia, la delincuencia y las drogas signan la vida de Traoré, que le atribuye su desmesura a los maleficios de que fue víctima. Como ha señalado la crítica, en varios relatos de Lugar se afirma la superioridad ontológica y antropológica de la ficción por sobre lo real, aspecto que se confirma aquí, cuando la Plaza Vendôme se desrealiza para los barrenderos, fascinados por la historia que, en abismo, tensiona los

${ }^{125}$ En "Madame Madeleine" Saer ironiza sobre las opciones que otorga la ciudadanía europea. Como se recordará, se oponen aquí las elecciones de Madame Madeleine, una respetable anciana normanda, a las veleidades políticas de su hija Muriel, quien en 1968 "se mezcló con la muchedumbre de jóvenes que, en las calles del Barrio Latino, salían en las mañanas de mayo a cambiar la vida" (108) y eligió más tarde el aspecto "social" de su carrera de medicina. Mientras Madame Madeleine siente "un desdén por lo extranjero [...] [para] la hija, en una obcecación antitética, la pobreza, la piel oscura, la intemperie, eran prueba suficiente de integridad e inocencia" (108). Muriel termina casándose con un médico árabe argelino, adaptado perfectamente a la cultura francesa y juntos tienen a un hijo llamado Claude tan árabe como su padre. Cuando la pareja muere en un accidente, Madame Madeleine debe hacerse cargo de su nieto, "un extranjero diminuto, de piel oscura" (110). Ironía del colonialismo: "de ahora en adelante lo extranjero, lo exterior, era ella la que lo encarnaba" (110).

${ }^{126}$ En "Traoré" se articula esta otra cartografía de la clandestinidad y la miseria en la que viven los inmigrantes: "en Barbés y al norte de Barbés, en las inmediaciones de la estación de metro Marcadet-Poissonières, en las ocupaciones ilegales de la rue Vitruve, o en las cortadas de Charonne algunas de las cuales dan a los fondos del cementerio del Père Lachaise, o en los inquilinatos ruinosos cerca de la Place des Fêtes, o en los hoteluchos detrás de la Gare de Lyon, [...] y también en Marsella, o en las bodegas de los barcos o en los camiones frigoríficos donde viajan como ganado para entrar clandestinamente en Europa" (Saer, Lugar 33).

${ }^{127}$ Como advierte Arce en "Un enigma familiar: los últimos relatos de Juan José Saer": "En la saga completa, la riqueza está siempre relacionada con la inmoralidad y con la violencia" (120). 
estereotipos sobre los migrantes y desafía los discursos policiales, psiquiátricos y periodísticos que intentan normalizarlos y excluirlos.

Esa "perspectiva exterior" que Saer había aprendido de Gombrowicz y que permitía desfamiliarizar lo propio se extrema en Lugar porque el concepto de "exterior" es llevado a sus últimas posibilidades: así el lager en el que Goldenstein pasa dos años de su vida; ${ }^{128}$ la luna desde la que el astronauta comprueba la enigmática condición de la tierra; y la nueva patria de "Lo visible". Este extraordinario relato sobre la explosión de la central de Chernobyl interroga una vez más las nociones de patria y de regreso. E1 narrador, un viejo habitante del pueblo, vuelve junto a otros de su generación a su tierra natal, a pesar de la prohibición de las autoridades, y allí comparten una efímera "edad dorada", sin embargo, lo invisible acelera la mutación de las cosas y produce un "nuevo mundo, colateral del primero" (114), sacándolos del mundo visible, "su patria común" (114) y revelándoles el verdadero aspecto del universo: “es más que probable que, privado de exaltación pero también de pena, visto desde algún imposible exterior, el mundo sea neutro blanco" (115).

\footnotetext{
${ }^{128}$ Ante sus interlocutores perplejos, Goldstein [...] afirmaba que en tanto que hombre, su cuerpo y su mente habían sufrido [...] pero que, en tanto que pensador, esos dos años representaban para él su diploma 'con felicitaciones del jurado' en antropología" (Saer "Con el desayuno", Lugar 69).
} 


\section{4. "NOTICIAS SECRETAS" DE UN VIAJE IMPOSIBLE}

La experiencia del viaje en Saer, como se intentó mostrar hasta el momento, desborda los géneros privilegiados del viaje y ocupa buena parte de su producción ficcional y ensayística, y sobre todo se produce, desde los primeros poemas que escribe en París, en su poesía. Como ha señalado Sergio Delgado, el tema del viaje atraviesa gran parte de los poemas de El arte de narrar. En muchos de ellos el exilio, lo extranjero, la casa natal y los desplazamientos constituyen el motivo central; otros se construyen alrededor de las aventuras, mudanzas y exilios de personajes famosos -reales y ficcionales- como Dylan Thomas, Cristóbal Colón, Robinson Crusoe, Nietzsche o Rubén Darío, entre muchos otros.

El viaje asume en este poemario, así como en la poesía inédita, diversos sentidos: una dimensión filosófica más general que homologa viaje a derrotero vital y presenta la vida en la tierra y principalmente la vida en el extranjero como un naufragio y un destierro del paraíso perdido; ${ }^{129}$ como aventura y desarticulación de los valores y las convenciones sociales de la cultura y también, como se verá, como metáfora de búsqueda y derrota de una generación ("El Graal”). Saer revisa y desarticula los viajes de intelectuales, escritores y pintores que se desplazan hacia las grandes metrópolis para completar su formación profesional o bien eligen fugarse hacia regiones ignotas vinculadas con lo salvaje. Varias de sus poesías se asientan sobre una disonancia fundamental entre el carácter topográfico y referencial que suelen asumir los relatos de viajes, y el carácter filosófico y abstracto que privilegia Saer en sus poemas, que desafía el anclaje engañosamente referencial que prometen los títulos. ${ }^{130}$

\footnotetext{
129 "Viamonte al oeste", por ejemplo, es un poema escrito en el Hotel Lyon el 14 de abril de 1964, no incorporado en El arte de narrar. El yo lírico parece mirar desde la altura y se autodefine "náufrago yo en mi pleamar/ Estoy lejos de mi tierra, que tiene banderas de ramas y un río/ [inmortal./ También estos hombres llevan en su frente la señal de un paraíso perdido" (Saer, Poemas 100). Otros poemas, como "Moisés", reiteran esa intemperie: "Puedo ver desde aquí la ciudad que destella/ en el llano; sus columnas de humo se levantan hacia el cielo como espejismo. [...] 'Ahí está la ciudad prometida, a la que nunca llegarás'. Ahora siento mis propias/ lágrimas, y el viento que golpea,/ árido, mis mejillas” (Saer, Poemas 115).

${ }^{130}$ En "Apuntes sobre la poesía de Juan José Saer", Edgardo Dobry señala que a diferencia de lo que ocurre en sus cuentos (en los que coincide con Juan L. Ortiz) en la poesía de Saer "el paisaje es mental, literario; si la naturaleza comparece es en forma de bodegón, como en 'Café y manzanas', donde cierta urgencia agrava con las cosas la aspiración trascendental” (185-6).
} 
“Noticias secretas (1976-1982)" es el nombre de una extensa sección de El arte de narrar que Saer incorporó a su libro en la segunda edición, en 1988. Como advirtió Delgado, el nombre evoca el informe reservado que Jorge Juan y Antonio de Ulloa presentaron ante el Rey sobre el verdadero estado militar, administrativo y eclesiástico de los dominios coloniales de la Corona, llamado "Noticias secretas de América". Los años coinciden además, señala también Delgado, con el período en el que Saer se vio imposibilitado de regresar a Argentina durante la dictadura militar.

La mayoría de los poemas incluidos en este apartado refieren de un modo u otro a célebres viajeros aunque también incorporan retratos poéticos de personajes mitológicos y reflexiones sobre la escritura y la contemplación. Interesa ahora detenerse en aquellos que explícitamente hablan del viaje y que convendría considerar en dos grupos, por un lado, habría una serie de poemas que podrían formar parte de un diario de viaje poético que registra el recorrido del sujeto por pequeñas poblaciones de Finisterre y España; por el otro, una segunda serie de poesías construida alrededor de fragmentados retratos de viajeros famosos a partir de los cuales Saer reflexiona sobre los límites y las posibilidades de los viajes en la modernidad.

\subsection{Diario de viaje por el fin de la tierra}

"Extranjero en Aix", un poema inédito incorporado en Poemas y datado en 1990 en Cadaqués permite recuperar un dato biográfico: Saer solía vacacionar en Provence, al sur de Francia, y en Cadaqués, la costa catalana, junto a su mujer Laurence Guégen por aquellos años. ${ }^{131}$ Mucho tiempo antes ya había inscripto sus viajes por Santa $\mathrm{Fe}$ en poemas como "Nocturno a Rosario I y II", “Crepúsculo en Helvecia" u "Octubre en Tostado". Saer lo explica en la nota autobiográfica inédita que está entre sus papeles: por cuestiones de trabajo antes de entrar a dar clases en el Instituto de Cine ayudaba a su padre y eso lo obligaba a viajar por el norte de la provincia. Odiaba esos viajes que a veces duraban hasta tres o cuatro semanas pero de ellos le quedaron recuerdos maravillosos: "Aún hoy me sé quedar horas enteras mirando el mapa de la provincia, y

\footnotetext{
${ }^{131}$ Así lo comenta su última esposa en una entrevista. Cfr. Corradini, Luisa. "Argentino de mate y asado" (Entrevista con Laurence Guéguen). La Nación, 08 de diciembre de 2007. Disponible en http://www.lanacion.com.ar/968402-argentino-de-mate-y-asado
} 
de cada nombre de esos pueblos perdidos me vienen recuerdos intensos y luminosos. La costa, sobre todo, parece haberme marcado para siempre" (Saer, Poemas 341).

Podría pensarse entonces que los poemas "Plozevet", "Lesconil", "Plougastel Saint-Germain", "Huelgoat", "Moulin de Brenizenec" y "Vecindad de Logroño" componen un fragmentado diario de viaje que permite reconstruir los desplazamientos del poeta por las pequeñas localidades de Finisterre y del norte de España. Además de la filiación que encuentra Delgado entre el viaje y la constitución de la poesía modernista (Martí y Darío), explicitada por el célebre poema de Saer "Rubén en Santiago", podría pensarse esta selección poética dentro de un corpus mayor de diarios de viaje inscriptos en poemarios argentinos, ${ }^{132}$ como El junco y la corriente, para mencionar el más significativo, el poemario que Juan L. Ortiz escribió hacia 1957 después de su viaje a China como integrante de una comitiva de intelectuales y artistas financiada por el Partido Comunista. ${ }^{133}$

${ }^{132}$ Podrían mencionarse también Veinte poemas para ser leídos en el tranvía (1922), de Oliverio Girondo e incluso "El Edén", el poema-diario escrito a cuatro manos por Juan María Gutiérrez y Juan Bautista Alberdi en 1843.

${ }^{133}$ Sería interesante detenernos brevemente en este poemario de Juan L. Ortiz porque permitirá establecer ciertas continuidades y diferencias con el "diario" de viaje de Saer. Habría que señalar en primer lugar que el poeta entrerriano llevó una "agenda" de viaje en la que apuntó las excursiones, salidas, encuentros y paseos que realizó durante su estadía en China. Allí leemos: "Llegada a Shangai [...] Visita a viviendas para obreros"; "Visita al Museo Lou-Sing" (Ortiz, El junco y la corriente 143). Según advierte Francisco Bitar en la introducción, el diario de viaje del poemario mantiene el orden de los lugares y ciudades que el escritor había apuntado lacónicamente en su agenda. Los poemas despliegan los apretados nombres del cuaderno y son su puesta en movimiento, "su des-sustantivación, donde el nudo del nombre se desatará en hilos de naturaleza fluida y fluctuante [...]. El junco y la corriente se erige como el auténtico diario de viaje y permite pensar, para el caso de Ortiz, en la constitución de una Vida-Obra, de una obra vivida" (Bitar en Ortiz XXVI). Es significativo además que el poemario no sólo incluye los poemas chinos sino también una serie de homenajes que Juan L. le dedica a sus amigos y también una serie más breve de extensos poemas sobre el territorio nacional ("Entre Ríos", "A la Argentina", "Al Paraná" y "Al Villaguay"). Entre los poemas chinos y los "poemas argentinos", "Entre Ríos" funciona como punto de transición entre un espacio y el otro, aunque las tres partes, señala Bitar, podrían considerarse una sola, el libro es finalmente "el libro de los nombres", el poemario de la desterritorialización, de la sobreimpresión del acá sobre el allá en el que Ortiz trata de asimilar ese universo desconocido al mundo familiar. Álvaro Fernández Bravo lo analiza como un caso de "cosmpolitismo provinciano" (cfr. "Juan L. Ortiz y la poesía china: Un episodio de cosmopolitismo provinciano") y señala que el poemario revela una afinidad entre el paisaje chino y el paisaje entrerriano y universaliza elementos fundamentales como el río y el sauce. Interesa señalar en relación con Saer que también aquí el breve diario de viaje se incorpora a una proyecto mayor, en este caso, la sección "Noticias secretas", incorporada a su vez al libro El arte de narrar, y que de manera similar a El junco y la corriente, también tiene su propia sección de "homenajes" (a Nietzsche, a Fernando Pessoa, a Cervantes) y poemas que aluden al aura provincial de Santa Fe ("Álamos", "Parras de las parrillas", "De los álamos"). Ambos "diarios", el de Saer y el de Juan L. Ortiz, ordenan su recorrido con títulos que aluden a los nombres de las ciudades y estaciones que recorren, pero allí donde Ortiz ampliaba y ponía en movimiento los nombres quietos de su agenda de viaje, 
Si leemos esta serie de poesías en esta clave, descubriremos que el yo viajero recorre las poblaciones que están sobre el límite de Finisterre, más o menos de norte a sur, hasta llegar a Logroño. Se trata, como ocurrirá en varios poemas, de una escritura que se asienta sobre territorios que alguna vez constituyeron el límite de la geografía conocida. ${ }^{134}$ Finisterre, cuyo nombre francés deriva del latín y significa "fin de la tierra”, está ubicado en el extremo occidental de la región de Bretaña, en la que Saer vivió la mayor parte de su vida en Francia, y es la punta de proa de Europa hacia el Atlántico. Ofrece a los viajeros una variedad de paisajes tanto en su interior como en la costa, que se descompone en playas, acantilados, dunas, estuarios, arrecifes e islas. Sin embargo, poco del paisaje alcanza a reconocerse en el diario de viaje, que ya desde el primer poema, "Plozelet", inscribe una escisión fundamental entre el "reino de lo exterior", austero y preciso: "un techo/ negro, árboles/ colinas nítidas" (117) y la pesadilla y el delirio del sujeto lírico, que enuncia desde un "nosotros": "divisamos, grisáceo, el mar indeterminado,/ que apuntala nuestra locura con sus razones" (117). El mar, siempre indeterminado en Saer, parece solidarizarse con el delirio del sujeto poético.

Cabría entonces preguntarse qué es lo que registra este diario. Como puede observarse, se privilegian las posibilidades de la mirada del viajero, que contempla, entrevera y divisa, pero sobre todo se registra la progresión de eso "otro" que siempre subyace como amenaza en los textos de Saer, y así leemos en "Lesconil": "Lo otro viene en esos barcos livianos/ desde el crepúsculo, hacia el puerto, en el sol [...] lo otro son esos barcos, que vuelven, cada día, a completar, en tierra firme, su naufragio" (118).

La glosa de los paisajes de Finisterre se organiza bajo las mismas tensiones que Saer ha ensayado anteriormente sobre la condición matérica y rugosa del mundo. Leemos por ejemplo en "Plougastel Saint-Germain":

Noches solidarias: por dentro

Y por fuera, la misma, pareja, oscuridad

De tanto en tanto una estrella verde, como un centro

o un grumo, más bien, no de luz, sino de alteridad (Saer 119).

Saer parece presentar el nombre como ruina, como la última huella del paisaje real, detrás del cual el poeta despliega, una vez más, las obsesiones perceptuales y filosóficas del viajero.

${ }^{134}$ Así también en el poema "En avión" se mencionan las columnas de Hércules, en alusión al Estrecho de Gibraltar, que era el límite del mundo civilizado y que, como ha advertido Delgado, convoca a una gran tradición de viajeros y navegantes del Mediterráneo. 
Como ha señalado la crítica, ${ }^{135}$ estos poemas que Saer compone entre 1976 y 1982 suelen abandonar la extensión que presentaban sus largos poemas narrativos de la primera sección (“El arte de narrar 1960-1975”) y acentúan el recurso de la condensación. El paisaje se descompone en unidades elementales que evocan además un tiempo inmemorial. Así se lee en "Huelgoat", una pequeña comuna del interior de Finisterre: "Humo en los bosques, el supuesto/ animal, que es nuestra herencia,/ y la roca-/ [...] Lo humano/ es ahora un recuerdo frágil, el olor del humo,/ el musgo tierno, inmemorial,/ sobre las raíces" (120) y también en "Moulin de Brenizenec”: “Árbol, roca, latido, accidentes" (121). La condición rugosa del paisaje aparece más bien como una suma de "apariencias adentro de algo en donde/ [rueda] la bolsa lisa del mundo" (121) y lo humano va desapareciendo hasta el último poema de la serie, "Vecindad de Logroño", en el que sólo quedan las instrucciones para hacer un poema futuro y cada imagen está precedida del infinitivo "Anotar". Sin embargo, lo que se anota no es sólo el boceto visual que podría querer apuntar un viajero apurado, sino una construcción poética sofisticada que contradice el verbo que la presenta. "Anotar: en la siesta que arde/ la noche involuntaria hace señas,/ desde lejos, ubicua,/ en la constancia amarilla [...] Anotar: abismos soleados/ en días cuyo nombre es legión" (122).

El poema captura algunos rasgos del paisaje español, los viñedos y el faro, ${ }^{136}$ aunque estas especificidades se diluyen en un espacio más bien metafísico y enigmático. "Vecindad de Logroño" es, finalmente, una puesta en abismo del mismo proceso de constitución del diario y lo que muestra, precisamente, es esa tensión entre las operaciones de un escritor viajero que debe "anotar" lo que ve durante el viaje y sus obsesiones sobre el paisaje y el acto de percepción, que desbordan el ameno recorrido turístico y lo vuelven consciente del delirio y la pesadilla de lo indistinto.

Por supuesto, leer estos poemas como partes de un diario poético obedece a una decisión de lectura que busca pensar los movimientos de autofiguración de Saer en el extranjero. ${ }^{137}$ Las operaciones anteriormente descriptas (recorrer París como Rubén

\footnotetext{
${ }^{135}$ Cfr. la "Introducción" que Sergio Delgado escribe para Poemas. Borradores inéditos III.

${ }^{136}$ Logroño, al norte de España, es la capital de La Rioja y fue históricamente un lugar de paso, de cruce de caminos y de disputas fronterizas entre los antiguos reinos hispánicos. Por allí pasaba el Camino de Santiago y por ello se caracteriza por ser la ciudad sin mar que ostenta sin embargo un faro simbólico que orientaba a los peregrinos.

${ }^{137}$ Las poesías incorporadas a este corpus responden oblicuamente a las características del género "diario de viaje". Según advierte Penhos en Ver, conocer, dominar, los diarios de viaje suelen organizarse por jornadas y siguen el movimiento cronológico de la expedición. Presentan una temporalidad precisa para reforzar la autenticidad del escrito y registran los movimientos de los viajeros, alternando entre descripción y narración. Como se vio, las poesías que Saer
} 
Darío/ adoptar la perspectiva de Gombrowicz para mirar Europa y Argentina/ proyectarse en los desplazamientos de Pichón Garay) se completan aquí a partir de ese proceso de enajenación biográfica que describía Colombi en "El viaje, de la práctica al género", mediante el cual el viajero de fines del siglo XIX (como Pierre Loti, Paul Groussac y otros) renunciaba al egotismo biográfico para convertirse en un discreto narrador que sustraía su biografía en favor de una apertura "impersonal” al paisaje.

\subsection{Islario: los límites del viaje}

La segunda serie de poemas que conforman "Noticias secretas" es más heterogénea que la primera y permite abordar los viajes de famosos personajes. "Islas" se concentra en los viajes de Rimbaud y Gauguin. El poema parece registrar con cierto grado de melancolía un pasado en el que todavía era posible pintar, escribir y viajar de manera radical: "Ayer nomás había islas todavía; islas/ y desiertos; algunos se fueron" (114) y apunta entonces el caso del "pibe de Charleville", en alusión a Rimbaud, "que se las tomó" y empezó a negociar armas y hombres hasta que fue tomado por la gangrena. Sin embargo, será el retrato de Gauguin el que desarrolle con mayor exhaustividad, concentrándose en los episodios más conocidos de su leyenda artística: su pasado como agente de bolsa, su tormentosa residencia en Arlés con Van Gogh, el abandono de su familia, la dura subsistencia del pintor y sus viajes, cuando, internándose en el mar, sintió cómo el ruido de la espuma "iba borrando/ los ecos del discurso de Mallarmé" (114).

El poema cita y reescribe las cartas y los artículos de Gauguin, compilados en Escritos de un salvaje, y permite observar la singular interpretación que Saer ensaya, desarticulando la lectura convencional sobre la "huida" del pintor hacia lo salvaje: "Y no son, como/ se podría pensar, las Evas de doce años, ni lo exótico/ lo nuevo en una palabra, lo que llama./ Mar, playa y cocotero: todo lo que se encuentra, a plazo incluso [en las Agencias" (Saer, "Islas", El arte de narrar 115) sino el deseo, expresado por el mismo Gauguin en una carta a un amigo que Saer retoma, de encontrar "un rincón de sí

incorpora en "Noticias secretas" sugieren un recorrido pero no se organizan en función de los desplazamientos reales del escritor ni se ordenan cronológicamente. Por el contrario, muestran y a la vez escamotean las referencias espaciales y temporales. 
mismo todavía desconocido [...] ver de más cerca, el núcleo, remoto,/ del que golpes sucesivos, empastándose, la separaron" (114). ${ }^{138}$

Lectura interesada de Saer, entonces, que puede verse por ejemplo en el modo en que reescribe los artículos escritos por el pintor. En "Notas sobre el arte. Exposición universal", Gauguin explica en su defensa de la cerámica: "La materia salida del fuego reviste, pues, el carácter del horno y se hace, en consecuencia, más grave, más seria, a medida que va pasando por el infierno" (Gauguin, Escritos de un salvaje 65). Sin embargo, en la poesía de Saer, no será la cerámica sino el propio artista el que temple su deseo a través del fuego infernal del viaje: "La materia/ adquiere así la cualidad del horno,/ volviéndose más grave, menos banal,/ después de atravesar, lenta, el infierno" (114). Las islas (que como suele ocurrir en Saer, no se nombran) pasan de ser un punto en el mapa, "un destello, irisado por la espuma" (114) a ser un lugar en el que el pintor puede estar a solas consigo mismo. Un pasaje, de lo geográfico a lo filosóficoexistencial que también se explora en otros textos como Las nubes y La ocasión pero que aquí adquiere además la modulación pictoricista de los cuadros de Gauguin: "Cuerpos violetas, eléctricos, senos recién nacidos,/ y el pan que se daban unos a otros,/ [...] cuerpos celestes, rojos, amarillos, azules/ en el aire gris verdoso de la tormenta volcánica,/ tocados aquí y allá por esa brasa secreta-" (116) y la modulación musical que Saer evoca en sus primeros poemas, ${ }^{139}$ y que se le niega en sus poemas parisinos. ${ }^{140}$

${ }^{138}$ En "Exotismo" César Aira persigue la formulación y el devenir histórico de lo exótico y advierte que la difusión del género es paralelo a la expansión capitalista y a la creación de nuevas nacionalidades que se fetichizan como mercancías. Las tierras lejanas (África, Persia, América, Tahití, la China) son literatura ready-made. El exotismo ostenta sus procedimientos particulares: trabaja sobre la superficialidad y pone al mismo nivel lo trivial y lo importante a partir de una mirada esteticista, irresponsable y desjerarquizadora que no puede profundizar en las estructuras socioeconómicas e históricas de los escenarios culturales que pretende mostrar, por lo cual "el exotismo es el instante de la constitución de la mirada" (Aira, "Exotismo" 77). Saer desarticula esas "islas" ready-made de Gauguin y Rimbaud para reclamar una experiencia que está en las antípodas del exostismo y que dialoga con la escritura viajera que Aira identifica en Raymond Russel: "llevada a sus últimas consecuencias, la lógica del exotismo debería revelar una extrañeza radical, que no entrara en los moldes mentales o lingüísticos del autor. Al llegar allá, al trópico o a la isla perdida no debería encontrar lo que ya conoce sino algo tan distinto que sólo pueda contenerse en una lengua nueva, un nuevo saber... O en todo caso debería reducirse al silencio o al balbuceo" (Aira, "Exotismo" 78).

${ }^{139}$ Cfr. "Motivos del canto", el primer poema que Saer publicó en El Litoral en 1954, reproducido en Poemas. Borradores inéditos 3. En la "Introducción" al volumen, Sergio Delgado explica que en los poemas de juventud, que Saer publica hasta 1957 en el diario, el tema dominante es el origen de lo poético como canto.

${ }^{140}$ Como se analizó anteriormente, los poemas que Saer escribe durante su llegada a París parecen confirmar esta ausencia musical y la dificultad del canto: "Estaba mudo el chorro de Verlaine./ Ninguna música en ninguna fuente" (Saer, "A Rubén Darío", Poemas 156). Cfr. también "Gloria de Vallejo". 
En las islas, en cambio, "una región en la que todo es solidario [...] "y en el que el canto de lo único,/ de la mañana a la noche, canta/ en el árbol entero y en cada una de sus hojas" (115).

"Islas" evoca entonces un momento del pasado, a fines del siglo XIX, en el que todavía era posible, para el artista moderno, fugarse y cortar con el planeta "abarrotado de ciudades, de bancos, de esposas fieles, de cenas, de pintores oficiales y de máquinas" (116), y en este sentido Rimbaud, que viaja primero a Java en 1876 y luego a África en 1884, es el poeta que establece el patrón más radical de ruptura que explorarán un poco más tarde Gauguin, pero también Henri Matisse y Henri Rousseau, entre otros. Ambos, Gauguin y Rimbaud, señalan puntos de inflexión, a la vez, en la historia del arte y en la historia de los viajes y combinan ambas dimensiones de maneras disímiles: Gauguin desarrolla su estilo y fundamentalmente su pensamiento filosófico y pictórico por el que es reconocido a partir de sus viajes a Martinica y la Polinesia; Rimbaud, en cambio, abandona la escritura literaria para siempre cuando se interna en la selva javanesa y más tarde en la naturaleza del Cuerno de África. ${ }^{141}$

Para el momento en el que Saer construye su obra no quedan al parecer en el mundo "islas y desiertos", paradoja del viaje explorador, que cuando pretende aumentar el conocimiento de la geografía, acota las esperanzas de lo desconocido. Efectivamente, como advierte James, cuando Rimbaud parte hacia Java, el mundo dejaba de guardar espacios totalmente desconocidos y el ensueño oriental, que había movilizado a varias generaciones de artistas franceses, se disipa ante el progresivo descubrimiento del

\footnotetext{
${ }^{141}$ Se trata, en ambos casos de artistas que rompieron radicalmente con las formas de escribir y de pintar de su época y se convirtieron en los precursores de las vanguardias del veinte. Rimbaud, retomado anteriormente por Saer en el argumento de Glosa, "Carta a la vidente", es señalado con frecuencia como uno de los antecesores del surrealismo por los cambios de escala y las yuxtaposiciones desconcertantes que practica en Iluminaciones; y además, según Jamie James es el poeta que inaugura el "modernismo literario", ampliando el vocabulario disponible para la poesía y realizando algunas innovaciones formales revolucionarias, como el verso libre. Gauguin, por su parte, fue reconocido como el pintor postimpresionista que, tanto por los temas tratados en sus pinturas como por el uso experimental del color y el estilo sintetista, fue referente fundamental del expresionismo alemán y del fauvismo. Ambos son, además, grandes viajeros. En 1880, después de muchos viajes y regresos a Charleville, Rimbaud se detuvo en Adén y pasó allí once años trabajando como traficante de oro y marfil en el Cuerno de África. Según consigna James retomando a Grahan Robb, desde 1875 a 1877 Rimbaud pasó veintiuno de treinta y seis meses en el mar o en el camino, visitó trece países y viajó más de cincuenta mil kilómetros. Verlaine lo nombró "el hombre de suelas de viento". También Gauguin viajó mucho y fue de París a Bretaña, luego a Martinica, visitó Tahití por primera vez en 1891, regresó a Francia y volvió a partir a Tahití y a las Islas Marquesas hasta establecerse en la isla Hiva-Ova en 1901.
} 
Oriente real, menos extravagante y exótico que el fraguado por la imaginación y la literatura. Ya desde mediados del siglo XVIII los viajes de exploración estaban obteniendo sus máximas conquistas. Louis Antoine de Bouganville fue el primer navegante francés en circunnavegar el globo (1766-1769) y se convirtió en un héroe de la Ilustración después de la publicación de sus memorias Viaje alrededor del mundo (1771), donde ofreció una sugestiva descripción de Tahití como paraíso terrenal que alimentó el sueño erótico de muchísimos pintores y escritores. Pero además, en este progresivo dominio del mapa mundial cabría mencionar como uno de los mayores hitos culturales e ingenieriles la construcción del Canal de Suez que unía el Mar Rojo y el Mar Mediterráneo y reducía el paso de Europa al Oriente Lejano de cuatro meses a seis semanas.

Siete años después de su inauguración, Rimbaud cruza el Canal a bordo del Prins van Oranje rumbo a Java como mercenario de un ejército holandés. Como advierte James, para 1876 Asia ya se estaba volviendo cognoscible; Le Tour du Monde publicaba artículos ilustrados sobre lugares tan exóticos como Angkor y los trenes de vapor cruzaban los campos de arroz coloniales: "Para los tiempos de Rimbaud, la era de la exploración en el Oriente Lejano se acercaba a su cierre [...]. Las maravillas no eran ahora conjuradas por videntes sino creadas por científicos e ingenieros. [...] El triunfo del racionalismo en Europa después de Darwin hacía que la magia fuera tan poco plausible en Java como en París" (James 152-155-6). En El viaje imposible, un libro de 1997, Marc Augé vincula este progresivo achicamiento del mundo en relación a la industria del turismo que ofrece un espectáculo estereotipado del mundo globalizado y determina previamente los lugares visitables y las imágenes a ellos asociados:

El viaje imposible es ese viaje que ya nunca haremos más. Ese viaje que habría podido hacernos descubrir nuevos paisajes y nuevos hombres, que habría podido abrirnos el espacio de nuevos encuentros. Eso ocurrió alguna vez y algunos europeos sin duda experimentaron entonces fugitivamente lo que nosotros experimentaríamos hoy si una señal indiscutible nos probara la existencia, en alguna parte del espacio, de seres vivos capaces de comunicarse con nosotros (15).

Este es el momento de clivaje en la historia de los viajes sobre el que parece volver el poema de Saer, agudizado en el momento de escritura de estos poemas, cuando el escritor ni siquiera puede regresar a su país de origen. El exotismo de agencia turística no constituye ninguna promesa, por eso, a diferencia de la salida tomada por 
Gauguin y Rimbaud, Saer resiste el mundo literario parisino y viaja, imaginariamente, a su propia isla criolla a cuya fundación asisten los personajes de la saga en El limonero real y el mismo escritor, en El río sin orillas. Un islario menos exótico y pródigo en colores que el de Gauguin pero "en el [que también] un signo débil/ podría, probablemente, centellear" (Saer, "Islas", El arte de narrar 115).

Gauguin, nunca nombrado en el poema, comparte la experiencia del entenado cuando arriba sin saberlo a las inmediaciones de la tribu colastiné: "balanceándose en el mar verde viajó en busca/ de las señales, fugitivas [...] hasta que vio llegar, de un modo discontinuo, con sacudones/ [rápidos, la isla" (116). Sus viajes por mar evocan además los de otros viajeros que también aparecerán en el poemario, como Colón y Robinson Crusoe. Gauguin y Rimbaud serán, de algún modo, aventureros, como señalaba Simmel para ese tipo de subjetividad moderna, y se diferenciarán de la suerte infructuosa de Colón, que navegando por el mar monótono sin olas ni espuma no podrá divisar "por encima de lo liso, ardua, la cresta" (Saer, "Historia de Cristóbal Colón” 128). Y así como aquí Saer demora el encuentro entre el navegante y la tierra, cuestionando el proyecto exploratorio de la conquista, "Nuevas aventuras de Robinson Crusoe", por su parte, vuelve a mostrar lo irrisorio de las mediaciones culturales y técnicas para el trato con el desierto, que terminan develando, en realidad, "continua/nuestra locura" (127).

Otros dos poemas de la sección, "En avión” y "El graal” podrían leerse juntos, como sugiere Delgado, porque provienen de una de las libretas de viaje que Saer acostumbraba a llevar en sus viajes, particularmente en sus regresos a Argentina. Del cuaderno que escribe en 1982 durante su primer regreso al país luego de la dictadura, el escritor extrae las conocidas "Notas en vivo" para la preparación de Glosa, pero no copia estas dos poesías que sí ingresarán en la segunda edición de El arte de narrar, sin las fechas que aparecían en el original (1982) y con un agregado de seis versos en el caso de "El Graal". "En avión", adelanta o inscribe una preocupación que el escritor desarrollará en abundancia en sus futuras notas de viaje, en las que pueden rastrearse varios fragmentos escritos desde y sobre el viaje aéreo. En este caso en particular, interesa notar que este breve poema de apenas cinco versos condensa varios de los sentidos que sobre el viaje había desplegado en poemas anteriores. Si bien el sujeto lírico cruza el espacio en un transporte "moderno", alude al "viejo mar", ese que ya han surcado en su poemario Colón, Crusoe, Rimbaud y Gauguin, y que ahora disipa la niebla matutina para descubrir las columnas de Hércules, es decir, el promontorio del Estrecho de Gibraltar, antes observadas por los dioses que hoy están ausentes. 
Como se adelantó, las "Noticias secretas de América" eran el verdadero informe sobre el estado de las colonias españolas, escrito durante el siglo XVIII por dos marinos y científicos de la Ilustración que formaron parte de la expedición científica hispanofrancesa (1735-1746) organizada por la Academia de Ciencias de París con el objetivo de medir el arco del meridiano terrestre en el Ecuador y dictaminar la verdadera forma y las dimensiones exactas de la tierra. Las "Noticias secretas" de Saer, podría pensarse, se ofrecen como el informe poético reservado que revela la pérdida del aura de los grandes viajes de exploración y de aventuras filosóficas y artísticas; registra una vez más la ausencia de los dioses y recala en las frustraciones de los viajeros, detrás de cuyos vanos intentos culturales, imperiales y técnicos aflora la indeterminación, el delirio y la pesadilla.

"El graal", confirma en otra clave el estribillo que se repetía en "Islas" sobre la ausencia de "islas y desiertos". En este caso, el poema, que en primera instancia parece aludir a la búsqueda artúrica del Santo Grial, se transforma luego en la constatación de la imposibilidad de esa (y de otras) búsqueda(s). El paisaje, que todavía en el viaje por Finisterre podía verse nítido y austero, revela ahora directamente "incertidumbre y perplejidad": "el viaje/ se volvió errabundeo, y el aura/ solidaria, retirándose,/ nos transformó en manada. ${ }^{142}$ [...] Nos creeríamos perdidos,/ si fuésemos capaces, todavía,/ de distinguir un lugar./ Confusos, vacilamos:/ salimos a buscar no sabemos qué,/ ya no nos acordamos bien cuándo" (Saer, "El graal”, El arte de narrar 144). Delgado lee aquí una derrota generacional: "Es indudable que el grupo, evocado en el 'nosotros', no alude a los caballeros del ciclo artúrico sino, más bien, a una generación de artistas e intelectuales argentinos que floreció en los años sesenta, a la que Saer pertenece, que vio sus sueños aniquilados por la sangrienta y triste historia de la década siguiente" (Delgado, "El poeta en el andén" s/p) e identifica el aura solidaria en relación a la red de escritores congregados alrededor de la figura de Juan L. Ortiz, muerto en 1978, cuya ausencia, sumada al exilio, la desaparición y la muerte, convirtió a esos sujetos en "manada". El viaje se convierte en "errabundeo" y el "lugar" queda desterrado incluso como posibilidad, último eslabón en esta serie de sucesivas pérdidas del viaje y del espacio.

\footnotetext{
${ }^{142}$ Aura solidaria que sí podía leerse en el poemario de Ortiz, en la serie de homenajes que le dedica a sus amigos del lugar (José Pedroni, María Luisa Anido, el doctor Larcho, Juan José Saer, Hugo Gola, entre otros). A diferencia de Saer, Juan L. sí puede regresar e inscribe esa experiencia en "Villaguay (vidalita de la vuelta)", último poema que cierra el libro. Más adelante, en la tercera parte de la tesis, se trabajará particularmente el tema del regreso.
} 
Los poemas de "Noticias secretas" se escriben en el umbral de los límites geográficos y temporales de los viajes: describen por un lado el posible viaje de un sujeto imaginario que recorre localidades de Finisterre y Logroño, el límite occidental de Europa; alude a los antiguos límites marinos, el Estrecho de Gibraltar y el mar indeterminado que intenta atravesar Colón en su búsqueda de las Indias; pero también registra el ocaso de los viajes de exploración en sus distintas vertientes: el viaje artístico de fin del siglo XIX; el viaje conquistador del siglo XVIII y el viaje místico del Santo Grial. El conocimiento fehaciente del mundo y el registro minucioso de los rincones más alejados del globo dificulta la fuga hacia lo desconocido, y así los viajes de Rimbaud y Gauguin también parecen imposibles en el momento en el que escribe Saer. La posibilidad de buscar un lugar queda ya totalmente obliterada si se repone la situación política durante la que se escriben estos poemas, que les deja a intelectuales, escritores y artistas un único desplazamiento posible, el exilio, agudizando la diáspora y el errabundeo de una generación que había crecido al calor de la figura tutelar de Juan L. Ortiz.

Sin embargo, a pesar del deterioro del mundo y del achicamiento pasmoso del espacio, muchos viajeros de Saer son, sin embargo, aventureros: ${ }^{143}$ para el entenado su convivencia con los colastiné significa la aventura más importante de su vida y la determina por completo; y así también el delirante viaje sobre la llanura que emprende el doctor Real junto a la caravana de locos. Ambos regresarán, desde la madurez y la vejez, a reflexionar sobre ese islote vital que irrumpió la continuidad de su existencia. Pero también Rimbaud y Gauguin son, a su modo, aventureros. Si agregamos las aventuras "filosóficas" y "artísticas" de la zona la lista se engrosaría, pero también podrían mencionarse fugaces aventuras: el desplazamiento de Barco y su hermano en "La tardecita"; el mensaje conceptual que depositan los jóvenes Tomatis y Barco en el centro de la isla en "La costra reseca" e incluso la caminata del Matemático y Ángel

143 "Un islote vital", así define George Simmel a la aventura, caracterizada como un acontecimiento periférico con respecto a la continuidad de la vida, con cierto aire forastero, pero que guarda con ella un vínculo misterioso y potente. Un islote, además, porque posee orillas bien definidas que giran alrededor de un núcleo de sentido interno que se vuelve necesario para el aventurero. Inextricablemente ligada con la juventud, su fuerza radica en la extremosidad con que nos hace sentir la vida y no depende del "contenido" de la hazaña. El aventurero comparte los rasgos del jugador, del artista, del filósofo y del genio, y permite diferenciar además el espíritu romántico del espíritu histórico, este último, más ligado a la actitud reflexiva del viejo, que se orienta retrospectivamente hacia los contenidos de la vida, pero descarnados ya del vivir inmediato. 
Leto en Glosa, minada irónicamente de irrisorios y "urbanos" peligros, que seguirá reverberando, recortada y nítida, en el recuerdo de ambos muchos años después. A continuación se intentará observar precisamente de qué paseos, aventuras y exploraciones está hecha la zona. La espesa temporalidad de los viajes que reescribe Saer recupera, como veremos, "islas y desiertos" para la ficción. 



\section{PARTE: LOS VIAJES DE LA ZONA}

Ellos mismos eran ese lugar [y] como lo llevaban adentro, era como si ese lugar se desplazase con ellos a cada desplazamiento [...] eran ellos los que infundían realidad a los otros lugares que visitaban; iban materializando, con su sola presencia, el horizonte incierto y sin forma. Ellos eran el núcleo resistente del mundo (Saer, El entenado 168).

Saavedra: Desde el punto estrictamente literario (si es que existe), ¿cuál es la función de esos desplazamientos espaciales?

Saer: Creo que esto tiene que ver con que el espacio se va creando con el desplazamiento mismo de los personajes. Y al mismo tiempo, todos los espacios quedan relacionados. El hecho de ir y venir, por ejemplo, produce cierta continuidad de diferentes espacios puramente imaginarios. [...] no es que uno esté en París porque allá la vida es más intensa, o se pueden ver más exposiciones, o las francesas son más querendonas, ¿verdad? Es, simplemente, el mismo espacio (Una forma más real 65).

Mucho se ha discutido sobre la construcción de la zona en la poética de Saer, entendida por algunos, en los albores críticos, como una forma sofisticada del regionalismo y por otros como el ápice negativista de la experimentación ensayada sobre la famosa unidad de "lugar". Lo que tiene, sin embargo, de más sorprendente, es que Saer construye un espacio - a esta altura sobra decir si es o no imaginario-, sobre una tectónica móvil: el lugar no es fijo, es más bien una zona antisísmica que para perdurar y sobrevivir al prolongado exilio y a los cambios materiales que necesariamente la modificaron, se construye sobre una plataforma que acompaña esos movimientos, aun cuando se vea anegada, más de una vez, por sismos e inundaciones.

La zona, dirá Saer, está hecha de las diversas formas del desplazamiento, y sus sucesivas fundaciones, destrucciones y modificaciones acompañan o se escriben junto a los movimientos migratorios, exilios y viajes que le dieron forma a buena parte del paisaje nacional. La zona no es fija, entonces, por tres razones: por un lado, como el mismo Saer lo explicita en la entrevista de Saavedra, está hecha a partir de los movimientos que realizan sus personajes, que la abandonan, regresan a ella, la visitan, la expanden, la surcan en canoa, a caballo o en automóvil, la caminan, la escriben, la antologan, la olvidan. Pero además, la zona es "transportable" porque Saer nunca deja de escribir sobre ella en Francia y porque puede reescribirla, desde la distancia, a partir de la extensa biblioteca de viajeros que exploraron el mismo espacio e inscribieron los 
primeros signos reconocibles sobre ella. El paisaje natal se reconfigura, como se verá, a partir de esta "perspectiva exterior". Por último, la zona se desdibuja y sus contornos se borronean bajo una idea de continuum que Saer diseña a partir de los movimientos hechos por sus personajes, -y por él mismo- que, al desplazarse, unen puntos distantes y disuelven las singularidades "propias" del paisaje. Por eso la celebrada zona oscilará entre la precisión minuciosa y la incorporación crítica y por momentos paródica de ciertos elementos "típicos" y una progresiva idea de "neutralidad" que le hace concluir al escritor que todos los lugares, son, finalmente, el mismo lugar, desarticulando de ese modo las variables pintorescas o exóticas del paisaje. ${ }^{144}$

Zona antisísmica, transportable, neutral y continua cuyos orígenes Saer interroga a partir de las sucesivas fundaciones e instituciones que configuraron la historia nacional y que persigue hasta la conformación de uno de sus escenarios privilegiados: la ciudad de provincias. Esa pregunta por la genealogía de la región, que el escritor comenzó a formularse casi en los inicios de su carrera y cuya consolidación se da entre la publicación de El entenado (1983) y Las nubes (1997) coincide, sintomáticamente, con una serie de experimentaciones plásticas sobre temas afines que estaba llevando adelante el artista y amigo personal de Juan José Saer, Juan Pablo Renzi. ${ }^{145}$

${ }^{144}$ En La invención de lo cotidiano, Michel de Certeau distingue las nociones de lugar y espacio. Mientras el lugar es un orden según el cual los elementos se distribuyen en relaciones de coexistencia y adoptan posiciones en una configuración estable, el espacio incorpora las variables de dirección, velocidad y tiempo: "El espacio es un cruzamiento de movilidades [...] un lugar practicado" (de Certau 129, cursiva en el original). Interesa el carácter performativo que de Certau le asigna a los relatos, como aquellas instancias capaces de convertir lugares en espacios y viceversa. Efectivamente, los textos de Saer escenifican ese momento de pasaje en el que el lugar -la ciudad, la zona, la costa, las islas-deviene espacio, y en ese sentido se abre a la indeterminación de los desplazamientos que dibujan los personajes.

${ }^{145}$ A comienzos de la década del ochenta, Renzi pintó una serie de cuadros titulados "Desde el Alcázar", "El delirio de Humboldt", "La tristeza de Darwin", "La Desesperación de Bompland" y "Delirios en Cuernavaca". Según sus propias palabras: "En estas pinturas [...] intentaba, imaginariamente, reproducir las sensaciones que el continente americano produjo en los famosos "viajeros" europeos" (Renzi "Autobiografía", La razón compleja 99). En ellas, Renzi vuelve a experimentar con líneas más ligadas al neoexpresionismo o "Nueva Imagen" y desata la expresividad de la mancha, del color y de la luz que había regulado en su período anterior (el retorno al realismo de los setenta). En dichas imágenes coexisten y se tensionan figuras de la naturaleza (pájaros, ramas, hojas) representadas con bastante verismo, con otras más imaginativas y esquemáticas, realizadas dentro de las líneas de la abstracción y del expresionismo. Los títulos de las obras conservan además algo del resabio conceptual que Renzi había indagado previamente. Una serie formal cuyas tensiones parecen explicarse en las ocurrencias de los títulos, como si una naturaleza "expresionista" y explosiva pudiera dar cuenta del delirio, la tristeza y la desesperación de aquellos viajeros, exploradores y naturalistas que habían venido precisamente a dominarla, explicarla y catalogarla, tensión similar, como se verá, presentan las ficciones de Saer que también se ocupan de los viajeros del siglo XIX. Es importante mencionar, además, que varios cuadros de Juan Pablo Renzi fueron utilizados como 
En Genealogías culturales Florencia Garramuño identifica algunas constantes en una serie de novelas publicadas entre las décadas del ochenta y del noventa en Argentina, Brasil y Uruguay. El corpus que arma se compone entre otros textos de $E l$ entenado (1983) de Saer, La liebre (1991) de César Aira, Fuegia (1991) de Belgrano Rawson, Em Liberdade (1981) de Silviano Santiago y ¡Bernabé, Bernabé! de Tomás de Mattos. Estas novelas se aglutinan en relación a la peculiar reescritura que hacen del pasado en un momento histórico caracterizado por la recuperación democrática y el interés hacia prácticas memorialistas. Garramuño señala que estos relatos se construyen como genealogías culturales que reescriben textos referenciales $-\mathrm{y}$ no meramente textos ficcionales o literarios- que además son fundacionales (ya sean las crónicas de la conquista como los discursos nacionales de formación del estado durante el siglo XIX). En ellos las identidades individuales e incluso nacionales quedan desplazadas por la construcción y definición de identidades culturales -una raza, una etnia, una comunidad- que desafían las fronteras de la nación. Pero además, estas novelas señalan ciertos momentos de clivaje en el corpus de cada uno de los escritores estudiados porque se produce en ellas un cierto retorno - crítico- al realismo y a ciertos géneros del pasado que privilegian modos narrativos más lineales y referenciales: relatos de viaje, autobiografías, memorias, novela epistolar, usados además como un modo de intervenir en los usos contemporáneos del realismo: la literatura testimonial o documental que prolifera a partir de la reinstauración de la democracia en el caso de Argentina y Uruguay y, en el caso de Brasil, a partir del retorno de los exiliados políticos en 1979.

Ahora bien, si atendemos a la producción saeriana podemos observar que esa contemporaneidad cronológica detectada por Garramuño se mantiene en cierto punto pero también se desplaza hacia atrás. Es cierto que varias de las ficciones de Saer que reescriben textos de viajeros y revisan genealogías culturales se publican en las décadas del ochenta y del noventa, como el caso paradigmático de El río sin orillas (1991), pero es también posible rastrear esas preocupaciones mucho antes: El entenado (1983) comienza a escribirse a fines de 1978. La ocasión, escrita vertiginosamente en veinte días en 1987 y publicada un año después ya estaba en los proyectos de escritura de Saer desde 1960. La poesía "Fragmentos de un 'Juan Moreira' " fue escrita probablemente en 1975 e incluida, sí, en la edición de 1988 de El arte de narrar. "El intérprete" y "Paramnesia", dos relatos sobre la conquista española forman parte de dos libros imágenes de la etapa expresionista del pintor, el Jinete azul. 
anteriores, La mayor (1976) y Unidad de lugar (1967) e incluso es posible encontrar resabios de la fundación colonial de la zona en La vuelta completa, la primera novela escrita por Saer entre 1961 y 1963. Es decir, si bien la reescritura de textos fundacionales -y el retorno a ciertas formas narrativas más vinculadas al realismo- se intensifica o estabiliza en las publicaciones realizadas durante las décadas señaladas por Garramuño, el viaje y la relación con la biblioteca viajera es una constante que atraviesa toda la literatura de Saer. La zona se compone, entonces, desde sus inicios literarios, como un espacio configurado por las travesías y extravíos de viajeros que llegaron para conquistar, cartografiar, explorar, habitar y dejar el territorio. Así como en los cuadros de Renzi el anacronismo expresionista viene a develar una percepción anómala y delirante de la naturaleza, reeditando los tópicos humboldtianos del sublime americano, también en Saer esas ficciones que reescriben y traducen culturalmente los textos del origen intervienen, anacrónicamente, las imágenes y discursos codificados en los relatos de viaje.

Esta segunda parte de la tesis es una exploración de los distintos desplazamientos que hicieron posible la zona, desde los viajes de la conquista hasta la conformación de la ciudad saeriana. En el primer capítulo, "Los viajes de la fundación” se indaga de qué maneras Saer reescribe el viaje marítimo en una serie de obras: "El intérprete", "Historia de Cristóbal Colón” y El entenado. Como se verá, el espacio indeterminado del océano expone la modernidad como síntoma y fija las coordenadas de percepción del paisaje americano a través del contacto primordial entre sujetos y lenguas. Saer desarticula la retórica imperial, entre otros procedimientos, a partir de las interrupciones que opera sobre el relato oficial de la Historia, porque se detiene allí donde la voluntad imperial fracasa y se doblega. Relatos como "Paramnesia" y La vuelta completa exhiben esos cortes y muestran los sucesivos emplazamientos y derivas de la zona.

El segundo capítulo, "Un desierto para la zona", explícitamente reescribe los títulos ya conocidos de Tulio Halperín Donghi y Fermín Rodríguez y se propone revisar qué ficciones del desierto retoma Saer en su particular versión de la nación decimonónica. ${ }^{146}$ Como se verá, el escritor explora y reversiona muchas de las

\footnotetext{
${ }^{146}$ En Una nación para el desierto argentino, Tulio Halperin Donghi revisa los diferentes proyectos de nación que se fraguaron desde la generación del 37 hasta el triunfo de Roca en 1880. El extenso "prólogo" que presenta la antología de documentos reunidos por el historiador se encabalga sobre una serie de preguntas sobre la eficacia y los alcances de los distintos planes de organización nacional y va constatando, a partir de las voces de los protagonistas de esta historia, el eclecticismo sistemático que caracterizó a la élite letrada así como a los proyectos
} 
cristalizaciones asociadas a la llanura presentes en una amplia biblioteca de viajeros (Darwin, Ebelot, Hudson, Prado, Mansilla, Sarmiento, Bon Head). Se explorarán aquí fundamentalmente "El viajero", "Fragmentos de un Juan Moreira", La ocasión y Las nubes. En algunos casos, el cotejo con versiones anteriores de algunos de estos textos permitirá comprender la importancia de la "perspectiva exterior" que adoptó Saer fundamentalmente después de su traslado a Francia así como verificar que la preocupación por los textos fundacionales de la nación no es una emergencia de su obra tardía sino un interés que despunta en sus inicios.

El tercer y último capítulo está centrado en la urbe como enclave geográfico y espacial cuyos vínculos con el desierto Saer continúa explorando todavía en la representación de la ciudad de los años sesenta. Novelas como La vuelta completa, Cicatrices y Glosa permiten pensar estos vínculos así como comprender los nuevos desplazamientos que los personajes de la zona realizan por el espacio urbano, desarticulando muchas veces el "mapa" de Santa Fe y Rosario. Por último, cabría señalar que El río sin orillas, por ser un ensayo que revisa precisamente las genealogías culturales del paisaje del Río de la Plata y se escribe en el umbral de muchísimas escrituras de viajeros, intelectuales y artistas que van desde la conquista hasta la década del noventa, se retoma en los distintos capítulos de esta segunda parte, y será nuevamente abordado en la tercera parte de la tesis.

políticos y económicos que guiaron el desarrollo del país. ¿Por qué, se pregunta Halperín Donghi, una clase tan fuerte como la de los terratenientes porteños no podía defender eficazmente sus intereses?, ¿el problema radica, como sugiere Sarmiento, en el ausentismo político de la clase terrateniente?, ¿es el asunto de la campaña un tema político, económico, social-cultural o su definición está abierta a las fuerzas económicas de Estados Unidos y Europa? En 1883 Sarmiento advierte, en una carta de tono melancólico, que a pesar de la excepcionalidad de la Argentina y de los esfuerzos que se comprometieron en sus progresos, estos "carecen de unidad y consistencia" (citado por Halperin Donghi 140). El historiador concluye que "los cambios vividos en la Argentina son, más que el resultado de las sabias decisiones de sus gobernantes posrosistas, el del avance ciego y avasallador de un orden capitalista" (140). A lo largo de su texto se van pautando y reconsiderando los distintos "comienzos" de la historia argentina -1837, 1852, 1880- para determinar que el triunfo del Estado central que coronó la conquista del desierto "no se parece a ninguna de las naciones que debían construirse, nuevas desde sus cimientos, en el desierto pampeano" (148). Fermín Rodríguez reescribirá el título invirtiendo los términos: Un desierto para la nación, porque los proyectos políticos catalogados y razonados por Halperin Donghi hubieran sido imposibles sin "el acopio de un desierto para la nación: un bien territorial y textual que el estado y la literatura argentina no han dejado de repartirse desde su fundación" (15). Desde su perspectiva, el desierto es "una suerte de artefacto discursivo que provee las imágenes en torno de las cuales se hace, se deshace y se rehace el sentido de vacío de lo argentino" (14). El desafío será pensar qué "desiertos" imagina la "zona" saeriana, qué otros recomienzos de la historia argentina postula y qué proyectos políticos, económicos y socioculturales revisa, desvía y reescribe. 


\title{
1. LOS VIAJES DE LA FUNDACIÓN
}

\author{
Fundo en esta llanura alucinada \\ Los años por venir y su veneno; \\ Fundo río, salitre, campo, aguada. \\ Por mí el vacío va quedando lleno. \\ Fundo este espacio lleno de señales \\ donde hombres flotan lentos, como ahogados \\ en un agua sin nombre y sin orilla. \\ (Saer, "Juan de Garay", Poemas 238) \\ Yo empezaría \\ Si tuviese un lugar \\ O hubiese un lugar \\ Por donde empezar \\ (Saer, s/t, Poemas 223)
}

Orígenes, fundaciones, (falsos) nacimientos, cosmogonías, comienzos. La literatura de Saer está escandida por las distintas variantes míticas, geológicas, antropológicas y religiosas de los orígenes. ${ }^{147}$ Cada versión supone por un lado una experimentación literaria de apropiación y reescritura y una reflexión sobre la genealogía de la narración (Arce 2009). Una de esas variantes sobre la que Saer regresará en varias de sus ficciones es la del origen histórico del espacio americano según fue fraguado por la mirada imperial de los conquistadores y exploradores. Saer escribe el extenso episodio de la conquista y colonización española a lo largo de casi toda su obra: desde el relato de la fundación de Santa Fe que narra Barco en La vuelta completa hasta la versión consumada del arribo de los españoles en El entenado, pasando por "Paramnesia" (Unidad de lugar, 1967), "El intérprete" (La mayorArgumentos escritos entre 1969 y 1975), “La historia de Cristóbal Colón” (en "Noticias

\footnotetext{
${ }^{147}$ Diversos críticos han enfatizado el tratamiento del origen en la poética saeriana. Cfr. Premat, Julio. La dicha de Saturno y Arce, Rafael. La felicidad de la novela. En un artículo anterior sobre El entenado, Arce enumera estas variantes: "este ciclo [cosmogónico] comenzaría con la reescritura de la Teogonía que se ensaya en el centro de El limonero real, continuaría con la irrisión del Génesis en el comienzo, vuelto estribillo, de Nadie nada nunca, y llegaría hasta el relato del origen de la Zona y del hombre saerianos en El entenado. Podemos llamar a esta serie el ciclo cosmogónico de la saga. [...] El entenado [tenía que] multiplicar los mitos de origen, exacerbarlos. Hesíodo y la Biblia ya habían sido utilizados. Entonces: Heródoto, Tótem y tabú, la picaresca, Lévi-Strauss, Hans Standen, Ulrico Schmidl. Más acá del mito, o los mitos, de origen del universo, entonces, se multiplican varios otros mitos de origen: de la historiografía, de la cultura, de la novela, de la antropología, del continente americano, de la novela americana" (Arce, "Juan José Saer: la genealogía del relato”, s/n).
} 
secretas" 1976-1982) de El arte de narrar y la sección "Verano" de El río sin orillas (1991).

El poema "Juan de Garay", ${ }^{148}$ no incorporado en El arte de narrar, está construido sobre una yuxtaposición extravagante porque modifica el régimen verosímil del verbo performativo por excelencia: "fundo", adosándole una serie de elementos "fundados" que escriben proyectivamente la historia política del país, desde la fundación hasta fines del siglo XX, y además enuncian lo que Juan de Garay jamás hubiera reconocido estar fundando: el hambre, el rencor, la pesadilla. Pero además, el poema retoma algunos de los espacios predilectos de la ficción saeriana: la llanura, los arrabales y el río sin orillas. En esta apretada síntesis de la historia nacional se fundan los trenes y la explotación agrícola-ganadera, y se anticipan, también "los cuerpos mutilados", y los "hombres [que] flotan lentos, como ahogados" (238). El poema es vertiginosamente anacrónico y condensa lo que sus ficciones irán desarrollando según ritmos, dilataciones y longitudes desiguales.

La historia de las fundaciones se reconstruye, fragmentaria y caprichosamente, de adelante para atrás. Al comienzo Saer menciona las sucesivas fundaciones de la ciudad y repasa el curioso episodio del tigre y el fraile que se cuenta en La vuelta completa y que data de fines del siglo XVII. Retrocede a la destrucción del fuerte de Sancti Spiritus, el primer asentamiento español construido en suelo argentino, fundado por Sebastián Gaboto en 1527 a orillas del río Coronda, y destruido por los indios dos años después. Se remonta luego a la llegada de los españoles -las expediciones de Juan Díaz del Solís al Río de la Plata y de Francisco Pizarro en Perú- para llegar al momento fundacional en el que las carabelas de Colón surcaron el mar en 1492.

Son variados los géneros bajo los que se ensaya esta dilatada temporalidad: un cuento, un "argumento", una novela, una parodiada fábula fundacional, un poema, un ensayo. Como se verá, cada torsión y cada insistencia permite leer no sólo la variación poética y política que Saer prueba sobre el "relato" de la conquista sino también una prolongada polémica literaria que el escritor entabla contra las formas del naturalismo regionalista, la literatura del boom, la novela histórica y las formas del testimonio

\footnotetext{
${ }^{148}$ Este poema no tiene fecha, forma parte de los "Poemas sueltos" incorporados en el tercer tomo de Borradores inéditos. Los editores consideran que varios de los textos aquí incluidos forman parte de la etapa francesa de Saer, escritos después de 1969.
} 
latinoamericano; ${ }^{149}$ y ofrece además una reflexión sobre sus propios procesos de escritura.

Como ha argumentado la crítica, no se trata de leer en Saer un regreso a los modos retóricos y a las convicciones filosóficas del discurso historicista, sino de pensar qué imágenes selecciona, reescribe o torsiona del extenso episodio de la conquista. Podrá observarse que se privilegian los momentos en los que se fractura el código de la retórica imperial (Añón 2016) y naufragan, ${ }^{150}$ aunque sea momentáneamente, los proyectos exploratorios y colonizadores de la metrópolis. Saer deja constancia de la conquista española en el momento en el que sus monumentos y fuertes son incendiados y destruidos, sus empalizadas abandonadas y sus escaramuzas guerreras fracasan o prueban la resistencia de las tribus americanas. Captura los momentos de vacilación de los "capitanes" -Colón y Juan Díaz del Solís-, así como la lengua anfibia y bífida de los intérpretes y entenados que, aunque logren aprehender algo del pasado y hayan sido testigos de la vida de las tribus, propician, también, su destrucción. Interesará indagar en este sentido de qué viajes y detenciones está hecha la zona y qué edificios y ruinas dejó la empresa colonial como marca de su paso y asentamiento en el territorio.

\subsection{El mar: puntuación y extravío de la historia}

En 1985 Saer escribió "El barco fantasma”, un poema que no se incluyó luego en las sucesivas ediciones de El arte de narrar y que imagina un barco habitado por "sombras de capitanes,/ niebla de marineros, grumete de humo" que se desliza en silencio por las aguas del mar, sin piloto ni vigía ni destino al cual arribar, "pasando una y otra vez,/ por el mismo/ lugar [...]/ como el barco del mundo/ por el mar/ de la noche" (Saer, Poemas 210). El mundo es, sugiere el poema, una máquina oxidada abandonada

\footnotetext{
${ }^{149}$ Además de las entrevistas y los ensayos en los que explícitamente se expide contra estas poéticas, una extensa bibliografía ha trabajado estas polémicas. Cfr. entre otros: Premat, Julio. "Saer: un escritor del lugar" en Héroes sin atributos; Sarlo, Beatriz. "El margen de todo" en Zona Saer; Dalmaroni, Miguel. "El largo camino del 'silencio' al 'consenso'. La recepción de Saer en la Argentina (1964-1987)" y Arce, Rafael. La felicidad de la novela. Sobre la desarticulación del testimonio, cfr. Balderston, Daniel. "El entenado. Del recuerdo a la voz" y Genealogías culturales de Florencia Garramuño.

${ }^{150}$ En "Figuraciones y usos del viaje en cartas de la conquista de América", Valeria Añón revisa las principales codificaciones de la retórica imperial, articulada principalmente entre la tradición de la epístola por un lado y el discurso legal y el relato de viaje, por el otro. Esta retórica se trama a partir de seis elementos fundamentales: la mirada imperial que se despliega sobre la "zona de contacto"; el encuentro con el otro; las tensiones entre narración y descripción; la digresión controlada; el itinerario y la inscripción de una itinerancia o cambio en el viajero.
} 
al azaroso movimiento de las aguas, poblada de fantasmas y esqueletos. La imagen, que es una variación "existencial" del típico imaginario del barco fantasma y una forma más o menos inédita, dentro de la obra de Saer, para aludir al carácter contingente y precario del universo, ¿podría leerse también, caprichosamente, como la coda poética de las memorias del grumete de El entenado? Hay allí, como se ha glosado infinidad de veces, otro barco, que transporta a la expedición de Juan Díaz del Solís y deposita en tierra a un puñado de hombres cuya suerte será ser la presa de caza y deseo de una tribu de indios colastiné que cíclicamente celebra un festín antropófago para afirmar su presencia en el mundo. El grumete, el único que sobrevivirá a la matanza, regresará diez años después a España, a bordo de otro barco, conducido esta vez por el capitán Sebastián Gaboto, como el extraño cautivo que apenas puede balbucear el español y testigo de uno de los acontecimientos más extraordinarios de la conquista.

La llegada de las grandes embarcaciones que envía el Viejo Mundo para explorar y conquistar las tierras desconocidas inscriben, aunque difusamente, la Historia en el relato, pero la posición experiencial y la obstinación escritural del grumete, convertido en un viejo imprentero que escribe sus memorias, no será tan diferente de la de ese barco fantasma que pasa "por el mismo lugar" en la noche del mundo. La crítica ha estudiado con exhaustividad los vínculos entre la literatura de Saer y la historia ${ }^{151}$ y ha desanudado las fibras intertextuales que traman su particular variación de la conquista española ${ }^{152}$. Sin embargo, la mayor parte de los estudios priorizan el momento

${ }^{151}$ Sobre la relación entre historia, tiempo y experiencia en la obra de Saer, cfr. entre otras referencias: El espesor del presente de Florencia Abatte; La dicha de Saturno de Julio Premat; Genealogías culturales. Argentina, Brasil y Uruguay en la novela contemporánea (1981-1991) de Florencia Garramuño y Narraciones viajeras. César Aira y Juan José Saer de Nancy Fernández.

${ }^{152}$ La temprana reseña que Gramuglio escribió sobre El entenado para Punto de vista, "La filosofía y el relato" (1984), anticipa los principales caminos que tomará la crítica posterior y advierte que esta novela despertará "las seducciones de la intertextualidad" (35), como se verá, una de las vías predilectas de los estudiosos de la obra. Muchos géneros, discursos y escritores "resuenan" en El entenado: ecos de la novela picaresca, de los relatos de viajes, de las meditaciones roussoneanas, de las novelas filosóficas, de aprendizaje, satíricas y moralizantes (Defoe y Swift particularmente).

Por un lado, El entenado se conectará con una extensa serie de intertextos: el extenso corpus de crónicas de Indias, informes de exploración, textos etnográficos, filosóficos y psicológicos - Hans Staden, Ülrico Schmidel, Jean de Léry, Alvar Núñez Cabeza de Vaca-; los relatos que recogen anécdotas de Francisco del Puerto, el famoso grumete sobre cuya vida estaría inspirado el personaje de Saer; y también Herodoto, Montaigne, Freud, Busaniche. Pero además, la novela comenzará a establecer vínculos con sus pares contemporáneos, novelas que también recogen episodios del pasado fundacional (Garramuño 1997) entre los que pueden mencionarse La liebre (1991) de Aira y Fuegia (1991) de Belgrano Rawson, por nombrar solo algunas. Así, El entenado mostraría las formas de un retorno a la autobiografía y al relato 
“etnológico" de la novela, es decir, el momento en el que el grumete desciende en el suelo barroso a orillas del Paraná y se transforma en espectador y def-ghi, pero soslayan la travesía marítima que lo ha acercado a esas tierras y que lo devolverá más tarde a España. Así, la crítica lee los momentos pregnantes del festín antropófago y de la orgía ritual, ${ }^{153}$ pero olvida a menudo otros aspectos de la experiencia del grumete. El poema

etnográfico, usualmente presentes en el corpus de los informes de exploración, pero que la novela explícitamente cruzaría para corroer esa pretendida garantía de objetividad que, en los textos clásicos, los mantenía rigurosamente separados. Otros críticos, en esta serie más o menos contemporánea, vincularán la obra con El informe de Brodie de Borges (cfr. entre otros Premat 1996 e Iglesia 2003) pero también con grandes obras de la literatura universal: Robinson Crusoe (Gramuglio 1984), El corazón de las tinieblas (Abbate 2014 y Gamerro 2015) e incluso Retrato de un artista adolescente (Díaz Quiñones 2010). De la extensísima lista de abordajes críticos, pueden mencionarse algunos que específicamente han reflexionado sobre algunos de estos vínculos intertextuales. Cfr. entre otros: Reati, Fernando. "Posse, Saer, Di Benedetto y Brailovsky: deseo y paraíso en la novela argentina sobre la Conquista"; Sztrum, Marcelo. "Variación y fronteras lingüísticas en El entenado de Juan José Saer"; Gnutzmann, Rita. "El entenado o la respuesta de Saer a las crónicas", De Grandis, Rita. "The First Colonial Encounter in El entenado by Juan José Saer: Paratextuality and History in Postmodern Fiction"; Romano Thuesen, Evelia. "El entenado: relación contemporánea de las memorias de Francisco del Puerto"; Manzi, Joaquín. "Novela y crónica del descubrimiento en el Río de la Plata".

Gran parte de la crítica, a la vez que plantea estos vínculos, se encarga de advertir el uso irónico, desplazado, anacrónico, filosófico y contrafáctico que Saer hace de los textos de la tradición. Me interesa retomar para el caso la reflexión de Florencia Abbate, quien señala algo interesante al discutir la filiación que parte de la crítica hizo de El entenado como nueva novela histórica. Esta lectura se difundió sobre todo a partir de los artículos de Fernando Aínsa y proponía que este tipo de ficciones eran la contracara de la historia oficial. Abbate señala que esta interpretación obtura la originalidad que presenta la novela de Saer en su modo de representar la historia y advierte que ésta no puede ser comprendida si se lee desde una tradición realista, porque el narrador, ajeno tanto a las versiones oficiales y a las contra-oficiales, enuncia desde una perspectiva oblicua con respecto a la dimensión histórica de su experiencia.

${ }^{153}$ Los estudios críticos que abordan más puntualmente el episodio caníbal son: Díaz-Quiñones, Arcadio. "El entenado: Las palabras de la tribu". El crítico señala que la novela revisa las nociones de lo "bárbaro" y de lo "salvaje" a partir de una relectura de Heródoto y del ensayo "Des cannibales" de Montaigne, que inaugura la tradición del "salvaje noble". El entenado problematiza a Heródoto y a su idea de vacío y puebla el desierto. A su vez Hanno Ehrlicher, en "Funciones de la antropofagia en la Verdadera historia de Hans Staden y en El entenado de Juan José Saer" sostiene que Saer se reapropia de las figuraciones del canibalismo presentes en el texto de Staden a través del giro freudiano que "reescribe" (Umschrift) el mito, colocando al caníbal ya no como una otredad externa sino interna instalada en la memoria filogenética de los sujetos. Wilfrido Corral en "El canibalismo de la crónica colonial en la novela contemporánea: un ejemplo argentino", sostiene que el canibalismo puede ser también entendido como metáfora de lectura y escritura que fagocita los modelos tradicionales a la manera de la antropofagia literaria brasileña. También pueden mencionarse los trabajos de Albornoz, María Victoria. "Caníbales a la carta: mecanismos de incorporación y digestión del 'otro' en El entenado de Juan José Saer"; el de Iglesia Cristina. "Cautivos en la zona. Sobre El entenado de Juan José Saer" y el de Corbatta, Jorgelina. "Presencia del canibalismo en El entenado de Juan José Saer". Sin embargo, interesa particularmente la lectura de Gamerro en "La orgía indígena de Echeverría a Saer" porque retoma la figura del malón y de la orgía indígena (caníbal) en la literatura argentina, pasando por Echeverría, Hernández y Mansilla hasta llegar a Saer, quien extrema y complejiza el tratamiento de la "orgía indígena" para convertirla en "festín caníbal", dislocando la serie anterior. Saer no retoma la discusión donde la habían dejado estos escritores 
"Historia de Cristóbal Colón", bastante contemporáneo de la escritura de El entenado permite revisar ese momento previo al arribo. ${ }^{154}$ Nos detendremos, entonces, en el viaje marítimo que acerca y distancia al entenado de las costas del litoral.

Como se verá, los viajes en barco constituyen por un lado el momento en el que el tiempo histórico (las expediciones de Solís y Gaboto) interrumpe el tiempo cíclico de la tribu, pero además, se ofrecen como el espacio en el que va ingresando la indeterminación y la contingencia. El mar se forja como un espacio abstracto y muestra la insuficiencia de los conocimientos astronómicos y científicos. El viaje marítimo representa el síntoma de la modernidad y consolida las formas de la racionalidad imperialista, pero porta también las semillas de la barbarie y del delirio y modifica a los sujetos viajeros minando su subjetividad y los valores y esperanzas que abrigaban en tierra firme. Al regreso, la expedición de Gaboto termina llevando a un ex cautivo sospechado de cargar para siempre con las marcas de lo salvaje. El poema sobre Colón, escrito entre 1976 y 1982, se puede leer junto a El entenado. De esta manera Colón y Solís se convierten en dos capitanes que no sólo vehiculizan los intereses económicos y políticos de la Corona sino que además ponen a prueba una racionalidad que encuentra sus límites en el mar y en la selva americana.

El título del poema parece evocar Los diarios del Almirante de Cristóbal Colón, el diario de navegación que el almirante genovés escribió durante la extensa travesía desde Puerto de Palos hasta la isla Guanahani, y que incorpora además los tres viajes restantes que hizo al continente. Una misma ansiedad signa las entradas del diario, y entre los informes náuticos sobre los cambios de rumbo y la cantidad de leguas recorridas puede leerse el deseo de los marineros de avistar tierra, acrecentado a medida que esa tierra les enviaba señales: la presencia de ciertos peces y de ciertos pájaros - una garza, un rabo de junco, un alcatraz- que solo se aventuran a pocas leguas del suelo firme y las "muchas manadas de yerba, que se desprenden posiblemente de alguna isla" (104). En varias ocasiones se engañan: "De allí fueron ad Sudueste hasta conocer que lo que dezían que avía sido tierra no lo era, sino cielo" (110) hasta que, en la madrugada del 12 de octubre, ven tierra y desembarcan. Como advierten Añón y Teglia, el

sino que la remonta hasta sus orígenes metafísicos, desarticulando de paso las dicotomías clásicas entre civilización y barbarie. Una imaginación más cercana a la de Conrad y a la de Herzog.

${ }^{154}$ En "El entenado: eslabón perdido", Julio Premat señala que la travesía del océano no sólo supone un desplazamiento en el espacio sino también un regreso en el tiempo, porque el espacio americano está sobredeterminado como un universo arcaico, y además, el viaje les abre el camino hacia la insensatez, el delirio y la contingencia. 
derrotero marítimo inscripto en el diario de bitácora del primer viaje colombino está determinado fundamentalmente por dos elementos: la inscripción hiperbólica de los indicios de tierra, comentada más arriba, y la amenazante "calma" que dificulta muchísimo el desplazamiento de las carabelas. El poema de Saer reescribe el Diario del Primer Viaje operando sobre ambos elementos: exacerba la detención, paradoja extrema del desplazamiento, pero desecha las señales de tierra: el mar de Saer repite la monotonía, uniformidad y abstracción del desierto: "Horizonte, a mi alrededor,/ qué vacío te deja este mar blanco, sin olas, sin espuma [...] En la gran luz monótona, que no huele/ ni cambia de este día perpetuo, donde/ [...] no pareciera verse aparecer/ de un mundo, nuevo, o ya recorrido, qué más da,/ por encima de lo liso, ardua, la cresta" (128).

Saer además problematiza las diferencias entre conquistados y conquistadores, desarticulando de ese modo las clásicas oposiciones entre salvajes y civilizados y las configuraciones de la alteridad, porque en el fondo, sugiere, todos buscan diferenciarse del magma de lo indistinto. Colón confiesa: "Un mundo,/ se me obliga, para poder,/ en adelante/ existir, o ser algo,/ a descubrir, otra cosa,/ más sólida, o, como dicen, más real,/ que el mar de aceite/ que no me lleva/ ni más adelante ni más atrás" ("La historia de Cristóbal Colón”, El arte de narrar 128) y los colastiné comen carne humana: "porque para ellos no había otro modo de distinguirse del mundo y de volverse, ante sus propios ojos, un poco más nítidos, más enteros, y sentirse menos enredados en la improbabilidad chirle de las cosas" (Saer, El entenado 183-184). ${ }^{155}$

De todos los viajes que componen "la zona", el viaje de la conquista es sobre el que Saer vuelve una y otra vez. "El intérprete" y El entenado se pliegan entonces como imágenes de un díptico cuyo filo es el arribo de los conquistadores que viajan en

155 En el capítulo ya citado de Facundo o Martín Fierro, Gamerro advierte la original distribución de las diferencias entre civilización/ barbarie, control/desenfreno que ensaya Saer en su novela, que ya no se dividen entre culturas diversas (los indios y los europeos, en el esquema clásico) sino como momentos de una misma cultura porque el desborde compulsivo al que se abandona la tribu durante el festín caníbal está secundado por una matanza aséptica y metódica, y los encargados de llevarla adelante se abstienen pudorosamente de probar carne humana, mostrando un alto grado de control emocional y de "civilización" y rompiendo de ese modo el clisé decimonónico que suponía que quienes se entregaban a la matanza eran los primeros en saciar su hambre, una forma del mentado "vampirismo" indígena. Los indios de Saer, en cambio, son seres mesurados, rápidos, austeros y eficientes que viven ansiosos como el hombre moderno. 
barco, ${ }^{156}$ y juntos permiten comprender qué sucedía a ambos lados de la orilla. Vemos en primer lugar:

los barcos carniceros avanzando desde el mar hacia la costa, puntos negros primero, filigranas llenas de coladuras más tarde, $\mathrm{y}$, por último cascos panzones sosteniendo las velas y una selva de palos y de cables deslizándose rígida hacia adelante y mostrando de un modo gradual la fiebre de una muchedumbre de hombres activos (Saer, "El intérprete", La mayor 177-8).

Pero sabremos más tarde de qué sueños, deseos, incertidumbres y rencillas se compone esa "muchedumbre de hombres activos". El viaje que emprende el grumete con "hambre de alta mar" está alimentado por las relaciones y leyendas fabulosas que escucha de boca de los marineros, "los chinos, los indios, un nuevo mundo, las piedras preciosas, las especies, el oro, la codicia, la fábula" (Saer, El entenado 11). Las naves parten auspiciadas por la arenga del capitán, que exalta la disciplina, el coraje, el amor a Dios, al Rey y al trabajo, pero a medida que los tripulantes se alejan del hogar los alcanza el delirio y se sumergen en un estado de somnolencia alucinada: "nuestra sola convicción y nuestros recuerdos no eran fundamento suficiente. Mar y cielo iban perdiendo nombre y sentido" (Saer, El entenado 14). El capitán se desdobla, ${ }^{157}$ uno es el que transmite las órdenes que emanan de la corona, y el otro el que mira un punto fijo e invisible en el mar y el cielo, ensimismándose a medida que avanza el viaje hasta desaparecer casi por completo en el interior de su camarote. El grumete, a su vez, debe abandonarse al tráfico sexual que hacen de él los marineros y sabe usufructuar su cuerpo imberbe y ambiguo para sacar provecho de su situación y obtener los favores y la protección de sus amantes. Después de tres meses de travesía, los marineros pasan de lo uniforme a lo múltiple y la lisura del mar se vuelve arena, vegetación y presencia animal. Ante la imposibilidad de determinar dónde han llegado, los marineros se

\footnotetext{
${ }^{156}$ Intento leer aquí la escena de arribo de los españoles de un modo genérico, sin detenerme en las diferencias geográficas e históricas de las llegadas de Solís y de Pizarro.

${ }^{157}$ De la extensa bibliografía que se escribió sobre El entenado, son relativamente pocos los estudios que abordan la figura del capitán. Se destaca en este sentido el trabajo de Cristina Iglesia. En "Cautivos en la zona. Sobre El entenado de Juan José Saer" señala que la escisión del capitán es también la del texto y lee con agudeza los desplazamientos enunciativos y retóricos de la voz del capitán, en quien las órdenes y arengas convencionales que transmite en un principio devienen luego suspiro profundo de horror (y no pieza oratoria que selle el descubrimiento) y cuyas fórmulas bautismales prueban su ineficacia sobre un territorio refractario y mudo. Finalmente, cuando el capitán está a punto de pronunciar una frase que emana directamente de su experiencia y que introduce la carencia como paradigma perceptivo del paisaje americano ("tierra es esta sin"), una flecha atraviesa su garganta y convierte su convicción en incertidumbre absoluta. La diferencia, advierte Iglesia, no se puede narrar.
} 
dividen en fracciones detentando unos y otros los poderes y valores del imperio, hasta que, después de haber bautizado en vano el espacio que atraviesan, son muertos y devorados por la tribu de los colastiné.

Felipillo y el grumete parecen ser los precursores de la discusión que mantienen Pichón Garay y Lalo Lescano sobre las posibilidades de recuperar una región. Felipillo, una vez bautizado por los españoles e incorporado a la empresa conquistadora como intérprete entre ambas culturas es aquel que no puede recobrar el pasado, aun cuando siga viviendo en la tierra de sus padres, porque fue testigo del despojo y del progresivo asentamiento de los hombres carniceros. En cambio, el entenado, alejándose de la zona en el momento previo a la destrucción de la tribu, que irónicamente, él mismo propicia cuando indica la ubicación y las costumbres de los colastiné, puede, hacia el final de su vida, recobrar para la memoria algo de su experiencia e inscribir en esa selva de palos y filigrana negra el errabundeo cíclico del que fue testigo y es narrador.

Dos imágenes coronan el regreso del entenado y fijan el carácter alucinado de la experiencia americana, la primera es aquella que el narrador tiene de la tribu mientras se aleja en canoa: "el conjunto de la tribu [...] fue por primera vez una evidencia que yo podía percibir desde afuera" (Saer, El entenado 123) hasta que, de repente, un recodo del río borra la visión y sale de ese sueño para siempre, "perspectiva exterior" que es para Saer condición necesaria para narrar la singularidad de un territorio. La segunda es una de las imágenes más bellas de la obra: el entenado rema durante la noche y parece que lo hiciera sobre la noche misma, de manera que cuando sus remos rasgan el agua, el reflejo de las estrellas se rompe y los puntos luminosos pasan a ser manchas informes. Podría pensarse que la novela prefigura aquí el trabajo posterior de la escritura, el reguero de tinta que inscribe, confusamente, esa intimidad entre el cielo y el río e interviene el dibujo del cielo con sus remos, volviendo el reflejo una mancha. La escena de escritura con la que cierra la obra permite observar este vínculo: "A lo que vino después, lo llamo años o mi vida [...] cuya corriente, como un río arcaico que arrastra los trastos de lo visible, me dejó en una pieza blanca, a la luz de las velas ya casi consumidas, balbuceando sobre un encuentro casual entre, y con, a ciencia cierta, las estrellas" (El entenado 223).

Antes de regresar a España, el entenado se embarca por segunda vez en un barco español, se trata esta vez de la expedición de Sebastián Gaboto. El viaje de regreso es el reverso pesimista y restaurador del primer viaje: las que antes fueran "orillas primordiales" y "vida primigenia" se llenan ahora de los numerosos cadáveres de 
españoles e indios que flotaban alrededor de las naves después de la destrucción de la tribu; el viaje marítimo pierde el carácter disolvente del primero, capaz de desterrar de los hombres sus más arraigadas creencias, y por el contrario, confirma en los europeos sus presunciones y prejuicios; el paisaje abstracto y delirante es trocado por el efecto aglutinador de los mecanismos y dispositivos retóricos del poder y así, el entenado es obligado por sus semejantes barbados a recuperar una lengua capaz de satisfacer los múltiples interrogatorios que le hacen y debe recobrar las costumbres y las formas corporales, aunque nada de eso mitigue la radical extrañeza que porta, como un virus, hacia el Viejo Mundo. ${ }^{158}$

\subsection{Ruinas y fundaciones}

Si la zona está hecha de viajes y desplazamientos es porque además de las detenciones, las mudanzas y los arraigos de los viajeros, éstos materializan su presencia a través de la construcción de fuertes, empalizadas, edificios y ciudades. Podría decirse que así como la literatura de Saer no deja nunca de contar el origen -en sus múltiples versiones- reitera también un relato sobre las sucesivas fundaciones y ruinas que configuran el relieve mutante de la zona y muestra el costado precario, ilusorio y alucinado de las diferentes configuraciones que los viajeros proyectaron sobre el territorio americano. Así aparecía, entonces, esa pared estragada y abandonada por los españoles en "El intérprete" como cifra de la lengua carnicera y signo del exilio al que fue confinado Felipillo, y así también quedará más tarde la Casa de Salud de Las nubes, reducida a ruinas cuando las fuerzas militares independentistas, pretextando que los doctores eran espías de España, saqueen y destrocen el edificio y dispersen a los enfermos en la llanura.

Interesa ahora "Paramnesia", el cuento de Unidad de lugar cuya "acción" tiene lugar después de la destrucción del fuerte de Sancti Spiritus en 1529. Entre una diseminación de cadáveres y escombros humeantes yacen un soldado y un fraile

\footnotetext{
${ }^{158}$ En La vuelta incompleta, Nicolás Lucero advierte a propósito de la exotopía interior - la extrañeza de sí que acontece a muchos personajes saerianos-, que "los relatos de viajeros de Saer conllevan siempre a este doble movimiento de encuentro con el otro y regreso a la extrañeza de sí, al punto que, en El entenado, es tan decisivo el viaje del grumete [...] y su experiencia con los indios colastiné, como el regreso a España como extranjero de sí mismo [...]. Este es uno de los tantos regresos al útero como forma del exilio en la narrativa de Juan José Saer" (90).
} 
moribundo y con ellos habla el capitán, que da vueltas entre el fuerte, el río y el bosque. El epígrafe que abre el cuento es "No se ve cosa en el sol que no sea real", extraído de la "Vida de Marco Bruto" de Francisco de Quevedo. Allí, el sol es maestro de los monarcas y Quevedo dictamina cómo debería ser un buen gobernante y cómo se dan las sucesiones de poder, comparando la tarea de gobierno con la del sol. A la cita extraída por Saer le siguen los siguientes fragmentos que podrían destacarse: "[el sol] es vigilante, alto, infatigable, solícito, puntual, dadivoso, desinteresado y único", siempre ofrece sus favores a la naturaleza y "es [...] sumamente llano y comunicable: ningún lugar desdeña" (Quevedo, Vida de Marco Bruto 23). Es bien conocido el efecto distorsivo y alucinatorio que adquiere la luz solar en los relatos de Saer y particularmente en el cuento "Fotofobia", que forma parte del mismo libro en el que se publicó "Paramnesia".

El relato parece subvertir el epígrafe quevediano para mostrar que lo que precisamente está quebrado es la relación entre el sol, lo real, el "real" y la voluntad que emana del Imperio - representado aquí en los tres personajes que reúnen el poder de la iglesia, la fuerza militar y el gobierno-. Como ha señalado Fermín Rodríguez, junto con la empalizada del 'real', cae la mirada realista del paisaje porque un paisaje debería abrirse a la razón descriptiva, y aquí se ofrece desgarrado en una fuga de percepciones -la textura y la temperatura de la arena, la luz refractándose sobre las paredes de adobe, el olor de los cuerpos, el estruendo del cuerpo al entrar en el río-. Lo que el ataque de indios parece haber desatado sobre el fuerte es, precisamente, el devenir, transformando a los representantes de la civilización en "tigres" que pueden ser sacrificados e instaurando un estado de mutación permanente que amenaza y desfamiliariza el reducido terreno dominado por los españoles: “el capitán sentía que no había esfuerzo que estuviera a su alcance [...] para impedir el cambio: alguien moría de pronto [...], la gangrena avanzaba [...] caían lluvias que cambiaban el color de la arena y el de los árboles" (Saer, "Paramnesia", Unidad de lugar 230). Por eso, atacado de paramnesia, ${ }^{159}$ el capitán le exige al soldado que sea el garante de lo real y que recobre para él las

\footnotetext{
${ }^{159}$ La paramnesia es una perturbación de la memoria que se caracteriza por la distorsión de los recuerdos. El sujeto tiene "falsos" recuerdos que cree verdaderos y que sustituyen a los hechos reales. Además, hay un tipo de "paramnesia reduplicativa" que perturba las percepciones espaciales y hace pensar que un escenario ha sido duplicado o reubicado en otro lugar. Las acostumbradas perturbaciones de la percepción sobre las que Saer trama su poética se solapan en este libro con la presencia explícita de una variedad de enfermedades y anomalías físicas: la fotofobia, el cáncer, la amputación, la paramnesia.
} 
peripecias del viaje y del relato oficial: "que hay un océano y que nosotros lo cruzamos con el adelantado" (237). El soldado, como Sherezade, intercambiará su relato por un poco de agua para el fraile y le contará una historia que Saer también ha extraído de Quevedo, una anécdota curiosa que él recoge en su epistolario sobre una broma entre el Rey y el cochero, pero que además evoca la lucha de España contra los moros y la leva que llevó al soldado a esas orillas del mundo. Frente a la constatación que hace el capitán sobre el carácter fragmentario de esa porción del mundo y de ese corte del presente en el que se encuentran, el relato del soldado reincorpora el episodio al tiempo histórico y retoma la afirmación imperialista de España, extrayendo, de la materialidad perentoria de las ruinas, el recuerdo inverosímil de Madrid y de Segovia.

También en las crónicas de Indias se incorporan estos relatos de destrucción, y así abundan por ejemplo en Derrotero y viaje a España y Las Indias de Schmidel, en el que se cuenta el terrible sitio que padecieron los soldados en Buenos Aires a manos de cuatro naciones indias y la destrucción del fuerte de Corpus Christi, fundado en 1536 en un lugar cercano a las ruinas del fuerte de Sancti Spiritus, sitiado durante catorce días por los timbúes, quiénes además quemaron sus ranchos y los atacaron con lanzas. Sin embargo, el discurso de Schmidel, fuertemente modelizado por su fe protestante, señala al cabo de la descripción: "pero Dios el Todopoderoso no les concedió tanta gracia, aunque estos susodichos indios quemaron nuestro lugar" (18) y a pesar de la tragedia que narra no deja nunca de contabilizar muertos, medir pérdidas materiales, registrar estrategias bélicas y contar cómo, después de innumerables trabajos, ganaron los cristianos. La estrategia de Saer, al parecer, no es contar la "contracara" de la historia oficial (de hecho, nunca hablan en sus textos "los vencidos"), sino elegir en qué momento darle punto final al episodio histórico que reescriben sus cuentos, novelas y poesías.

El corte visibiliza los momentos de fragilidad, fracaso y pérdida, (en los cronistas no falta el reconocimiento de estos momentos, pero éstos suelen acomodarse en un relato teleológicamente orientado a contar las victorias finales de la civilización). Saer corta siempre antes, esa es una de sus estrategias con respecto a los modos de reescribir la historia, corta el poema "antes" del descubrimiento de Colón, y "antes" de que el capitán y algunos de sus hombres pudieran huir, como efectivamente ocurrió. El capitán de "Paramnesia" es, a este respecto, "moderno" y pesimista: renuncia a Dios y se niega a cumplir el deber de enterrar a los soldados: "Anda, ve, cuéntale al Santo Oficio que me he cagado en Dios y en sus muertos" (Saer, "Paramnesia", Unidad de lugar 238). 
Sin embargo, no sólo se cuentan las ruinas, sino también las sucesivas fundaciones. Así, La vuelta completa, la primera novela que escribe Saer (aunque la publique en segundo lugar), eminentemente urbana, se retrotrae a los orígenes fundacionales de la ciudad. Barco y Pancho visitan la costanera y se ubican frente al puerto. Un camalotal que trae el río le evoca a Barco la historia de los sucesivos desplazamientos de la ciudad, fundada por Juan de Garay en 1573 pero trasladada varios años después entre 1650 y 1660 a unos $80 \mathrm{~km}$ de su ubicación original porque sus barrancas eran continuamente erosionadas por las crecientes del río y grupos de aborígenes asolaban la región. El extenso discurso de Barco incluye no sólo un recuento histórico sobre el origen del asentamiento urbano sino también una explicación del funcionamiento del río, sus afluentes, las periódicas crecidas que inundan el campo, las islas y los caminos. Incorpora además un comentario "políticamente correcto" sobre la humillación aborigen. Por fin, Barco narra la historia que deseaba contar: una especie de fábula que él ha escrito sobre un episodio ocurrido en el Convento de los Franciscanos, construido por los “pobres indios” en las barrancas vírgenes del río.

El episodio debió haber formado parte de las historias que circulaban entre viajeros y locales porque Darwin la recoge en su Diario del viaje de un naturalista alrededor del mundo, incorporada por él cuando se refiere al carácter aluvional del delta del Paraná formado por islas sucesivamente creadas y destruidas, bajo cuya espesa vegetación suelen refugiarse capibares y jaguares, y añade a continuación: "Me contaron que pocos años antes un jaguar enorme había penetrado en una iglesia de Santa Fe; dos curas que entraron, uno tras otro, fueron muertos por la fiera, y un tercero que acudió escapó con dificultad" (Darwin 144). Barco transforma la historia y la cuenta a modo de fábula, ${ }^{160}$ explicitando a medida que lo hace las "licencias poéticas" y las características antropomórficas adjudicadas al tigre (que viaja durante días sobre el gran camalotal y experimenta primero desesperación y luego indiferencia); incorpora digresiones reflexivas sobre el comportamiento de los hombres o las diferentes concepciones de la naturaleza que hay entre Europa y América e interpela a Pancho, su

\footnotetext{
${ }^{160}$ Inspirada, según anota María Bermúdez Martínez en Las florecillas de San Francisco, una recopilación de episodios de la vida de San Francisco y de sus primeros compañeros. En uno de estos capítulos se cuenta cómo San Francisco logra domesticar a unas tórtolas salvajes que habían sido apresadas por un cazador. Con unas simples palabras y exhortaciones el fraile las convierte en "mansas" y les construye unos nidos en los que las palomas se quedan, ponen sus huevos y comparten su vida con los frailes. El cuento de Barco cambia tórtolas por un tigre hambriento y las sencillas palabras de San Francisco por un extenso discurso de autoexamen espiritual y filosófico que aburre y malhumora al tigre, quien, después de escuchar largo rato a Fray Bonifacio, pega un salto y se lo come.
} 
interlocutor: "¿Estoy yendo demasiado lejos para tu gusto naturalista propio de la época? (Saer, La vuelta completa 206).

Hacia el final de su relato, en el que finalmente el tigre entra al convento y se come al único de los frailes que no poseía ningún defecto a no ser el de la soberbia de no poder pecar, Barco reconoce que "no hay moralejas ni significados más allá de lo que se dice" (213) y añade que ha contado una historia real, y que Pancho puede ir a buscar las marcas de las garras del tigre a la mesa grande del museo, clara parodia de la obsesiva búsqueda de veracidad que ostenta la literatura de los cronistas que aseguran "haber estado" en el lugar de los hechos y atestiguado con sus propios ojos lo narrado. El relato de Barco se asume literario y exhibe su proceso de construcción, desarticulando de paso el gusto naturalista de la época, la moraleja de la fábula religiosa y la pretensión verista del lenguaje. El largo monólogo de Barco que se expide a sabiendas de que Pancho "ya sabe" todas esas cosas es una presentación interesada de la ciudad imaginada por Saer para sus futuros lectores. La primera novela, cuyo escenario es eminentemente urbano, debe develar de qué está hecho ese espacio, de qué materiales, escenas, sujetos e historias, y el escritor comienza a mostrar aquí, ya tempranamente, el carácter irrisorio que caracteriza a las fábulas del origen.

\subsection{El paisaje saltado: primeras imágenes para el desierto}

El corpus de la conquista y particularmente El entenado permiten hallar la arqueología de las imágenes cuyo devenir y transformación decimonónica Saer abordará después en Las nubes y en La ocasión; es decir, ciertas imágenes y tópicos con los que viajeros y escritores nacionales fraguaron una determinada idea de territorialidad y alteridad.

La literatura de Saer ensaya variaciones sobre el paisaje de la zona, para enumerar algunas: lo descompone en manchas en El limonero real, lo vuelve una miríada de puntos luminosos en Nadie nada nunca, lo lleva al blanco y al negro suprematista en "A medio borrar" y apela a la abstracción geométrica en El río sin orillas. El paisaje de El entenado prueba su propio régimen de visibilidad y lo ofrece como imagen saltada, barrida. Como se recordará, después de la cacería que sufren los compañeros del entenado, éste es llevado en andas por los indios. El relieve del suelo y la carrera que dura muchas horas le ofrecen al personaje una imagen a saltos: 
un paisaje desconocido todo alterado por los saltos a los que me obligaba mi carrera ininterrumpida -de modo tal que todo lo visible a mi alrededor temblaba y parecía cambiante, deforme, capaz de desplazarse vertical y horizontalmente, como si cada cosa estuviese constituida por numerosas pátinas de forma idéntica mal superpuestas unas sobre las otras-, ver otra porción de ese paisaje desconocido en estado de reposo no me resultó menos extraño y singular (Saer, $E l$ entenado 34).

Si como sostiene Pratt, las escenas de arribo de la literatura de viaje son sitios potentes para enmarcar las relaciones de contacto y fijar los términos de su representación, la extensa escena de El entenado inaugura al menos dos cosas: el flechazo en la garganta del capitán corta, como ha señalado Fermín Rodríguez, con el mandato performativo de fundación que instala la carencia en el paisaje americano ("tierra es esta sin"), pero además le propone al entenado un paisaje que, a saltos o en reposo, no puede ser fijado por la percepción y se presenta como una suma de pátinas que tiemblan y se desfasan sin formar una imagen homogénea y quieta. La escena de arribo comparte esa condición de fragilidad, de aparición y desaparición que DidiHuberman le adscribe a las imágenes-mariposa: "como las alas de una mariposa, la aparición es un movimiento perpetuo de cerramiento, de abertura, de cerramiento otra vez, de reabertura... Es un batir de alas, un latido" (Didi-Huberman 9). La experiencia del entenado troca la mirada imperial: "el ojo que mensura, reordena, jerarquiza lugares y habitantes" (Añón 26) por la mirada intermitente, necesariamente incompleta de aquella que reconoce en el paisaje americano la condición frágil de la falena, porque ésta, advierte Didi-Huberman, no podría ser reconocida en su integridad bajo el ojo agudo de la ciencia que clava el cuerpo de la mariposa en un panel de corcho y la clasifica: “¿No vale más una mariposa esquiva pero viva -móvil, errante, que muestra y oculta su belleza con el batir de sus alas-, aunque no podamos reconocerla bien, aunque por ello nos sintamos frustrados e inquietos? (Didi-Huberman 9).

La imagen saltada que no reposa e inquieta al grumete hasta que deja la tribu funciona a la par de la lengua colastiné y juntas configuran, imagen y lengua, la particular modulación que Saer le irá adscribiendo al imaginario del desierto. Los viajes de la conquista incorporan en la configuración de la zona el problema de las lenguas. Leídos como un díptico, El entenado y "El intérprete” permiten pensar que el español, esa lengua que, como los barcos, se desempasta a medida que el intérprete la incorpora, es "como esa pared, compacta, inútil y sin significado [que] [...] enceguece cuando la luz rebota contra su cara estragada y árida. Una pared para arañar hasta que sangren los dedos o para chocar contra ella, sin una casa atrás a la que entrar para que nos defienda 
su sombra" (Saer, "El intérprete”, La mayor 179). La lengua española funda el exilio constitutivo del sujeto y se yergue como un cielo amenazante: "camino por la playa, un hombre viejo encorvado bajo la bóveda de voces enemigas que se extiende interminable sobre mis ruinas comidas por la selva" (179).

Saer materializa el idioma, ${ }^{161}$ a la vez, pared ruinosa y bóveda que irradia desde las ciudades sus rumores sobre la selva. El mundo se enuncia en la lengua de los colastiné, un idioma contradictorio e imprevisible que condensa los atributos de la lengua altamente formalizada que Saer ya había ensayado en novelas anteriores, y llevado a altos grados de experimentación en Nadie nada nunca o El limonero real. Así, cuando el entenado glosa el comportamiento lingüístico de la tribu tenemos la sensación de estar leyendo la imposible descripción de una lengua poética que atentaría a cada momento contra la comunicación y la representación: una lengua que no tiene verbo “ser", solo "parecer", vocablo negativo que más bien desgasta la percepción y le resta contundencia; una lengua en la que un vocablo puede significar también su contrario o designar a la vez cosas dispares; y una misma palabra, pronunciada de diferentes maneras, nombrar lo presente y lo ausente.

La lengua de los colastiné condensa los experimentos lingüísticos de la poética saeriana y permite comprender de qué están hechas las imágenes del desierto, el horizonte y la llanura decimonónica que desplegará el escritor más tarde en La ocasión y en Las nubes: predominancia de una incierta percepción por sobre la confianza en las esencias; convivencia de opuestos y apertura plurisignificante, condensación de tiempos y ensanchamiento del "espesor del presente". ${ }^{162}$

En una entrevista realizada por Matilde Sánchez en 1985, Saer señala sobre El entenado: "Lo que hice fue una exploración fantasmática a través de nuestras imágenes espectrales. [...] Los actos de los indígenas son metáforas de nuestros propios fantasmas [...]. Es cierto que se trata de una 'relación' aunque está llena de transgresiones deliberadas al género" (Una forma más real 43) y detalla las transgresiones temporales a partir de las cuales desarma la cronología de las crónicas a partir de dilataciones y condensaciones que responden a la subjetividad del grumete. En una entrevista muy

\footnotetext{
${ }^{161}$ En La dicha de Saturno, Premat advierte que la lengua colastiné está descripta en términos de vegetación sobreabundante y que se utilizan para describirla las mismas metáforas que se usan para aludir a la materia regresiva y oscura que amenaza constantemente al hombre saeriano: materia y lengua se presentan como "ciénaga", pasta que está al borde de la disolución.

${ }^{162}$ Cfr. el libro de Florencia Abbate, El espesor del presente. Tiempo e historia en las novelas de Juan José Saer.
} 
posterior, hecha para la edición crítica de El entenado-Glosa, advierte: "El libro más cercano a El entenado es el libro de Staden, que leí en italiano [...]. De Schmidel no, aunque en él hay canibalismo, en el día de Corpus Christi, es extraordinario" (Una forma más real 213). ¿Por qué elige a Staden por sobre Schmidel?, ¿qué tono imaginario permite leer esa elección? Saer conoce las diferentes versiones del canibalismo y advierte la ironía del festín caníbal en el día de Corpus Christi, pero, como señala Aira, ${ }^{163}$ no elige la vía del humor para narrar el festín caníbal sino la vía metafísica (Gamerro), psicoanalítico-freudiana (Erlicher y Premat) ${ }^{164}$ y filosóficoreflexiva (Gramuglio) que le provee el texto de Hans Staden. Interesa anotar esta selección y ese deliberado desplazamiento del tratamiento irónico porque permiten pensar cómo se reconfigura el imaginario sobre la conquista y cómo se preparan las imágenes del desierto: una vía más afín a la perspectiva crítica y pesimista de Martínez Estrada y de David Viñas. Saer recién comenzará a hacerle lugar al "humor" en una novela bastante posterior, Las nubes, que como veremos más adelante, sí abreva en una tradición de la literatura de viajes que incorpora escenas jocosas de carnaval pampeano y tropiezos en la llanura.

El entenado será la única ficción de Saer en la que los indios efectivamente actúen como protagonistas. La novela clausura y condensa su destrucción y lo último que vemos de ellos son sus cuerpos flotando en el río. Las novelas sobre el siglo XIX, a diferencia de casi toda la literatura de frontera, no tendrán como problemática la lucha contra el indio. Saer no tematiza en sus ficciones las guerras de fortines ni la solución final roquista. ${ }^{165}$ Aparecerán, sí, como errático fantasma de la llanura en La ocasión pero no tendrán aquí la entidad de los colastiné y no constituirán una verdadera amenaza para la transformación del campo; los indios que acompañan de lejos la caravana de locos en Las nubes son más espectadores alucinados que actores peligrosos y se pliegan

\footnotetext{
${ }^{163}$ En "Zona peligrosa" Aira advierte que Saer neutraliza el humor: "Pocos escritores modernos son tan serios como Saer; hay un mecanismo en él que vuelve serios hasta los chistes. No es un defecto" (68).

${ }^{164}$ Premat sostiene que el paradigma psicoanalítico no funciona como clave interpretativa de la obra: "Saer, como proponía Barthes, parece atravesar el monumento psicoanalítico como admirables avenidas de una gran ciudad: como una ficción" ("El eslabón perdido. El entenado en la obra de Juan José Saer" 79-80).

${ }^{165}$ En el dossier genético de El entenado puede encontrarse una escueta pero significativa frase, escrita en una pequeña hoja suelta guardada en el primer cuaderno de la novela: "ROCA Y LOS INDIOS". Los críticos comentan al respecto que esta asociación "corrobora la intencionalidad de integrar, en la historia de los colastiné y de su desaparición dramática, una alusión a la Conquista del desierto llevada a cabo por el general Roca y a las masacres de indígenas en el siglo XIX argentino" (Premat en Saer, Glosa-El entenado 444).
} 
con docilidad a la frontera móvil que caracteriza al grupo de viajeros. Origen, resistencia y destrucción de los indios se narran en El entenado y sólo allí.

La novela inscribe, en la lengua colastiné y bajo el régimen saltado del paisaje, la maquinaria del desierto que funciona y se replica en las novelas posteriores de Saer: "El horizonte circular que me había parecido al principio indiscutible o compacto, era en realidad, tal como lo designaba el idioma de esos indios, un almacén de supercherías y una máquina de engaños" (El entenado 173). Formas similares de pensar el espacio ya habían sido experimentadas en novelas anteriores, como Nadie nada nunca, pero se mixturan aquí con las formas de enunciación retórica y con los tópicos que se desarrollaron durante el siglo XIX, como si Saer sometiera esa experimentación visual y formal a la imaginación de la conquista: detención y refutación del movimiento, ${ }^{166}$ irrealización del paisaje, descripción poética y ruptura del acontecimiento se leen ahora en conjunción con los tópicos de la tradición. Como se verá en el siguiente capítulo, $L a$ ocasión y Las nubes desarrollan y complejizan este imaginario, un mandato, digamos, de la lengua acontecimental de los colastinés y del derrame visual del paisaje saltado.

\subsection{El verano: la estación del descubrimiento}

El río sin orillas realiza diversas operaciones sobre la materia sobre la que Saer ya había experimentado en sus ficciones. ${ }^{167}$ En primer lugar, y convocado por el encargo de hablar del Río de La Plata, el paisaje del ensayo ya no será eminentemente el de la costa del Paraná que siempre aparece en sus ficciones sino el de la llanura pampeana.

\footnotetext{
${ }^{166}$ La refutación del movimiento, el experimento filosófico que Saer reedita en varias de sus ficciones, atenta ahora contra la voluntad férrea de los viajeros expedicionarios cuyo signo era precisamente el avance, a toda costa, por los territorios desconocidos. Así, en la introducción que escribe para Derrotero y viaje a España y Las Indias de Ulrico Schmidel, Loreley El Jaber señala que la crónica de Utz es el relato de un recorrido y allí leemos: "quedamos dos días en la localidad y nos aprestamos para el viaje y tomamos para nosotros lo que allá necesitábamos y atravesamos el río Paraguay y vinimos a la localidad donde vive el rey en persona"; "[nuestro capitán] quiso marchar tierra adentro"; "él quería partir río abajo"; "navegamos". El entenado, en cambio, narra una detención.

${ }^{167}$ La crítica ha caracterizado este libro como el "des-ensayo" del no-ser nacional escrito por un apátrida "que insistía en la inconsistencia de la identidad" (Dalmaroni, "Lo incalculable" 47); y como un artefacto dislocado y monstruoso que descalabra formatos genéricos, fábulas de identidad y mitos de origen (Gerbaudo, "Irrecibible, monstruoso, inclasificable", Zona de prólogos 179). Desde esta perspectiva, el ordenado racconto con que empieza la primera sección del ensayo, titulada "Verano", que va desde el despertar geológico de las proximidades del río hasta la fundación de la pampa gringa funcionará como una lectura crítica, irónica y desarticuladora del mito del origen.
} 
Una variación geográfica que si bien no lo aleja de la constante de sus preocupaciones, lo emparienta más directamente con los clásicos tópicos del desierto. Saer amplía y explicita la biblioteca viajera, repone las referencias históricas y los nombres de los protagonistas allí donde antes sólo escribía "el capitán”, “el soldado”, “el fraile” o "el grumete"; suma otros episodios de la conquista, expande las referencias a nuevos viajeros y también alude a la situación de los indios de la Patagonia, un territorio no explorado en su ficción.

Además desarticula el "pathos" de la conquista sudamericana, mucho más pobre y menos maravillosa - señala con ironía- que la de las grandes culturas aborígenes. Fue por error que Juan Díaz del Solís, Magallanes y Gaboto arribaron a estas tierras, porque en realidad buscaban las islas Molucas y el paso interoceánico, y fue por azar que un puñado de indios se encontrara con la expedición de soldados de Solís. El mentado "encuentro de los mundos" y choque cultural se degrada a mera cacería y los españoles, ante los ojos de los indios, no fueron dignos siquiera de un banquete antropofágico; por el contrario, allí mismo donde les dieron muerte se los comieron. Si como se sostiene, el descubrimiento de América termina de consumar la mentalidad moderna y provee una serie de representaciones sobre la alteridad y sobre el Yo que articula esos discursos, Saer muestra de qué maneras sucumbe la racionalidad europea a medida que se acerca al continente americano, un desplazamiento en el espacio que provoca que los viajeros, se adentren en dimensiones insospechadas de su propio ser.

La condición ensayística del "tratado imaginario" le permite a Saer contar interesadamente los episodios restantes de la conquista, que, como vimos, en su ficción se esforzaba en "congelar", aunque aquí también encadena fracasos, disturbios y derrotas: el fin trágico de Magallanes en las Filipinas a manos de los indígenas; la fundación de Buenos Aires de Pedro de Mendoza, quien acosado por la enfermedad y el delirio introdujo entre sus filas turbulencias psicológicas y tironeos por el poder. Cuando puntualiza el caso de Gaboto y del fuerte de Sancti Spiritus se permite una digresión autobiográfica que interrumpe el relato histórico a partir de la apropiación familiar de la historia al señalar que ese fuerte fue fundado casi enfrente de su casa. El pueblo, que en la actualidad se llama Puerto Gaboto está rodeado de algunas colonias cerealeras entre las que se encuentra Serodino y, confiesa Saer: constituyen el "espacio arcaico de mi infancia y uno de mis recuerdos justamente, unos cuatrocientos quince años después de la fundación del fuerte, es el de una tarde de domingo, en que estoy saliendo del río, aterrorizado, con una sanguijuela pegada en el pecho" (56). Un salto 
temporal que solapa la memoria histórica y la memoria personal y que desemboca en la sugestiva imagen de Saer desdoblado: ${ }^{168}$ el niño que corre desde la playa dorada con la sanguijuela pegada al pecho y el escritor adulto que, sentado en una máquina de escribir, lo mira y registra esa imagen -y sólo esa- obsesivamente.

Saer comparte la perspectiva de David Viñas -transversal y transtemporal- a la hora de leer el extenso corpus de la conquista. En su ensayo desarticula la iconografía "estúpida" que muestra a los indios como sujetos sumisos y deslumbrados por los conquistadores y advierte: "el intercambio de atrocidades -también los indios eran oblicuos y brutales- solo acabará en 1880 , con el exterminio definitivo de una de las partes en conflicto" (70-1). La mirada de Saer es, como ha señalado abundantemente la crítica, anacrónica, y detecta las constantes en la formación de ese territorio nacional:

ya tenemos tres elementos casi constantes de la región: un puñado de dirigentes que reivindican toda una serie de privilegios, una mayoría de pobres diablos de diversas nacionalidades a los que la miseria empujó a América [...] y una vasta masa anónima, los indios, relegada a las tinieblas exteriores (Saer, El río 67).

Pero además, lo que ha permanecido y lo que ha fundado, verdaderamente, la pampa, no es la voluntad racional de conquistadores, exploradores y emprendedores capitalistas, sino el empecinamiento ciego de caballos, vacas y perros: "bestias multitudinarias que, con su proliferación desmedida, fundaron, prescindiendo en un primer tiempo del hombre, nuestra cultura" (78). El extenso recuento de la conquista culmina en el desglose de los elementos humanos, animales y paisajísticos que formaron, en el siglo XIX, las principales imágenes de la pampa gringa y los grandes latifundios de fines de siglo. La fundación, despojada de los fueros humanistas y racionales con que siempre fue pensada, deviene animal.

\footnotetext{
${ }^{168}$ En Modos del ensayo, Giordano advierte que una de las características esenciales del ensayo será la "intrusión de la subjetividad en el discurso del saber" (242). Frente al especialista, que desatiende la propia emoción, el ensayista siempre afirma una "perspectiva". Se trata de una subjetividad insistente, irreductible: "asistimos a un desenmascaramiento: en lugar de ocultar [la vida] (exigencia que el saber se impone), el discurso del ensayo muestra, como espectáculo y también como objeto de conocimiento, la subjetividad que lo enuncia" (243).
} 


\section{UN DESIERTO PARA LA ZONA}

José:

$[\ldots]$

Estos pueblos se me antojan a veces como un pan en llamas.

Rafael:

Un pan en llamas, sí, un pan en llamas y una llave en llamas que hubiese debido, inocente, abrir ese pan. Los tigres comen cruda la carne que pillan en la matanza y las cabezas de los mejores se hacen tasajo en la punta de las picas. El diablo bendeciría este siglo, si fuera capaz de bendecir (Saer, "Diálogo bajo un carro", El arte de narrar 30-1).

En una entrevista realizada por María Esther Giglio Saer declara a propósito de su experiencia en la llanura:

Yo creo que ese inmenso vacío, esa imposibilidad de fijar la vista en algo hace que si de pronto un pájaro levanta vuelo desde los pastos, ese pájaro cobra una presencia tan nítida y compacta a fuerza de existir que crea en nosotros un sentimiento de extrañeza. Sentía eso cuando era chico. Yo vivía en Santa Fe, en un pueblito de la llanura que se llamaba Serodino y, a menudo, dos o tres chicos salíamos al campo con las gomeras a cazar. $\mathrm{O}$ a nada. $\mathrm{Y}$ de pronto nos separábamos, cada uno se quedaba solo, perdido entre los pastos a menudo más altos que uno, en aquella planicie y... no sé, pero recuerdo que me invadía un sentimiento muy extraño. De despersonalización, de desrealización (Una forma más real 142).

Efectivamente, si se repasan las ficciones en las que Saer retoma la tradición de la pampa decimonónica -"El viajero", La ocasión, Las nubes, El río sin orillas, entre otros- lo primero que puede advertirse es que el desierto produce una doble desestabilización: por un lado convierte lo real en imágenes, y concomitantemente, despersonaliza a los sujetos que quedan impregnados de ese aura de irrealidad.

Paradoja visual del desierto donde lo más nítido y recortado en sus perfiles adquiere pronto un aspecto fantasmal, de aparición, y el sujeto aparece "desrealizado" en esa indefinición de límites entre el espacio y su propio cuerpo. ${ }^{169}$ En El río sin orillas

\footnotetext{
${ }^{169}$ En la misma entrevista, Saer aclara: "Yo lo he sentido estando en la llanura [...] hay una pérdida de sentido de lo interior y lo exterior, como si no se supiera quién contiene al otro" (142).
} 
Saer precisará los efectos distorsivos de este paisaje, que perturba las percepciones en dos sentidos. Por un lado, en tanto espacio vacío que facilita la proliferación de lo idéntico y sigue una tendencia serial y repetitiva que parece agrupar todo por colonias: lirios, vacas, caballos; y por el otro, cuando algo irrumpe el vacío, ya sea que alguien o algo atraviese el espacio y vaya comprimiéndose hasta desaparecer, o bien porque algo magnetiza la mirada, el espacio alrededor se vuelve abstracto y "al cabo de cierto lapso la percepción ya no ve un caballo, tal como lo conocía en su campo visual, sino una masa oscura y palpitante, un ente problemático [...] que adquiere la nitidez enigmática de una visión" (Saer, El río 120). Por ese carácter disruptivo de la percepción familiarizada y por la posibilidad de "develar" eso otro, el desierto es, en Saer, un dispositivo literario contracultural. El desierto saereano se escribirá como un espacio intersticial fraguado entre las sucesivas formulaciones históricas, literarias, económicas y políticas que lo redefinieron a lo largo de la conformación del estado nacional y la certidumbre de su anomalía inconquistable. Saer escribirá, entonces, a contramano de algunas de las cristalizaciones más mentadas sobre la llanura: no es verdad que pueda leerse el desierto (cuyos matices y diferencias son tan inaccesibles como los blancos superpuestos de una tela suprematista); no es verdad que el desierto permita el desplazamiento (por el contrario, atenta contra la superstición del movimiento) y por último, no es verdad que el desierto despierte en los viajeros la sensación de libertad: el cielo es una bóveda férrea y kafkiana que oprime con su omnipresencia.

Ese carácter ilusorio que Saer le atribuye al desierto es, además, una reescritura y un homenaje a Ezequiel Martínez Estrada. En la presentación de La ocasión, Gramuglio advierte: "La novela elabora la imposibilidad de conocimiento y su lectura remite a la frase de Martínez Estrada: Todo es espejismo en la llanura" (Gramuglio citado en Frassoni y Schettini 13). ${ }^{170}$ En Radiografia de la pampa leemos:

La amplitud del horizonte, que parece siempre el mismo cuando avanzamos, o el desplazamiento de toda la llanura acompañándonos, da la impresión de algo ilusorio en esta ruda realidad del campo. Es la pampa; es la tierra en que el hombre está sólo como un ser abstracto que hubiera de recomenzar la historia de la especie $-o$ de concluirla. [...] La pampa es una ilusión; es la tierra de las

\footnotetext{
${ }^{170}$ Esta advertencia de Gramuglio en realidad es una refutación a las declaraciones que Saer había hecho sobre La ocasión cuando vino a presentarla al Centro Cultural San Martín en septiembre de 1988. El escritor dijo que este relato era más lineal porque pretendía llegar a un público más amplio. Gramuglio desarticula la idea de linealidad y repone la complejidad del texto aduciendo que en realidad cuenta dos historias. Cfr. Frassoni Fernando y Adriana Schettini. "Las claves múltiples". Página/12, jueves 8 de septiembre de 1988, p. 13.
} 
aventuras desordenadas en la fantasía del hombre sin profundidad (Martínez Estrada 12-13).

Saer reivindica en más de una oportunidad la figura de Martínez Estrada, injustamente relegada por la crítica, y considera que Muerte y transfiguración de Martin Fierro es uno de los textos fundamentales de la literatura argentina del siglo XX. ${ }^{171}$ Saer y Martínez Estrada coinciden en su indagación no esencialista de la historia nacional, aspecto que se destaca en El río sin orillas: "Únicamente nuestros mejores pensadores, como Ezequiel Martínez Estrada, [...] comprendieron que un país no es una esencia que se debe venerar sino una serie de problemas a desentrañar" (97). Radiografía de la pampa, advierte Prieto, tiene un carácter fundacional e intenta construir una historia en un continente excluido de la historia a partir de una impronta metafísica y negativa que expone una visión desencantada y pesimista del pasado leído en relación al presente político del escritor. Perspectiva diacrónica y crítica que también Saer retomará en su tratado imaginario pero que funcionará también, condensada, en varios de sus textos de ficción, en los que la violencia política del presente se proyecta y deforma las violencias del pasado.

Saer trama sus textos a partir de una serie de reescrituras, citas, parodias y transgresiones sobre la extensa biblioteca decimonónica ¿qué imágenes retoma y cuáles desecha?, ¿en qué medida irracionalidad y deseo reescriben -como pintaban en Renzila agenda civilizatoria y ordenadora de los exploradores, topógrafos militares y pioneros que llegaron a la pampa?, ¿cuántos desiertos intervienen en la imaginación febril de los narradores que encarnan en esta zona de su literatura?, ¿qué pinturas del arte nacional quizás reescribe o adopta Saer?

\subsection{La ocasión}

La ocasión (1987) es la primera novela cuya acción transcurre en el siglo XIX y reescribe uno de los viajes nacionales por antonomasia: la llegada de la inmigración al

\footnotetext{
${ }^{171}$ Premat se ha encargado de deslindar algunos de los vínculos entre Saer y Martínez Estrada, señalando por ejemplo que comparten la misma posición desenmascaradora de la tradición (operación que Martínez Estrada lleva adelante sobre todo en Muerte y transfiguración) y valoran la mirada desplazada y excéntrica de los viajeros ingleses, cuya legitimidad y originalidad solía faltarle a buena parte de la literatura nacional. Martínez Estrada recupera las crónicas de los viajeros ingleses y la literatura de Cunninghame Graham y de William $\mathrm{H}$. Hudson, éste último, como veremos, de gran importancia para Saer.
} 
país. Sin embargo, Saer elige para hacerlo a uno de los personajes más singulares de su obra y las excentricidades de Bianco signarán las anomalías del paisaje. Por supuesto, ese primer desplazamiento se descompone en innumerables recorridos por Europa y la pampa, y en cada uno de ellos la ficción se abre a las pesquisas más fascinantes sobre la biblioteca del siglo XIX. Como se verá, la escritura de La ocasión se concentra en veinte días y se dilata en veintiocho años. Esa extensísima escritura, suspendida y retomada en más de una oportunidad, permite volver a interrogar los "comienzos" de Saer y repensar las derivas de su obra tardía.

\section{El montaje aberrante del arribo}

Después de haber viajado y vivido en diferentes países y de haber convencido a cientos de campesinos pobres de Italia de instalarse en la llanura rioplatense, Bianco arriba al puerto de Buenos Aires y lo primero que observa es una de las imágenes más codificadas por la mirada de los viajeros, el perfil costero en el que no se destacan accidentes geográficos singulares: "La tierra sin relieves a ras del agua, sin una sola roca, penetrando en el gran río marrón que prolongaba el mar, la costa desierta, el caserío insignificante" (Saer, La ocasión 27). Hasta aquí, la lógica económica que permea el traslado -el interés del gobierno argentino de poblar las tierras al noroeste del país, los títulos de propiedad que carga Bianco sobre veinte leguas cuadradas de buenos campos y la promesa de trabajo y prosperidad hecha a los inmigrantes- se corresponde con esa vista urbana hecha desde el río, útil para los navegantes a la hora de identificar los puertos.

Como señala Penhos en Ver, conocer, dominar. Imágenes de Sudamérica a fines del siglo XVIII, el modelo de "Vista desde el río" registraba en general los accidentes geográficos, las montañas, las bahías y promontorios que volvían singular un determinado espacio geográfico, aspectos que no se hallaban al momento de llegar al puerto de Buenos Aires. Sin embargo, a pesar de esta carencia, los inmigrantes se vuelcan arracimados y contemplan "como hechizados el borde de lo desconocido" hasta que, en un determinado momento, Bianco "desvió la mirada del desierto estimulante que lo esperaba [...] y la fijó en el anular hinchado y rojo, deformado por un gran reborde de pus alrededor de la uña [...] el punto en el que su cuerpo concentraba los últimos vestigios de las humillaciones pasadas, la expulsión final de esos sedimentos de 
materia corrupta y engañosa" (Saer, La ocasión 28). Ese desvío de la mirada, desde la visión panorámica de la ciudad al absceso de pus, inaugura una oscilación que se reiterará en varias ocasiones, del futuro promisorio al pasado; del paisaje al cuerpo; de la mirada abarcadora que da la perspectiva desde el río, al foco en detalle de la corrupción corporal: la típica escena de llegada se narra a partir de un montaje aberrante. Saer retoma uno de los géneros topográficos de la pintura, "la vista desde el río" y la desvía. El dístico abre entonces la posibilidad de dos derroteros que se comunican y se modifican: los cuerpos y los paisajes. Como se verá a continuación, $L a$ ocasión pone a circular una serie de imágenes sobre las posibilidades de un cuerpo sobre la llanura y discute algunas de las cristalizaciones visuales que habían configurado tanto los textos cuanto las imágenes del arte nacional en ciernes.

La pregunta será entonces qué flujos, cortes y transformaciones existen entre esos cuerpos deformes, enfermos, violentados, fascinantes o autómatas y las sucesivas modulaciones del paisaje que pone en escena La ocasión, de modo reiterado y anacrónico: el desierto, el campo domesticado, la llanura cósmica y darwiniana, el campo de la fábula cristiana.

\section{Cuerpos en la llanura}

Por sus indeterminaciones natales, raciales y lingüísticas Bianco es, de todos los personajes viajeros que inventó Saer, el que ostenta más pasmosamente su condición extranjera. La indefinición irónica que señala su nombre, llamarse "Bianco" siendo pelirrojo y las variaciones que ensaya -Burton, Andrew Burton, A. Burton- se corresponden con su ambigua procedencia: dice haber nacido en Malta, de tradición mixta, oriental y occidental. Posteriormente adoptará la nacionalidad italiana pero antes pasará una temporada en Prusia, "su patria de adopción" aunque cobrará notoriedad como mentalista en Inglaterra. Francia será el lugar fatídico en el que es refutado por los positivistas. El traslado constante lo familiariza con varias lenguas y le da a su pronunciación una impronta singular: puede hablar en francés, inglés, italiano y español e incluso mezclar, en una misma frase, palabras de uno u otro idioma, aunque pronuncie todos ellos con un acento "peculiar y extranjero".

Si como señala Graciela Villanueva en "Inmigrantes y extranjeros en las leyes y en la ficción", la literatura escrita alrededor de la década del ochenta asumía y 
exacerbaba las marcas de extranjería de los personajes inmigrantes a través de una serie de cristalizaciones toponímicas y topográficas, podría pensarse que La ocasión a la vez satura y desarticula esas orientaciones del género. Las ficciones escritas alrededor de esta temática enmarcan, en primer término, al extranjero en un ámbito particular: la pulpería, la colonia y los campos alambrados y sembrados en el campo moderno, el río o el prostíbulo, los barrios populares de la ciudad o el cementerio. Bianco transita por varios de estos espacios pero su "lugar" es diferente, se trata del rancho minimalista que se ha hecho construir en medio del campo para tener tiempo para pensar y escribir la refutación a los positivistas. En segundo lugar, Bianco escapa también al sistema de estereotipos que solía circunscribir y conjurar la alteridad de los inmigrantes porque no posee ni la extroversión ruidosa de los italianos ni el amaneramiento de los gestos de un francés, y como veremos a continuación, su perfil se constituye más bien a partir de una serie infinita de máscaras. Su nombre, oscilante, como vimos, tampoco termina de responder a la "simbología onomástica" de la que habla Villanueva, característica común en la figuración del personaje inmigrante a través de cuyo nombre el lector podía intuir no sólo el rasgo predominante de su personalidad sino también la atribución ideológica de la comunidad de la que provenía. El "Bianco", traducido al español, reduplica esa indefinición esencial del personaje. Finalmente, además de los estereotipos, la onomástica y la adscripción topográfica, Villanueva señala que uno de los mecanismos textuales más utilizados en la construcción de la figura del extranjero era la representación del español que hablaban, teñido según los casos, por la coloración del habla de sus orígenes, aspecto que tampoco presenta Bianco, extraterritorial a todas las lenguas por igual.

Si Bianco no es ni italiano ni francés, ni prusiano ni inglés, ¿podría llegar a convertirse, después de todo, en un gaucho? Antes de ir a visitar a sus vecinos, los Garay López, Bianco pasa seis meses en la llanura, viviendo todo el tiempo a la intemperie y casi sin bajarse del caballo, como el personaje de Aballay. Aprende la lengua y observa con mirada pragmática cada cosa del paisaje, distingue pastos y animales y soporta con indiferencia las tormentas y el calor. Aunque por momentos parece una presencia fantasmal atravesando los campos y esquivando las zonas habitadas, se ha preocupado por imprimir en la llanura su presencia y por establecer así sus dominios. Sin embargo, no participa de la "fantasía de inversión" que caracterizó a algunos viajeros ingleses, quienes, fascinados por los valores que aún conservaba el 
gaucho como el último reducto resistente a la degradación de la burguesía, soñaban con participar de algún modo de esa vida dura pero heroica.

En Bianco no hay una mirada nostálgica -a diferencia de Ebelot o de Hudsonpor aquellos sujetos y costumbres que el progreso inevitablemente arrasaría porque en él no se plantea como un conflicto la pérdida de esa comunidad formada por indios y gauchos. No hay tensión entre modernidad y contramodernidad, ni entre progreso y tradición. Saer invierte las valoraciones y desestabiliza los atributos tradicionalmente asignados a la civilización y a la barbarie: si el gaucho o el indio estaban asociados a la fuerza ciega de la violencia -amen de los atributos positivos que les atribuyen algunos viajeros-, en Bianco lo que anida como fuerza ciega es el progreso económico, connatural a otros viajeros, como Ebelot, Bon Head o Darwin, pero exento en él de la piedad, el asombro y la nostalgia con la que ellos advierten la pérdida del pasado. Bianco se convierte así en "un hombre de la zona", mejor, en un colono propietario: ${ }^{172}$ "Lo que los peones creen que Bianco ha realizado para ser igual a ellos, en realidad, atravesando sin detenerse en él el pasaje de esa identidad, lo ha hecho para diferenciarse mejor de ellos" (Saer, La ocasión 87).

Esa diferencia entre el sujeto y el espacio queda materializada en la imagen que abre la novela. Bianco, parado en medio de la llanura y a unos pocos metros del rancho, se destaca del fondo gris que lo circunda. La modestia precaria y cromática del cielo y de la pared de adobe contrasta con el lujo y la saturación de su vestimenta: "da la impresión de ser, durante unos segundos, no un ser humano, sino la estatua que lo representa, una reproducción en madera, tamaño natural, recubierta de colores un poco chillones, un anacronismo recién pintado erigido en medio de la llanura" (14). ${ }^{173}$ Como sugieren varias lecturas críticas, las novelas en las que Saer retoma y reescribe episodios de la historia se inscriben bajo una mirada anacrónica que yuxtapone, al tiempo de la ficción, el tiempo contemporáneo de la escritura, y lleva por ende sus preocupaciones lingüísticas, filosóficas y políticas. Interesa destacar en qué medida ese gesto de anacronismo se juega también en las imágenes a través de las cuales Saer refunda el desierto, como en este caso, en el que el retrato de Bianco se incorpora como disonancia

\footnotetext{
${ }^{172}$ En su análisis de La ocasión, Fermín Rodríguez piensa al personaje en relación a los colonos ingleses que, a diferencia de los viajeros, no sólo pasaban a inspeccionar el territorio sino que se instalaban en él y desde allí tramaban sus relatos.

${ }^{173}$ Julio Premat señalará que en La ocasión hay una distancia entre el tiempo en el que transcurre la acción y el tiempo de la escritura, que incorpora "una dimensión virtual, fantasmática que va a la par con su artificialidad, a medias dibujo y a medias construcción imaginaria" (La dicha de Saturno 324).
} 
material y cromática. Pero además, habría que agregar que a medida que transcurre la historia, esa escultura se descompone en un paroxismo de imágenes o máscaras: ${ }^{174}$

las máscaras de La Valette, de Oriente, de Londres, de Prusia, de París, de Buenos Aires, se apelmazan, viscosas, contra su cara, y la deforman, la borran, la vuelven mera materia perecedera y residual, lo transforman a él mismo en el argumento viviente de los que odia, de los que, arrancándole la máscara en París, creyendo descubrir su verdadera cara, dejaron en su lugar un agujero negro, que él va llenando, poco a poco, con títulos de propiedad, con ganado, con ese rancho... (Saer, La ocasión 97).

A fuerza de querer confundir a los otros a propósito de su origen, termina volviéndose opaco y brumoso para sí mismo. El juego de máscaras que deforman y borran el rostro hasta dejar al descubierto el hueco es un procedimiento moderno que Saer ya había ensayado en sus textos más experimentales, -como en la pesadilla que recuerda el matemático en Glosa, por ejemplo- ${ }^{175}$ En este sentido, Julia Kristeva habla de la posibilidad de ser "extranjeros para nosotros mismos": "Extrañamente, el extranjero habita en nosotros: es la cara oculta de nuestra identidad, el espacio que arruina nuestro hogar [...]. Síntoma que vuelve precisamente el "nosotros" una noción problemática, tal vez imposible, el extranjero empieza cuando somos conscientes de nuestra diferencia y termina cuando nos reconocemos todos en tanto extranjeros, rebeldes a los vínculos y a las comunidades" (Extranjeros para nosotros mismos s/p). ${ }^{176}$

El derrotero del cuerpo que abría ese dístico inicial de ingreso al desierto permite observar además el funcionamiento de otros cuerpos en la llanura. La crítica señala a menudo que a pesar del pasado como mentalista y del presente en el que Bianco puede

\footnotetext{
${ }^{174}$ La mutación acelerada de máscaras se opondría, en el relato, al daguerrotipo, un dispositivo que le permitiría no transparentar su desorden interior y ofrecer una imagen clara, "sin estridencias ni transiciones bruscas, como un daguerrotipo" (Saer, La ocasión 116).

${ }^{175}$ En un sueño, el Matemático despliega una extensa cinta de pequeños retratos cuyas mutaciones lo perturban y crean una especie de caricatura en movimiento. Las sucesivas efigies se borran y él se da cuenta de que es su propia piel la que está siendo desgarrada, comprende que "[en] el lugar que ocupaba su cuerpo, no quedaría nada, ningún meollo, ningún signo, ni siquiera algo que ese cuerpo puramente exterior hubiese estado trayendo dentro -nada, ¿no?, aparte de un vacío, una transparencia" (Saer, Glosa 144).

${ }^{176}$ Esta es la cita completa en inglés: "Strangely, the foreigner lives within us: he is the hidden face of our identity, the space that wrecks our abode, the time in which understanding and affinity founder. By recognizing him within ourselves, we are spared detesting him in himself. A symptom that precisely turns "we" into a problem, perhaps makes it impossible.The foreigner comes in when the consciousness of my difference arises, and he disappears when we all acknowledge ourselves as foreigners, unamenable to bonds and communities" (Kristeva, $\begin{array}{lllll}\text { Strangers to ourselves } & 1) . & \text { Disponible }\end{array}$ http://www.ces.uc.pt/ficheiros2/files/Julia Kristeva_Strangers to Ourselves.pdf
} 
domesticar la intemperie y reducirla a sus fines comerciales, hay una serie de cuerpos que lo fascinan pero se sustraen a su dominio: el cuerpo de Gina, la irrupción de la tropilla de caballos salvajes y la aparición de los jinetes gauchos que responden a Juan, el hermano tirano de Garay López.

Se ha señalado oportunamente la correspondencia entre el cuerpo de Gina y la llanura. Su rostro es comparado con un territorio inextricable que a Bianco le gustaría reconocer a pesar de que nada se deslice en la superficie, "una simplicidad, tan diáfana y natural, podría ser la prueba, no de la inocencia que sugiere, sino de una desviación más grande" (Saer, La ocasión 101). El retrato dilatado que la novela ofrece de Gina oscila entre una serie de imágenes que la ofrecen como una mujer "elástica" y dura, como una fuerza capaz de desbaratar la "máquina Bianco" y concentra, una vez más, en un detalle, la agitación imperceptible. Bianco recuerda que una vez, antes de casarse con Gina, la sorprendió mirando impasible una escena en la que un caballo intentaba penetrar a un yegua, y él sólo pudo distinguir cómo sus uñas intentaban arañar y arrancar un pedazo de corteza "como si toda la emoción que Bianco espera encontrar en la cara, ya hubiese descendido a lo largo de su cuerpo y estuviese evacuándose por las uñas ovales y filosas" (113). Esta imagen perturbadora es captada por Bianco y contemplada en su detalle porque es precisamente allí, en los confines de los cuerpos donde se leen los síntomas de los personajes. ${ }^{177}$

En Ante la imagen, Didi-Huberman reflexiona sobre la cuestión del detalle en la pintura y advierte que este conocimiento acercado de la tela esconde una aporía, puesto que aquello que respondería a la fineza de la observación y a la voluntad de deslindar la totalidad en sus mínimas unidades significantes e iconográficas, termina encontrándose con "la tiranía de la materia". El crítico reclama que habría que pasar de la superficie pulida del cuadro al espesor de la pintura, para encontrar en él no sólo detalles, sino trozos, un término que toma prestado de Proust, más cercano a la "duración temblorosa en lo visible" y al destello. ${ }^{178}$ El detalle es una circunscripción perfectamente divisible

177 Según confiesa el mismo Saer en la entrevista realizada por Miguel Russo, esta imagen formaba parte de su "educación sentimental" en el campo y era parte de los placeres secretos de la infancia: "Yo era feliz en el campo. No irremediablemente: dependía del entorno afectivo, de la salud. Después detesté el campo, pero de pibe me encantaba la familiaridad con los animales, tomar leche al pie de las vacas, ir a ver las cuadreras. La crueldad también: ir a pescar ranas, juntar pajaritos muertos, torturar hormigas. Y, un poco más grande, con seis o siete años, las cosas secretas: ir a ver como cogían los caballos" (Citado en Russo s/p).

${ }^{178}$ Para llevar adelante su argumentación, Didi-Huberman analiza el juego entre detalle y trozo en algunas obras de Johannes Vermeer -Vista de Delft, La encajera- y polemiza con las posturas críticas de Erwin Panofsky y Svetlana Alpers. Si bien en La ocasión no se describen 
del espacio figurativo que puede medirse, nombrarse y que colabora como clave del espacio mimético; en cambio, el trozo es una zona de intensidad coloreada que es captado como una intrusión, que no puede nombrarse y que una vez descubierto permanece como algo problemático, un síntoma, provocando el derrumbamiento de la ilusión representativa e imponiéndose como soberanía de presentación de la materia pictórica. Interesa esta diferenciación porque efectivamente, allí cuando la narración se "acerca" a fragmentos reducidos de los cuerpos de los personajes - la delicada mano de Gina, el absceso de pus en el dedo de Bianco-, aun cuando se trate de fragmentos figurativos, éstos funcionan más como trozos de la pintura que como detalles de representación: desarreglan las relaciones entre lo global (el rostro inmutable de Gina; la escena típica del arribo) y lo local y se resisten a la interpretación, fulgurando a lo largo de la novela.

Bianco fracasa en su intento de conocer a Gina como antes pudo conjurar la tierra americana -su naturaleza, su clima y sus habitantes-. En varias oportunidades se compara su actividad con la de un topo que ha logrado cavar túneles subterráneos en la llanura y que se ha ramificado en ella, imagen de lo subterráneo que se repite para el caso de Gina. Como un excavador, Bianco quiere penetrar el interior misterioso. Se aplica como topógrafo y como naturalista cuando se dice que mira el crecimiento del vientre de Gina como si estudiara "el crecimiento de un batracio o el desarrollo de una planta" (141), y la compara con uno de esos insectos que erotizan la rama en que se apoyan y segregan "algo", un veneno, una materia innombrable.

La correspondencia entre el desierto y Gina se materializa a través de la emergencia del gigante y el paroxismo de esa materia se desencadena en una de las imágenes más pregnantes del texto. Cuando Bianco se arrodilla para ayudarla a bañarse el cuerpo de Gina se gigantiza:

Gina le parece enorme, casi infinita, prolongándose en círculos de carne que forman una vasta pirámide cuya cúspide, afinándose, parece ir a perderse en la penumbra del techo [...] durante unos segundos le parece percibir, del otro lado de la piel, de la protuberancia dura del ombligo, [...] el magma de materia en acción, agitándose en combinaciones y en transformaciones sin límite, los charcos abigarrados de sustancia entrechocándose y entremezclándose, sin otra finalidad

propiamente "pinturas", se retoma aquí esta reflexión porque permite pensar esa condición paradojal de la mirada que rige la novela, que a la vez que intenta "acercarse", se ve constantemente repelida por un exceso de materia que "desentona" o "desborda" y que se impone con la fuerza de una imagen. 
que esa fabricación constante de humores, de tejidos, de concreciones repetitivas, pasajeras, monótonas, inhumanas (Saer, La ocasión 189).

La mirada de Bianco intenta atravesar la materia proliferante del cuerpo de su mujer, pasar de la superficie - la piel tensa del vientre, la mirada impasible- hacia lo que se desata en su interior, porque sabe que, si pudiera dominarla, sería toda la materia la dominada. Como señala Susan Stewart en On longing: Narratives of the Miniature, the Gigantic, the Souvenir, the Collection, al revés de la miniatura, que representa lo íntimo y lo doméstico, lo gigante se abre hacia lo infinito, lo exterior y la naturaleza. La relación fundamental que el sujeto guarda con lo gigante se articula con el vínculo que mantiene con el paisaje y así como la miniatura está en el origen de lo privado, lo gigante está en el origen de la historia natural y de la historia política. Se vuelve una figura-interfaz entre lo natural y lo humano. Las pisadas de los gigantes explican los fenómenos geográficos, le dan forma y sentido al mundo. Interesa aquí cómo esa imaginación proliferante sobre el cuerpo femenino evoca la proyección distópica del origen: lo gigante transgrede los límites y las reglas, es una sobreabundancia de lo natural que afrenta y desequilibra el sistema cultural.

\section{El caballo y la mancha de tinta}

Cierro los ojos y veo una bandada de pájaros. La visión dura un segundo o acaso menos; no sé cuántos pájaros vi. ¿Era definido o indefinido su número? (Borges, “Argumentum ornithologicum”, El hacedor 162)

El desierto saeriano convierte todo en imagen. Esa es la hipótesis inicial que guía alguna de estas reflexiones. ¿Qué ocurre sin embargo cuando esa maquinaria distorsiva se aplica sobre una de las imágenes más expandidas y codificadas de la llanura? El caballo, indisociable al gaucho y al indio, ha concentrado siempre la atención de los escritores de la gauchesca y de los pintores de temas criollistas y ha disparado la atención de los escritores viajeros ocupados en fijar los principales rasgos de la pampa. Presencia continua y turbadora en varias de las ficciones de Saer -y principalmente en Nadie nada nunca- los caballos reaparecen en La ocasión como tropilla salvaje que irrumpe en la llanura, muy analizada por la crítica. Caballos y 
paisaje adquieren una consistencia plástica, son, antes que materia efectiva del mundo, un borrón en la línea del horizonte:

El borroneo leve, móvil, que alteraba la línea en la que cielo y tierra gris se juntan, se ha transformado en una mancha nerviosa, alargada, que empieza a cobrar relieve sobre la línea horizontal, y poco a poco, $[\ldots]$ se desagrega y se transforma en una infinidad de puntos, y después de manchas oscuras que se sacuden y que van agradándose, progresivas, y levantando un rumor [...]. La enorme tropa de caballos oscuros que se acerca a toda velocidad alborotando el desierto un poco adormecido [...] masa sombría y palpitante, de una multitud unificada por todos sus miembros y al mismo tiempo dispersa en cada uno de ellos. [...] Vigorosos, disciplinados y salvajes, parecen la pasta arcaica del ser desplazándose como un viento cósmico, dividida en un número indefinido de individuos idénticos [que cuando se alejan por el lado opuesto del horizonte] revela[n] la naturaleza insidiosa de su aparición fugaz y problemática, de materia rugosa o de visión (Saer, La ocasión 28-32).

Como en "El intérprete", lo que viene desde el horizonte irrumpe primero como presencia plástica y luego se corporiza, se vuelve materia rugosa, piel, músculos y nervios, y una vez que pasa recobra su presencia de mancha y lo deja a Bianco con una doble preocupación, una contemporánea de sus cavilaciones ¿cómo contabilizar y domesticar esos cuerpos dispersos?; una anacrónica, de la que participa Saer, ¿cuán real es esa aparición? Algunos críticos han señalado que Saer siempre recordaba un chiste de Macedonio Fernández a propósito de la inexistencia de los gauchos, o de su existencia solo como forma de diversión de los caballos. No se trataría en este caso de un malón indio ni de una avanzada del ejército, sino de una tropilla más literaria que real, macedonina, la que irrumpe el aislamiento de Bianco.

En “Juan José Saer, a medio escribir”, Mariana Di Ció retoma el dossier genético de La ocasión y señala que es posible encontrar entre el material prerredaccional una serie heterogénea de documentación que reúne textos y anotaciones dispares, ${ }^{179}$ desde fragmentos sobre el ápeiron y apuntes sobre la técnica del animismo hasta una detallada descripción de los síntomas y causas de la fiebre amarilla. Entre estos materiales se incluyen una serie de citas de Ebelot copiadas en francés, ${ }^{180}$ así como también algunos

\footnotetext{
${ }^{179}$ Una parte de este dossier fue publicado en el primer volumen de los Papeles de trabajo bajo el título "Documentos y variantes de La ocasión (1961-1987)". Para la descripción del material preparatorio o prerredaccional y el material "a medio escribir", cfr. Di Cio, Mariana "A medio escribir".

${ }^{180}$ Saer, junto a Jean-Didier Wagneur, escribió la presentación de La Pampa: mours sudaméricaines, la versión francesa de Recuerdos y relatos de la guerra de fronteras de Ebelot, reeditado en Francia en 1992 por editorial Zulma. Ese texto luego fue incorporado en El concepto de ficción.
} 
fragmentos de La guerra del malón, de Manuel Prado, especialmente anotaciones sobre "los blancos de Villegas", un episodio bastante singular en el que se destaca el aspecto “irracional" del enfrentamiento.

En 1907 Manuel Prado publicó La guerra del malón, una memoria de guerra escrita a propósito de su participación en la Conquista del Desierto bajo el mando del Coronel Conrado Villegas, en la línea de fortines desde Trenque Lauquen hasta Choele Choel. ${ }^{181}$ Saer toma algunos fragmentos de uno de los episodios allí relatados sobre el robo que los indios hicieron de una tropilla de caballos blancos reunida y cuidada especialmente por Villegas. En el capítulo XIV Prado destaca de qué se trataba esta famosa tropilla:

Reunió, para su cuerpo, más de seis mil animales de silla; y, luego, seleccionado lo mejor de lo más bueno, formó un grupo de seiscientos caballos blancos, tordillos o bayos claros, destinados a servir de reserva o para el combate. Y aquella masa que de lejos parecía una bandada misteriosa de fantasmas, llegó a obtener renombre en la frontera. Los blancos de Villegas infundían terror en el aduar del salvaje; y no hubo malón que se atreviese a desafiar la rapidez y el aguante de aquellos fletes insuperables. Cuando el " $3^{\circ}$ de fierro" se enhorquetaba en su reserva parecía una tropa de titanes volando en alas del huracán. Y al soplo gigantesco de aquella tromba las indiadas huían despavoridas, abandonando sin combate, sin amago de resistencia siquiera, el robo y los cautivos que llevaban (Prado 84-5).

Los "blancos" son el motín más preciado del desierto y los indios realizan un golpe maestro al llevárselos, poniendo en ridículo el honor de Villegas y la seguridad del campamento. El episodio narra la cólera del coronel al enterarse de lo sucedido y las peripecias guerreras que tuvieron que hacer los soldados para recuperar la caballada, temerosos de encontrarse a su regreso con la ira irracional de su superior que les había aconsejado, antes de partir, que no se atrevieran a volver sin los caballos.

Narrado en dos capítulos, el episodio concentra un gran interés dramático, Prado se detiene en la psicología de los soldados, pinta el perfil terrible del coronel y narra con dinamismo las escenas de guerra con los indios en las tolderías. Habría que observar entonces que Saer realiza una operación de depuración dramática. Lo que resta del "robo de los blancos" es una pura imagen, una tropilla ciega que atraviesa el horizonte sin jinetes -ni indios ni soldados- que se disputen su dominio, y sustraída incluso del afán utilitario y comercial de Bianco, que fascinado ante la aparición, no puede calcular

${ }^{181}$ Sobre el corpus de relatos expedicionarios cfr. Torre, Claudia. Literatura en tránsito: La narrativa expedicionaria de la Conquista del Desierto y "Estudio preliminar". El otro desierto de la Nación Argentina: antología de narrativa expedicionaria. 
exactamente el número de caballos y corre detrás de ellos infructuosamente. Lo que sí queda del episodio de Prado, como si Saer hubiera tamizado esa historia de frontera y trabajara con el sedimento concentrado de su narración (algo que reaparece, como veremos, en el texto de Ebelot) ${ }^{182}$ es la cualidad sublime de la tropilla, debida en gran parte a su carácter fantasmal y a su aparición en masa: "Y aquella masa que de lejos parecía una bandada misteriosa de fantasmas" (Prado 84) que Prado asocia a las ideas de huracán, tromba, tropa de titanes y soplo. La ausencia del componente humano que regula el ir y venir de "los blancos" encuentra además de una interpretación "literaria", una explicación histórica: para los años en que transcurre la ficción, ${ }^{183}$ las guerras de frontera se disputaban bastante más al sur del territorio en el que Bianco y los López Garay ostentaban sus tierras. La novela recoge algunos hilos menores de esa gran historia - las referencias a la zanja que hace el español de la fonda, por ej., la historia incrustada del gaucho desertor del Ejército Grande- pero la acción pasa por otros conflictos. El desierto, su infinitud, su indomabilidad, su carácter inaprensible y fantasmático se reactualizan en las imágenes de los cuerpos, el de Gina y el de la tropilla ciega de caballos. Sin embargo, nada de todo eso parece afectar la transformación efectiva del campo que el mismo Bianco vehiculizaría a través de sus proyectos de alambrado y de fabricación y exportación de ladrillos.

Hay sin embargo, además de esta primera, otras imágenes de caballos. Después de haber mirado extasiado la tropilla, Bianco decide regresar antes de lo planeado a la

\footnotetext{
182 Siguiendo el camino inaugurado por Humboldt y continuado por varios de los viajeros ingleses que arribaron al Río de la Plata, Ebelot extiende una mirada a la vez pragmática y estética sobre el paisaje y sus principales componentes. Destaca por un lado las características utilitarias de los caballos en la pampa, reflexionando sobre las excelentes cualidades de las razas de los caballos argentinos, señalando la relación consustancial entre caballo, gaucho y recado, y criticando además el poco cuidado que se le dispensaba a la caballada en los fortines. Pero además, atento como siempre a las derivaciones estéticas, filosóficas y más precisamente literarias de los asuntos que constituían sus reflexiones, también advierte el carácter pintoresco de estos animales. En "El boleador", uno de los relatos en los que pinta magistralmente a este "tipo" de la pampa, se ocupa de reivindicar la osadía de los boleadores de avestruces y gamas y advierte que les faltó un Feminore Cooper para ser tan célebres como los cazadores de Canadá. Al comparar ambas escenas - los cazadores canadienses cazando de a pie en sus campos de nieve y los gauchos fronterizos en la pampa sin límites cazando de a caballo y acompañados de sus galgos- recomienda este último cuadro a un pintor y a continuación glosa él mismo, y en extenso, esta escena de cacería. Interesa particularmente la deriva que se da en este pequeño relato: un cuadro de costumbres se transforma en una pintura cuyo atractivo principal no es el cazador sino las extraordinarias posibilidades pictóricas del caballo en movimiento.

${ }^{183}$ En Las tres vanguardias, Piglia precisa la temporalidad de la novela, entre 1854 y 1871 y señala que lo que se narra es contemporáneo de la presidencia de Sarmiento.
} 
ciudad y monta su caballo, llevando además uno de recambio. Se reitera aquí el pasaje entre lo nítido y lo fantasmal que caracteriza al desierto:

El hombre y los caballos, encastrados en la llovizna, bien nítidos a causa de los destellos húmedos y grises, tienen sin embargo algo de fantasmáticos en el campo liso y vacío y tan idéntico a sí mismo en todas sus partes, que a pesar del trote rápido, ellos parecen estar realizando una parodia de cabalgata en el centro exacto del mismo espacio circular [...] hasta dar la impresión de que los cascos chapalean, en su pantomima monótona de cabalgata, en un charco de tinta" (Saer, La ocasión 32- 33).

Saer retoma una de las imágenes prototípicas de la biblioteca decimonónica, la cabalgata por el campo, y reitera algunos de los tópicos más frecuentemente asociados a la llanura: su monotonía, vacío y uniformidad, factores que precisamente transforman al par hombre-caballo en una fantasmagoría. El escritor mantiene y exacerba esa cualidad abstracta de la llanura pero tuerce su correlato épico: si en Ebelot, en Sarmiento y en Darwin, era precisamente esa extensión desmesurada la que le daba al jinete la posibilidad de avanzar libremente, aquí es el movimiento el que se vuelve imposible, pantomima y simulacro, hasta que el mismo paisaje, sensible a sus elementos, termina empastándose en un charco de tinta.

Las dos imágenes en las que aparecen los cuerpos de los caballos establecen mutaciones visuales en el paisaje a partir de la preponderancia de lo pictórico: el "borroneo" de la línea del horizonte, la mancha, los puntos nerviosos, el charco de tinta, las derivaciones de la luz. Sin embargo ¿es realmente anacrónica -y novedosa- esta inclusión? Como se sabe, muchas narraciones viajeras ponen de relieve las relaciones entre viaje, imagen y dominio a través de constantes menciones a los instrumentos de observación y medición del territorio, así como a las formas de captura del paisaje a través de diversas modalidades plásticas. ${ }^{184}$

\footnotetext{
${ }^{184}$ Algunos estudios han enfatizado la preeminencia de lo visual y la importancia que tenían los instrumentos de observación, medición y catalogación a la hora de enfrentarse con espacios desconocidos, principalmente en los relatos de exploración y conquista del siglo XVIII. Estos análisis han establecido el funcionamiento del instrumental óptico para la difusión y afianzamiento del orden político colonial. Cfr. Pratt, Mary Louise. Ojos imperiales. Literatura de viajes y transculturación y Penhos, Marta. Ver, dominar, conocer. Imágenes de Sudamérica a fines del siglo XVIII. Penhos señala que el "papel que se asignó a las imágenes en los viajes político-científicos, de registro fiel de lo vivido y observado [...] las sitúa en un lugar central que nos apela a interrogarlas en su carácter de representaciones privilegiadas de las relaciones entre visualidad, conocimiento y dominio" (Penhos, Ver conocer dominar 19).
} 
Tanto los relatos que conforman La pampa como aquellos dedicados a la participación de Ebelot como ingeniero militar en la construcción de la Zanja de Alsina están plagados de referencias visuales. Saer destaca esta característica en "Ebelot", el ensayo que le dedica a la reedición francesa de su libro. Ebelot es el maestro de los "croquis" y a partir de esta herramienta - lingüística y visual- condensa con dinamismo los enfrentamientos bélicos entre soldados e indios y las costumbres gauchas que le interesa preservar. Pero además, en varias oportunidades menciona los instrumentos -el largavista, los mapas- que tenía a disposición para entender y mirar el fascinante espectáculo de los malones, e incluso describe el movimiento de los jinetes indios en términos no tan alejados a los de Saer: "A una media legua se distinguía una mancha confusa, inmóvil. [...] Finalmente la mancha inmóvil se puso en movimiento, y después al galope perfecto" (Ebelot, La pampa 164). La distorsión borrosa del paisaje ya estaba en la biblioteca decimonónica. Sin embargo lo que en Ebelot -pero también en otros viajeros- permitía recuperar, medir y vigilar el paisaje, condensándolo finalmente en una serie de imágenes decodificables; en Saer más bien desgarra la sutura empírica y revela la condición inauténtica y simulada de la experiencia: así el horizonte se abre a partir de una acción de borrado cuya irrupción es una tropilla salvaje que pasa -como en otra dimensión- y desaparece; así el hombre de negocios y propietario cabalga sin moverse y termina empastado en una mancha de tinta.

La tercera imagen que interesa analizar es la de los jinetes gauchos que acompañan a Juan, el hermano "salvaje" del doctor Garay López. Como en las otras oportunidades, se trata una vez más de una aparición sublime que fascina a Bianco y que comparte con las demás ese doble carácter: un exceso de realidad que deviene ruina o espejismo. Al igual que los caballos salvajes, el grupo de peones que rodea a Juan y que se ha detenido en la orilla opuesta de la laguna no le dirigen ni una mirada. Bianco "los ve exteriores, de una sola pieza, extranjeros a la piedad y a la vacilación, idénticos al soplo que los mueve, capaces de fidelidad y de violencia, sin que, igual que los pumas y las serpientes, violencia y fidelidad signifique nada para ellos" (Saer, La ocasión 95).

La mirada que Bianco fija en el grupo de peones gauchos participa del código de percepción y valoración que esgrimieron y reactualizaron las diferentes oleadas de viajeros, desde aquellos que como Francis Bon Head o Joseph Andrews reconocieron con franca admiración los atributos positivos del gaucho -ejercicio de la libertad dado por la extensión de las llanuras, independencia de los bienes materiales y códigos de 
conducta dignificadores - hasta las apreciaciones formuladas por Darwin y Ebelot. Éste último en particular esboza una versión del "gaucho malo" que parece dialogar con la imagen saeriana. En "El galgo moro", Ebelot describe a este tipo de personaje que le ha declarado la guerra a los jueces y a la policía, un individuo que "se echó al desierto, confiando en su cuchillo [...] para hacer respetar sus gustos de vagancia y de soledad. Tienen indudablemente mucho de tigre [...] la misma sed de sangre [...] pero participan también de su soberbia, de su valor, de su astucia" (Ebelot 35). ${ }^{185}$

Esa consustancialidad peligrosa - ya establecida por Sarmiento- que Ebelot advierte entre el desierto y los sujetos que engendra (para Bianco: la tropilla salvaje, los gauchos refractarios, la misma Gina) se da en términos de soplo y fuerza ciega y reitera, en términos pintorescos, las pinturas sobre la pampa. Pero una vez más, la mentalidad pragmática de Bianco torcerá la indeterminación ciega del desierto y logrará que Juan les enseñe "a esos gauchos asesinos a fabricar ladrillos, y [él mismo] por primera vez en su vida será capaz de ver un poco más allá de su absurda fijación monomaníaca con el ganado, aceptando que los miles y miles de extranjeros que están llegando al país puedan sembrar un poco de trigo en el borde de sus campos" (Saer, La ocasión 216).

\section{Otro episodio de la fiebre amarilla en la ciudad}

Antonio Garay López es el otro cuerpo que obsesiona a Bianco y que se le opone casi como lo hace el cuerpo de Gina. Garay López es un joven doctor que vive en Buenos Aires y detesta la ciudad. Forma parte de la élite de provincias que ha estudiado en Europa y se jacta de ser descendiente del fundador, Juan de Garay. A diferencia de la estridencia cromática que ostenta el cuerpo y las vestimentas de Bianco, Garay López elige colores sobrios y tonos apagados y, se dice, su elegancia linda con el dandismo.

\footnotetext{
${ }^{185}$ En uno de los relatos sobre la Conquista del Desierto, "La expedición al Río Negro" confiesa sus reparos ante el futuro del territorio nacional una vez quedara despejado de indígenas: "¿no se vería pronto recorrido por bandas de merodeadores de raza blanca, o mezclado de desertores del ejército, gauchos alzados contra la civilización refractarios de toda especie a quienes el desierto atrae y acoge, que tiene con él, tal como los indios, afinidades tan decididas que se diría engendradas espontáneamente, como las junglas crean al tigre y los alrededores de los ranchos abandonados la cicuta?" (288). Ebelot disputaba el modelo económico y político de los grandes latifundios que se proyectaba para esas tierras ganadas al indio y proponía un modelo más afín con el tipo de colonización norteamericana, fundado en un sistema de pequeñas comarcas agrícolas que les permitirían al colono y al gaucho emanciparse del poder de los grandes estancieros.
} 
Tiene además inclinaciones filosóficas - le habla a Bianco de Paracelso y de Pitágorasy literarias -es capaz de recitar en sus idiomas originales versos de Coleridge y Baudelaire- y está proyectando escribir una alegoría teatral llamada Los reyes magos. $\mathrm{Su}$ historia personal y la historia de su familia están íntimamente ligadas con la historia nacional: "su propia familia es prácticamente la más poderosa. El gobernador es un tío suyo, hermano de su madre. Multiplicarse ellos y el ganado, ensanchar sus tierras: es todo lo que les interesa" (Saer, La ocasión 65). Bianco constata con perturbación el parecido físico que guarda con Gina:

parecían hechos de la misma sustancia, la misma pasta elástica, juvenil y nerviosa que había sido amasada de una sola vez y después repartida en dos mitades iguales para darles forma y soltarlos al mundo, llevando siempre la marca del origen común, e incluso la diferencia de sexo parecía borrarse (Saer, La ocasión 134-5).

La versión paranoica del origen de Bianco y Gina, como si fueran de la misma pasta -o formaran parte del mismo soplo que anima a los caballos y a la llanuraexacerba su propia extranjería y ha sido analizada por algunos críticos como una semejanza siniestra que trasciende incluso voluntad y deseo y se constituye como la exteriorización de la materia que Bianco no puede someter. ${ }^{186}$

Sin embargo, ese retrato ligeramente feminizado de Antonio Garay López (rostro excesivamente pálido y miembros delicados) sufre una fuerte transformación cuando éste regresa a la ciudad. Lo que alcanza a ver Bianco cuando vuelve a su casa después de haber recibido el extraño dístico profético del Tape Waldo, es la versión grotesca de su caro dottore, desaliñado, con la cara hinchada y la piel de un rosa vivo encendido. Saer procede como un naturalista y sigue metódicamente los síntomas de la fiebre amarilla, el mal que ha transformado a su amigo. Sabemos que se documentó para hacerlo porque, como se dijo antes, entre el material prerredaccional de La ocasión se encontraron abundantes anotaciones sobre las causas y sintomatología de la enfermedad y así describe su aliento fétido, el color rojo de su cara, los párpados rojizos y más tarde el violáceo amarillento y los puntos rojos que van cubriendo la piel.

En 1871 Juan Manuel Blanes pintó uno de los cuadros más famosos de la historia del arte argentino, Un episodio de fiebre amarilla en Buenos Aires. Desconocemos si Saer efectivamente tuvo en cuenta esa pintura a la hora de recrear el

${ }^{186}$ Cfr. "La Fuerza y el vacío", el segundo capítulo del libro de Rafael Arce, Juan José Saer: la felicidad de la novela. 
episodio "local" de la peste pero podría decirse casi con seguridad que conocía el cuadro de Blanes porque éste forma parte del acervo visual y simbólico del público rioplatense desde su primera exposición en el foyer del Teatro Colón. Blanes es uno de los "primeros modernos", según anota Laura Malosetti Costa, un pintor uruguayo que sin embargo formalizó algunas de las escenas fundantes de la historia nacional oficial. Según su concepción, el arte debía ser útil y edificante y debía "sacar a la luz las verdades históricas que viven confundidas en el ruido del desasosiego político y social" (Blanes en Malosetti Costa "La cuestión del público" 158). Un episodio de fiebre amarilla en Buenos Aires fue recibido entusiastamente por la mayoría de los críticos y seguido con fervor por una masa de hombres y mujeres que acompañaron el traslado del cuadro hasta su lugar de exposición.

El masivo impacto que produjo puede comprenderse cuando se observa que el cuadro condensa una serie de sentidos sociales que estaban en conflicto durante su ejecución. En primer lugar, la imagen fue tomada por Blanes de un episodio efectivamente ocurrido y difundido en numerosos periódicos de la época: se había encontrado el cadáver de una joven mujer italiana, Ana Bristiani, de cuyo pecho un niño intentaba amamantarse en un cuarto de conventillo de la calle Balcarce. Los miembros de la Comisión Popular fueron representados en el cuadro por los retratos de Roque Pérez y Manuel Argerich, quienes iban en general acompañados de fuerzas policiales. Como se recordará, el lienzo muestra en primer plano la imagen idealizada de la mujer y del niño recostados en el piso del cuarto, mientras que en el margen izquierdo del cuadro se alcanza a ver el cadáver del padre tieso y acostado en su lecho. En el umbral de la puerta que divide lumínicamente la imagen entre el exterior iluminado por la luz diurna y el interior en sombra, se hallan tres personajes: el muchacho, seguramente otro inmigrante que ha dado aviso del lamentable hallazgo; y los ya mencionados Roque Pérez y Manuel Argerich, abogado masón el primero y médico el segundo, que miran respetuosamente la escena en un gesto de detención y recogimiento.

Laura Malosetti Costa analiza las importantes variaciones entre el primer boceto de la obra y el lienzo terminado y encuentra allí, en las diferentes poses y gestos de los personajes, la conversión de "la crudeza y el morbo de la noticia en un objeto codiciable, apetecible, en un recuerdo 'civilizado' de la peste [...] un tránsito del pathos al ethos, de la barbarie a la civilización" (Malosetti Costa, Los primeros modernos 78).

El episodio saeriano de la peste invierte, como intentará mostrarse, gran parte de la codificación visual y política del cuadro de Blanes. En primer lugar, Blanes buscaba 
exaltar los valores heroicos de la ciencia y el progreso y señalar, además, a los responsables por la difusión de la peste. En una entrevista sobre la reedición de Indios, ejército y frontera David Viñas sostiene: "En la Argentina, en los años 1860 y 1870, la secuencia es: paraguayos, montoneros, indios. Liquidados, la búsqueda del otro distinto y peligroso termina en el inmigrante. Desaparecidas las tolderías convencionales, aparecen las 'tolderías rojas': los malones ya no vienen del Sur, sino de Barracas, o de La Boca..." (Prieto, Archivo de desapariciones s/p).

Dos veces Bianco visita a Garay López durante su enfermedad, las dos veces buscando una confesión que le aclare o le confirme más bien sus presunciones sobre lo que sucedió aquel día en el que, volviéndose antes del campo, los encontró a Gina y al doctor hablando en un clima equívoco de gran complicidad e intimidad. Sin embargo, la confesión que obtiene de Garay López es otra: fue él quien llevó la epidemia a la ciudad cuando, asustado, huyó del Hospital de Buenos Aires al darse cuenta de que al menos dos pacientes morían de fiebre amarilla. Lo primero que revierte Saer es el esquema de la culpa. Resultará entonces que un habitante legítimo de la civilización, hombre de ciencias y descendiente de conquistadores es quien dispersa la enfermedad, no por causas heroicas sino porque teme el contagio. Pero además, es Bianco, al fin de cuentas, un inmigrante "italiano", el que lo visita en su lecho de muerte. Saer va incluso más allá en la desacralización del episodio y se comporta como un verdadero pintor naturalista al describir detalladamente los estragos corporales de la enfermedad. A diferencia de la idealización que practica Blanes, embelleciendo a la mujer y borrando los síntomas de la fiebre -sorprende la blancura y el aspecto "saludable" del cadáver- y soslayando en la sombra el cuerpo del padre, la pintura de Saer focaliza en el cuerpo enfermo:

Enteramente desnudo, Garay López está tirado en la cama, sin almohada, inmóvil, los ojos bien abiertos clavados en el techo, y aparte del cabello y de la barba renegridos y de los pelos del pubis renegridos, toda la piel de su cuerpo es amarilla, azafranada, y, a causa del sudor, relumbra un poco contra las sábanas empapadas. No solo tiene el olor, sino también el color de la paja descompuesta (Saer, La ocasión 206).

En contraste también con la deferencia respetuosa de los representantes de la Comisión popular, que en el cuadro final de Blanes se han sacado el sombrero en señal de respeto y se detienen ante la imagen desgarradora, Bianco se adelanta y golpea suavemente con su bastón la mejilla tiesa de Garay López y lo instiga para que confiese. Lo que en el cuadro de Blanes estaba relegado a la sombra como esbozo de cadáver 
masculino, pasa aquí al primer plano. Sin embargo, la imagen de la madre muerta que ocupaba el centro de la representación se recobra en la reescritura saeriana a partir de las últimas palabras de Garay López, que repite en un delirio final: "Me privó de madre al nacer" (Saer, La ocasión 206).

Por último, en el cuadro hay una oposición clara entre la oscuridad del interior del conventillo y la luz que viene del exterior, "una luz sanitaria", la llamará Daniel Santoro, porque viene precedida del dúo de doctores que le oponen, a la cruz que apenas se distingue sobre la cabeza del hombre muerto, la luz de la ciencia y el progreso, la luminaria del estado que llega para salvar, pero también para señalar, a los infectados. Los hombres, a contraluz, se recortan sobre el umbral y la atención lumínica se concentra en el pecho de la madre, convertida en un cuerpo deseable a pesar de la muerte. Saer borra las diferencias lumínicas entre el adentro y el afuera y, una vez más, fuerza una correspondencia entre el paisaje y aquellos sujetos hechos "de la misma pasta" que le da forma a la llanura: "Es igual que si los mismos cambios de color que contaminan la luz del sol, el horizonte y el follaje, estuviesen produciéndose en la piel humana, como si el mundo estuviese cambiando y las sustancias caprichosas que, combinándose entre ellas, [...] hubiesen decidido darle una apariencia extravagante, para variar el verde sempiterno de los árboles y el azul monótono del cielo" (Saer, La ocasión 196). La fiebre es un episodio colorista que irrumpe la monotonía cromática de la llanura. Bianco permanece inmutable a esa transformación del universo, como si después de haber pasado por tantas identidades diferentes, nada bastase para disolver "el coágulo de sombra que lo constituye" (196).

\section{Espiritualismo y capital en tierras de promisión}

Así como la serie de los cuerpos proliferaba en una abigarrada descomposición de imágenes y modos de habitar la pampa, La ocasión multiplica las versiones del desierto y descalabra la temporalidad histórica en la que transcurre la acción de la novela a partir de un montaje temporal y visual que yuxtapone paisajes de épocas y lugares remotos: desde el escenario bíblico de Belén hasta el campo modernizado de la agricultura. Cada una de estas variaciones prueba las posibilidades del delirio, la profecía y el espiritualismo contra los fueros pragmáticos de la racionalidad capitalista y positivista. 
Por un lado, la alegoría teatral de Garay López, Los reyes magos, ${ }^{187}$ podría leerse como un comentario en abismo sobre algunos de los conflictos de la novela: el más evidente es el de la pregunta por el hijo que obsesiona a Bianco, ${ }^{188}$ porque también aquí hay tres extranjeros acompañados de un grupo de pastores que atraviesan esperanzados la llanura buscando el paradero de un niño y deseando "que un acontecimiento, una aparición, venga por fin a sacarlos de esa red gris, campesinos, nobles, mujeres, hombres, [...] los que en la luz del sol no encuentran otra cosa que hambre, pena o delirio, los que quieren saber si por fin su presencia en esos caminos pedregosos y blancos que el día calcina obedece a una casualidad o a un llamado" (Saer, La ocasión 54). Sin embargo, los tres reyes se desplazan infructuosamente porque bajo el signo de la estrella que les indicaría el lugar del nacimiento encuentran un establo vacío y los habitantes de Belén les aseguran que no ha nacido ningún niño. ${ }^{189}$

El dilema -que podría leerse bajo la clave edípica que sigue Premat sobre la incertidumbre con respecto al padre que campea el relato- se plantea además las

187 "Madrigal" condensa la misma historia que cuenta la alegoría de Garay López: "Pastores, /la estrella/ no lleva a nada/ su trayectoria es azar,/ aparición fugitiva [...] la adoración/ error o cálculo/ en un establo/ vacío" (Saer, El arte de narrar 152). El poema desestabiliza una vez más todas las certezas: lo visible, el firmamento, la propia mano, el pensamiento y la adoración. Lo que en La ocasión permitía refractar otras problemáticas de la novela -la dudosa paternidad de Bianco; la oposición entre locales e inmigrantes- se ubica aquí en otro orden. "Madrigal" forma parte de las poquísimas poesías que Saer decide incluir en la última sección de El arte de narrar, llamada La guitarra en el ropero, que recoge poemas escritos entre 1981 y 1987. Se trata de seis poemas breves que reiteran varias de las obsesiones poéticas de Saer y vuelven a interrogar la noción de espacio y permanencia. En este sentido "Madrigal" y "Ruidos de agua" indagan la posibilidad de un mundo en el que haya algo más que azar o espejismo, pero otros poemas, como "Señales del río Lot" o "Haiku" atemperan ese fracaso y postulan que "El azar se transforma/ en mundo, y/ el mundo/ en belleza" (149) cada vez que el río se convierte en un signo que envía sus señales o una planta tiembla antes de la tormenta ("Haiku").

${ }^{188}$ Como se recordará, uno de los misterios que la novela deja sin resolver es la paternidad del hijo que Gina espera. La perturbación y los celos dominan a Bianco después de la equívoca situación de íntima complicidad que presenció entre su esposa y Garay Lopez. Esa escena obsesionará al personaje durante toda la obra y permanecerá como un nudo irresuelto.

${ }^{189}$ El motivo de Belén vuelve a aparecer en un breve "apunte" que Saer incorpora en $L a$ narración-objeto a propósito del cuadro de Pieter Brueghel el joven, El Censo de Belén (1566), para reflexionar sobre el uso de la tercera persona. Como en otras obras del pintor, el motivo central pasa desapercibido: "Es por esas razones que la Sagrada Familia llega a Belén y pasa inadvertida en medio del traqueteo del censo [...] el narrador la incluye en el conjunto de la muchedumbre, y si es cierto que no está lejos del centro del cuadro, aparece relativizada y como traspapelada por la neutralidad de los acontecimientos" (Saer, La narración-objeto 190). La tercera persona, ubicada entre la visión del individuo aislado y la mirada de Dios, repone la concepción de narración saeriana: "un punto de vista miope o ciego [que] restituye la opacidad del mundo, [y] se vuelve, gracias a un movimiento de despersonalización aparente, un procedimiento al servicio de la comicidad o de la ironía" (190-191). "Madrigal" y la alegoría de Garay López agudizan ese movimiento y el censo, herramienta de control estatal e imperial, devela su futilidad frente a la "incertidumbre universal" (191) que campea en lo empírico. 
mismas dicotomías que desarrolla el drama mayor: la diferencia irreductible entre nativos y extranjeros y entre una imaginación idealista y una pragmática positivista: "Los de Belén se sonríen entre ellos: son campesinos, claro, pastores, y los reyes vienen de Oriente, donde la gente es demasiado crédula, un poco atrasada; tienen la mirada extraviada, y, aunque ignorantes, parecen de buena voluntad" (Saer, La ocasión 58). Leído en perspectiva, la novela proyecta sobre la alegoría cristiana el problema de la inmigración europea a tierras americanas y se articula como un comentario irónico y pesimista sobre las esperanzas de progreso que venían a buscar los inmigrantes. El establo vacío es, una vez más, la refutación de la materia, la prueba positiva de que no hay milagro en el mundo.

Por otro lado, la novela incorpora y desarticula otra forma de la espiritualidad. En Cuando la ciencia despertaba fantasías, Soleidad Quereilhac advierte una particular y productiva amalgama entre ciencia, espiritismo, prensa y literatura en la época de entresiglos, uno de cuyos productos fueron las fantasías científicas de Eduardo L. Holmberg, Leopoldo Lugones, Horacio Quiroga y Atilio Chiappori, preocupadas en explorar un perturbador oxímoron de época, el de lo espiritual-material, que suponía que la investigación y la experimentación científicas permitirían comprender y develar muchos de los misterios del espíritu.

En este sentido, cabría entender al personaje de Bianco en relación a los derroteros que transitó el movimiento espiritista desde sus comienzos, cuyos primeros cultores y médiums se sometieron muy tempranamente a las colaboraciones y refutaciones de las sociedades científicas, que sin embargo, se mostraban interesadas en sus elucubraciones. Como explica Quereilhac, "a medida que el movimiento teosófico se expandía, comenzaron a hacer oír, también, las críticas de sus detractores” (128), como el informe escrito por la Society for Psychical Research que presentó como una de las mayores impostoras de la historia a la reconocida ocultista rusa Madame Blavatsky.

Varios relatos de Las fuerzas extrañas (1906) presentan algunos de los principales núcleos problemáticos que Saer recompone en La ocasión, particularmente para los casos del Tape Waldo, Bianco y su disputa con los positivistas. ${ }^{190}$ Los relatos teosóficos de Lugones problematizan los vínculos entre ciencia y teosofía y postulan la

\footnotetext{
${ }^{190}$ Como se recordará, en París Bianco es convocado por la Academia de Ciencias que lo llama para que haga una demostración pública de sus poderes telepáticos. Allí sufre el "gran escándalo" que signa su vida y es humillado por los miembros de la institución. Ultrajado viaja a América con el fin de encontrar un espacio adecuado a la escritura de la Refutación a los positivistas.
} 
idea de la superioridad e inconmensurabilidad de las fuerzas ocultas por sobre los conocimientos científicos y las habilidades técnicas del hombre. ${ }^{191}$ En "La Fuerza Omega", por ejemplo, se presenta el descubrimiento de fuerzas interetéreas y en la voz del protagonista volvemos a escuchar la voluntad espiritual de Bianco: "La identidad de la mente con las fuerzas directrices del cosmos [...] es cada vez más clara; y día llegará en que aquella sabrá regirlas sin las máquinas intermediarias, que en realidad deben ser un estorbo" (Lugones 14). "El Psychon", por otro lado, repone el contexto de suspicacias que algunos científicos manifestaron ante las experiencias del ocultismo. Paulin, el protagonista del relato, es, como Bianco, un forastero, un científico que, por ser además espiritualista, es mirado de reojo por las academias.

En algunos cuentos de Lugones conviven el progreso rural y la experiencia espiritista y científica. ${ }^{192}$ El paisaje agrícola puede alojar narraciones extraordinarias y

${ }^{191}$ En al menos dos ocasiones Saer menciona a Lugones: en La vuelta completa y en El río sin orillas y en ambos casos para hacer referencia a Las Odas seculares (1924). Miguel Dalmaroni retoma la cita de La vuelta completa como epígrafe de Una república de las letras y advierte que Saer recupera uno de los momentos más caricaturescos del escritor y lo hace ingresar en una "escena típica de examen escolar argentino [que] representa, en este sentido, un lugar común del fastidio artístico de varias generaciones de escritores y lectores" (17). Pancho Expósito se queja de ese lastre literario que se arrastra todavía entre los contenidos escolares, y cita un ilegible e indigerible fragmento de las Odas sobre la enmienda del código rural. Sin embargo, en El río sin orillas Saer retoma a Lugones para acrecentar su extenso catálogo de los colores del río. Vuelve a citar Las Odas seculares y si bien le imputa todavía una "incorregible pomposidad" y una "intrincada retórica finisecular" (Saer, El rio 220-1), no deja de anotar y precisar su sensibilidad perceptual: "las modificaciones cromáticas debidas a los reflejos del cielo" (Saer, El río 220-1) que el escritor supo finalmente percibir, para descomponer los matices fluviales en "la plata de la luna" o "fuego de fierro" (221). Este apartado sobre La ocasión busca trascender el fastidio y la ironía a partir de los que Saer recuperó a Lugones en su primera novela e indagar qué diálogos pudo haber establecido no sólo con Las fuerzas extrañas sino con el ambiente de época que ese libro aglutinó, principalmente sus preocupaciones teosóficas, sus reversiones sobre el origen y sus postulaciones sobre la paideia nacional. En "Leopoldo Lugones. La construcción de imágenes de escritor" Gramuglio postula que el nacionalismo es inseparable de las estrategias literarias y formales del escritor y advierte que por "nacionalismo" entiende un conjunto de ideas que tienden a promover un determinado "destino nacional": "sea éste la constitución del Estado, la integridad territorial, la restauración o el logro de la congruencia entre la unidad política y la unidad cultural, la homogeneización de la población y aun la expansión colonial" (99). Son precisamente estos factores los que aparecen en ciernes en La ocasión y por ello intentará pensarse qué de ese nacionalismo de Lugones se actualiza, desviándose, en la novela de Saer.

${ }^{192}$ Cfr. "Un fenómeno inexplicable" cuya acción transcurre en una geografía bastante similar a la de La ocasión: "la región agrícola en la que se dividen las provincias de Córdoba y Santa Fe" (Lugones 33). El narrador, un hombre que está de paso por aquellas regiones se hospeda en la residencia de un inglés viudo que posee la mejor casa de la colonia. Como se recordará, el inglés ha sido subteniente del ejército de la India, donde enfermó de algo extraño. En su acento extranjero le cuenta al narrador su experiencia como yoghi y el desdoblamiento que sufrió su personalidad, cuyo doble resultó ser un mono. Ironía del colonialismo, el doble del inglés es una criatura salvaje, "negro como mi propia sombra y melancólico al modo de un hombre" (39). 
permitir contactos con otras dimensiones espirituales. Como señala Quereilhac, en Lugones cabría encontrar "la proyección fantástica de un sueño espiritualista: el despliegue fabuloso de la intensidad del espíritu por sobre la debilidad de la materia" (209). En La ocasión, por el contrario, el imaginario espiritista de Bianco se paraliza ante la otra "fuerza ciega" que lo anima: la racionalidad pragmática del progreso "licúa", para tomar una metáfora de "El Psychon", las posibilidades espiritualistas de Bianco y vuelve a mostrar su estrepitoso fracaso.

En relación precisamente a las posibilidades y las limitaciones de esas "fuerzas extrañas" es necesario subrayar en esta oportunidad la forma en que la novela dialoga con las formas estilísticas y pedagógicas que formaron parte de esa sensibilidad de época que Lugones fraguó de manera bastante admirable en ese puñado de relatos que forman el libro. En "El juicio del siglo: Leopoldo Lugones revisitado" Dalmaroni ensaya una nueva relectura sobre su obra que busca pensar las condiciones de legibilidad de Lugones en el presente (la conmemoración del Bicentenario) y antologa su fastidiosa, módica y estratégica presencia en Borges, Piglia, Saer y Aira. Sin embargo, como el mismo Dalmaroni señala, como escritor-artista y convocado por Joaquín V. González (ministro político del presidente Roca) Lugones fue quien le dio forma escrita al proyecto liberal-oligárquico de modernización del Estado (a partir de $E l$ imperio jesuítico; Odas seculares y Didáctica). Esa paideia estatal, concentrada en esas y otras intervenciones, ya comienza a desplegarse en los relatos reunidos en Las fuerzas extrañas. Interesa este aspecto porque La ocasión se presenta, finalmente, como una desarticulación paródica de morales pedagógicas en disputa y reescribe, explícitamente o no, varias de las alternativas que se vehiculizan en los cuentos de Lugones. Según Dalmaroni, el escenario pedagógico que pone en juego el libro se debate entre dos niveles de enseñanza, la destinada a aquellos poco capacitados para aprender lo incógnito ("La fuerza Omega", "El psychon”) y la educación de "los muchos que deben ser educados en una koiné normalizada por el amo" (Dalmaroni, Una república de las letras 112) que no debe excederse en la "paciente integración pedagógica" si es que no se quiere poner en peligro el estado y la ciudad ("Yzur", Los caballos de Abdera", 193 "La lluvia de fuego"). Bianco fracasa en su comercio con las fuerzas extrañas y falla en

\footnotetext{
193 "Los caballos de Abdera" es un relato sobre los riesgos que pueden producirse a causa de una ampliación excesiva de los límites de la ciudadanía (recordemos que los caballos de Abdera se convierten paulatinamente, a causa de una tarea educadora proverbial, en bestias refinadas que adquieren gustos artísticos, nombres humanos y disposiciones intelectuales, y en las que se despierta un instinto de rebelión que los hace saquear la ciudad como una "masa rebelde").
} 
su intento de transmitirle a Gina sus inquietudes telepáticas, sin embargo es quien puede domesticar y conducir tanto las expectativas de la masa inmigratoria que lleva a los confines sudamericanos como las formas anticuadas de la oligarquía nativa representada en Juan, el hermano barbarizado de López Garay.

Otra zona de la divulgación científica, señala Quereilhac, también explorada en los medios de prensa de la época y en las narraciones de Lugones era el caso de los llamados "sensitivos": los médiums, los niños prodigio y clarividentes o las mujeres que podían percibir la inminencia de la muerte. Muchos de estos "casos" fueron noticia en las revistas y materia de elucubración literaria. La extraña historia del Tape Waldo podría ser la de uno de estos "sensitivos". Como se recordará, este es el segundo relato enmarcado de la novela que encuentra su inicio en las batallas del Ejército Grande pero cuyo desarrollo es contemporáneo de la historia principal. Como en toda la obra, se trata de perseguir la huella de los "marcados" en la llanura, aquellos cuyo cuerpo llevan una inscripción anómala que señala una falta, una desproporción, una discapacidad: el Tape Waldo, la Violadita - pero también el mismo Bianco y el doctor López Garay enfermo de fiebre- . Esta segunda historia se teje a partir de los movimientos que trazan los personajes: las apariciones esporádicas que el gaucho desertor hace en su rancho para embarazar a su mujer o violar a sus hijas mayores y las peregrinaciones milagrosas del Tape Waldo y La Violadita, después de haber sido liberados de su padre por la acción justiciera de sus hermanos mayores.

El Tape Waldo, que al presenciar el homicidio de su padre había gemido durante meses hasta callar por completo, recupera la posibilidad de hablar pero sólo lo hace para lanzar oscuras profecías en dísticos octosilábicos. Su fama empieza a crecer y él y la Violadita atraviesan el campo en todas direcciones, hasta más allá de Buenos Aires, hasta las cercanías de Córdoba: "Empezaron a ser una figura familiar del paisaje [...] ella toda de blanco y él de gauchito requintado, de opereta, ancho y tieso" (Saer, La ocasión 163). El mismo Bianco va a consultarlo para probar la autenticidad del fenómeno y descubrir si se trata de un mistificador, y lo describe como a un autómata: "Bianco tiene la impresión de que la masa rechoncha y atildada [...] es una especie de autómata que funciona con un mecanismo interno muy complicado del que los raros gestos exteriores, lentos y repetitivos, no alcanzan a dar una idea de los engranajes múltiples y ocultos que les permiten producirse" (Saer, La ocasión 174). La llanura no sólo engendra imágenes, simulacros y parodias, desbaratando la nitidez de las cosas, engendra también seres monstruosos. 
Como señala María Negroni a propósito de las muñecas, los dobles y autómatas que aparecen en su Galería fantástica, se trata de "figuras que están supuestamente inanimadas, y que representan el terror a que lo inanimado se anime, o que lo animado se petrifique [...] figuras esquivas, que están a caballo entre lo humano y la máquina" (Negroni $\mathrm{s} / \mathrm{n})^{194}$. Por mucho que el autómata vista los atuendos del gaucho y fatigue la llanura, la extranjería de sus predicciones es puesta de manifiesto: "ese don no le viene de las palabras sino que [...] el rumor condescerá durante unos instantes a transvasarse imperfectamente en palabras que serán, respecto de él, sin excepción, inevitablemente extranjeras" (Saer, La ocasión 175-6). Los versos confusos del Tape Waldo reviven las esperanzas de sentido de "los que miran perplejos transcurrir sin razón aparente los días y las noches [...] los que se mueren de hambre, de frío, de tristeza, en los baldíos borrosos de los arrabales" (219), como la estrella de Belén había esperanzado a pastores y reyes, pero unos y otros permanecerán sin respuesta. En este caso, la "magia", o el don, recordémoslo, están regenteados por los sujetos marginados de las guerras patrias: la hermana mayor de La violadita, hija de un gaucho desertor y ex prostituta, y un sargento retirado de la Guerra del Paraguay que allí perdió su brazo. El mecanismo que activa el "don" y que perfecciona el dispositivo no es otro que el de una emergente empresa capitalista familiar que intercambia versos apenas audibles y difícilmente codificables por caramelos, billetes y regalos.

La historia enmarcada del Tape Waldo es quizás una de las más espectaculares de Saer porque no sólo reescribe en clave gauchesca e irónica la fantasía de los autómatas y los coloca en plena pampa sino porque además retoma una de las imágenes claves de la llanura, la ficción geológica del imaginario darwiniano:

Los llamaban de todas partes y ellos cruzaban el campo en todas direcciones [...] hasta las cercanías de Córdoba, en los caseríos precarios que iban formándose en la superficie chata de la tierra más antigua del mundo, cubierta por el sedimento de continentes y de especies desaparecidas y molidas por el tiempo y por la intemperie, ese espacio irreal y vacío que los conquistadores ponían especial cuidado en esquivar (Saer, La ocasión 163).

\footnotetext{
${ }^{194}$ Negroni, María. "El Gótico es una grieta en el mundo de la luz y la razón” (entrevista realizada por Alejandro Alonso). Revista Axxón. Ciencia ficción en Bits, Diciembre de 2009. Disponible en http://axxon.com.ar/rev/2009/12/maria-negroni-el-gotico-es-una-grieta-en-elmundo-de-la-luz-y-la-razon-por-alejandro-alonso/
} 
En diálogo con la ficción geológica y evolutiva de Darwin, Saer imagina la llanura como el futuro que le espera al resto del mundo: ${ }^{195}$

Eran como una persistencia irrisoria que, desafiando sin saberlo la molienda cósmica que había puesto la llanura pelada como ejemplo de lo que les esperaba a los otros continentes, a las cimas supuestamente majestuosas y a las nieves ilusoriamente eternas, a las especies ávidas y en pretendida evolución, cruzaban al paso los campos desolados [...] [y] aun los indios [...] los dejaban seguir su camino (Saer, La ocasión 163).

Como ya se ha señalado a propósito de El río sin orillas, Saer es un gran lector de Darwin y acude a sus escritos para diversas operaciones. No sólo recupera la biografía del científico, glosa los principales aspectos de su investigación y encarna una defensa frente a quienes lo acusaban de ser un espía inglés, sino que también utiliza varias de sus imágenes en comparaciones libres (la fosforescencia del mar patagónico para indicar el vago resplandor de los faroles de los autos en plena tormenta, por ejemplo) y establece con él un pacto íntimo, familiar, de lectura. Darwin no sólo le interesa por la calidad de su prosa ni por su curiosidad insaciable - aspectos que también destaca- sino porque ayudan, a un hombre de la llanura como Saer, a "comprender las sensaciones íntimas que parecían inseparables del propio ser y que van desplegándose en lo exterior, al mismo tiempo autónomas y familiares" (Saer, El río 101). Como él mismo indica,

${ }^{195}$ Charles Darwin (1809-1882) partió siendo un joven naturalista a fines de 1831 en el HMS Beagle, al mando del capitán Robert Fitz Roy. El objetivo de la expedición era completar el cartografiado de las costas de Tierra del Fuego y de la Patagonia y los estudios de las corrientes marinas alrededor del globo. Arribaron a Sudamérica en febrero de 1832 y permanecieron allí hasta 1835, cuando la embarcación siguió rumbo a Tahití. En ese tiempo Darwin visitó los puertos de Brasil, desembarcó en Montevideo y recorrió gran parte de la Banda Oriental, Buenos Aires, Santa Fe, la Patagonia, Tierra del Fuego y Chile. Los "desvíos" de Darwin, que lo hacían internarse en tierra, le permitieron acopiar una gran cantidad de especímenes de plantas, insectos, rocas y restos fósiles que periódicamente enviaba a Inglaterra, así como asignarle, a ese espacio desconocido, las características de un paisaje legible. A su regreso en Inglaterra publicó el Diario del viaje de un naturalista alrededor del mundo, cuyo éxito superó largamente el informe de la expedición escrito por Fitz Roy. Veinte años más tarde publicará $E l$ origen de las especies. Uno de los aspectos que interesa subrayar aquí, por su relación con la prosa saeriana, es que la "ficción geológica" y la "ficción evolutiva" desarrolladas por Darwin fueron posibles por su particular forma de percepción temporal. Al respecto, Fermín Rodríguez señala que el naturalista era capaz de detenerse en detalles y texturas en los que podía percibirse el paso lento e imperceptible del tiempo: "La historia natural produce una nueva máquina de hacer hablar la vida, de arrancarla de su fijeza por medio del lenguaje, según una ficción geológica atenta a las huellas escritas sobre la superficie de las cosas, a sus roces, sus contactos, sus texturas, rugosidades y durezas" (Un desierto para la nación 82). Una temporalidad, como también ocurrirá en Saer, que excede la temporalidad humana y deshumaniza el paisaje. 
Darwin realiza varias de sus observaciones muy cerca de la casa natal del escritor, cuestión clave para la reescritura familiar de la historia argentina que Saer ensaya:

Durante muchas leguas —escribe Darwin — al norte y al sur de San Nicolás y de Rosario, el país es realmente chato. No se puede considerar exagerado nada de lo que los viajeros han escrito a propósito de esa nivelación perfecta. [...] cuanto más la llanura es nivelada, más el horizonte se aproxima de esos límites estrechos: de modo que a mi juicio, esto es suficiente para destruir ese aspecto de grandeza que se cree encontrar obligatoriamente en una vasta llanura (Saer, El río 118).

Como ha sugerido Adolfo Prieto, Darwin sucumbe algunas veces a las “ensoñaciones cosmogónicas", esos momentos en los cuales, capturado por una evidencia misteriosa del presente, se retrotrae imaginariamente al comienzo de los tiempos. Así, la comparación entre los hallazgos fósiles de la costa entrerriana y los de Carmen de Patagones desemboca en "un juego especulativo que no tarda en convertirse en verdadera imaginación poética, y los huesos, y las conchillas y las arenas se abren a la fascinante y novedosa descripción de un Génesis con plataformas continentales que se desplazan, con tierras que surgen del fondo del mar, con especies animales que transmigran y cambian" (Prieto, Los viajeros ingleses 79). Seducido por el juego de las imágenes, estas ensoñaciones no caben en el lenguaje del naturalista y desbordan hacia lo poético. Fermín Rodríguez apunta este trasvasamiento: "El acto de imaginación del naturalista, que sostiene el despliegue del paisaje, vacila por una pasión que resquebraja la mesura estética: la experiencia de lo sublime, lo impensable tomando cuerpo en la llanura" (72-73). También en Saer la ficción histórica se fuga hacia la espiral -poética y visual- de la imaginación geológica y a partir de ella se abre una brecha temporal en la narración. Según Fermín Rodríguez, si en las vistas de Humboldt el hombre se contrae frente a la majestuosidad de la naturaleza americana, en Darwin el ser humano desaparece en el tiempo. La llanura saeriana desafía o más bien impugna la impugnación humboldtiana sobre el escaso interés de los llanos rioplatenses y chilenos de las tierras templadas, porque ese paisaje chato y pelado es lo que les espera a las cumbres majestuosas y a las selvas espesas repletas de especies en pretendida evolución. Saer parece rescatar aquí la reflexión final de Darwin, cuando en su diario de viaje, después de haber reconocido la falta de grandeza de la llanura, se pregunta:

¿Por qué, pues, estos áridos desiertos han echado tan profundas raíces en mi memoria? [...] Difícilmente puedo analizar estos sentimientos; pero en parte dimanan del libre campo dado a la imaginación. Las llanuras de Patagonia son sin 
límite; [...] llevan el sello de haber permanecido como están hoy durante larguísimas edades, y parece que no ha de haber límite en su duración futura. Si nos pusiésemos en el caso de los antiguos, que consideraban la tierra como una llanura rodeada de una zona infranqueable de aguas o de desiertos caldeados por un calor irresistible, ¿quién no miraría estos límites postreros de las exploraciones humanas con un sentimiento de profunda y vaga curiosidad? (Darwin 411).

Ese territorio sublime disuelve las fronteras discursivas y abre el Diario hacia la imaginación poética y fabulosa, mítica. Saer destaca de Darwin no sólo su habilidad de descifrar el pasado sino también de predecir el futuro porque, sugiere, sus reflexiones políticas aún suenan contemporáneas y Darwin pudo prever el exterminio aborigen cuando presenció las campañas que Rosas libraba en su contra. ${ }^{196}$

Sin embargo, en un horizonte más cercano, es otro el destino que le depara a la llanura. Ya sea mediante el arte predictivo del Tape Waldo, las dotes visionarias de Bianco, la promesa religiosa del nuevo pastor de hombres o el presagio geológico darwiniano, La ocasión apunta a un futuro que se revela siempre como ininteligible, inaudible, fracasado, vacío, inexistente. Una a una caen las promesas del idealismo, de la religión e incluso de la ciencia evolucionista que raya en lo poético. Sin embargo lo que sí se sostiene y crece es la imagen de una pampa futura configurada por la mirada pragmática de Bianco que proyecta alambrar los campos, ${ }^{197}$ fabricar ladrillos, fomentar la agricultura por sobre el modelo ganadero y exportar luego el trigo para venderlo en los mercados europeos. ${ }^{198} \mathrm{El}$ último de los desplazamientos que ofrece la novela es el

\footnotetext{
${ }^{196}$ Al respecto, Fermín Rodríguez señala: "De la extinción de especies al exterminio de indios hay pasos imperceptibles y zonas de indeterminación donde la naturaleza se historiza y la historia se naturaliza. A la luz de los hechos posteriores, la ficción paleontológica de Darwin está llena de presagios" (87).

${ }^{197}$ En Historia del alambrado en la Argentina, Noel Sbarra explica cómo se incorporó el alambrado en los campos argentinos y argumenta que fue un factor fundamental en el desarrollo de una época nueva de la economía rural. Intoducido por primera vez por Richard B. Newton en 1845 y utilizado por Franz Halbach para cercar la primera estancia argentina diez años después, el alambre produjo significativas transformaciones: permitió parcelar las grandes extensiones de tierra, facilitó la cruza de haciendas criollas y el cultivo de los campos. Sbarra menciona a su vez las reglamentaciones y litigios legales a que dio lugar el alambrado, cuando los dueños de las estancias cercenaban los caminos públicos que quedaban luego dentro del límite de sus tierras. El cercado modificó finalmente el paisaje y las faenas rurales que habían anotado con curiosidad los viajeros (se terminaron las rondas nocturnas para impedir la dispersión del ganado así como las boleadas de avestruces, venados y gamas): "La pampa fue domesticada: la llanura ilímite quedó encerrada en la jaula brilladora de los alambrados. Ya no es la pampa de Mac Cann, que la discurrió a su antojo; ni la de Darwin, al que impresionó hondamente su 'silencio de muerte', ni la de los increíbles baqueanos" (Sbarra 104).

${ }^{198}$ Este salto de la imaginación que proyecta, por sobre las condiciones actuales de un territorio, un futuro diseñado de acuerdo a las necesidades del progreso económico también se verifican en algunos de los viajeros ingleses que visitaron el país durante las primera décadas del siglo XIX.
} 
del éxodo masivo de aquellos que huyen de la peste, entre ellos, Bianco y Gina a punto de dar a luz. La pareja se aleja hacia el campo y una vez más el paisaje se vuelve imagen cuando se desplazan lentamente en un carro tirado por bueyes: "se diría que [...] alguien va tirando el paisaje entero hacia atrás, haciendo estremecerse a los bueyes y al carro a cada sacudida, igual que si estuviesen pegados a la alfombra beige que hace las veces de suelo" (Saer, La ocasión 210). La ironía final que le espera a Bianco es que será precisamente allí, en ese rancho filosófico minimalista, pensado para escribir su refutación a los positivistas el lugar del pacto económico con Juan, el verdadero patrón del campo, que caerá rendido, nueva ironía, bajo el influjo material y venenoso del vientre en expansión, aquel cuya paternidad permanecerá desconocida.

\section{"La ocasión": un comienzo de "larga exposición"}

En 1960 Saer amplía su biblioteca y comienza a interesarse en textos del siglo XIX. Así lo recordaba en "Libros argentinos":

La serie del medio siglo de la editorial universitaria, me reveló también muchos textos apasionantes del siglo anterior, como La guerra al malón, del comandante Prado, el libro de Guinard, Tres años de cautividad entre los patagones, o el pasaje de las Memorias del general Paz que narra su prisión en la Aduana de Santa Fe. [...] La serie despertó en mí el gusto por los documentos de ese tipo, lo cual me llevó a la admirable colección El pasado argentino de Gregorio Weimberg, de la que leí muchos volúmenes. A principios de los años setenta hice comprar la serie entera en dos ejemplares para la Universidad de Rennes, lo cual me produjo, en las noches del invierno bretón, lluvioso y gris, muchos momentos agradables. Buena parte de esos autores son extranjeros, particularmente ingleses o franceses, pero para mí, [...] son auténticos clásicos argentinos (Saer, "Libros argentinos", Trabajos 194).

Este temprano interés de Saer hacia los textos del siglo XIX y hacia la biblioteca de los viajeros coincide cronológicamente con el comienzo efectivo de su literatura. Cuando publica En la zona advierte, ya desde las "Dos palabras" liminares, el carácter proyectivo del libro, y sorprende la enorme autoconciencia del escritor que tan tempranamente pudo advertir las direcciones de su obra futura y condensarlas aquí:

Como señala Adolfo Prieto en Los viajeros ingleses y la emergencia de la literatura argentina, cuando Joseph Andrews visita Tucumán no deja de observar el potencial económico del paisaje. Tucumán es al mismo tiempo el Jardín de la República y el sitio propicio para la inversión de capitales. En varias ocasiones, su celebración romántica del paisaje se ve interrumpida por un salto hacia adelante en el que Andrews imagina los efectos de la explotación económica. 
"Para todo escritor en actividad la mitad de un libro suyo recién escrito es una estratificación definitiva, completa, y la otra mitad permanece inconclusa y moldeable, erguida hacia el futuro en una receptividad dinámica de la que depende su consumación" (Saer, En la zona 421). Es posible leer en el libro, como ya se ha aventurado, la presencia conjunta de Borges y de Arlt: “A partir de 1955, Arlt y Borges entraron en mi vida, como en la de tantos lectores de mi generación, a la que le tocó hacer la síntesis de esos dos grandes escritores" (Saer, "Libros argentinos", Trabajos 191). Sin embargo, podría pensarse que hay otro comienzo en la literatura de Saer, menos “espectacular" que el profetizado En la zona y que recién se materializa en textos tardíos, una vez que Saer ya se ha vuelto un escritor reconocido y ha radicalizado los caminos de la experimentación. Esa temprana fascinación por la biblioteca del siglo XIX coincide, entonces, con ese comienzo alternativo: la escritura de una primera versión de la que será posteriormente La ocasión, que como veremos también condensa toda una zona de problemas e incluye nombres de personajes que aparecerán mucho después.

Aunque levemente posterior en cuanto a los acontecimientos narrados en la novela, la escritura de "La ocasión" comenzó en 1960 y continuó a mediados de los setenta. ${ }^{199}$ Se trata de un breve relato homónimo dividido en diecinueve fragmentos que relata “otra ocasión” aunque, como señala Mariana Di Ció, comparte algunos elementos con la novela, ciertos personajes, un mismo enclave sociohistórico y aspectos que atraviesan la narrativa saeriana en torno a la indagación de lo real y la condición inestable del sujeto. ${ }^{200}$ El mismo Saer advierte con respecto a las sucesivas versiones de

\footnotetext{
${ }^{199}$ No es mi intención detenerme en la comparación de ambos, remito para eso al artículo "Juan José Saer, a medio escribir" de di Ció.

200 "La ocasión" cuenta la historia de un puñado de personajes en torno a un drama "familiar" que se revela además como un conflicto policial. Un inglés instalado en la zona se ha llevado a la hermana de Juan, el capataz de la estancia, para que trabaje como empleada, y durante una borrachera se la ha entregado a cuatro ingleses que estaban de paso por el Establecimiento. Después la ha echado desnuda al campo. El narrador es el hijo del dueño de la estancia y profesa una relación ambigua con Juan porque si bien eran como hermanos desde niños, ahora se le presenta como alguien desconocido y temible. La historia transcurre entre la estancia, el río y la ciudad. En el campo el narrador comparte las actividades de los peones, va a la pulpería y se hace visitar todas las noches por dos jóvenes prostitutas. En la ciudad, asiste junto a su familia al teatro y participa de las discusiones políticas que enciende en la mesa familiar su futuro cuñado, un joven intelectual de provincias. Por otro lado, Juan logra vengarse y mata al inglés en una laguna. Unos indios de la zona atestiguan el crimen y lo venden a las autoridades. El relato retoma conflictos propios del género gauchesco pero también abre una serie de cuestionamientos sobre la subjetividad, la percepción y el sentido que reescriben anacrónicamente las tribulaciones de Juan y del narrador. Podría argumentarse que entre esta primera versión y la novela finalmente editada no hay demasiados puntos en común, aunque se
} 
esta obra: "Once años más tarde dejé todo aquello y la retomé. La escribí en 20 días" [...] [De lo que había escrito antes tomé] imágenes, situaciones. Nada de lo escrito. La escritura se deslizó a velocidad" (Giglio, Una forma más real 148). ${ }^{201}$

"La ocasión" es el laboratorio de prueba para muchas de las imágenes de la llanura y el campo que reaparecerán en textos posteriores editados -la novela homónima pero también Las nubes- aunque "la escritura" sea otra. El relato podría pensarse como esas fotografías de larga exposición que capturan los elementos estáticos pero también las temporalidades múltiples que inscriben los cuerpos en movimiento frente al obturador. En este caso podría pensarse que la exposición prolongada del texto a las circunstancias vitales de Saer -su traslado a París- y a las modificaciones de su propia obra lo vuelve un enclave privilegiado para observar cómo se transforma su lectura de la tradición.

La primera distancia que cabría señalar con respecto a la primera versión de $L a$ ocasión es la relativa ausencia de la "perspectiva exterior" (lo mismo sucedía en su reescritura de "A medio borrar") que caracteriza la focalización de Bianco en la primera versión del relato: ${ }^{202}$ aquí el narrador no es un extranjero sino el hijo del dueño de la estancia, un sujeto que comparte a medias la vida de los peones del campo y la vida social de la ciudad. Nuevamente se trata de un médico que ha estudiado en Europa y reside en Buenos Aires, "doble" de Juan, el capataz con quien compartió su infancia pero al que ahora teme. El narrador participa de las formas de sociabilización cultural de ambos mundos: comparte el trabajo y el asado con los peones y frecuenta la pulpería pero también asiste al espectáculo de vistas animadas en el teatro de la ciudad. Innominado, este personaje es la bisagra que reúne y separa las imágenes de la vida salvaje y de la urbe. Cuando el narrador abandona el campo, es el paisaje el que retrocede: "veía, desde la canoa, la tierra amarilla y retroceder, de un modo gradual, los montes, los esteros, el agua. Toda esa vida salvaje, temible, negra, ese hormigueo, no

reitera, como se vio, el título y el marco espacio-temporal y algunos personajes permiten evocar los que aparecerán muchos años después en La ocasión.

${ }^{201}$ De acuerdo a lo que señalan los editores, en la tapa de la carpeta en la que se encontró "La ocasión" se lee el título del texto y abajo "Paraná, 1961/ Guadalquivir, 1973/ Sena, 1984" (Saer, Papeles 370). Esta anotación, señalan, supone una miniversión legendaria de escritura escandida por tres ríos. Las fechas corrigen ligeramente las que Saer recuerda en entrevistas posteriores. Según la hipótesis de Di Ció, Saer escribe un primer manuscrito de doce páginas en la que figuran once secciones, años después relee el manuscrito, transcribe y sigue escribiendo, sumándole a esa versión original siete secciones más.

202 "Relativa" ausencia porque el narrador no deja de ser un personaje que ha vivido y ha estudiado en el exterior y porque el centro de sus cavilaciones es precisamente el progresivo distanciamiento de su "doble" local y "barbarizado". 
era más que un recuerdo que se alejaba [...] a medida que la ciudad luminosa con sus casas blancas, sus negocios, mi casa, mi familia, mis amigos, iba pasando, por pedazos, de la memoria a la experiencia" (Saer, "La ocasión", Papeles 354). Cuando se acerca a caballo el efecto es inverso: "Atravesé, a caballo, el campo, los arrabales, viendo venir hacia mí los campanarios, los techos rojos, los jardines" (355). El fragmento en el que se inscriben estos desplazamientos comienza con un nuevo encuentro sexual -infructuoso como los de Nadie nada nunca- entre el narrador y las prostitutas que manda a llamar todas las noches, y culmina con la imagen bucólica de sus tres hermanas, vestidas de blanco, que se han reunido en el patio bajo el sol y observan el “trabajo de la aguja sobre la tela blanca" (Saer, "La ocasión”, Papeles 355).

El relato funciona como un muestrario de la pampa y pivotea sobre diferentes temporalidades del desierto -desde las ficciones del origen hasta 1870 aproximadamente- casi al modo en el que Ebelot compendiaba, en algunas imágenes, los "tipos" y "costumbres" que estaban desapareciendo del paisaje nacional. ${ }^{203} \mathrm{La}$ ficción revisa el mapa social de la llanura: no falta la mención a los extranjeros -no sólo los ingleses sino también la noticia de un grupo de italianos que se afincaría en la zona $-^{204}$; los gauchos y peones de campo; el estanciero y su capataz; el hermano profesional que ha estudiado en Europa y desdeña la vida de provincias; las hermanas y las mujeres que trabajan detrás de la pulpería como prostitutas; el intelectual de provincias, Herrera; los indios, los soldados y las fuerzas del orden. Y están, también, los escenarios: la amplia casa familiar de la ciudad, el teatro, el puerto y la prisión de la aduana, ${ }^{205}$ los arrabales, el puesto junto al río, el campo a medio alambrar, el rancho, las islas y la pulpería -el lugar en el que suceden las desgracias y corren los rumores, como afirmaba Ebelot-. Como se verá, incluso en este texto de inicios, Saer comienza a

\footnotetext{
${ }^{203}$ Dice por ejemplo que referirá su experiencia en la pulpería porque esta es como el teatro en el que ocurren todos los dramas de la pampa. Tanto la pulpería como la galera condensan los mapas sociales y culturales de la llanura. La galera es como un Arca de Noé de la que salen el estanciero (el de antaño y el moderno, que quiere dejar el ganado y establecer un centro agrícola); el pulpero, el gaucho (cuya progresiva desaparición Ebelot registra con mirada nostálgica); las señoras; los italianos comerciantes; los vascos y los policianos que llevan a los criminales a la ciudad. La galera es además un lugar en el que circulan noticias y chusmeríos, el "periódico" andante del campo.

${ }^{204}$ Construidos sobre la estereotipia de la visión utilitarista de su emplazamiento y su forma característica de hablar el español.

${ }^{205}$ La prisión de la Aduana es significativa porque allí se aglutinan los diversos personajes del drama de la conquista, indios, soldados, gauchos hoscos, perros: "el relente de todas las guerras pasadas, de la guerra presente y de las guerras por venir, flotaba en el aire febril del atardecer caluroso" (Saer, "La ocasión", Papeles 369).
} 
ensayar algunas reelaboraciones sobre el catálogo tradicional de la pampa que ficciones posteriores como Las nubes terminarán de distorsionar.

El relato, como decíamos, se sostiene sobre una arquitectura temporal compleja porque mientras en el plano de las acciones se pone en escena el funcionamiento de un desierto más o menos domesticado, (el campo alambrado, la llegada de los inmigrantes, la expansión de la ciudad y los tratados comerciales con los ingleses del Establecimiento) la imaginación del narrador parece levemente anacrónica y carga con un trauma del desierto que pareciera desconocer o revelar el carácter ilusorio de ese dominio: "éramos una mancha iluminada en un punto impreciso de una inmensa realidad negra. Toda la luz se concentraba en nosotros, por no decir en mí. Desde la oscuridad estarían contemplándonos, con asombro, los tigres, las culebras, los sapos, las lechuzas, los indios” (Saer, “La ocasión”, Papeles 344).

En La ocasión la llanura convertía todo en imagen, ruina o visión ¿qué relación entre ojo y desierto se había establecido en su primera versión? La llanura modernizada -el relato transcurre a medida que se va alambrando el campo y cumple, anacrónicamente, el proyecto de Bianco- es panóptica: un ojo permanentemente abierto que atestigua los crímenes, los desplazamientos y los vejámenes que sufren los personajes, y es también una boca que murmura, vende y castiga: "En esta tierra oscura, donde todo y todos nos vigila, después, de noche, ¿cómo dormir?” (351) y "No fue por él que lo supe, porque él no contaba nunca nada. Alguno, en el puesto que está después de la laguna, en el camino a Santa Rosa, me lo contó" (339). ${ }^{206}$ "La ocasión” oscila entre aquello que todos saben que ha ocurrido - la afrenta del inglés y la posterior venganza de Juan- y lo que permanece oculto y sustraído a la mirada. El episodio, podría decirse, moreirista, en el que Juan mata al inglés al borde de la laguna se narra a partir de una elipsis en la que el narrador, testigo del crimen, describe los extraños movimientos del inglés como si fueran un efecto de su borrachera o de su locura y no como el resultado de las puñaladas de Juan:

el largo cuerpo rojizo del inglés se bamboleaba. Me di cuenta de que estaba un poco borracho [...] Se dejó caer en el suelo, estirando los brazos, parecía

\footnotetext{
${ }^{206}$ ¿Qué es lo que se sabe y todos han escuchado?: "Lo que decía el silencio de los peones era lo mismo que me habían dicho en el puesto de la laguna, lo mismo que él sabía, y que sabía que yo sabía: Hunter, el inglés, que se había llevado a la hermana de Juan a vivir con él al Establecimiento, con el pretexto de emplearla como sirvienta, se había emborrachado el sábado a mediodía, [...] y se la había entregado a los cuatro ingleses que lo visitaban, de paso para Córdoba" (Saer "La ocasión", Papeles 343).
} 
crucificado, estaqueado más bien. [...] Hacía muecas, abriendo la boca, apretando los dientes, cerrando los ojos, y en un determinado momento hasta sacaba la lengua afuera, como si se burlara de alguien. [...] Se tomó la cabeza entre las manos, sosteniéndola por la frente, y apoyando los codos en las rodillas empezó a balancearse (350).

Pero aquello que el narrador oculta (el cuerpo de su "hermano" asesino), lo revelan los indios, que también han atestiguado el crimen y han corrido a contárselo a Mr. Savage a cambio de tabaco.

Como se vio, en apenas algunas páginas el relato se teje sobre una serie de conflictos dispares - las tensiones entre nativos y extranjeros, entre porteños $\mathrm{y}$ provincianos, entre la ley del estado y la ley del gaucho que debe vengar a su familia, ${ }^{207}$ entre la ciudad y el campo- la focalización narrativa es, de todos modos, anacrónica respecto de ellos y participa más bien de la sensibilidad moderna de los personajes saereanos que se asumen como semiciegos y se obstinan en la percepción del mundo aun cuando conozcan su carácter ilusorio y contingente, como si este narrador fuera el antepasado criollo de Tomatis o del Gato Garay. ${ }^{208}$ Borrado por la presencia del padre y desconociendo ahora al que había sido su doble, ${ }^{209}$ busca infructuosamente un sentido en el encuentro sexual que repite todas las noches en el campo y solo puede contener o conjurar momentáneamente su irrealidad cuando se detiene en las texturas del mundo:

no había más que mirar las hojas duras que hacían destellar los faroles, de un verde profundo, o la noble lisura de la madera, o el cuero usado y vuelto transparente de los rebenques [...] o las caras barbadas hechas de sola

\footnotetext{
${ }^{207}$ Josefina Ludmer señala con respecto a Juan Moreira que pasa de la legalidad a la ilegalidad por una injusticia y ocupa, como Martín Fierro, la posición de un sujeto entre dos culturas y justicias: la oral, la ley tradicional del honor y el valor, y la justicia escrita moderna, la ley del poder: "Con esas dos muertes 'justas', por una injusticia económica y por una injusticia del poder estatal, el gaucho Moreira encarna la violencia popular en su estado puro, dirigida directamente a la opresión: sus víctimas son los enemigos del pueblo. [...] hace la travesía necesaria del justiciero popular" (Ludmer, El cuerpo del delito 233). Sin embargo, a diferencia de Moreira y de Fierro, Juan no se convierte en un héroe popular, es acusado por su propia hermana y tratado con cierta deferencia solo por ser el capataz de uno de los mayores estancieros de la zona. Reclamado por las leyes del honor y la venganza no participa del sistema del reconocimiento de esa ley y es subsumido por la maquinaria moderna de la prisión.

${ }^{208}$ En "Los aros de acero de la sortija", el prólogo que escribe sobre "La mayor", Miguel Dalmaroni señala sobre "Carta a la vidente" que si bien el narrador refuta la convicción rimbauldiana sobre el carácter visionario del poeta, permite que algo pueda recobrarse: "que el mundo resplandezca, si uno de los modos del mundo es el resplandor" (Saer, "Carta a la vidente", La mayor 211).

${ }^{209}$ La extranjería se juega de otra manera, no ya como desapego del lugar sino del "otro", el doble, que ahora se desconoce: "Y con él, ya que el mismo pecho, el de su madre, nos había, en la infancia, amamantado, si veníamos, casi, del mismo barro [...] no debía haber una certidumbre? Y sin embargo, un rato antes, [...] yo había tenido miedo. Miedo de que me matara" (Saer, "La ocasión", Papeles 351).
} 
exterioridad, para comprender por fin cuál era la materia feliz de la que el mundo estaba hecho. $\mathrm{Y}$ en ese tiempo espeso, sin cortes, $[\ldots]$ vinieron a incrustarse, $[\ldots]$ redondas y claras, las historias. Quedé solo entre los árboles, con mi vaso de vino, bajo los faroles. [...] La eternidad entera no hubiese podido nada contra ese minuto. [...] Algo que había estado faltando acababa de venir, finalmente, a ocupar su lugar (Saer "La ocasión", Papeles 367).

"La ocasión", escrita, como se dijo, a lo largo de veinte años, es acaso la versión "criollista" de "La mayor" o de Nadie nada nunca. Alguien que no es Tomatis ni el Gato Garay pero que se les parece recobra "el don" de un instante en el que se precisan las texturas, el mundo y las historias. Este breve relato, que permanece como un episodio flotante en la larga trayectoria escritural saereana, participa a la vez de las preocupaciones filosóficas contemporáneas del escritor y de la selección tardía que textos como La ocasión y Las nubes harán sobre ese muestrario de la llanura decimonónica. Por eso en el texto resuenan, más incluso que en otros, muchos de los relatos que Saer estaba construyendo paralelamente y que escribiría después: la ficción del origen que evoca el nacimiento de las islas ensayado en El limonero real; ${ }^{210}$ una versión anterior y campera del arrabal que se presenta ya más urbanizado en los relatos de En la zona; fragmentos que reiteran obsesivamente la "nada" que significa el mundo como en Nadie nada nunca; nombres de personajes como el de Morvan, Juan, Garay López que retomaran ficciones posteriores y la idea de los indios espías, recuperada en Las nubes.

\section{2. "Fragmentos de un Juan Moreira"}

En El arte de narrar Saer publica "Fragmentos de un Juan Moreira". El poema pertenece a la primera sección del libro, es decir, aquellos poemas que fueron escritos entre 1960 y 1975 y publicados por primera vez en 1977. Como se sabe, el folletín de

\footnotetext{
${ }^{210}$ Uno de los fragmentos de "La ocasión" parece ser una versión condensada del origen fluvial que El limonero real desarrollará: "ha de haber habido un tiempo, difícil de medir, en el que en esta tierra no había nada: ni las bestias, ni los indios, ni los árboles. Y después, de a poco, han debido brotar, del agua, las islas, una tierra homogénea, sin detritus, sin huesos, una costra barrosa, neutra. Después ha de haber habido un tiempo de vida grumosa, larval, sin distinciones. Un gran pantano de vida, toda a la misma altura, en la misma fase: la vida viscosa, ciega, móvil, sin individuos todavía, sin especies. Y después, un buen día, de la nada, los loros han debido echarse a volar rayando, amarillos, verdes, el cielo azul. Han de haber emergido, del barro blando, ásperos, los yacarés. Han de haberse multiplicado, lentamente, los árboles. Los algarrobos, las víboras, las vizcachas, los laureles, los árboles. [...] Y han debido llegar después los indios -Dios sabe de dónde- a crear el pasado y a adorar" (345).
} 
Eduardo Gutiérrez fue retomado y reversionado muchas veces en teatro, cine y literatura y la figura de Moreira fue además objeto de importantes representaciones pictóricas. ${ }^{211}$ En fechas más o menos contemporáneas a la reelaboración poética que hará Saer, César Aira publica Moreira (1975) y Néstor Perlongher su poema "Moreira", incluido en Alambres (1987). ${ }^{212}$

La primera deriva que cabría señalar entre el folletín de Gutiérrez, publicado en la sección de "Dramas policiales" del diario La Patria Argentina, y la poesía de Saer es precisamente una deriva genérica que arrastra, por supuesto, condiciones de producción y recepción totalmente diferentes. Como señala Ludmer, Moreira es el héroe popular de la era de la prensa y de la modernización tecnológica y cultural y su configuración se hace posible gracias a las "tecnologías de la verdad" que apelaban al trabajo con pruebas y testigos y permitían llevar adelante una verdadera investigación del caso. El

${ }^{211}$ En relación a su representación pictórica, Malosetti Costa señala que en la exposición colectiva de artistas nacionales que habían estudiado en Europa que se organizó en 1891 tanto Della Valle como Mendilaharzu presentaron sus representaciones de Juan Moreira y fueron duramente criticados por otros pintores, literatos y críticos de arte -Auzón, Schiaffino y Carlos Gutiérrez, el hermano de Eduardo Gutiérrez- por no haberse ceñido al espíritu del texto original y haberse apartado de la imagen popular del gaucho. Mendilaharzu pintó, según señala Schiaffino, a un gaucho "gordo y bajito" y retrató, en contraposición, al juez enemigo de Moreira a partir de una esbelta estampa. Se distingue entonces entre la verdad histórica -en la que el personaje bien podría haber sido así- y la leyenda popular "con su flujo de lógica poética [...] que no aceptará nunca un Juan Moreira que no sea fisiológicamente el fiel trasunto de su psicología tan poco complicada, tan simple. Moreira encarna hoy en el pueblo argentino el morisco orgullo de nuestros gauchos, la altivez nativa unida al coraje indomable" (Schiaffino en Malosetti Costa, Los primeros modernos 262). Los ecos de Moreira en pintura también pueden rastrearse en la muestra Fragmentos de El Moreyra, de Oscar Suárez (Disponible en http://www.elsuarez.net/past-exhibition).

${ }^{212}$ Varios estudios críticos se han concentrado en analizar las diferentes versiones de Moreira, desde el folletín que escribe Gutiérrez entre 1879 y 1880 en La Patria Argentina a las diferentes versiones teatrales, cinematográficas, poéticas y noveladas. En 1886 Gutiérrez escribe, junto a José Podestá, una nueva versión teatral de la obra. En el "Prólogo" a Juan Moreira, Alejandra Laera explica que posteriormente Moreira fue relegado a un espacio marginal, eclipsado por el lugar que había ganado Martín Fierro como héroe nacional después de los festejos del Centenario de Mayo, aunque su historia siguió contándose en las ediciones populares del libro a lo largo de las décadas del treinta y del cuarenta. Los años setenta proveyeron un contexto social y político en el que el caso del gaucho perseguido volvió a circular a partir de nuevas versiones y sentidos políticos: Juan Moreira la película que Leonardo Favio estrenó en 1973; la ópera prima de César Aira Juan Moreira (1975), la incorporación de Moreira como personaje de la historieta Inodoro Pereyra, el renegau de Roberto Fontanarrosa; los poemas de Perlonguer y Saer. En "Cuatro versiones de Moreira", Gamerro advierte que, a diferencia del Martín Fierro de Hernández, el Moreira de Gutiérrez es un personaje a medio hacer, un "gólem gaucho" cuya potencia precisamente radica en esa indefinición, y se actualiza con fuerza en cada una de sus versiones. Es precisamente esa potencia de la indefinición la que permite la reescritura saeriana, una versión que la crítica en general no analiza o menciona solo al pasar. Cfr. al respecto: Ludmer, Josefina. "Los Moreira"; Gamerro, Carlos "Cuatro versiones de Moreira"; Villanueva, Graciela. "Avatares de Moreira"; Laera, Alejandra. "Prólogo. Metamorfosis de un héroe popular argentino: las mil caras de Juan Moreira" y Retamoso, Roberto. "Reescrituras del Moreira". 
Moreira de Saer, en cambio, es ya un sujeto absolutamente literario que sufre, como veremos, una estilización poética de condensación. ${ }^{213}$

Tal como lo presenta Eduardo Gutiérrez, Moreira es el "judío errante": "El gaucho viene a ser un paria en su propia tierra" (34), aquel en el que mejor se cumple esa "encrucijada de destierros" que determina a los hombres según Saer: un exilio "circunstancial", el de aquellos que deben abandonar la patria para defender su vida y su dignidad, que en Moreira se cumple cuando debe abandonar a su familia después de las primeras dos muertes; el exilio "estructural" que sienten los hombres que no comparten el modo de vida de una sociedad alienada, en este caso la impuesta por la ley de un Estado en vías de modernización que le impone a un gaucho trabajador y honesto como él someterse a la imparcialidad de la justicia; y el "exilio ontológico" que acompaña siempre al sujeto y que en él crea una "segunda naturaleza" en la que el hábito con la muerte es cada vez mayor. Moreira llega como una piedra "tirada por el desierto/ como si hubiera rebotado contra la pared de su exilio" (Saer, "Fragmentos de un Juan Moreira", El arte de narrar 77). Alejado por la injusticia y la brutalidad de la ley estatal de su hogar y expulsado de la "legalidad del estado", a pesar de haber matado "en buena ley" a Sardetti (el inmigrante italiano que le debía dinero) y a Don Francisco, (el teniente alcalde representante del estado que lo castigaba injustamente), ${ }^{214}$ sus derroteros por los pueblos de la provincia giran en espiral alrededor de su hogar y son a la vez atraídos y expulsados por la presencia de las partidas que salen a buscarlo. ${ }^{215}$

\footnotetext{
${ }^{213}$ Según ha señalado Roberto Retamoso en "Reescrituras del Moreira", a diferencia del folletín, fuertemente enraizado en lo real, en datos y referencias a través de las cuales Gutiérrez enfatiza la "verdad" de los acontecimientos, el poema de Saer problematiza lo real y configura un personaje más trabajado por lo incierto que por la fatalidad que caracteriza al héroe original.

${ }^{214}$ Es Josefina Ludmer quien distingue entre ambas modalidades de la ley. El pasaje de la legalidad del estado a la ilegalidad por una injusticia es la travesía necesaria que tiene que cumplir todo héroe y justiciero popular. Las dos primeras muertes son "justas" desde esta perspectiva porque Sardetti y Don Francisco son enemigos del pueblo.

${ }^{215}$ En El tiempo vacio de la ficción, Alejandra Laera traza el mapa de la errancia de Moreira y explica el doble funcionamiento de los espacios interiores de la campaña (estancias, pulperías, prostíbulos) como refugio y posibilidad de socialización pero también como zonas de riesgo a las que llegan las partidas. Por ese motivo, la localización del gaucho en estos espacios interiores es coyuntural y su imposibilidad de permanecer en ellos es el motor de las novelas populares. Si bien el desplazamiento por la campaña es considerado una tendencia natural del gaucho, en los folletines de Gutiérrez esa errancia está inducida por la persecución y no es una elección personal de sus personajes. El gaucho aquí empieza su itinerancia una vez que se ha "desgraciado". En el caso de Moreira, oriundo de Matanzas, partirá siempre hacia el oeste y tendrá como escenario fundamental el partido de Navarro, desde donde hará diversas incursiones hasta encontrar la muerte en el prostíbulo La Estrella, en Lobos.
} 
El epígrafe que abre el poema: "Y todavía estoy en el principio", retomado del folletín de Gutiérrez, da la clave de lectura que realizará Saer. El sintagma es parte de la confesión de Moreira después de haberse cobrado su primera víctima, el italiano Sardetti: “-Y todavía estoy en el principio -había dicho amargamente el gaucho-, aquella muerte es el principio de mi obra, y don Francisco es el fin con que tengo que estrellarme" (Gutiérrez 56) y anuncia una escalada cíclica de muertes y de violencia que en el poema se cumple maquinalmente: "Los movimientos mecánicos de su brazo apuñalando/ un único cuerpo -el suyo-, muerto un millón de veces/ y vuelto a renacer un millón de veces en la monotonía del llano" (78). Ese único cuerpo apuñalado del poema borra virtualmente la multitud de cuerpos ajusticiados por Moreira en la versión original. Es decir que con respecto a la variedad novelística de Gutiérrez, ${ }^{216}$ que despliega una gran cantidad de personajes y de escenarios, el poema de Saer cumple una función de condensación radical: reduce todos los cuerpos a uno, el de Moreira, y todos los enfrentamientos al momento de su muerte, elimina los nombres propios de los amigos y enemigos del gaucho - reiterados y presentados con exhaustividad en el folletín- y condensa el escenario en La estrella, la pulpería-prostíbulo en la que muere el personaje pero que en el poema adquiere una significación mayor como "menhir en el centro del espacio devorador" (78). "Fragmentos de un Juan Moreira" hace foco en el episodio final de las aventuras del personaje, reduce en apenas algunos versos su biografía y expande una zona que el folletín solo menciona de manera superficial y romántica, la vida íntima del héroe como padre y esposo.

En la excelente lectura que hace Ludmer al analizar las diferentes versiones y reescrituras de Moreira, se señala que las diversas representaciones del mito van trazando una historia literaria de la violencia en la Argentina desde fines del siglo XIX hasta la actualidad. Cada reelaboración del mito hace visible una nueva forma de la violencia de estado, de la violencia política y de la violencia popular. Desde otra

\footnotetext{
${ }^{216}$ Graciela Villanueva explica en "Avatares de Moreira" que la versión novelística de Juan Moreira responde a las exigencias estilísticas y de difusión del folletín: "Además de los defectos y de las cualidades inherentes a la precipitación con que se escriben las obras que se publican por entregas en periódicos (hipérbole, repetición y ciertas incoherencias, pero también vivacidad y dinamismo para atraer al lector) podemos señalar, como rasgos característicos del folletín en general y de Juan Moreira en particular, la redundancia, la multiplicación de las peripecias, el juego periódico con el suspenso (al final de cada entrega) y la búsqueda de efectos inmediatos (a través, por ejemplo, de la explosión de imágenes)" (1168-9), y agrega además que los orígenes románticos del folletín perviven en el dramatismo con el que se cuentan las acciones y el tono épico que revierten los procesos sociales, aunque el personaje de Moreira deconstruya el héroe ejemplar del romanticismo y lo convierta en un "héroe prontuariado".
} 
perspectiva, en "Cuatro versiones de Moreira" Gamerro retoma una hipótesis de Ezequiel Martínez Estrada y advierte que "El drama social de Martín Fierro condesciende en Juan Moreira a melodrama; la gauchesca deja de ser política y social y empieza a hacerse policial” (2). ${ }^{217}$ ¿De qué violencia habla este poema de Saer, que suprime los enfrentamientos y resume a los enemigos de Moreira en "Dueños" y "Propietarios"?, ¿qué usos de la gauchesca reactiva o eclipsa? ${ }^{218}$

La última parte del poema se compone de dos estrofas que parecen desprenderse de la contingencia particular de la historia de Moreira para retrotraerse al tiempo de la conquista y posterior explotación de la pampa. De los "Dueños" que codician los senos de Vicenta a los "Propietarios" que "se echaban desnudos/ y solitarios en el amanecer acariciándose/ los muslos velludos" (Saer 80), el poema da un salto que va de la biografía poética de Moreira a la reflexión crítica de la historia; de la escena doméstica de paternidad y trabajo a la dilatada escena de la conquista que parece retroceder o escribir la historia para atrás. ${ }^{219}$ Primero un "ellos" (no especificado en el poema): "Mantenían el control del cuero y la plata./ Gastaban a sus mujeres en trabajos de descendencia./ Se ajaban ejerciendo las artes de comerciar y gobernar" (81) es decir, un momento de relativa estabilidad económica y política pero al que se llega por instancias previas de conquista militar: "Iban a la guerra poniéndose la casaca militar sobre el paletó/ y volvían con olor a pólvora y a caballo", y aún hacia atrás: "habían ido avanzando a través de la tierra desde el mar, dejando un rescoldo de poblaciones de la hoguera de sus [batallas" [...] delante de ellos ondulaba el desierto [...] sin nada sólido

${ }^{217}$ La hipótesis que desarrolla Ezequiel Martínez Estrada en Muerte y transfiguración del Martín Fierro es que en la novela la injusticia social y el desorden gubernamental se suplantan con la injusticia personal de un mal funcionario; la mala política con el mal político. Se plantea una reducción del funcionamiento social a algunos de sus agentes. Gamerro advierte entonces que la persecución de Moreira termina respondiendo al capricho de un individuo. Interesa subrayar, más allá de los debates que podrían despertar estas hipótesis, que la poesía de Saer se escribe a contrapelo de esta reducción "melodramática" y "policial" de la injusticia, para reponer, precisamente, la dimensión social e histórica de la serie política.

${ }^{218}$ En El género gauchesco. Un tratado sobre la patria Josefina Ludmer explica que el folletín de Gutiérrez pone en juego otro uso del género, no ya el género gauchesco definido por la voz del gaucho, sino el pasaje a la novela, "con las voces del gaucho y las palabras letradas delimitadas nítidamente, separadas, en Juan Moreira y Don Segundo Sombra" (49).

${ }^{219}$ Este pasaje puede comprenderse mejor a la luz de una reflexión sobre Moreira que se desarrolla en El río sin orillas. Allí Saer comprende a los "bandidos justicieros" (Juan Moreira y Hormiga Negra) como la prolongación legendaria del gaucho, aunque con rasgos más urbanizados, y a su vez como precedentes de los anarquistas que llegaron al país durante las primeras décadas del siglo XIX. Moreira es la bisagra en la que se pliegan el campo y la ciudad: "Juan Moreira, el héroe popular por excelencia, se hace matar en un prostíbulo suburbano en una emboscada que le tiende la policía. La violencia [...] abandona la llanura y se instala en la ciudad (Saer, El río 178). 
para fundar en él” (81). ¿Qué violencia visibiliza el Moreira de Saer? Al parecer según esta escritura retrospectiva, toda la violencia: ${ }^{220}$ la agresividad sexual, social $\mathrm{y}$ económica que impuso la conquista y el posterior afianzamiento de esos Dueños y Propietarios sobre el desierto. ${ }^{221}$ Según Premat, a partir de la descripción de la llanura que Saer traza en La ocasión, la recreación del siglo XIX es anacrónico y en realidad remite constantemente a la época de la escritura de Saer. No es casual, agrega, que aparezcan textos como ese y El entenado en ese período de fin de la dictadura de la Argentina de los ochenta. Desde esta perspectiva podría pensarse que Moreira, escrito en algún momento entre 1960 y 1975, no es solo producto de esa violencia consustancial a la emergencia de la pampa -que encarna, como vimos, muriendo y resucitando muchas veces ${ }^{222}$, , sino también del clima de violencia que permea otros textos de Saer, como Responso y Cicatrices, vinculados con la proscripción del peronismo y la Revolución Libertadora. ${ }^{223}$

Esta segunda lectura es posible porque la poesía de Saer no sólo reelabora la genealogía de Juan Moreira sino que traza relaciones intertextuales hacia la propia obra de Saer. La muerte de Moreira se cuenta poéticamente a través de una escena de cacería que es igual a la que aparece en el poema que Tomatis escribe en Cicatrices. Leemos en la poesía de Saer: "para acorralar a la liebre, tiene que haber un punto/ más adelante del

${ }^{220}$ Esto es posible, además, porque como señala Gamerro en "Cuatro versiones de Moreira", Moreira es un personaje bisagra que puede articular distintos espacios -el campo, la ciudad y las orillas- y diferentes formas de ejercer el coraje: "Juan Moreira hace de puente entre la gauchesca y la futura literatura de orilleros: la de Carriego (el Carriego depurado por Borges) y la del mismo Borges" (3). El poema de Saer usufructúa ese carácter de "pasaje", estrechando la contigüidad entre el presente de la narración y la presencia anacrónica y transversal del desierto. ${ }^{221}$ El tono de esta última parte de "Fragmentos de un Moreira" evoca el tono pesimista de Radiografía de la pampa de Ezequiel Martínez Estrada en el que también el racconto de la historia se hace a partir de la configuración de ciertos personajes arquetípicos que condensan los rasgos de los distintos grupos que formaron parte de la historia de la pampa. También M. Estrada comprenderá las distintas conquistas como una sola: "A la conquista del territorio para la Corona siguió el otro absurdo de la conquista del alimento para el ausente y, al fin, este otro que es el tercer aspecto, el actual, igualmente lógico: la conquista de la riqueza para el capital extranjero en el ferrocarril, el frigorífico y el trust cerealista" (26).

${ }^{222}$ En el folletín es el amigo Julián quien celebra esa fuerza vital que caracteriza a Moreira: "Julián había abrazado a Moreira con el placer inmenso que le causaba la resurrección del gaucho, a quien había visto muerto más de diez veces durante aquella lucha encarnizada" (Gutiérrez 81).

${ }^{223}$ Por eso, el personaje no puede estar configurado con los atributos melodramáticos que Gutiérrez le prodiga hasta el hartazgo a su héroe, capaz de matar a una decena de hombres sin inmutarse pero sensible hasta las lágrimas cuando se trata de recordar a su familia: "el paisano se había enternecido de tal modo que se vio obligado a secar con el poncho un par de lágrimas que rodaron por sus temblorosas mejillas, dando a su cara, hermosa y varonil, una expresión de ternura infinita" (Gutiérrez 81). 
cual la liebre no pueda avanzar, / para que esté cansada/ tiene que haber un campo por el que haya corrido [...] únicamente la lucecita que él llevaba dentro era irreal" (Saer, "Fragmentos de un Juan Moreira", El arte de narrar 79). ${ }^{224}$ Como se sabe, la cacería remite en Cicatrices al episodio de Luis Fiore, obrero y ex sindicalista que mata a su mujer cuando salen a cazar y se suicida durante la indagatoria. En "Cicatrices de Juan José Saer: El peligroso juego de la literatura" Panesi explicita este vínculo que evoca el poema de Tomatis: "significativamente este poema se refiere a una cacería -una liebre, un obrero-" (4). Leído en esta red intertextual, el poema de Saer podría vincularse a este contexto particular de la violencia, aunque habría que advertir que en el racconto condensado de su biografía se elude la participación política de Moreira como puntero electoral e incluso su papel como víctima de una sociedad injusta. Como ocurre a menudo y ha señalado la crítica, la historia política no alcanza para determinar los sentidos de los textos y el Moreira de Saer, precisamente por las derivas de su genealogía, es un personaje perfecto para iluminar tanto la violencia fundacional de la pampa como para sugerir la violencia política contemporánea al momento de su escritura.

\subsection{Los extraviados}

En los mapas de la pampa, nombres como "El perdido" señalan una geografía de extraviados que no han sabido atravesar la llanura por la "uniformidad del desierto [que] desbarata la superstición del movimiento" (Saer, El río 120). A pesar de la prodigiosa capacidad de leer la escritura infinitesimal del suelo que ostentan baqueanos y rastreadores, la pampa es como un cuadro suprematista del que es muy difícil distinguir los matices del blanco y percibir diferencias en lo idéntico: “en los siglos pasados más de un viajero, víctima de la ilusión de avanzar giró en redondo durante días hasta que lo voltearon el cansancio, el hambre y la sed” (120). Así resume Saer, más de veinte años

\footnotetext{
${ }^{224}$ Vale aclarar que la versificación del poema es distinta en Cicatrices. Por otro lado, en "Fragmentos de un Juan Moreira", la poesía incluida en Cicatrices se encuentra enmarcada en una estrofa más extensa que destaca por la atención material que el poema despliega sobre el proceso de erosión y corrosión del viento, la arenisca, el agua, el polvo y el ramaje, suerte de introito al tema de la cacería. El verso final "únicamente la lucecita que él llevaba dentro era irreal" se repite en ambas versiones. Como ha señalado Mariana Di Ció, Saer prueba diversas variaciones sobre esta misma imagen, la de una luz que se enciende adentro de un personaje, en textos diversos que van desde la primera versión de "La ocasión" a El entenado, y por supuesto, Cicatrices y el poema sobre Moreira.
} 
después, el argumento de "El viajero", para incorporarlo en una cartografía más vasta de extranjeros, pero también de nativos, que podrían fácilmente perderse en el paisaje ilegible.

Si Bianco es el extranjero por antonomasia que, durante su primer contacto prolongado con el campo parece "haberse metido bajo la piel de la llanura y haber cavado en ella sus propias galerías como un topo, el haberla atravesado indemne, aceptando sus leyes sin sin embargo dejarse aniquilar por ellas" (Saer, La ocasión 87), Jeremy Blackwood es su versión deprimida y extraviada. A pesar de compartir algunos atributos físicos y emocionales - los dos son pelirrojos, extranjeros y parecen impasibles- Bianco triunfa sobre la llanura allí donde Blackwood, su reverso negro como lo indica el nombre, fracasa.

"El viajero", uno de los argumentos de "La mayor" es la contracara del relato de viaje, una especie de antiescritura que borra, ahueca y desquicia el modelo predilecto de los viajeros imperiales -aquel que inscribe positivamente la experiencia de un cuerpo que avanza sobre un territorio, armado de dispositivos de visión y medición y respaldado por una tradición viajera-. De los diversos experimentos formales que ensaya Saer en La mayor, es este uno de los que más acerca la prosa a la poesía y a una arquitectura visual en la que los huecos y las repeticiones remedan, a primera vista, los extravíos, retrocesos y vueltas en falso del personaje. Recordemos que se trata del racconto de los últimos días de Jeremy Blackwood, un agente y explorador inglés que en nombre de la Compañía debe establecer los puntos cardinales y encontrar el saladero, pero que se ha perdido en una llanura monótona, monocroma e idéntica a sí misma que le hace dar vueltas y retornar siempre al mismo sitio en el que encendió una hoguera cuando la lluvia le dio una mínima tregua. La situación es desesperante: sin caballo ni forma de guiarse mediante las estrellas y desconociendo el idioma, Blackwood no puede hacerle frente al pajonal acuciado por la neblina. El texto acribilla la retórica de exploración que desplegaron numerosos viajeros ingleses que comenzaron a llegar a América desde 1820 en adelante. ${ }^{225}$

\footnotetext{
${ }^{225}$ Saer escribió una primera versión de este argumento, incluida entre las "Hojas sueltas I. Fines de los 60 y años 70" en los Papeles de trabajo II. "A los viajeros ingleses" podría leerse como un boceto argumental de "El viajero" en el que ya se inscriben algunos elementos fundamentales de la versión terminada, aunque también haya, entre una y otra, importantes modificaciones. No sólo el nombre del personaje es otro, Thomas Hutcheson, sino que se trata fundamentalmente de un relato más tradicional en cuanto a su forma, más compacto y homogéneo porque no está abierto a esa red de espacios en blanco que desgarra y "agujerea" el texto en su versión final, traduciendo en la materialidad del relato las detenciones del personaje
} 
Como señala Mary Louise Pratt, estos viajeros que visitaban Hispanoamérica después de la independencia no estaban interesados en descubrir un mundo primigenio, sino en explotar sus materias primas. El recorrido paradigmático que seguían era desembarcar en el puerto de Buenos Aires, atravesar por tierra las pampas argentinas, cruzar la cordillera de los Andes y visitar posteriormente Chile y Perú, para regresar desde allí en barco hacia Europa. Los informes, crónicas y relatos que escriben responden a la "retórica de conquista", caracterizada por la mirada pragmática, economicista y en general antiesteticista que encontraba en la sociedad hispanoamericana y en la naturaleza indomable obstáculos para el desarrollo industrial europeo. Su "reinvención de América" consistía en dar la imagen de una sociedad atrasada y descuidada, de hábitos indolentes, y cuya naturaleza daría verdaderamente provecho si fuera explotada por la racionalidad económica imperial. ${ }^{226}$

Uno de los textos más comentados a este respecto es el de Francis Bon Head, viajero inglés que escribió sus Rough Notes Taken During Some Rapid Journeys (1826) después de haber atravesado en distintas direcciones el territorio con el propósito de informar sobre las posibilidades de explotación de las minas de oro y plata en Argentina y Chile, misión que cumple con muchísima celeridad y rigor y de la cual extrae dos textos. En el Reports on the Failure of the Río de la Plata Mining Association (1827)

y los huecos de la llanura. Podría conjeturarse que Jeremy Blackwood radicaliza el extravío de Thomas Hutcheson. Allí donde Hutcheson todavía guarda el reloj e intenta darle cuerda, el otro lo rompe, ya consciente de su total inutilidad. Hutcheson, aunque esté perdido, todavía piensa en la posibilidad de anotar las características de los pajonales y maldice a Dios por la monotonía de la llanura. La versión preliminar termina con la imagen del viajero que prosigue su camino. Desconocemos si Saer dejó inconcluso este relato o si pensaba terminarlo allí, pero el final de "El viajero" cierra lo que su borrador dejaba inconcluso: Jeremy Blackwood vuelve a encontrarse con el montón de cenizas sobre el que había esparcido los vidrios de su reloj roto y sabemos "que no dejó ni rastro de su viaje" (Saer, "El viajero", La mayor 205).

${ }^{226}$ Según afirma Adolfo Prieto, de entre los viajeros ingleses que vinieron a Argentina entre 1820 y 1835 al menos catorce de ellos escribieron sobre su experiencia y se configuraron como agentes transmisores de las potencialidades y riesgos que suponía invertir en estas tierras. Es posible observar en los relatos de Francis Bond Head, Joseph Andrews y Edmond Temple el progresivo dominio material y lingüístico que adoptaron sobre los diversos territorios que atravesaban, y su despliegue de una mirada que a la vez que reconocía las propiedades del paisaje y valoraba ciertos atributos de indios y gauchos, no dejaba de ponderar las potencialidades de explotación económicas para Inglaterra. Por supuesto, muchos viajeros ingleses ofrecieron una mirada mucho más heterogénea sobre el territorio hispanoamericano. Pratt analiza el caso de Francis Bon Head como una importante excepción a esa tradición. Retomando su estudio, el clásico libro de Adolfo Prieto se encargará de deslindar entre aquellos textos de viajeros ingleses escritos estrictamente bajo la lógica comercial y aquellos que, influidos por el gran modelo de viaje de Humboldt, establecieron diversas combinaciones entre el discurso racionalista y el romántico-humboldtiano. De la lección del gran maestro extraen el gusto por el relato, la inscripción de la peripecia personal, el intento de captar la especificidad del paisaje americano y de observar la armonía entre el hombre y la naturaleza. 
inscribe su recorrido oficial y alerta a sus compatriotas sobre los riesgos de invertir en la explotación minera; en el ya mencionado Rough Notes toma apuntes en momentos de relativa tranquilidad y despliega una sensibilidad que, sin dejar de ser pragmática, está abierta a la fantástica contingencia del paisaje americano. Jeremy Blackwood es, desde esta perspectiva, la contrapartida melancólica y fracasada de Bon Head y allí donde el otro triunfa, éste fracasa. Señala el primero: "El mayor peligro al cabalgar en las Pampas son las constantes caídas que se producen porque los caballos tropiezan con las madrigueras de los biscachos [...] uno no puede evitar imaginar qué desdichada situación sería romperse un miembro o dislocarse una articulación a tantas millas de distancia de cualquier clase de asistencia” (Bon Head 60). Así precisamente comienzan las desdichas del personaje de Saer: "su caballo había tropezado en un agujero se había quebrado la pata delantera" (Saer, "El viajero", La mayor 201). Como advierten Fontana y Román, las pampas están "undermine", minadas por las trampas de las vizcacheras, y suponen un peligro constante para el jinete que puede trastabillar y caerse.

Pero además, allí donde Francis Bon Head, entusiasmado ante la posibilidad de convertirse en indio, cabalga desnudo por la llanura pero conserva, envuelto en un pañuelo de seda, su reloj, "único resto british [que permite advertir] sobre aquello que Head nunca abandona, su lugar de partida" (Fontana y Román 16), Blackwood rompe su reloj y disemina los restos sobre el montículo de ceniza de una hoguera que había encendido días atrás, esperanzado de que alguien pudiera encontrarlo. A diferencia de sus compatriotas, atraviesa solo ese espacio y no puede siquiera nombrarlo: "Se paró y miró el horizonte el pajonal no sabía que se llamaba así" (Saer, "El viajero", La mayor 202). A la marcha de avance, celeridad y eficacia que supone una encomienda semejante, Blackwood le opone un andar errante y fatigado que no hace más que dar vueltas sobre el mismo sitio: el desierto se ha convertido en laberinto.

"El viajero" se teje sobre la red discursiva de la biblioteca viajera, pero además la excede para incorporar al menos dos textos borgeanos: "El Aleph" y "Los dos reyes y los dos laberintos", ambos de El Aleph (1949). Leído intencionalmente, ${ }^{227}$ bajo este

\footnotetext{
${ }^{227}$ Este es el cuento completo de Borges: "Cuentan los hombres dignos de fe (pero Alá sabe más) que en los primeros días hubo un rey de las islas de Babilonia que congregó a sus arquitectos y magos y les mandó construir un laberinto tan complejo y sutil que los varones más prudentes no se aventuraban a entrar, y los que entraban se perdían. Esa obra era un escándalo, porque la confusión y la maravilla son operaciones propias de Dios y no de los hombres. Con el andar del tiempo vino a su corte un rey de los árabes, y el rey de Babilonia (para hacer burla de
} 
último relato se narra el intercambio de dos laberintos que participan de órdenes distintos: el que ofrece el rey de Babilonia, un "laberinto de bronce con muchas escaleras, puertas y muros" (Borges, "Los dos reyes y los dos laberintos", El Aleph 580) expone con soberbia la sabiduría de magos y arquitectos, es, podría decirse, el laberinto de la civilización. El que devuelve el rey de Arabia, luego de haber conquistado y arrasado al pueblo de su enemigo, es el laberinto salvaje del desierto: "donde no hay escaleras que subir, ni puertas que forzar, ni fatigosas galerías que recorrer, ni muros que te veden el paso" (Borges 580). Allí muere el rey de Babilonia como el explorador inglés del argumento saeriano muere en el desierto argentino de hambre y de sed. El relato de Borges, enmarcado en la atmósfera religiosa del comienzo, culmina diciendo: "La gloria sea con Aquél que no muere”, imploración que Saer reescribe irónicamente: "Gloria A los viajeros ingleses y sobre todo Gloria A Jeremías Blackwood que no dejó ni rastro de su viaje" (Saer, "El viajero", La mayor 205). El laberinto del desierto termina venciendo al de Babilonia, evocado en este caso por la ciudad de Londres que el viajero inglés atisba como si fuera una visión: ${ }^{228}$

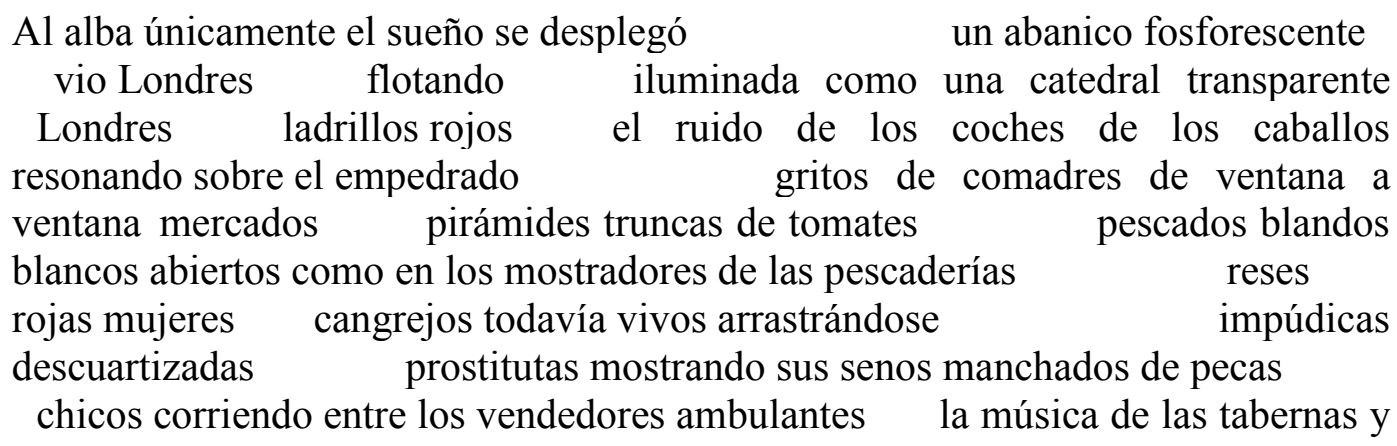

la simplicidad de su huésped) lo hizo penetrar en el laberinto, donde vagó afrentado y confundido hasta la declinación de la tarde. Entonces imploró socorro divino y dio con la puerta. Sus labios no profirieron queja ninguna, pero le dijo al rey de Babilonia que él en Arabia tenía otro laberinto y que, si Dios era servido, se lo daría a conocer algún día. Luego regresó a Arabia, juntó sus capitanes y sus alcaides y estragó los reinos de Babilonia con tan venturosa fortuna que derribó sus castillos, rompió sus gentes e hizo cautivo al mismo rey. Lo amarró encima de un camello veloz y lo llevó al desierto. Cabalgaron tres días, y le dijo: ‘ $¡ O h$, rey del tiempo y sustancia y cifra del siglo!, en Babilonia me quisiste perder en un laberinto de bronce con muchas escaleras, puertas y muros; ahora el Poderoso ha tenido a bien que te muestre el mío, donde no hay escaleras que subir, ni puertas que forzar, ni fatigosas galerías que recorrer, ni muros que te veden el paso.' Luego le desató las ligaduras y lo abandonó en mitad del desierto, donde murió de hambre y de sed. La gloria sea con Aquél que no muere" (El Aleph $580)$

${ }^{228}$ La correspondencia entre Londres y el laberinto se reitera también en "Abenjacán el bojarí, muerto en su laberinto": "Para quien verdaderamente quiere ocultarse, Londres es mejor laberinto que un mirador al que conducen todos los corredores de un edificio" (Borges, El Aleph 577). 
de los mendigos ciegos elevándose por encima de la muchedumbre (Saer, "El viajero", La mayor 204)

A diferencia del Aleph "universal" que ve el personaje llamado Borges, el del viajero inglés parece desprenderse y trabajar en el interior de uno sólo de sus sintagmas, que la prosa poética de Saer dilata hasta desgarrar: "vi un laberinto roto (era Londres)" (Borges, "El Aleph", El Aleph 595). Frente a la monotonía y la soledad, frente a "la tentación de lo idéntico y lo inmóvil" el Aleph imperial prodiga una serie heterogénea y abigarrada de imágenes que comunican la vida bulliciosa de la ciudad, exacerban los sentidos de la percepción y configuran un áspero montaje alimenticio y sexual, en el que se muestran y descomponen cuerpos de prostitutas, reses, pescados y cangrejos.

Allí donde se fractura el discurso utilitario-economicista del viaje comercial, el argumento saeriano se descompone en una prosa poética que presenta la paradoja de un texto imposible, aquel que podría haber dejado Jeremy Blackwood antes de morir. "El viajero" es un largo epitafio para una tumba que pierde sus rastros en la llanura. La biblioteca viajera se lee, sin embargo, a través del cristal borgeano hecho de varios desiertos. Renzi podría haber pintado "El viajero" para incluirlo en su serie de viajeros y exploradores amargados, melancólicos o enloquecidos. Como se vio, no es este el único caso de viaje que fracasa en la literatura de Saer, "Paramnesia" y El entenado ofrecen otras versiones desdichadas de la conquista.

\subsection{Las nubes}

En 1997 Saer publica Las nubes, la novela que culmina con el ciclo de relatos dedicados a la pampa decimonónica. Si la primera versión de "La ocasión", aquel relato que Saer había comenzado en la década del sesenta y reescrito durante años, funcionaba como un laboratorio de imágenes y como un muestrario de los personajes y escenarios de la llanura, Las nubes llega para coronar y desquiciar ese experimento. Por un lado porque, como sostiene Sarlo en "Aventura de un médico filósofo", Saer parece estar usando el mismo archivo de lecturas sobre los viajeros del siglo XIX en el Río de la Plata que había previamente utilizado para escribir el prólogo a Las pampas de Ebelot y para El río sin orillas, pero además, porque a ese acervo clásico se ha sumado su propia producción anterior en la que también problematizó las imágenes vinculadas a los viajes y a los viajeros. Las nubes reescribe, como ha apuntado suficientemente la crítica, la 
literatura de viajes, pero también $s u$ literatura de viajes, la del propio Saer. En este sentido, la novela no sólo recoge y rearticula las imágenes "clásicas" de la biblioteca viajera sino también, como un gran dispositivo que deglute experimentos previos, las imágenes "saerianas" del siglo XIX. ${ }^{229}$ La memoria del doctor Real participa de ciertas pretensiones científicas pero no se priva de incorporar notas de sesgo autobiográfico y elucubraciones filosóficas. Retoma además la prosa de observación naturalista de Humboldt, el viajero quizás más "contemporáneo" de la caravana de locos, y escritos como el de Francis Bon Head, Ebelot y Mansilla, cuya incipiente comicidad comienza a disolver el tono más pesimista -deudor de Martínez Estrada- de las ficciones anteriores.

Como se sabe, el tema del viaje es insoslayable cuando se trata de Las nubes y la crítica que se ha ocupado de la novela advirtió tempranamente el parentesco que su escritura guardaba con la biblioteca de viajeros del Río de la Plata que Saer ya había venido trabajando en obras anteriores. En el vértice de los diversos géneros que toca -novela de aventuras, de viaje, filosófica y de caracteres- Sarlo advierte en "Aventura de un médico filósofo" el particular trabajo que la obra realiza sobre la tradición literaria argentina y sobre algunos tópicos clásicos (los atributos del paisaje: extensión e ilusión horizontal; la atención a la luz y al cielo; la presencia de postas y fogones en los que circulan rumores sobre los indios y la descripción de tipos pampeanos). Pensando posiblemente en los diálogos que la obra traza con la biblioteca viajera nacional e internacional -Humboldt pero también Sarmiento, Mansilla o Güiraldes- y en la forma en que las memorias del doctor Real se presentan como un posible texto apócrifo, se ha

\footnotetext{
${ }^{229}$ Esto puede observarse, por ejemplo, a partir del doble retrato que hace de Osuna: en primer lugar y retomando la imagen pintoresca del baqueano que ha construido la tradición de viajeros, el doctor Real evoca como "imagen primordial" de su viaje a "Osuna galopando paralelo al sol naciente que, al subir desde el lado del río, nimbaba de rojo el costado derecho del jinete y del caballo mientras el perfil izquierdo permanecía todavía borroneado en la sombra" (Saer, Las nubes 64). Una imagen romántica que parece estar reescribiendo, entre muchas otras posibles, la que destaca F. Bon Head: "el perfil salvaje y pintoresco de un gaucho en el horizonte; su poncho escarlata flameando detrás de él, sus bolas girando alrededor de su cabeza" (142), que luego en Saer deviene, por los efectos visuales del horizonte, una parodia de cabalgata que transforma el pintoresco andar del gaucho en una "cabriola irreal" un poco alocada "como la de esos muñecos de papel exageradamente desarticulados que alguien manipula con un hilo invisible y que se agitan en silencio en el aire hasta que se desmoronan, deshechos, en el suelo" (Las nubes 180), imagen "degradada" que evoca al charco de tinta en el que chapaleaban los caballos desde La ocasión. Y también reaparece, aunque menos elaborada, la imagen del autómata que también había aparecido en aquella novela, y que sirve ahora para presentar la mutación que ha experimentado Troncoso, uno de los pacientes, después de un paroxismo frenético: "se me acercó con sus trancos rígidos, muy semejantes a los de un autómata que había visto una vez en París" (Las nubes 209). Las nubes no se detiene en estas imágenes, las toma junto al acervo de las otras y continúa elaborando y precisando imágenes nuevas.
} 
subrayado el carácter ficcional, imaginario y filosófico del viaje (Sarlo 1997); metafísico y paródico (Reati 1997) y se lo ha leído como una nueva versión de la nave de los locos (Vezetti 1997 y Reati 1997). ${ }^{230}$

De este modo, Fernando Reati afirma que la deuda que Saer contrae con el relato de viajes es engañosa porque no se trata de un desplazamiento territorial o material sino de uno eminentemente metafísico y espiritual, ${ }^{231}$ en el que se persigue algo intangible y no un fin pragmático - militar o financiero- como el que guiaba a los viajeros decimonónicos. ${ }^{232}$ Alan Pauls, en una breve reseña que escribe para el Suplemento Radar, también advierte sobre la fragilidad geográfica del paisaje al que llama "escenario abstracto", "geografía virtual”.

Posteriormente Margarita Merbilhaá y Fermín Rodríguez, retomando algunas de las coordenadas anteriormente descriptas, leerán los efectos no determinantes que las condiciones políticas y naturales imprimen sobre las acciones de los personajes y pensarán en Las nubes como un episodio ficcional en el que Saer continua dirimiendo reflexiones filosóficas sobre la historia y el mito que ya había sondeado previamente en intervenciones ensayísticas y literarias (Merbilhaá 2011) ${ }^{233}$ o, según apunta Fermín Rodríguez, la leerán como un episodio en la larga serie de reconfiguraciones en torno a las imágenes del desierto y de la nación, ${ }^{234}$ en donde el viaje del doctor Real revela una dimensión paralela del viaje científico de Humboldt.

\footnotetext{
${ }^{230}$ Vezetti lee a su vez la caravana de pacientes mentales como una nueva versión de la "nave de los locos" cuya excursión hacia lo "otro" se ve enfatizada por la superposición de la locura humana y la presencia desbordante de la naturaleza, aspectos que revelan ocultas correspondencias de lo real y se ofrecen como un espejo deformante de la racionalidad de los "cuerdos".

${ }^{231}$ Cfr. Reati, Fernando. "Las nubes: un viaje por la pampa".

${ }^{232}$ Esta lectura privilegia el pasaje que el narrador y sus acompañantes realizan por el mundo de la locura hacia una dimensión metafísica de lo real porque el loco es el mensajero que trae las noticias de un mundo desconocido a cuyos bordes llegaría el narrador en esa experiencia de extrañamiento del paisaje, y por lo tanto, concluye Reati, el viaje por la pampa es ilusorio, innecesario, un escenario en el que se realiza el verdadero viaje hacia una experiencia alternativa.

${ }^{233}$ Cfr. Merbilhaá, Margarita. "Hacia una 'memoria del lugar': entre pasados imaginados y presentes leídos".

${ }^{234}$ En relación a este tipo de lectura, en "Outlaws of the Pampa: representations of the gaucho and the indigenous in Las nubes (1997) and La ocasión (1988) by Juan José Saer", Nicholas Kramer subraya las representaciones de la otredad (indios y "gauchos malos") que vehiculizan La ocasión y Las nubes. En ambas el personaje protagonista se enfrenta a un adversario que acecha en la pampa. Según su hipótesis, la forma en que Bianco y Real se vinculan con estas figuras de la alteridad revelan distintas concepciones sobre la nación. En el caso de Las nubes, las precoces ideas terapéuticas de Real y Weiss y el modelo de conducción de Real determinan una forma de aproximación al cacique Josesito que representa una perspectiva de la otredad alternativa a la ética de conquista de Bianco.
} 
Sin desconocer el inmenso valor de estas lecturas que señalaron aspectos insoslayables de la novela y advirtieron los diálogos que establece con las más variadas tradiciones literarias y filosóficas - desde la presencia de la IV égloga de Virgilio hasta las evocaciones sarmientinas- es preciso por un lado profundizar la coordenada del viaje para leer, en la particular reescritura saeriana de la tradición, la dimensión material que asume el desplazamiento en la obra y ponderar los efectos -ahora sí distorsivos, pictóricos e imaginarios- que las turbulencias políticas y naturales ejercieron sobre esos sujetos viajeros; y por el otro identificar esos movimientos señalados por la crítica entre racionalidad y locura, mundo real y realidad metafísica como un borde difuso que, sin la radicalización saeriana, ya aparecían en la escritura "pragmática" de algunos viajeros decimonónicos como Francis Bon Head o en las experiencias místicas y animistas de William H. Hudson.

Saer advierte en una entrevista que las "precisiones" en literatura pueden hacerse por una razón documental "realista" o para agregar más confusión, y confiesa que quería escribir una novela que transcurriera en el siglo XVIII en Argentina pero que eligió la temporalidad de Las nubes porque esa fecha (1804) era anterior a todo acontecimiento importante en la imaginería histórica del país, previa a las Invasiones Inglesas y a la Revolución de Mayo. La acción debía transcurrir además en una "tierra de nadie" sin imagen propia, o mejor, con la imagen fantasmática de la llanura. Ese lugar caracterizado por su pobreza imaginaria y material (pocos habitantes, pequeñas ciudades prácticamente incomunicadas, precarias líneas de postas) fue el privilegiado para que la escritura pudiera proyectar sus imágenes sobre un escenario "vacío". ${ }^{235}$ En el fragmentado y anacrónico derrotero por el siglo XIX que ensaya Saer, Las nubes es la que va más atrás en el tiempo para retrotraerse a ese momento previo a la proclamación de la patria a partir de una forma poética que radicaliza la mezcla heterogénea que caracteriza a la nación y por eso toda la novela podría leerse bajo la idea de la “condensación oximorónica". A su vez, por la heterogeneidad inverosímil de sujetos, espacios y lenguas reunidas en la caravana que atraviesa la pampa, Las nubes pareciera rearticular la idea de "frontera" poniéndola, literalmente, en movimiento. La patria en ciernes es una inquieta frontera que se hace y se deshace en la llanura, y que avanza a tientas por el desierto esquivando inundaciones, sequías, incendios y ataques de indios.

\footnotetext{
${ }^{235}$ Retomo aquí las reflexiones que Saer compartió en el programa de Cristina Mucci, "Los siete locos", cuando vino a Argentina para presentar Las nubes. Link del video disponible en https://www.youtube.com/watch?v=LZ240LYgNlo
} 


\section{La caravana: frontera díscola del desierto}

En Las nubes se narra el desplazamiento de una caravana de locos desde Buenos Aires hasta Santa Fe en agosto de 1804. Francisco Real, el médico psiquiatra y escritor de la memoria en que se evoca ese viaje singular es el encargado de llevar a cinco pacientes mentales a la Casa de Salud, instalada a dos o tres leguas de Buenos Aires, en un lugar llamado Las tres acacias. Descartado el traslado fluvial y con los objetivos de observar la máxima seguridad y cuidar la frágil condición de la tripulación se decide hacer el viaje por tierra y alquilar para eso cinco carretones tirados por caballos "de ésos que utilizan los viajantes que recorren los espantosos caminos de ese inmenso territorio para ir a comerciar desde Buenos Aires hasta Chile" (Saer, Las nubes 98) y que están arreglados en su interior como pequeños recintos, a la vez dormitorios y sala de estar. Sin ser exactamente iguales, los carretones de Las nubes se emparientan con las galeras de Ebelot, los "barcos de la pampa" de Sarmiento y el carruaje de Francis Bon Head, grandes y lentos transportes que atraviesan morosamente el territorio pero permiten disponer de algunas comodidades mínimas. Como se dijo anteriormente, la galera representaba el Arca de Noé de las pampas y congregaba a los diferentes actores del drama del desierto - estancieros, pulperos, gauchos, señoras, italianos, vascos, policías y criminales-. Ebelot advierte que "[las galeras] llevan las semillas de la civilización, los diarios, los aventureros, son las precursoras del riel, las avanzadas del progreso" (Ebelot 66).

Este sentido señalado por Ebelot es el que se privilegiará en la iconografía del desierto para representar el drama de la conquista. Malosetti Costa y Penhos apuntan que en muchas representaciones de la pampa decimonónica los ranchos, las carreteras y los transportes señalaban la proeza de la presencia humana, una coordenada que puede seguirse en las acuarelas de Emeric Essex Vidal (Coche de postas, 1818), en los grabados de León Palliere (La galera) y en las pinturas de Prilidiano Pueyrredón (Un alto en el campo) y Pedro Figari (La carreta y Recogiendo un pasajero). ${ }^{236}$

\footnotetext{
${ }^{236}$ En la mayoría de estas imágenes la presencia abultada de la carreta rompe la monotonía horizontal de la llanura. Estos transportes pueden aparecer desplazándose por el paisaje, y en este caso se destacará el movimiento de caballos y jinetes, o bien durante el momento de descanso en el que la caravana se detiene, y hace, como señala Pueyrredón, un "alto en el camino". En este tipo de imágenes se privilegian las microescenas de sociabilidad criolla: mientras algunos descansan apoyados sobre un árbol, otros conversan, toman mate o alimentan a los caballos.
} 
En Rough notes, Francis Bon Head distingue los dos modos de atravesar el desierto, en carruaje o a caballo, y si bien a medida que conoce el territorio preferirá y gozará viajando extensas jornadas a caballo sin el estorbo de equipaje ni sirvientes que lo demoren en su veloz carrera, para su primer viaje se aprovisiona de un gran carruaje y señala a propósito del grupo designado para acompañarlo: "eran de todos colores: negro, blanco y colorado; y nunca se formó conjunto de aspecto tan extravagante" (Bon Head 36). Describe a continuación los preparativos del viaje y el acopio de víveres y de armamento para el gran esfuerzo que suponía recorrer más de novecientas millas por las pampas. El mismo "cándido" asombro parece permear las escrituras de Bon Head y de Francisco Real. El primero advierte que a pesar de la chatura del país, el terreno presentaba varias alteraciones: arroyos, riachuelos y pantanos que los carruajes pasaban de formas inverosímiles como de ningún modo podrían hacerlo los soldados en Inglaterra. Interesa detenerse en una anotación al pie que incorpora el viajero, cuando señala que por observar el cuadro extraño que hacía el carruaje dejó de mirar para adelante y tropezó con su caballo en una vizcachera, el gran peligro de la llanura, como ya comentamos anteriormente:

Apenas es posible concebir vista más extravagante que nuestro carruaje y carro toldado, galopando por la llanura sin camino y precedido o seguido por la tropilla de treinta a setenta caballos salvajes, sueltos y a todo galope, arreados por un gaucho y su hijo, y a veces por un par de muchachos. El cuadro parece corresponder al peligro que positivamente existe de cruzar regiones deshabitadas, $\tan$ frecuentemente invadidas por los indios (Bon Head 38).

Francis Bon Head se permite desviar su mirada del camino para contemplar un cuadro extravagante, una composición de carruajes y caballos salvajes cuyo abigarramiento inverosímil se corresponde, señala, con los peligros del desierto. La singular escritura de Head se cifra en esos momentos en el que, aún como representante del capitalismo financiero británico, abandona la vigilancia sobre el terreno para deleitarse en una contemplación que excede y cuestiona las expectativas y costumbres que trae desde Europa. Claudia Román y Patricio Fontana, en el estudio preliminar dedicado a Bon Head advierten la particular fisonomía de las pampas, minadas por las vizcacheras: "Las pampas del capitán Head -en las que una y otra vez irrumpen situaciones propias de la farsa o del slapstick- nunca podrían haber sido el escenario de las ceremoniosas escenas finales de El gaucho Martín Fierro (1872) o de Don Segundo Sombra (1926)" (18). También el doctor Real observará, en ese umbral de estar a la vez 
dentro y fuera, la particular carga que debe conducir a través de la llanura: "Éramos un convoy diverso y colorido: una parte de la escolta nos precedía y la otra cerraba la marcha" (Saer, Las nubes 165). Los ocho carretones de que se compone ese convoy (cinco para los pacientes, uno para Francisco Real, el séptimo como almacén y el último para las mujeres que escoltaban a la tropa) reúnen y condensan, en su brillante y estrafalaria heterogeneidad, no sólo los diferentes caracteres de la llanura sino también los escenarios principales en los que se desarrolla el drama del desierto, que Saer había presentado en textos anteriores, pero que aquí aparecen juntos y en movimiento. Para repasar: los carruajes en que harán la travesía pertenecen a una de las familias de los pacientes y llegan a la ciudad acompañados por una feria de comerciantes y por un grupo de actores ambulantes.

Los ocho carromatos se acomodan en los arrabales (no pueden penetrar el espacio urbano a causa del barro) y desde las orillas ofrecen los productos de contrabando cuya circulación estaba prohibida por el monopolio comercial que había decretado el virreinato español. Desde un primer momento, la caravana arrastra a un grupo de sujetos díscolos que viven y comercian al margen de la ley pero a la vista de todos; y se ubica en las afueras de la ciudad pero atrae hacia ella a las familias pudientes que llegan para probar "el sabor de los arrabales" (149). Esa condición fronteriza y estrafalaria se exacerbará en el desierto. A contrapelo de su ordenada iconografía, que cuando incorporaba medios de transporte buscaba señalar el avance de la civilización, Saer parece retomar la tradición más desmesurada y extravagante que lee en autores como Francis Bon Head.

Con el lento movimiento de la caravana es toda la frontera la que se desplaza. En Indios, ejército y frontera, David Viñas hablará de un "intermedio fronterizo" constituido por "indios-gauchos, montoneros derrotados, desertores, lenguaraces, pulperos itinerantes, espías y 'bomberos', cautivos y ex cautivos de uno y otro signo" (86) para dar cuenta de esta suma de sujetos anfibios que, en el vértice de la frontera, trafican armas, lenguas y cuerpos. La frontera captura a estos sujetos cuando han devenido otra cosa o se sostienen sobre diferencias aparentemente irreconciliables, como la del "indio-gaucho". Como se recordará, la caravana de Las nubes también está formada por este tipo de personajes "fronterizos" que desafían hasta el ridículo y la parodia la homogeneidad de los "tipos" sociales: la monja ninfómana y el indio hiper religioso podrían ser buenos ejemplos. 
En este sentido, la pampa "fronteriza" que Saer imagina en desplazamiento está más cerca de la de Mansilla que de la de Sarmiento. ${ }^{237}$ En Facundo o Martín Fierro, Carlos Gamerro los distingue: la mirada de Sarmiento corta, separa y descarta, delimitando la frontera entre la civilización y la barbarie; Mansilla en cambio "superpone, yuxtapone y zurce. Su frontera es un lugar de transiciones, de inversiones y empalmes, una orilla" en la que habitan seres mixtos, "indios gauchos", "cautivas que desean quedarse en las tolderías, indios cristianizados, indios que comparten cenas con dandis" (Gamerro, Facundo o Martín Fierro 151). Convendría recordar acá también la lectura propuesta por Fontana y Román, que encuentran en el humor y la gracia de las Rough notes de Francis Bon Head, un "precursor" para las zonas más lúdicas de Una excursión a los indios ranqueles y también de novelas como La liebre (1991) de César Aira. Desde esta perspectiva, Las nubes empalma en esta tradición de díscolos fronterizos de la llanura.

La caravana condensa, como dijimos, los escenarios, yuxtaponiendo en el espacio acotado de los ocho carromatos un hospital ambulante, la pulpería y el almacén del vasco, y el prostíbulo en el que viajan tres prostitutas, una de ellas francesa. Pero además condensa las diversas lenguas que habla el desierto: el español ilustrado que ostenta el narrador, cruzado por las referencias a filósofos y escritores franceses; la lengua popular y campesina que hablan Osuna y el sargento Lucero; el guaraní de los soldados de la tropa, provenientes de Corrientes y de Asunción y que apenas balbuceaban algunas palabras en español; la doble lengua de Sirirí, el indio mocoví que oficia como intérprete; el francés de barrio popular parisiense en que la prostituta francesa interpela y discurre con el doctor Real, que se asombra de poder hablar el

\footnotetext{
${ }^{237}$ Como han advertido Alejandra Laera, Graciela Batticuore y Loreley El jaber en "Aventura y relato. Apuntes para una historia literaria de la frontera", al tematizar la frontera Mansilla recoge formulaciones previas y abre el camino hacia configuraciones futuras. En este sentido, Mansilla anuncia la apertura de los estudios sobre la frontera más allá de su acepción político-territorial, como límite o borde, zona de choque y avance, y permite sumar una dimensión cultural que dota de sentido simbólico a los aspectos geográficos, políticos y militares que se juegan allí. Después de revisar la noción tradicional de frontera inaugurada por Turner en 1893, las autoras destacan líneas de interés en los estudios críticos que pensaron la frontera en la conformación de la identidad nacional (David Viñas, Jens Anderman, Álvaro Fernández Bravo) y concluyen en una definición ampliada: la frontera como "rasgo topográfico, como región geográfica en la que interactúan diversas culturas, como espacio de enfrentamiento y asimismo de inclusión, como espacio militar, económico y cultural, como una región, un proceso, un discurso" (16). Interesa esta perspectiva para pensar ese "intermedio fronterizo en movimiento" que Saer pone a circular en las caravanas.
} 
idioma de Rosseau y Buffon en pleno desierto. ${ }^{238}$ Hasta aquí la variedad lingüística de los "cuerdos", (categoría dudosa y claramente cuestionada en la novela). Como ya ha estipulado la crítica, los diferentes pacientes representan, cada uno de ellos, un caso de desvarío social, político, religioso, filosófico, y fundamentalmente lingüístico, y así la lengua místico-pornográfica de Sor Teresita; el mutismo melancólico del joven Parra, las variantes de entonación de la frase que Juan Verde repite hasta el infinito, el "asedio bucal", sonoro y gestual de Verdecito; y la verborragia política de Troncoso, comparable al programa de los sectores más radicales de la Revolución según Reati.

Intensa, colorida y polifónica, la frontera móvil de la pampa prueba los límites de la llanura y se prueba a sí misma en tanto comunidad tangencial que sólo es posible durante el viaje, porque luego, cuando llegue a destino, se disolverá y diseminará en el cuerpo social regular de un estado en ciernes: el de las fórmulas de la "salud mental", las guerras revolucionarias o los enfrentamientos entre malones y blancos. ${ }^{239}$ En dos

\footnotetext{
${ }^{238}$ Esta incorporación del francés podría acaso ser la caricatura paródica de una escena de los relatos de frontera de Alfred Ebelot. Aquí, el francés se alegra de haber encontrado un interlocutor, el comandante Eliseo Acevedo, con quien puede rememorar su país natal e intercambiar impresiones sobre el filósofo Amadeo Jacques, por quien comparten admiración. Una frágil condición de iguales que el monumento lingüístico y cultural ha trazado entre dos sujetos dispares. La prostituta que habla, como bien lo reconoce Real, el francés de los barrios populares, no pertenece a esa lengua culta que el narrador maneja por haber hecho parte de su formación académica en Francia - está leyendo además la versión francesa de los tomos de Virgilio que le regalara el señor Parra-: "las palabras que profería la mujer parecían desentonar en ese paisaje, pero al mismo tiempo me daban la oportunidad de practicar en medio del desierto el idioma de Rousseau y de Buffon" (Las nubes 162). A diferencia de la experiencia de Ebelot, el narrador hace un uso privado de esa lengua universal de la civilización y la lengua popular y experiencial de la prostituta -que acude a él para contarle sus peripecias, no para hablar de filosofía- rompe la fantasía cultural del doctor cuando le pide que le pague por las charlas que comparten. Cuando la lengua se vuelve objeto de deseo, el dinero devuelve los sujetos y las lenguas a su orden.

${ }^{239}$ En Literatura y frontera, Álvaro Fernández Bravo se interroga por las relaciones entre paisaje y nación en la literatura producida desde y sobre las fronteras, consideradas según su condición histórica, su nomadismo y su fluidez semántica. De acuerdo a su formulación, la "frontera" es un eje discontinuo que reaparece en la cultura y se modifica históricamente al que habría que pensar en su dimensión extranacional (aunque sin soslayar las particularidades nacionales). Interesa que el autor se propone "ubicar la frontera ya no en la geografía sino en la temporalidad de la Nación (o lo que es igual: viajar a la frontera como en un viaje al pasado de una cultura), [lo cual] implica situarla en una suerte de inconsciente psíquico de la Nación y se trata quizás del procedimiento territorializador por excelencia" (18). Los truncos, delirantes e imposibles proyectos políticos y afectivos que vehiculiza la "frontera" de Las nubes funcionan de alguna manera como ese "inconsciente" negado de la patria, aunque no impliquen necesariamente un "viaje al pasado" colonial sino más bien la apertura a tiempos disímiles de la historia que no cuajaron ni se actualizaron. Fernández Bravo apuesta a desarticular la genealogía de la frontera: "Es por ello que la frontera -su fluidez semántica, su nomadismo e inaprehensibilidad- buscó ser detenida, congelada por el discurso del poder. Con ese propósito intentó escribírsela y leérsela como algo fijo, inalterable, ahistórico, trascendental y natural: las fronteras de la Nación estaban allí desde siempre, como un testimonio de la morfología
} 
ocasiones, sin embargo, el precario grupo se aproxima a su disolución y en ambos casos es la materialidad ígnea del paisaje la que amenaza y desdibuja los contornos, de por sí, lábiles, de la caravana. Por un lado, el veranito de San Juan que irrumpe el riguroso invierno e instala una progresiva barbarización que afloja las determinaciones sociales; por el otro, el fuego, clásico tópico de la pampa, extrema la figura oximorónica y prueba qué sucede cuando todos, animales y seres humanos, cómplices y enemigos, se refugian en el acotado espacio de la laguna para salvarse de las llamas.

En el primero de los casos, los personajes de la caravana bordean peligrosamente las atracciones del desierto, próximos a esa experiencia del viaje conocida como la “fantasía de inversión”. Viajeros como Francis Bon Head, Auguste Guinnard -cautivo en territorios patagónicos entre 1856 y 1859- y Chaworth Musters -inglés desinglesizado que escribe At home with the Patagonians - también habían fantaseado o se habían visto inmersos en procesos de contigüidad entre lo conocido y lo desconocido, suspendiendo momentáneamente varias de las normas morales, filosóficas y culturales que le daban forma a su mundo para adscribir, también por cierto tiempo, a las formas de sociabilidad, comercio y desplazamiento de las comunidades aborígenes con que frecuentaban.

Experiencia semejante había atravesado Bianco en La ocasión, y ahora experimentan los viajeros de la caravana de Las nubes, que sin desear convertirse en "otros" prueban vedadas o antiguas formas de vida comunitaria. Cuando se instala el "verano de San Juan", desafiando las rigurosas leyes del invierno en la pampa, el calor agobiante marca el ritmo del viaje y propicia, como lo llama Fermín Rodríguez, un “estado de excepción”, un universo exclusivo con sus propias leyes: "ese aire ardiente y embrutecedor que borraban, reduciéndonos a nuestras lánguidas e idénticas sensaciones, nuestras diferencias" (Las nubes 220). Se relajan las costumbres, los soldados se pasean andrajosos y muestran partes "indecorosas" del cuerpo y las mujeres andan directamente desnudas: “cuando pasábamos por algún río, casi todo el mundo se desnudaba, sin siquiera esperar la oscuridad, y se iba a retozar, con placer animal, en el agua tibia y turbulenta” (220). La descripción que hace el doctor Real de esos días

inveterada de la Patria; solo bastaba que la ciencia determinara su itinerario [...] y la literatura lo revelara públicamente para desvanecer toda sospecha acerca de su localización" (25) y advierte además que la "hibridación" suele mentarse como un riesgo en las narrativas de la frontera a los ojos del Estado: "las alianzas posibles entre distintos grupos étnicos locales o incluso las alianzas potenciales con otros poderes políticos 'extranjeros'" (57), riesgo que Las nubes problematiza y parodia a partir de las circunstanciales simpatías entre Sor Teresita y los soldados, o entre Troncoso y los indios. 
afiebrados parece responder más bien a la alegre promiscuidad que Head encuentra en las chozas gauchas o en los baños colectivos en el arroyo de Mendoza, y que prefiere a la indeseable separación de sexos en el teatro de Buenos Aires. No se trata, como en los casos antes mencionados, de una verdadera inversión al contacto con el mundo de la barbarie sino de una pausa que "relaja" las costumbres y acerca el mundo humano al animal.

Sin embargo, sí hay un personaje que desafía los difusos límites de la caravana y queda prendado del desierto: Troncoso será quien sufra para siempre esa metamorfosis cuando vaya al encuentro de los indios:

el aspecto de Troncoso se había degradado todavía más, y ya lo único que brillaba en su cuerpo ennegrecido por el sol, por el polvo y por la mugre, eran los ojos desorbitados y brillantes, desmesuradamente abiertos, que refulgían en la cara ya casi enteramente comida por el pelo y la barba, [...] lo que daba el aspecto de un animal salvaje [...]. Esa impresión la daba también su voz [que] había enronquecido y [...] a la distancia parecía un ladrido, o un rugido, o unos gargarismos cavernosos anteriores a cualquier lenguaje conocido (Saer, Las nubes 205).

Así como Francis Bon Head conservaba, como reaseguro british, el reloj inglés mientras cabalgaba desnudo por la pampa, el doctor Real establece la diferencia entre la suspensión controlada de las leyes y la conversión absoluta de Troncoso, que tras haberse fugado al desierto para vehiculizar su delirante proyecto político, cae más allá, y queda del otro lado, como un enviado que podría traernos noticias "de un mundo desconocido". Las nubes añade, al plano exiliar que supone salir de la ronda de las caravanas donde todavía resisten ciertas formas de la civilización, el afuera, ya no sólo de la barbarie y de la violencia política, sino de la locura, de la que ya no puede regresarse. Quien vislumbra ese horizonte y puede finalmente volver es, como se recordará, el doctor Real, cuando, suspendido junto a su caballo en una clásica experiencia de extrañamiento, se sabe de repente expulsado del mundo familiar "si este lugar extraño no le hace perder a un hombre la razón, o no es un hombre, o ya está loco" (Saer, Las nubes 185 cursiva en el original).

Pese al desborde corporal y anímico que caracteriza el "estado de excepción" en el que se mueven los personajes, Las nubes no deja de sancionar el regreso a un orden y exhibe, como el reverso del turbulento proyecto político revolucionario (que indirectamente terminará colocando a un "loco" en el poder, porque Juan Manuel de Rosas preside el territorio cuando Real escribe sus memorias), el fracaso de esos otros 
proyectos políticos y afectivos que proliferan entre la carga de enfermos mentales que conduce Real, no sólo el proyecto político de Troncoso, ${ }^{240}$ sino también el proyecto místico-pornográfico que Sor Teresita imagina, deseante, para los cuerpos de la llanura e incluso la curación filantrópica que los doctores buscan procurarle a los enfermos.

El segundo momento que mencionábamos tiene como escenario principal el incendio en la llanura que termina encerrando literalmente a los personajes, a los caballos y a los animales salvajes en la laguna: "Teros, ñanduces, liebres, garzas, guanacos, perdices, y hasta un par de pumas, rondaban en las inmediaciones del agua" (Saer, Las nubes 227). Contradiciendo los instintos y las costumbres ancestrales de los animales, la novela postula esta convivencia inverosímil y la laguna se convierte en ese “espejo acuático que [...] parecía una pesadilla oval pintada por un artista demente, y engarzada en un marco de llamas" (Las nubes 236). La presencia del fuego adquiere al principio las dimensiones de un sublime infernal y se describen las explosiones "de las columnas furiosas de chispas y de materia ígnea que pasaban volando y crepitando" (235).

${ }^{240}$ Troncoso le envía a diario al doctor Real un delirante programa político bajo el que pretende abolir el poder del rey español y el de su virreinato, y terminar, además, con el poder del Sol y los astros para crear una nación de tribus federadas que tendría como líder a un hombre extraordinario, él mismo, supremo rey-sacerdote y jefe militar de las tribus. Ante la vista de los despojos que el cacique Josesito ha dejado en el camino, Troncoso huye para convencerlo de rendirse y contribuir así a federar las tribus de América en un solo estado independiente. Es posible leer aquí, como ha señalado Reati, los programas políticos de los sectores más radicales de la independencia; y en la figura barbarizada del personaje los rasgos más salientes de Facundo, como ha señalado Sarlo. Sin embargo, quizás también podría reconocerse bajo el impetuoso personaje al excéntrico coronel Lucio V. Mansilla, quien, como el mismo Troncoso, parte de una frontera ya un poco barbarizada hacia la barbarie por antonomasia, Tierra Adentro. Como se recordará, después de haber bebido del cuerno de aguardiente que le convida una y otra vez Epumer, el coronel tiene un sueño en el que se ve él mismo investido como emperador de las tribus ranquelinas, Lucius Victorius Imperator: "Yo era emperador de los ranqueles. Hacía mi entrada triunfal en Salinas Grandes. Las tribus de Calfucurá me aclamaban. Mi nombre llenaba el desierto preconizado por las cien leguas de fama. Me habían erigido un gran arco triunfal" (Mansilla 248). La fantasía, que ha surgido entre la borrachera y el sueño, reaparece algunos capítulos después, bajo la figura de la locura: "Murmuré: Lucius Victorius Imperator. Me pareció sonoro. Pero la onomancia me dijo: ¡Loco! Me miré la palma de la mano, consulté sus rayas, y la quiromancia me dijo, dos veces: ¡Loco! Vi cruzar una bandada de loros, observé su vuelo, y la ornitomancia me dijo, tres veces: ¡Loco!” (Mansilla 362). Efectivamente, aquello que en las Excursiones se vive como ensueño, ebriedad y locura, última precaución que Mansilla esgrime contra esa imagen de la fantasía, atraviesa a Troncoso, quien, como sabemos, cruza efectivamente la frontera de la "cordura" para llevar noticias de un mundo desconocido. Como ha señalado Cristina Iglesia en La violencia del azar, Mansilla es el gran traductor, el gran lenguaraz de las dos barbaries, la de los indios y la de Rosas, pero se encuentra a salvo de ambas. Las memorias del doctor Real se escriben en ese hiato, entre la locura efectiva de sus pacientes y la sinrazón efectiva y tiránica de Rosas, que gobierna, como se dijo, mientras él escribe sus memorias desde Europa. 
En otras oportunidades Saer ha modulado imágenes similares sobre el incendio en la pampa, y así puede leerse en "Campos quemados", un poema escrito entre 1960 y 1975: “...Hay una franja móvil/ de fuego bordada en el tejido tenso del bastidor de la amplia oscuridad./ Gritos de pájaros enloquecidos, cenizas en el viento. El alba ¿encontrará los rescoldos finales, o aquella/ vieja amenaza que día y noche/ nos acompaña/ llegará hasta este mundo con su fuego irreal/ para escribir, por fin, borrándonos, la ardiente profecía?" (El arte de narrar 46). El poema condensa en doce versos las principales imágenes sublimes que escande la prolongada escena narrativa de la novela, -la peligrosa glotonería de los pájaros que los hace abalanzarse sobre las llamas para pescar a los insectos que saltan rostizados; la línea de fuego que circunda el bastidor de la noche, y también, por fin, la amenaza escatológica del incendio mítico, que también llegaba en la fantasía del juez de Cicatrices--, sin embargo, lo que la poesía deja en suspenso, exacerbando el costado metafísico del fuego, la prosa de Las nubes lo resuelve:

el fuego, en su estúpido viaje hacia el norte, por esa vez, nos había acordado un nuevo plazo [...] consumiéndonos, las llamas hubiesen consumido también nuestro delirio [pero] [habiendo] pasado de largo sin siquiera detenerse para aniquilarnos, nuestro delirio, intacto, podría recomenzar a forjar el mundo a su imagen (Saer, Las nubes 237).

Una vez que las llamas se alejan rumbo al norte y se prepara la tormenta de Santa Rosa, se recupera la dimensión más banal del viaje y la novela nos informa que el vasco reparte alegres porrones de ginebra entre los soldados. Saer reescribe así la larga serie de imágenes sobre el incendio a partir de una sutil mezcla de sublime y banal cuyo germen ya se encontraba en sus autores predilectos. ${ }^{241}$

\footnotetext{
${ }^{241}$ También Francis Bon Head desarticula los clásicos tópicos del sublime: "Me senté y miré en derredor, y en toda mi vida he visto mezclado tanto de sublime y ridículo. Mientras los elementos se enfurecían, y el trueno estallaba y rugía muy cerca de nosotros, el relámpago cambiaba por un instante la noche en día. Durante estos relámpagos, veía a mis compañeros, llamándose a gritos, en las posturas más cómicas. Algunos acostados, temerosos de sentarse, agarraban los ponchos y ropas que querían escapárseles; otros, que habían perdido la ropa, corrían en paños menores al cuarto de la posta..." (150).
} 


\title{
"A Rabbit as King of the Ghosts": ${ }^{242}$ ciencia natural $y$ fantasmas
}

\author{
Las nubes es también un extendido diálogo entre el Saber (el Doctor Weiss) y lo
}

Real (su discípulo local, el Doctor Real), conversación que se teje aquí alrededor de uno de los relatos más sobresalientes: el viaje de naturalista de Alexander Von Humboldt. Como podrá observarse, la presencia material y distorsiva del paisaje que señalábamos anteriormente se actualiza también en la vida natural y en los códigos de aprehensión naturalista que vehiculizan los personajes. En primer lugar hay varias reminiscencias humboldtianas en la figura del Doctor Weiss, ${ }^{243}$ a quien le interesan todas las

${ }^{242}$ En una hoja suelta incluida en el Dossier de La grande, Saer anota: "Los animales como fantasmas, espectros, presencias unidimensionales ("A rabbit as King of the ghosts" W. Stevens 209)" (Papeles II 355). Se trata de una anotación de los años ochenta, cuando Saer recogía ideas para El intrigante. Se recupera aquí el título del poema de Stevens por la condición fantasmática y espectral que subraya el escritor y que Las nubes retomará.

${ }^{243}$ Una coincidencia en primer lugar "biográfica" que se vuelve significativa por dos motivos, por un lado, porque como señala Pratt: "Humboldt existió y existe no como un viajero o como un escritor de libros de viajes sino como un hombre y una vida, de un modo que sólo fue posible en la era del individuo" (Ojos imperiales 219) y en segundo lugar porque el género de la biografía asume una importancia fundamental en la estructura de la novela, cada vez que el prolongado retrato de un personaje -el doctor Weiss pero también los locos que forman parte de la caravana y los principales acompañantes del doctor Real- interrumpe el relato de viaje. Los críticos de Humboldt han destacado su inagotable energía, capacidad y educación, "su carácter audaz y su apasionada autorrealización" (Pratt 219) y lo presentan como "joven e hiperactivo [...] Humboldt escaló volcanes, descendió a minas y cuevas, remontó ríos, navegó lagos, contempló eclipses, [...] cabalgó entre llaneros por las estepas venezolanas, describió los ruidos de la selva y capturó en sus jaulas de naturalista cuanta especie cayera en sus manos" (Rodríguez 41). Como se recordará, el Doctor Weiss goza de la misma energía y ha pasado por similares aventuras, y ambos representan, en el vértice de la nueva relación que América entabló con Europa en el momento de descomposición de la hegemonía española, el hecho de ser los portadores de una novedad científica y filosófica: la nueva mirada científico-romántica inaugurada por Humboldt, y el ensayo terapéutico y filantrópico que el Doctor Weiss pretende ensayar con los locos de Sudamérica. Ambos arriban en un momento de fuerte inestabilidad política, guerras y revoluciones, pero deben contar con la autorización de la corte española y costear, con su esfuerzo económico, los planes que tengan en el "nuevo", o "reinventado" continente. En Un desierto para la nación, Fermín Rodríguez apunta algunos aspectos de esta coincidencia entre los viajeros: "El doctor Weiss tiene mucho de sabio romántico 'totalizador', al estilo de Humboldt" (62). Efectivamente, como han subrayado Rodríguez, Pratt y Prieto, su afán es conducido por la "fantasía de un conocimiento unificado del mundo", capaz de encontrar las fuerzas invisibles que subyacen en la naturaleza. Humboldt reinventará América ofreciendo "una naturaleza plástica, dramatizada y turbulenta, percibida como proceso de transformación y de violentas metamorfosis" (Pratt 46) un mundo en constante erupción, cuyos descalabros se corresponden con la agitación política revolucionaria y que también se dará como la naturaleza "delirante" de Las nubes. Por último cabría destacar que, como señala Pratt, la naturaleza humboldtiana no fue aquella accesible y categorizable de los linneanos, fundada en el reino de lo visible, sino una naturaleza impresionante y sublime que la ciencia debía capturar en sus fuerzas invisibles. El mismo salto parece presentarse entre los apuntes vagamente linneanos de las libretas de Saer y la naturaleza proliferante y perturbadora de sus ficciones. 
manifestaciones, desde los astros hasta las florcitas más insignificantes que colecciona en un herbario, porque sabe que no hay jerarquías en la naturaleza y que en cada fenómeno natural pueden leerse las leyes que rigen al universo, aunque reconoce también que a medida que avanza el conocimiento, aumenta el lado oscuro e indescifrable del mundo. Por otro lado, el doctor Real realiza también algunas observaciones "naturalistas" de aficionado cuyo efecto es precisamente mostrar cuan hondo y perturbador puede ser ese "lado oscuro" intuido por el doctor Weiss.

Mientras avanzan por la llanura, el narrador distingue entre un viajero y un naturalista, y señala que aquellas irrupciones que podrían interesar al viajero cuando interceptan su avance por el campo -el salto de una liebre o el vuelo de una perdizterminan volviéndose

al cabo de cierto tiempo [...] más que familiares y flotan, fantasmáticas, más allá de la experiencia y más allá del conocer. La vida que hormiguea entre sus pastos [...] que podría ocupar la existencia entera de un naturalista, para el viajero [...] se empasta en la más uniforme monotonía. [...] Lo mismo que el mar, la llanura es únicamente variada en sus orillas: su interior es como el núcleo de lo indistinto (Saer, Las nubes 176-7-8).

Interesa esa transición que va de la mirada particularizada y especializada del naturalista a la percepción extrañada del viajero, que sabe que cuando "algo fuera de lo común acontece, tan intenso y nítido es su acontecer que [...] siempre su evidencia excesiva nos parecerá problemática" (Saer, Las nubes 178). La llanura monótona, serial, "núcleo de lo indistinto" que campea el relato desarticula las prerrogativas clasificatorias del conocimiento naturalista y produce, como se verá, una percepción del paisaje natural más próxima a las experiencias animistas de William Henry Hudson.

El desierto que deben atravesar los viajeros de Las nubes también es “excepcional" en relación a los fenómenos climáticos que perturban el orden acostumbrado y exacerban la fragilidad del paisaje. Las crecidas del río y el cambio súbito de temperatura que ha instalado un verano en medio del invierno modifica sensiblemente las costumbres de los animales: "la inconsecuencia que suponía la presencia de ciertas especies en un terreno que no tenían la costumbre de frecuentar, le daba al viajero la impresión de que ese trastocamiento producía en los animales una suerte de desorientación, de inquietud y aún de pánico, que los hacía olvidarse de sus actitudes ancestrales" (181). Es decir, en el vértigo de desplazamientos que produce el desierto de principios del siglo XIX - guerras de independencia, presencia atemorizante 
del indio, incendio en la llanura- el mundo natural también se ve afectado y desborda la representación clásica de la lámina naturalista:

La presencia de tantas especies diferentes en un espacio tan reducido [...] le daba al paisaje el aspecto abigarrado que tiene la disposición arbitraria de ejemplares diferentes en una lámina de naturalista. Esa impresión de seres pintados que, desde mi infancia, suelen darme a veces los animales. [...] Y esa exterioridad inaccesible de figuras pintadas que presentan, en la soledad de la llanura se refuerza todavía más, lo que los vuelve casi fantasmales (Saer, Las nubes 182).

La ficción saeriana termina de desarticular la autoridad científica del "saber" y socava las certezas de las clasificaciones y de sus representaciones visuales. El mundo animal, trastornado, revela una faz perturbadora y fantasmal que saca al sujeto del paisaje familiar:

Durante unos segundos, tuve [...] la total convicción de que sabía más del universo que yo mismo. [...] A causa de esa convicción me encontré, de golpe, en un mundo diferente, más extraño que el habitual y en el que, no solamente lo exterior, sino también yo mismo éramos desconocidos. Todo había cambiado en un segundo y mi caballo, con su calma impenetrable, me había sacado del centro del mundo y me había expelido, sin violencia, a la periferia (Saer, Las nubes 185).

Ese cruce entre mundo natural y extrañamiento del paisaje no sólo puede leerse en tantas otras ficciones de Saer (el caso quizás paradigmático es "En la tardecita") sino también en otro gran viajero y naturalista que Saer privilegia a la hora de observar la naturaleza: William Henry Hudson. ${ }^{244}$ En Allá lejos y hace tiempo el escritor recuerda con fruición cómo se paseaba a caballo por el campo o se tiraba a ras del suelo entre las verbenas para gozar del deleite físico que le procuraban los sentidos al contacto con las irrupciones cromáticas, lumínicas y olfativas de la llanura. Se trata de un "deleite" sublime que al tiempo que le causa placer también lo asombra y lo sobresalta, y reconoce a veces no poder "tolerar" una puesta de sol. En ocasiones el sentimiento animista es tan poderoso que le hace perder el sentido de lo real, ${ }^{245}$ cuando, fascinado o capturado por una manifestación de la naturaleza en la que para él anida lo sobrenatural: “el misterio crecía hasta que la sensación de deleite se trocaba en terror y el terror

\footnotetext{
${ }^{244}$ Los vínculos entre el particular naturalismo ensayado por Hudson y Saer se estudiarán en profundidad en la tercera parte de la tesis.

${ }^{245}$ El animismo era un sentimiento usualmente asociado a la infancia o a las "mentes primitivas", según él mismo señala, que supone "la proyección de nosotros mismos dentro de la naturaleza, la facultad y la comprensión de una inteligencia como la nuestra, pero más poderosa, en todas las cosas visibles" (Hudson, Allá lejos y hace tiempo 180).
} 
aumentaba hasta que no lo podía soportar más. Apresuradamente escapaba, para recuperar el sentido de la realidad y de la seguridad, dentro de la casa, donde había luz y compañía" (Hudson, Allá lejos y hace tiempo 184). Él mismo reconoce que en la era científica en la cual escribe sus memorias, el animismo se ha entremezclado con el "sentimiento estético" y puede hallarse en la poesía de escritores como Wordsworth. El misterio que le suscitaba la contemplación de la naturaleza no podía resolverse a partir de los libros de historia natural que encontraba en la biblioteca familiar, y desbordaba hacia la poesía y la filosofía.

Las nubes, se dijo, reescribe una extensa biblioteca de viajeros y de escritores de la tradición nacional, pero lo hace encadenando y exacerbando, como intentó mostrarse, los momentos en que esas narrativas "desbordan": el delirio sublime y animista de Hudson; el desvío jocoso de Francis Bon Head; el extremo onírico e imperial de Mansilla y el catálogo omnicomprensivo y escenográfico de Ebelot. Las nubes sobreescribe además las cabriolas y espejismos del desierto que Saer ya había probado en sus ficciones anteriores. En ese tiempo previo a la "historia nacional", en esa tierra "vacía" e indistinta, Saer dibuja un acontecimiento nimio en el que se cifra una forma díscola y fronteriza de la patria. Ese pasaje fugaz e insignificante para la historia es recuperado en la memoria del Doctor Real, posible escritura apócrifa y ficcional que leerá con deleite Pichón Garay en su departamento de París, al final del verano, y de la que podrá extraer, "la memoria de este lugar, o de cualquier otro", porque, como dice Soldi, "lo que es válido para un lugar es válido para el espacio entero" (12). 


\section{MANCHAR EL MAPA URBANO: DESPLAZAMIENTOS EN LA CIUDAD DE LOS SESENTA}

Cuando Arcadio Díaz Quiñones le propone a Saer establecer un mapa de la zona, el escritor despliega un mapa de Santa Fe, le borra el nombre a la ciudad y comienza a ubicar los principales lugares de las ficciones. Según Premat, que rescata esta escena, así se convierte un espacio existente en un espacio ficticio. De los diferentes escenarios que ofrece la ya reconocida "zona" -el río, las islas, el campo, el puerto y la urbe- la ciudad es uno de los espacios privilegiados en las ficciones de Saer. Como ha señalado la crítica, encabalgada entre un estatuto imaginario y un referente empírico más o menos cercano a Santa Fe y Rosario, la ciudad saeriana puede organizar el derrotero de los personajes pero también devenir una experiencia irracional. Nos centraremos aquí en los modos en los que Saer reescribe ficcionalmente la Santa Fe de los primeros años sesenta en tres de sus novelas: La vuelta completa, Cicatrices y Glosa.

Como se verá, la ciudad de Saer no es un espacio replegado sobre sí mismo: a nivel espacial, sus bordes difusos se tocan con las islas, el campo y el río; a nivel temporal la urbe guarda la memoria del desierto y vuelve a contar los relatos de la fundación. En estas operaciones distorsionadoras de la representación urbana se leerá una vez más cómo Saer se sustrae y discute con las principales morales -ideológicas y estéticas- de los sesenta: el debate sobre el compromiso y las prerrogativas vistosamente vanguardistas y lúdicas del boom.

En la zona, el primer libro de relatos de Juan José Saer, registra un desplazamiento decisivo para su obra: después de haber abandonado el puerto, un arrabal con tintes borgeanos y faulknerianos, la ficción pasa "Más al centro" y se ubica prioritariamente en la ciudad. ${ }^{246}$ Sin embargo ese espacio explorado con fruición por sus personajes se abre a la indeterminación: la ciudad es, en palabras de Pichón Garay, una "abstracción que nos concedemos para darle un nombre propio a una serie de lugares fragmentarios, inconexos, opacos, y la mayor parte del tiempo imaginarios y desiertos de nosotros" (Saer "A medio borrar", La mayor 149); una constante espacial que

\footnotetext{
${ }^{246}$ En una entrevista realizada por Graciela Speranza, Saer señala el parentesco formal y temático que el mundo marginal de En la zona guarda con la ficción orillera de Borges y con la novelística de Faulkner. Un interesante análisis sobre el tema puede encontrarse en Juan José Saer: la felicidad de la novela de Rafael Arce, quien sostiene que el arrabal saeriano, ubicado en la zona portuaria, se extrae del arrabal borgeano.
} 
escamotea, sin embargo, la definición de un lugar y que se caracteriza por ostentar los signos de la destrucción y del delirio.

En ese sentido, podrían leerse los libros de Saer no, o no solamente como la historia de una ciudad, sino como los modos de su extravío, que desde los primeros asentamientos urbanos de los colastiné hasta el deterioro de la ciudad de los noventa en La grande, se reiteran en cada una de sus ficciones. Si por un lado Saer, como una especie de topógrafo, define los límites del espacio urbano y caracteriza su fisonomía arquitectónica, botánica y social, por otro lado borronea y mancha la grilla urbana que reaparece casi obsesivamente en los distintos derroteros que trazan los personajes cuando se mueven por ella.

En ese arco al que se abre, con hiatos, la "zona", desde el siglo XVI hasta principios o mediados de la década del noventa, un tiempo insiste en la mayor parte de sus novelas y relatos, la fecha precisa del año $1961,{ }^{247}$ en la ciudad cuyo referente no se nombra, pero que puede identificarse con Santa Fe o Rosario. ${ }^{248}$ Como se verá, las tres novelas que más claramente abordan esa constelación espacio-temporal escamotean de diferentes formas los rasgos típicos de la década. ${ }^{249}$ Por un lado, fuertemente comprometidas con la urbe, no muestran, sin embargo, una ciudad en pleno desarrollo urbanístico ni tampoco revelan el agitado brillo de la bohemia artística sino más bien un

\footnotetext{
${ }^{247}$ En el mismo ensayo, Arce señala precisamente que el epicentro borroso del espiral que traza la temporalidad en la obra saeriana es ese año de 1961, "no un año sino una época: aquella que Soldi y Gabriela reconstruyen en la historia de la vanguardias locales y aquella que es la de la juventud de Gutiérrez" (Arce, La felicidad de la novela 189).

${ }^{248}$ En numerosas entrevistas Saer señala la importancia que tuvieron ambas ciudades en su vida personal y en su aprendizaje literario: Santa Fe representa la creación literaria y Rosario el pensamiento filosófico, la sociología y el psicoanálisis, dos líneas que convergen en su producción artística. En una conversación con Gastón Bozzano, reconoce "en la ciudad que yo he inventado [...] sus dimensiones no corresponden a Santa Fe, sino a una ciudad un poco más grande. Y esa ciudad es Rosario" (Una forma más real 127). En el clásico estudio "El lugar de Juan José Saer", Gramuglio establece una primera identificación y señala que la ciudad de Santa $\mathrm{Fe}$, que nunca se nombra, tiene un referente real a partir del cual se despliega la construcción del espacio imaginario. Mucho después, Premat, sin desmentir la localización geográfica de las ficciones saerianas, discutirá sin embargo su carácter "imaginario" y propondrá en cambio la imagen de un escritor que apuntaba en sus libretas de viaje diversidad de rasgos sobre la ciudad -el clima, la vegetación, los modos de hablar y la arquitectura-, dignos de un escritor naturalista, para mostrar cómo ese "parentesco" problemático entre el territorio de sus ficciones y el espacio de Santa Fe aumentaba en la producción tardía del escritor.

${ }^{249}$ En "Juan José Saer y el relato regresivo. Una lectura de Cicatrices", Premat apunta con respecto a los años sesenta en Argentina y a la politización creciente de los intelectuales, que en la novela la historia no es lo que sucede sino lo que ha sucedido. La Revolución Libertadora y la proscripción del peronismo "no explican los acontecimientos de la novela, sino que se presentan como causas difusas, incomprensibles pero indiscutibles, de dramas que confunden lo individual y lo colectivo" ("Juan José Saer y el relato regresivo" 504).
} 
espacio fantasmal, manchado y borrado, que es, en La vuelta completa, una versión moderada y lacónica de Santa Fe; en Cicatrices, el resabio alucinado de las derrotas del peronismo pero también el vértigo violento del origen, y finalmente en Glosa, una grilla ideal que muestra su reverso grumoso y atormentado.

Publicada en 1966, La vuelta completa fue escrita entre 1961 y 1963 y por lo tanto es la novela cuya escritura es contemporánea al momento histórico al que se refiere en la ficción. Cicatrices, publicada en 1969, pero escrita en 1967, revisa los meses que van de febrero a junio para concentrarse en los avatares de cuatro personajes el significativo día del primero de mayo de 1961. La escritura de Glosa, publicada en 1986, comenzó en 1982, momento coincidente con una de las vueltas de Saer a la Argentina. Si bien el recordado comienzo de la novela juega con la indeterminación temporal ("Es, si se quiere, octubre, octubre o noviembre, del sesenta o del sesenta y uno" (Saer, Glosa 13)), la narración termina precisando, sospechosamente, un día en particular: 23 de octubre de 1961.

En La ciudad vista, Beatriz Sarlo propone que tanto la ciudad "real" como la "ciudad escrita" tienen sus recorridos y mapas, sus calles y barrios que funcionan como zonas de anclaje, como efímeros puntos de contacto en que se toca lo real. Sin embargo los vínculos entre un espacio y otro no pasan por la fidelidad de la adecuación sino precisamente por las desviaciones: allí podemos leer el modo en que se piensa, se imagina y se proyecta una ciudad, desde un orden literario - la novela policial, la ciencia fícción, etc.- o de acuerdo a un orden prescriptivo -utopías, distopías, géneros morales-. El primer interrogante será pensar qué desviaciones aparecen en estas novelas de Saer entre la ciudad de la ficción y la Santa Fe 'real', no para cotejar de manera rudimentaria $-\mathrm{y}$ confirmar el fracaso- de la voluntad representativa del lenguaje, ${ }^{250}$ sino para observar, en la distorsión de la urbe, las morales -formales y políticas- que refundan la noción de espacio en Saer.

\footnotetext{
${ }^{250}$ En Zona Saer, Sarlo se detiene en las principales acciones que comparte la sociedad de amigos de la zona: comer, hablar y desplazarse y advierte que Saer es minucioso en los recorridos de sus personajes, aunque también los rearma, contradiciendo el mapa urbano: "Los itinerarios no siempre siguen el trazado de la ciudad de Santa Fe y sus alrededores, pero Saer usa nombres que son inmediatamente familiares a quienes los conocen" (111-2), apegado a los nombres, es "infiel" a los recorridos. En una charla con Roberto Maurer, Sarlo le pregunta sobre los lugares de algunas de las narraciones de Saer, y Maurer advierte las "incongruencias" del recorrido que se inscribe en la primera ficción que transcurre en la ciudad, "Algo se aproxima": "Podría decirse: a Saer le interesa más el puente y el río que el recorrido, en la noche, por esas calles, cuyas direcciones sobre el mapa parecen contradictorias. Así funda la ciudad para su literatura y confirma que 'no hay paisaje sin su historia (su relato)' " (Sarlo, Zona Saer 112).
} 
Interesará en segundo lugar pensar los desplazamientos urbanos como una forma específica y acotada del viaje en Saer, cuyas distintas formalizaciones escriturales y visuales organizan la estructura de los textos y las relaciones entre los personajes. En Caminantes, Edgardo Scott advierte que "caminar" es una forma de vitalismo que implica una cierta desposesión, y declina el verbo en sus múltiples variantes: la errancia, el vagabundeo, la flânerie, el peregrinaje y el paseo. A su vez, señala que durante muchos siglos las ciudades tuvieron el tamaño de la marcha. A partir del siglo XIX, con la aparición del ferrocarril, y posteriormente los automóviles, colectivos y subterráneos, los desplazamientos a pie quedaron reducidos a breves distancias. Como se verá, la ciudad de Saer parece por momentos recuperar esa "dimensión de la marcha", aun cuando sus personajes la atraviesen en modernos medios de transporte o crucen en lancha hacia las islas del Paraná.

\section{1. Santa Fe en los sesenta: la Atenas de Sudamérica}

La ciudad es el paisaje predominante de los sesenta y el principal escenario de las transformaciones de la década. Como sostienen Sergio Olguín y Claudio Zeiger, el interés está centrado en "la clase media de las ciudades, los intelectuales, los artistas y los marginales de la sociedad industrial" (368). Los críticos e historiadores enfatizan el surgimiento de actitudes cuestionadoras de los saberes y las morales establecidos y los cambios que se produjeron en todos los órdenes: las formas de sociabilidad, las costumbres, las instituciones, las prácticas artísticas y políticas, los medios de comunicación, la conformación del público y las relaciones de poder. Heredera del existencialismo sartreano y de las teorías del compromiso y atenta a los procesos de descolonización de las guerras antiimperialistas, la época concebía que el cambio era necesario y urgente. Se trataba, en este sentido, de un momento afirmativo, enfático y polémico que redefinió las relaciones entre historia y literatura. Como se vio en la primera parte de la tesis, esta preocupación política excedió el marco nacional, extendiéndose al continente, particularmente atento a los alcances de la reciente Revolución Cubana. Andrea Giunta buscará comprender la coyuntura epocal de Argentina en relación a un contexto internacional de transformaciones estéticas y sociales, y sostendrá que fue precisamente ese carácter "internacionalista" asumido por la vanguardia el que estableció una nueva dirección para la historia del arte nacional. 
Santa Fe participa del apogeo que caracteriza a la época, y fue llamada 'la Atenas de Sudamérica' por concentrar un cúmulo de experiencias artísticas diversas. El propio Saer reconoce, en una entrevista otorgada a Pilar de Castro, el auge cultural de la ciudad: "Santa Fe, a finales de los años cincuenta, era una ciudad que tenía cuatro grandes librerías, cuatro cineclubs, como diez o doce teatros independientes, un salón de Bellas Artes [...] y una escuela de cine de proyección continental" (Saer en de Castro 94). ${ }^{251}$ Como afirma Luis Müller en "Santa Fe en la segunda mitad del siglo XX", ya desde 1940 puede observarse una fuerte impronta de renovación y crecimiento urbano, así como la construcción de nuevos edificios públicos y obras de arquitectura moderna. ${ }^{252}$ La ciudad, hasta entonces chata y horizontal, comenzó a perfilarse en vertical e incorporó algunos edificios de altura en la zona del centro. Además, durante la década del sesenta se realizaron grandes obras de infraestructura que la vincularon con el resto de la región, ${ }^{253}$ y se incorporaron pasajes peatonales que modificaron la red circulatoria interna en la que las galerías comerciales diseñaron una nueva forma de organización espacial para comercios y oficinas.

Las ficciones de Saer, como se sabe, ponen en movimiento a varios personajes que transitan la ciudad y producen una serie proteica de imágenes que se solapan y fundamentalmente se desvían de la "Atenas" de Sudamérica. Como sugiere Frisby en Paisajes urbanos de la modernidad, los observadores que habitan la ciudad se sitúan a distintas distancias y pueden ofrecer modos diversos de representar el paisaje urbano, o

\footnotetext{
${ }^{251}$ Como se recordará, el escritor participó activamente del medio artístico e intelectual de la ciudad hasta su partida a Europa en 1968. A mediados de la década del cincuenta entró en contacto con escritores como José Pedroni, Juan L. Ortiz y los intelectuales del grupo literario "Adverbio" (formado por Hugo Gola, Hugo Mandón y José Luis Vittori) y más adelante conoció también al grupo de jóvenes escritores, profesores y estudiantes de Rosario (María Teresa Gramuglio, Noemí Ulla, Nicolás Rosa, Adolfo Prieto, Aldo Oliva, Josefina Ludmer y Norma 'Bibí' Castellaro). Desde 1956 comenzó a trabajar como periodista en El Litoral, medio en el que publicó sus primeros poemas y algunos cuentos y en el año 1959 se hizo cargo, junto a Gola y Vittori, de su suplemento literario. A partir de 1962 dictó clases en la Escuela de Cine de Santa Fe, creada por Fernando Birri, órgano fundamental de la renovación cinematográfica que marcó a una nueva generación de cineastas y de la cual Saer y Gola representaron el ala más "vanguardista", como el mismo Saer declara en sus entrevistas.

${ }^{252}$ Puede mencionarse el edificio de Correos y Telecomunicaciones, inaugurado en 1959, que modificó el perfil de la ciudad. Ubicado frente al Puerto y a una importante avenida, siguió los parámetros arquitectónicos y estéticos del "International Style" y llamó la atención de los santafesinos por algunos de sus aspectos modernos, como la gran superficie vidriada de sus ventanales o los tubos neumáticos que servían para transportar la correspondencia.

${ }^{253}$ Principalmente el Túnel Subfluvial que une Santa Fe y Paraná y la Autopista Santa FeRosario.
} 
bien a partir de una mirada panorámica, ${ }^{254}$ o bien a partir del cifrado estereotipado de la "postal". ${ }^{255}$ Pero además, los sujetos pueden otorgar una perspectiva desde el interior de las calles a partir del callejeo -ya veremos que las distintas formas de callejear ofrecen construcciones espaciales diversas-, que en Saer se realiza particularmente de a pie o en automóvil. En La ciudad a lo lejos, Nancy señala que una urbe es primeramente una circulación que no se organiza en relación a un territorio sino que organiza ese territorio "según direcciones, tensiones y asignaciones: aquí la estación, aquí la municipalidad, aquí el correo..." (110) y que el transeúnte es el personaje de la ciudad, quien, al pasar de un lugar a otro, reúne lugares distanciados, quien "apresurado o que pasea, atareado u ocioso, camina junto a otros transeúntes, tan cercanos y tan lejanos, familiarmente ajenos" (48-49). El viaje "urbano" se vuelve entonces productivo porque las travesías por la ciudad disparan los imaginarios y "la urbe programada para funcionar, diseñada en cuadrícula, se desborda y se multiplica en ficciones individuales y colectivas" (García Canclini 109).

En La grilla y el parque, Adrián Gorelik enumera los sentidos usualmente asociados a la idea de grilla: una parrilla de manzanas que cuadricula el territorio; una estructura artificial que supone su explotación capitalista; un esquema que vuelve a los

\footnotetext{
${ }^{254}$ En La ciudad a lo lejos Jean Luc-Nancy complejiza la idea clásica de "panorama", que suponía una visión en altura que al tiempo que le permitía al espectador dominar el territorio, no lo comprometía corporalmente y lo resguardaba en la distancia. Nancy, que piensa la ciudad en su precariedad y en los albores de su mutación, evoca el "plano caballero" como aquella representación que podía recortar artificialmente el paisaje urbano, a la vez hundida como desde una elevación que domina, pero dispuesta de manera que se podían observar las calles y plazas al mismo tiempo que las casas y edificios. Sin embargo, advierte, la fisonomía de la urbe escapa a su contemplación absoluta y se repliega en el relieve de chimeneas, torres, antenas y campanarios: "La ciudad retira algo de su ser al régimen de la visión. Se niega a estar solamente colocada como un objeto" (Nancy, La ciudad a lo lejos 64). Cuando Saer retoma la visión panorámica sus personajes se detienen a contemplar, como lo hacen en La vuelta completa Pancho y Barco: "Llegaron al puente colgante con el sol ya alto. [...] Se detuvieron en mitad del puente mirando el agua: el río estaba crecido, opulento y furioso [...]. Hacia el sur se divisaban las construcciones portuarias: interminables galpones de cinc, duros muelles de piedra gris, elevadores de granos semejantes a rascacielos, barcos ultramarinos de chimeneas humeantes cargando cereal" (193-194). Sin embargo, como veremos en Cicatrices, también compartirá las mismas aprehensiones que Nancy y mostrará cuan insuficiente y equívoca puede resultar esta visión supuestamente abarcadora.

${ }^{255}$ También según Nancy "la postal es a la identidad de la ciudad lo que la foto de identidad es a la persona: inexpresiva, sin espesor, [...]; un signo de reconocimiento, pero no una presencia, ni un encuentro" (La ciudad a lo lejos 44). Efectivamente, así funciona para la glosa automatizada que despliega el Matemático cada vez que lo interrogan por su paso por Europa: "Siena es una imagen rojiza, elevada en la bruma caliente del atardecer; París, una lluvia inesperada; Londres, un problema de alojamiento" (Saer, Glosa 24).
} 
sujetos seres anónimos e imposibilita la agrupación comunitaria. Sin embargo, advierte, la grilla también ha funcionado como un instrumento de intervención urbanística y por lo tanto de reforma social, como configuradora de ciudadanía. El espacio público debería entenderse no como algo dado sino como "el producto de una colisión, fugaz e inestable, entre forma y política" (Gorelik 20). Interesa pensar qué movimientos, o en términos de Sarlo, qué desvíos produce Saer con respecto a la trama urbana, y por ende, qué sociedad se desprende de ella, así como atisbar, en esa eclosión fugaz de "forma" y política, cómo se presentan los espacios públicos en la visión atormentada de la ciudad, cuando por "forma" entendemos, también, "imagen".

\section{2. La insistencia del tiempo en la ciudad}

La vuelta completa es, como se dijo, la novela cuya escritura es contemporánea al tiempo de la ficción y extemporánea, como ha comentado la crítica, con respecto a las publicaciones literarias hegemónicas. ${ }^{256}$ Marcos Rosemberg, hacia el final del debate que mantiene con Rey, se adscribe a un regreso "materialista" de la existencia y sentencia: "Nosotros vivimos en América, en la Argentina, en esta ciudad. Estamos ahora en este bar. Es un sábado del mes de marzo del año mil novecientos sesenta y uno: ése es el terreno real donde deben comenzar todas las preguntas y todas las investigaciones" (Saer, La vuelta completa 33). Sin embargo, un poco más adelante, la misma novela se encarga de suspender esa contingencia epocal para imaginar una ciudad inmutable:

Era la misma ciudad de diez años atrás, él lo sabía: los pequeños, graduales cambios en la fachadas, en las hileras de casas a lo largo de las veredas ahora desiertas, no hacían más que probar de un modo sutil su identidad y su permanencia; la misma de diez, quince, hasta veintinueve años atrás; y a partir de esa fecha, el instante de su nacimiento, azar o lo que fuere, contando para atrás, la ciudad también permanecía, objetiva e inmutable, un todo dado al que el azar se había incorporado sumisamente, para conformarlo, aun mínimamente, por toda la eternidad (Saer, La vuelta completa 179).

\footnotetext{
${ }^{256}$ Cfr. el ensayo ya mencionado de Rafael Arce, donde se explicita que esta segunda novela de Saer es la menos "legible" porque no participa de las formas literarias hegemónicas inauguradas por Rayuela y las ficciones que forman parte del Boom, y por supuesto, el ya mencionado estudio de Miguel Dalmaroni, "El largo camino del 'silencio' al 'consenso'. La recepción de Saer en la Argentina (1964-1987)", donde se explica que al menos hasta principios de los ochenta, Saer parecía ilegible para casi todos: la nueva izquierda comprometida, los intelectuales revolucionarios, los entusiastas del Boom y los detractores de Borges, etc.
} 
El contrapunto entre la afirmación del presente y la inmutabilidad de la ciudad permite vislumbrar hasta dónde Saer participa y se sustrae de las morales sesentistas. Como advierte Susana Cella, la literatura, la historia y la política se ligan de un modo nuevo y se abandona toda idea de atemporalidad: "El presente es el tema y es el punto de partida de toda reflexión, de toda acción" (Cella 9). Si bien este apotegma, que parece casi calcado de las palabras de Marcos Rosemberg, no termina de refutarse en la historia, queda suspendido por otras temporalidades que parecen ir a contrapelo del progreso histórico, y a pesar de que el deambular de los personajes descubre por momentos fragmentos de una ciudad moderna, ${ }^{257}$ La vuelta completa insiste en fabricarse un pasado en el que todo o casi todo ya ha sido hecho. Pancho, que ha regresado a la ciudad después de su último tratamiento en Buenos Aires, despliega una mirada nostálgica que evoca los patios con aljibe de las orillas borgeanas; ${ }^{258}$ Rey es el personaje que ya no escribe, a pesar de que en su juventud se haya metido de lleno en la atmósfera de la literatura, ni tampoco puede comprometerse políticamente, a pesar de haber sido él quien afilió a Marcos Rosemberg al partido.

Por su parte, Marcos Rosemberg, que se piensa a sí mismo como un "intelectual” y así también comprende a su amigo Rey, esgrime un repliegue regional y lúcido del compromiso, porque según él la historia, contrariamente a lo que se cree, no solo tiene inclinaciones hacia las ciudades elegantes y cosmopolitas sino también a los pequeños enclaves del mundo, una región, una pequeña ciudad de provincias:

Vos conocés la costa, no necesito contarte que por ahí hay miles de personas, miles y miles, que viven en condiciones generales no ya infrahumanas, sino extrahumanas. En la ciudad misma: cinturones de villas miserias, injusticia, humillación, prepotencia y desprecio [...] el mundo de cada hombre es su cuerpo, su cara, su tierra, su ciudad, su 'ambiente' como se dice ahora, y no podemos alejarnos mucho de todo eso porque entonces nos perderíamos para siempre (Saer La vuelta completa 34-35).

\footnotetext{
${ }^{257}$ Podría mencionarse, entre otros fragmentos, el siguiente: "Hacia el centro, la calle aparecía intensamente iluminada por letreros luminosos y focos de alumbrado; parecía adornada por una cúpula festiva, de todos colores, el ancho corredor de un desfile de carnaval después que todo el mundo se ha ido a dormir" (Saer, La vuelta completa 173).

258 "Contempló con placer, y no sin nostalgia, las viejas esquinas sin ochavas acabadas en el filo atenuado de las casas de adobe y techo de tejas, las viejas casas coloniales mechando de vez en cuando las largas veredas. El barrio viejo de la ciudad, y también la zona del puente, por la libre amplitud del espacio sobre el río, eran los lugares preferidos por Pancho [...]. De vez en cuando, al atardecer, se detenía frente a una puerta abierta y observaba del interior de la casa: un patio con aljibe y galería, y una cargada glicina o una parra llenando el patio de sombra" (Saer, La vuelta completa 110 ).
} 
La vuelta completa es probablemente la novela que más explícitamente "presenta" la ciudad. Repasemos: Cuando a Rey le piden que indique su procedencia para identificarse en el hotel, dice simplemente "ciudad", y más allá de la chanza y el leve contrapunto que mantiene con el empleado de la recepción, parece afirmar algo: el personaje saeriano es eminentemente urbano pero el sustantivo común "ciudad" suspende la adscripción inmediata al referente real y abstrae sus principales elementos. Pero además, la novela, dividida en dos partes, encuentra su tectónica en el callejeo urbano que practican Rey y Pancho, con sus dosis de contemplación, deriva y cruce con otros personajes de la saga. En tercer lugar, el texto se vuelve gozosamente expositivo sobre la ciudad, no sólo por el tono beligerante de los debates sobre el compromiso político (Rey/Rosemberg, pero también Ángel Leto/César Rey) sino también porque se preocupa por contar su historia. Como se vio, el larguísimo monólogo en el que Barco le cuenta a su amigo Pancho la historia de la fundación de Santa Fe: “-¿Sabías que a nuestra pobre ciudad la anduvieron llevando de un lugar a otro durante diez años? -dijo, [...] Sí, sabías" (Saer, La vuelta completa 195) no hace sino proyectar un auditorio invisible sobre el que se descarga un extenso discurso sobre los orígenes históricos de la ciudad, pero en el que no se ahorra el componente fabuloso, de leyenda, que acompaña toda crónica de fundación, y añade además comentarios, esta vez sí, muy de época, que denuncian retrospectivamente el maltrato que sufrieron los indios en manos de los españoles. Abundan, por último, descripciones de la rutina de la ciudad y de su atmósfera provinciana, a través de las cuales Saer despliega su interés arquitectónico. ${ }^{259}$

\section{3. La grilla se incendia: desplazamiento alucinado por la costra reseca}

Una vez conocidos el mapa urbano en que se cruzan los personajes de la saga y el componente fabuloso y violento que esconde su fundación, la ciudad saeriana está definitivamente preparada para volverse, ya desde un comienzo, podrida y literaria. ${ }^{260}$ Esto ocurre en Cicatrices: "Sodoma era Disneylandia en comparación con esta ciudad

\footnotetext{
259 “[...] entró en su casa, empujando la alta y trabajada puerta de gruesa madera barnizada, abierta entre dos balcones bajos de balaustrada de bronce, abiertos en una gris fachada típica de las casas construidas alrededor del año treinta, productos de un bienestar reciente otorgado por el comercio, y de un gusto recargado" (Saer, La vuelta completa 109).

${ }^{260}$ Para revisar las múltiples referencias literarias a las que acude la novela, cfr. el artículo de Julio Premat "Juan José Saer y el relato regresivo. Una lectura de Cicatrices".
} 
podrida" (Saer 17), ${ }^{261}$ le señala Tomatis a Ángel, para convencerlo de fraguar "literariamente" la información climática en la sección Estado del Tiempo en la que ha empezado a trabajar: "Empezás por proponerme que difunda un chaparrón que nunca ocurrió y vas a terminar por inducirme a anunciar una lluvia de fuego" (17), anuncio que precisamente la novela hará, a través de la visión incendiaria del juez López Garay.

¿Qué vestigios quedan de aquella ciudad luminosa, de esa Santa Fe, faro cultural, "Atenas de Sudamérica" y promesa de vanguardia? Cicatrices condensa por un lado la anotación obsesiva de las calles, edificios públicos y parques que atraviesan los personajes, y exhibe por el otro el extravío y la disolución de la grilla santafesina. Es quizás el episodio del juez el más significativo para pensar esta oscilación. Como se recordará, el personaje atraviesa en automóvil unas calles azotadas por la lluvia y la niebla:

Tomo San Martín hacia el norte, doblo en el bulevar, llego hasta la boca del puente colgante. [...] Tengo la sensación, por un momento, de no llevar ninguna dirección y hallarme en la más completa inmovilidad. [...] Está amaneciendo, pero la niebla acuosa envuelve de tal modo, apretadamente, el automóvil, que no puedo distinguir nada, salvo la carrocería inerte del automóvil y las densas masas blanquecinas en lento movimiento que han borrado la costanera, si es que hay una costanera, y que entorpecen completamente mi visión, si es que hay algo -aparte de la niebla- en que yo pueda desplegar mi visión (Saer, Cicatrices 222).

Así concluye la loca carrera que el juez ha mantenido a lo largo de varias páginas, después de haber circulado laberínticamente por la ciudad y haber visto desplegarse, en sesiones de vigilia y sueño, una visión extrañada de la misma en la que los gorilas habitan el espacio urbano: "En la primera esquina, un gorila solitario, envuelto en un impermeable azul y con un sombrero hundido en el cráneo. [...] Gorilas se pasean detrás de los ventanales de la planta baja, detrás incluso de los altos mostradores" (Saer, Cicatrices 156-7). Sin embargo, las visiones no se circunscriben al espacio citadino y abren una grieta temporal indefinida en la que el personaje es testigo de las ceremonias de una horda de gorilas primigenia:

Veo generaciones y generaciones de gorilas, avanzando desde la oscuridad. Hordas hostiles babeando en los primeros crepúsculos con mezcla de terror y extrañamiento. [...] Las hordas se pasean inquietas por un claro del bosque [...] el gorila hembra y el gorila macho se abrazan y ruedan por el suelo, levantando nubes de polvo [...]. Están otra vez en el mismo claro, con el horizonte de árboles

\footnotetext{
${ }^{261}$ Idea que ya se adelanta al comienzo del texto: "Hay esa porquería de luz de junio, mala, entrando por la vidriera" (Saer, Cicatrices 9), y más adelante: "Bloque, qué va a ser un bloque, esa luz de porquería: no sé de qué sol podrido puede estar llegando" (Saer, Cicatrices 10).
} 
y rocas por los cuatro costados, en los que la mirada rebota. [...] El que cruza la línea [...] desaparece, y no vuelve nunca más. [...] Quedan entonces agazapados, armados con sus picas, sus piedras y sus flechas, en espera de que algo vivo cruce la línea de peligro para arrojarse sobre él y destrozarlo. Cuando el animal emite sus últimas palpitaciones cálidas y queda tieso, muerto, ellos lo llevan hasta la cueva y allí lo reparten (Saer, Cicatrices 175-8).

La extensa descripción de la ceremonia parece anunciar algunas escenas de $\mathrm{El}$ entenado. Como explica Gamerro, Echeverría fija algunos de los rasgos predominantes de la orgía indígena: en primer lugar es "el cambalache de las conductas [donde] todo se da mezclado y revuelto" ("La orgía indígena de Echeverría a Saer" 110) y es el resultado de una fantasía blanca en la que la imagen del indio resulta ser "un negativo de la imagen que el criollo quería tener de sí mismo, un monstruo armado con los pedazos amputados de la vida corporal, emocional y psíquica de aquellos señores victorianos" (112). Según Gamerro, la orgía indígena se extrema en El entenado y llega a ser "festín caníbal", sin embargo, Saer se esfuerza por revelar el alto grado de civilización de los indios, contradiciendo así el paradigma decimonónico clásico. La ceremonia que se cumple una vez por año, con su secuencia de cacería, preparación del festín, banquete, euforia alcohólica y desenfreno sexual les produce a los colastiné una sensación de desazón y tristeza, similar a la "melancolía extrañada [en que los gorilas] pasan las horas de ocio, hasta que otra vez el sol comience a declinar" (Saer, Cicatrices 178).

Saer, continúa marcando Gamerro, devuelve la discusión a sus orígenes, allí donde puede leerse el radical enfrentamiento del hombre con la naturaleza y con la extensión ilimitada, e inventa nuevas oposiciones que trascienden la dicotomía sarmientina: "lo real y lo irreal, lo nominado y lo innominado, lo uniforme y lo múltiple, lo rugoso y lo liso, lo borroso y lo nítido, lo humano y lo no humano" (123). Es decir, así como en El entenado se retrotrae la empresa colonial a su dimensión metafísica, Cicatrices abre la significación político-peronista de la palabra "gorilas" para volver a decir el origen mítico, absurdo y violento que caracteriza a nuestra especie, ${ }^{262}$ y para señalar allí, en ese momento fuera del tiempo, el trazado de los límites de un territorio, más allá de cuyo horizonte los seres desaparecen, se esfuman y mueren. Esos mismos gorilas y sus descendientes son los que interrumpen, de tanto en tanto, el

${ }^{262}$ El juez le dice a Ángel: "Los hombres son un rebaño de gorilas salido de la nada. Y eso es todo" (Saer, Cicatrices 190). 
recorrido vertiginoso del juez, que lejos de avanzar por la retícula urbana, se siente “inmóvil" y "sin dirección".

En La ciudad a lo lejos, Nancy intenta capturar las últimas imágenes de la ciudad entendida como monograma de la civilización y entrever qué nuevas configuraciones espaciales se forman en el mundo que habitamos: "ciudad incivil", "urbanidad suburbanizada" o "sobreurbanizada". Resulta imposible, enfatiza el autor, "mirar la ciudad a lo lejos", recortar sus aristas precisas, y ahora solo queda escuchar el rumor incierto de la ciudad incivil. Interesa el gesto visual y sonoro con que Nancy abre la serie de ensayos que forman su libro y el punto de fuga en el que se coloca para reflexionar sobre una imagen que se aleja. Podría imaginarse a Saer en una actitud similar, captando lo que se escapa, lo que se reprime, lo que se disuelve, borra e incendia de una ciudad que es, todavía para los incipientes años sesenta, una urbe plena de sentido y eje del modelo desarrollista provincial. Señala Nancy: "La ciudad se inciviliza y revela la incivilidad de la civilización: a saber, no exactamente su barbarie ni su salvajismo [...] sino simplemente el hecho de que la civilización -la 'nuestra', a la que llamamos desordenadamente 'técnica', 'capitalista', 'humanista', 'informática', 'globalizante'- no solamente no hace 'cultura' [...] sino que se propaga y prolifera en todos los sentidos a la vez [...]" (La ciudad a lo lejos 14).

La ciudad de Cicatrices comparte, en este sentido, algunos rasgos de la ciudad incivil, porque la grilla urbana en la que se levantan nuevos edificios, se abren pasajes y galerías y se tienden puentes hacia el resto de la región termina borroneándose bajo el andar laberíntico de sus habitantes. Como señalaba Gamerro para las escenas de malones y orgías indígenas, la imagen de la barbarie es una fantasía blanca y victoriana; en este caso, del juez rico y culto de la saga, que traduce inútilmente El retrato de Dorian Grey mientras es asaltado por visiones en las que no se conjura el salvajismo del otro sino más bien el terror hacia el abismo vertiginoso del espacio:

Después, casi inaudible, comienza la crepitación. Pero es más que la de un campo de trigo quemándose, por muy amplio que sea. [...] Un incendio más grande. Ahora veo colinas, ciudades, llanuras, selvas, quemándose, ardiendo lentamente, con llamas de una altura pareja que se extienden como una capa amarilla sobre la superficie del planeta, consumiéndolo. [...] La horda de gorilas, surgida trabajosamente de la nada, aferrándose con dientes y garras a la costra reseca, ha entrado nuevamente en la nada, sin un solo lamento. Ha sido como un mal espejismo, una pesadilla turbadora debatiéndose contra las piedras inmóviles en medio de un espacio nítido y enloquecedor. Veo la bola de fuego girar y después el fuego disminuir hasta apagarse por completo y la primera brisa pura formar 
unos exangües remolinos con las cenizas ya frías de la antigua horda por fin apaciguada (Saer, Cicatrices 221).

El fuego, que ha venido anunciándose en escenas anteriores, termina de expandirse en la coda final del capítulo y podría remitirnos una vez más al tópico del incendio en la Pampa, presente en la literatura y la pintura argentinas y que, como vimos, Saer retoma en "Campos quemados" y en Las Nubes. ${ }^{263}$ En Facundo Sarmiento explica que Echeverría ha vuelto su mirada poética al desierto porque "allá en la inmensidad sin límites, en las soledades en que vaga el salvaje, en la lejana zona de fuego que el viajero ve acercarse cuando los campos se incendian, halló las inspiraciones que proporciona a la imaginación, el espectáculo de una naturaleza solemne" (47-48). Sarmiento captura al hombre en ese estado intermedio entre el sueño y la vigilia cuando se enfrenta a la naturaleza, ${ }^{264}$ y como explica Jens Anderman, reconoce la funcionalidad "poética" de la violenta interacción de las diferencias que imposibilitarían la integración nacional.

Lo que hace Sarmiento, dice Anderman, es postular la productividad poética de la barbarie, es decir, la funcionalidad de lo disfuncional para la construcción de una nación: "Descubre la utilidad política de lo poético y consigue [...] someter el statum romántico al servicio del telos progresista que es la lucha contra la barbarie en las filas del partido de la civilización" (Anderman 43). Saer extrae de la lección sarmientina la predilección por la diferencia, productiva política y poéticamente, pero somete y ridiculiza el "telos progresista" del desarrollismo provinciano y del incipiente vanguardismo sesentista a una visión absurda, el sueño de un blanco, pretendidamente

${ }^{263}$ Sarmiento reflexiona en Facundo sobre el carácter estético y sublime de los incendios de la llanura, producidos por causas naturales y artificiales y señala además que los accidentes de la naturaleza producen costumbres y usos singulares en los pueblos, entre ellos, la costumbre de quemar una parte del terreno para poder retirarse del fuego que invade y quema los pastizales. Como hace notar Adriana Amante, Luis Felipe Noé retoma un fragmento de este texto en su cuadro "Tormenta en la Pampa. Homenaje a una pintura escrita por Sarmiento" (1991), en el que se exhibe la fuerza descomunal de las tormentas. Podría mencionarse también, como el heredero díscolo de este tópico, la novela de César Aira Un episodio en la vida del pintor viajero, en la que una fabulosa sesión de rayos eléctricos se descarga sobre el paisaje mendocino y sobre el pintor Johann Moritz Rugendas, transformando para siempre su suerte. Por su parte, la tradición pictórica también ha ensayado esta imagen, y así puede mencionarse por ejemplo la temprana acuarela de Thomas Gibson, un hacendado escocés instalado en la zona del Tuyú, que pintó The pampas. Strange appearance assumed often by smoke from burning some part at sunset de 1838.

264 “¿Dónde termina aquel mundo que quiere en vano penetrar? ¡No lo sabe! ¿Qué hay más allá de lo que ve? [...] He aquí ya la poesía: el hombre que se mueve en estas escenas, se siente asaltado de temores e incertidumbres fantásticas, de sueños que le preocupan despierto" (Sarmiento, Facundo 49). 
sofisticado y culto, que lo incendia todo. No otra versión del sublime pampeano ni una reactualización del romanticismo estético sino más bien el anuncio exasperado y pesimista de la escena en que Tomatis miraba y descomponía el cuadro ya descompuesto de Van Gogh. El discurrir dubitativo del juez: "[...] las densas masas blanquecinas en lento movimiento que han borrado la costanera, si es que hay una costanera" (Saer, Cicatrices 222) resuenan en la glosa de Tomatis: "Y en la pared, sobre el escritorio [...] el Campo, ¿pero es verdaderamente un campo? ¿pero es verdaderamente trigo?” (Saer, "La mayor", La mayor 128).

La indeterminación visual a la que la niebla somete la ciudad, exasperada en la visión incendiaria del juez, se explicita en la voluntad de "borrar" todo experimentada por el ex sindicalista Luis Fiore, que después de haber asesinado a su esposa y de haber tratado de matar, sin lograrlo, a su hija, reflexiona: "Entonces comprendo que he borrado apenas una parte, no todo, y que me falta todavía borrar algo, para que se borre por fin todo" (Saer, Cicatrices 251).

\section{4. La ciudad suspendida: condensación y apertura vegetal americana}

La ciudad de Saer se abre en al menos dos series de fantasías "territoriales" que se reiteran en diversos textos: por un lado, hay personajes que condensan y repliegan imaginariamente el emplazamiento físico en el que se encuentran y llevan la representación de la ciudad a su mínimo. Por otro lado, la urbe se abre a un denso tejido vegetal y animal. Para el primer caso en La vuelta completa Pancho Expósito piensa en:

la súbita paradoja de ese cuarto cerrado y oscuro en medio de una ciudad abierta e iluminada, poblada por la vida densa y apacible del crepúsculo [...]. Pero si salía a la calle, descubriría a la vez otra paradoja, exactamente el reverso de la primera: la ciudad iluminada y abierta era una leve luz frágil, rodeada por la noche del mundo, por la incesante tiniebla (Saer 158). ${ }^{265}$

\footnotetext{
${ }^{265}$ Varios puntos de contacto podrían establecerse entre la posición intimista y barrial del imaginario borgeano y algunas de las operaciones espaciales y urbanas trazadas por Saer. Ambos desarrollan fundamentalmente una "cartografía horizontal" y subjetivizan las calles, hechas de "ellos mismos", para el caso de Saer, o por "la entraña de mi alma" (Borges, "Las calles", Fervor de Buenos Aires 15) para el caso de Borges. Sin embargo interesa anotar en esta oportunidad una insistencia visual: así como en Saer, la ciudad se recorta como un espacio iluminado en medio de las tinieblas, la versión íntima y familiar de la fundación de Buenos Aires le hace a Borges escribir: "Una manzana entera pero en mitá del campo/ expuesta a las auroras y lluvias y suestadas./ La manzana pareja que persiste en mi barrio:/ Guatemala,
} 
La imagen, potente por su minimalismo formal y por su contraste lumínico, sustrae a la ciudad de la región y de las redes circulatorias que la conectarían con otros pueblos y capitales. Sin embargo, los mismos textos que "cierran" imaginariamente la urbe, la abren a la densidad vegetal, acuática y terrestre del paisaje natural. Como ha señalado Rafael Arce, la ciudad de provincia vuelve inoperante la dicotomía ciudad/campo o civilización/barbarie y habría que pensar siempre en una contigüidad entre la ciudad, el campo y las islas.

Efectivamente, Cicatrices conecta la ciudad al espacio del campo en el último de los capítulos, cuando Luis Fiore sale a cazar acompañado de su mujer y de su hija: “de los dos lados del sendero, hay algunas casas medio cubiertas por el follaje, pero después no queda más que el sendero que se angosta internándose en el campo [...]. Del otro lado hay un gran pastizal [...] y más allá de la laguna, algo más alta, la ciudad" (Saer, Cicatrices 228). Esta incursión en el campo permite obtener otra vista urbana, y nos descubre su perfil productor y portuario, aquel al que se había arrimado, pero sin penetrar, el juez López Garay. Una visión que si bien ordena cierta mirada panorámica: "hacia la izquierda, [...] las chimeneas de la estación de trenes [....]. Del otro lado están las torres de la iglesia de Guadalupe" (Saer, Cicatrices 229), termina obstaculizada por "los pastos, que por momentos entorpecen mi visión, como una bruma" (229). ${ }^{266}$

Sin embargo, el vínculo de lo urbano con lo natural se había explicitado ya en $L a$ vuelta completa. Como se vio en capítulos anteriores, en su relato sobre el origen de la ciudad, Barco refiere que con las inundaciones periódicas, el río Paraná podía traer cualquier cosa, y que a diferencia de Europa, acostumbrada a considerar como exótico todo lo que no perteneciera al continente,

Serrano, Paraguay y Gurruchaga" (Borges, "Fundación mítica de Buenos Aires", Cuaderno San Martín 83).

${ }^{266}$ Como se recordará, también en Glosa la ciudad se da a la apertura vegetal del parque en el que culmina la caminata de Leto y el Matemático. En las "Notas críticas" a la novela Premat sostiene que se trata de una apertura al pasado histórico y a un universo primitivo y natural. Lo primero que se observa es la iglesia colonial y el museo etnográfico "protegidos, restaurados, expuestos para preservar, contener, incluso representar y aún prolongar el pasado [...], [aunque] no escapan a la extrañeza sin nombre del presente" (Saer, Glosa 235). Luego Leto prosigue por el parque y se encamina hacia el lago, allí donde "la ciudad, con su entrecruzamiento prolijo y casi primitivo de calles rectas y su estruendo difuso, parece desintegrarse a sus espaldas, entrar también ella, con todas sus presencias improbables en ese lugar sin nombre al que el nombre de pasado, de tal fácil pronunciación, parece cuadrar tan bien" (236). Esa desintegración de la urbe en el espacio "natural" del parque y en el pasado se condensa en la imagen final de la novela: la especie desconocida de pájaros, extraviada probablemente de su flujo migratorio, que revolotea alrededor de una pelota amarilla cuyas irradiaciones misteriosas concentran y a la vez disuelven el universo. 
nosotros los americanos sabemos que, agolpada en el suburbio de nuestras ciudades está la selva, devoradora de ciudades, o la llanura siempre idéntica a sí misma en la que un hombre puede volverse loco de soledad y tristeza, y si vemos aparecer un día un tigre sobre un camalotal, lo primero que haremos es tratar de cazarlo antes que especular sobre la significación de su presencia en una región donde se supone que nunca ha habido tigres (Saer, La vuelta completa 205).

La novela, escrita entre 1961 y 1963, parece evocar algunos de los debates sobre lo real-maravilloso y la presencia desbordante de la naturaleza, ${ }^{267}$ pero la narrativa de Saer elige: deja de lado la preferencia humboldtiana por la selva y las grandes elevaciones, ${ }^{268}$ y desarrolla en cambio una versión lacónica y refractaria a las modas del boom, ${ }^{269}$ participando más bien del vértigo sarmientino, aquel de "la llanura siempre idéntica a sí misma en la que un hombre puede volverse loco de soledad y tristeza" (Saer, La vuelta completa 205), como vimos que le ocurre a varios de los viajeros que

${ }^{267}$ Las principales consideraciones sobre este tópico las inaugura, como se sabe, Alejo Carpentier en el "Prólogo" a El reino de este mundo (1949). Sus consideraciones sobre el carácter real-maravilloso de la naturaleza $-\mathrm{y}$ de la historia- americana, en oposición a la búsqueda artificiosa de lo sobrenatural en Europa señalan el rumbo de muchas de las novelas latinoamericanas incorporadas al "boom".

${ }^{268}$ Saer retoma en este párrafo dos imágenes del repertorio humboldtiano, la selva y la llanura, frecuentado y reescrito innumerables veces por escritores y viajeros en la tradición de la literatura nacional. Como analiza Mary Louise Pratt en Ojos imperiales. Literatura y transculturación, Humboldt jugó un papel fundamental en la reinvención ideológica de América del sur a comienzos del siglo XIX porque refundó la mirada sobre el paisaje americano como Naturaleza virgen, extraordinaria y sublime. A partir de Cuadros de la Naturaleza y Vistas y monumentos los lectores seleccionaron un repertorio de imágenes sobre el continente que funcionaron metonímicamente para designarlo. Fueron fundamentalmente tres: la superabundancia de los bosques tropicales (el Amazonas y el Orinoco), las montañas (la Cordillera de los Andes y los volcanes de México) y las vastas planicies interiores (los llanos de Venezuela y las pampas argentinas). Como explica Fermín Rodríguez, el ensayo "Estepas y desiertos" que Humboldt hizo de los llanos venezolanos "comienza con una doble tensión espacial: los planos se presentan en contraste con la 'exuberancia' de las selvas tropicales y la riqueza de especies vegetales de los valles de Caracas. [...] A partir de entonces, la identidad del paisaje se describe negativamente por lo que le falta" (Rodríguez 47). Sin embargo, el gesto de Humboldt tiene un estatuto "poético", enfatiza Rodríguez, porque transforma el desierto en un paisaje: "extrajo de la materia indiferenciada de lo visible algo que no contaba para la imaginación científica y geográfica de la época [...] el cuadro del desierto fue el tener lugar del lugar" (Rodríguez 47).

${ }^{269}$ Como sostiene Rafael Arce en La felicidad de la novela, La vuelta completa fue la novela menos leída de la trayectoria saeriana: "La falta de espectacularidades procedimentales de esta novela, publicada en la época de Rayuela y de furor de la estética del boom [...] no sólo la hizo ilegible para la crítica de entonces, sino que la convirtió en una de las novelas menos legibles para toda la crítica saeriana" (156). Saer le opone, según Arce, a las facilidades de la vanguardia, una escritura lacónica que sin embargo inaugura procedimientos formales que luego terminarán de desarrollarse en el trayecto que va de Cicatrices a "Sombra sobre vidrio esmerilado". 
transitan sus ficciones. A su vez, La vuelta completa, sin desconocer los debates estéticos y políticos del momento, se distancia de la moral del "escritor sesentista".

Olguín y Zeiger, en "La narrativa como programa, compromiso y eficacia" resumen las conocidas fórmulas de este programa, entre las que se pueden nombrar la impronta del compromiso sartreano, la responsabilidad del escritor como afirmación ética; la posición vanguardista, de avanzada intelectual y la búsqueda de lo experimental; la incorporación de las voces de la otredad -el marginal y el loco- y el deber de la ficción de 'poner al hombre en situación'. En el mundo de La vuelta completa la alternativa a la responsabilidad ética del intelectual y del militante -bandera que proclaman, no sin reservas- Marcos Rosemberg y Ángel Leto- es la desesperación, la locura o el suicidio; la alternativa a la novela "abierta", lúdica y experimental, vistosamente vanguardista, es una escritura "clásica" que como sostiene Arce, narra en tercera persona y en pretérito el encuentro más o menos azaroso de unos personajes en la ciudad; y por último, la alternativa a la urgencia y a la dimensión de futuro es la certidumbre de que las mejores épocas quedaron en el pasado.

\section{5. Fiebre y geometría: dripping sobre la retícula hipodámica}

En la misma ciudad de La vuelta completa y Cicatrices se encuentran y caminan durante 21 cuadras, una mañana de octubre de 1961, Ángel Leto y el Matemático. Glosa es una novela cuya estructura formal es tributaria de la grilla urbana y se divide en "Las primeras siete cuadras", "Las siete cuadras siguientes" y "Las últimas siete cuadras". La novela llega para enfatizar un movimiento que insinuaban las novelas anteriores, la tensión entre la ciudad ideal, geométrica, calculada, "ajedrezada" y la ciudad "real", que en Saer nunca se verifica completamente como tal.

En las "Notas críticas" a Glosa, Premat advierte que Saer trabajó con el mapa de la ciudad en la fase prerredaccional. La importancia del trazado urbano en la organización de las peripecias, las anécdotas y los juegos temporales (analepsis y prolepsis) puede observarse en el material genético de la novela, en el que aparecen varios esquemas de estructuración escandidos por las calles transversales a San Martín que atraviesan los personajes (Catamarca, Rioja, Tucumán, Primera Junta, Mendoza, Salta, Rosario...). El mapa como principio organizativo también se inscribe como 
huella en los sucesivos íncipit que probó Saer y que luego atenuará en la novela cuando, como veremos, revele la insuficiencia del trazado urbano.

Leto y el Matemático caminan siempre en línea recta por calle San Martín. No se trata del callejeo errabundo de Pancho, Barco y César Rey, ni tampoco de las vueltas alucinadas y laberínticas del juez de Cicatrices. Las diversas maneras de transitar la urbe generan formas diferenciadas de pensar e imaginar la ciudad, en este caso, la recta del recorrido habilita la comprensión geométrica de la grilla y del comportamiento automovilístico y le permite a la ficción recurrir al modelo urbano ideado por Hipodamos, ${ }^{270}$ referencia que se repetirá a lo largo del texto:

Pero ya han llegado a la esquina, ese ángulo recto que, en los cálculos sumarios de Hipodamos, interrumpiendo abrupto la vereda, introduciendo un hiato evidente para conductores y peatones, facilitando la orientación, la circulación y la visibilidad, geometrizando de un modo ilusorio el espacio que, a decir verdad, no tiene forma ni nombre, pondría un orden convencional en las mañanas del Pireo (Saer, Glosa 99).

Sin embargo, la ciudad real es más ruidosa y desordenada que la imaginada por el urbanista griego: "alguna bocina [...] la excitación nerviosa de los conductores [y el] rumor general de la ciudad [...] agrega algunas variables imprevistas al esquema ideal de intersecciones periódicas concebido por Hipodamos" (Saer, Glosa 116). Tampoco el semáforo, invención histórica del maquinismo que se agrega al proyecto abstracto de Hipodamos, logra ordenar el caos, porque su periodicidad mecánica resulta "inadecuada a la no periodicidad de los fenómenos" (Saer, Glosa 172). De este modo, la caminata al parecer recta y tranquila que comparten dos buenos conocidos una mañana contradice el esquema ideal de ciudad y muestra su reverso: el paisaje onírico de la pesadilla del Matemático es precisamente una "ciudad imprecisa y desierta" (Saer, Glosa 141). ${ }^{271}$

\footnotetext{
${ }^{270}$ Hipodamos de Mileto fue un arquitecto griego conocido como el "padre del planeamiento urbanístico" e inventor de la retícula. Fue el primer arquitecto que concibió el planeamiento urbano y la estructura de una ciudad a partir de un punto de vista que privilegiaba la funcionalidad. La organización en damero, con calles anchas que se cruzaban en ángulos rectos, dialogaba con la filosofía de la época que buscaba alcanzar una sociedad ideal, por eso en sus diseños primaban los valores de la lógica, la claridad y la simplicidad. Además imaginaba una ciudad cuyo territorio estuviera dividido en tres zonas, la sagrada, la pública y la privada, y en tres clases: la de los artesanos, la de los labradores y la de los guerreros. Saer lee en la ciudad moderna las pervivencias de esta vieja idea hipodámica y la cuestiona: "Al mismo tiempo, ese aglutinamiento por profesiones, por clase, del que no desconoce las razones así llamadas económicas y sociales, le hace concebir la ciudad no como si estuviese dividida en barrios o en zonas, sino en territorios en su acepción de espacio animal, de demarcación abstracta y violenta, de fortificación ritual y sanguinaria" (Saer, Glosa 199).

${ }^{271}$ La crítica que se ha ocupado de analizar el aspecto espacial de la obra advierte por supuesto la confrontación entre el trazado lineal de la calle San Martín, la continua mención de los puntos
} 
Esto es así porque, una vez más, Saer subjetiviza la trama urbana: "la calle recta que van dejando atrás, está hecha de ellos mismos, de sus vidas" (Saer, Glosa 160). ¿Qué imagen o representación visual es capaz de captar entonces, no ya el mapa extensivo de la urbe, sino la cartografía intensiva que traza la singular caminata de los personajes? No un mapa ni un plano: un cuadro.

Será el dripping de Rita Fonseca el que suspenda a Leto de la caminata y del rumor de la ciudad cuando mire "una acumulación de gotas, manchas, regueros, salpicaduras de pintura fluida de varios colores que se superponen, contrastan, se anulan, se mezclan, se combinan" (Saer, Glosa 182) en donde: ${ }^{272}$

ningún color predomina, a no ser por las titilaciones, no periódicas porque su distribución en el conjunto no obedece a ninguna periodicidad, con que sobresalen de tanto en tanto, y siempre en relación estrecha, como se dice, con los demás. [...] Por otra parte, las manchas y los regueros tortuosos continúan hasta los bordes, los cuatro costados clavados al bastidor, de modo tal que se comprueba que lo que ha quedado detrás del bastidor es la continuación de la superficie visible [...] (Saer, Glosa 182-183).

El cuadro de Fonseca es el espacio en el que se hace visible la imprevisibilidad fenoménica que intenta conjurar la retícula de Hipodamos. De este modo, como ya vimos, ingresa la vanguardia pictórica en la historia de la "ciudad". Rita Fonseca y Héctor son los pintores que encarnan algo de esa experimentación formal que perseguían los artistas sesentistas. Ambos han estudiado en la Escuela de Bellas Artes pero Héctor ha pasado una temporada en Europa "visitando museos y manteniendo discusiones teóricas con la crema de la vanguardia europea" (Saer, Glosa 186) y tiene “obras premiadas en San Pablo y en Venecia y cinco o seis cuadros en museos de Europa colgados en las salas de la vanguardia internacional" (192). Héctor, pintor de

cardinales, la orientación precisa y los cincuenta y cinco minutos de caminata; y los tropiezos, las continuas interrupciones que cortan el flujo temporal a través de prolepsis y analepsis, los cruces de calle que se revelan absurdamente complicados y las bocacalles que introducen el caos, las reflexiones filosóficas sobre el movimiento y la percepción. Cfr. al respecto las "Notas críticas" de Premat y el texto de Lucero, Nicolás y Daniel Balderston "Diálogos, risas y tropiezos en Glosa", incluido en la edición crítica de la novela.

${ }^{272}$ En las "Notas críticas" de Premat anteriormente mencionadas se explica que la idea de incluir drippings figura repetidas veces en la fase prerredaccional de la novela. De hecho, las tapas de las primeras ediciones de la obra remiten a este tipo de técnica pictórica. En la edición prínceps de Glosa (Editorial Alianza, 1986) figura un fragmento de una obra de Juan Pablo Renzi, "En escena 3: Champagne" que además de incorporar el chorreado de la pintura también incluye grafías que también gotean sobre la tela. La tapa de la primera edición española (Editorial Destino, 1988) presenta uno de los dripping más conocidos de Jackson Pollock ("Número III"). 
cuadros monocromos y geométricos, el exacto reverso de la pintura atormentada de Fonseca, participa más cómodamente del movimiento internacionalista que caracterizó el arte de los sesenta. A diferencia de él, Rita Fonseca nunca ha salido de Santa Fe, viste siempre la misma ropa, "los pies enfundados en unos zapatones de hombre todos gastados, la cara sin maquillar, siempre con un Gavilán o un Colmena colgando entre los labios, las uñas desparejas" (Saer, Glosa 186). ${ }^{273}$

Ese "espesor del presente" que Abbate identifica en la densa temporalidad de la novela también puede observarse en los pliegues del espacio urbano. La ciudad de Glosa está encabalgada sobre fragmentos de otras ciudades: la ideal y geométrica de Hipodamos; la ciudad pesadillesca del Matemático; los recuerdos de infancia de Leto; y finalmente la ciudad persecutoria de la dictadura, porque como sostiene el Matemático, el tiempo no es como esta calle: tiempo y espacio son dos órdenes inconciliables. Lo que resulta significativo al tener en cuenta la fecha de escritura del texto es que coincide con una de las vueltas de Saer a la Argentina, experiencia que el escritor consignaba en unas pequeñas libretas de viaje. ${ }^{274}$ Algunas de las imágenes urbanas que anota en ellas son reutilizadas para la escritura de Glosa, es decir, la luz, el cielo y los árboles de principios de los ochenta se proyectan sobre una ciudad más antigua, y la vuelven, como imaginaba Pancho en La vuelta completa, inmutable. No todas esas anotaciones

273 Saer elige el perfil menos espectacular y menos "internacionalista" de la vanguardia. Dalmaroni explica que Fonseca es "una mezcla de Pollock, Espino y Celia Schneider" (Dalmaroni, "El empaste y el grumo" 406). Fernando Espino fue un pintor rosarino que nació en 1931 y murió en Santa Fe en 1991. En La trama bajo las apariencias. La pintura de Fernando Espino, Hugo Gola, Hugo Padeletti y Juan José Saer apuntan algunas recurrencias de sus pinturas, señalando que en medio del aislamiento provinciano, Espino supo construir una poética propia que retomó y digirió de un modo muy particular una gran variedad de herencias pictóricas, desde el americanismo y la pintura primitiva hasta las vanguardias contemporáneas, el arte geométrico sensible y el informalista. Sus composiciones, que podrían comprenderse dentro de la abstracción concretista, están realizadas por lo general en pequeño formato e incorporan manchas informales, puntos, trazos y figuras geométrico-sensibles, con un leve apoyo en la figuración en algunas obras. Su estilo se caracteriza por una gran austeridad formal y cromática, una economía expresiva que lo llevó a experimentar exhaustivamente cada material y enriqueció el tratamiento de las superficies del cuadro: materia delgada, gruesa, raspados y collage. Saer sintió una temprana admiración por el pintor y utilizó una de sus obras para la portada de Palo y hueso (1965).

Los vínculos entre Fernando Espino y Rita Fonseca así como las distintas variantes de la abstracción que retoma la poética de Saer fueron trabajados en Maranguello, Carolina. "Una geografía pintada: paisaje y abstracción en ficciones y ensayos de Juan José Saer" publicado en Anclajes, vol. XXI, n. ${ }^{\circ}$ 1, enero-abril 2017, pp. 43-58, disponible en file:///D:/Downloads/11365502-1-PB\%20(2).pdf

${ }^{274}$ Algunos fragmentos de estas libretas fueron retomados y pasados en limpio por el propio Saer como parte del material preparatorio de Glosa. Estas Notas en vivo (sep-oct. 1982) se incluyeron en la edición crítica de la novela coordinada por Premat. 
se filtran, sin embargo, en la versión definitiva de la novela sino solo aquellas que podrían haber estado siempre, pero que la visita de Saer al país reactualiza. ${ }^{275}$ No se incluye, por ejemplo, la siguiente entrada: "Multiplicación de cirujas" (Saer Glosa-El entenado 391), que podría ser una referencia contemporánea del momento de escritura, pero sí notas que hablan sobre el reflejo del sol en las veredas, sobre las variedades de árboles del parque Sur, ${ }^{276}$ o sobre la diversidad y forma de las nubes.

Como se vio, el espacio predilecto de varias ficciones saerianas es la ciudad de principios de los sesenta, un referente espacio-temporal que Saer a la vez muestra y oculta y que va construyendo sus difusos contornos a partir de algunos contrapuntos. Entre el presente 'urgente' del compromiso y la inmutabilidad; entre una retícula de calles, barrios y edificios públicos que se aproxima a la ciudad ideal de Hipodamos y la ciudad "borrada" por la niebla y el incendio en la que los personajes se inmovilizan sin dirección; entre la urbe aislada de la región y la ciudad abierta a la naturaleza, Saer va construyéndose a sí mismo un lugar alternativo con respecto a las morales estéticas e ideológicas de los sesenta. Esos modos imaginarios y empíricos que asume la ciudad de la ficción cuando se despega y distorsiona la "Atenas" vanguardista, eufórica y desarrollista permite comprender una vez más cómo participa y se distancia el escritor de algunos de los principales debates de la época: el debate sobre el compromiso sartreano, sus elecciones sobre la vanguardia y su modo lacónico de responderle a las prerrogativas lúdicas y experimentales del boom.

\footnotetext{
${ }^{275}$ Premat, Vecchio y Villanueva analizan los documentos preparatorios de la novela, entre los que se pueden encontrar varios "inicios" para Glosa y los distintos esquemas de calles que sirvieron para la planificación y la redacción de la obra. En una de las versiones, Saer traza un detallado y muy explicativo mapa de la ciudad en el que aparecen sus calles, sus zonas y las características de cada barrio. Sin embargo, advierten, esto luego no aparece en la versión definitiva de la novela y eso daría cuenta de que el detallismo referencial es uno de los aspectos que el escritor quería corregir. En las marginalias se mencionan las calles que van recorriendo los personajes: "esta mención es [...] una actualización constante del esquema en damero" (en Saer Glosa-El entenado 508), y allí podrían leerse la geografía y la historia del país: "Para un argentino, aunque no sea santafesino, la serie geográfica que figura en los márgenes es significativa (Santiago del Estero, Catamarca, Rioja, Tucumán, Rosario, Buenos Aires), ya que parece incluir al relato en un mapa del país, así como puede verse una segunda serie, que alude constantemente al pasado nacional (Junín, Suipacha, Primera Junta, Juan de Garay, Moreno): pasado y espacio, cultura e imaginario, todo el poder de los nombres como signo de gran intensidad semántica $-\mathrm{y}$ en particular de reminiscencia- figura así en la frontera entre el texto y su 'afuera'" (508).

276 "Junto con los tres enormes palos borrachos de detrás del convento, y del gran ombú que bordea el agua, hay también pinos y paraísos muy jóvenes que crecen en la barranca, hacia el río. Todos estos árboles constituyen la vegetación del parque Sur" (Saer, Glosa-El entenado 394).
} 
El sujeto saeriano es, como dijimos, eminentemente urbano y transeúnte, y sus viajes despiertan imaginarios temporales que abren el presente de los sesenta hacia múltiples tiempos: el pasado inmediato por el que se siente nostalgia; el pasado histórico, lejano y violento de la colonización y fundación de la ciudad; el momento mítico y barbárico de la horda de gorilas, pero también el "futuro" de los ochenta desde el que Saer vuelve, a la vez, al país y al territorio de sus ficciones. Entre las esquirlas de la grilla se adivinan las formas de una ciudad incivil que no puede ser capturada a lo lejos porque se borronea, se incendia y se pierde, y de la lista de calles que enumera Saer como si fuera un escritor naturalista para bosquejar Glosa no quedan ni un mapa ni un plano sino un cuadro informalista y rugoso, único instrumento que detiene el andar de los personajes y captura algo de esa imprevisibilidad azarosa, no periódica, de la vida urbana y que acaso permite mirar esa "ciudad a lo lejos", un poco más de cerca. 


\title{
III PARTE: LA VUELTA IMPOSIBLE
}

\author{
Vuelvo por fin al arroyo \\ junto al cual antes temblé... \\ Ay, vidalita de estas orillas, \\ todo en el aire me llama aquí \\ (Ortiz, "Villaguay", El junco y la corriente 133).
}

Después de haber viajado por China y Moscú como parte de una delegación cultural del Partido Comunista, Juan L. Ortiz escribe "Villaguay (vidalita de la vuelta)", último poema de El junco y la corriente que funciona, según advierte Francisco Bitar, como un epílogo que condensa las partes anteriores, ¿a qué arroyo vuelve el poeta? El final obliga al lector a regresar al principio. Juan L. Ortiz vivía en ese momento en Paraná pero en su poema regresa a Villaguay, allí donde transcurrió parte de su infancia y donde cursó los años de su escuela primaria.

Como se había anticipado en la primera parte de este trabajo, algunas de las poesías de la sección "Noticias secretas" permitían seguir un itinerario fragmentado en el que el sujeto poético de las poesías de Saer recorría algunas localidades francesas, reflexionaba sobre famosos viajeros e incorporaba una amarga reflexión sobre la imposibilidad de volver, hacia 1982, no sólo a la Argentina sino a la comunidad afectivo-intelectual que se había dispersado en exilio y había quedado desgarrada después de la experiencia dictatorial sufrida en el país. Allí donde Juan L. Ortiz regresaba porque sentía en el aire un llamado, apelando a la forma popular de la vidalita, Saer atestiguaba el achicamiento progresivo del mundo y la imposibilidad de distinguir un lugar al cual dirigirse.

Sin embargo, ya en "Villaguay" Ortiz introducía una distinción importante: "El país quedó muy lejos/ pero no las manos fieles.../ Ay, vidalita de los cariños/ todo en el aire me llama aquí" (Ortiz 134). Saer volverá, aun cuando sea imposible, para interrogar ese hiato entre el país (las formas cristalizadas de lo nacional) y las manos fieles de los amigos, "las manos [que] prenden el fuego/ de las memorias queridas" (Ortiz 135).

¿Cuál es la ética que subyace bajo las formas atemperadas del regreso en Saer?, ¿qué nuevas referencias viajeras y literarias abre la vuelta?, ¿en qué se transforma el escritor cuando retorna?, ¿qué interrupciones se suceden entre él, el paisaje y la lengua?, 
¿qué formas escriturales inaugura el regreso? Diversos textos de Saer, ficcionales, ensayísticos y autobiográficos retoman el tópico del "regreso", característico de la literatura de viajes. Entre la vuelta fugaz de Pichón y el regreso definitivo de Gutiérrez, podrían mencionarse la expectativa frustrada del Doctor Real de visitar Bajada Grande; el regreso-fundacional de Wenceslao en El limonero real y los varios retornos que el propio Saer inscribe en sus libretas de viaje, en El río sin orillas y, por supuesto, en La grande, entre otras varias ocurrencias. ${ }^{277}$ Así como Saer revisa y reescribe las múltiples versiones del origen (sus variantes míticas, religiosas, psicoanalíticas, históricas y lingüísticas), también reformulará las variaciones del tópico del nostoi, una preocupación, como veremos, que no se instala sincrónicamente con su propia experiencia pero que, progresivamente, va anudándose a ella, ganando, diríamos, un espesor "biográfico" sin perder sus derivaciones literarias y su productividad escritural.

Uno de los tópicos más comúnmente asociados a la "vuelta" es la nostalgia. Interesa en este caso retomar las reflexiones que ensaya Barbara Cassin en La nostalgia porque a través de los casos de Ulises, Eneas y Arendt, la escritora desnaturaliza la idea de "nostalgia" asociada a la añoranza del hogar para develar que se trata, una vez más, de una ficción, un hecho de cultura. En primer lugar Cassin desmonta la legitimidad filológica y "clásica" sobre la que suele asentarse la palabra "nostalgia" para señalar que no se trata de un término griego sino suizo, acuñado por un médico en 1578 para denominar una extraña enfermedad de "añoranza por el país natal” padecida por los soldados mercenarios suizos. La palabra, advierte, está "mestizada históricamente" y no tiene nada de original pero, como todos los orígenes, sirve "retrospectivamente".

La nostalgia concentra, además, sus propios horrores. Por un lado, volver al hogar es, desde Ulises en adelante, elegir "la condición mortal": renunciar a la belleza divina e imperecedera de la ninfa para asumir el envejecimiento propio y el de los seres queridos. Pero además regresar al oikos concita un riesgo, la posibilidad de no reconocer lo propio y de no ser reconocido, allí donde la patria es unheimlich, continúa Cassin, la casa natal no da evidencias de sí misma, una experiencia, como se sabe, sobre la que Saer reflexiona en El río sin orillas y experimenta en muchísimas de sus ficciones de regreso.

\footnotetext{
${ }^{277}$ Como señala Pratt en Ojos imperiales, la literatura latinoamericana del s. XX está marcada por manifiestos de retorno, desde "Cuaderno de un retorno al país natal" de Aimé Césaire, hasta Rayuela, el Canto General de Pablo Neruda, Pedro Páramo de Juan Rulfo o Vuelta, de Octavio Paz (418).
} 
La Odisea es la historia del nostoi por antonomasia. Sin embargo Cassin advierte que allí donde se escribe la versión "original" del regreso vinculada a la recuperación de la patria y de la identidad, arraigada como estaba arraigado el lecho nupcial tallado por el mismo Odiseo, se aloja otra versión de la nostalgia que abre la historia hacia la indeterminación. Después de regresar al hogar, vengarse de los pretendientes y pasar una larga noche con Penélope, Ulises deberá volver a partir para reconciliarse finalmente con Poseidón. Así se lo ha anunciado Tiresias en el inframundo: el héroe deberá viajar al extremo de lo extranjero, mucho más allá del Mediterráneo, y allí deberá cargar sobre sus hombros el remo; y cuando se cruce con otro caminante y éste le pregunte “¿qué es esa pala para granos que llevas sobre tu hombro brillante?” habrá llegado a su destino, un lugar tan remoto en el que no conozcan el mar, ni las islas ni las embarcaciones. Poseidón habrá extendido los límites de su poder y el héroe podrá regresar a su hogar. ${ }^{278}$

Es decir que Ulises de regreso en Ítaca todavía no volvió, y ese "todavía no" es el tiempo de la nostalgia. Cassin trabajará sobre las fibras paradojales de la añoranza, advirtiendo su doble condición, la del arraigo y la de la andanza porque, ¿habrá un lugar tan alejado en el que no se conozcan los rudimentos de la navegación y no se tengan noticias del mar?, ¿hasta qué límite podría extenderse esta aventura y cómo rearticula la idea de "casa" para Odiseo? Habría que pensar entonces en este doble carácter de Ulises, aquel que siente dolor por no regresar a su patria, y aquel que siente añoranza de las andanzas y cuyo oikos se ha ampliado hasta los confines del Mediterráneo.

En 1969 Saer escribirá "El paraíso recuperado”, una pequeña composición en prosa en la que reconstruye la experiencia parisina en términos de "pesadilla": "Salía a caminar por calles pulidas por el uso, y llegaba hasta el Sena verde. Pensaba, fumando, apoyado en la baranda de un puente antiguo, que había en el mundo una casa que era la mía, con palmeras y un sol obsceno, carnal, resbalando sobre las hojas de los paraísos.

\footnotetext{
${ }^{278}$ Las peripecias posteriores al regreso de Ulises a Ítaca fueron recogidas por Pierre Grimal en el Diccionario de la mitología griega y romana (que Saer consultaba según consta en las notas preparatorias para La grande). Efectivamente, después de la matanza de los pretendientes Ulises partió a pie a través del Epiro hasta el país de los tesprotos y allí ofreció el sacrificio ordenado por Tiresias. Vivió allí un tiempo junto a la reina Calídice, y volvió una vez más a Ítaca. Hay además otras historias sobre las aventuras de Ulises en Italia. Se contaba en especial que el héroe y Eneas se habían encontrado durante sus viajes y se habían reconciliado. Ulises se habría establecido en Tirrenia (el país etrusco) y habría fundado treinta ciudades. Tomó allí el nombre de "Nano" que, en lengua etrusca significa "Errante". Tácito cuenta que Ulises había llegado en sus viajes hasta las orillas del Rin: "como el nombre de Heracles, el de Ulises se había puesto en relación con las diversas fases del descubrimiento del occidente lejano, no sólo por el episodio de los Cimerios sino por los viajes misteriosos realizados en los últimos años de su vida" (534).
} 
[...] Caminaba plagado de nostalgia y deseo hasta que anochecía" (Saer, Papeles II 28). Sin embargo, el desenlace del escrito contradice lo que anuncia su título y Saer comienza, muy tempranamente, a desarticular el tópico de la nostalgia por la casa natal, porque aun cuando ha regresado a ella y ha recuperado la luz del verano y el rumor conocido de los insectos, volverá a preguntarse: “Ahora que he vuelto, la pesadilla de París, ciudad que pertenece a otros, se ha borrado. [...] ¿qué otro lugar habrá en el mundo, para que yo quiera -nudo de deseo y nostalgia- estar en él y no aquí? (1969)" (Saer, Papeles II 28).

Nostalgia del desarraigo y de la andanza. Saer cargará sobre sus hombros el remo brillante de su escritura hasta el extremo del lenguaje conocido en el que ya no se reconozcan las lenguas de la prosa y de la poesía; y ampliará, en su andanza, los márgenes de la patria. La metáfora marina del Mediterráneo se troca aquí por la de la cuenca fluvial del Paraná; las islas griegas por las pequeñas islas aluvionales y más humildes que se hacen y deshacen en el río. En el centro de la escritura regionalista, en las variaciones de lo local y de lo nacional pero también en las pretensiones cosmopolitas de la literatura "mundial", Saer ha clavado el remo de lo indistinto, un signo anómalo, una escritura desconocida, al principio inasimilable, que justamente por su persistencia y su coherencia ha transformado la forma de "serle fiel a una región".

La vigilancia de la nostalgia es doble: Ulises debe velar porque Ítaca se mantenga en su corazón y porque no se pierda la visión de sus andanzas. Interesa destacar esta idea de "vigilancia" porque, como se verá, Saer efectivamente sigue de cerca las inevitables transformaciones sociolingüísticas, urbanas, políticas y afectivas de la zona, anotándolas en sus libretas de viaje cada vez que regresa al país, y a su vez resiste el regreso definitivo, sabe que debe continuar "en viaje".

Como se verá, lejos de sostener el regreso sobre la relativa inmutabilidad del oikos, Saer advierte que no pueden recuperarse ni la casa ni el paisaje natal porque tal cosa no existe, ${ }^{279}$ y constata en cambio una particular desconexión entre el sujeto que vuelve y el espacio "familiar" por el que circula, a veces con indiferencia de forastero o de "turista forzado".

La nostalgia y el regreso permiten además apelar a una dimensión histórica y cultural que incluye pero excede lo individual. En The Future of Nostalgia, Svetlana

\footnotetext{
${ }^{279}$ Puede leerse en La pesquisa: "ser adulto significa justamente haber llegado a entender que no es en la tierra natal donde se ha nacido, sino en un lugar más grande, más neutro, ni amigo ni enemigo, desconocido, al que nadie podría llamar suyo y que no estimula el afecto sino la extrañeza" (Saer 98).
} 
Boym distingue el carácter más bien individual de la "melancolía" del carácter histórico que puede asumir la "nostalgia" cuando se la lee dialécticamente en relación a una historia de la modernidad. La nostalgia aparece como un mecanismo de defensa en tiempos de aceleración y de trastornos históricos como las revoluciones y la caída de antiguos imperios, aunque también se siente nostalgia por los sueños e ilusiones revolucionarias incumplidas. La nostalgia, que a primera vista aparece como un anhelo espacial, es, advierte Boym, un anhelo fundamentalmente temporal y traza el espacio en el tiempo y el tiempo en el espacio -idea importante para la reformulación espaciotemporal que Saer ensaya sobre la patria-. Anhelamos otro tiempo -el tiempo de la infancia, el ritmo más lento de nuestros sueños, el tiempo de las esperanzas utópicas hoy obsoletas-. La nostalgia se vuelve de este modo una clave que permite vincular la biografía individual y la biografía de grupos o naciones.

¿Qué vínculos se establecen entre los fugaces regresos de Saer al país y la biografía de la nación?, ¿entre su regreso como escritor que vive en Francia y su familia de inmigrantes sirios? Podría retomarse en este sentido uno de los intereses que despliega Molloy en "Dislocación e intemperie: el viaje de vuelta", allí donde ella piensa en la figura del "retornante" en la historia de las migraciones culturales y más particularmente en la literatura argentina. Podría trazarse entonces una historia de la literatura argentina que siga la huella de los "regresos" de los escritores. Una historia que podría comenzar con el poema "El regreso" de Esteban Echeverría, en el que el yo romántico idealiza una idea de patria vinculada con la revolución, ${ }^{280}$ incorporado en el mapa más vasto del retorno de los exiliados del '37; y podría continuar revisando las vueltas de las ficciones nativistas de las décadas del veinte y del treinta, uno de los regresos que Molloy retoma en su ensayo para contraponer dos modos del "retornante". Por un lado el modelo de los hijos de la patria que regresan para descubrir quiénes son y quiénes quieren ser luego de haberse "educado" en Europa y de regresar a una patria idéntica, como en Raucho de Güiraldes. Por el otro, el regreso iconoclasta de Borges, que en el barco que lo trae al país después de su periplo europeo hace alarde de extranjería, se autofigura como un disidente y retoma una Buenos Aires escandalosamente "anacrónica" no porque sienta nostalgia de la ciudad que dejó sino

\footnotetext{
${ }^{280}$ Cfr. el artículo de Jorge Monteleone "La hora de los tristes corazones. El sujeto imaginario en la poesía romántica argentina" incluido en el segundo volumen de la Historia crítica de Jitrik, La lucha de los lenguajes, dirigido por Julio Schvartzman.
} 
porque esa ciudad de las orillas no le recuerda nada, y sobre esa nada podrá inventar una urbe a su medida.

Esta historia imaginaria del regreso podría escribirse sobre los tiempos heterogéneos de los distintos viajes, desplazamientos y diásporas que dispersaron a los escritores en distintas circunstancias históricas y durante estadías muy disímiles: los viajes de la vanguardia de los años veinte y la de los sesenta, los diferentes retornos de los exiliados de los setenta, los regresos de escritores que, como Ortiz, se ausentaron muy poco tiempo pero que igualmente se autofiguran como retornantes, y por fin, debería escribirse atendiendo a quienes, como Saer, no regresaron, pero cuyas obras nunca dejaron de escribirse en relación a un territorio y a una lengua "natal".

Junto a las palabras "percepción”, “memoria”, “zona”, "paisaje” y “extranjería”, la palabra "regreso" ya forma parte del vocabulario-Saer y ha sido indagada por algunos trabajos críticos. ${ }^{281}$ En Relatos de regreso. Ensayos sobre la obra de Juan José Saer, Luigi Patruno revisa la vuelta como principio constructivo en la obra saeriana y retoma diversos tipos de regreso (el de los personajes de la zona; el de la vuelta a la narración y el del propio Saer a la Argentina). El crítico considera El entenado como fícción clave para pensar este tema y señala que a partir de allí "el relato de regreso constituye una especie de molde, porque a partir de un imposible ontológico (el retorno a los orígenes) y de una insostenibilidad estética (la desconfianza en la representación) se abre el espacio para una novedad: el proceso reflexivo y el inicio de una narración inteligible" (16). Las "escenas de regreso" se ofrecen, señala, no como una ocasión para restablecer una autoridad sobre lo propio sino como desencuentro o disolución de la identidad pensada en términos homogéneos. Los sucesivos desencuentros de la vuelta que se dan en sus ficciones y en El río sin orillas van multiplicando una suerte de escena inconclusa. Según Patruno, entonces, los regresos -usualmente diferidos y fracasados-, no generan relatos de "recuperación" sino de "reflexión" a partir de los cuales Saer

\footnotetext{
${ }^{281}$ En La vuelta incompleta Nicolás Lucero reflexiona sobre la polisemia de la palabra "vuelta", como regreso, giro, vagabundeo: "implica remontarse a lo elemental y arcaico, y también reanudar, insistir, reincidir" (23). Advierte que el viaje ritual de regreso a la zona estructura además muchas de las narraciones de Saer; que el retorno se confunde con el exilio y "que muchos de esos itinerarios, como los de Pancho Expósito, Gutiérrez, Pichón Garay y el entenado, concluyen con la vuelta del personaje al lugar desde el que había regresado, como si en el lugar del origen lo esperara la constatación de que sólo hay vueltas" (23). A Lucero le interesa subrayar que estas vueltas permiten interrogar el problema del "personaje" que Saer exploró en la novela, una reflexión que también apuntalaremos al seguir los derroteros de algunos personajes en relación a ciertos aspectos específicos de la narración.
} 
diseña una imagen de intelectual cosmopolita que opera sobre el territorio como si fuera un extranjero, un "viajero", y no un sujeto que retorna a su hogar.

Rafael Arce, en La felicidad de la novela, revisa la doble coordenada del viaje que estructura las narraciones de Saer -el arribo y el exilio- y sostiene que, paradójicamente, esta última es "la condición de posibilidad de la experiencia del propio lugar" (114), para subrayar que el sujeto saeriano se define a partir de su "no pertenencia”, un presentimiento y una convicción que se leen por ejemplo en la ausencia de afectación de Pichón Garay cuando pasa en lancha por la casa de Rincón en la que desaparecieron a su hermano y a Elisa, o en el extrañamiento de lo familiar que sufren Barco y su hermano en "La tardecita".

Sin embargo, más allá de estos valiosos antecedentes críticos es aún preciso interrogar el regreso como una coordenada que estructura transversalmente la producción tardía de Saer y que le permite imaginar nuevas formas de autofiguración que no necesariamente se comprenden bajo la figura del "intelectual cosmopolita". A diferencia de lo sostenido por Patruno, interesa subrayar aquí las formas anómalas del retorno en Saer, no asentado bajo la figura estabilizadora y omnicomprensiva del cosmopolitismo sino sobre las inciertas esquirlas de percepción que fraguaron los tempranos viajeros y exploradores del territorio nacional. Nos preguntamos además, retomando a Rafael Arce, ¿qué otras formas del viaje hay entre los arribos y exilios?, ¿a qué breves paseos, vueltas y peregrinajes intelectuales y afectivos se entregan los personajes de Saer cada vez que regresan a la zona?

Tramar esta tercera parte de la tesis alrededor de la idea del regreso supone un un primer problema: ¿por qué hablar de "regreso" para un escritor que, efectivamente, nunca volvió a instalarse en el país y cuya literatura desarticula las ideas de nostalgia, recuperación y paisaje natal? Y sin embargo, Saer regresa. Año tras año se somete a los mismos rituales de la despedida francesa y la bienvenida argentina, como se describe en El río sin orillas y se reconstruye en Retrato de Juan José Saer, el film de Rafael Filipelli. Pero además, podría pensarse, Saer nunca deja de regresar a la zona, la inscribe en cada uno de sus textos aun cuando, en libros como Lugar, se aventure por parajes desconocidos y pise la superficie de la luna o el paisaje radiactivo y tóxico de Chernobyl. La posición de Saer es aquella que él mismo señalaba, escribir "entre dos aguas", y, podría agregarse, entre dos nostalgias, la del hogar y la de la andanza. A lo largo de esta última parte se revisarán precisamente esas escrituras encabalgadas en la distancia. 
En primer lugar se trabajarán las variantes del regreso que aparecen en $E l$ limonero real, el libro que Saer escribe entre la zona y Francia. Como se verá, el regreso al espacio isleño retoma por un lado La Odisea pero también la tradición de viajeros que configuró las primeros atributos estéticos y políticos del paisaje fluvial. Después de algunos años sin poder regresar al país, desde 1976 hasta 1982, Saer comenzará a visitar periódicamente la Argentina, no sólo para reunirse con familiares y amigos sino también para participar de entrevistas, presentaciones y festivales. El comienzo de su obra tardía coincide con una progresiva visibilización de su figura de escritor y un crecimiento del conjunto de sus lectores. En este marco las variantes ficcionales y ensayísticas del regreso comienzan a tramarse con su propia biografía. El segundo capítulo de esta parte estará dedicado a explorar los regresos de Pichón Garay en La pesquisa, "En línea” y "Recepción en Baker Street”. Como se verá, las vueltas de este personaje pondrán a girar una serie de variantes míticas y policiales sobre el paisaje de la región asolado por la dictadura, el exilio y la muerte de algunos personajes de la zona.

En tercer lugar se leerán El río sin orillas y las Libretas de viaje de Saer como dos variantes en las que se combinan el viaje con lo ensayístico, lo ficcional y "las escrituras del yo". Como se verá, frente a esa creciente estabilización de la figura pública de Saer, el escritor vuelve a multiplicar sus proyecciones en una heterogénea y anacrónica galería de viajeros y artistas. Por último, en el cuarto capítulo se analizará $L a$ grande, la novela del regreso que al tiempo que actualiza la representación urbana de la ciudad se retrotrae al momento de los inicios: vuelve Willy Gutiérrez, el personaje que se había esfumado misteriosamente en su primer libro En la zona; pero también "regresan" las referencias literarias que guiaron las primeras incursiones de Saer en la literatura: José Pedroni y Cesare Pavese; y se retoman, por último, las referencias culturales del mundo sirio de su infancia y juventud. 


\section{LA ISLA PORTÁTIL: VARIACIONES SOBRE LA ESCRITURA FLUVIAL}

El tópico del regreso aparece tempranamente en la obra de Saer y no está inmediatamente asociado a su propia experiencia de retorno. En su producción temprana lo encontramos vinculado a las variantes espaciales que había abierto En la zona. Por un lado el regreso literario de las orillas en relatos como "El camino de la costa" (de Esquina de febrero) y por el otro, el regreso urbano de "Por la vuelta" (Palo y hueso), en el que Pancho Expósito vuelve a la ciudad después de haber pasado una temporada en una clínica mental de Buenos Aires. Será sin embargo El limonero real el libro que gire alrededor de las posibilidades e imposibilidades del retorno y que asuma y desquicie algunas de las variantes literarias del tópico. La novela se escribe sobre el hiato que ha dejado en una humilde familia de la costa el regreso imposible del hijo que se fue a la ciudad y murió al caer de una obra en construcción, e inscribe, en uno de sus recomienzos, la reescritura paródica del relato de regreso por antonomasia, la Odisea, ${ }^{282}$ que cruzará, como veremos, con la biblioteca de viajeros que exploraron el río y formalizaron sus principales atributos.

El limonero real es el libro que Saer escribe literalmente "entre dos aguas" porque su escritura comienza en Santa Fe, hacia 1964, y culmina en 1974 en Francia. En esos diez años Saer escribirá además textos que tematizan el exilio - La mayor- y una gran cantidad de poemas y ensayos. Sin embargo, interesa subrayar la fidelidad a ese proyecto "portátil" que le hace continuamente "volver" al territorio isleño. Considerado por algunos como el "gran texto de definición y experimentación de Saer" (Premat, Papeles 378), el escritor irá encontrando allí las características de su obra posterior. ${ }^{283}$

\footnotetext{
${ }^{282}$ En el prólogo a El limonero real que escribe para la edición del CEAL, Mirta Stern señala: "una historia universal del relato, algunos de cuyos principales momentos son revisados en forma paródica, [...] como en el cuento de hadas o los relatos míticos que incluye la novela, y en el de algunos textos, ya sea clásicos como la Odisea, o de filiación bíblica como el Génesis parodias ambas cuya presencia además contagia los dos puntos de partida fundamentales en la representación literaria de la realidad, dentro de la cultura occidental" (VIII).

${ }^{283}$ La forma de trabajar la narración que experimenta Saer en El limonero real y que seguirá funcionando en algunas de sus ficciones posteriores fue tempranamente analizada por Noé Jitrik en "Entre el corte y la continuidad. Hacia una escritura crítica" (1978). Más allá de las filiaciones que traza con la novela objetivista interesa esa dinámica de corte y continuidad que Jitrik identifica en el funcionamiento de la novela, en el que cada acción, aunque parezca fragmentada, permite ser reintegrada a un continuo cuya fuerza radica no tanto en la historia sino en las potencias -obsesivas y reiterativas- del significante. En La vuelta incompleta, Nicolás Lucero pondera este trabajo de Jitrik porque es uno de los primeros en proponer uno de los tópicos más pregnantes de la crítica saeriana: la negatividad. Efectivamente, Jitrik interroga
} 
La novela funda, como se sabe, uno de los espacios privilegiados de la territorialidad saeriana: las islas inestables del Paraná y escribe las diferentes versiones de su origen, repasa sus inundaciones y sequías, y las inscribe en la historia política contemporánea al momento de escritura. Nadie nada nunca y La pesquisa continuarán indagando los avatares políticos y afectivos de este paisaje, allí donde desaparezcan el Gato y Elisa y por donde pasará Pichón Garay, cuando regrese después de veinte años para vender los bienes familiares que le quedan.

Como ha señalado la crítica, la novela presenta un mundo en el que es inminente la ruptura del orden cíclico e inmóvil que hasta entonces había caracterizado a la comunidad de isleños (fijación que puede observarse en la repetición de los nombres entre padres e hijos) y en cada una de las vueltas del relato observamos los signos de esta disolución: en la ciudad muere el hijo de Wenceslao y se prostituyen las hijas de Rogelio; las familias se empobrecen y el escenario natural replica los signos de decadencia del mundo social. La isla define su estatuto territorial, afectivo e imaginario a partir de las derivas, desplazamientos y regresos que se producen desde y hacia sus orillas. Sin embargo, como ocurre con otros espacios -el mar, el desierto y la ciudadlas islas de Saer están temporalizadas según dimensiones múltiples. En ese sentido, podrían pensarse dos dimensiones temporales del regreso, por un lado aquella en la que se cuenta la dilatada historia de la familia de Wenceslao, desde el hiato que abre la muerte del hijo hasta la parcial recuperación del duelo; y por el otro, la serie de textos fundacionales - La Biblia, La Odisea y la tradición de escritura fluvial- que la novela abre en uno de sus recomienzos, y cuyas fibras terminan enlazándose con la primera "historia" de la familia.

el carácter productivo de esa negación: la negativa permanente e inmóvil de la mujer que se niega a asistir a la celebración de Año Nuevo desencadena por un lado acciones y reacciones en los otros personajes; y además una reiteración de imágenes y modos de contar que intentan dar con esa misteriosa y hermética resistencia. El corte y la continuidad también funcionan en relación al ritmo que produce el recomenzar de cada uno de los fragmentos antecedidos por "AMANECE/ Y YA ESTÁ CON LOS OJOS ABIERTOS": un sostenuto interrumpido que encabalga dos acciones: contar y reanudar. El movimiento de la novela estará dado, concluye entonces el crítico, por "la obsesión, suspensión, repetición [que] son como niveles de la insistencia, fuerza del significante, manifestación del significante en tanto, insatisfecho, se reproduce sin cesar en la narración que reabsorbe sus propios hilos -sus modos- y vuelve a hacerlos emerger" (Jitrik "Entre el corte y la continuidad" 107). 


\subsection{Ulises carapachayo: un regreso irreverente a los orígenes de la tradición fluvial}

Como decíamos, El limonero real recomienza nueve veces a partir del ya célebre dístico "AMANECE/ Y YA ESTÁ CON LOS OJOS ABIERTOS” para contar la historia de una familia de isleños, los preparativos y la celebración del Año Nuevo. El tiempo concentrado de las pocas acciones narradas - una austeridad argumental que ya forma parte del estilo Saer- se tensiona a partir de un montaje temporal a partir del cual puede reconstruirse la historia de la familia de Wenceslao, la decadencia económica del espacio isleño y el origen arcaico de la isla. Entre las secuencias que reiteran, y en cada variación, amplían el tiempo de lo narrado, incorporando elementos no mencionados anteriormente, la novela intercala dos núcleos narrativos que irrumpen, por su heterogeneidad genérica y su variación temporal, el discurrir acontecimental del texto. Se trata por un lado de una secuencia en la que se reescriben el Génesis y la Odisea, ${ }^{284}$ y por el otro, de la incorporación de un cuento maravilloso.

En “3 novelas argentinas Saer-Tizón-Conti” Beatriz Sarlo advierte que son precisamente esos dos textos anómalos los que encierran la clave ideológica de la obra, historias que abarcan desde la creación de las islas hasta la aparición de un sistema de gobierno injusto; y un cuento infantil de pescadores resignados que deben aceptar su destino. Por su parte, Graciela Montaldo habla de "géneros intercalados" que incorporan nuevos registros lingüísticos y que vuelven a contar la historia de la familia de Wenceslao, pero cuyo espectro temporal amplía hacia atrás y hacia adelante los hechos narrados en el resto de la novela. Ambas incrustaciones genéricas se diferencian, sostiene, por su linealidad cronológica, con la fragmentación y dislocación del resto de los tramos. Montaldo advierte que la novela parodia la epopeya homérica del viaje del héroe y esto puede observarse en la "degradación" de los motivos clásicos, allí donde Ulises se transforma en un humilde pescador, el mar en un río, Circe en una curandera engualichadora y los pretendientes en gavilanes. Premat, por su parte, agrega que ambos relatos ostentan un valor de origen en vínculo con el aire de inicio cósmico que permea

\footnotetext{
${ }^{284}$ La incorporación del Génesis y de la Odisea sutura una de las interrupciones del lenguaje más experimentales que prueba la obra de Saer. Como se recordará, después de zambullirse en el río Wenceslao pierde la conciencia y su lengua comienza a desintegrarse en una serie inconexa de ruidos que desembocan en un rectángulo negro que ocupa parte del blanco de la hoja. Sin embargo, para seguir narrando la escritura también debe "regresar" al orden alfabético y a los relatos de fundación del mundo.
} 
el resto de la obra, ${ }^{285}$ y señala que aportan inteligibilidad y permiten conocer las causas de la muerte del hijo y la progresiva decadencia social de los isleños. Se trata de un regreso "irreverente" a las fuentes para recuperar la posible fuerza narrativa que está contantemente amenazada en las ficciones de Saer por ese "inexpresable" que aplaza indefinidamente el sentido.

Como se recordará, a la zambullida de Wenceslao en el río le sigue una especie de delirio en el que paulatinamente lo real se transforma en una serie de manchas, luces y ruidos. El mundo se borra y el abecedario se descompone entre las últimas zetas que anuncian el hueco negro y las aes que avizoran el regreso al lenguaje: un viaje lingüístico que ya ha sido glosado muchas veces por la crítica, ${ }^{286}$ y comprendido como cifra de la escritura saeriana, como ápice de la experimentación y del negativismo que caracterizan esa etapa. Interesa señalar, sin embargo, que el regreso a la escritura es, a la vez, indisociable con el regreso a un territorio particular y al momento genesíaco de formación de las islas del Paraná. Allí donde ni el hijo de Wenceslao, muerto en la ciudad, ni las hijas de Rogelio, que allí ejercen la prostitución, "vuelven”, la ficción regresa dos veces.

El primero será el retorno lingüístico recién mencionado, que desemboca en la parodia del génesis bíblico; el segundo retorno alude a esa comentada parodia de la Odisea. Si se retoma la hipótesis de Sarlo sobre la concentración ideológica que guardan los dos episodios anómalos de la novela, cabría sostener que lo que se escribe como crítica ideológica debería pensarse también sobre la variación que Saer le imprime no sólo a los grandes textos de la tradición -la Biblia, la historia de Homero- sino

\footnotetext{
${ }^{285}$ En "Un realismo de lo irreal: la imaginación material", Rafael Arce analiza el origen de la isla a partir de la fenomenología microscópica bachelardiana y advierte que en la imaginación material de Saer predomina el origen acuático, presente en el río, el "agua negra" pero también en el barro y en la "pasta". La isla oculta en su revés el barro primigenio y el universo saeriano, cuyo nacimiento apenas se produjo, ya muestra las trazas de su aniquilación. En La felicidad de la novela, Arce examina además cómo Wenceslao se reapropia del origen y su historia personal reescribe la historia del universo: "El sueño cosmogónico de Wenceslao toma su material de la vigilia: el comienzo del mundo es el comienzo de su mundo, filogénesis y ontogénesis coinciden" (76).

${ }^{286}$ Stern señala además que hay un núcleo experiencial fundamental que es la inmersión de los personajes en el río, un pasaje por las aguas que adquiere una proyección casi mítica en el que se "nada" con la "nada", como espacio simbólico de la génesis textual. La disolución del discurso en la "nada" discursiva se produce cuando Wenceslao se sumerge en un medio líquido y va proyectando la imagen de un retorno al seno materno. La novela, concluye Stern, pone en escena la génesis de una determinada relación con la escritura y dramatiza la destrucción y el renacimiento de la letra.
} 
también a la tradición local de viajeros y políticos que ya habían fraguado una historia del río asentada en similares referencias, pero con signo inverso.

Los cronistas que acompañaron las primeras expediciones de Juan Díaz del Solís y de Magallanes suelen coincidir en la descripción de las islas y del Paraná como un espacio encantado signado por la abundancia de su vegetación prodigiosa y por la anchura inverosímil del río, de orillas tan alejadas que no podían ser capturadas a la vez por la mirada. ${ }^{287}$ Alonso de Santa Cruz, el cosmógrafo de la expedición de Sebastián Gaboto y autor del Islario General de todas las islas del mundo elogia la bondad de las aguas, la abundancia de la pesca y la variedad de la fauna. Muchos de estos atributos positivos fueron retomados por visitantes posteriores. En El tempe argentino (1858) Marcos Sastre ofrece una representación absolutamente idealizada del territorio isleño, lugar que aloja, señala, un "edén perdido" delicioso y placentero en el que podría reproducirse una nueva edad de oro. Con "vista hechizada" avanza en su canoa y al adentrarse en los canales describe el agua apacible como un espejo, y queda deslumbrado ante la riqueza vegetal y animal que prolifera sin trabajo en suelos de reciente formación. El carapachayo, hombre de las islas, es quien habita esas comarcas encantadas y allí reside "bajo ese humilde techo pajizo", como un hijo de la naturaleza que lleva una vida frugal e independiente. El mismo Sastre formará parte de esa vida isleña cuando ocupe una de las islas del Delta.

Otros viajeros, como la escritora Lina Beck-Bernard, en excursión por las islas, oscilarán entre una visión sublime del río Paraná como otro desierto y el encantamiento más pintoresco de sus islas, cuya vegetación es comparable a la de un invernadero templado de los jardines reales de Europa. Fray Mocho, en su Viaje al país de los matreros, incorporará una nota más oscura y romperá el encantamiento, advirtiendo que las islas constituyen un desierto más temible que el de la pampa, una zona al margen de la ley que no reconoce la "autoridad" del presidente ni del gobernador y donde van a refugiarse los que huyen de la justicia, región de matreros que comparten los atributos de la naturaleza de la región: cautela, disimulo y rastrería.

Varios de estos cronistas hacen alusión a la fisonomía singular de las islas, cuyas continuas apariciones y desapariciones vuelven el paisaje inestable, sin embargo, será Eduardo L. Holmberg quien apele, en "Formación del Paraná y sus islas" (1910) a la

${ }^{287}$ Los textos de Sastre, Holmberg, Lina Beck-Bernard y Fray Mocho que se comentan a continuación fueron retomados de Amaro Villanueva et al. Islote municipal: antología de textos. Paraná: Universidad Nacional de Entre Ríos, UNER, 2014. 
ficción geológica que ha aprendido de Darwin para explicar la progresiva formación del estuario y de sus afluentes hasta la consolidación, siempre provisoria, de sus islas, formadas a partir de la acción del junco, que detiene la arena y la arcilla y acumula sedimentos y residuos.

Entre unos y otros interesa destacar El Carapachay de Sarmiento porque allí se retoman y reescriben las mismas fuentes de las que parece abrevar Saer en El limonero real, aunque, como se verá, con signo inverso. ${ }^{288}$ Como relata Liborio Justo en el prólogo que escribe para esta obra, ${ }^{289}$ Sarmiento sintió atracción por las islas del Delta, incitado por las noticias que de ellas le llegaban y convocó a un grupo de amigos para hacer un viaje de exploración. En "Formación. Tradiciones. Tiempos históricos" referirá la "parte heroica y mitológica de las Islas" (59) y ofrecerá su propia versión del surgimiento, que retomará parte del imaginario geológico, así como una reescritura personal del génesis bíblico:

El junco es el primer día de la creación de las islas; las cardas y el ceibo hacen la mañana y la tarde del día segundo. [...] Un roedor sin nombre es el primer

\footnotetext{
${ }^{288}$ Sería necesario advertir por un lado que esta hipótesis sobre las posibles vinculaciones entre El Carapachay y Saer surgió del productivo intercambio que se dio en el Taller de filosofía "Welcome to the Shade. Sarmiento en el Delta", dictado por los profesores José E. Hage y Gustavo I. Míguez, entre mayo y junio de 2017 en la Casa Museo Sarmiento. Se trató de un taller en el que se revisaron distintos momentos de la obra de Sarmiento y particularmente las diversas modulaciones que sufrió la dicotomía clásica entre civilización y barbarie cuando el escritor descubrió el Deltá del Paraná, experiencia a partir de la cual vehiculizó dos utópicos proyectos, convertir el Delta en un Missisipi sudamericano y próspero y Argirópolis. Me gustaría señalar que la participación de Juan Bautista Duizeide en el taller fue importante para pensar esta vinculación y agregar que él mismo trabaja sobre El Carapachay en el ensayo "Escrito sobre el agua", advirtiendo que tanto en Saer como en Sarmiento el río tiene un olor nutricio que se presta a la revisión genesíaca. Este ensayo forma parte del Tomo I - Lenguas de la serie Desierto y Nación, coordinada por Hage y Míguez.

${ }^{289}$ Es pertinente aclarar que El carapachay está formado por una serie de notas que Sarmiento publicó en El Nacional desde 1855 a 1883 y fue publicado por primera vez bajo el título El camino del Lacio en 1913 como parte de las Obras Completas organizadas por Ausguto Belín y editadas por la Editorial de la Facultad. Se sabe que Saer fue un entusiasta lector de Sarmiento desde los primeros años de su formación. En "Libros argentinos" señala que a partir de 1958, cuando empieza a cursar en la Facultad de Filosofía y Letras sistematiza su conocimiento sobre la literatura argentina del siglo XIX y sitúa como uno de sus autores predilectos a Sarmiento, cuyos "Viajes" pondera y sobre los cuales escribe un artículo incluido en El concepto de ficción. Sin embargo, es preciso advertir que hasta donde se ha podido averiguar, no puede afirmarse que Saer haya leído El Carapachay en particular. Por ese motivo no se leerán estos episodios de El limonero real como una reescritura de los artículos de Sarmiento. Lo que resulta interesante, de todos modos, es contraponer ambos textos porque, aun dialogando sobre un mismo territorio y sobre unas similares referencias literarias, Sarmiento y Saer reescriben el génesis de las islas del delta de acuerdo a su propia historia política contemporánea y allí donde el primero avizora un futuro promisorio, el segundo registra la decadencia y el empobrecimiento y manifiesta las tensiones no resultas entre la ciudad y la costa.
} 
cuadrúpedo que reina en esta creación embrionaria. [...] Manadas de carpinchos (babirusa) frecuentan sus costas, bañándose en los canales las noches de luna. [...] Y esta es la mañana del día tercero, que la tarde la forman los duraznales que empiezan a mostrarse de trecho en trecho con sus sábanas de flores rosadas en la primavera. [...] Como se ve, la creación está tocando a su apogeo de belleza a medida que se asciende río arriba, hasta las islas de Santa Fe y de Corrientes (Sarmiento, El carapachay 53-4-5).

Como se recordará, el génesis de Saer también combina el conocimiento geológico con la Biblia:

Era vea un solo ver agua. Agua y después más nada. Más nada. Aparece en eso una islita. [...] Al rato había tantas [...] que usted podía pasar saltando de una a la otra. [...] Ahí quedó nomás la isla secándose al sol. [...] El agua también bajó [...] así se formó la barranca, que el agua come. [...] Menos mal que se largó a llover $[. .$.$] y cuando pararon los aguaceros, no va que aparece toda la tierra vea$ llena de unas hojitas verdes, así de chiquitas, que empezaron vea a brotar. Toda la tierra llena de hojitas verdes [...] y cuando menos nos descuidamos ya estaba toda la isla llena de yuyos de sapo, de verbenas, de cardos, de sauces, de curupíes, de algarrobos, de laureles. [...] no va que una vez que bajamos la barranca vimos salir del agua unos animalitos de lo más raros. [...] Cuando menos nos dimos cuenta empezó a haber perros, pajaritos, nutrias, comadrejas, vacas. [...] Diga que la tierra era buena y daba de sobra todos los años (Saer, El limonero real 153).

Hasta aquí los principales tópicos se mantienen: la formación aluvional de las islas, el secado de la formación barrosa y el posterior y abundante crecimiento vegetal y animal, la bondad de las cosechas. En ambos textos, además, hay un sujeto isleño que precede a la fundación de las islas: el carapachayo en Sarmiento es un bípedo anfibio que si bien aparece el sexto día de la creación parece haber estado siempre allí. Se alimenta de pescados, naranjas y duraznos y sus ocupaciones son análogas, nos dice Sarmiento, a las producciones del país: "corta leña, da caza a los tigres, hace carbón, colecta cueros de nutria, lleva a Buenos Aires lanchadas de duraznos" (Sarmiento, Carapachay 57) y es la versión isleña del gaucho (no anda a caballo sino que boga en chalanas por los canales misteriosos del río). Del génesis se pasa a una de las aventuras de la Odisea; del mito genesíaco a la historia política contemporánea. Sarmiento advierte que no hay carapachayas pero sí una mujer terrible, una Eva llamada "Manuela" (en clara alusión a Juan Manuel de Rosas) que seduce a los jóvenes dependientes de San Fernando y los hace derrochar las fortunas de sus patrones "llevando uno a sus islas, cual otra Calipso a gozar de sus espantables encantos, habiendo desaparecido, muerto o ahogado [...] sin que la justicia hubiese podido nunca averiguar nada, ni el rumor público justificar sus sospechas" (Sarmiento, Carapachay 
56). Sarmiento apelará varias veces a figuras de la antigüedad clásica para configurar el Carapachay como un espacio apropiado para desarrollar su proyecto civilizatorio de pequeños productores, ${ }^{290}$ más afín al modelo del oeste norteamericano y propicio al desarrollo del comercio y la comunicación fluviales.

En El limonero real, del génesis criollo, como lo llama Gramuglio, se pasa a un momento más "antropológico" (según lo define Rafael Arce) de división del trabajo. Los isleños se dedican a las cosechas y al trabajo manual mientras que el Cabezón es designado para filosofar y pensar cómo conjurar la muerte y evitar que se malogren los cultivos. Rápidamente comprende su posición y abusa de su poder. Cansado de trabajar para el Cabezón, Wenceslao parte en su canoa "cosa de encontrar alguna isla donde afincarme y hacerme una posición" (Saer, El limonero real 157) pero esa búsqueda, que podría ser la de Eneas cuando persigue un lugar para refundar Troya, se trama en realidad como el regreso de Ulises a su propia isla. La crítica ha señalado que, frente a la discontinuidad temporal que caracteriza al resto de la novela, los relatos incrustados ostentan cierta homogeneidad cronológica, sin embargo, aquí Wenceslao-Ulises erra entre las islas durante mucho tiempo hasta que encuentra/reencuentra la propia, un descalabro de la racionalidad temporal del mito que echa luz sobre la idea de "regreso" que la obra de Saer posteriormente desarrollará ¿no es siempre el mismo lugar al que se regresa, y una vez allí, no se difiere siempre el reconocimiento?

Las peripecias del Ulises criollo permiten además leer no sólo una parodia del texto clásico sino un desmontaje de los tópicos isleños antes mencionados: el río no es un espejo de aguas bondadosas sino un hervidero pantanoso en el que abundan nubes de mosquitos. Las graciosas islas de Sastre que invitaban al viajero a afincarse no parecen ahora tan propicias y Wenceslao pasa años en la intemperie y no encuentra donde conchabarse: "Entre la crecida y los cabezones no había nada que hacer y todo el mundo andaba galgueando" (159). Hasta que finalmente toca las orillas de su islita, se reencuentra con su mujer, su hijo y los perros y matean hasta el atardecer. Se encargan luego de limpiar el terreno, alambran, plantan nuevos árboles y despejan el espacio para que el limonero, que está en la isla desde antes del nacimiento de Wenceslao, con su ciclo de flores y frutos, siga floreciendo. La interferencia temporal es ida y vuelta, y allí donde el tiempo mítico irrumpe el presente del relato (el que va del primer amanecer del

${ }^{290}$ Él será el primer Herodoto de esas comarcas; él y sus amigos serán como Jasón y los argonautas en busca del vellocino de oro; Sarmiento será además el Virgilio rioplatense y el Delta del Río Paraná será el nuevo Lacio americano, perfecto asilo para su proyecto inmigratorio como Roma fue el refugio de los troyanos en el Lacio. 
último día del año hasta el amanecer siguiente), el tiempo "criollo" desarticula, ${ }^{291}$ parodiando, el mito y devuelve un mundo sin dioses, donde las injusticias, las demoras y diferencias se juegan en el plano social y no divino.

Por diferentes vías, la novela encuentra las formas de un regreso: el extrañamiento y el aura mortífera que le sigue a la muerte del hijo se irá atemperando parcialmente hasta que Wenceslao pueda recuperar una forma habitable de la isla; la pérdida del lenguaje y del mundo abre la ficción a un vértigo temporal que llega hasta el origen de los relatos, que incluso parodiados y desarticulados podrán reanudar la historia de los isleños. En el cruce que forman isla y lenguaje, el limonero real es ese oikos que regula las fugas, los desplazamientos $\mathrm{y}$ las vueltas del viaje.

${ }^{291}$ Que oscila entre referencias temporales claras, como la marca de los cigarrillos Colmena, de 1970, y una vaga referencialidad que llega hasta la tradición gauchesca del siglo XIX; acumulando refranes y usos coloquiales del lenguaje. 


\section{UNA VUELTA DE PICHÓN GARAY}

Pichón Garay, el que se ha ido en "A medio borrar" después de discutir con Lalo Lescano si se puede ser fiel a una región, regresa veinte años después a la zona con la excusa de liquidar los últimos bienes familiares. Los avatares de Pichón se anudan, como ha señalado suficientemente la crítica, con los desplazamientos biográficos del propio Saer, y allí donde uno viajaba a París y se instalaba en el Hotel Minerve, el otro firmaba en ese mismo lugar la serie de poemas publicados en los Cuadernos Hispanoamericanos de Madrid; ${ }^{292}$ ambos viajaban en tren para dar clases en la Universidad de Rennes, y, mientras atravesaban el paisaje de la Bretaña leían una biografía de Rubén Darío. En "Primera estación”, un poema inédito, Saer amagaba con el regreso de Pichón, nunca efectivo hasta su vuelta de La pesquisa.

En escritos sueltos de los años noventa es posible seguir el itinerario de Pichón Garay por Estados Unidos. De acuerdo a lo que leemos en los Papeles de trabajo II, Saer tenía la costumbre de apuntar anotaciones, protohistorias, reflexiones y sueños en las hojas de los hoteles y residencias en los que se alojaba, y así puede leerse en las dos hojas del "Palmer House. The Princeton University Guest House" un breve relato sobre un viaje a Princeton hecho por Pichón y Babette. Sin embargo, ni el "regreso suspendido" de "Primera estación" ni este breve texto pasan a la obra publicada y por lo tanto los viajes protagonizados por este personaje se circunscribirán a los intercambios entre París y "la zona".

Después de 20 años de ausencia, como decíamos, Pichón vuelve a su ciudad natal. Una serie de textos se aglutinan alrededor de La pesquisa para contar esa vuelta y sus posteriores efectos: "Recepción en Baker Street", un cuento de Lugar (2000) que concentra su acción en lo que sucede inmediatamente después de los acontecimientos narrados en la novela; Las nubes, cuya acción ocurre un año después y le provee a Pichón una doble satisfacción: saber que Tomatis cumplirá su promesa de visitarlo en

${ }^{292}$ En el argumento "Me llamo Pichón Garay" de La mayor, el personaje dice: "Vivo en París desde hace cinco años (Minerve Hotel, 13, rue des Ecole, 5ème)" (Saer 199). Esta dirección concuerda, advierte Martin Prieto, con la que el propio Saer incorpora como parte de la firma con la que rubrica los catorce poemas publicados en 1970 en los Cuadernos Hispanoamericanos de Madrid, reunidos bajo el título "Poetas y detectives". Saer y Pichón "comparten" el mismo espacio parisino. Poesía, biografía y escritura ficcional se anudan en la inscripción topográfica, aunque por supuesto, el argumento termine problematizando la identidad que se enunciaba en el título. 
París, y acceder a otro misterioso texto recogido por Soldi y titulado por él mismo "Las nubes"; "En línea", otro cuento de Lugar, que transcurre un par de años después de esa visita de Pichón Garay pero expande argumentalmente los mismos conflictos que se habían abierto en su regreso y La grande, finalmente, en la que todavía se evoca esa mítica visita y se agregan nuevos detalles sobre el encuentro de Pichón y Gutiérrez. Es decir, una serie de ficciones que se publican entre los noventa y el año 2005 recupera para el mundo de Saer el regreso de Pichón en los ochenta, momento en el que Saer comienza a volver periódicamente al país luego de seis años de ausencia.

El regreso de Pichón contribuye a consolidar lo que Beatriz Sarlo llama en Zona Saer esa "tribu" o "sociedad de personajes" que funciona como un principio constructivo de su obra y como una respuesta en partes "reactiva" a la amonestación que la teoría literaria de los setenta y principalmente los fundamentos del Nouveau roman habían vertido sobre el carácter perimido de la categoría de "personaje". ${ }^{293} \mathrm{Al}$ contrario, argumenta Sarlo, la fuertísima impronta de esta sociedad de amigos, que Saer parecía ya haber programado desde el inicio de su obra (desde "Algo se aproxima" hasta La grande) le asegura además una continuidad en un mundo frágil que siempre parece a punto de desaparecer y le ofrece un "idiolecto" que no solo reconocen los lectores de Saer sino también los personajes más jóvenes, como Soldi o Nula, que aunque se sientan a gusto con los "mayores", se asumen levemente exteriores a ese núcleo, como si vivieran en un espacio y un tiempo diferentes.

Tres son los personajes principales que se reiteran en esta serie de obras del "regreso" de Pichón Garay: él, Tomatis y Soldi, un joven y fervoroso lector que no desestima pasar unos años en el exterior para aprehender las principales herramientas de la teoría literaria. En La pesquisa el elenco se extiende a los hijos, el "francesito" hijo de Pichón; Alicia, la hija de Tomatis y Julia, la hija -ya adulta- de Washington Noriega, que regresa de Córdoba para ocupar la antigua casa de su padre y custodiar sus papeles. Este trío es fundamental, si, como sostiene Sarlo, La pesquisa ya marca el comienzo de un “deliberado desenlace” (Zona Saer 92) que se consumará en La grande.

\footnotetext{
${ }^{293}$ En "La posición estética de Saer", Florencia Abbate condensa los principales planteos estéticos que Saer formuló en sus ensayos escritos entre 1969 y 1980 y en las novelas publicadas en ese período. Advierte que si bien su idea de vanguardia es afín a la del Nouveau roman, se distancia de varios de sus postulados, en primer lugar porque defiende la representación como una tarea inherente de la literatura y además porque frente a la sospecha de los autores franceses con respecto a la idea de "personaje", que a sus ojos había ido perdiendo las prerrogativas referenciales que antes ostentaba, los personajes de Saer destacan por su humanidad y carnalidad.
} 
En un juego de vigilancia mutua, sostenido por supuesto en la amistad, el afecto y la admiración, los tres personajes despliegan una serie de prevenciones, expectativas, deseos y precauciones sobre los demás. Pichón, el recién llegado, está en el centro de las especulaciones y su llegada aviva el recuerdo de su hermano desaparecido durante la dictadura; para Soldi, que no los conocía a ninguno de los dos, conocer a Pichón alcanza para conocerlos a ambos; para Tomatis, en cambio, el regreso tardío de su amigo abre viejas heridas, porque cuando desaparecieron el Gato y Elisa, Pichón se negó a regresar de Europa y a dejar a su nueva familia en París.

Como era de esperarse, el regreso de Pichón Garay desarticula la nostalgia por el lugar de origen pero permite constatar la permanencia de un núcleo de sentidos, tonos, complicidades y silencios en medio de un mundo inevitablemente transformado por la violencia política, la intemperie, la dispersión, la muerte, el exilio y los cambios urbanos. Esta vuelta, fraguada por Saer en un momento maduro de su obra y más o menos paralela a sus propios "viajes" al país, se teje alrededor de una serie de constantes: por un lado, implica un intercambio dinámico de historias cuyo estatuto de verdad es permanentemente cuestionado. Esas historias, que oscilan entre el género policial, el relato mitológico y la narración "histórica", ${ }^{294}$ comparten en general el atributo del "enigma" de la autoría - de los textos y de los crímenes- y parodian las pretensiones verídicas y hermenéuticas que ostentan originalmente estos géneros -la interpretación psicoanalítica, la deducción policial, los fueros realistas de la historia-. El tráfico de relatos sedimenta la amistad entre Pichón y Tomatis (ya se volverá más

\footnotetext{
${ }^{294}$ Cfr. Villanueva, Graciela. "De Tebas a la zona: derroteros policiales del mito de Edipo". Villanueva advierte que vincular el policial con la mitología clásica es una práctica bastante extendida entre críticos y escritores que buscan legitimar un género a veces considerado subliterario. El mito de Edipo y la versión de Edipo Rey de Sófocles han sido particularmente leídos como un policial avant la lettre, sobre todo por el funcionamiento de los enigmas que Edipo resuelve y que involucran el crimen de Layo. Sin embargo, varios estudiosos han subrayado también las distancias entre el policial y el mito a propósito de la escandalosa coincidencia, en el texto clásico, entre el detective y el criminal, y también por la irresolución final del crimen, aspectos que en realidad serían transgresivos del género. Según continúa explicando Villanueva, Saer retoma precisamente estos aspectos transgresivos en La Pesquisa y La grande: "De este modo, a través de una hipótesis análoga a aquélla con la cual en $L a$ pesquisa Tomatis cuestionaba la primera solución del enigma de los asesinatos de las viejecitas (una solución modelada sobre la reformulación psicoanalítica del mito de Edipo) y dejaba perplejo a un lector que no lograba saber cuál era la versión 'verdadera', en estas páginas de $L a$ grande la aplicación estricta a la historia de Edipo de las reglas de racionalidad del policial de enigma resulta también paradójicamente desestabilizadora, porque, [...] ataca los cimientos de la lectura tradicional y de la lectura psicoanalítica de la historia de Edipo, pilares de nuestra cultura contemporánea ("De Tebas a la zona" 11).
} 
adelante sobre esto), funda el interés mutuo entre Pichón y Soldi, y permite además una serie de reflexiones autorreferenciales sobre preocupaciones que Saer había desplegado acerca de su propio proyecto -la posibilidad de un poema narrativo; ${ }^{295}$ las diferencias entre un ciclo y una saga; ${ }^{296}$ una nueva descarga sobre el género 'novela' y sobre el

295 "Recepción en Baker Street" ficcionaliza el proceso de composición de un poema narrativo. Como se sabe, Saer ya había expresado en varias oportunidades su deseo de borrar los límites entre los géneros y proyectaba hacer una novela en verso. Muchas de las poesías de El arte de narrar son, efectivamente, poemas narrativos que despliegan el retrato de algún personaje histórico o ficcional, como hará Tomatis con Sherlock Holmes. La variante incorporada aquí es que se tratará de un enigma policial en verso, cuyo único antecedente en la historia de la literatura, se jacta Tomatis, es el Edipo Rey de Sófocles, leído, interesadamente, como policial, bajo ese cruce entre mito, crimen y enigma que también Pichón había ensayado en su relato del caso parisino (En La grande Tomatis le enviará una carta a Pichón en la que ensaya in extenso esta reescritura de la tragedia clásica como si fuera un policial). Tomatis no sólo termina "relatando" su caso sino que además devela las indecisiones, tanteos y expectativas que guarda con respecto a la forma elegida, y teme, por ejemplo, que una digresión cómica dilate demasiado el meollo de la historia. A medida que avanza el relato oral de Tomatis, deteniéndose en las variables históricas, políticas y psicológicas del caso y de sus protagonistas, su conversión en "poema" parece cada vez más lejana, un proyecto prácticamente inviable. Los últimos poemas que Saer escribió y decidió publicar son los que forman parte de "La guitarra en el ropero" (1981-1987) de El arte de narrar. Sin embargo, todavía en un libro del 2000 el escritor sigue planteándose algunos dilemas que había tanteado en sus primeros textos de poesía ¿Cómo cruzar los atributos de la prosa -distribución- y de la poesía -condensación-?, ¿cómo contar la historia de un personaje mítico y legendario en relación a las contingencias políticas y afectivas de quien escribe en el presente? Como ha señalado Sergio Delgado en la introducción a los Poemas. Borradores inéditos III, "las vidas o si se quiere las biografías de los personajes de El arte de narrar podrían leerse como trazadas, conversadas o escritas, a su vez, por cualquiera de los personajes de las narraciones de Saer, que se pasan el tiempo escribiendo o hablando de literatura" (23). Tomatis quiere escribir un extenso poema en verso, con algunos pasajes rítmicos en alejandrinos y rima consonante. Sus irónicas pretensiones literarias lo hacen colocarse en pie de igualdad nada menos que con Sófocles, e incluso se atribuye la exclusividad de pergeñar un crimen múltiple. Termina, sin embargo, contando "humildemente" la historia de sus tanteos y perplejidades, y ofreciendo, en cambio, una historia fabulosa contada en la mejor prosa de la "zona": una conversación entre amigos que es a la vez un duelo de policiales bajo el cual Pichón y Tomatis se encuentran y reconcilian.

${ }^{296}$ En el cuento "En línea", antes de resumirle a Pichón el argumento del texto hallado con Soldi, Tomatis observa que el dactilograma encontrado bien podría ser un fragmento de En las tiendas griegas o bien un texto independiente, tributario del cuerpo principal, "así que ese texto breve y otros que eventualmente pudiesen existir y fuesen apareciendo, formarían no una saga, para lo cual es necesario que entre los diferentes textos haya una relación cronológica lineal, son más bien un ciclo, es decir [...] un conjunto del que van desprendiéndose nuevas historias contra el fondo de cierta inmovilidad general" (Saer, "En línea", Lugar 25). La misma distinción había sido hecha por Saer en algunas entrevistas de los años ochenta, en las que se distanciaba de la idea de saga porque esta suponía "la continuidad histórica de los acontecimientos y la continuidad biográfica de los personajes con el fin de completar la inteligibilidad de la representación" (Saer, Ensayos, 151). El "ciclo" abre espectralmente la posibilidad infinita de que nuevos textos puedan ser encontrados en "las bibliotecas de la ciudad, olvidados también entre las páginas de algún libo, de algún legajo, o sepultados en algún arca o cajón" (Saer, "En línea", Lugar, 25) y rompe las expectativas totalizadoras de la saga decimonónica. Nuevamente aquí Saer recoge otra hebra de reflexión crítica medular para su proyecto de escritura y confirma, vía Tomatis, la dirección de su obra, una advertencia 
relato histórico en particular; la sospecha imperecedera sobre la percepción de lo real-. ${ }^{297}$

Por otro lado, como se verá, no sólo se intercambian historias sino paisajes. En los relatos del regreso de Pichón se produce una interferencia espacial entre París y la ciudad natal. El paisaje de la región, opaco y mudo a las vagas expectativas de Pichón, terminará tomando y transformando el espacio parisino. Como ocurrió en El río sin orillas, la vuelta a la región implicará además volver a narrar su historia y comprobar los efectos del tiempo y de la modernización sobre la costa, el campo y la ciudad. Lejos de presentarse como la arcadia de la infancia, la patria se vuelve espacio de ruinas de aire cósmico.

En "Dos razones", Saer reflexiona sobre La pesquisa y señala que durante las primeras etapas de escritura sentía que se estaba apartando de su "manera" y de sus textos anteriores, hasta que se dio cuenta de que "no solamente no transgredía nada, sino que más bien estaba operando por enésima vez el eterno retorno de lo idéntico. Sin darme cuenta había cambiado caballos por viejecitas, y estaba escribiendo otra vez la misma novela de siempre" (Saer, La narración-objeto 158). Separados por la inundación y la contingencia en “A medio borrar”, los mellizos Garay compartirán sin

bastante significativa además si la leemos dentro del conjunto de relatos formados por Lugar, el libro que quizás más se distancia del resto de la obra, pero que continúa formando parte de su "ciclo".

${ }^{297}$ La diatriba contra el género "novela" se ofrece aquí bajo la forma más banal de los celos mutuos. El grupo de vagos intelectuales de la zona y amigos de Washington Noriega desacreditan las pretensiones edípicas y comerciales de su hija, interesada en sacarle un provecho económico a la extensa novela encontrada entre los papeles de su padre. Ellos saben, en cambio, que "la palabra novelista entre los labios de Washington tenía siempre un matiz despectivo" (Saer, La pesquisa 67-8). En sus ensayos de los setenta y ochenta y en varias entrevistas Saer desarticula los fueros realistas y comerciales del género. En "La novela" (1981) resume sus problemas (su origen históricamente ligado el ascenso de la burguesía; el uso exclusivo de la prosa; la causalidad lineal que guía su composición; su hiperhistoricidad; su generalizada connivencia con la ideología reinante de la época; su adaptabilidad a la industria cultural y su esencia mercantil y estandarizada de acuerdo a las posibilidades de venta y distribución). Saer recupera entonces la tradición de aquellos novelistas experimentales, como Proust, Faulkner y V. Woolf que han arrancado a la novela de las condiciones extraartísticas que la condicionaban y han enriquecido la prosa a partir de los procedimientos artísticos aprendidos de la poesía. En las tiendas griegas, dactilograma que Washington guardaba bajo el rótulo "Inéditos ajenos", defrauda las pretensiones de Julia y desarticula las constantes del género: su acción pasa en las inmediaciones del campamento griego pero no toca sus principales hitos, es antiépica, trabaja con lo "menos novelable" de la guerra de Troya. Sus 800 páginas desgastan el "acontecimiento" y complican la posibilidad de publicación. La "novela" se transforma en una extensa reflexión sobre la verdad de la experiencia y la verdad de la ficción y sus desprendimientos posteriores (el dactilograma de "En línea") problematizan la condición verídica de lo real y las posibilidades cognoscitivas de la percepción sensorial, algo que Saer venía haciendo desde los comienzos de su proyecto literario. 
embargo algo más que correspondencia e intercambio de libros: a cada uno le corresponderá una forma - extraña- del relato policial y para ambos la forma policial establecerá oscuros vínculos con la dictadura. También Carlos Tomatis contará un policial para recibir a Pichón. ¿Por qué la insistencia de este género para contar la historia de los hermanos y sobre todo para narrar el regreso de uno de ellos? ? $^{298}$

Las ficciones de Saer suelen contraponer personajes que comparten una actividad, amistades, acuerdos políticos y estéticos, pero se diferencian porque uno se ha ido de la zona o viaja frecuentemente al extranjero y el otro se ha quedado. Sucede entre los pintores Héctor y Rita Fonseca y también entre los escritores Pichón y Tomatis. De ese modo, la existencia de los dos polos parece funcionar como un reaseguro para no caer ni en un "etnocentrismo provinciano" (Saer, La pesquisa 52) ni en la supuesta superioridad europea, primeras prevenciones que los amigos que se reencuentran deben sortear.

\section{1. "Una mañana deliciosa": opacidad y vislumbre}

Antes de partir en lancha hacia la casa de Washington Noriega, Pichón está interesado en recorrer lugares a trasmano, ya "casi legendarios" después de tantos años de ausencia de su región natal, aunque advierte que la ansiedad, la nostalgia y la impaciencia con la que ha esperado el viaje se han trocado rápidamente en atonía e indiferencia: "una ausencia de emociones previstas, tal vez demasiado esperadas, que lo hace percibir a la gente, a los lugares y a las cosas, con el desapego de un turista forzado" (Saer, La pesquisa 56) y a diferencia de su hijo, que parece haberse adaptado rápidamente, él considera su lugar con la mirada vacilante de un "forastero". Camina por una ciudad familiar pero que ahora recobra "a pesar del encanto intermitente, con un poco de extrañeza" (55) y registra los cambios que se han sucedido en su ausencia. La casa de Washington Noriega, sin su presencia, "le ha parecido a Pichón un poco más grande de lo que la consideraba en su recuerdo, y tal vez por eso también un poco más desolada" (74). Pero sobre todo, lo que registra Pichón es un cambio de órdenes: de "la camaradería viril del anciano solitario con la fatalidad rugosa y fugitiva de las cosas"

\footnotetext{
${ }^{298}$ A propósito de estos interrogantes se retomarán algunas de las ideas que Carlos Gamerro desarrolla en "Juan José Saer, policial y dictadura", un artículo de Facundo o Martín Fierro. Los libros que inventaron la Argentina (2015).
} 
(75), de su hospitalidad austera, solidaria y ya "legendaria", al orden femenino impuesto por Julia, dedicado "al combate constante [...] de la polución, el desgaste, el óxido, la desintegración" (75), pero refractario al antiguo círculo de amigos de su padre. El patio le revela además un aspecto desconocido:

Ese lugar que creía conocer de memoria le pareció muy distinto y por esa misma razón extraño, novedoso, ligeramente inquietante tal vez, como si las pruebas de un tiempo que sigue fluyendo sin nosotros, se hubiesen acumulado en los troncos enormes y rugosos y en las copas desmesuradamente expandidas de los árboles (Saer, La pesquisa 81).

En este sentido, las peripecias, distancias y proximidades que Pichón establece con el paisaje de la zona, Saer parece haberlas vivido en carne propia y haberlas escrito en El río sin orillas: ansiedad previa, voluntaria exposición al paisaje con la esperanza de que una singularidad reconocible emerja de su fondo opaco, indiferencia, atonía, mirada extranjera del foráneo. Sin embargo, tanto en su "tratado imaginario" como en La pesquisa, algo finalmente emerge. Pichón parece comprobar lo que Washington le había advertido veinte años atrás sobre el viaje: "viajar es pasar de lo particular a lo universal, y a medida que uno va viajando lo particular va volviéndose universal" ("A medio borrar", La mayor 166) porque descubre, después de tratar infructuosamente de que suba algún "hálito singular" del pasto grisáceo, del cielo o de la vegetación polvorienta que "la proximidad y la vista del agua le produjeron una especie de alegría fugaz que atribuyó no a su afinidad con ese río preciso, sino a la alerta general de sus entrañas, de sus sentidos y de su piel, acosados por el calor, el cansancio y la sed, ante la presencia benévola, inmediata y genérica del agua salvadora” (Saer, La pesquisa 84).

El espacio natal, en general átono, neutro e irreconocible puede capturar, sin embargo, al que regresa a partir de una irrupción epifánica (la que ocurre, por ejemplo, en El río sin orillas, cuando el escritor se encuentra, camino a Santa Fe, con un camión de vacas cuyo olor y mugidos lo instalan de repente en una zona de familiaridad) pero también a partir de la evidencia de los efectos distorsivos que el tiempo ha operado sobre la materia. Así, el paisaje de la infancia y la juventud se desarticula en tanto arcadia legendaria e inmutable y muestra los signos de su ruina. Esto ocurre en el paisaje postindustrial que Saer mira con fruición estética en El río sin orillas, ${ }^{299}$ y

${ }^{299}$ En El río sin orillas (1991) Saer admite la fascinación que siente por los puertos y galpones
semiabandonados y por los camiones oxidados en la llanura, por un lado porque los objetos
emparchados, arreglados y vueltos a usar forman parte de una esfera familiar y afectiva de la 
volverá a ocurrir en La pesquisa, en el extenso excursus mediante el cual la ficción traza el mapa geográfico de la zona, evocando el tejido fluvial que forman el Colastiné, el Paraná, el Ubajay y los canales formados por las islas aluvionales, y recordando la época de gloria y decadencia del puerto de ultramar de Colastiné Sur. El calado del puerto nuevo en la ciudad, y la construcción del largo canal de acceso a los muelles desde un nudo intrincado de islas y ríos contribuyeron a la decadencia del puerto y con ello también desapareció el pueblo y la estación, se derrumbaron los muelles y galpones, y la maleza fue borrando los caminos que llevaban al puerto. De todo ello quedan restos, ruinas: un despacho de bebidas hecho de latas y de madera de cajón, algunos trechos de vías oxidadas, unos lingotes de hierro, algunas bases de casillas de madera. Sin embargo, considerados

desde cierta distancia, desde el río o desde el medio del campo por ejemplo, los vestigios de ocupación humana son por cierto invisibles, a no ser por el rancho de lata, los eucaliptos y los troncos negros y geométricos, que recuerdan ciertos dibujos de Piranesi, [...], el lugar parece tan virgen y deshabitado como debía serlo, abstracción hecha del clima, de la erosión y de los depósitos aluviales, el día en que, después del último sobresalto geológico, el suelo, el agua, el aire y la vegetación, encontrando cada uno su lugar, graduales, se apaciguaron. (Saer, $L a$ pesquisa 92).

Pichón encuentra, a su regreso, no tanto el paisaje de su infancia cuanto un espacio que, después de haber sido fatigado por hombres de las más variadas nacionalidades y oficios, utilizado como vaso comunicante y nudo de operaciones entre las islas y la ciudad, borra los vestigios de ocupación humana para recuperar el aura cósmica y geológica del principio de los tiempos, nuevo bucle darwiniano que Saer no se cansa de ensayar sobre el paisaje de su región, al que vuelve como un "forastero" que es casi un explorador de tierras desconocidas, y que permite pensar en el carácter contingente de los paisajes, porque "por larga que sea su presencia material en su

que carecen los objetos nuevos y seriados recién salidos de fábrica. Pero además porque estos artefactos, despojados de su utilidad para la circulación capitalista, parecen reponer, en "las deformaciones de la carrocería, las abolladuras de puertas, [y las] porciones de pintura descascaradas" (El río 239) algún vestigio aurático y alcanzar: "ese estatuto envidiable de objeto único que es la finalidad principal del arte" [porque en ellos se juegan] "la participación necesaria del tiempo, la mano, la inspiración y el azar", (239) atributos esenciales del arte según Saer. Es decir, hay un programa estético y político que puede derivarse de esta selección. En estos artefactos y espacios abandonados el tiempo reúne de manera ejemplar naturaleza y tecnología, azar y artesanado. Saer parece indagar los efectos "artísticos" de la intemperie: "Toda esa tecnología arcaica a la espera de una improbable segunda oportunidad, supone un anacronismo industrial y económico, pero en cambio, por haberse desembarazado del prejuicio de utilidad y por haber empezado a empastarse otra vez en la naturaleza y a confundirse con ella, ha terminado por ganar su autonomía estética" (239). 
relación con el imaginario social, poseen una vida (múltiples comienzos, transformaciones de sentido, exangües sobrevidas, resurgimientos, desaparición)" (Silvestri, El color del río 41). En este sentido, las ruinas del antiguo apogeo industrial, comercial y técnico del puerto y la naturaleza de la región se imbrican y producen un paisaje singular "temporalizado" en direcciones múltiples. En El tiempo en ruinas, Marc Augé advierte:

Las ruinas añaden a la naturaleza algo que no es ya historia pero sigue siendo temporal $[\ldots]$ propone a la mirada y a la conciencia la doble evidencia de una función perdida y de una actualidad total aunque gratuita. Es un paisaje que impone a la naturaleza un signo temporal y, en respuesta, la naturaleza termina de eliminar su carácter histórico empujándolo hacia lo intemporal. El tiempo 'puro' es ese tiempo sin historia del que únicamente puede tomar conciencia el individuo y del que puede obtener una fugaz intuición gracias al espectáculo de las ruinas (46-47).

No es, entonces, el tiempo de "su" pasado, ni el tiempo de su infancia el que recupera Pichón, sino ese tiempo "puro", indeterminado y "exterior" al que asiste cuando mira el paisaje, cuya mutación ya había empezado cuando Pichón era chico y cuya transformación, indiferente y persistente, continuará, prescindiendo de su mirada. Sin embargo, ese paisaje que por momentos lo deja indiferente, interfiere en París:

Está viéndose ya en la esquina, bajo el sol, cerca del puesto del vendedor de helados protegido por el toldo a rayas rojas y blancas, anchas. De antemano ha sentido, al cruzar la calle desde la vereda de sombra a la del sol, el asfalto, blando a causa del calor, bajo la suela de sus mocasines marrones (9).

Así, el comienzo deliberadamente ambiguo de Las nubes podría inducirnos a pensar que estamos, una vez más, bajo el ardiente sol santafesino, pero aquí Pichón Garay sale de su departamento parisino para regresar un poco más tarde, dispuesto a leer el manuscrito que Soldi le ha enviado en un diskett. Es el seis de julio, el año anterior pasó unas semanas en su ciudad natal y ahora, inclinado sobre la ventana: "va auscultando, más que los detalles exteriores de la noche, las sensaciones que esos detalles despiertan en él, y que lo retrotraen al pasado, a su infancia sobre todo, a punto de inducirlo a pensar que muchas sensaciones que él ha creído siempre propias de un lugar, eran en realidad propias del verano" (Las nubes 15).

Todavía en Las nubes las reminiscencias se despliegan a partir de un destello material del mundo, el calor, la noche, el clima templado. Sin embargo en el relato "En 
línea” bastará con el despliegue virtual del verano que Pichón recibe de parte de Tomatis mientras conversan por teléfono. Así, a pesar del hábito de incredulidad con el que Pichón escucha en general a Tomatis, puede "ver", desde el invierno parisino, la “mañana deliciosa” de la zona: “ 've' la mañana luminosa de primavera, el toldo de lona verde que imprime sobre las baldosas rojas de la terraza una sombra benévola y a Tomatis" (23). Se produce una escisión entre la percepción de Pichón, atenta a lo que captan sus estímulos sensoriales, y su imaginación "que se pasea por la terraza roja y soleada, por la mañana, según Tomatis 'deliciosa' " (Saer, "En línea”, Lugar 25). La interferencia del paisaje tiene el efecto de suspender el presente de Pichón, sustrayéndolo no sólo del "chisporroteo empírico de los estímulos" sino incluso del propio relato que le hace Tomatis. La imagen "forjada sin un solo elemento material, a no ser las dos o tres frases circunstanciales de Tomatis, [...] ahora nítida, brillante y férrea, ocupa la totalidad de su mente" (26) y convierte a sus propias sensaciones en algo remoto y fantasmal.

Como se recordará, lo que le cuenta Tomatis por teléfono y luego lee el mismo Pichón porque, como otras veces, Soldi ha copiado el dactilograma y se lo ha enviado, es una pequeña historia en la que el Soldado Viejo y el Soldado Joven discuten sobre la posibilidad de que la Helena que los griegos han ido a buscar a Troya sea en realidad un simulacro fraguado por un rey hechicero, y que la verdadera está sana y salva esperando a Menelao. El Soldado Viejo escucha con incredulidad la versión del Soldado Joven porque siempre ha podido distinguir lo "visible" (la rugosidad de la piedra, del árbol, del agua) de lo "invisible" (la transparencia vacía del aire) pero consciente en llevar a cabo la "prueba" que, siempre según el Soldado Joven, les permitiría determinar con justeza la condición material o simulada de Helena. Para eso deberían exponer el cuerpo en cuestión a la primera luz del alba y si este fuera un cuerpo real de materia compacta, nada ocurriría. Si fuera, en cambio, un simulacro, el cuerpo empezaría a tornasolarse hasta volverse transparente y desvanecerse en el aire. Y "como todo el mundo sabía en el campamento que Helena, a la madrugada, mientras los troyanos dormían, tenía la costumbre de pasearse por las murallas, mirando en dirección de las naves griegas [...] y suspirando por su tierra natal" (28), se acercan a la muralla y comprueban, efectivamente, que se trata de un simulacro, pero que también ellos, "la ciudad de Troya y el campamento griego [...] se vuelven manchas luminosas, se tornasolan, vertiginosos, se vuelven transparentes y después se desvanecen" (30). Esta confidencia 
tardía que le han hecho los dioses sobre el valor real del mundo reconcilia al escéptico y resignado Soldado Viejo con ellos.

En "Dislocación e intemperie: el viaje de vuelta", Sylvia Molloy advierte sobre la alienación básica de las narrativas de regreso "con toda su miseria fantasmagórica y/o su esplendor [...]. Se trata de una sacudida existencial, una disrupción de lo familiar que el retornante [...] opera ya con su retorno, ya con el mero hecho de pensar en su retorno" (24). El final de "En línea" parece sugerir que todo ha sido un sueño pero desarticula en la última línea este clásico final para dejar abierta la indeterminación y sobre todo la posibilidad de que el mundo sea, efectivamente, un simulacro. De clara filiación borgeana, posible homenaje a "Las ruinas circulares", "En línea" radicaliza las posibilidades de recuperar el paisaje natal. Ese paisaje átono y opaco que lo había sumido en la indiferencia en su regreso efectivo a la zona, retorna, convertido en "imagen" o "simulacro" a través de la voz de Tomatis y se apodera absolutamente de la atención imaginaria de Pichón, que desconoce su entorno empírico y sus propias sensaciones. Toda vez que alguien (Helena o Pichón) se asoma para capturar una imagen de su tierra natal, el mundo devela de qué está hecho, o mejor, devela el vacío material que lo constituye y cobran entidad las imágenes forjadas "sin un solo elemento material" que han sido templadas, sin embargo, en un improbable y remoto espacio natal.

\subsection{Washington Noriega en Baker Street: policial, amistad y dictadura}

Los textos y las historias viajan y se desplazan junto a los personajes. En un reconcentrado ritual mágico el Matemático abre en el exilio europeo el poema escrito por Tomatis; Pichón Garay le envía a su hermano una novela del Marqués de Sade; los amigos comparten chismes, informaciones sobre el clima, discusiones literarias. Será, sin embargo, el regreso de Pichón a la zona el suceso que desencadene un intercambio fructífero de historias de misterio. Como ya se adelantó, Pichón les cuenta a Soldi y a Tomatis el extenso caso policial del asesino de viejitas que ocurrió a pocas cuadras de su casa, en el que se mezcla, al relato policial, una crítica a la sociedad de consumo y al orden capitalista francés, y una explicación psicoanalítica que retoma el mito griego de la violación de Europa. Los locales, a su vez, responden. Soldi lo lleva a examinar el dactilograma de 800 páginas llamado En las tiendas griegas cuya acción transcurre 
íntegramente en el campamento griego y en el que se contraponen dos verdades, la verdad de la experiencia del Soldado Viejo, y la verdad de la ficción del Soldado Joven. Tomatis, a su vez, le propone un doble policial a su viejo amigo Pichón y en las formas sucesivas y contrapuestas que adquirirán sus historias podría leerse condensada la historia del país y la historia de su amistad.

Efectivamente, el primer "policial" de Tomatis no es otra cosa que su propia versión del caso contado por Pichón Garay, y allí donde la prensa francesa, las instituciones médicas y la policía veían un caso de esquizofrenia que culpabilizaba a Morvan -justificándolo, por la vía psicoanalítica- y restauraba el “orden” de la institución, en la versión de Tomatis es Lautret quien mata por puro gusto y afición. Al respecto, advierte Gamerro: "Tomatis le retrueca con una explicación argentina: no necesitamos madres abandónicas, padres suicidados y desdoblamientos psíquicos. Basta con el deseo y la voluntad de matar, por que sí; basta con la posibilidad de hacerlo impunemente" (Facundo o Martín Fierro 440). Si La pesquisa pudiera ser leída como una novela de la dictadura, señala Gamerro, podría entenderse la explicación de Tomatis como la resolución argentina del enigma parisino: "El asesino que nos propone Pichón es un complejo comisario parisino; el de Tomatis, un simple torturador argentino" (440).

En "Para una reformulación del género policial argentino", Gamerro advierte que desde los tempranos setenta hasta fines de los ochenta los escritores argentinos privilegiaron el policial negro, por su capacidad de incluir temas sociales y motivaciones económicas del crimen. A partir de los noventa, en cambio, asistimos a un revival del policial clásico, rastreable en un corpus de novelas argentinas entre las que menciona La pesquisa. Este resurgimiento se explica porque, a diferencia del policial negro, el clásico no tiene por qué mezclarse con la realidad social y sus escenarios son, en general, exóticos y alejados (París, Oxford, ambientes cerrados y fantasmales). ${ }^{300}$ Entre una y otra variante, entre las décadas del setenta y del noventa, continúa explicando Gamerro, la dictadura fue una singularidad dentro de nuestra historia que nadie pudo predecir ni explicar: "Pichón y Tomatis resuelven dos veces el enigma del

\footnotetext{
${ }^{300}$ En "Repensar el policial hoy en la Argentina", Jorge Lafforgue discute algunas de estas hipótesis de Gamerro y releva una nueva serie novelas y relatos que cuestionan productivamente la diferenciación entre ambas vertientes del policial y permiten leer las pervivencias del policial negro en textos de los años noventa y el 2000.
} 
asesino de viejecitas, porque no pueden ni siquiera comenzar a resolver el de la desaparición del Gato y Elisa" (Gamerro, Facundo o Martín Fierro 439). ${ }^{301}$

La segunda historia policial de Tomatis es la que cuenta en "Recepción en Baker Street", ${ }^{302}$ cuando, después de levantarse de la mesa del bar por la tormenta, los tres amigos se encuentran con Nula y se refugian en la terminal de ómnibus. Aquí Tomatis toma la palabra y cuenta que está pensando escribir un poema narrativo basado en el caso de un envenenamiento de 16 recién nacidos y una enfermera que tuvo lugar hace 50 años en Inglaterra. La historia transcurriría en Londres, unos años antes de la Segunda Guerra Mundial y tendría como protagonistas a Sherlock Holmes y a Watson, retirados hace mucho tiempo y ya muy ancianos. Como en "Sombra sobre vidrio esmerilado", este cuento tardío de Saer vuelve a poner en escena las decisiones, deseos, rechazos y contingencias que forman parte de una escena de escritura. ${ }^{303}$ Tomatis analiza los recaudos que se deben tener al tratar con un personaje mítico como Sherlock:

Al personaje mítico hay que presentarlo no a través de los detalles psicológicos de su personalidad verdadera [...] sino en un orden protocolar de rasgos cristalizados que nos permiten reconocerlo de inmediato y aceptar en él cualquier manera de pensar y de actuar, por inverosímil que parezca, siempre y cuando se adapte al esquema de ese reconocimiento. Pero ya van a ver que, si logro traspasarlo a lo escrito, mi Sherlock Holmes no habrá sido totalmente refractario a la contingencia (Saer, "Recepción en Baker Street", Lugar 92).

Efectivamente, el personaje que fragua Tomatis dista bastante del de la ficción de Connan Doyle y adquiere, a medida que avanza la narración, caracteres que evocan a la también mítica figura de Washington Noriega. Esto puede observarse en la actitud de los interlocutores que escuchan a Tomatis: "El tal Pichón Garay exhibe una sonrisa ausente, como si las palabras de Tomatis hubiesen despertado en él no una emoción

\footnotetext{
${ }^{301}$ Este cruce entre policial y dictadura vuelve a explicitarse en El río sin orillas, cuando Saer advierte con ironía que esa vocación proliferante y repetitiva de la llanura se manifiesta también a nivel histórico bajo la figura del "serial killer": "Durante dos o tres años, el mismo esquema de secuestro, suplicio, muerte, desaparición, se aplicaba todos los días. El mismo perfil forjado por la pretensión quirúrgica y la obsesión demente de los asesinos, pero también del azar, designaba a las víctimas" (195).

${ }^{302}$ Desde la perspectiva del "regreso", según Gamerro, este cuento consolida y estrecha aún más la amistad entre Pichón Garay y Tomatis.

${ }^{303}$ Tomatis exacerba aquí uno de los personajes típicos de Saer, el escritor. Como ha advertido Nicolás Lucero en La vuelta incompleta, ya en los textos de "Más al centro" (En la zona) se incorporan formas de abordar la narración que Saer seguirá explorando después. En "El asesino" se introduce el personaje escritor que presenta a consideración de sus interlocutores sus fantasías, sus proyectos creativos nunca realizados o sus irreverentes lecturas literarias y filosóficas.
} 
inmediata, sino una reminiscencia" (92, el subrayado es mío). Se explica más tarde que las ideas políticas de Holmes habrían ido cambiando, y que si hasta la Primera Guerra Mundial habían sido más bien conservadoras,

se habrían ido modificando en la versión que daría de ellas mi poema narrativo, bajo la influencia de ciertos hechos históricos, como la Revolución Rusa, el asesinato de Rosa Luxemburgo, la crisis económica de 1929, el ascenso del fascismo y del nazismo, la guerra de España y las innegables conquistas del Frente Popular. [...] Holmes habría ido adoptando poco a poco ideas socialistas, incluso anarco-sindicalistas (Saer, "Recepción en Baker Street”, Lugar 100).

Como se sabe, el último libro publicado por Arthur Connan Doyle, tres años antes de morir, es Sherlock Holmes sigue en pie (1927), por lo tanto, la primera operación de Tomatis es extender por varios años las vicisitudes del personaje. Sin embargo, el cambio más radical tiene que ver con un trastrocamiento de orden ideológico. Como explica Clemens Franken, ${ }^{304}$ Sherlock Holmes se formó en el ambiente del positivismo de fines del siglo XIX, y las herramientas analíticas del detective son fundamentalmente científicas, se basan en la observación directa y en el método de la abducción, sostenido sobre sólidos códigos referenciales propios de las ciencias experimentales y sobre conocimientos generales acerca del comportamiento y la cultura. Holmes desdeña a la policía pero trabaja con ella para sostener la legalidad y el status quo y por ello las contingencias históricas y sociales están generalmente ausentes de sus narraciones: "Doyle prácticamente no se interesa por una explicación sociológica o psicológica de los motivos (avaricia, venganza, codicia) de los criminales. [...] Doyle no plantea problemas morales sino intelectuales, convirtiéndose así enteramente en un representante del relato de acertijo con su respectiva pérdida de realismo" (Franken 121).

El poema narrativo que proyecta Tomatis tuerce la pretendida neutralidad de Doyle e incorpora lo político en el centro del crimen. La resolución del caso confirma el viraje ideológico de Holmes porque su hipótesis es que el culpable del crimen de los 16 recién nacidos no es, como se cree, la enfermera, sino Lord W., representante principal de una de las familias más antiguas de Inglaterra, la única que podía constituir una alternativa a la dinastía reinante. Por eso cuando efectivamente la culpabilidad del Lord queda demostrada y éste, embaucado por los ancianos Holmes y Watson, intenta suicidarse, Holmes grita: “-Impídale tomar [el veneno], inspector! ¡La horca estaría

${ }^{304}$ Cfr. el artículo de Clemens K. Franken "Arthur Conan Doyle y su detective científico". 
menos ocupada en sofocar a los hijos del pueblo si recibiese con más asiduidad las testas coronadas!" (Saer, "Recepción en Baker Street”, Lugar 105).

Bajo el retrato mítico de Sherlock Holmes, a medias fraguado entre los vestigios literarios fijados por Connan Doyle y las atribuciones "erróneas" y anacrónicas de Tomatis, podría encontrarse el rostro fantasmal de Washington; ${ }^{305}$ y en las reuniones viriles que mantienen Watson y Holmes hasta la vejez, desdeñando silenciosamente los experimentos culinarios de su ama de llaves, el aura solidaria y austera que Pichón y Tomatis habían extrañado cuando fueron recibidos por Julia en la renovada y "feminizada" casa de Noriega.

Las relaciones que Saer guarda con el policial datan, como él mismo advierte, desde su infancia y juventud, cuando leyó toneladas de novelas; y alternan con momentos de relativo alejamiento y desinterés por el género. En 1965 escribió un ensayo sobre El largo adiós de Raymond Chandler, incorporado mucho después en $E l$ concepto de ficción; probó él mismo diferentes reescrituras del policial y reflexionó sobre esta práctica en las "Dos razones" que escribe sobre La pesquisa y Las nubes (en La narración-objeto). En estos textos críticos pueden leerse no sólo las predilecciones de Saer como lector sino también su interés en la productividad estética del género. Consciente de su relativo empobrecimiento, advierte: "Me pareció que volver a los orígenes del género podía ser una solución interesante, no para parodiarlos, sino para tomarlos otra vez como punto de partida y avanzar a partir de ellos en mi propia dirección" (Saer, "Dos razones", La narración-objeto 160). Esta certidumbre, que Saer se atribuye para La pesquisa, también permite leer el poema narrativo proyectado por

\footnotetext{
${ }^{305}$ En Glosa nos enteramos del pasado político de Washington Noriega. Washington había militado en grupos socialistas, comunistas y anarquistas hasta que en el año 46 rompió con su grupo y encabezó una fracción que adhirió al peronismo, a partir de lo cual fue acusado de "traidor fascista" por sus ex camaradas de izquierda. Los peronistas terminaron asignándole una diputación provincial pero al poco tiempo Washington comenzó a representar la oposición de izquierda en el partido. Lo acusaron entonces de estar a sueldo de los soviets. Por aquella época vivía constantemente amenazado y sobrevivió algunos atentados hasta que tocó fondo, sufrió una depresión y terminó pasando una temporada en el manicomio. Al salir de allí abandonó para siempre la política. Como advierte Sarlo en Zona Saer, la política aparece como un espesor inesperado en la construcción del personaje de Washington Noriega y en la reunión de amigos que asiste a su cumpleaños. Allí pueden leerse distintas fibras de la historia política: Rodolfo Walsh; los sucesivos fracasos de los militares de izquierda que quisieran formar filas al interior del peronismo y también las alusiones al sindicalismo, en la presencia de dos amigos de Washington, Sadi y Miguel Angel Podio, que forman un "círculo exterior; [y] funcionan como esas hebras de pasado que no se han cortado del todo" (Sarlo, Zona Saer 69). Es interesante además que Soldi haya encontrado el dactilograma, fragmento o desprendimiento de En las tiendas griegas, ordenando precisamente los libros políticos de Washington.
} 
Tomatis. Pero además, Saer confiesa preferir a Raymond Chandler sobre Dashiell Hammett porque el mundo de este último tiende deliberadamente a la estilización, "en tanto que el de Chandler va enriqueciéndose hasta convertirse en una pequeña comedia humana" (Saer 158-9) y su protagonista, Philip Marlow es una conciencia trágica. La novela parodia la vida del investigador deductivo y solitario. En el ajedrez de El largo adiós Saer encuentra: "la cristalización mítica de la amistad entre dos hombres, relación que parece purificada y serena en la contienda intelectual desinteresada de la que aceptan las leyes y la ceremonia" (Saer, "El largo adiós", El concepto de ficción 250-1).

Es decir, por sobre el calculado juego de acertijos y pistas, Saer privilegia el espesor trágico y humano del policial y busca adaptar el género a su sistema narrativo personal. Lo hace varias veces, en las sucesivas historias que encarnan los destinos de los hermanos Garay. Así, como se decía anteriormente, los dos policiales que "cuenta" Tomatis permiten recomponer fragmentariamente la historia de la violencia política del país (la resolución argentina del enigma parisino) pero también la historia de una sociedad de personajes que había quedado fracturada como efecto de esa violencia. Reescribiendo a Sherlock Holmes, produce un espacio ficcional y utópico en el que pueden reincorporarse los valores y las prácticas perdidas por años de exilio, separación y tormentos. La historia de los hermanos Garay culmina en ese "último" caso. Por eso resolverlo significa refundar la amistad y probar los efectos de una inteligencia comprometida ahora sí con la justicia social y la suerte de los humildes.

En "Dislocación e intemperie: el viaje de vuelta", Sylvia Molloy repasa el tópico del regreso en algunas de las ficciones de Borges y descubre en "El milagro secreto" una nueva versión del "regreso a casa". El cuento reescribe, según Molloy, "Occurence at Owl Creek Bridge" de Ambrose Bierce. En ambos relatos Dios o una fuerza sobrenatural le concede a un hombre condenado a muerte un último deseo: en el cuento de Bierce, el condenado pide volver a su hogar junto a su familia; en el de Borges, terminar una obra de teatro. Molloy afirma "la conexión entre regreso a casa y la creación literaria puede ser, en última instancia, la gran contribución del retornante, puede ser la recompensa final del retorno" (34). El espacio natal al que vuelve Pichón está a medias fraguado entre los vestigios materiales y afectivos de la zona, y ese proyecto de poema en verso que le cuenta Tomatis, nueva "casa" en la que los amigos podrían volver a encontrarse. 


\subsection{El canto de Ulises}

Después de visitar la casa de Washington Noriega e inspeccionar el dactilograma que con tanto celo custodia su hija, Soldi, Pichón y Tomatis regresan en lancha a la ciudad. En el camino, Tomatis recita en italiano los versos 112 a 120 de "El canto de Ulises" que forma parte del "Infierno", canto XXVI de la Divina Comedia:

O frati, dissi che per cento milia perigli siete giunti a l'occidente, a questa tanto picciola vigilia d'i nostri sensi ch'è del rimanente, non vogliate negar l'esperïenza, di retro al sol, del mondo sanza gente.

Considerate la vostra semenza: fatti non foste a viver come bruti, ma per seguir virtute e canoscenza (Citado en Saer, La pesquisa 96). ${ }^{306}$

El fragmento poético interrumpe la descripción del paisaje cuando "la lancha navegaba, no en el río del anochecer, sino en una penumbra rojiza, extraña y grave" (95). En ese momento de pasaje lumínico y de indeterminación espacial, la moderna lancha del padre de Soldi se convierte, en la imaginación paródica de Tomatis, en la embarcación que llevaba a Ulises y sus compañeros más allá del mundo conocido. Efectivamente, el episodio que se cuenta en "El canto de Ulises" evoca la segunda salida del héroe después de haber regresado a su hogar, cuando, tentado por el ansia de conocimiento, abandona nuevamente a su familia y parte con una pequeña tripulación. Ulises, a través de la captatio benevolentiae, intenta convencer a sus compañeros de atravesar el Estrecho de Gibraltar, argumentando que no debían negarle a sus sentidos la posibilidad de la experiencia porque ellos, superiores a los animales, fueron hechos para perseguir virtud y conocimiento.

Nadie comenta el arrebato poético de Tomatis y la lancha comienza a aminorar la velocidad, buscando un lugar para atracar. Interesa, sin embargo, que en una novela sobre la vuelta de Pichón Garay y sobre el doble misterio a desentrañar - policial y literario- Saer retome precisamente la versión dantesca de Ulises, no la del héroe

\footnotetext{
${ }^{306}$ Se ofrece la siguiente versión, realizada por la profesora Claudia Fernández Speier, a cargo de la cátedra de Literatura italiana de la UNLP, que tuvo la gentileza de traducir este fragmento para la ocasión: "Oh hermanos", dije, "que a través de miles / de peligros han llegado al occidente / a esta vigilia nuestra tan pequeña/ de los sentidos que nos queda,/ no le quieran negar la experiencia/ de atrás del sol, del mundo sin gente./ Consideren su semilla:/ no fueron hechos para vivir como brutos/ sino para seguir virtud y conocimiento".
} 
paradigmático del regreso sino la del condenado en el infierno que encontró la perdición durante su último viaje por los confines del mundo. ${ }^{307}$ Así como en El limonero real, Saer ensayaba las formas paródicas de una Odisea criolla, fluvial y carapachaya en la cual Wenceslao efectivamente retornaba a su hogar después de un extenso periplo por el Paraná; en La pesquisa, Ulises es el que reniega de su hogar y se lanza al mar en busca de prodigios. Como advertía Cassin, el tiempo de la nostalgia es ese "todavía no" del héroe que, volviendo, aún no ha regresado. Una detención similar mantendrá a Pichón Garay entre las actualizaciones -átonas, opacas- del paisaje natal y la imaginación material que es capaz de instalar ese espacio en pleno departamento parisino. Distinta será, como se verá después, la versión de los nostoi y la reescritura exiliar de la Odisea que retome Saer para La grande.

Será precisamente aquí cuando se evoque por última vez la mítica vuelta de Pichón a la zona. El episodio, retomado más de una vez y resumido en pocas palabras: "Pichón había pasado un par de meses en la ciudad con el fin de liquidar los últimos bienes de la familia" (La grande 21), sirve por un lado para reponer algunos datos sobre la misteriosa figura de Willy Gutiérrez; permite incluir a Pichón en ese concierto final de personajes y contraponer, por supuesto, las figuras opuestas del regreso: "Como podrás comprobar, nuestros destinos son antagónicos: yo había venido a vender una casa, y él a comprar una" (Saer, La grande 21), le escribe Pichón Garay a Tomatis una semana después de regresar a París y de haberse cruzado por pura casualidad con

\footnotetext{
${ }^{307}$ En "El último viaje de Ulises", Borges retoma este episodio de la Divina Comedia y explica que la montaña entrevista por el griego y su tripulación es la santa montaña del Purgatorio, prohibida a los mortales. Los exégetas de la obra han comparado al Dante con Ulises y han establecido constantes y diferencias entre ambos. Borges advierte que así como los viajes de Ulises definen por completo al personaje, los de Dante no, porque su objeto final no es viajar sino hacer un libro. Según su usual operación de lectura, Borges se aparta de las discusiones teológicas que animaron la exégesis clásica de la obra para leer en esa comparación una preocupación de índole literaria. Para Borges, este episodio tiene que ver con los conflictos que le producía a Dante la publicación de su obra, una escritura no menos ardua ni arriesgada que el último viaje de Ulises. Y Borges insinúa una filiación interesante: "Devotas del mar y de Dante, las dos literaturas de idioma inglés han recibido algún influjo del Ulises dantesco" (388). Menciona en esa línea a Eliot, Andrew Lang, Longfellow y Tennyson. El Ulises infernal por supuesto también se conecta con el Ahab de Moby Dick. Un movimiento típico de Borges que universaliza los motivos, vinculando en una "Posdata de 1981" al Ulises dantesco con los "famosos exploradores que arribarían, siglos después, a las costas de América y de la India. Siglos antes de la escritura de la Comedia, ese tipo humano ya se había dado. Erico el Rojo descubrió la isla de Groenlandia hacia el año 985. [...] Dante no pudo saber esas cosas. Lo escandinavo tiende a ser secreto, a ser como si fuera un sueño" (389). Interesa esta lectura "irreverente" porque efectivamente el modesto periplo fluvial que emprendieron Pichón, Tomatis y Soldi no sólo implica un "viaje" sino sobre todo, un "arriesgado" e incierto hallazgo literario.
} 
Gutiérrez en el avión a Buenos Aires, donde este le cuenta que ha vuelto al país para comprar una casa en Rincón y mudarse definitivamente a la zona. 


\section{LOS REGRESOS DE JUAN JOSÉ SAER}

Desde 1982, o sea después de la Guerra de Malvinas y de la declinación del poder militar en la Argentina, vengo sometiéndome, una o dos veces por año, a esa gimnasia. [...] El mito de reencontrar los afectos y los lugares de mi infancia y de mi juventud me incitó a efectuar esos viajes repetidos que se han transformado, después de casi una década, en una costumbre (Saer, El río 11-12).

Así describe Saer "la gimnasia" de sus regresos al país, antecedidos y proseguidos por los mismos rituales de despedida parisina y bienvenida argentina, generalmente en primavera. Un viaje, advierte Gramuglio, que por sus constantes le confiere a la vuelta del escritor algo del "eterno retorno, con su promesa engañosa de abolición del tiempo" (El lugar de Saer 77). Se sabe que en 1976 Saer había viajado por última vez a Argentina junto a su mujer en medio del clima opresivo que acababa de imponer la dictadura y que había elegido camuflarse como sujeto extranjero hablando en francés. ${ }^{308}$ Recién seis años después, cuando comienza a declinar el poder militar, como él mismo señala, regresa para reencontrar los afectos y los lugares de su infancia. Una motivación doble, entonces, política y afectiva, lo hace volver. La motivación profesional de sus regresos queda al parecer silenciada o al menos elidida de ese relato "mítico". En "La música de las palabras", Alan Pauls repone ese otro motivo:

Aunque temporariamente, Juan José Saer está de vuelta por estos pagos, y otros aires parecen soplar, hoy, alrededor de su obra.[...] Pero si Saer está de paso por la Argentina, no es sólo para cosechar estos módicos frutos de la gloria literaria, reencontrase con amigos, visitar su provincia ('Nací en Serodino!' se jacta, fervoroso) y padecer reportajes: el motivo de este ritual, que Saer repite con cierta regularidad cada dos años, es la aparición de su última novela, Glosa, con la que la editorial Alianza inaugura una colección de escritores argentinos" (Una forma más real 69).

\footnotetext{
${ }^{308}$ Saer había estado en un congreso en Colombia a principios de 1976 y llegó a Argentina el 24 o el 25 de marzo de ese mismo año. En 1975 Gramuglio se había exiliado en Buenos Aires y se encontró con Saer en su departamento porteño. El escritor estaba preocupado por Antonio di Benedetto y hablaba en francés para camuflarse como escritor extranjero. En la entrevista que mantuvieron con Gramuglio hablaron sobre El arte de narrar y sobre la posibilidad de difuminar los límites genéricos entre prosa y poesía. En la reseña que Rosa Boldori escribe sobre Cicatrices en mayo de 1976, "Experimentación y Apocalipsis en Cicatrices de Saer", puede encontrarse una referencia a dicha entrevista. Fue Martín Prieto quien nos permitió reconstruir esos días de la vuelta de Saer al país en 1976 durante las clases dictadas en el marco del seminario "Juan José Saer en la historia de la literatura argentina" en el mes de septiembre de 2017 en la Universidad Nacional de Rosario.
} 
Saer volvía al país también para presentar sus libros y participar de la vida literaria. Como ha argumentado la crítica que se encargó de leer la recepción del escritor en Argentina, la década del ochenta marcará una importante inflexión en la valoración de su figura y los regresos al país contribuirán, aunque siempre de manera resistente, a su progresiva afirmación. Si bien durante la década del setenta, como asegura Dalmaroni, el nombre de Saer está prácticamente ausente en la prensa cultural argentina, los intelectuales y amigos de Saer preparan su "regreso" desde las páginas de Los Libros y sobre todo desde Punto de Vista, que acompaña puntualmente la publicación de sus obras con elogiosas reseñas críticas. En los ochenta el CEAL comienza a reeditar varios textos de Saer y se suma al reducido núcleo de amigos y persistentes lectores, un nuevo grupo de jóvenes que se reunían a discutirlo en los encuentros coordinados por Beatriz Sarlo, Josefina Ludmer y Nicolás Rosa. Además del premio "Boris Vian", otorgado a Saer en 1982, la década se caracteriza por la incorporación de varias de sus obras en los programas universitarios de literatura argentina, un movimiento que multiplicó el lectorado y culminó en el Coloquio dedicado al escritor celebrado en la Facultad de Humanidades y Artes de la UNR en 1987. En 1986 Saer había publicado Glosa en la editorial Alianza con quien sería su editor casi exclusivo a partir de ese momento, Alberto Díaz: “Glosa [...] inicia una etapa de profesionalización creciente en la trayectoria del escritor, de la mano de un aumento tanto de las tiradas de sus ediciones como de la presencia de Saer y de sus obras en los medios de prensa no estrictamente especializados" (Dalmaroni, "El largo camino del silencio al consenso" 660). ${ }^{309}$

Gran parte de las entrevistas que se realizan en el país comienzan en general apuntando que, una vez más, el escritor ha regresado. Saer solía quedarse en la casa de sus amigos María Teresa Gramuglio y Juan Pablo Renzi durante sus estadías en Buenos Aires. Después de la muerte del pintor en mayo de 1992, comienza a hospedarse en la casa del santafecino y cineasta Nicolás Sarquís. Varias entrevistas se realizan en estas casas, pero también en el café de La Paz, en el vestíbulo de algún hotel o en el Puerto. En general, los entrevistadores comienzan retratando a Saer: sus rasgos árabes, su humor campechano, su amabilidad y su reticencia a hablar de temas que no sean estrictamente literarios, a los que responde con rigor y cautela, sopesando sus afirmaciones con matices y mostrando los tanteos de su pensamiento. Si pudiera

${ }^{309}$ Siempre que se cita este artículo de Dalmaroni se lo toma de la edición crítica de Glosa-El entenado, de la Colección Archivos coordinada por Julio Premat. 
trazarse un rápido muestrario de las obligaciones profesionales que lo traen al país podríamos señalar las siguientes: en 1983 participa de una charla a la que lo invita Sarlo junto al grupo de estudios que coordinaba en una oficina del CEAL, allí lo entrevistan Mónica Tamborena y Sergio Racuzzi (Sergio Chejfec); en 1986 viaja para la presentación de Glosa en el Hotel Bauen de Buenos Aires junto a Ricardo Piglia; en 1988 viene a presentar La ocasión; regresa en 1994 para asistir a un encuentro junto a Piglia en el Foro Gandhi y además para presentar su nueva novela, La pesquisa. Ese mismo año participa de la filmación Retrato de Juan José Saer que preparaba Rafael Filippelli, proyecto que se lleva a cabo en París, Buenos Aires y Colastiné Norte, en casa de Marilyn Contardi y Raúl Beceyro; en 1998 Saer viaja para participar como jurado en el Festival Internacional de Cine de Mar del Plata y para brindar una conferencia, "Aspectos del relato de ficción” en el Teatro del Centro cultural Parque de España de Rosario; en 1999 llega al país apenas unos días antes de la edición de su nuevo libro de ensayos La narración-objeto; en el 2000 viaja a Rosario para participar en el VIII Festival Internacional de Poesía y es invitado a programas televisivos (Los siete locos); en 2002 participa de una entrevista abierta en el marco de la $V$ Bienal de Arte Joven de Santa Fe; en 2004 Fernando García recorre junto a él las zonas de sus ficciones, en una vuelta que denomina "el safari Saer"310 y a fines de 2004, participa de un diálogo con el público en el que repasa su trayectoria en el marco de unas jornadas en torno a su obra organizadas por el MALBA. En 2005, recuerda Gramuglio, Saer les seguía anunciando a sus amigos y afectos su próxima visita en primavera, aun sabiendo que estaba atravesando la terrible enfermedad que lo llevaría a la muerte ese mismo año, imposibilitando para siempre sus regresos, y cerrando ese efecto de "eterno retorno" que su amiga creía percibir en sus sucesivas vueltas. Ese viaje, continúa Gramuglio, sería muy especial: “[Saer] presentaría su nueva novela, La grande, una de las más altas apuestas de su proyecto narrativo; en Santa Fe recibiría un título honorífico en la Universidad Nacional del Litoral; la ciudad de Rosario lo declararía huésped ilustre" ( $E l$ lugar de Saer 80).

Este somero mapa de sus regresos, para nada exhaustivo, busca mostrar que efectivamente la figura de Saer, incluso a su pesar, comenzaba a cristalizarse hacia la década del noventa y principios del 2000 (la metáfora "Safari Saer" es suficientemente

\footnotetext{
310 "Hay que explicar este safari Saer. Vinimos hasta Santa Fe [...] para recorrer, junto con el escritor, Colastiné, playa Rincón, Santa Fe y Serodino. Un día entero por los escenarios de su vida y ficción. Y después, el regreso a Buenos Aires, en la ruta con uno de los mejores escritores vivos de la Argentina" (García, Una forma más real 183).
} 
escandalosa al respecto). Sin embargo, como ha advertido Graciela Speranza, el escritor es "un extranjero inasible de vuelta en la casa natal. Tal vez por eso conversa con la familiaridad de quien se reconoce en el espacio y la lengua propios y al mismo tiempo deja entrever cierta distancia: la mirada sesgada de un viajero inglés del siglo pasado, o mejor, la ironía provocadora de Gombrowicz" (en Speranza, Una forma más real 95). Podría leerse, entonces, detrás de los hitos que apuntalan su afirmación pública, (una afirmación siempre resistente, cuyo valor en gran medida es ese carácter refractario), ${ }^{311}$ una escritura íntima del regreso a partir de la cual Saer ensaya figuraciones más inusuales que le permiten, como se verá, mantener una relación de proximidad deliberadamente distanciada y un tanto extranjera con respecto al territorio de su infancia y de sus afectos.

\subsection{Las libretas de viaje y El río sin orillas: apuntes para una memoria del lugar}

Efectivamente, los regresos del escritor quedan apuntados en unas pequeñas libretas de viaje que Saer comenzó a utilizar desde 1982 hasta el año $2000,{ }^{312}$ en las que hacía observaciones sobre sus viajes por América Latina y algunas regiones de Francia pero donde fundamentalmente inscribía sus visitas al país. Utilizadas en general para la anotación en vivo, estas libretas acopian una gran cantidad de apuntes y bocetos e incorporan los más diversos tipos textuales: instrucciones de escritura, citas, pensamientos, borradores de poemas y de cartas, registros del natural, impresiones urbanas, notas preparatorias para novelas y ensayos. Como señala Sergio Delgado en la "Presentación" que hace de ellas, se trataba de cuadernos de formato de bolsillo que Saer utilizaba en sus paseos para la anotación rápida, en vivo. En varias entradas él mismo reconoce estar escribiendo en algún medio de transporte en movimiento y por lo tanto su escritura se vuelve irregular o poco legible. Se sabe además que conservó las

\footnotetext{
${ }^{311}$ Es el argumento que utiliza Matilde Sánchez para hacerlo hablar en "La literatura es objeto y misterio": "Con anotaciones para dos novelas simultáneas y ganas de comprar libros recién editados por autores argentinos, Juan José Saer vino a pasar un mes al país y repartió su tiempo entre Buenos Aires -en su caso esto significa una mesa del bar La Paz- y su ciudad natal, Santa Fe. Aunque se resiste a los reportajes ('no tengo nada que decir, además siempre prefiero ser discreto'), no fue difícil convencerlo con el argumento de que alguna indiscreción esporádica haría más notoria su ausencia en los medios argentinos" (Una forma más real 38).

${ }^{312}$ La fecha de la primera de las libretas, 1982, coincide con el primer viaje que Saer realizó después de haber vuelto a la Argentina en marzo de 1976. Se desconoce por el momento si el escritor llevaba "libretas de viaje" similares en años previos.
} 
libretas mucho tiempo y que al menos una de ellas estaba bastante deteriorada y podemos imaginárnosla saliendo de ese "cajón" que el escritor ha volcado sobre la mesa de trabajo a la hora de escribir otro texto heterogéneo que también se trama al calor de sus regresos: El río sin orillas. Allí anota sobre ese carácter mezclado: “abro el cajón [...] y me pongo a buscar los residuos más sugestivos, para organizarlos después con un orden propio [...] un híbrido sin género definido" (Saer, El río sin orillas 17).

Las libretas se vuelven de ese modo un residuo de anotaciones e impresiones a las que Saer siempre regresa para confirmar alguna apreciación sobre el paisaje, pero fundamentalmente para notar que las percepciones, ideas y asociaciones que le trae regresar al país, ya las había anotado previamente, y más de una vez, en sus cuadernos de viaje: "y, como de costumbre, al sacar la libreta de apuntes para anotar en ella [...] algún pensamiento inédito, he descubierto que ya lo había consignado en algún viaje anterior" (Saer, El río sin orillas 21). Carácter paradojal de una escritura que, destinada a captar lo imprevisto y lo inédito, parece "haber ya sido escrita", aspecto iterativo que no sorprende en el proyecto literario saeriano y permite incorporar estos textos al resto del corpus que también se desarrolla a partir de reiteraciones y variaciones.

Entre la vida y la escritura las libretas de viaje ocupan un lugar intersticial: se abren a lo íntimo (ya veremos de qué clase de intimidad se trata) y a la vez, esa materia recién nacida de la intimidad exhibe su proceso de transformación y su pasaje a la ficción. Las libretas se configuran en varias entradas como un espacio de trabajo cotejable con las ficciones que Saer estaba escribiendo en paralelo. ${ }^{313}$ Pero a la vez, esta

\footnotetext{
${ }^{313}$ Si se tiene en cuenta el extenso período en el que Saer utilizó estas libretas se podrá observar que no sólo permiten reconstruir fragmentariamente algunos de los viajes del escritor sino también las búsquedas, lecturas, anotaciones y tanteos previos para futuros ensayos y novelas. Allí encontramos algunas de las poesías que luego incorporará, con mínimas variaciones, en $E l$ arte de narrar; reflexiones y apuntes para sus ensayos sobre viajeros como Gombrowicz y Sarmiento; observaciones que luego formarán parte de novelas como Glosa, Lo imborrable y La grande, incorporadas a veces directamente como el pensamiento de alguno de los personajes o bien como precisiones acerca del sentido de sus textos. En El lugar de Saer Gramuglio insistirá en leer los borradores (entre los que encontramos las Libretas) como un espacio de trabajo con la forma, una "fábrica", metáfora que toma de Schklovsky y que le sirve para oponerse a la lectura que habían ensayado Monteleone y Gola sobre cierta epifanía mística de la escritura poética en Saer: "no iluminaciones radiosas e irradiantes, sino el arte sombrío, trabajo, búsqueda, experimentación" (Gramuglio, El lugar de Saer 125). La libreta que llevará Nula en La grande podría leerse como una puesta en abismo de la práctica que el propio escritor ejercitó durante años. Allí el personaje anota todo lo que cree podría servirle para escribir su futura Ontología del devenir: no solo reflexiones filosóficas sino también evocaciones de su infancia en el campo y apuntes sobre la percepción del paisaje y de la naturaleza: "El caos percibido como armonía por deficiencia sensorial. Vuelo de mariposas. [...] Ilusión óptica y realidad exterior (Horizonte, paralelas, etc.)" (Saer, La grande 182).
} 
escritura se sitúa en un segundo espacio de intercambio, entre la experiencia del regreso del escritor y los modos de percibir el paisaje nacional de los viajeros sobre los que Saer estaba escribiendo y reflexionando. Vida y trabajo, experiencia perceptual de Saer y de los viajeros quedan, por supuesto, anudados, compuestos de las mismas fibras.

En "Escribir el regreso" Luigi Patruno trabaja con las "Notas en vivo (sep-oct. 1982)" que Saer extrajo de una de sus libretas y utilizó como material preparatorio para Glosa. Atendiendo a este recorte, Patruno no lee estas "Notas" como un diario de viaje sino como "otro" libro de Saer que podría figurar autónomamente en su obra y que se configura como espacio de experimentación lingüística, despliegue de estrategias autofigurativas e interrogación por la novela en preparación. Patruno indagará fundamentalmente las tonalidades íntimas que podrían desprenderse del acto mismo de anotación, aunque las notas parezcan negar la efusión intimista. Señala, asimismo, que el diario de Saer no funciona al modo de un diario convencional en el que un escritor podría configurar su imagen de autor consagrado puesto "que el yo autoral se borra y se desvanece en los matices de las impresiones" (Patruno 75); una estrategia de "desmontaje autoral" que Premat ya había advertido en operaciones previas de Saer y que pueden rastrearse en "Una concesión pedagógica”, de Juan José Saer por Juan José Saer, que según Premat obedece a un imperativo estético: borrar la vida privada para que los textos se juzguen por su valor literario.

Efectivamente, son escasas las menciones en las que Saer cuenta qué sensaciones le produce regresar al país o encontrarse con viejos amigos y familiares: "Atmósfera matinal en el avión, temperatura agradable, sol tempranero. [...] En un determinado momento, no sé por qué, me sentí allá (en la infancia) en alguna mañana arcaica de Serodino. Goce fugaz" (Saer, Libretas 304). Si seguimos el razonamiento que el propio Saer hace en "La perspectiva exterior", podríamos pensar que estas son las libretas que lleva de viaje un escritor y no un hombre. En el mencionado ensayo Saer advierte con admiración que el Diario argentino de Gombrowicz se ocupa muy poco de la vida íntima de su autor porque el interés de sus páginas radica en que trata menos de acontecimientos que de problemas. ${ }^{314}$ Saer distingue al hombre del artista y señala que el verdadero escritor no puede definirse a sí mismo como comunista, ni liberal, ni individualista, ni polaco, ni francés ni argentino, porque ser definible en algún aspecto

\footnotetext{
${ }^{314}$ Gombrowicz, según afirma Giordano en Una posibilidad de vida: Escrituras intimas, es quien clausura la época de la literatura intimista a través de la "insincera sinceridad" de su Diario.
} 
del reparto de roles sociales es privilegio de hombres, pero no de artistas: "La certeza de esa desnudez no sólo orienta o preside, sino que incluso es la justificación última de su trabajo" (Saer, "La perspectiva exterior", El concepto de ficción 17).

Por ese motivo, la escritura heterogénea de las libretas se inscribe, difusamente, entre diversos géneros del yo -el diario de viaje, el diario de escritor, el borrador- ${ }^{315}$ sin adscribir completamente a ninguno; y anuda los regresos de Saer a las derivas de la intimidad. ${ }^{316}$ Diversos escritores y críticos han reflexionado sobre esta problemática. ${ }^{317}$ Más allá de las diferencias de sus textos, la intimidad se verifica como un espacio que escapa a la dicotomía entre lo público y lo privado ${ }^{318}$ no involucra la identidad ni la introspección sentimental de la subjetividad porque cada vez que acontece lo íntimo, un

${ }^{315}$ Las escrituras del yo, el giro subjetivo y las indagaciones sobre lo íntimo han despertado el interés de la crítica (Adolfo Prieto, Alberto Giordano, Nora Catelli y Silvia Molloy, entre otros). Según han señalado varios especialistas en Saer y se ha comentado a lo largo de esta tesis, el escritor se sustrae de la voluntad autobiográfica, asordina su figura pública y multiplica las proyecciones del yo en un haz muy heterogéneo de personajes históricos y ficcionales. Sin embargo, hay instancias que concentran una reflexión sobre los modos, aunque oblicuos y velados, en que cristalizan ciertas experiencias biográficas. En Una posibilidad de vida: Escrituras intimas, Giordano definirá el "diario de escritor" (como el que llevan Gide, Pavese, Cheever y Musil) como aquel que se escribe a sabiendas de que en algún momento será publicado pero que además es imaginado como parte de la obra de un escritor. No es exactamente este el caso de Saer, cuyas libretas no fueron escritas con ese propósito, pero algunas de las características señaladas por Giordano podrían pensarse para Saer, en relación a la "perspectiva literaria" que rige las anotaciones de este tipo de escritura. El diario de Barthes, por ejemplo, sin renunciar al registro de lo íntimo, expone el encuentro de notación y vida desde una perspectiva literaria y desde allí interroga el valor y la eficacia del hábito. La práctica del diario les plantea a los escritores problemas específicos de técnica literaria, en relación a la posibilidad que tiene el lenguaje para capturar fragmentos de vida, así como también problemas vinculados a los riesgos de la autofiguración. Por otro lado, de los diferentes tópicos y atributos que caracterizan al género del diario, Nora Catelli advierte que la secuencia cronológica de la escritura es quizás el más importante. En una nota suelta incluida en Los papeles de trabajo II Saer reflexiona sobre la escritura de diarios íntimos y cuestiona su estructura, "calada sobre el tiempo lineal" (98), que oculta la verdadera naturaleza del tiempo -caótico, inasimilable, ciego y anónimo-, concepción temporal que efectivamente funciona en la escritura de sus libretas, cuya frágil cronología se disuelve en las reiteraciones, obsesiones y azarosas observaciones del escritor.

${ }^{316}$ Patruno retoma, para pensar esa veta "íntima" de las libretas, algunas reflexiones de César Aira y Alan Pauls, que acá también serán retomadas, junto a otras formulaciones.

317 Cfr. Catelli, Nora. En la era de la intimidad: seguido de El espacio autobiográfico; Giordano, Alberto. La contraseña de los solitarios: Diarios de escritores, Una posibilidad de vida: Escrituras intimas y Vida y obra: Otra vuelta al giro autobiográfico; Aira, César. "La intimidad" y Alan, Pauls. "El fondo de los fondos".

${ }^{318}$ En "La intimidad", César Aira advierte que el "derecho a la privacidad" sigue funcionando en relación a lo público, y es en cambio "por fuera de este reconocimiento, en el margen interno del destino individual que escapa a la factura general de la Historia, [donde] estaría la especificidad de lo íntimo" (3). 
reducto de extrañeza y de indeterminación irrumpe la figuración de quien escribe; ${ }^{319}$ la intimidad es entonces separación pero también, como apunta Alan Pauls en "El fondo de los fondos", proximidad, contemporaneidad y aleación con el presente:

¿cuál es el núcleo crucial, la parte íntima de la intimidad que el diario toca? [...] Se podría decir, en principio, esto: algo tan antiguo y tan pasado de moda como una relación de proximidad. Como la intimidad, fundada en el sueño de una distancia en grado cero, todo diario es un sistema de producción de cercanía, de vecindad, incluso de contemporaneidad. Democrático y voraz, el diario íntimo se permite incorporarlo todo: lo banal y lo extraordinario, lo personal y lo histórico, lo insignificante y lo admirable (Pauls, "El fondo de los fondos" $\mathrm{s} / \mathrm{p}$ ).

De hecho, advierte Pauls, cuando Roland Barthes revisa su diario, se deleita sobre todo reencontrando lo que él mismo denomina "inflexiones", las contingencias medio fantasmales que habían capturado una luz, una temperatura, una calidad del aire. Este sería el tipo de "intimidad" saeriana, no confesional, no determinable según algún tipo de categorización social previa, sino más bien un tipo de aproximación que, según veremos más adelante, también guarda relaciones con el haiku. Interesa en ese sentido pensar las libretas de Saer a partir de una pregunta que Giordano toma de Canetti: “¿Qué acciones y qué pasiones despierta la práctica del diario cuando la sostiene alguien que 'escribe muchísimo'?” (La contraseña de los solitarios 49), porque lo que importante ya no es sólo el carácter documental del escrito sino la figura del diarista que va componiéndose y descomponiéndose en el ejercicio de la notación incidental.

Las libretas forman parte de una "escritura tardía" en la trayectoria de Saer. Si efectivamente, como propone Dalmaroni en "La vuelta incompleta", el momento de mayor descomposición experimental "negativista" se produce entre El limonero real (1974), La mayor (1976) y Nadie nada nunca (1980) y luego su poética se va atemperando y encontrando las formas de un regreso, vuelta que se termina de completar en La grande, sería posible comprender la escritura de estas libretas en ese momento de clivaje señalado por el comienzo de la escritura de Glosa (1982) y la publicación de El entenado (1983). Al respecto, Premat y Chejfec coinciden en que es a partir de esta novela cuando se produce una reorientación de la producción de Saer que llega para darle un "relato fundador" a la zona y reinventar lo propio: la figura de autor y el lugar de lo narrado.

319 Según consigna Giordano retomando a Luis Pardo, lo íntimo "Tiene que ver con la manifestación de una distancia indecible que impide tanto identificarse, apropiarse sin restos de uno mismo, como ser identificado; una distancia que fuerza la enunciación, hace hablar o escribir, y transforma secretamente cualquier performance autobiográfica en una experiencia de la propia ajenidad" (Una posibilidad de vida 206). 
En este sentido, estos textos resultan claves para comprender cómo se transforma la idea de "zona" en la producción tardía del escritor. Como se sabe, en general se ha enfatizado el carácter "imaginario" y ficcional de la "zona" como un espacio eminentemente "literario". El mismo Saer se ha encargado de privilegiar esta lectura y ha señalado en su ensayo sobre Onetti: "el territorio en el que un narrador instala sus ficciones, solo tiene un parentesco lejano con el espacio o la geografía habitados por los seres de carne y hueso que chapaleamos en lo empírico" (Saer, "Sobre Onetti y La vida breve", Trabajos 240-241). Sin embargo, cuando Julio Premat se interroga por la “zona" y retoma los documentos preparatorios para la escritura de Glosa o La grande, encuentra entre las libretas de viaje a Santa Fe anotaciones sobre el clima, la vegetación y los modos de hablar, e identifica esa vertiente evidentemente referencial que había quedado un poco soslayada, un "parentesco" entre el territorio de las ficciones y el espacio de Santa Fe y sus alrededores que, señalará Premat, aunque pueda ser "lejano", aumenta en las obras posteriores del autor. ${ }^{320}$

Pero además, las libretas forman parte fundamental del "corpus del regreso" del escritor. En el ya clásico texto Travel as metaphor, Georges Van Den Abbeele señala que en la economía de todo viaje el punto de partida nunca coincide con el punto de retorno, y ese oikos, paradójicamente, puede provocar la mayor desorientación una vez que se ha producido el desvío del viaje. Las libretas de Saer revelan qué sucede cuando el espacio natal se convierte, a partir de una "perspectiva exterior", en otro viaje hacia lo "desconocido" o hacia lo parcialmente olvidado. El río sin orillas, como se verá, también participa de este grupo de textos. No sólo tematiza la experiencia del retorno e inscribe lo autobiográfico como uno de los modos del ensayo, sino además explicita, multiplica y abre la biblioteca de viajeros sugerida en las Libretas. Por ese motivo, en algunos pasajes se intentará pensar el regreso del escritor en ese terreno fangoso que se forma entre las notas sueltas de las Libretas y la forma desplegada y ordenada de El río

\footnotetext{
${ }^{320}$ En "El largo camino del silencio al consenso", Dalmaroni explica este énfasis en relación a las obsesiones críticas que se fraguaron alrededor de las ideas de "autorreferencialidad" e "intertextualidad" y que privilegiaron la atención sobre la zona de acuerdo a esta lectura: "no parece casual al respecto que la crítica de entonces haya preferido explicarse (cuando lo hizo) las recurrencias saerianas a 'la zona' y a un grupo de personajes tan reconocibles y definidos, en tanto reescrituras de Faulkner o de Onetti, es decir en términos de intertextualidad. [...] La cuestión resulta iluminada por lo que propone Florencia Garramuño cuando asocia el paso de ese predominio de la lectura intraliteraria y autorreferencial a la posibilidad de una lectura de la representación de la experiencia, con el momento del proyecto saeriano que representan $E l$ entenado y Glosa" (647).
} 
sin orillas que en varios casos retoma esas anotaciones y las incorpora en una argumentación mayor.

Tanto los cuadernos como el largo "tratado imaginario" permiten reponer esa proximidad deliberadamente distanciada que Saer estableció con la región a partir de una serie de proyecciones más inusuales, resistentes y anacrónicas con respecto a las cristalizaciones que, cada vez con mayor asiduidad y entre un público cada vez amplio, habían comenzado a congregarse alrededor de su figura. Así Saer pareciera tomar notas sobre los paisajes, la flora, la fauna, las condiciones climáticas y los modismos del habla como lo haría un extranjero, munido de los conocimientos que había leído en los libros de viaje. Modos difusos y no programáticos de volver que podrían leerse en relación a ciertos protocolos de observación practicados por naturalistas y topógrafos que tempranamente formalizaron los aspectos más singulares del paisaje nacional; pero también próximas al lingüista y al etnógrafo interesados en registrar formas coloquiales del habla y situaciones de la cotidianeidad social de una comunidad.

\section{Saer como naturalista amateur}

Entre las anotaciones para futuros textos, las impresiones urbanas y la captura de los matices cromáticos del Paraná, las libretas de Saer registran con intensidad la flora, la fauna y las condiciones climáticas de la zona, apelando al poder de observación del escritor. Sorprende en principio encontrar no sólo una descripción minuciosa de los especímenes naturales de la zona sino también la incorporación de vocabulario científico y de ciertos criterios de observación naturalista que Saer parece seguir como un naturalista aficionado, retomando fundamentalmente a W. H. Hudson.

Como señala Foucault en Las palabras y las cosas, "la historia natural no es otra cosa que la denominación de lo visible" (148) y el naturalista es, según Linneo, "[quien], 'distingue por la vista las partes de los cuerpos naturales, los describe convenientemente según el número, la figura, la posición y la proporción, y les da nombre' " (178). Efectivamente, en muchos de los pasajes que encontramos en las libretas, Saer se encarga de nombrar a las especies vegetales y animales que se cruza en los diversos desplazamientos que realiza por paisajes urbanos y naturales, adosándoles su nombre científico y describiendo con exactitud las ocurrencias cromáticas de flores y pájaros. Puede leerse por ejemplo: "Retama amarilla: Fam. Leguminosas Spartium 
junceum" (Saer, Libretas 290) o "Bignoniáceas. Jacarandá mimosifolia. Jacarandá Tarco NO argentino (Plaza España)" (Libretas 292), resabios linneanos de clasificación botánica que pueden en principio sorprender pero que paulatinamente se vuelven parte de un fragmentado diario de naturalista que Saer va incorporando en sus libretas. ${ }^{321}$

El "visible" constituido por la historia natural, continúa explicando Foucault, tenía sus limitaciones y restricciones formales. En primer lugar, durante el siglo XVII se subordinan los sentidos de la percepción al sentido privilegiado de la vista y se restringe su dominio a la faz superficial, por lo cual sólo era posible describir a los seres vivos a partir de 'objetos filtrados': líneas, formas y relieves, un tipo de composición que incluso desestimaba la importancia del color como elemento útil. En segundo lugar, la historia natural se caracteriza por suturar el hiato entre las palabras y las cosas a partir de una red precisa de nombres, una clasificación que "vuelve visible" la naturaleza a partir de la conformación de un "sistema" que reúne en una serie de rasgos limitados las constantes y las variaciones de las especies: "la historia natural es contemporánea del lenguaje, [...] fija los elementos comunes e impone, por último, los nombres. Clasificar y hablar tienen su origen en ese mismo espacio que la representación abre en el interior de sí misma" (Foucault, Las palabras y las cosas 176).

Si la literatura de Saer puede ser leída como una insistente problematización de lo real y un trabajo exhaustivo y experimental sobre ese hiato existente entre mundo y lenguaje, podría parecer extraño en principio esa irrupción naturalista y ese afán por nombrar y clasificar que atraviesa su escritura. Un sugestivo fragmento de El río sin orillas acerca algunas claves para comprender este afán taxonómico:

El inmenso obelisco de cemento que adorna [la avenida Corrientes] no constituye para mí su atracción principal, sino los palos borrachos (choricia speciosa), con sus troncos inflados y espinosos de un verde claro, árboles de los que no he podido todavía, mediante la observación directa, deducir el ciclo de floración, ya que he visto ejemplares florecidos en diferentes épocas del año [...] lo que

${ }^{321}$ Carl Von Linneo (1707-1778) se formó como científico, médico y botánico en Suecia y Holanda y formuló su sistema en tres obras claves: Systema naturae (1735), Fundamenta botánica (1736) y Classes plantorum (1738). Allí estableció los fundamentos para el esquema moderno de la nomenclatura binomial (que caracteriza a los seres vivos según dos nombres, el nombre del género y el nombre específico) y que fue inicialmente pensado para el reino vegetal y luego adaptado por Linneo para el reino animal. A mediados del siglo XVIII era reconocido como el principal naturalista de Europa. Su sistema fue muy difundido por la gran cantidad de discípulos que viajaron por distintas partes del mundo con el fin de recolectar muestras y especímenes. Como señala Penhos (2005), las ideas y debates que se produjeron en el terreno de la historia natural en Europa repercutieron profundamente en la obra de los demarcadores en Sudamérica. 
confirma una anotación anterior en mi libreta de apuntes: ' 4 de abril. Av. 9 de Julio a las 11.45. En taxi. Palos borrachos florecidos (rosa, blanco, marfil). Acacias o tipas muy verdes todavía' [...]. En las ciudades del litoral [...] tres grandes árboles se disputan el estrellato estético cuando avanza la primavera, y florecen en este orden: el lapacho, cuyo nombre científico se me escapa, la acacia amarilla, lo bastante frecuente en Europa como para que el nombre latino que la identifica merezca ser mencionado, y el jacarandá o jacarandá mimosifolia... (Saer, El río 26-27).

El primer gesto de Saer es correr la mirada del ícono turístico de la ciudad capital -el Obelisco- para centrar su atención en la variedad de árboles que crecen en Avenida Corrientes. Como él mismo lo explica en la introducción, El río sin orillas fue un libro por encargo dirigido principalmente a lectores europeos, por lo tanto el escritor se ve en la necesidad de explicar algunos rasgos del paisaje rioplatense que serían evidentes para el lector argentino. ${ }^{322}$ En este sentido, la incorporación de la clasificación linneana parece funcionar como una lengua franca que comparten sus lectores americanos y europeos, porque como señala Foucault, por sobre la lengua cotidiana, la historia natural construye un edificio lingüístico en segundo grado en el que reinan "los Nombres exactos de las cosas", un lenguaje que no le deja lugar a la incertidumbre y desplaza hacia los márgenes de la "litteraria" 323 todo lo que se imaginaba y se fabulaba, los saberes populares sobre el objeto. Así se entiende, en primera instancia, la inclusión de los nombres latinos de las diferentes especies de árboles, una taxonomía dirigida al parecer para los "lectores idiotas", así los llama, en el sentido de "profanos".

La inclusión de la taxonomía linneana se justifica de este modo en el prolongado ensayo que le dedica al Río de la Plata, aunque resulta un tanto más enigmática en una libreta cuyo destinatario era el mismo escritor. ${ }^{324}$ En varias oportunidades será él quien busque, mediante la observación directa, determinar el ciclo "anómalo" de floración de los árboles mencionados, autofigurándose como un naturalista amateur que exhibe en

${ }^{322}$ Es preciso aclarar que luego relativizará esta clasificación entre lectores europeos y argentinos o entre especialistas y profanos para terminar señalando que su libro "no se dirige a ningún lector en particular" (Saer, El río 20) aunque por momentos se detenga a explicar algunos términos específicos, como el de "boleadoras", "para el lector idiota -que puede ser también rioplatense-" (48) o precise distancias geográficas entre pueblos de Santa Fe.

${ }^{323}$ Esto puede observarse en la clasificación ideada por Linneo, para quien cualquier animal podía ser descripto a partir del siguiente orden: nombre, teoría, género, especie, atributos, uso y, para finalizar "litteraria". Es decir, todo lo que se había dicho, se imaginaba y fabulaba sobre ese ser vivo quedaba desplazado hasta el límite de la clasificación.

${ }^{324}$ Aunque puede entenderse, claro, que al menos ciertos fragmentos de las libretas funcionaron como el espacio de trabajo y de acopio de vocabulario que después incluiría en los textos editados como El río sin orillas. 
sus libretas las deducciones que saca y el proceso mediante el cual se apropia del vocabulario científico: "braquicéfalo $=$ de cráneo redondo/ Dolicocéfalo $=$ de cráneo ovalado" (Saer, Libretas 298). Sin embargo, como se verá, la operación naturalista ensayada ocasionalmente por Saer excede y problematiza ese "visible" restringido y esa lengua "neutra" de la historia natural para incorporar y traer a un primer plano eso que había quedado desplazado por la taxonomía linneana (la "litteraria"). Saer no persigue ningún interés utilitario cuando identifica plantas y animales o determina ciclos de reproducción y floración. Pero hacerlo, incluso obsesivamente, le permite refundar las coordenadas espaciales y temporales del paisaje natal. La contemplación "naturalista", como se verá, constituye una forma de volver a calibrar la percepción sobre la flora, la fauna y los fenómenos meteorológicos de la región sobre los que nunca dejará de escribir.

\section{Otro naturalista en el Plata}

En "La perspectiva exterior", cuya notas preparatorias aparecen en la segunda de las libretas de viaje, Saer postula que es precisamente esa "perspectiva exterior" el modo en que la cultura argentina se relaciona con Occidente pero también la mirada que moldeó las primeras impresiones sobre nuestro paisaje:

Esa literatura de viajeros es contemporánea a la aparición misma del país [...]. Félix de Azara, Millau, Mac Cann, Woodbine Hinchliff, Alfred Ebelot, [...] Albert Londres, el incomparable W.H. Hudson, que idolatraba hasta nuestros peores defectos, los mismos que también a Borges le parecen virtudes, han sembrado de imágenes y experiencias argentinas varios idiomas del mundo ( $E l$ concepto de ficción 20).

Interesa particularmente esta mención de Hudson porque es el escritor que mejor representa esa mezcla de poesía y naturalismo aficionado que también probará Saer en sus regresos al país y además porque es el viajero que aparece explícitamente mencionado en sus libretas así como en las notas preparatorias para novelas como La grande. En varias oportunidades Saer sigue sus huellas. Constata en sus propios recorridos observaciones del escritor: "En el peaje cerca de Zárate, los aguaciles que se 
adelantan a la tormenta, de los que habla Hudson" (Saer, Libretas 312) ${ }^{325}$, o lo incorpora como instrucción de lectura y escritura: "El domingo, la bandada de pirinchos, entre los árboles, el suelo, etc., contentos a causa del buen tiempo. (Ver Hudson). Las corbatitas, El benteveo" (Saer, Libretas 372).

Según Carlos Gamerro en "Hudson y la invención del paisaje", Hudson fue uno de los primeros escritores que realmente "vio" el paisaje de la pampa y supo derramar una mirada minuciosa sobre plantas y animales, una verdadera "contemplación" que puede hallar como único ejemplo comparable en Argentina la poesía de Juan L. Ortiz. ${ }^{326}$ En Ficciones culturales y fábulas de identidad en América Latina, Graciela Montaldo ha señalado a su vez que la figura de Hudson fue retomada en distintos momentos de la historial de la cultura argentina. En primer lugar, fue leído a principios del siglo XX como parte del acervo tradicionalista del "pasado nacional" y cronista de una vida rural no contaminada por la inmigración y la vida urbana. Esa perspectiva cambió durante el debate sobre la cultura nacional que se produjo en torno al peronismo, momento en el cual Martínez Estrada rescató al "extranjero" Hudson, provocativamente, como uno de los fundadores de la literatura nacional. El escritor fue luego desplazado a un plano borroso de la literatura argentina después de los cincuenta y "excepto por la relectura crítica que hace Martínez Estrada (Hudson como literatura argentina de resistencia) y por la reescritura muy mediada que hace Borges de algunos procedimientos, no volverá a ser incorporado más que esporádicamente" (Montaldo 136). Sin embargo, podríamos encontrar también, en la doble estela con que la crítica caracteriza a Hudson, "poeta y naturalista", a Saer, quien como se sabe, también ha reconocido como maestro al poeta entrerriano y es un gran lector de las operaciones críticas de Martínez Estrada y de Borges. ¿Qué linajes comienzan a armarse o a enriquecerse si conectamos el paisaje de Saer ya no solo con el enigmático detenimiento de Juan L. Ortiz sino también con el activo, ${ }^{327}$ y un tanto melancólico deambular de Hudson?

\footnotetext{
${ }^{325}$ En "tormentas de alguaciles", uno de los apartados de El naturalista en el Plata y también en Allá lejos y hace tiempo, Hudson presenta a estos insectos a partir de un dato curioso, que es el mismo que recoge Saer en sus libretas: "Los grandes alguaciles aparecen en el verano y en el otoño; no con el viento, sino precediéndolo y lo más extraño es que no se los ve en toda la región hasta ese momento" (Hudson, El naturalista 109-110).

${ }^{326}$ En este linaje de poetas-naturalistas, resulta sugerente la siguiente afirmación de Beatriz Sarlo en "La duda y el pentimento": "La naturaleza de la región, Ortiz la describe con esa lengua de herborista, de mirador de pájaros y de miniaturas, que es lo opuesto al pintorequismo congelado del regionalismo arqueológico" (274).

${ }^{327}$ En varias oportunidades Saer se refiere a la poética de Juan L. Ortiz, para quien el "paisaje" no constituye un determinismo geográfico o regional sino una interrogación deslumbrada ante la
} 
"Perhaps I may say that my life ended when I left South America", reconoce Hudson en una entrevista hecha por Morley Robert en su biografía. Hijo de una pareja de colonos norteamericanos radicados en el Río de la Plata durante los tiempos de Rosas, Hudson vivió en la llanura desde 1841 a 1874, aprendió a observar la naturaleza vagabundeando por el campo y abandonó voluntariamente América para adoptar su nueva patria cultural en Londres, desde donde se dedicó a escribir sobre esa experiencia fundante. Salvando las distancias, la trayectoria vital e intelectual de Hudson puede ser parangonada a la de Saer: ambos se autoexilian, más o menos a la misma edad y escriben desde Europa textos que no dejan de evocar las tierras en las que vivieron durante su infancia y juventud. Ambos son, de alguna manera, escritores "excéntricos" que escriben desde metrópolis culturales -el Londres del capitalismo imperial y el París de la vanguardia estética y política- sin asimilarse a ellas y vuelven el margen cultural y lingüístico en el que se encuentran una zona de productividad estética y de resistencia política. ${ }^{328}$ Ambos son, a la vez, científicos amateurs (particularmente Hudson) y escritores de ficción, ${ }^{329}$ que retoman y a la vez se distancian del naturalismo practicado por científicos como Darwin, Humboldt o Azara.

proliferación material de la naturaleza, muy afín a la experimentada por el propio Hudson: "Para la poesía de Juan el paisaje es enigma y belleza, pretexto para preguntas y no para exclamaciones, fragmento del cosmos por el que la palabra avanza sutil y delicada, adivinando en cada rastro o vestigio, aun en los más diminutos, la gracia misteriosa de la materia" (Saer, "Juan", El concepto de ficción 82).

${ }^{328}$ Saer habla con orgullo de su voluntaria vida al margen del mainstream literario parisino y Sarlo comenta en Zona Saer que a pesar de manejar perfectamente la sintaxis y el léxico francés, elige hablar "con una tozuda fonética santafesina" (53). Montaldo enfatiza el carácter excéntrico de la escritura de Hudson que, desarrollada en el contexto de la literatura del imperio (Conrad y Kipling) emerge como una voz excéntrica que basa sus ficciones en la naturaleza y el recuerdo de una antigua patria. Pero a su vez el propio Hudson es un excéntrico en Londres, pobre y ajeno a una cultura que no termina de asimilarlo y debe aprender a dominar el inglés como lengua extranjera. Hudson habla un "mal inglés" y "cuando se tiene que enfrentar a la identidad deseada (la inglesa) surgen las diferencias y debe establecer su lugar subordinado en una sociedad en la que no hay sitio claro para él" (Montaldo, Ficciones culturales y fábulas de identidad 129).

329 Retomo esta idea de Graciela Montaldo, quien caracteriza el particular naturalismo practicado por William H. Hudson. En primer lugar, es un científico amateur capaz de participar a la vez tanto de las emergentes revistas científicas de la época como de esa "literatura menor" que recogía experiencias de contacto con la naturaleza (actividad 'naturalista' de muchos ciudadanos, composiciones escolares cuyo tema era la vida silvestre). En segundo lugar, se reapropia del discurso científico como si se tratara de un "saber personal" basado en la observación directa o en los testimonios recogidos 'directamente' en el territorio, y menos en los libros, aunque, por supuesto, Hudson dialogue con otros naturalistas en sus trabajos, y también lo haga Saer. Se trata además, en ambos casos, de escritores cuyas observaciones se localizan en territorios íntimos. Señala Montaldo a propósito de Hudson: "sus reflexiones [...] sobre la naturaleza [...] son también una suerte de 'viaje interior', a medias científico, a medias 
Fermín Rodríguez distingue diferentes formas de la práctica naturalista, por un lado aquella llevada a cabo según los tiempos del progreso científico y regulada por las instituciones y los estados que pagaban las exploraciones, como en los casos de Darwin y Humboldt y por el otro, aquella ensayada por Hudson en sus "días de ocio", como una forma de perder el tiempo y vagabundear, aun cuando el resultado de esos paseos fueran "inútiles investigaciones". Entre la observación científica y la experiencia personal, Hudson practica, señala Montaldo, una ciencia desinteresada que se presenta como un lugar de fractura del saber que desestabiliza la autoridad científica incorporando el conocimiento de vecinos y de pobladores. Saer, podría pensarse, anota lo que le interesa, no hay sistematicidad en sus libretas sino más bien una mirada que apunta lo que se cruza en su camino de forma un poco aleatoria y que se encuentra varias veces observando - "improductivamente"- lo mismo.

Saer parece mirar, por momentos, a través de los ojos de Hudson, quien, como ha señalado Fermín Rodríguez, captura jirones de percepción, formas que se hacen y se deshacen en la llanura. En Allá lejos y hace tiempo, una extensa memoria sobre su infancia y juventud en Argentina, evoca el deleite físico y espiritual que sentía por el mundo visible y la comunión casi mística que experimentaba con la naturaleza. Los recuerdos de experiencias y personajes de su infancia así como las manifestaciones más íntimas de su vida anímica -sus tribulaciones religiosas, el afecto que sentía por su madre- conviven y se amalgaman muy bien con la incorporación de los nombres científicos y las descripciones de algunas especies vegetales y animales de la pampa, y su uso de la nomenclatura linneana es bastante similar al practicado por Saer: le sirve en general para alertar a sus lectores ingleses sobre las particularidades de la naturaleza americana así como para establecer comparaciones con especies animales y vegetales por ellos conocidos. Se trata, como también aparecerá en Saer, de un naturalista atento a los matices cromáticos y a los cambios lumínicos. En El naturalista en el Plata se puede leer por ejemplo: “Gynerium argenteum (cortadera) [...] cuando la luz atenuada da aspecto de vaga neblina a los profusos penachos, el viajero no puede menos de imaginar que esos matices tan variados son debidos a los rayos horizontales del sol o al reflejo de la vaporosa niebla del crepúsculo" (Hudson 13). Saer señala a su vez: "En Entre Ríos, el miércoles, por el camino de tierra, cruzó un cuis. Pelambre entre azulada y verdosa, entre acero y bronce" (Libretas 287). La anotación, que podría ser un haiku,

místico, para tratar de responder preguntas sobre la subjetividad" (Ficciones culturales y fábulas de identidad 125). 
captura un escenario y fija allí una brizna de acontecer. El boceto tomado del natural intenta reproducir la mutación cromática que experimenta el pelaje del animal mientras cruza ante los ojos del observador y reaparecerá, con mínimas variaciones, en $L a$ grande.

En Allá lejos y hace tiempo pueden leerse las diversas fibras que componen el particular interés naturalista de Hudson así como las mutaciones que fue sufriendo en su infancia. El escritor asume la supervivencia del animismo en sus cavilaciones sobre el mundo natural pero se reconoce como un "converso" que ha pasado de compartir el sentimiento religioso protestante heredado de su madre al evolucionismo darwiniano que recibe como un mandato de la parte "científica" de su familia: el hermano mayor que regresa al hogar y rompe con el mandato materno. Advierte, sin embargo, que no es la explicación científica la única suficiente: "En forma insensible e inevitable, me había convertido en evolucionista, aunque nunca del todo satisfecho con la selección natural como la única y suficiente explicación de los cambios en las formas de vida" (Allá lejos 260) porque el sustrato místico y animista que alimentó sus primeros contactos con el mundo natural seguirá funcionando siempre y lo acompañará incluso cuando, ya viejo y alejado de Argentina, recapitule sus años de infancia y sus aventuras en la pampa.

Interesa pensar esa parcial "conversión" experimentada por Hudson cuando "la mente científica" de su hermano lo gana para las filas del naturalismo para reflexionar sobre el modo en el que se articula esa doble mirada, que, capaz de reconocer el orden en el que se inscriben los seres vivos, no deja de deleitarse con sus colores o de extrañar la migración de los pájaros que le dan forma a su casa natal. Aunque menos sistemática y mucho más aleatoria, el naturalismo amateur de Saer también oscilará entre los saberes aprendidos de Darwin o recogidos en los manuales de botánica y las variaciones poéticas que ensayaron Borges, Lugones, Juan L. Ortiz o Akinari sobre la variedad cromática del pelaje de los caballos, el ciclo de crecimiento de los árboles y el catálogo impresionista de los colores del río.

A medida que se desplaza por la ciudad o viaja entre los pueblos linderos de la zona, Saer inscribe, como se dijo, la multiplicación azarosa de animales y plantas. Lo que en los naturalistas anteriores es garantía de conocimiento verdadero y recopilación interesada para futuros trabajos de explotación económica, en Saer deviene escritura del tiempo y ejercicio de precisión espacial. Saer no escribe un diario de viaje convencional, escandido por el tiempo cronológico de días y semanas sino un fragmentado libro de apuntes cuya temporalidad la dan los ciclos naturales de 
reproducción de animales y plantas o las modificaciones climáticas significativas que anuncian los cambios de estación: "Principio del invierno. Plantas todavía florecidas: Hibiscos rosa o rojos. Estrella federal. Algunos aromos" (Libretas 335) o "Surubí: fin de septiembre a fines de abril. Dorado: fin de septiembre a fines de abril. Amarillo: invierno. Moncholo: toda época" (Libretas 292). Abundan además las anotaciones en las que Saer señala la presencia de determinados árboles en lugares característicos de la ciudad como el Parque España, la plaza o el Convento, como si el escritor pudiera trazar un mapa botánico del espacio urbano cuyos mojones serían los palos borrachos, los pinos, los jacarandás en flor y las araucarias. La historia natural se vuelve, como señala Natalia Brizuela en Fotografia e imperio, una nueva manera de construcción del espacio, señalamiento que ella hace para el momento en que la disciplina se consolidaba a comienzos del siglo XVIII pero que se manifiesta también en la versión libre -íntima y local- que Saer hace de ella.

Como aquellos exploradores y naturalistas que admira y cita en El río sin orillas y otros ensayos -Darwin, Azara o Hudson-, Saer despliega una mirada dinámica y directa del espacio, propia del viajero que lo transita pero que también puede detenerse a contemplar o a esperar que ciertos fenómenos naturales se produzcan. ${ }^{330}$ Incorpora a su vez varios sentidos que exceden el sentido privilegiado de la vista que ponderaba la disciplina en sus comienzos. ${ }^{331}$ La descripción naturalista que Saer aprende de sus maestros se convierte en otra forma de la detención poética y lo obliga a precisar texturas y formas, a diseccionar las partes visibles del objeto, y a recomponerlo utilizando la descripción combinada, recurso también empleado por Azara y otros, que consistía en describir un animal o una planta comparando sus partes con animales y plantas conocidos:

El timbó tiene vainas negras que se parecen un poco a las del algarrobo, pero que son enroscadas y duras. El aguaribay de lejos se parece al sauce, porque su fronda

\footnotetext{
${ }^{330}$ Marta Penhos también verifica esta doble posibilidad en la mirada de los expedicionarios y advierte por ejemplo que Félix de Azara desplegaba por un lado una visualidad dinámica que le permitía captar la realidad viva de los animales y plantas en su hábitat, pero también una mirada minuciosa que se fijaba en ciertos objetos y era capaz de precisar la ubicación geográfica de cada especie, sus medidas, proporción, color y particularidades morfológicas: "el dato preciso y la observación aguda se insertan en el relato, actuando como anclaje científico de la experiencia del viajero" (208).

331 "Al llegar a la vereda roja, más ancha, que bordea el convento se empieza a oír de la palmera y los pinos que se elevan en medio de los canteros de césped, un canto de pájaros múltiple y sostenido" (Saer, Libretas 294).
} 
es un poco transparente y cae hacia abajo como la del sauce llorón, pero las hojas son más chiquitas y se presentan en racimos. Tiene un frutito redondo, bien rojo, que cuelga en racimos poco espesos. La vaina del jacarandá es achatada y dura. El timbó es un árbol extendido y petizón. Ya hay paraísos florecidos (20 de septiembre). La tipa es una especie de acacia muy grande. También hay ceibos. Junto con los tres enormes palos borrachos de detrás del convento, y del gran ombú que bordea el agua, hay también pinos y paraísos muy jóvenes que crecen en la barranca, hacia el río (Saer, Libretas 286).

Sin embargo, como decíamos al comienzo, algunas de las fichas que ensaya Saer incluyen y desbordan la notación naturalista. El 2 de diciembre apunta en la libreta negra:

LLEGÓ EL COLIBRÍ. A las cuatro y media de la tarde, un poco más temprano que de costumbre. [...] El colibrí -lomo de un verde azulado, metálico, brillante, pecho grisáceo y cola negra separada del resto del cuerpo por una raya casi blanca- picoteó durante más o menos un minuto algunas flores en su planta habitual y después se dirigió hacia otra maceta donde había un segundo ejemplar de la misma especie. [...] Yo también lo había visto en años anteriores, en la misma planta, aunque un poco más tarde; también mi hermana se asombra de que hubiera llegado tan temprano. Me pregunto si no adelantó su visita a causa de unas nubes que estaban llegando del este y que parecían anunciar tormenta (Saer, Libretas 312).

En primer lugar, la observación minuciosa no es privativa de este tipo de descripción sino que participa de una forma de contemplación que Saer ha ensayado desde los comienzos de su literatura sobre muy diversas manifestaciones del orden material del mundo: los filamentos de la carne, las gotas de sudor del Gato Garay o la mancha que deja el cuerpo aplastado de una araña. Pero además, interesa en este caso cómo el rápido boceto que captura del natural se funde en una experiencia del tiempo que comparte con su hermana y permite advertir que su relación con el colibrí y las flores rojas sobre las que se posa está largamente fundada en muchas otras tardes compartidas. $^{332}$

Como se recordará además, alrededor de la mágica irrupción del colibrí se estructura el último capítulo escrito por Saer en La grande "DOMINGO. El colibrí", cuando la aparición súbita del pequeño pájaro en la casa de Gutiérrez captura la atención de todos sus invitados: "Magia legendaria del colibrí, que aparece con la regularidad de las constelaciones, súbito, en los jardines, y vuelve a desaparecer con la

332 También Hudson le dedica un extenso capítulo al colibrí y Saer lo retoma en uno de los "Apuntes" de La narración-objeto "El colibrí según Hudson". 
misma rapidez, igual que si fuese un espejismo o una visión. El ser entero del mundo parece concentrarse, durante unos minutos, en una de sus partes, alada y vistosa" (421). Es decir, la estampa naturalista se abre a una dimensión de la cotidianeidad afectiva del escritor y a sus predilecciones de lectura, y la "autoridad científica" se diluye en los pareceres que comparten Saer y su hermana, ese "saber de los vecinos" y los pobladores que también Hudson recogía con cuidado para amenizar sus catálogos. ${ }^{333}$ La observación radiosa del pájaro imanta la prosa de $L a$ grande y concentra allí una reflexión temporal sobre el presente, la percepción y la belleza.

En este sentido, cabría entender la descripción naturalista que Saer ensaya en sus libretas como otra versión del "modo Saer" de la contemplación, vinculada además con un tipo de concentración que ya había experimentado entre fines de los setenta y principios de los ochenta traduciendo haikus. El haiku es, como él mismo apunta en las notas de preparación para La grande, "vividez, epifanía. [...] el residuo de una lucidez momentánea que integra al sujeto en el universo y al universo en el sujeto" (Saer, Papeles II 370) y como señala Sarlo retomando a su vez a Barthes, constituye otra forma de notación precisa de la naturaleza, de los cambios de temperatura y luminosidad.

El río sin orillas se cierra con una escena en la que se agudiza la percepción y el escritor, que hasta ese momento había encontrado el paisaje opaco y refractario, puede momentáneamente reconocer su familiaridad. Pieza principal de ese momento es el "sauce" sobre el que el escritor se ha apoyado para fumar mientras contempla el río. La pieza botánica que había aparecido en una de las fichas de naturalista de las libretas se resignifica aquí y adquiere una dimensión preponderante. En primer lugar, advierte, hablar del sauce no es una concesión al color local sino una "precisión obligatoria teniendo en cuenta que este árbol es el primero en presentar, en los comienzos de la primavera, una fronda tupida" (Saer, El río 210), característica que le hace evocar la amonestación de Akinari en contra de los sauces, (porque así como son los primeros en florecer engañados por las tibiezas de la primavera, son también los primeros en perder sus hojas en los primeros fríos). El sauce le permite además unir París y Santa Fe: "En París, el verdadero instrumento de medida que anuncia la primavera no son los termómetros y barómetros de la Meteorología nacional, sino el gran sauce que se alza

\footnotetext{
${ }^{333}$ Saer también pinta con los colores de la literatura: "Cuando está un poco crecido el río es azulado, idéntico color que en el río de la Plata ('era azulejo entonces como oriundo del cielo')" (Saer, Libretas 282). Incorpora aquí la variación borgeana del azul del poema "Fundación mítica de Buenos Aires".
} 
[...] en el Square de l'Ile de France" (210). El comportamiento un tanto caprichoso del sauce, que ocurre indistintamente en París, Santa Fe o en el Japón de Akinari, borronea las especificidades de la región y lo vuelve cifra de pasaje. El árbol tiene además un prestigio especial en muchas literaturas pero es Juan L. Ortiz quien terminó de formular su carácter aurático titulando a los tres volúmenes de sus obras completas En el aura del sauce. Ese es el sauce sobre el que Saer se apoya a fumar, un árbol más literario que real, que no renuncia, de todos modos, a sus especificidades botánicas.

\section{“Ojos inventivos": corografía y paisaje}

En sus cuadernos de viaje, Saer abre una ventana para mirar el amanecer sobre el mar Caribe en Venezuela y visita los Andes en el extremo norte de América del Sur; se despierta con placer en el frío toledano y apunta los nombres de varias regiones francesas que lo muestran recorriendo el país desde la costa este (Isla de Ré, Nantes, La Rochelle) hasta la zona fronteriza de la ciudad de Mulhouse, en la que descubre los restos de esa parte de Europa septentrional en la que parece sobrevivir el fantasma del nazismo y de la guerra. Sin embargo, a pesar de apuntar estos recorridos, puntualizar algunas fechas y anotar mínimas sensaciones que le disparan los espacios desconocidos, Saer no despliega en sus libretas otros viajes que no sean "el viaje" que lo devuelve, periódicamente a la Argentina desde 1982. La casi por completo ausencia de estampas de esos otros viajes que Saer realizó por el continente latinoamericano y europeo lo confirman en una actitud que había sostenido al llegar a París en 1968. Recordemos que también en ese momento en el que se muda, sin saberlo, definitivamente a Francia, hay escasísimos textos, en su mayoría no publicados por Saer, que lo muestran recorriendo la ciudad parisina, cuyo tono dista, como ya vimos, del asombro y el entusiasmo de varios de los escritores e intelectuales latinoamericanos que viajaron a Europa por los mismos años.

En las Libretas y en El río sin orillas podemos ver a Saer paseando por barrios de Santa Fe, viajando en ómnibus o en auto desde Buenos Aires a Rosario, visitando Entre Ríos y navegando en balsa por el río Paraná. El escritor registra mientras tanto los cambios edilicios y de planificación urbana en la ciudad, apunta sus predilecciones arquitectónicas, se preocupa por averiguar el nombre desconocido u olvidado de un arroyo. Es, como el Borges de "Las inscripciones de los carros", un cazador de 
escrituras y en varias ocasiones lo encontramos leyendo la grafía heterogénea de la ciudad, desperdigada en placas y carteles, ${ }^{334}$ y fundamentalmente escuchando las voces y los modismos del habla en sus diferentes registros y alturas: el cuchicheo, la queja, el grito de un canillita que vocea El Litoral, una despedida en la terminal. Se trata en general, como ocurría con la notación naturalista, de captar una imagen precisa y de anotar bajo qué circunstancias temporales y espaciales se produjo esa toma. Como sugiere Delgado en la presentación que hace de las libretas, algunas de dichas anotaciones irán a parar a las ficciones y ensayos de Saer -transcribe las primeras veintidós páginas de la libreta negra como las "Notas en vivo" para Glosa; colecciona imágenes para La grande- y otras permanecerán como escritura íntima, sin embargo interesa subrayar la continuidad esencial que atraviesa la escritura de los cuadernos, que no distingue una impresión fugaz percibida por Saer de una observación realizada por Tomatis o Pichón Garay.

Saer nace en Serodino y se traslada a Santa Fe en 1949 porque su padre quería hacer estudiar a los hijos varones de la familia. En la entrevista con Miguel Russo evoca la primera imagen que tuvo de la ciudad, mientras viajaba en tren junto a su hermana y a su madre:

Unos veinte kilómetros antes de llegar, el tren se detuvo para dar paso a otro en sentido contrario. Desde allí vi Santa Fe por primera vez. Bajamos en el medio del campo y yo no podía creer lo que veía. Me acerqué a un señor y le pregunté “¿es tan grande Santa Fe?" Mi hermana me dio el único coscorrón en mi vida y me dijo que me callara. Había una suerte de vergüenza porque se supiera que veníamos del campo (Saer en Russo s/p).

Santa Fe se le aparece como una ciudad enorme, agigantada por el contraste de su reciente vida en el campo. Ante ella, Saer sólo puede hacer una pregunta que delata su origen y avergüenza a la familia. Durante su juventud, la etapa de su formación voraz como lector, Santa Fe expandirá aún más sus límites para ocupar la geografía borrosa de todas las ciudades leídas por Saer: "El Dublín de Joyce es Santa Fe; San Francisco o Los Ángeles, todo ese universo de Chandler es Santa Fe; la Viena de Freud es Santa Fe; el sur de Faulkner eran los alrededores de mi pueblo" (Saer en Russo s/p). Casi veinte años después de haberse trasladado a Europa regresará al país y a su ciudad para

\footnotetext{
334 Anota Saer en la Libreta negra: "En un camión: visite Helvecia. Capital del amarillo" (Libretas 313). La misma frase aparecerá en La grande y será leída por Gabriela cuando un camión con acoplado los sorprenda mientras conversan con Soldi y Nula en el camino que va a la casa de Gutiérrez.
} 
observarlos desde una renovada distancia. ${ }^{335}$ Esa primera visión que captura siendo un chico desde el tren se diseminará en muchas y diversas imágenes que irá apuntando en sus libretas. La exploración del espacio natal que Saer experimenta en sus cuadernos -y en los textos que se hacen con/fundidos en esa escritura- podría pensarse como una dilatada respuesta a esa pregunta de la infancia sobre el tamaño de la ciudad. Para responder, Saer multiplicará los puntos de vista, recorrerá otras zonas aledañas, y dispondrá de una serie de representaciones visuales en las que se cruzan viaje, contemplación y experiencia: mapas, vistas, postales, croquis y manchas coloreadas.

Desde el avión mientras regresa a Argentina, el escritor describe a vuelo de pájaro el punto de confluencia del río Paraná con el río Uruguay y señala que:

la distancia, eliminando accidentes y rugosidades, resuelve todo en geometría: ese peñasco estéril y poroso que llamamos luna, se estiliza en círculo perfecto para nuestros ojos inventivos que, incapaces de ver los detalles, le otorgan la apariencia de un arquetipo. [...] El triángulo de tierra, de un verde azulado, apretado por las dos cintas inmóviles casi incoloras, yacía allá abajo, en medio de una inmensa extensión chata del mismo verde azulado, inmóvil, inmemorial y vacía (Saer, El río 14-15 las cursivas me pertenecen).

El territorio, percibido a la distancia, se convierte en un mapa que insistirá en otras oportunidades a lo largo del ensayo, una textura que no es sólo de tierra, agua y vegetación sino que se desmaterializa y se pictorializa a medida que esos ojos inventivos, no pudiendo ver los detalles, geometrizan el espacio y saturan los matices de los colores en tres: verde, azul y marrón. Diversos estudios indican una fuerte conexión entre mapas y pinturas. En El arte de describir, Svetlana Alpers trabaja la presencia cartográfica en el arte holandés y señala que en cuadros como El arte de la pintura de Jan Vermeer, "el mapa se nos presenta como un cuadro en sí mismo” (180). Si como se sugirió anteriormente, los paseos y las anotaciones de Saer evocan por momentos los desplazamientos interesados que topógrafos y cartógrafos realizaron sobre el paisaje nacional -tanto en las libretas de viaje como en El río sin orillas ${ }^{-}$, se puede observar que su escritura incorpora y reescribe, redibujando, la textura de los mapas y a su vez que sus recorridos por la zona confirman o distorsionan las referencias topográficas

\footnotetext{
${ }^{335}$ Similar cambio de perspectiva y de valoración asalta al doctor Real cuando planea el regreso a la ciudad que queda en frente de su lugar de nacimiento: "Como mi lugar de nacimiento era un caserío exiguo amontonado en la cima de la barranca que dominaba el río, a cada visita la ciudad me parecía grande, agitada y colorida [...] pero ahora volvía después de tantos años, habiendo hecho un rodeo por Madrid, Londres, París y aun Buenos Aires, mi mirada [...] la reducía a sus justas proporciones" (Saer, Las nubes 77).
} 
existentes. Saer escribe, dibuja y pinta una corografía del Litoral, es decir, una descripción que se vincula con las aptitudes del artista. ${ }^{336}$ Interesará entonces ver cómo se cruzan, en su mirada, modos de contemplar que forman parte de la tradición de viajeros sobre cuyas obras Saer estaba escribiendo, pero también otras tradiciones pictóricas que dialogan con las preocupaciones experimentales que ya había ensayado en obras de ficción anteriores. ${ }^{337}$

Entre los mapas y las pinturas hay una relación productiva, propone Alpers, y en muchas ocasiones los mapas sugieren imágenes a los artistas holandeses. Saer señala por ejemplo, sobre el curso del río: "Su forma verdadera [...] difiere de su apariencia empírica y, tal como podemos verificarlo en cualquier mapa, se avecina mucho a la del escorpión, con la bahía de Samborombón [...] y la bahía de Montevideo que forman las pinzas, y el último tramo del río Uruguay formando la cola" (Saer, El río 30) y encuentra en esa forma la cifra del destino que les cupo a los primeros conquistadores, como Juan Díaz del Solís, el descubridor del río, que murió a manos de los indios. Saer manipula el mapa, lo da vuelta y descubre el dibujo de un cuerpo: "y entonces aparece con claridad la silueta de un pene, con las dos bahías [...] figurando sin error posible los testículos, penetrando hacia el interior de la tierra, de la que la provincia de Entre Ríos contendría el útero" (30). Dos versiones del mapa mirado con "ojos inventivos" que terminan siendo vinculadas por Saer en una lectura histórica y mitológica de la tierra. ${ }^{338}$ Si bien en las libretas no aparece específicamente el "mapa" aunque sí, como veremos, señalamientos espaciales en el territorio, el escritor ensaya una reelaboración libre de ciertos géneros topográficos de pintura asociados: los paisajes cartográficos $o$ panorámicos y las vistas urbanas.

${ }^{336}$ En El arte de describir, Svetlana Alpers retoma la distinción que Ptolmeo hace en su Geografia, entre el aspecto matemático de la geografía, que se ocupa del mundo entero, y los aspectos descriptivos o la "corografía", que se ocupa de lugares particulares. Mientras que la primera se vincula con las aptitudes del matemático, la corografía lo hace con las aptitudes del artista.

${ }^{337}$ Esto puede observarse en varias de las anotaciones de las Libretas: desde la referencia a las pinturas rupestres: "En un campo a lo lejos cuarenta o cincuenta vacas oscuras que pastan, todas vueltas en la misma dirección. A la distancia parecen inmóviles. Asociación: Lascaux" (Saer, Libretas 313); imágenes que modelan la luz como si se tratara de un cuadro impresionista: "Delicia de la llanura la primavera: <matas> de flores amarillas, cardos rosas, planos decrecientes de árboles, hasta volverse brumosos, a pesar de la luz cenital, en el horizonte circular" (Saer, Libretas 307) y también referencias a la pintura vanguardista. Aparece como se verá más adelante la alusión explícita a Kandinsky, pero también vagas anotaciones sobre la estética futurista: "Lo malo de los aviones es que apenas toman altura, al <poeta $>$ que mira la tierra por la ventanilla lo asalta una irrazonable estética futurista" (328).

${ }^{338}$ Y que sintomáticamente coloca a Entre Ríos (Juan L. Ortiz) como el espacio uterino originario de la historia del Río de la Plata. 
En primer lugar, Saer se comporta por momentos como un expedicionario que realiza ciertos señalamientos sobre el terreno y hace anotaciones sobre rutas y caminos: "Ruta de Santa Fe a Rosario. Aromos, grandes y chicos. Sauces. Eucaliptus" (Saer, Libretas 287); “Al Sur de Coronda, los campos son más trabajados" (Saer, Libretas 287) o simplemente muestra el límite geográfico: "Provincias linderas" (287). Se trata en estos casos de observaciones muy breves cuya sintaxis remeda el apunte rápido de un croquis hecho a mano alzada y plantea los principales elementos del paisaje en términos de figura y fondo: "Campo raso y, al fondo, arboledas. Bañados. Molinos" (Saer, Libretas 287). ${ }^{339}$

Las libretas de viaje registran, como venimos viendo, los movimientos del escritor en diferentes medios de transporte pero también los momentos en que se detiene a contemplar una escena en particular, para lo cual privilegia los lugares en altura:

VISITA A ENTRE RÍOS: [...] Regreso por la balsa a cadena del arroyo Las Conchas. Yo hice pasar la balsa. Después, la Toma Vieja. Es el punto más alto del Paraná y sin duda de la región. Había miles de estudiantes porque era el 21 de septiembre. En el río, remansos encadenados. Movimiento en espiral. El centro del remanso es liso, pero se ve, ligeramente turbulento, el círculo exterior en el que el agua se agita un poco. Volvimos por la isla Berduc. Crepúsculo sobre el arroyo Miradero, que bordea la isla y va a morir al Colastiné. Este, desde el puente, inmenso y luminoso en el crepúsculo. Muy crecido. La silueta de un hombre de pie en una canoa solitaria (paisaje típico). Viniendo por la nueva autopista, vemos el sol crepuscular, un enorme disco rojo, hundirse rápido detrás de la costanera y de los monoblocs escasos que se yerguen entre las casas chatas de una o dos plantas (Saer, Libretas 286).

En primer lugar, varias de las anotaciones de Saer sobre el territorio despliegan a la vez una doble preocupación que Alpers ya advertía en la pintura holandesa de índole cartográfica: señalar desde dónde se obtiene una vista revela una voluntad de documentación por un lado, y de representación estética por el otro. No es la primera vez que el escritor indica no sólo desde dónde se posiciona para escribir, sino incluso la hora exacta en la que toma alguna anotación, bosqueja una escena y captura el juego de luces y sombras, un comportamiento, podría decirse, que lo emparienta una vez más con los pintores impresionistas. La vista desde el "punto más alto del Paraná" se vuelve

${ }^{339}$ En El río sin orillas Saer regresa a sus libretas y luego de consultar el atlas del Instituto Geográfico Militar, verifica sus impresiones previas: "[el atlas] incluye en la zona pampeana las provincias de Buenos Aires, de Santa Fe y de Entre Ríos, y en mi libreta de apuntes de varios años antes de haber concebido este libro, la anotación lacónica de Provincias linderas coincidía, sin saberlo, con la delimitación técnica [...] del atlas en cuestión" (Saer, El río 39). 
panorámica pero también se demora en el río, uno de los temas predilectos de su escritura. El fragmento condensa una serie de tensiones entre la "aventura" que emprende Saer cuando visita Entre Ríos y la imagen típica que captura su ojo: la silueta de un hombre a contraluz, parado sobre una canoa. Plegándose a esa voluntad documental que permea buena parte de sus apuntes parece no poder elidir dicha imagen, pero se apura en aclarar que se trata de un paisaje típico, o podríamos decir, "pintoresco".340

A su vez, la imagen termina describiendo la puesta del sol en el paisaje urbano. Interesa señalar, en este sentido, que en las libretas abundan las alusiones al cielo, a las tormentas y al sol. Como señala Silvestri, los viajeros expedicionarios que recorrieron el paisaje del Plata estaban muy atentos a los distintos aspectos astronómicos, atmosféricos, lumínicos y climáticos del cielo y esto constituyó una serie de tópicos que se reiterarían en muchos de sus textos. Las libretas de viaje de Saer devienen un registro lumínico de la ciudad y sus alrededores y el escritor detalla los efectos del sol sobre los transeúntes y los edificios: "Aun viniendo por el lado de la sombra, al cruzar la calle [...] y llegar a la vereda del museo, el sol cae sobre las veredas. Con la ampliación de la calle, ya no hay más vereda de sombra y todo está bajo la luz" (Saer, Libretas 290).

El paisaje que captura en sus cuadernos comparte, como dijimos, algunos de los tópicos presentes en las escrituras de viaje. Sin embargo, en otros momentos las libretas se vuelven un terreno de experimentación pictoricista:

La llanura como semiesfera. Siempre se está en el centro de la base. La bóveda celeste es como una pantalla en la que fuese apareciendo un espectáculo cambiante, abstracto, con aquí y allá y de tanto en tanto, algunos caprichos vagamente figurativos, como una bandada de pájaros, de los que solamente la

\footnotetext{
${ }^{340}$ Según señala Silvestri en El lugar común, la categoría de lo pintoresco se inspira en lo natural a través del disfrute de productos amables y fue una de las vías para comprender y articular imágenes de un mundo en permanente cambio y ebullición. Hacia la segunda mitad del siglo XIX, las imágenes provenientes del imaginario pintoresco entraron en decadencia y se convirtieron en clisé porque no podían encarnar los destinos viriles de la Patria ni responder al imaginario nacional. Lo pintoresco reúne entre sus componentes el del "color local" y es precisamente esto contra lo que reniega Saer. En El río sin orillas declara explícitamente su posición al respecto, y ante el efecto que causó en él una tormenta impresionante que se desató sobre Buenos Aires, aclara: "tan impresionante que más de un lector podrá sospechar que, a causa de los riesgos de pintorequismo - semejantes a los riesgos decorativos de toda obra pictórica- de la empresa en que me debato, me dejo tentar, teniéndome incapaz de despertar una curiosidad más elevada, por el color local" (33).
} 
formación en ángulo conserva algún residuo de abstracción (Saer, Libretas 309). ${ }^{341}$

En este y otros fragmentos, Saer parece reeditar impresiones del paisaje que ya había desarrollado previamente y despliega las variantes de una misma predilección contemplativa. En una nota suelta de los borradores, señala por ejemplo sobre el Campo de trigo con cuervos de Van Gogh que se trata de una imagen a mitad de camino entre lo figurativo y lo abstracto y en varias oportunidades -en argumentos como "El intérprete", en novelas como El entenado, Las nubes o La ocasión- presenta el horizonte como un dispositivo de transformación plástica que regula el pasaje entre formas reconocibles y manchas o espejismos. En "Del horizonte del paisaje al horizonte de los poetas", Michel Collot advierte que una de las principales características del horizonte es su función de cierre, que hace del paisaje un "conjunto" homogéneo. Al interior del marco, la mirada puede entablar relaciones entre un número limitado de formas y de colores: "el ojo se vuelve artista, y el paisaje "se hace cuadro" (Collot 12), proporcionando además un fondo, generalmente el cielo. Sin embargo, la línea del horizonte es paradojal, porque a la vez que hace del paisaje una totalidad y lo delimita en la perfección de una figura eminentemente visible y legible -esa "semiesfera" en el caso saeriano- también lo coloca en el borde de lo invisible y de lo ilimitado, y así se abre a la imaginación poética y, en este caso, pictórica.

Las libretas de Saer inscriben de este modo a un sujeto que intenta capturar algo de ese paisaje "familiar" y extraño a la vez: así se explicaría en principio la escritura obsesiva de los milímetros de lluvia, la anotación escrupulosa de la hora y el lugar en el que se toman determinadas vistas, la reposición exacta de las referencias topográficas y el registro de las distancias de rutas y caminos. Sin embargo, habría que agregar, es tan pregnante la función "escritural" que se derrama sobre el paisaje mientras Saer lo recorre, que los mismos materiales que, anotaciones atrás, emergían nítidos, se pueden volver de un momento para el otro, "materia engañosa", como lo harían en cualquiera de sus ficciones: "masas coloreadas de materia engañosa... en la mañana de diciembre... muy luminosa; en el ómnibus, yendo a lo de Roberto, por Vélez Sarsfield cerca de las vías que cruzan bulevar Gálvez, y después las casillas detrás de la

${ }^{341}$ En El río sin orillas, reescribe este pasaje y conecta esa pureza formal y ligeramente geométrica del cielo con el viejo tópico de la ausencia de accidentes geográficos de la llanura, en el que insistieron viajeros como Darwin. 
Costanera; el agua dorada y crespa, de consistencia casi dura, como dulce de leche oscuro, muy brillante" (Saer, Libretas 300) y la luz, que Saer ha modelado de múltiples maneras siguiendo por momentos los tópicos de la tradición, parece despegarse del paisaje conocido: "En la ciudad: hacia el oeste, al anochecer, el gran sol circular cercano a la tierra; luz de un rosa químico, vivo y azulado, inhumano y distante, venido de otra parte" (305). Saer explota las variaciones cromáticas y táctiles que pueden adquirir los elementos de la región y si por momentos respeta la paleta figurativa, por el otro, desquicia y subjetiviza la fisonomía cromática del lugar. El color "dulce de leche oscuro del río", sinestesia que permite comprender además la consistencia dura del agua, y "el rosa químico, inhumano y distante" desconvencionalizan las múltiples puestas de sol que se repiten en las libretas y que bordean peligrosamente el "paisaje típico". Como señala Collot, los poetas modernos ya no esperan que el horizonte les muestre el acceso a otro mundo, sino que les revele que "nuestro mundo es diferente al que creemos, porque esconde una reserva inagotable de nuevas perspectivas, ya no es la imagen parecida a una identidad propia, sino la distancia interior de una íntima alteridad" (17). Según Collot, el escritor hallará esa revelación en "la travesía del lenguaje", o en términos de estas libretas, en la variación experimental -poética y pictoricista- de los tópicos del viaje.

El punto de vista de Saer es el de un viajero que se mueve permanentemente a diferentes alturas, y así como puede desplegar "vistas a vuelo de pájaro" que miniaturizan la fisonomía urbana: "La ciudad chata, como aplastada, y las casas diminutas tienen algo de panteones" (Saer, Libretas 282), también puede detenerse en los detalles de las plantas e incluso en elementos de desecho que comienzan a configurar un paisaje urbano muy distinto al de las vistas urbanas más panorámicas y al de los paisajes naturales:

Manchas de aceite sobre el asfalto. En contacto con la humedad (¿?) las manchas de aceite de auto se diluyen y se tornasolan. Queda un gran dibujo abstracto, de líneas curvas irregulares que podrían hacer pensar en cierto período de Kandinsky. Las líneas están marcadas varias veces, siguiendo el contorno de los colores. Más que líneas, son más bien franjas de colores que se acompañan, paralelas, encerrando un plano vagamente oval recubierto de color. Los tonos tienen todos un tinte que podríamos llamar ferruginoso. [...] Después vienen unas franjas de índigo, de malva, de azul verdoso y de un verde que evoca el cloro y que va destiñendo en un amarillo sulfuroso [...] ¡Flor venenosa y fugaz del asfalto!” (Saer, Libretas 327-328). 
En esta última descripción la mirada del naturalista que Saer ha aplicado anteriormente sobre el timbó o el aguaribay se despliega ahora sobre la "flor venenosa del asfalto", glosada de manera ecfrástica como si fuera un cuadro abstracto de Kandinsky. Nuevamente, como en el ejemplo anterior, la imagen se tensiona entre el aspecto referencial y figurativo (la mancha de aceite), y el carácter abstracto, de pura mancha colorida. El descubrimiento de esta nueva especie floral le ofrece a Saer una paleta que oscila entre el imaginario natural y el industrial, los colores son ferruginosos y evocan sustancias químicas como el sulfuro y el cloro.

"Las únicas formas válidas de negociar con este mundo, esperando captar aun así los ritmos del cosmos, son caminar y nadar" (Sinclair 21), dice Iain Sinclair en Los ríos perdidos de Londres, ${ }^{342}$ "Caminar y nadar", o, podría decirse, "Detenerse y refrescarse en las aguas de un ignoto brazo del Paraná”, el binomio también se devela en Saer como la conjunción feliz que permite "captar los ritmos del cosmos". Como se recordará, una de las imágenes más pregnantes y hermosas de El río sin orillas, que abre y cierra el apartado "Primavera" del libro es aquella en la que Saer está fumando debajo de un sauce mirando el río mientras observa la llegada de una mujer y dos chicos que llevan a su caballo para que se refresque. Gracias al "don" del presente y al "don" de la escritura, el sujeto puede diseminarse en una multiplicidad de personajes y objetos, le explica Flaubert a Louise Colet en una carta. ${ }^{343}$ Así también, esa "aproximación deliberadamente distanciada" con la que Saer regresa al país se suspende cuando las sensaciones de la mujer se transfieren a su propio cuerpo: "Y a medida que la mujer iba adentrándose en el río, y el nivel de agua iba cubriendo sus tobillos, sus pantorrillas, hasta llegar a la rodilla, la sensación de frescura iba subiendo también por mis propias piernas, gratificándome con esa caricia líquida" (El río 217).

\footnotetext{
${ }^{342}$ Los ríos perdidos de Londres es un ensayo sobre los antiguos cursos de agua de Londres, ahora entubados en nombre del progreso y la racionalidad moderna, a partir de los cuales Sinclair traza una memoria colectiva de la topografía londinense declinada por los vestigios poéticos de la tradición literaria inglesa. De los autores que retoma se destaca William Blake pero también "la tradición autobiográfica, exploratoria y errante de Montaigne, Rousseau, Sir Thomas Browne, es decir, de los grandes caminantes, de los grandes líricos introspectivos de la observación" (Scott, en Sinclair 11).

${ }^{343}$ Dice Flaubert: "Es algo delicioso escribir. [Hoy he sido] hombre y mujer a la vez, amante y querida al mismo tiempo; estuve paseando a caballo en un bosque, en una siesta de otoño, bajo las hojas amarillas, y yo era los caballos, las hojas, el viento" (Saer, El río 210).
} 


\section{Anotar en varias lenguas: estampas rioplatenses y citas extranjeras}

Como se dijo anteriormente Saer no es un escritor "extraterritorial" y permite desafiar la hipótesis de Steiner sobre el vínculo casi obligatorio entre modernidad literaria y escritura en otra lengua. Habla en perfecto francés con fonética santafesina; españoliza las palabras francesas que incorpora en sus poemas parisinos y escribe toda su obra en español. Entre las fichas naturalistas y los bocetos de paisajes, se encuentran en sus libretas de viaje varias instantáneas lingüísticas que registran el habla rioplatense: “Las chicas argentinas dicen mucho ¡Ay! 'Ay, me voy a comprar unos zapatos', ‘Ay, tengo que tomar el colectivo', etc." (Saer, Libretas 288). En algunos casos Saer anota en qué situación captura estas formas que llaman su interés: "7 de agosto 1988/Con Clara y Laurence en el avión. Frase oída en el aeropuerto de Río, por una señora 'bien' argentina: 'te lo entregan tipo una'" (304). En otras, accedemos a la cita lacónica que se desprende del contexto: "Hace calor. -Sí. Está apretando. 'Está apretando el calor" (295)" o se incorpora sólo su emisor: "María Teresa: Si no dobla a la esquina estamos fritos" (296). Muchas de estas notas de observación lingüística forman parte de las "Notas en vivo" que el escritor transcribió para Glosa. ${ }^{344}$ Pero además, Saer copia citas del francés (unos versos de Theodor Hannon; un fragmento de las Cartas a Theo; una cita del artículo "Joyce y su tiempo" de Broch que utilizará para La grande, entre otras) y del inglés (copia unas líneas de El Mercader de Venecia) y anota palabras que busca en el diccionario mientras lee El coche de correo inglés, de Thomas de Quincey.

Las citas literarias en sus idiomas originales, las frases sueltas escuchadas en algún medio de transporte y las locuciones curiosas que recoge en sus desplazamientos conviven en una pluralidad lingüística en la que el escritor se mueve con comodidad. Sin embargo, esa mezcla de lenguas en la que lo vemos leyendo y pensando pareciera no "afectar" el español rioplatense que Saer elabora en sus ficciones.

Como comentamos en la primera parte, en "Entre dos aguas", Saer reflexiona sobre los problemas específicos del escritor en el exilio. La lengua extranjera, señala, ejerce una presión constante sobre la lengua materna, mayor cuanto más cercana es, y

\footnotetext{
${ }^{344}$ Por supuesto, como anota Lucero en La vuelta incompleta, estas expresiones comunes y giros idiomáticos también estarán sometidas a un proceso de experimentación verbal que termina extrañándolos: "En una sintaxis que se interrumpe, cómicamente, con una frecuencia exasperante, el narrador vuelve una y otra vez sobre lo dicho para desautomatizar los modos de decir ('por el rabillo, como lo llaman, del ojo', 'hace, como se dice, silencio', 'volver, como se dice, sobre sus propios pasos', 'a decir verdad -es un decir, ¿no?-)” (208).
} 
así "[el estilo del escritor exiliado] corre más riesgo en España que en Francia, y en Francia más que en Alemania o en Suecia” (Saer, Ensayos 202) por lo cual si antes no ignoraba "el cuidado y la labor que exige la elección de cada palabra, en las antípodas del espontaneísmo o del naturalismo lingüístico" (Saer, Ensayos 202) ahora deberá extremar la vigilancia para que la "lengua invasora" no corrompa su escritura, porque aunque el idioma argentino provenga del español de España, difiere radicalmente de él, en especial el habla. ${ }^{345}$ El vocabulario entre bélico y positivista de Saer ("riesgos", "lengua invasora", “contaminación") vuelve a graficar un conflicto de larga data en la historia de la literatura argentina: la tensión entre "lengua nacional" y lenguas extranjeras. Ese conflicto que también Borges y Arlt habían problematizado en el ensayo homónimo "El idioma de los argentinos", reaparece en El río sin orillas para señalar que el castellano de la región pampeana es producto de ese sincretismo cultural que caracteriza al Río de la Plata, "modificado por aportes sintácticos y léxicos de origen portugués e italiano, con un acento particular que difiere totalmente de todos los acentos españoles" (Saer, El río 166), y nutrido además de términos indígenas y rurales y de palabras del lunfardo adoptados por el habla familiar.

"El idioma de los argentinos", el ensayo que Borges escribió en 1928 para elucidar la singularidad de la lengua nacional (distanciándola a la vez del hispanismo y del lenguaje del arrabal) se configura, señala Sarlo en "Oralidad y lenguas extranjeras", como una nueva versión de la utopía literaria: Borges asegura que sería posible captar una nacionalidad semántica en el "tono" y en la "connotación" de la voz oral y se respalda en un puñado de escritores del siglo XIX que escribieron esa voz (Sarmiento, Vicente Fidel López, Lucio Mansilla, Eduardo Wilde), prueba de una argentinidad preexistente que le sirve para distanciarse tanto de los excesos y deformidades del lunfardo como del español castizo. Por supuesto, remite a una tradición fuerte del siglo XIX para postular una nacionalidad literaria que puede hacerse un lugar en la literatura universal, pero sin caer en los problemas del nacionalismo, y legitima la "buena mezcla" de

345 Esta percepción es compartida con otros escritores exiliados. En ¿Quién de nosotros escribirá el Facundo?, José Luis de Diego consigna que la mayor parte de los testimonios dan cuenta de una situación lingüística particular, el "estrabismo lingüístico" que se produce cuando un escritor habita un país en el que se habla la misma lengua, pero de otro modo: "el mayor extrañamiento se produce no ante una lengua foránea, sino ante un uso diferente de la propia" (181). 
lenguas extranjeras y nacionalidad literaria que él mismo practicará en Historia Universal de la Infamia. ${ }^{346}$

Interesa subrayar que tanto Borges como Saer encuentran el español rioplatense en el "tono" y en la "connotación de la voz oral", en los gestos menores del idioma. En Borges, lo que distingue nuestra lengua del español castizo es apenas un matiz: "matiz que es lo bastante discreto para no entorpecer la circulación total del idioma y lo bastante nítido para que en él oigamos la patria. [...] Pienso en el ambiente distinto de nuestra voz, en la valoración irónica o cariñosa que damos a determinadas palabras, en su temperatura no igual" (Borges, "El idioma de los argentinos" 146-7). Saer encuentra ese "tono" en los detalles: "-No, no me interesa rescatar nada [le responde a Prieto]. ${ }^{347}$ Tomo notas de cosas que me llaman la atención, algunos detalles lingüísticos, detalles de conversaciones, expresiones como 'el calor está apretando', o 'está bien ubicado', que no se si las voy a utilizar, pero que me llaman la atención" (Prieto, Una forma más real 112 las cursivas me pertenecen). No "rescatar", podría decirse, pero sí al menos "actualizar" las formas del habla cotidiana del idioma rioplatense para no perder el tono ni ceder a las deformaciones que podrían ejercer el español y el francés en Europa, una práctica que no sólo se lee en el interés caprichoso que Saer despliega en sus libretas sino también en Retrato de Juan José Saer, en donde lo vemos preguntando por las nuevas expresiones con cierto asombro y entusiasmo.

En "Desde lejos: la escritura a la intemperie", Sylvia Molloy advierte el mismo riesgo identificado por Saer y señala que para el escritor que se ha alejado de su casa natal:

\footnotetext{
${ }^{346}$ En El otro Borges, el primer Borges, Rafael Olea Franco revisa ese proceso que va de los primeros poemarios del escritor hasta Historia universal de la infamia (1935) en el que Evaristo Carriego (1930) tendrá una importancia fundamental como configurador de su "estética de las orillas". El libro, señala, además de ser una biografía apócrifa de Carriego, incluye una serie de textos ("El truco" y "Las inscripciones de los carros") en los que Borges plantea su concepción de las orillas y comienza a producir esos famosos pasajes entre lo criollo y lo universal. Rafael Olea Franco advierte que lo vanguardista en Borges es su modo de leer la heterogeneidad discursiva y "marginal" desde una perspectiva literaria: las inscripciones "sentimentaloides" de los carros, una milonga, un tango; y también un verso de El paraíso perdido de Milton o un pasaje de Shakespeare. En el centro de esa escritura orillera está "la búsqueda de la exacta oralidad [porque] como explica Borges tiempo después: 'En mi corta experiencia de narrador, he comprobado que saber cómo habla un personaje es saber quién es, que descubrir una entonación, una voz, una sintaxis peculiar, es haber descubierto un destino" " (248).

${ }^{347}$ En la entrevista que le realiza en la casa de los Beceyro en Colastiné Norte, después de una tarde de filmación junto al equipo de Filipelli, Martín Prieto le pregunta a Saer si toma apuntes cuando vuelve a Santa Fe y si le interesa rescatar el estado del uso de la lengua.
} 
La misma lengua que uno se llevó afuera, la que era casera, por así llamarla, al trasplantarse se desfamiliariza, se vuelve otra, es y no es del todo la lengua de ese homeland que se dejó atrás. Se tiene la sensación, a veces, de estar hablándola entre comillas. [...] Escribir afuera propone siempre ese vaivén: ni se llega ni se regresa del todo (Molloy s/p).

Las libretas de Saer, pero también varios de sus borradores, muestran la experiencia que Molloy ha sintetizado en el título de su libro "Vivir entre lenguas", una práctica que el escritor ensaya a partir de ese registro aleatorio de las novedades y curiosidades del español rioplatense y de las citas políglotas que anota.

Ese devenir constante de la lengua, el hábito de "saca[r] palabras de todos los ángulos" (Artl 143) era enfatizado precisamente en el otro "idioma de los argentinos", el artliano, en el que además de amonestarse la gramática anticuada de Monner Sanz se apelaba a otra tradición para justificar la natural disposición al cambio (Last Reason, Féliz Lima, Fray Mocho) y se abrían las peligrosas compuertas del lunfardo y de las "malas lenguas de la inmigración”, antes cerradas por Borges. Sesenta años después, Saer disuelve el conflicto (su lengua está efectivamente asentada sobre aquella prestigiosa tradición decimonónica que ostentaba Borges, pero, como hijo de inmigrantes sirios, no puede ignorar la valiosa sedimentación de las lenguas y dialectos inmigrantes, como tampoco desconocer la pervivencia de palabras indígenas, y mucho menos negar el sustrato cultural universal que amplía los horizontes idiomáticos y literarios del idioma) y lo desplaza porque sus problemas contemporáneos son otros: las lenguas a las que está expuesto el exiliado y el progresivo vaciamiento que el neoliberalismo y la homogeneidad totalizadora de la cultura operan sobre la densidad lingüística. Lo que Arlt y Borges unían, cada uno a su manera, Saer lo separa: patria y lengua serán en adelante entidades diferenciables.

En La nostalgia, Barbara Cassin reflexiona sobre los vínculos entre exilio y lengua materna a partir de la trayectoria filosófica, política y lingüística de Hanna Arendt, exiliada de Alemania durante el nazismo, refugiada en Francia y naturalizada finalmente en Estados Unidos. Arendt reconoce que la lengua es lo único que un refugiado puede llevarse de su antigua patria: "siempre me esforcé por conservar intacta y viva esa cosa irremplazable" (citada en Cassin 77). Salvando todas las distancias entre el exilio político de Arendt y el traslado de Saer a Francia, interesa destacar algunos contactos en su forma de comprender los vínculos entre lengua, patria y exilio. Cuando Günter Gaus le pregunta a Arendt si extraña la Alemania anterior al nazismo, ella dice: “La Europa del periodo anterior a Hitler? Le aseguro que no guardo ninguna nostalgia. 
¿Qué quedó de eso? Queda la lengua” (en Cassin 69). Pueblo y lengua se escinden, y Arendt se desentiende de las determinaciones culturales, religiosas y políticas que supuestamente deberían identificarla y no se siente más alemana que judía, "ser judía, mujer" forman parte de los datos indudables de su vida, no de una pertenencia voluntaria e inmediatamente politizable. La lengua materna, señala Cassin, está unida a la posibilidad de "inventar" y también, retomando a Arendt, a la posibilidad de resistir a los clichés, no sólo de la lengua de origen sino de la nueva lengua adoptada por el exiliado, algo que se exacerba ante la problemática de la "crisis de la cultura" y la cultura de masas. La lengua materna puede dejar de serlo "cuando ya no se inventa, [o] cuando ya no es ni siquiera verdaderamente "lengua" para todos esos auditorestransmisores política y humanamente idiotas, paralizados de banalidades y que no poseen ningún juicio reflexivo o crítico" (Cassin 81). Una crítica a la cultura del consumo, a la banalización y a la espectacularización que Saer también hará, como se sabe, desde la beligerancia adorniana que caracteriza sus ensayos y El río sin orillas, y que incluso puede leerse en algunas de las notas de las libretas, en las que reflexiona sobre la televisión, la política y las prácticas mercantiles y marketineras de algunos escritores que salen en el diario opinando sobre cualquier cosa.

Esa escisión entre lengua y nación atribuida a Hanna Arendt también puede observarse en Saer, sobre todo si tenemos en cuenta en qué momento del ensayo se incorpora su reflexión sobre el español rioplatense. Será precisamente durante el "Invierno" cuando "la lengua" aparezca exhibiendo su amalgama llena de tensiones y conflictos no del todo resueltos, la estación que Saer elige para prodigar los horrores de la violencia política que fundó el país y se mantuvo férrea hasta el presente del neoliberalismo, allí donde se propone más explícitamente desarticular la posibilidad de una idea afirmativa de identidad nacional. Borges había terminado su ensayo apelando a ese llamado utópico de recomposición del legítimo idioma:

Vivimos una hora de promisión. Mil novecientos veintisiete: gran víspera argentina. [...] La esperanza es amiga nuestra y esa plena entonación argentina del castellano es una de las confirmaciones de que nos habla. Escriba cada uno su intimidad y ya la tendremos. Digan el pecho y la imaginación lo que en ellos hay, que no otra astucia filológica se precisa. [...] El porvenir (cuyo nombre mejor es el de esperanza) tira de nuestros corazones (Borges, "El idioma de los argentinos" 149-50). 
Saer, que en este mismo apartado ha denostado el carácter demasiado festivo y épico que asumía la "violencia" en el recuerdo de los mayores de Borges y en su temprana aprobación de la "caballerosidad" de los militares, y termina en cambio diciendo: "En vez de querer ser algo a toda costa -pertenecer a una patria, a una tradición, reconocerse en una clase, en un nombre, en una posición social, tal vez hoy en día no pueda haber más orgullo legítimo que el de reconocerse como nada, como menos que nada [...] ninguna identidad afirmativa ya es posible" (Saer, El río 206).

\section{Las especies predilectas: el jardín secreto de la lengua}

Los regresos de Saer al país coinciden, como se vio, con esa progresiva confirmación de su literatura y de su figura de escritor entre un público cada vez más amplio. Además de visitar amigos y familiares y de recorrer los paisajes de su infancia, Saer debe participar de festivales, charlas y presentaciones y dar entrevistas a medios de amplia circulación. Las libretas de viaje y El río sin orillas permiten reconstruir su experiencia del regreso, a medias fraguada entre lo biográfico, lo ficcional y lo ensayístico; entre vida y escritura; entre percepciones familiares y extrañezas, desconocimientos y nuevos hallazgos. Premat señala sin embargo que "aún en los últimos años de su vida, cuando la repercusión mediática de su obra lo llevó a sistemáticas intervenciones públicas, el mismo rechazo siguió, a su manera, actuando" (“Saer: un escritor del lugar” 198). Una tensión que él mismo señalaba entre la fuerte presencia autoral que se desprende de la coherencia de su obra y el borramiento de su imagen que el escritor perfecciona yéndose a Francia. Quisimos leer en El río sin orillas pero sobre todo en esos pequeños cuadernos de escritura íntima la posibilidad de ensayar autofiguraciones que desarticularan no su propia figura pública (también hecha de resistencias, silencios y performances poco coloridas), sino la idea y expectativas asociadas a un escritor fuerte que visita su patria de origen con un estilo consolidado y un conocimiento fundado sobre la región que viene representando desde los comienzos de su proyecto artístico. Por el contrario, esa "perspectiva exterior" que Saer ha aprendido de los viajeros y exploradores y fundamentalmente de Gombrowicz suspende el reconocimiento para privilegiar un modo interrogativo de recorrer el territorio, deudor, por supuesto, de Juan L. Ortiz, cuyo homenaje se extiende por varias páginas en El río sin orillas. 
En "Lengua privada y literatura" Saer advierte: "el uso personal de la lengua es el jardín secreto en el que cada uno cultiva las especies de su predilección" (Saer, Trabajos 38) y sostiene que esa plasticidad para anexar nuevas zonas del lenguaje y la posibilidad de pensar a las palabras como sedimentos de asociaciones y connotaciones personales solo puede darse en el ámbito de la lengua materna. El escritor que, estando en París, habla un perfecto francés con tono santafesino puede, en sus regresos y en un momento de clivaje de su poética, anexar nuevas palabras y cultivarlas en el "jardín privado" de su lengua materna.

A diferencia de Hudson, que en medio de un estado de fuerte debilidad física puede recobrar las aventuras y vibraciones de su infancia vivida en las pampas sudamericanas: "tuve una clara, continua y maravillosa visión del pasado y me vi tentado [...] a escribir esta narración" (Allá lejos 8), Saer, que desconfía hace tiempo del poder evocativo de la memoria, vuelve para interrogar las formas del habla y las formas del paisaje. En este sentido convierte el avatar naturalista y viajero en una versión de escritura exiliar y poética, pero no nostálgica. ${ }^{348}$ Lo curioso no es tanto que Saer recolecte nomenclatura científica o comparta protocolos de observación de antiguos viajeros, sino cómo el vocabulario aséptico de la botánica y algunas de esas formas de aprensión espacial se vuelven parte de su "lengua privada", agudizando su modo de contemplación.

"El paseante es el hombre que abandona la causa, su causa [...], renuncia a la fricción y los esmeros para olvidarse de sí, para perderse en el mundo" (Scott, Caminantes 31). Así, mientras camina, viaja en colectivo o se detiene a observar el río desde un puente, Saer especula e interroga la textura botánica, topográfica y lingüística del paisaje rioplatense como si fuera, por momentos, un naturalista aficionado a lo Hudson, un viajero explorador o un lingüista caprichoso que colecciona preciosos "detalles" de la lengua coloquial. Sin embargo, esa indagación que aleatoriamente va asentándose a través de las notas y ordenándose en El río sin orillas no está interesada en señalar lo absolutamente singular de la zona, sino por el contrario, en indicar su parentesco disolvente con el mundo. Tanto en las libretas como en el ensayo Saer desarticula el "color local" apelando a una historización de larga duración capaz de

\footnotetext{
${ }^{348}$ A diferencia de Hudson, que inscribe su experiencia de la pampa sudamericana como un intento por conservar algo de esa naturaleza primitiva de su infancia, Saer, como se vio, desarticula el tópico de la nostalgia en varios de sus escritos ensayísticos y ficcionales. Cfr. "El paraíso recuperado" (1969).
} 
saltar de la captura del instante al tiempo de los orígenes geológicos y cósmicos del universo:

lo exterior de un lugar no es más que la manifestación de algo que no es propio de ese lugar y que está, no propiamente en ninguna parte, sino en todas, lo que equivale a decir lo mismo. Los grandes ríos que forman el de la Plata, multiplicándose a medida que bajan del norte [...] no tienen nada de exótico y son el resultado de una serie de contingencias geológicas, geográficas y humanas en las que, por debajo del color local, el Logos común prosigue el soliloquio de su empastamiento con el mundo (Saer, El río 219-20).

Un empaste entre naturaleza e historia y entre geografía, cartografía y lenguas. La rotunda negativa saeriana a la pregunta de Martín Prieto sobre el acto de "rescate" del estado de la lengua en uso, quizás incluso demasiado enfatizada por Saer, permite observar que sus regresos terminan de desarticular las ideas abstractas de "patria" y “nación”, de identidad afirmativa y homogénea.

Saer vuelve después de la Guerra de Malvinas y comprueba los estragos sociales y culturales que ha dejado la Dictadura Militar; registra con fruición estética las ruinas del paisaje postindustrial y portuario que se herrumbran y autonomizan como piezas de contemplación y memoria; ironiza a propósito de las monumentales y grotescas moles de consumo que se levantan sobre los terrenos pantanosos de la zona y evoca la imagen del puente colgante, ahora desierto y silencioso. Ante la desorientación provocada por el oikos, Sylvia Molloy dirá que la única seguridad será el "simulacro del hogar que el viajante, la persona dislocada, lleva consigo en sus viajes: un hogar portátil” (27). Las libretas son, en parte, ese simulacro de hogar que el autor llevará consigo en sus desplazamientos y actualizará en cada uno de sus regresos. 


\section{LA GRANDE: REGRESO ORIENTAL Y TIEMPO ESCÉNICO}

La grande es la novela radiosa del regreso, a la vez de su consumación y de su imposibilidad. Como se adelantó, a medida que avanza, el corpus del regreso de Saer se va anudando progresivamente a la biografía del propio escritor, incluso a contramano de su resistencia autobiográfica o, como diría Premat, como "autobiografía cifrada". ${ }^{449}$ En esta oportunidad Saer recuperará un aspecto casi siempre soslayado: su pasado como hijo de inmigrantes árabes. La novela no solo retorna a la propia obra, a partir de las abundantes referencias intertextuales que le propone a sus viejos lectores, sino también a los "inicios" del aprendizaje literario. Se vuelve, como veremos a José Pedroni y a Cesare Pavese. El retorno se transforma en una pieza clave que a la vez le permite al proyecto saeriano "continuar". No se regresa para clausurar ni para develar lo que textos anteriores habían elidido o aplazado (más allá de que, como ha afirmado Rafael Arce, la novela tenga "a priori” todos los elementos patéticos de final de saga) sino para sumar "otra vuelta" e incorporar nuevas esquirlas narrativas que futuras ficciones podrían haber desarrollado.

Interesa subrayar en este sentido que si bien La grande comienza a gestarse paralelamente a la escritura de Glosa no es sino muchos años después cuando el regreso deviene principio de acción, de reflexión y de reescritura. Llamada en un principio El intrigante, Saer escribió en primera instancia gran parte del capítulo sobre el falso vanguardista Mario Brando y desarrolló la historia sobre el precisionismo. En este primer momento acopió además una gran cantidad de información sobre los movimientos literarios de la ciudad y sus articulaciones con la política. En una segunda instancia, desde 1995 hasta el año 2000, Saer preparó la novela pero aún no estaban definidos varios de los nombres de los personajes. Gutiérrez era todavía "Toublanc" y la anécdota que se cuenta en "Recepción en Baker Street" se seguía incluyendo como parte de la novela, hasta que finalmente se autonomizó como relato en Lugar y por lo tanto como "antecedente" o presentación de Nula. Es decir que para ese momento $L a$ grande todavía no se pensaba como historia que viniera a trabajar sobre las elipsis

\footnotetext{
${ }^{349}$ La dimensión autobiográfica alrededor del retorno puede observarse también, apunta Premat, en el personaje de Nula que lleva el nombre de la madre de Saer y en sus recuerdos que son los de la infancia de Saer, así como en el tema del "guionista cínico" que regresa a la zona. Además, entre los cuadernos de notas aparecen fotografías de retornos de Saer a Santa Fe.
} 
abiertas por "Tango del viudo", y por ende, como "regreso" de un personaje de la zona. Esta relación recién se concreta en la última etapa, el momento de redacción de la obra, que comienza en octubre de 2001 y continúa hasta la muerte de Saer en 2005.

El retorno de Willy Gutiérrez, el joven que había partido misteriosamente después de quemar sus papeles y que reaparece, también inesperadamente, treinta años después no es el único desplazamiento que ocupa las páginas de la novela. Saer vuelve a tocar aquí las variantes del viaje, en algunos casos, para confirmar y radicalizar viejas apreciaciones - la parodia del viaje de los sesenta, la diatriba contra la sociedad europea-; para darle espacio a nuevas formas del desplazamiento -la beca de estudio en el exterior de los jóvenes investigadores de la ciudad- y también para recuperar una memoria de la inmigración -a partir de la reconstrucción de los viajes de Yusef, el abuelo árabe de Nula- ${ }^{-}$La biblioteca viajera se concentra ahora en las referencias a los nostoi griegos, a la versión operística del Ulises de Monteverdi y a la mención de Dante, alrededor de quien Saer parece disputar con Mario Brando una definición de poética y de patria.

\subsection{Por fin, Pedroni}

En el relativamente escaso anecdotario sobre Saer flotan algunas escenas de iniciación literaria: además de los viajes en lancha para visitar la casa de Juan L. Ortiz, se evoca también la visita que un sábado de invierno de principios de los cincuenta Saer le hizo al poeta José Pedroni, cuando, “al trasponer el umbral, entr[ó] a la vez en la casa de José Pedroni y en la literatura" (Ensayos 196). ${ }^{350}$ Por vocación de demora y calculada resistencia estética, Saer tarda en "cumplir" con los escritores que de alguna manera u otra intervinieron en sus años de aprendizaje (entrega los saludos de Raúl Gustavo Aguirre a René Char cuando ambos ya han muerto; homenajea a Borges en su obra tardía cuando se ha diferenciado lo suficiente de él) y cumple recién veinte años más tarde -en Glosa y en El río sin orillas - una invitación que le había hecho José Pedroni en los años de iniciación. Como él mismo cuenta, Pedroni, el poeta de la inmigración, le había dedicado un extenso poema al oficio de albañil de su padre y le sugiere a Saer que escriba sobre el almacén de ramos generales que su familia tenía en

\footnotetext{
${ }^{350}$ Saer cuenta esto en "José Pedroni", el prólogo que escribe para la tercera edición de su Obra poética publicada por la UNL en 1999.
} 
Serodino, “en razón según él del carácter mágico y poético que surge de la acumulación y de la variedad de mercancías que existe en esos lugares" (El río 165). Y así Saer cumple, muchos años después, la demanda del poeta sencillista. En Glosa, Leto evoca sus años de infancia cuando viajaba para visitar a su familia en el pueblo y recuerda "el negocio de ramos generales de su abuelo" (70) a partir de una extensa enumeración de los productos del negocio que culmina en la caja de "Quaker Oats", cifra de la "puesta en abismo" y del infinito al que podría conducir ese catálogo.

En El río sin orillas, el almacén de ramos generales es el aleph material de la pampa gringa y responde a las necesidades de alimentación, esparcimiento y trabajo de los diferentes grupos de inmigrantes, a quienes conecta, de algún modo, con sus propios orígenes. Saer contrapone esta antigua forma del comercio, que satisface necesidades concretas, a "la abundancia irritante" de los supermercados actuales, que crean deseos inexistentes en los consumidores. Como se recordará, le dedica El río sin orillas a sus padres pero no habla propiamente de su padre como negociante. Se limita a exponer el funcionamiento del almacén como cifra de la heterogeneidad de la llanura y suspende, una vez más, la nota biográfica y afectiva que se desprende, y en abundancia, del poema de Pedroni. ${ }^{351}$ Lo que en El río sin orillas aparecía formulado como parte del escenario de los pueblos del interior, se torna en La grande ocasión de rememoración de la infancia de Nula pero también espacio fascinante por un principio estético y misterioso: la repetición de los productos, que el personaje reencuentra, de manera grotesca, en el hipermercado.

Será recién en esta novela cuando Saer recupere para la ficción el universo árabe de su familia y la historia de su inmigración. Como se vio, el escritor había comenzado a asumir su pasado como hijo de inmigrantes sirios -y como inmigrante él mismo en Francia- cuando se mudó al extranjero, pero hasta 1968 reconoce haberse distanciado paulatinamente del seno familiar. ${ }^{352}$ La crítica que se ha ocupado de la novela en general se ha centrado en el regreso de Willy Gutiérrez a la zona, estableciendo las relaciones pertinentes con obras anteriores y ponderando los efectos de esa vuelta. Por

\footnotetext{
${ }^{351}$ En las "Palabras a mi padre y a su digna herramienta" puede leerse: "Padre: aquí me tienes, triste,/ pensando todavía/ en lo raro que fuiste.// Por haberte servido/ sin hablar,/ atado a tu silbido/ hasta que fui a estudiar,/ yo tenía derecho/ a tu cuchara de albañil/ la más honrada entre diez mil;// pero no me la diste:/ como la cruz en tu pecho,/ orgullo de tu vejez,/ ella fue puesta a tus pies/ cuando te fuiste./ Y aquí me tienes, triste". (Extraído de https://josepedroni.es.tl/Otrosd--Palabras-a-mi-padre-y-a-su-digna-herramienta.htm)

${ }^{352}$ Remito al capítulo I. 2 en el que se reconstruye esta relación entre Saer y sus familiares sirios.
} 
ese motivo, interesa reflexionar también sobre esa aparición tardía del mundo siriolibanés de su infancia, que no ha sido lo suficientemente explorada. Como se verá, Saer presenta ambas historias a partir del díptico inicial que abre la novela: la expedición de Nula y Gutiérrez.

La vuelta de Gutiérrez y su "ingenuo afán restitutivo",353 le permite retomar las fibras del pasado del elenco "estable" de personajes que hacía mucho no aparecían, como los Rosemberg y Sergio Escalante. El asado es, como se sabe, la instancia de reunión que los congrega a casi todos, viejos y jóvenes, presentes y ausentes. E1 personaje de Nula, sin embargo, le permite a Saer abrir una nueva zona de personajes y de historias y reconstruir su propio origen como hijo de inmigrantes sirios. Aparecido por primera vez en "Recepción en Baker Street", Nula es amigo de Soldi y de Tomatis y conoce a través de ellos a Pichón Garay. Junto a Soldi y Gabriela, Nula forma parte de la nueva generación de jóvenes de la "zona", los espías del presente que especulan con interés el pasado mítico y bohemio de sus mayores. Las actividades entre las que se reparte son la filosofía y la venta de vinos y mientras se desplaza por la ciudad visitando a sus clientes anota en una pequeña libreta recuerdos, impresiones y reflexiones para un paradójico proyecto: "La ontología del devenir". Nula forma parte de una familia árabe y su nombre es "la versión árabe de 'Nicolás'” (Saer, La grande 78). El segundo capítulo de la novela, "Miércoles. La manzana" ${ }^{354}$ detalla su historia, y para explicar el azaroso primer encuentro con Lucía Riera, se remonta hasta la explosión del big bang, nuevo giro hacia el origen cósmico que es preciso hacer para narrar las peripecias de este nuevo personaje; porque hablar de Nula es hablar desde cero, inventar otro origen para la narración y fundamentalmente, como se verá, reescribir, orientalizar, la zona.

La ficción recupera algunos episodios de la historia familiar: sabemos que el padre de Nula fue un militante político que murió asesinado en una pizzería de Buenos Aires en 1975. El hecho es oscuro porque no se aclara si lo mataron sus amigos o sus enemigos y abre, como ha señalado Sarlo, un nuevo capítulo del ciclo político que no venía relacionado estrictamente con las novelas anteriores. La vida un poco errante del padre y su muerte prematura constituyen un misterio para el abuelo Yusef. Como el

\footnotetext{
${ }^{353}$ Cfr. el artículo de Beatriz Sarlo "El tiempo inagotable" (2005), incluido en Escritos sobre literatura argentina. Allí señala que Gutiérrez es una pieza que no termina de encajar entre sus contemporáneos, precisamente porque su "patética ingenuidad" desentona con lo que queda en ese mundo: la sorna, la comicidad, la resignación y el sarcasmo. Escalante, rechazando su invitación al asado, le muestra que su deseo de restitución es ilusorio.

${ }^{354}$ La novela está organizada según los días de la semana, de martes a domingo, una estructura temporal aparentemente sencilla que, por supuesto, el "presente espeso y múltiple" hará estallar.
} 
padre de Saer, Yusef llegó de Damasco a fines de los años veinte para trabajar como empleado de un tío suyo en un pueblo a orillas del Carcarañá. Nula reflexiona sobre la idea de familia en tanto "fenómeno material" y observa que está en movimiento y en cambio constante. En "Historias de familia", un ensayo de Trabajos, Saer postulaba que "ni siquiera los mitos de papel [...] pueden escapar al principio de realidad que supone la pertenencia a una familia" (171 cursivas en el original) y revisaba diferentes ficciones vinculadas al tratamiento de este tópico. En relación a este "ajuste de cuentas" con lo familiar, la historia de Nula reescribe, como se adelantó, textos anteriores. El detallado y hermoso catálogo de las primeras sensaciones de la llanura que tuvieron Nula y su hermano Chade cuando iban a visitar a su abuelo al pueblo es, podría pensarse, otra versión de "En la tardecita", 355 pero también de "Lo que es mejor a orillas del Paraná que en París" un texto autobiográfico que Saer escribe alrededor de 1971. Recordemos, aquí Saer enumeraba de forma vertiginosa:

El pan casero, el aire en invierno, los caballos, el jacarandá florecido, el amarillo y el moncholo, [...], el sol de enero y de febrero, los ríos espesos y entrecruzados [...] la voz de las mujeres, el atardecer sin ruidos, el humo, la soledad [...] el zenit, el esperma, la tierra [...] la llovizna, octubre, el sueño, el frío, los papeles, las lágrimas, los nombres (Saer, Papeles II 55-6).

La grande extiende el catálogo y lo ordena, clasificando las sensaciones en táctiles, olfativas, gustativas, auditivas y visuales. Lo nuevo que irrumpe, yuxtaponiéndose y acoplándose al mundo criollo de la zona, ${ }^{356}$ es el mundo árabe que Saer recupera, por primera vez, en su última novela:

${ }^{355}$ Como se recordará, "La tardecita" es un cuento de Lugar que Saer le dedica al "ingeniero Saer", su hermano. El relato es en realidad la historia de los efectos de una lectura porque mientras Horacio Barco lee un breve relato de Petrarca, La ascensión al Monte Ventoux, recuerda una tarde en la que con su hermano mayor se adelantaron a sus padres y fueron solos al pueblo en el que vivía casi toda su familia a pasar las vacaciones de Semana Santa. La escena es muy similar a la contada en la novela, cuando Nula evoca las vacaciones que pasaban junto a su hermano Chade en el pueblo en el que vivían su abuelo, sus tíos y sus primos. El cuento se detiene, sin embargo, en el camino que recorren los hermanos, desde la ruta asfaltada hasta la entrada del pueblo, en ese momento del atardecer en el que la luminosidad crepuscular se vuelve lívida y ultraterrena modificando el aspecto familiar del paisaje para revelar su verdadera extrañeza. Barco percibe por primera vez que el mundo no le pertenece y que es exterior a él. $L a$ grande desarrolla lo que este relato no cuenta - porqué para Horacio Barco ese pueblo era el "paraíso", qué percepciones sensoriales podía extraer de ese lugar, que costumbres y rituales compartía con sus seres queridos-, y al hacerlo, orientaliza la experiencia.

${ }^{356}$ En "La vuelta incompleta (una pintura)", Miguel Dalmaroni comprende este episodio como una mini-novela de formación cuyo prototipo está en la biblioteca criollista, en Juvenilia y en los primeros capítulos de Don Segundo Sombra, donde se cuentan las peripecias de la niñez iniciática en el campo. Podría sumarse a estas filiaciones Allá lejos y hace tiempo de Hudson, 
[el olor] de una especie de aserrín comestible que se llamaba yátar y que el abuelo recibía de tanto en tanto de Damasco e iba comiendo de a poco, poniendo un montoncito sobre un pedazo de pan y rociándolo con aceite de oliva; [...] [el sabor] de la comida árabe, menta, zapallitos, limón, berenjenas, trigo triturado con carne cruda y cebolla, y, en verano, mechada de pedacitos de hielo; el del mate cocido con leche y azúcar del desayuno; [...] las conversaciones en árabe entre el abuelo y sus paisanos o los miembros de la familia que vivían en el pueblo [...] la radio que sacaban a la galería si hacía buen tiempo para escuchar en una estación de Rosario La hora siriolibanesa y la voz doliente de Um Kalzúm que se diseminaba por el patio soleado, en la quinta, en el huerto y en el jardín [....]; las palabras árabes: bab (puerta), jushbe (pan), jalib (leche), jabibi (querido), betenyan (berenjena), blad (la tierra natal), etcétera. [...] el horizonte vacío de la llanura, irreal, [...] las bandadas de mariposas amarillas que, volando en grupo, aleteaban todas y se asentaban en las partes húmedas de la tierra después del paso del regador; [...] los jinetes que pasaban a caballo al trote corto y $[. .$.$] dirigían hacia la esquina del almacén un saludo. [...] (Cada vez que se$ acordaba de estas sensaciones, Nula las anotaba en una libretita). (Saer, $L a$ grande 84-86).

Saer orientaliza la zona a través de la recuperación del universo familiar árabe de su infancia y traduce las palabras que formaban parte de su cotidiano. ${ }^{357}$ De los variados repertorio de lo "oriental" que fraguó la sensibilidad intelectual y literaria nacional, ${ }^{358} \mathrm{el}$

sobre todo en lo que hace a esa sociabilidad heterogénea con los distintos personajes de la llanura.

${ }^{357}$ La grande también será una renovada ocasión para reflexionar sobre la lengua natal y las lenguas del extranjero, y así Gutiérrez intercalará, de vez en cuando, palabras en otros idiomas, o Pichón Garay escribirá un poema en francés parodiando a La Fontaine.

${ }^{358}$ Este apartado se circunscribe al análisis de La grande. Sin embargo, podría pensarse en ulteriores trabajos en qué medida Saer dialoga con las representaciones y el mundo de referencias oriental no sólo a partir de su propia historia familiar sino también en relación a ciertas zonas de su biblioteca (haikus; literatura japonesa). Como se vio, además, en Lugar se problematizan algunos conflictos de geografía política, imperialismo e inmigración que tienen la otredad oriental en su centro. En el ya clásico Orientalismo, Edward Said apela a las codificaciones imperiales que configuraron el "orientalismo", un discurso que se produce desde el exterior Occidental y que aglutina una serie de motivos, declaraciones e imágenes que otorgan significación a "Oriente". Ese entramado no se limita a una geografía precisa y suele incorporar a los países árabes de África, Siria, Palestina, China, India, Japón, e incluso Rusia. En El oriente desplazado, Martín Bergel estudia cómo se modificaron las representaciones argentinas del "Oriente" y advierte una diferencia fundamental entre lo que denomina "la matriz orientalista sarmientina" del siglo XIX y el despertar del "Oriente invertido", una nueva imagen que comienza a emerger a principios del siglo XX y termina de condensarse alrededor de la década del veinte. Lo que Bergel señala es que el signo negativo a partir del cual los letrados decimonónicos habían leído lo oriental (haraganería, violencia, despotismo), como un parámetro que había que rechazar en la construcción de una nación moderna, comienza a invertirse después de la Primera Guerra Mundial y de la "crisis de Occidente" que trae aparejada. Esta nueva sensibilidad ubicó a Oriente ya no como el espacio de la otredad sino como un espacio de "complicidad" y recuperó el archivo de lecturas románticas europeas (Pierre Loti, FrançoisRené Chautebriand) que los letrados del siglo XIX habían desestimado. El modernismo, continúa explicando Bergel, rescató precisamente los valores del exotismo, el espiritualismo, la 
archivo oriental aquí seleccionado privilegia una memoria íntima y familiar de la inmigración que apela a imágenes, experiencias, sensaciones y referencias que tienden a verosimilizar ese mundo, asimilándolo, como veremos, al paisaje criollo de la zona, a través de un montaje que mistura ambos repertorios culturales: "el ruido complicado y rítmico, un golpeteo de cuero, madera y metal, de los sulkys, las jardineras y las chatas; las conversaciones en árabe entre el abuelo y sus paisanos o los miembros de la familia que vivían en el pueblo o que venían a visitarlo desde los pueblos de los alrededores e incluso de Rosario o desde Buenos Aires y una vez desde Colombia" (Saer, La grande $85)$.

Uno de los aspectos que resulta más significativo es la apertura al mundo lingüístico árabe del que Saer casi no había dado señales hasta ese momento. Del abuelo se dice que era uno de esos "turcos" acriollados que bien podía ser tomado por un gaucho, "e incluso cuando hablaba no tenía demasiado acento extranjero: había aprendido bien el castellano, excepción hecha de cuatro o cinco obstáculos [...] que delataban sus orígenes" (Saer, La grande 86). Interesa subrayar, además, que esa misma mezcla cultural -el universo criollo y el universo de la inmigración- también aparecía en el artículo de Saer "Los libros argentinos" ya comentado anteriormente, en el que el escritor confiesa haber leído por primera vez el Martín Fierro en los almanaques que colgaban en el almacén de ramos generales de su familia. ${ }^{359}$

La emigración árabe a la Argentina fue muy importante y se extendió por gran parte del territorio nacional, particularmente en las ciudades y en la región del noroeste, a la que llegaban en menor grado otras colectividades de inmigrantes. La familia de Nula parece encuadrarse entre la primera y la segunda oleada de inmigrantes sirio-

atracción por los lugares sacros, el misterio y la belleza de lo oriental como modelo alternativo de resistencia a la vez estética y política. Interesa destacar, sin embargo, que ese despertar oriental que circuló positivamente entre los círculos intelectuales y que colaboró en formas incipientes de una sensibilidad tercermundista distó mucho de la valoración peyorativa que siguieron recibiendo los inmigrantes árabes: "las representaciones orientalistas y las opiniones sobre los turcos y otros grupos migrantes generalmente marcharon por carriles bastante diferenciados" (Bergel 22). Como se vio, al menos en La grande, Saer no interviene en el terreno de discusiones políticas y estéticas sobre lo oriental. Del amplio repertorio de imágenes "orientales" sedimentadas en la cultura argentina - positivas y negativas- elige exclusivamente aquellas que contribuyen a verosimilizar una memoria de la inmigración, y frente al "exostismo" y el "ensueño" usualmente asociado al mundo árabe, se propone aquí asimilarlo al mundo cultural criollo.

${ }^{359}$ También el padre de Marcos Rosemberg, un judío comunista de Alemania que llegó al país a fines de los años veinte recitaba de memoria varias de las sextinas del Martín Fierro en un español cada vez más fluido e incluso las había adoptado como norma para su comportamiento. 
libaneses que llegaron al país. ${ }^{360}$ De acuerdo a los estudiosos, ${ }^{361}$ la cultura sirio-libanesa se adaptó rápidamente a la estructura social y cultural argentina aunque mantuvo desde su llegada un gran sentimiento de cohesión grupal. A diferencia de otros grupos culturales, prácticamente prescindieron del apoyo del estado nacional para asentarse y practicaron un sistema de "cadenas migratorias", en las que miembros de la comunidad ya asentados en territorio argentino facilitaban la llegada, el traslado y el alojamiento de los recienllegados. ${ }^{362}$ Algo de ese mundo familiar extendido ya se perfilaba en el

${ }^{360}$ La primera emigró desde 1860 a 1918/20 porque el gran crecimiento demográfico en Medio Oriente rompió el equilibrio entre población y tierra y la industrialización creciente dejó a muchos comerciantes y artesanos en una situación de gran inestabilidad. Pero además, las minorías cristianas -a las que pertenecían las familias de Saer y de Nula- sufrieron persecuciones en el Imperio Otomano, que tuvo control sobre Siria y el Líbano hasta la Primera Guerra Mundial (luego pasaron a dominio francés). La segunda oleada inmigratoria se produjo entre 1918/20 y 1945 y emigraron fundamentalmente musulmanes y drusos porque el gobierno francés le concedió una mayor participación a los árabes cristianos.

${ }^{361}$ Cfr. Bestene, Jorge e Ignacio Klich. "La inmigración siriolibanesa en la Argentina. Introducción"; Devoto, Fernando. Historia de la inmigración en la Argentina; Schamun, Alejandro. La colectividad Siria en la República Argentina; Bérodot, Solène y María Isabel Pozzo. "La inmigración sirio-libanesa en la ciudad de Rosario, Argentina: continuidades, desvanecencias e intercambios socioculturales" y Klich, Ignacio. "Árabes, judíos y árabes judíos en la Argentina de la primera mitad del novecientos".

${ }^{362}$ En "Árabes, judíos y árabes judíos en la Argentina de la primera mitad del novecientos" Ignacio Klich apunta que la inmigración de árabes y judíos no formaba parte de las expectativas de "mejoramiento de la estirpe humana" y de progreso nacional formuladas por las élites argentinas de fines de siglo XIX, que habían puesto sus esperanzas en la inmigración noreuropea: "Dada su desviación respecto de la corriente mayoritaria, judíos y árabes pronto habrían de figurar entre los 'exóticos', capaces de afectar la mezcla étnica del país hasta tornarla irreconocible" (Klich s/p). La comunidad sirio-libanesa, a pesar de profesar en general la fe cristiana - ortodoxos, maronitas y melquitas- era considerada en general como una comunidad de musulmanes. Esto, sumado a otras diferencias culturales, lingüísticas y de organización familiar agudizaba su extranjería ante la prensa y ante cierto sector de los políticos gobernantes que los consideraba un factor que comprometía la identidad étnica de la Argentina. Pero a su vez, más allá de estas diferencias culturales, la inmigración árabe y judía no era considerada beneficiosa en relación al progreso económico del país. Como se sabe, las élites argentinas no estaban interesadas en el desarrollo del sector terciario de la economía -el comercio minorista y el crédito al consumo-, actividades privilegiadas por estas comunidades, por ello "tanto árabes como judíos fueron estigmatizados como parasitarios e improductivos, sus mercachifles comparados con mendigos, o considerados como causa de competencia deshonesta y desleal para los comerciantes locales" (Klich $\mathrm{s} / \mathrm{p}$ ). Interesa rescatar estos aspectos del asentamiento árabe en Argentina porque a pesar de su integración en el país y el prestigio que fueron cobrando entre parte de la élite gobernante, el exotismo y la diferencia fueron experiencias comunes y agudizadas, subrayadas muchas veces por la literatura de las primeras décadas del siglo (cfr. por ejemplo la crónica de Roberto Arlt "Sirio libaneses en el centro"). La familia de Saer/Nula formó parte del grupo sirio-libanés dedicado al comercio y en algunos comentarios de Saer todavía se lee la pervivencia de esos prejuicios xenófobos hacia los "turcos". Lo que resulta interesante es que su ficción insista, sin embargo, en la integración de los modelos culturales, y así el abuelo Yusef resultará ser un "turco" perfectamente "acriollado", y Nula, un amigo más de la zona al que se reconoce por sus aficiones intelectuales, su conocimiento sobre 
comentario de Saer a propósito de esos "vagos personajes", tíos y primos lejanos, innominados, que formaban parte sin embargo del universo árabe de su infancia. Pero además, habría que subrayar que a pesar de asimilarse con bastante naturalidad a la cultura argentina, la comunidad sirio-libanesa no prescindió de sus propias instituciones y continuó desarrollando su cultura en suelo nacional. Aunque apenas mencionados, estos aspectos aparecen en el fragmento antes incluido. El recuerdo del programa de radio "La hora sirio-libanesa",363 y del Club Sirio-libanés de Rosario al que acudía el abuelo Yusef permiten reconstruir ese mundo cultural sirio en el que creció Nula.

A partir del personaje de Yusef, Saer vuelve a indagar la forma de una nación hecha de exilios múltiples y expande el mapa de la inmigración, generalmente circunscripto a españoles e italianos:

pobres diablos que atravesaron el mar desde Génova, desde Galicia, desde Marsella e incluso desde Dakar o desde Trípoli; que venían de España y de Italia, de Siria y del Líbano, pero también de Portugal, de Marruecos, de Europa Central, de Serbia o de Bielorrusia, de Irlanda o del Japón, escapándole a la opresión, a la guerra, a los pogromes, al imperio otomano, a la policía secreta, a la persecución política o religiosa, al hambre, a la pobreza, al destino (Saer, La grande 90).

El abuelo, que abandonó Damasco cuando era aún muy joven y pudo forjarse un "destino" a pesar de todas las vicisitudes de la inmigración y la intemperie, no puede sin embargo comprender el conflicto con su hijo ni su prematura muerte. La ausencia del padre de Nula, una ausencia política y divergente en la serie familiar, trastoca el mundo conocido de Yusef, que poco después del asesinato de su hijo envejece y enferma. Saer cierra el ciclo familiar de la inmigración apuntando una escena que quizás también reescriba y orientalice otro poema de Pedroni, el que el poeta le dedica a la muerte de su abuelo. ${ }^{364}$ Efectivamente, el abuelo Yusef muere después de un largo proceso de decadencia y abandono. Cuando Nula se acerca al cajón observa una vez más el "tatuaje azul, discreto, en el dorso de la mano derecha [...] tres puntos dispuestos en línea

el vino y su ironía candorosa, aunque su sangre "árabe" despierte entre sus amigos algún chiste sin mayor trascendencia.

${ }^{363}$ Este programa de radio comenzó a emitirse desde 1935 y estaba dedicado a las actividades, la cultura y la ciencia de los árabes, que previamente encontraba un canal de difusión en la publicación periódica El diario siriolibanés y también en La Nación, que comentaba las principales actividades de la comunidad y los homenajes a sus principales literatos.

${ }^{364}$ En "El entierro de mi abuelo" Pedroni llora la muerte de su abuelo y coloca la bandera italiana como cifra de su origen inmigrante: "Por el camino blanco/ se alargaba el cortejo.// A su paso, en las puertas, // se iba cerrando el pueblo.// Flor, crespón y bandera/ de Italia sobre el féretro.// A pulso conducido/ por los amigos viejos. [...] El ataúd bajaron/ a un hoyo recién hecho.// Me incliné temeroso/ para mirarlo adentro". Disponible en https://josepedroni.es.tl/Otros-d--El-entierro-de-mi-abuelo.htm 
horizontal que siempre lo habían intrigado y aunque de chico le había preguntado a su abuelo qué significaban, nunca había obtenido una respuesta satisfactoria" (Saer, La grande 93), tatuaje que también ha observado en otros árabes amigos de su familia. Recién muchos años después, al mirar en la televisión la ópera de Monteverdi La vuelta de Ulises y más precisamente la escena entre Euristea y Ulises que reconoce al mendigo por una cicatriz en el muslo, Nula grita “ ¡Nostoi!” y abre el canto XIX de la Odisea para explicar el episodio:

entendió la finalidad de los tatuajes azules [...] esos signos escritos en la carne anticipaban el nostos, el regreso, del que daban por descontado que estaría tan alejado del momento de la partida, que sus portadores volverían al lugar de origen tan desfigurados por las intemperies y las decepciones [...] que creían prudente muñirse de algún signo imborrable para ser reconocidos por quienes los habían visto partir, y seguían esperando, pacientes, su regreso (Saer, La grande 94).

La vistosa bandera italiana que entra al pueblo en el poema de Pedroni es trocada por los discretos puntos azules que se dibujan sobre la mano del abuelo Yusef. El reconocimiento al que estaba dirigido ese tatuaje se aplaza para siempre y el regreso se torna imposible. Esta escena permitirá leer el otro "regreso" a la zona, el de Gutiérrez, y comprobar una vez más el funcionamiento de la Odisea, ${ }^{365}$ que aquí le ofrece a Nula la posibilidad de descifrar o imaginar el misterioso significado de esos signos. $^{366}$

Sin embargo, la potencia oriental del texto trasciende el episodio familiar y la figura de Nula exhibe ostentosamente las marcas árabes no solo por su aspecto físico, ${ }^{367}$

\footnotetext{
${ }^{365}$ En "Saer: la escritura en expansión", Sergio Colautti advierte el doble funcionamiento del "mito" en la novela, porque si por un lado actúa como "cifra del tiempo quieto, como espacio no sujeto a la corrosión histórica", por el otro muestra sus signos menos visibles: "el pliegue de sus relatos luminosos deja vislumbrar, como una opacidad, 'lo imborrable' del devenir: en la caída ciega de Edipo, en la carencia de Diana, en la herida de Ulises, en las maderas gastadas del barco de Teseo, late esa certeza opaca de la disolución" (Colautti s/p).

${ }^{366}$ En las notas de La grande y en "Historias de familia", el ensayo antes mencionado, Saer se interesa por esos otros regresos griegos, dispersos y perdidos, pero también por otras versiones del mito de Ulises. Retoma las tradiciones del ciclo post-homérico anotadas por Pierre Grimal relativas a los amores adúlteros de Penélope, que lejos de esperar a Ulises, habría mantenido relaciones con todos sus pretendientes engendrando al dios Pan. Hacia el final del ensayo termina de hecho apelando a esta tradición: "Esta versión parece identificar a Penélope con la Diosa Blanca, la Gran Madre, figura central en los cultos de la prehistoria, de cuyo vientre fecundo salió a la luz del día, inacabada y sangrante, la familia humana" (Saer, "Historias de familia", Trabajos 176).

367 Así, por ejemplo, la forma en que Gabriela descubre sus rasgos "árabes" cuando se encuentran en el camino que lleva a la casa de Gutiérrez y que la hacen identificarlo como "turco".
} 
sino también por su doble inclinación al vino y a la filosofía. En esta yuxtaposición podría leerse otra forma de esa persistencia, sobre todo en relación a la importancia que el vino tenía para la poesía árabe, ${ }^{368}$ y por la mención de las Rubaiyat. Como se recordará, Nula y Diana se divierten seleccionando frases de Omar Kayam para utilizarlas con fines publicitarios para Amigos del vino, tarea difícil, advierten

porque el elogio del vino siempre viene acompañado en las Rubayatas por la reprobación violenta de alguna otra cosa, poder, religión, conformismo, muerte, temas excluidos de antemano del lenguaje publicitario [...]. Por ejemplo, una estrofa decía: Esta noche, dos copas de vino,/ me harán dos veces rico, lo cual es conforme a los fines publicitarios, pero el tercer verso, aunque antes rechazaré la razón y la religión, resultaba inadmisible en un mensaje comercial porque ofendía las veleidades racionalistas y los sentimientos religiosos del consumidor (Saer, $\mathrm{La}$ grande 174).

El fragmento expone las tensiones entre el lenguaje publicitario y la densidad filosófica de los poemas. En efecto, el persa Omar Kayam (1048-1131) escribió una serie de poemas -luego traducidos como las Rubaiyat ${ }^{369}$ que celebraban el disfrute del vino, del erotismo y del amor, y advertían sobre la fragilidad y la condición efímera de la belleza. Reflexionaban además sobre la vacuidad del conocimiento y de la ciencia y se mostraban proclives al libre pensamiento y en oposición a las instituciones (sobre todo religiosas). Kayam ha sido reputado como un poeta y un filósofo materialista, escéptico y pesimista que en varias ocasiones pregona el agnosticismo e incluso el ateísmo y sostiene que la naturaleza es sorda a los requerimientos humanos. Para él no existía nada más allá de la materia, y el mundo estaba hecho a partir de la unión de partículas que funcionaban por mera casualidad. ${ }^{370}$ Como podrá observarse, esta visión es bastante similar a la que Nula vuelca en sus libretas sobre el caos que reina en el mundo, a pesar de que la defectuosa percepción sensorial de los hombres pretenda leer en el vuelo sincronizado de las mariposas o en el movimiento acompasado de un cardumen, un sentido de orden y armonía. En el ejercicio de recorte y rearmado de las Rubaiyat que ensayan Nula y Diana, la poesía de Kayam devela lo que la lengua del comercio, del capitalismo y de la racionalidad moderna pretende ocultar: que existe la

\footnotetext{
${ }^{368}$ Cfr. Martínez Peláez, Agustín y Justo Romero Torres. "El vino en la poesía musulmana de al-Andalus". DOURO Estudos \& Documentos, vol. VI, n. ${ }^{\circ} 12,2001\left(2^{\circ}\right)$, pp. 9-22. Disponible en http://ler.letras.up.pt/uploads/ficheiros/9544.pdf

369 El nombre "rubaiyat" alude a la estructura formal de las poesías, formadas por cuartetos cuyos primeros versos riman juntos con el último, y el tercero es un verso libre.

${ }^{370}$ Una de las rubaiyat dice lo siguiente: "El vasto mundo: un grano de polvo en el espacio./ La vana ciencia de los hombres: palabras./ Los pueblos, las bestias y las flores de los siete climas: sombras./ El fruto de tu continua meditación: la nada" (Khayyam 30).
} 
muerte, que el mundo está vacío de sentido, que el vino puede acarrear malestar y que los placeres son finitos. Sin embargo, será en la escritura de sus libretas -en las que se mezclan anotaciones relacionadas al vino $\mathrm{y}$ reflexiones filosóficas, recuerdos $\mathrm{y}$ observaciones-, donde Nula pueda reescribir libremente al poeta persa y rendirle, quizás involuntariamente, tributo. ${ }^{371}$

El episodio oriental de La grande se circunscribe, como intentó mostrarse, a una serie de prácticas, valores, palabras y referencias culturales que Saer conoció en su infancia y que formaron parte activa de la cultura nacional. Sin embargo, como el mismo Saer, Nula se aleja paulatinamente del mundo familiar árabe, -que ha quedado escindido después de la muerte de su padre-, "defrauda" las expectativas burguesas sobre su posible futuro como médico y pasa, podría decirse, "más al centro", para comenzar a formar parte del elenco estable de personajes de la zona, a partir del encuentro fortuito y misterioso con Lucía, que intentará desentrañar durante años, y de su amistad con Soldi y Tomatis.

\subsection{Actuar el regreso: la zona mítica sobre las tablas}

Y pienso en la fuerza que devolvió a este hombre, arrancándolo al mar, a las tierras lejanas, al silencio que dura. Mi primo jamás habla de sus viajes. (Pavese, "Los mares del sur") ${ }^{372}$

\footnotetext{
${ }^{371}$ Sería interesante agregar finalmente que la mención de las Rubaiyat no sólo funciona en la novela como el acento oriental que puntúa la doble actividad de Nula -comercio del vino y filosofía- sino que también permite reconstruir un pequeño eslabón del "orientalismo argentino", como lo llama Axel Gasquet. Hacia principios del siglo XX Gasquet advierte que comenzó a formularse una mirada más positiva sobre el Oriente y una de las causas fue "la creciente presencia entre el público letrado de un acendrado interés 'real' por muchos pueblos y culturas de Oriente" (Gasquet 4). En efecto, los poemas de Kayam fueron parte de una difusión mayor de importantes obras orientales de ascendencia universal, como las Mil y una noches, el Ramayana o la epopeya del Bhagavad-Gita. Las cuartetas Rubaiyatas fueron traducidas de manera integral por Carlos Muzzio Sáenz-Peña y Joaquín V. González entre 1914 y 1917 y alcanzaron una gran difusión. Fueron además publicadas y retomadas por Jorge Luis Borges, cuyo interés en el mundo oriental trasciende las poesías de Kayam y permea buena parte de la concepción filosófica de su obra.

${ }^{372}$ Fragmento del poema "Los mares del sur", incluido en Trabajar cansa (1936). Además de los vínculos entre la concepción del tiempo mítico de Pavese, que se detallará a continuación, y La grande, sería posible mencionar muchos otros contactos entre las obras de ambos escritores. Efectivamente, Saer no sólo retomará la forma del "poema narrativo" ensayada por el escritor italiano sino varios de sus temas. Piglia ha subrayado por ejemplo que en la estructura abierta de las narraciones de Saer, en las que se reproduce el juego de encuentros y desencuentros entre los amigos "debemos ver la presencia de Pavese [...]. En las grandes nouvelles del autor de La casa en la colina los amigos pasan el tiempo conversando y vagando hasta el alba por una ciudad de
} 
La colorida dupla de caminantes que atraviesa en diagonal un campito abierto en las afueras de Rincón devuelve para la ficción al personaje de Willy Gutiérrez. Como Wakefield, Gutiérrez había desaparecido misteriosamente en "Tango del viudo" para retornar, de la misma manera, treinta años más tarde en La grande. Las causas de su partida: "Salí en busca de tres quimeras: la revolución planetaria, la liberación sexual y el cine de autor" (Saer, La grande 17) evocan el programa político y estético de los sesenta, parodiado por el personaje. Sabemos, por ese primer cuento de En la zona, que Gutiérrez se fue despechado por la traición amorosa de Leonor Calcagno; y por los escasos rumores que luego llegan sobre su vida en el extranjero, que lejos de dedicarse al "cine de autor", perfeccionó su borramiento volviéndose un guionista que firmaba con seudónimo.

Gutiérrez, en su aparente discreción y amabilidad, es un personaje que sobreexpone y aglutina las representaciones sobre la zona y sobre lo extranjero que la ficción y algunos ensayos de Saer ya habían manifestado con anterioridad. También como ocurría en el caso del Matemático cuando le preguntaban por su estadía europea, ${ }^{373}$ el relato se vuelve un vertiginoso fárrago de críticas, una pieza entera y

provincia" ("La amistad en Saer", Glosa-El entenado XIX). Pero además, el tema del desarraigo y del retorno se vuelve un tópico que atraviesa varias de las poesías de Laborare stanca. El personaje del hermoso poema "Los mares del sur" regresa después de veinte años al pueblo de Turín. Al igual que le ocurre a Gutiérrez, corren diversas leyendas sobre su prolongada ausencia. El punto de vista de quien "narra" es el de un primo más joven que ha permanecido en el pueblo y acompaña al viajero en su reconstitución del espacio y la lengua de su juventud. En la nota introductoria que abre la selección de poesías de Pavese, Guillermo Fernández advierte: "Los personajes son prostitutas, maestritas, pordioseros, campesinos, noctámbulos, borrachos, vagabundos solitarios que atraviesan plazas y calles desiertas, buscando el inexistente camino del retorno, sin más porvenir que el de sus propios recuerdos, inconscientemente inmersos en su 'inmadurez' de adolescentes, en el mito fundamental de la infancia del mundo" (Cesare Pavese $\mathrm{s} / \mathrm{p})$.

${ }^{373}$ Cuando le preguntan por su viaje a Europa, el Matemático entrega las mismas y escuetas "postales": "Siena es una imagen rojiza, elevada en la bruma caliente del atardecer; París, una lluvia inesperada; Londres, un problema de alojamiento y unos manuscritos en el Museo Británico" (Saer, Glosa 24). En sucesivas ocasiones el personaje salmodia estas imágenes arbitrarias que vienen a solaparse a los nombres de las ciudades: "fugaces, sucesivas, pulidas y simplificadas por la memoria caprichosa" (Saer, Glosa 109). La repetición casi exacta de los sintagmas que acompañan los nombres subraya que las imágenes de lo extranjero, que apenas concentran y disipan la experiencia fragmentaria, son piezas de discurso para el auditorio local, y un poco socarrón, de la zona. Por otro lado, la versión crítica que da Gutiérrez no es muy distinta de la que ofrece Pichón Garay en La pesquisa, cuando el personaje advierte las monstruosas prácticas de consumo que anteceden al festejo de la navidad así como las diferencias entre los verdaderos "ciudadanos" parisienses y los inmigrantes. Las contradicciones que aloja la política europea, y de manera más general, la mentada "civilización occidental" se condensan en la doble paternidad de Morvan, cuyo padre, un resistente comunista, fue abandonado por su madre, que eligió irse con un ocupante nazi. Dardo Scavino subraya esta dualidad monstruosa que la ficción le atribuye también a Zeus y derrama sobre la ciudad de 
solidificada que los personajes que han vivido en el extranjero repiten, ante la sospecha que pueda caber en sus coterráneos de haberse transformado o de haber caído en las "tentaciones" de Europa. Es Nula quien primero resume el monólogo de Gutiérrez sobre la banalidad, la rapacidad y el sensualismo estúpido y egoísta de los europeos. Pero esa "diatriba violenta" contrasta con la amabilidad y el tono paternal con que la pronuncia, un tono irónico y apacible que le hace decir a Gabriela en otra oportunidad: "Tiene talento escénico". Europa se da así como un espacio opaco a la experiencia, objeto de una crítica cultural ya ensayada, que sólo ha "marcado" la lengua del personaje. Europa es fundamentalmente un lugar en el que ya no hay Lugar y que ha frustrado las expectativas que Gutiérrez se había hecho de él: "Y los pocos lugares habitables que quedaban en esos territorios arrasados, los han transformado en el marco kitsch de sus ocios, el supuesto teatro de sus supuestos placeres supuestamente inolvidables" (Saer, La grande 190). ${ }^{374}$

Como contrapartida, el personaje ha regresado en busca del Lugar, o, podría decirse, ha vuelto a abrir ese Lugar a un tiempo que es el del mito, pero como veremos, esta apertura no está exenta del aire teatral e irónico que permea sus diatribas en contra del Viejo Continente y el regreso quedará nuevamente desarticulado o mejor, articulado como representación espectacular. De este modo, así como la presencia fantasmal de José Pedroni permitía recuperar el episodio oriental de la infancia de Saer, Cesare Pavese permitirá retomar la importancia del mito para esa suerte de tiempo recobrado que ensaya Gutiérrez cuando vuelve a la zona. ${ }^{375}$

París. Como se recordará, las pesadillas de Morvan revelan que los verdaderos dioses urbanos son los monstruos de la mitología griega, Escila y Caribdis, Gorgona y Quimera.

${ }^{374}$ Podría leerse la "diatriba" de Gutiérrez como un comentario o glosa de algunas de los cuentos de Lugar, el libro cuyos relatos tienen como escenario a Europa. Pero también como la coda del poema "Islas" que se analizó en la primera parte de la tesis. Como se vio, en algunos ensayos Saer arremete contra la mentada "racionalidad" europea y pretende desarticular lo "europeo" como principio identificador. Cfr. "Sobre la cultura europea".

${ }^{375}$ Según Miguel Dalmaroni, la novela emprende un regreso incompleto pero dichoso al mundo saeriano a través de un trabajo regresivo de la narración que busca recomponer ese mundo. Rafael Arce advierte en La felicidad de la novela que la vuelta de Gutiérrez es, a priori, la del "hombre que regresa al Lugar para recuperar el tiempo perdido" (186) y señala que la caminata que inicia la obra presenta un quiasmo temporal porque Nula camina por el presente y es espía de aquel tiempo desaparecido y Gutiérrez, anclado en ese mundo desaparecido, no puede "ver" los cambios del presente, pero ambos comparten la "ausencia" y por lo tanto una "distancia" de lo ocurrido en la zona. En este sentido, el regreso al Lugar tiene para Gutiérrez la forma de un hiato temporal, porque no se quedó en la zona para comprobar cómo su historia se bifurcaba de la historia de su propia epifanía y puede, al regresar, considerar no lo que efectivamente pasó o no pasó, sino lo que "habrá sido". Por su parte, en Relatos de regreso, Luigi Patruno entiende que la insistencia de Gutiérrez por el lugar donde pasó su juventud evoca la experiencia común 
Cesare Pavese es una de las referencias privilegiadas por Saer cada vez que lo interrogan sobre su biblioteca personal y particularmente cuando explica su adhesión a escribir sobre un territorio. En la entrevista que le hacen Premat, Vecchio y Villanueva, Saer se ubica en esta tradición de narradores: "Yo creo que la mayor parte de los escritores tienen un territorio, un territorio propio. Vos tomás Flaubert y es la Normandía. Eso marcó mucho la tendencia del siglo XX: tenés a Joyce, tenés a Faulkner, tenés a Pavese, tenés a Gadda [...]. Yo entré en esa tradición, que me gusta particularmente: reducir al máximo el lugar y usarlo metonímicamente" (Una forma más real 220). Sin embargo a Saer dice no interesarle la especificidad local ni el "hombre santafesino" sino el hombre en general, perspectiva, como veremos, que sí aparece en la concepción del "mito" desarrollada por el escritor italiano. En la entrevista realizada por Tamborena y Racuzzi (Chejfec), Saer integra a Pavese a la serie de escritores que, como Faulkner, Borges, Kafka y Virginia Woolf se "incrustan en uno y a través de los cuales se empieza a ver el mundo" (Una forma más real 29) e incluso señala, a propósito de la influencia de Robbe-Grillet, que si bien está dispuesto a aceptar cierto parentesco con el escritor objetivista "es Pavese lo que anda flotando” (29). ¿De qué manera flota Pavese, inclinación temprana y duradera en la obra de Saer, en $L a$ grande, como volvía a "flotar" Pedroni?

Cesare Pavese escribió una serie de ensayos en los que se vuelve central la noción de "mito" en el sentido, como se intentará demostrar, en que se reactualiza para esta última novela de Saer. En "El mito" señala: "Llamamos mítico a ese estado auroral, y mitos a las imágenes - que son siempre las mismas en un determinado individuo- que relampaguean en el fondo de la conciencia" (416), y escribe en "Del mito, del símbolo y de otras cosas":

Cada uno de nosotros posee una mitología personal (débil eco de la otra) que da valor, un valor absoluto, a su mundo más remoto, y le reviste pobres cosas del pasado con un ambiguo y seductor esplendor donde parece, como en un símbolo, resumirse el sentido de toda la vida. A este temps retrouvé no le falta del mito genuino ni siquiera la repetibilidad (La literatura norteamericana 367).

El tiempo del mito es un tiempo detenido, un instante vertiginoso en el que el sujeto sale de la temporalidad y contempla "la unicidad del lugar, símbolo encarnado de su fe, núcleo central de toda su vida interior" (Pavese, La literatura norteamericana

entre los sujetos exiliados, un "presentismo absoluto" que supone la alucinación inducida por el vivir en un tiempo inmóvil. 
415). Como los lugares tocados por un acontecer único en el que se manifiesta la divinidad del mito, "así retornan a la memoria de cada uno los lugares de la infancia; en ellos ocurrieron cosas que los hicieron únicos y los entresacan del resto del mundo con este sello mítico" (363). Y añade algo interesante para la paradójica concepción de "lugar" en Saer, el lugar mítico no es tanto el espacio singular sino el del nombre común, "el prado, la selva, la gruta, la playa, la casa, que con su indeterminación evoca todos los prados, las selvas, etc. [...] Esta unicidad del lugar es parte, por lo demás, de esa general unicidad del gesto y del acontecimiento, absolutos y por lo tanto simbólicos, que constituye el obrar mítico" (364).

Así parece funcionar el "mito" en La grande, las "primeras veces" irreductibles a racionalidad en que se formaron en la conciencia las imágenes aurorales y embrionarias de contacto con el mundo y con las cosas. Ese es el mundo al que Gutiérrez pretende volver. La novela pone a girar, como si descongelara, el mito de una generación (que se construye alrededor del año-época de 1961) ${ }^{376}$ y los mitos personales de Gutiérrez, pero también de Nula o de Tomatis, por mencionar solo a algunos personajes. Ese mito tiene una localización a la vez específica: el cuarto con la bicicleta en la que por primera vez Gutiérrez hizo el amor con Leonor Calcagno; la parrilla San Lorenzo, el Hotel Palace, el camino de la costa con su borde inestable de barro y río; y a la vez general: el mito se expande por la zona y se aloja en su rugosidad vegetal y fluvial, en el trazado urbano y en la contingencia de las estaciones. Esta es la paradoja espacial de Saer que puntúa sus ficciones y ensayos: el Lugar es todos los lugares, por eso en el cuaderno de Notas de La grande leemos la siguiente ocurrencia de Tomatis: "Esta ciudad tiene en común con Viena que está situada en el extremo de una llanura y que su río principal no la atraviesa, sino que pasa a un costado de ella; con Roma, que es más chica que Nueva York, y con Nueva York que muchos de los que viven en ella son inmigrantes o hijos de inmigrantes..." (Papeles II 398). El procedimiento se vuelve un vértigo que parodia y desarticula la comparación, porque asimilándose caprichosamente con cualquier ciudad, termina no presentando atribuciones específicas. Pero además, habría que agregar que el

\footnotetext{
${ }^{376}$ Como se vio en el tercer capítulo de la segunda parte, varias ficciones de Saer giran alrededor de esta época aun cuando ofrezcan una versión alternativa y menos "espectacular" de la década. Rafael Arce advierte sobre la importancia del año 1961 alrededor del cual se arremolina el tiempo de la novela, particularmente hacia el final. Será la época sobre la que investiguen Gabriela y Soldi y sólo los jóvenes, señala Arce, podrán volverla inteligible. Para Gutiérrez, en cambio, aquello por lo que vuelve no puede sumarse como una historia, sino más bien como una serie de momentos fragmentarios, "un repertorio de imágenes a las que ha permanecido fiel" (Arce, La felicidad de la novela 189).
} 
mito del regreso de Gutiérrez cuestiona la economía clásica del viaje que situaba en el oikos el garante del sentido y de la continuidad. ${ }^{377}$ Como se recordará, Gutiérrez no era de la ciudad y venía de un paraje llamado el Nochero, al norte de Tostado. Su abuela, muy pobre, logró mandarlo a estudiar a la ciudad y Gutiérrez hizo el bachillerato como pupilo en lo de los curas. Recién después comenzó a estudiar Derecho y se hizo amigo inseparable de Sergio Escalante, Marcos Rosemberg y César Rey. De joven, antes de partir de la casa en la que se encontraban con Leonor, vacía los cajones de los muebles y desmantela el espacio "como si la casa hubiera estado abandonada mucho tiempo, a partir de un gran desorden" ("Tango del viudo", En la zona 493) y reduce después a cenizas los viejos papeles, cartas, manuscritos, poemas y artículos en la gran hoguera que enciende en el patio.

Por lo tanto, cuando regresa, no es allí donde busca reinstalarse. La fenomenología bachelardiana permite pensar qué sucede cuando se expande la idea de casa y sostiene: "todo espacio realmente habitado lleva como esencia la noción de casa. [...] el ser amparado sensibiliza los límites de su albergue. Vive la casa en su realidad y en su virtualidad, con el pensamiento y los sueños" (Bachelard, La poética del espacio 35). Y agrega que "el espacio conserva tiempo comprimido" (38) [y es allí] donde encontramos esos bellos fósiles de duración” (39). De acuerdo a su lectura, la casa natal excede la función de la vivienda y no se circunscribe a un cuerpo físico, es un cuerpo de sueño y cada uno de sus reductos fue un albergue de ensueños, por eso, "habitar oníricamente la casa natal, es más que habitarla por el recuerdo, es vivir en la casa desaparecida como lo habíamos soñado" (47). Así regresa Gutiérrez, no para habitar la perdida casa de su infancia ni la desmantelada casa de su juventud sino para habitar cualquier casa (incluso la "mansión” del execrable doctor Russo) porque los límites de

\footnotetext{
${ }^{377}$ Sobre la idea de casa, cfr. el análisis de Luigi Patruno en "Sudestada", el capítulo que le dedica a La grande en Relatos de regreso. Allí Patruno indica que hay dos casas fundamentales en la novela, la que compra Gutiérrez y la que vende Pichón Garay. Tal como el mismo personaje lo explicita cuando le resume a Tomatis su encuentro con Gutiérrez en el avión a Buenos Aires: "Como podrás comprobar, nuestros destinos son antagónicos: yo había venido a vender una casa, y él a comprar una" (Saer, La grande 21). Pero además, podría pensarse, "la casa" cobra una nueva función en el escenario de los noventa y alude a una reconstitución de la zona. La omnipresencia del cartel de la inmobiliaria que Saer dibuja en sus cuadernos explicita la transformación del espacio urbano y se traza un nuevo mapa de la ciudad, de acuerdo a las operaciones inmobiliarias y a la instalación de los ricos en las zonas de Guadalupe y Rincón. Así, el "mapa" de la zona ya no será aquel de ojos inventivos que Saer miraba desde el avión, sino el que cuelga en la inmobiliaria de Moro: "acribillado de alfileres de colores diferentes que señalaban sin duda el estado actual de las diversas operaciones inmobiliarias que administraba su agencia" (Saer, La grande 22).
} 
lo natal se han expandido a la casa cósmica "una casa tan dinámica permite al poeta habitar el universo. O, dicho de otra manera, el universo viene a habitar su casa" (Bachelard, La poética del espacio 84).

La dialéctica del regreso de Gutiérrez opondrá, como veremos, el tiempo del mito al tiempo del presente y permitirá leer las transformaciones sociales, políticas y urbanas que han modificado la ciudad y sus alrededores. ${ }^{378}$ Como ha señalado Rafael Arce, el retorno se hace primeramente a la zona del "arrabal" de la que había partido la ficción de Saer, pero el espacio rural ha sido ahora ganado por la ciudad civilizadora, algo que ya había empezado a ocurrir en Glosa. Los dos personajes atraviesan los márgenes del pueblo donde se arraciman los ranchos, pero la pobreza ya no es la orilla arrabalera del juego, la prostitución y el delito, sino el saldo de miseria que se aglutina en las afueras de la ciudad de los noventa y a través de la cual los personajes pasan como un dúo chillón o "monstruo de feria". Cuando arriban finalmente al pueblo de Rincón se enteran de que Sergio Escalante está en el Club de caza y pesca EL AMARILLO. El club es, como ocurrirá en otras oportunidades, un híbrido temporal en el que se encabalgan el pasado y el presente: el piso todavía hecho de tierra apisonada, el techo de paja recientemente instalado. Esa será la "casa" del reconocimiento entre Gutiérrez y Nula, quienes apenas se ven, se nombran, y Nula observa: "ha habido reconocimiento, aprobación, confianza y pasado común" (Saer, La grande 44). Se trata, sin embargo, de un reconocimiento "demorado" que se dilata casi un año, porque recién después de esa cantidad de tiempo, aunque los dos saben de la vida del otro, los amigos finalmente se encuentran. Como el mismo Nula lo advierte, la epopeya de la Odisea es anacrónica en ese presente que atraviesan, por eso Saer invierte y parodia los signos del reconocimiento: no hace falta que Escalante descubra una antigua cicatriz en el cuerpo de su amigo para que éste se "revele", abandonando el disfraz del mendigo para asumir la forma plena del héroe; por el contrario, aquí lo que debe develarse es el paso del tiempo y la incipiente vejez de los "antiguos héroes", por eso Gutiérrez se saca la

\footnotetext{
378 Para reflexionar sobre el funcionamiento temporal de La grande, cfr. especialmente el capítulo que le dedica Florencia Abbate en El espesor del presente. Allí, Abbate considera que, al igual que ocurría en Glosa, el presente de la novela tiene un espesor multidimensional que incorpora el pasado de los recuerdos y el futuro de la imaginación. Frente a la temporalidad aparentemente lineal de la estructura organizada según los días de la semana, la ficción hace estallar la cronología a partir de la incorporación de continuas analepsis, prolepsis, y "pausas descriptivas" que dilatan la narración. Esta complejidad se comprende mejor cuando se observa que el tiempo de la novela es el tiempo -caótico- de la conciencia de los personajes y no un tiempo "externo" organizado según parámetros objetivos.
} 
dentadura postiza y exhibe el hueco que lo emparienta con la boca sin dientes de su amigo Escalante.

El regreso de Gutiérrez exhibe, a la vez, un doble comportamiento temporal. Por un lado desentumece, de golpe, el tiempo detenido a su partida, como si esos 30 años de ausencia hubieran sido apenas un paréntesis: "en vez de expresar la prudencia de una madurez alerta y desengañada, ese estilo tiene algo de juvenil, de adolescente incluso, como si después de más de treinta años de separación, algo hubiese quedado en suspenso en cada uno, para ponerse otra vez en movimiento, sin deliberación, al primer encuentro" (Saer, La grande 49). Por el otro, "las décadas de vida empírica", aunque impenetrables y misteriosas, se materializan en ese signo de decadencia corporal, aunque los personajes no se concedan "ni la nostalgia, ni la idealización ni la queja" (50). La escena se completa con el regalo que Escalante le ofrece a Gutiérrez, los primeros moncholos del año. La "expedición" por la zona, demorada y acuciada de pequeños peligros culmina en el ritual de la extracción de los legendarios y un poco folklóricos pescados de la zona, cuando Chacho, mandado por Escalante, se inclina sobre los moncholos y los abre de un tajo "su capa de arpillera le da el aspecto de un oficiante durante un rito arcaico" (57). La expedición recupera para el mundo del presente algo de la naturaleza turbulenta que se agita en el río y el ritual de la muerte de los animales sagrados. Sin embargo, lo que en El limonero real -el degüello del cordero-, era reescritura del mito bíblico y cifra de culpabilidad mítica, aquí convive con la banalidad del presente, porque los gloriosos moncholos terminan adentro de una bolsa de plástico del hipermercado Warden.

Esa misma lógica permea otros espacios del mito, mencionaré solo algunos: la parrilla San Lorenzo, conocida a fines de los cincuenta y ahora convertida en "un oscuro boliche de barrio"; el puente colgante, antes la mayor atracción turística de la ciudad y ahora una ruina de la que emerge, sin embargo, la "visión" de Gabriela y Soldi (la mítica escena en la que Tomatis le da a Barco su definición de novela: "el movimiento continuo descompuesto"); el cuarto con la bicicleta y la muñeca en el que Gutiérrez y Leonor hicieron el amor por primera vez; la cena que Gabriela acepta por lo que significa "comer esos pescados míticos en las inmediaciones mismas de Rincón" ( $L a$ grande 165); el Hotel Palace al que vuelve Gutiérrez para cenar con la ahora esperpéntica figura de Leonor Calcagno y la "reminiscencia física de primavera" (Saer, La grande 343) que recupera Tomatis mientras viaja en colectivo para visitar a su hija 
en Rosario, al recordar una mañana de juventud con Barco: “en la que la luz fluía de una manera especial sobre el agua y sobre todas las cosas" (345).

Gutiérrez es como Hujalvu, el pintor japonés de mariposas del que Pichón le habla a Tomatis en una carta. No se trata, como aseguraba un crítico occidental, de que se especializara en una misma especie de mariposas, la "Vanessa io", sino que pintaba siempre la MISMA mariposa. ¿Cómo podría ser esto posible, se pregunta Tomatis? En una vida de ochenta años, la mariposa se hubiera desintegrado, "a menos que, a partir de cierta altura, la pintara de memoria, no la materia, pulverizada después de décadas, sino la forma impresa en él para siempre, que por haberla observado hasta hacerla suya, era capaz de declinarla en todos sus estados posibles" (Saer, La grande 360). Una certidumbre similar asalta a Soldi cuando Gutiérrez graba con su cámara de video algunas escenas del asado: “ "nos guardará a todos embalsamados en sus cintas de video, en su cuarto de trabajo, que él llama la sala de máquinas, así como tuvo embalsamada en su memoria durante más de treinta años su juventud y todo lo que su juventud contenía'” (399).

El tiempo del presente por el que transitan Nula, Soldi y Gabriela horada el tiempo del mito y exhibe sus desgarraduras. El presente de la novela, como ha argumentado Abbate, es denso y complejo y pone a funcionar la máquina distorsiva y caótica del devenir. Durante esos 30 años de ausencia, la muerte, la intemperie, el exilio y el "progreso" han modificado la zona y la red de relaciones que la sostenían. Por eso, el tiempo del mito sólo puede reconstruirse pero no reactualizarse, y vuelve de dos maneras: en la investigación cuidadosa que emprenden Gabriela y Soldi del pasado literario de la ciudad (para la que cuentan con la valiosa y asombrosa memoria de Gutiérrez y el aporte de otros informantes; así como de un archivo conformado por las revistas de los diferentes movimientos literarios de la zona), y como puesta en escena teatral. Me interesa subrayar esta segunda instancia para repensar de qué formas "retorna" Gutiérrez.

En Saer y los nombres Dardo Scavino traza un breve recorrido de los modos que asume el tópico del theatrum mundi en algunas obras de Saer, desde El entenado a Lo imborrable, pasando por Glosa y La pesquisa, y advierte que lo teatral suele asumirse como aquella instancia de representación que provee parámetros simbólicos y normas de comportamiento sociales a los personajes, quienes a través de la asunción de algún papel y de la pronunciación de expresiones "convencionales" acaso puedan conjurar el 
"magma indiferenciado y viscoso" que suele acuciar en las ficciones de Saer. ${ }^{379}$ Interesa ahora pensar qué funciones adquiere lo teatral en relación al regreso de Gutiérrez y a la reconstitución del tiempo mítico, sobre todo teniendo en cuenta que, a diferencia de los otros ejemplos mencionados en los que lo teatral se anuda a algún tipo de conflicto, permite explorar en esta última novela sus posibilidades más "dichosas". 380

Si la "vuelta de Gutiérrez" es una puesta en escena, puntuada por el comportamiento excéntrico de su protagonista, el asado es su consumación (aunque

${ }^{379}$ Como se recordará, a su vuelta a España el grumete de El entenado terminará participando de una "comedia" sobre sus años entre los colastiné y actuará su propio papel: "El acceso al orden simbólico se consuma pues cuando las ficciones teatrales sustituyen las (supuestas) experiencias reales, cuando la leyenda reemplaza lo vivido" (Scavino 126). El tópico del theatrum mundi también se utiliza para referirse a la tribu indígena, en la que cada indio desempeñaba una función y cumplía su papel. La misma idea de representación reaparece en La pesquisa, porque según contaba el Soldado Joven (el personaje de En las tiendas griegas), en toda la Hélade las criaturas "remedaban" a los héroes griegos y a sus adversarios los troyanos: "De modo que también las leyendas sobre la guerra de Troya [...] constituían los parámetros simbólicos [...] de aquellos pueblos y dictaban así el libreto de los comportamientos sociales, como suele suceder con los mitos" (126-7). Glosa, por su parte, será presentada como una "comedia" que Saer le dedica a tres amigos. En la novela será el padre de Ángel Leto quien monte un escenario y actúe junto a Isabel y Lopecito: "Las caras familiares se volvían máscaras impenetrables y remotas y, por mucho que las interrogara no sacaba nada, pero nada ¿no?, de ninguna de ellas" (Saer citado por Scavino 127). La comedia es una variante del gran teatro del mundo en el cual los actores pronuncian "expresiones convencionales". Lo teatral reaparece en la pesadilla del Matemático, que sueña con una tira de papel en cuyos pliegues verá su propio retrato en "expresiones convencionales" que pretenden transmitir dolor, ingenuidad, inteligencia, avaricia, desprecio o picardía. Retiradas las máscaras teatrales no queda, sin embargo, ningún "yo". Scavino advierte aquí esa servidumbre con respecto a las "convenciones", a las "ficciones simbólicas". Finalmente Tomatis en Lo imborrable encuentra en la actuación una posibilidad para salvarse de la depresión en que estaba sumido: "poder ser durante dos horas un piloto de avión que tiene una amante [...] o un panadero cornudo podía salvarme de la demencia" (Saer citado por Scavino 146), aunque después de vacilar por unos días, termina decidiéndose por el soneto.

${ }^{380}$ Dalmaroni advierte que a diferencia de la radicalidad negativista y fragmentaria de varias obras anteriores, La grande junta por fin los pedazos que en Cicatrices no podían juntarse, y los abriga en ese presente: "Como si cediera con gusto a la ilusión de atar cabos y completar su comedia humana" ("La vuelta incompleta" s/p) la novela acentúa su costado balzaciano y colorista: "Los personajes se reúnen y se contentan, casi al unísono, en una apacible composición con el mundo que lleva al sosiego, intensamente conciliatoria incluso en sus momentos más irónicos: feliz" ( $\mathrm{s} / \mathrm{p})$. Por su parte, en El punto en el tiempo: Realismo y gran obra en Juan José Saer y César Aira, Valeria Sager retrotrae el comienzo de la "dicha" a La pesquisa porque una vez que Tomatis emerge del agua negra que lo acuciaba en Lo imborrable -donde predomina la oscuridad melancólica- "la obra comienza a moderar su negativismo" (181). La pesquisa es el "nudo" de la "gran obra" saeriana porque aglutina momentos y recuerdos de novelas anteriores y a su vez configura escenas que se retomarán en textos posteriores, y lo hace de un modo tan intenso como solo ocurre en La grande. Como se verá a continuación, lo teatral de la novela se dará como un tributo a esa felicidad identificada por la crítica. 
previamente haya otros momentos "teatrales" ${ }^{381}$ ). Como el mismo Nula y Tomatis lo advierten cuando miran a Gutiérrez, entre divertidos e incrédulos, llegar corriendo hacia sus invitados y señalarles la inminencia de la tormenta con movimientos paródicos: “[intuyen] que también eso es una reconstitución, la puesta en escena de algo perdido y que ni siquiera intenta recuperar sino que monta, por puro juego íntimo, en el tablado de su imaginación desencantada" (Saer, La grande 427). Como ha señalado Piglia, la amistad funciona en Saer como la familia en Faulkner, "es una red de tensiones, rupturas, relaciones, acontecimientos, historias antiguas, nuevas versiones" ("La amistad en Saer" XIX). Aquí los viejos amigos y los nuevos allegados responden al tributo de la amistad plegándose al juego teatral de Gutiérrez. Como se verá, la narración se satura de marcas didascálicas y los parlamentos, tomados o reformulados de algunas obras literarias -Balzac, Flaubert, Baudelaire- tejen, por sobre la conversación general, un texto cifrado que sólo los viejos amigos pueden reconocer aunque todos intuyan, más o menos, que forman parte de una representación: ${ }^{382}$

¡Aquí, aquí! -grita Tomatis golpeándose el pecho, parado en el borde del quincho, mirando hacia el cielo sombrío, y dirigiéndose a la sucesión interminable de relámpagos prolongados y de truenos [...] - ¡Si existís, canalla, golpeá aquí! ¡Te estoy desafiando! ¡A vos te hablo, cobarde! [y Violeta explica]: -No le hagan caso [...]. Eso también es una cita de Flaubert. [Y también Marcos Rosemberg, siguiendo las líneas de Tomatis, afirma la escandalosa sordera de Dios]: "Aun en medio del más pavoroso silencio. No oye - dice Marcos con seriedad apodíctica y deliberadamente teatral, y después de tomar un trago de champán, saboreándolo en forma ostentosa, alza la voz dirigiéndose a Gutiérrez con desenvoltura mundana -iWilli querido, este champagne français $-\mathrm{y}$ exagera la pronunciación francesa de las dos palabras- es el despelote! Cruzan, irónica, una mirada de inteligencia. [...] Lo tengo reservado para las grandes ocasiones -dice Gutiérrez. [...] Marcos sonríe, menos satisfecho del cumplido que de algún misterioso doble sentido que le ha parecido atisbar en esa frase convencional. [...] las ocho personas que se mueven [...] en el quincho iluminado, parecen representar en un

${ }^{381}$ Como cuando se habla del "talento escénico" de Gutiérrez a propósito de su diatriba contra los europeos, o cuando él mismo recita unos versos de Baudelaire del poema "Heautontimorumenos", basado a su vez en una comedia de Terencio, para responderle a Escalante.

${ }^{382}$ La "teatralidad" que asume el diálogo en esta novela es uno de los modos o una nueva vuelta de tuerca sobre ese principio estructurante de la narración saeriana. Efectivamente, como ha subrayado Nicolás Lucero en La vuelta incompleta "La literatura de Saer va a subordinar las historias a los diálogos entre los amigos: lo importante de los relatos será su capacidad de convertirse en el mito alrededor del cual se discute [...] es el diálogo en que va configurando el archipiélago que une y congrega sus textos [...] [que] no está exento de discusiones airadas, interpretaciones audaces y glosas deliberadamente digresivas [y] constituirá el modo privilegiado como volverán las historias y los personajes en la literatura de Saer" (46), para concluir más adelante: "La zona es un grupo de amigos que integran un diálogo fragmentario, con cesuras y también con recapitulaciones" (51). 
escenario una obrita realista, a tal punto que las frases surgen con celeridad y precisión de sus labios, como si no necesitaran formarlas previamente en su interior, y se tratara de réplicas de un texto ya escrito, aprendidas de memoria (Saer, La grande 429-30).

Esa "obrita realista" que parecen replicar con facilidad los invitados de Gutiérrez permite fijar las coordenadas de esta novela en relación con la gran tradición del realismo, ${ }^{383}$ pero también pensarla como un efecto retrospectivo de la coherencia total del proyecto saeriano. ${ }^{384}$ Los personajes "ya se saben" sus parlamentos $-\mathrm{y}$ conocen las respuestas de sus compañeros- porque han venido repitiéndolos, con variaciones, silencios y ripios, durante cuarenta años. ${ }^{385}$ Las "expresiones convencionales", como las

${ }^{383}$ Según Florencia Abbate en La grande se refuerza el componente realista de la obra en la recomposición de un territorio que se presenta casi como un "fresco social". Allí se entretejen las historias, las relaciones y las costumbres de un vasto conjunto de personajes de distintas generaciones. La novela, sostiene, presenta una impronta balzaciana, no solo porque hace reaparecer a numerosos personajes de textos anteriores sino también porque su trama de desarrolla mediante un mecanismo de sucesivos "encuentros". Esta filiación con la novela decimonónica además está sugerida por la referencia intertextual a la Educación sentimental de Flaubert, el libro que está leyendo Tomatis, y también por la cita de Balzac que hace Gutiérrez. 384 Valeria Sager considera la obra de Saer en el cruce productivo entre "gran obra" y "realismo", una "anomalía" desproporcionada que, junto a la de César Aira, irrumpe en la historia de la literatura argentina y también en la historia de su crítica y proponen, efectivamente, un proyecto novelístico sostenido capaz de crear un "mundo narrativo". A contramano de la crítica formalista que había enfatizado el costado negativista de la poética de Saer -apuntando su carácter discontinuo, fragmentado y en dispersión; y enfatizando los momentos suspendidos de presente- Sager observa que efectivamente "algo" continúa, se condensa, se transforma y permanece entre sus cuentos y novelas. Dicha perspectiva solo puede alcanzarse si se considera la obra como totalidad y permite pasar del "estilo" y del orden sintáctico -en el que se acumulan con fruición los experimentos lingüísticos de una parte de la obra saeriana y de las morales críticas nucleadas alrededor de Punto de Vista- al orden lógico, temporal y espacial de un mundo que se afirma nítidamente. "Gran obra" y "realismo" se definen como una forma particular de la "ocupación del tiempo", a partir del trabajo con magnitudes de larga duración. Lo singular de Saer sería que sus textos se tensan entre la detención y la aceleración de la intriga. El "obsesivo y apóstata" realismo en Saer -y el de Aira- se podría pensar como una "posición absolutamente antipedagógica, anticognoscitiva (aunque las posibilidades del conocer sean exploradas por Saer, lo son como interrogación o negación) y, podría decirse, radicalmente estética del realismo" (Sager 45). Lo real es algo construido por la narración en sus propios términos, que en Saer se da entre la desintegración fragmentaria y la duración constante (el movimiento continuo). La perspectiva de la "gran obra" resulta particularmente sugerente al analizar lo "teatral" de La grande porque permite entender la radicalidad que asume esa continuidad señalada por Sager. Como ella argumenta: "la forma de la gran obra exhibe que la verdadera importancia de lo acontecimental está en su posibilidad de prolongarse y reconfigurarse, por un lado, a través de la continuidad de las historias y del retorno a lo que ya fue escrito; y por otro lado, a través de los relatos en los que los personajes cuentan, se cuentan o vuelven a contar lo que sucedió" (156).

${ }^{385}$ Es lo que ocurre, por ejemplo, con el chiste de Tomatis, que puede en principio sorprender a Nula - porque es la primera vez que lo escucha- pero que es moneda corriente para Soldi y los demás. El chiste que repite siempre igual cada vez que un amigo lo cruza en alguna esquina o parada de taxi es el siguiente: "Estoy esperando el colectivo pero tuve que dejar pasar varios porque todavía no iban demasiado llenos" (Saer, La grande 163), un unipersonal de Tomatis 
llamaba Scavino, se han sedimentado -y apaciguado, como argumenta Dalmaroni- y la dicha ahora consiste en reconocer, entre esos pliegues gestuales y sonoros, la maestría de la interpretación. Sin embargo, el teatro parece cumplir acá una función suplementaria y actúa como el catalizador de las distintas instancias de representación y captura del presente que se aglutinan en el asado, así como de las evocaciones compartidas del pasado. En efecto, allí Violeta toma unas fotografías con la polaroid; Gutiérrez filma a los invitados con su cámara de video y Diana a su vez los dibuja representándolos como manchas coloreadas; y muchos de ellos se reúnen para contarse historias más o menos cómicas o absurdas de la época de la dictadura.

De esta manera, la gran puesta teatral que es el asado, con su decorado natural y artificial en el que no faltan las delicias de la comida y la bebida, permite "reconsiderar" esas imágenes míticas que habían quedado grabadas en la juventud. Sin embargo, como ya se ha subrayado, La grande reitera las ocasiones radiosas en que mundo y sujeto pueden, por fin, encontrarse, instantes compactos que detienen el devenir y se instalan en el presente, suspendiéndolo.

\subsection{La no-pertenencia: patria chica y exilio}

La grande permite reactualizar la reflexión sobre la patria que la obra ficcional y ensayística de Saer había formulado desde sus inicios. Se trata en esta ocasión de una disputa personal - pero fundamentalmente política y estética- entre Tomatis y Mario Brando, el dudoso líder del movimiento precisionista al que le está dedicada buena parte de la novela. Brando es la versión deprimida del viaje al extranjero, porque a pesar de haber viajado por Europa y de haber sido agregado cultural en Roma, dice Tomatis, era un provinciano. La disputa puede leerse en los modos de apropiarse de la obra de Dante Alighieri, referencia privilegiada por Brando y sobre quien escribió un ensayo: "Dante y la patria chica". ${ }^{386}$ Según Tomatis, este artículo describía las relaciones de Dante con

que Soldi desmonta: hace cuarenta años que Tomatis no se toma un colectivo y solo viaja en taxi. La misma sensación de reiteración se da cuando charlan Clara, Marcos, Leonor y Gutiérrez, los "cuatro tienen un pasado común, que de tan lejano se ha vuelto legendario, como si, ya inmodificable, hubiese sucedido en una dimensión diferente a esta en la que están ahora, hecha de espacio y de tiempo, de vacilación y de incertidumbre" (Saer, La grande 410-1).

${ }^{386}$ Sería pertinente aclarar que no es esta la única aparición de Dante Alighieri en la novela. En las notas de preparación incluidas en el Dossier sobre La grande, el descubrimiento de Beatriz Portinari que Dante relata en la Vita Nuova parece funcionar como intertexto para el momento en que Nula se cruza por primera vez con Lucía Riera (que para la etapa de realización del proyecto, aún no tenía ese nombre). 
Florencia y pretendía establecer "un paralelo con su propia persona, rebajando a Dante al nivel de un notable de provincia" (229). Como se recordará, en 1985 Saer había escrito un breve ensayo, "Caminaba un poco encorvado", inspirado en la figura de Dante, pero allí donde Brando lo identificaba con "la patria chica", ${ }^{387}$ Saer, sin dejar de reconocer la melancolía por su patria, enfatizaba el carácter productivo del exilio: "Dante, el gran desterrado, era, como es sabido, grave, sarcástico, amargo, un poco altanero. El exilo coincidió con su gloria -hasta los que lo amenazaban de muerte lo respetaban, y, fuera de Florencia, los poderosos se disputaban al huésped ilustre quien, por otra parte, no dudaba de su superioridad terrena ni de su investidura divina" (76-7). Brando es quien no puede usufructuar los beneficios del extranjero (dos según Saer: relativizar la supuesta superioridad europea y también los fueros nacionalistas). "Narcisismo y nacionalismo sufren, gracias al descentramiento y a la distancia, un rudo golpe" (75), advierte Saer, pero Brando continúa inmune al efecto de la extranjería. Allí, "provinciano" se vuelve un término peyorativo y el personaje se viste de todos los atributos execrables para el modelo de valores sostenido por Tomatis y su grupo de pertenencia: pretendidamente vanguardista, Mario Brando es en realidad un poeta mediocre cuyos "logros" poéticos solo pueden hallarse en los sonetos neoclasicistas que escribía -el estilo poético de sus enemigos literarios de la revista Espiga-; dictador entre sus discípulos literarios y orgánico a los gobiernos de turno. Brando utiliza la literatura para aumentar su figuración pública y a pesar de sus veleidades cientificistas y su pretensión de unir literatura y ciencia para superar el regionalismo, comparte el modo de vida de la burguesía más tradicionalista.

Frente al modelo de patria ostentado por Mario Brando, Tomatis reconoce una patria de desplazados a partir de la idea de la no-pertenencia: "ninguno de los presentes, piensa Tomatis, cree que el mundo le pertenece. Todos saben que están a un costado de la muchedumbre humana que tiene la ilusión de saber hacia dónde se dirige y ese desfasaje no los mortifica; al contrario, parece más bien satisfacerlos" (Saer, La grande 408). Se insiste en esa comunidad de "exteriores" a la muchedumbre, que "son los que con más justicia son capaces de juzgarla. Son pasto de su delirio, es cierto, pero también, color del mundo" (409). A lo largo de la novela, los personajes allí reunidos evocan en diferentes momentos a los "muertos" y "ausentes" de la zona: el

\footnotetext{
${ }^{387}$ Hacia el final de la novela, Gutiérrez identificará la extraña forma blanca que flota arriba del árbol aludiendo paródicamente a las veleidades literarias del líder precisionista: "Es Mario Brando, mandado por Dante, para confirmar su reconocimiento del precisionismo como único heredero legítimo del dolce stil novo" (Saer, La grande 432).
} 
recientemente fallecido director del Diario La Región, César Rey, Washington Noriega; y a los desaparecidos: el Gato Garay y Elisa, por eso Tomatis, al regresar de Rosario, imagina el mundo de los muertos y la ficción concluye: "su patria es el lugar a la vez extraño y familiar, inmediato y remoto, en el que los vivos cargan en sus hombros a los muertos, y únicamente con la muerte se liberan de la carga" (Saer, La grande 377).

Sin melancolía ni patetismo, La grande muestra que en el cruce entre patria y regreso está la muerte. El delicado tatuaje azul del abuelo Yusef se enciende lejos de Damasco y cuando ya no es posible retornar; la vuelta de Gutiérrez activa una memoria intergeneracional en la que se recuentan los muertos y desaparecidos, los ausentes de la zona, los que se han dispersado en el exilio y el olvido. El tiempo del mito -pretendidamente eterno o imborrable- deviene efímero y dichoso tiempo escénico. "Que el último apague la luz", indica Tomatis después de efectuar unos pases mágicos para conjurar la lluvia, como un mistificador o mago de circo, mientras los invitados abandonan el quincho para probar si la tormenta ha menguado, aunque permanezcan, para siempre, en la ficción. 


\section{RECAPITULACIÓN Y CONCLUSIONES}

Mais les vrais voyageurs sont ceux-là seuls qui partent

Pour partir; coeurs légers, semblables aux ballons,

De leur fatalité jamais ils ne s'écartent, Et, sans savoir pourquoi, disent toujours: Allons!

(Baudelaire, "Le voyage", Les fleurs du mal)

Nuevamente era presa de un temor: la sensación de ser aquí, después de todos estos años y en su último día, un extraño. Cuatro años, casi cinco, y seguía sintiéndose como un vagabundo en otro planeta (Lowry, Bajo el volcán).

Extranjero, inmigrante y exiliado, Juan José Saer no es, según la caracterización de Baudelaire, un verdadero viajero. Sin embargo, viaje y extranjería se vuelven instancias fundamentales para comprender las constantes modulaciones de su figura de escritor y para entender cómo se transforma el territorio intensivo sobre el que escribe durante toda su vida. Así pudo verse que la poética de Saer declina por las diferentes formas de la distancia: el descubrimiento, la exploración, el viaje de artista, el exilio, la diáspora generacional y la inmigración; y comprobar en cada una de sus vueltas, la persistencia de la irreductible extrañeza del espacio familiar. A lo largo de esta tesis se intentó dilucidar esa aparente paradoja que hacía del "escritor del lugar", el pulso escritural por el que se multiplicaban los viajes y desplazamientos, y observar las inestabilidades del paisaje cuya percepción, distorsión y reescritura Saer emprendía en medio de una extensa biblioteca viajera, nuevo simulacro de hogar portátil en las lluviosas noches de Rennes.

En la primera parte de la tesis se observó qué figuras de escritor adoptó Saer en el extranjero. Como se vio en los Papeles de trabajo, Saer conjura los primeros años de su experiencia francesa a partir de la escritura de poesías cuyo tema es el viaje y lo extranjero. En su gran mayoría, estos poemas ponen en escena a un sujeto lírico que se desplaza por París y se desdobla en una serie de escritores-viajeros -fundamentalmente Rubén Darío- a partir de los cuales puede situarse en la línea del "desencanto" de París. Esta versión crítica y pesimista, que retomaba el desencanto modernista, le permitió a Saer desarticular y oponerse al París de los sesenta y resistir otras imágenes cristalizadas del escritor-viajero: la del intelectual comprometido, la del embajador y representante de causas nacionales, la del escritor decidido a conquistar la legitimación de la metrópolis, la del escritor exitoso pero asimilado que adopta la lengua extranjera. 
Paulatinamente el privilegio inaugural otorgado a la poesía irá desplazándose y conviviendo con otros géneros que serán los encargados de vehiculizar las principales reflexiones de Saer sobre la vida en el exterior. A partir de las variadas formas del ensayo Saer despliega además sus preocupaciones políticas contemporáneas y disputa los sentidos cristalizados del "compromiso".

En el segundo capítulo de la primera parte pudo advertirse que a fines de los setenta comienzan a configurarse dos nuevas figuras de escritor en el extranjero: el inmigrante y el exiliado. Por un lado Saer se reconoce como inmigrante y se reincorpora a la serie familiar de inmigrantes sirios de la que había intentado desprenderse desde su juventud. Por el otro, el escritor desarrollará una extensa reflexión sobre el "exilio" y ampliará su significación desde el plano político hasta el plano ontológico. Así apelará a un linaje universal de escritores, exiliados de toda clase. Como se vio, Saer retoma algunos tópicos de la prosa testimonial de los exiliados de la dictadura militar argentina y reitera dos series genealógicas del exilio: la de los inmigrantes y la de los escritores proscriptos del siglo XIX; sin embargo también ofrecerá una serie alternativa que tendrá a Witold Gombrowicz como estandarte. Efectivamente, se vio que el escritor polaco, exiliado en la argentina, le provee a Saer un modelo de percepción del paisaje nacional, y una ética refractaria tanto hacia la encumbrada infalibilidad europea como hacia las prerrogativas de identificación nacional.

A la par de su definición de exilio, que podría considerarse bastante afín a las formulaciones que desarrollaron Jean Luc-Nancy y Giorgio Agamben, Saer irá consolidando una particular idea de "patria" que le debe mucho a la procaz "inmadurez" de Gombrowicz. Como se pudo ver en "Instrucciones del letrado Koei”, el escritor desarticula la patria como abstracción, cuestiona su determinación geográfica $\mathrm{y}$ lingüística y compone su propia versión -experiencial, temporal, íntima, material y móvil- de lo natal que encontrará en la idea de continuum una forma de conjurar las tensiones entre la extranjería y la región.

El tercer capítulo de la primera parte de la tesis estuvo dedicado a considerar las ficciones que Saer había comenzado a fraguar en el extranjero. La mayor ofrecía por un lado un catálogo de diferentes formas del desplazamiento que el escritor exploraría en textos posteriores y multiplicaba las escenas de partida del espacio natal. Se estudió con especial interés el efecto que el traslado de Saer produjo en la reescritura de "A medio borrar" y se comprobó que en ese cuento, a diferencia de su antecedente "Fragmentos", se modifica la relación de los personajes con respecto al viaje a Europa, se radicaliza la 
"perspectiva exterior" a la hora de intentar comprender el paisaje anegado por la inundación; y se consolidan los atributos que ostentarán todos los personajes viajeros de Saer. La partida de Pichón Garay permitió a su vez retomar la extraña despedida de Willy Gutiérrez y confirmar que la ética de la impasibilidad y la desarticulación de la nostalgia ya habían emergido como programa muy tempranamente en el primer libro de Saer. Según pudo leerse en varios de los argumentos de La mayor, la llegada al extranjero perfecciona el borramiento y el anonimato de los personajes y no ofrece, pese a las expectativas, imágenes de arribo. A su vez, pudo observarse que Lugar era el libro que coronaba la ampliación narrativa de lo extranjero. Como se vio, a diferencia de la relativa sustracción del espacio europeo que prima en las ficciones que Saer escribe cuando llega a Francia, aquí se incorporan nuevas formas del viaje -el turismo, la exploración espacial y la inmigración de árabes y africanos- que amplían el referente topográfico y radicalizan la crítica de la civilización europea que el escritor ya había ensayado en ficciones y ensayos previos y terminará de formular en La grande.

La noción de "extranjero" vuelve a ampliarse en el capítulo siguiente. En las poesías del apartado "Noticias secretas" se expande una vez más la geografía europea. Por un lado, leídos como un diario de viaje poético, algunos de los poemas allí incluidos permitieron recomponer un fragmentado viaje por ciudades de Finisterre y el norte de España. Sin embargo, se pudo observar que la representación opaca de los distintos paisajes europeos minaba las expectativas referenciales que auguraban los títulos de los poemas. Una segunda serie de textos ofrecía retratos de famosos viajeros a partir de los cuales Saer indagaba la noción de "límite" geográfico y registraba el ocaso de las distintas variantes del viaje de exploración: el viaje artístico de fin del siglo XIX, el viaje conquistador y la peregrinación mística del Santo Grial. La certidumbre de que ya no quedan "lugares" en el mundo se agudiza en "El graal" en relación a la experiencia del exilio político de una generación que quedó fragmentada en la diáspora y despojada del aura mítica que se congregaba alrededor de la figura de Juan L. Ortiz.

La segunda parte de este trabajo estuvo dedicada a explorar los diversos desplazamientos que configuraron la famosa "zona" de Saer, desde la conquista española hasta la fundación de la urbe moderna. El primer capítulo buscó leer los modos en los que Saer reescribió los relatos de fundación de diferentes cronistas y expedicionarios que trazaron las huellas inaugurales del paisaje. El viaje marítimo concentró las primeras reflexiones y permitió enlazar textos muy profusamente estudiados, como El entenado y "El intérprete", con otros menos trabajados. Se observó 
que la travesía marítima por un lado incorporaba el tiempo histórico en las ficciones a partir de las llegadas de Colón, Juan Díaz del Solís o Sebastián Gaboto, pero a la vez se abría a la indeterminación y al delirio. El mar, monótono, uniforme y abstracto, disolvía las certezas del proyecto imperial y mostraba la insuficiencia de los conocimientos científicos.

Se trabajó en un segundo momento con aquellos relatos que representaban las fundaciones y destrucciones de la empresa colonial española y pudo observarse que a diferencia de los relatos teleológicamente orientados escritos por los cronistas de la conquista (en los cuales a la destrucción, al incendio o a la pérdida de sus fuertes les seguía una ocasión de victoria), una de las operaciones más interesantes que Saer ensayaba con respecto a la historia era cortar ese discurso allí donde se ponía en evidencia la falla y el fracaso de la empresa colonial. El entenado fijaba, además, la arqueología de las imágenes del desierto cuyo devenir y mutación decimonónica Saer exploraría en sus novelas posteriores, y en este sentido cobró gran importancia la reformulación saeriana de la escena de arribo por antonomasia que fijó el contacto entre españoles e indios. Allí donde en general el ojo imperial mensuraba y jerarquizaba realidades, el ojo cautivo del entenado solo podía conocer una imagen agitada, inestable y frágil del paisaje americano, cuyo correlato lingüístico y filosófico lo daba la experimental e imprevisible lengua colastiné. Por último se analizó qué nuevas formas adquiría el relato genealógico en el ensayo El río sin orillas y se observó que la biblioteca viajera, aludida más o menos oblicuamente en las ficciones, se ordenaba, ampliaba y explicitaba; así como también se desarticulaba el pathos de la conquista americana. Afín a la perspectiva crítica de David Viñas y de Ezequiel Martínez Estrada, Saer leía transversal y transtemporalmente el corpus de la conquista y cuestionaba los fueros racionalistas y humanistas de la fundación.

El segundo capítulo, "Un desierto para la zona", se concentró en las diferentes ficciones del desierto del siglo XIX que Saer reescribe en novelas y poesías. Retomando algunas formulaciones de Ezequiel Martínez Estrada, el desierto saeriano perturbaba la percepción y permitía que emergiera eso "otro innominado" que la mirada familiarizada no veía. Entre las sucesivas formulaciones históricas, literarias y políticas del desierto, Saer cuestionaba las principales cristalizaciones sobre la llanura a partir de un programa negativo que exacerbaba, por el contrario, los efectos de ilegibilidad, detención y opresión. En primer lugar pudo confirmarse el interés que Saer experimentó por la biblioteca "viajera" y especialmente por los escritores del siglo XIX. Esa inquietud, 
como vimos, se materializó muy temprano en su obra a partir de los primeros tanteos del texto inconcluso y no editado "La ocasión", primera versión de la novela homónima. Esa primera ficción, que Saer comenzó a escribir en la década del sesenta y "continuó" escribiendo hasta su versión definitiva en 1987 dibuja "otro comienzo" para la obra de Saer y permite entender ese interés latente que recién comenzaría a efectivizarse en su producción tardía.

La ocasión se escribe en el vértice de muchísimas lecturas e imágenes sobre el desierto que Saer tensiona a partir de una apropiación anacrónica, pesimista y experimental. La novela retoma el viaje de la inmigración a través de la mirada descentrada del más extranjero de sus viajeros, el misterioso Bianco, y se expide sobre un momento particularmente delicado de la historia argentina: aquel en el cual comienzan a definirse las líneas de la paideia nacional, se está consolidando la conquista sobre el desierto y el paisaje está sufriendo las mutaciones que le impone la razón pragmática del progreso (que transforma la tierra sin límites en campos alambrados y determina nuevas formas de producción agrícola e importadora). La escritura sobrevuela y yuxtapone, entre muchas otras, la ficción geológica de Darwin, las preocupaciones teosóficas y nacionalistas de Las fuerzas extrañas de Lugones, los relatos expedicionarios de Ebelot y Prado y la famosa pintura de Blanes sobre la fiebre amarilla. A nivel general pudo observarse que la perspectiva - no asimilada ni nostálgica de Bianco- le permite a Saer trabajar con esos y otros materiales de la historia y de la literatura, depurando por un lado el efecto dramático y épico de algunos episodios de la Conquista del Desierto y conservando, por momentos, el carácter sublime y alucinado del paisaje. Cada una de las variantes del desierto permite oponer espiritualismo y racionalidad aunque las múltiples formas del misterio sucumban ante el avance ciego del progreso económico.

Se trabajó, además, con "Fragmentos de un Juan Moreira", la deriva poética que Saer escribió retomando el folletín de Eduardo Gutiérrez. El poema produce un desplazamiento genérico - de la versión folletinesca y melodramática a la condensación poética y depurada - en la cual los múltiples personajes y escenarios se reducen a un único cuerpo muerto infinidad de veces, el del propio Moreira, y a un solo escenario: la pulpería-prostíbulo La estrella. Si como ha afirmado la crítica, las sucesivas versiones de Juan Moreira permiten trazar una historia de la violencia en Argentina, el poema de Saer condensa transtemporalmente esas violencias, a partir de un vertiginoso movimiento que va retrospectivamente desde la opresiva e injusta legalidad del estado 
de fines del siglo XIX hasta la conquista española; y hacia adelante, hasta la violencia de la proscripción del peronismo. El carácter "inconcluso", de bisagra y pasaje usualmente asignado al personaje de Moreira -que une las orillas, la ciudad y el campo, y permite además el paso de la gauchesca a la literatura de las orillas-, habilita y potencia esa condensación.

En esta parte se examinó, además, el tópico de los extraviados de la llanura a partir del argumento "El viajero". Como se vio, la escritura fragmentada remeda en este relato una forma específica del territorio nacional: el pajonal acribillado de agujeros. Según pudo observarse, se fractura aquí el discurso utilitario-economicista del viaje comercial que habían desarrollado los viajeros ingleses. La eficaz celeridad que caracteriza sus desplazamientos es trocada por el errabundeo circular de Jeremy Blackwood, que transforma el desierto en un laberinto muy afín a la imaginación borgeana. Solo y perdido, despojado de cualquier marca british, el viajero sueña con su Londres imperial, pero muere en los confines desérticos y laberínticos de la orilla sudamericana: nueva forma del fracaso que Saer inscribe en su relectura de la historia de los viajes.

Las nubes fue la última ficción abordada en el capítulo dedicado al siglo XIX. La novela termina de coronar las experimentaciones que Saer venía elaborando sobre las imágenes del desierto desde 1960. Como pudo observarse, es allí donde el escritor le da un giro a su reescritura de la biblioteca viajera porque se aligera el tono pesimista y crítico anterior y comienzan a privilegiarse ciertas formas del humor y del delirio que Saer leía interesadamente en Francis Bon Head, Mansilla, Ebelot y Hudson, entre otros. A diferencia de La ocasión, cuya acción estaba ubicada en fechas "históricamente significativas", Las nubes elegía un tiempo al margen de los grandes acontecimientos históricos y en una "tierra de nadie" sobre la cual era posible proyectar la imagen fantasmática de la llanura. La caravana en la que se condensaban heterogéneas lenguas, sujetos y espacios del desierto permitió pensar que la novela problematizaba la idea de frontera sarmientina e imaginaba una efímera comunidad capaz de vehiculizar proyectos políticos y sexuales alternativos para la nación en ciernes, que por supuesto fracasarían y se disolverían apenas culminado el viaje. Se radicalizaban aquí, además, los efectos distorsivos del desierto que Saer ya había ensayado en ficciones anteriores, incorporados ahora en relación a las perturbaciones climáticas y al clásico tópico del incendio en la pampa (que Saer reescribe apelando a la sutil mezcla de sublime y banal que ensaya Francis Bon Head). Las nubes recupera además el viaje naturalista de 
Humboldt y desarticula las clasificaciones estáticas de la "lámina naturalista" a partir de la develación sublime y fantasmal de una naturaleza que en gran medida parece dialogar también con el deleite animista de las ensoñaciones de Hudson. Esta novedosa reescritura de la tradición se explica por la selección de los momentos en que las narrativas "desbordan": las "farsas" de Francis Bon Head, el delirio onírico e imperial de Mansilla, la animista y sublime experiencia de Hudson y el variopinto catálogo de Ebelot.

El último capítulo de la segunda parte buscó definir un espacio hasta el momento no explorado pero fundamental en la obra de Saer: la ciudad de los sesenta. Como se vio, varias de las ficciones urbanas del escritor giran en espiral alrededor de esta época, pero escamotean sus rasgos más representativos, optimistas y vanguardistas, abriendo la espacialidad de la urbe a la naturaleza de las islas, el campo y el río, y multiplicando el espesor de su temporalidad. Interesó particularmente leer en la ciudad moderna la irrupción de la memoria del desierto y la genealogía de su fundación. El concepto de "ciudad incivil" de Jean Luc-Nancy permitió pensar el carácter transitorio de la urbe y revelar "la incivilidad de la civilización", allí donde afloraban las visiones incendiarias del juez, la violencia política de la proscripción del peronismo y también la prospectiva represión de la dictadura. La ciudad saeriana, representada por momentos a partir de una estudiada precisión topográfica, arquitectónica, botánica y cartográfica mostraba sin embargo cuán insuficientes se volvían mapa y grilla para capturar la intensidad fenoménica de las experiencias de sus personajes, más congruentes con la atormentada pintura de Rita Fonseca. En las operaciones distorsionadoras de la representación urbana se leyó cómo Saer se sustraía y discutía con las principales morales -ideológicas y estéticas- de los sesenta: el debate sobre el compromiso y las prerrogativas vistosamente vanguardistas y lúdicas del boom.

La tercera parte de la tesis estuvo dedicada a revisar el regreso. Se observó un primer desequilibrio entre la escasez de testimonios sobre el arribo del escritor a Francia (más allá de las sí numerosas reflexiones sobre la extranjería) y las variadas escrituras del regreso a Argentina que Saer ensaya en múltiples géneros y va progresivamente anudando a su propia biografía. El retorno es una coordenada que estructura transversalmente la producción tardía de Saer y que, a contrapelo de la creciente notoriedad de su figura pública, le permite imaginar nuevas formas de autofiguración, anómalas, y una vez más, anacrónicas, que continúan estableciendo filiaciones con la biblioteca viajera. De acuerdo a su idea de "patria", Saer desarticula la posibilidad del 
regreso como recuperación y cuestiona el oikos como fijeza del sentido, agudizando las formas de la desconexión con respecto al espacio familiar.

En primer lugar se trabajó con El limonero real porque es la novela que se escribe entre la zona natal y el extranjero, proyecto portátil que le permite retornar a las islas del Paraná. Como se vio, su compleja temporalidad inscribía, en una de sus vueltas, un doble regreso al espacio isleño, lingüístico y territorial, a través de las reescrituras paródicas del Génesis y de la Odisea. El "gesto ideológico" que parte de la crítica identificaba en estos relatos incrustados, debía leerse también junto a la reescritura desacralizante que Saer ensayaba sobre la tradición fluvial decimonónica. En ese sentido se pudo observar que varios de los tópicos positivos asociados al río, transformado por algunos viajeros en un locus amoenus fluvial, eran invertidos en su escritura, porque Wenceslado, el Ulises-carapachayo criollo, padecía los rigores del Paraná hasta arribar a su isla. Se privilegió, entre estos antecedentes, El Carapachay de Sarmiento porque allí se retoman las mismas fuentes clásicas utilizadas por Saer y porque ambos reescriben el génesis de las islas del delta de acuerdo a su historia política contemporánea; pero allí donde Sarmiento proyectaba un futuro promisorio para la nación, Saer registraba la pobreza y decadencia económica del espacio isleño y la tensión irresuelta entre la ciudad y la costa.

En el segundo capítulo de esta tercera parte se reflexionó sobre el retorno de Pichón Garay. Por un lado, el personaje desencadena un dinámico intercambio de historias de misterio que sedimenta y en algunos casos, refunda el vínculo entre los amigos de la zona, y además le permite a Saer volver a reflexionar sobre las elecciones formales de su poética. Una vez de regreso, Garay desarticula la nostalgia por el lugar de origen y pese a las primeras expectativas, percibe con aire de "forastero" un paisaje opaco. Sin embargo el espacio natal captura al sujeto cuando alguna irrupción epifánica acontece y también cuando descubre el paisaje temporalizado de las ruinas posindustriales, un tiempo que se describe, otra vez, a través de un rizo darwiniano. Se comprobó además que ese paisaje átono y neutral seguía interfiriendo en París, a partir de un despliegue material (las condiciones del verano que se replican en Las nubes) y virtual (a través del relato de Tomatis en "En línea"), una interferencia capaz de suspender el presente parisino del personaje.

Por otro lado el regreso de Pichón producía un intercambio de historias policiales. Como se recordará, a su narración del caso parisino -cuya resolución es tributaria de los procedimientos del policial de enigma y del psicoanálisis- Tomatis le 
responde con una resolución "argentina" en relación a la reciente historia del país. Pero además Tomatis expone un futuro proyecto de escribir el último caso de Sherlock Holmes. Como se vio, a través de las modificaciones que Tomatis le imprime al legendario personaje, se dibuja en filigrana la figura de Washington Noriega y se reconstruye el aura solidaria y austera de sus encuentros, así como sus preocupaciones sociales.

Luego se trabajó alrededor de las libretas de viaje y El río sin orillas, escrituras que concentraban la experiencia del regreso de Saer, encabalgadas sobre lo biográfico, lo ensayístico y lo ficcional, entre vida y escritura, y entre percepciones familiares y nuevas perspectivas retomadas, una vez más, de viajeros y exploradores. Se observó que la heterogénea escritura de las libretas formaba parte de una etapa tardía en la trayectoria de su obra que coincidía con un momento de clivaje de su poética y que permitía comprender cómo se modificaba y refundaba la idea de zona. Saer establece una proximidad distanciada con la región a partir de autofiguraciones inusuales y, una vez más, anacrónicas, divergentes de esa progresiva visibilización que su figura y su obra habían empezado a cobrar desde la década del ochenta en adelante.

A este respecto, en primer lugar se observó que En el río sin orillas pero sobre todo en las libretas Saer incorporaba clasificaciones de la botánica y minuciosas descripciones de la flora local, comportándose como un naturalista amateur que retomaba fundamentalmente esa mezcla de poesía y naturalismo ensayada por William Hudson. Ambos recuperaban y a su vez desarticulaban el naturalismo practicado por científicos y viajeros como Linneo, Darwin o Humboldt. Por eso, exenta de sus criterios de rigurosidad y eficacia, la observación naturalista practicada por Saer significó una nueva forma de calibrar su percepción sobre la flora y la fauna de la región, le permitió además ejercitar una escritura del tiempo signada por el paso de las estaciones y los ciclos de reproducción de flores y animales así como trazar un somero mapa botánico de la ciudad. Como se vio, varias de las piezas botánicas capturadas en sus libretas se resignifican en sus libros de ensayo y ficción.

En segundo lugar Saer se presentaba no como un intelectual cosmopolita que volvía al país para reconocerlo, sino como un viajero -explorador, topógrafointeresado en interrogarlo como si lo desconociera o lo hubiera parcialmente olvidado. Retoma así algunos de los tópicos presentes en las escrituras de viaje: el punto de vista alto, la construcción de panoramas, la señalización de límites y caminos y la atención privilegiada a las condiciones lumínicas y atmosféricas. Con ojos inventivos Saer 
redibuja el mapa del delta del Paraná a partir de una lectura histórica y mitológica que regresa a la genealogía de la zona: el fracaso de Juan Díaz del Solís y la postulación de Entre Ríos como espacio genesíaco de la nación.

El interés de Saer en capturar formas desconocidas del habla cotidiana permitió volver a interrogar los "riesgos" que corría la lengua del exiliado en el extranjero y retomar una discusión de larga data en la historia de la literatura argentina sobre las tensiones entre lengua nacional y lenguas extranjeras, que Saer explícitamente evoca al retomar el sintagma "el idioma de los argentinos". La operación saeriana -afín en algunos puntos al exilio de Hanna Arendt- consistía en despojar a la lengua de las formas abstractas y las prerrogativas políticas de la "patria", escindir lengua y nación.

El último capítulo de la tesis estuvo dedicado a explorar los regresos de $L a$ grande. Por un lado, a partir del relato del episodio familiar de Nula, Saer pudo rescatar la memoria de su infancia como hijo de inmigrantes sirios. Se observó cómo se reescribía el tópico del nostos a partir del exilio religioso de sus familiares árabes, complejizando a la vez el mapa inmigratorio de la nación. Se estudió además cómo, apelando a la memoria de su infancia, el escritor orientalizaba la zona, incorporando una serie de percepciones sensoriales, referencias culturales y lingüísticas del mundo árabe a partir de las cuales reescribía el paisaje local que ya había ensayado en sus ficciones anteriores. De los variados repertorios de lo "oriental" que fraguó la sensibilidad intelectual y literaria nacional, Saer subrayaba la posible asimilación entre los universos culturales árabe y criollo, en detrimento de otras representaciones que agudizan lo exótico. Por último, esta extensa memoria de sus antepasados siriolibaneses fue leída como un homenaje tardío al "poeta de la inmigración”, José Pedroni, fundamental en los "inicios" de su aprendizaje literario.

Por otro lado, el retorno de Gutiérrez abría en la zona un "tiempo mítico" que fue leído en relación a la gravitación que Cesare Pavese tuvo siempre sobre la obra de Saer. Según pudo observarse, la ficción recupera los espacios de la mitología personal y generacional del personaje pero muestra también los signos de su degradación y transformación en el presente. El hiato temporal que parece descongelar Gutiérrez a su llegada no está exento, sin embargo, de un aire teatral y así el regreso se articula como representación espectacular. Según pudo observarse, La grande está saturada de marcas didascálicas, los personajes parodian parlamentos reformulados de obras literarias y así van componiendo un dilatado guión que solo pueden descifrar los viejos amigos, aunque todos se plieguen al juego de la representación. Lo teatral explora aquí, 
a diferencia de lo que ocurre en otras obras de Saer, sus posibilidades más dichosas y refunda el tejido afectivo de la zona. A contrapelo del modelo de "patria chica" que Mario Brando imagina, asimilándose con Dante Alighieri, Tomatis apuesta y reconoce en su grupo de amigos una "patria de desplazados" a partir de la idea de la no pertenencia. La novela no deja de evocar a los muertos y desaparecidos y sostiene que regresar, como señalaba Cassin, es asumir la "condición mortal". En el cruce entre patria y retorno está la muerte, activada como resto fantasmal en el asado, pero también las posibilidades radiosas del reencuentro y una forma apacible de la dicha.

A lo largo de la tesis se buscó contribuir al debate de la crítica y la historia de la literatura argentina, y en particular a los estudios sobre la poética de Juan José Saer desde una perspectiva que ponderara una dimensión fundamental de su obra que no había sido suficientemente explorada. Entusiasta lector de viajes y de mapas, caminante ocioso, inmigrante y exiliado, explorador y naturalista amateur: repensar las imágenes de escritor de Saer en relación a las proyecciones que abrían el viaje y la extranjería permitió por un lado visibilizar algunas de sus operaciones de repliegue y figuración menos conocidas, y fundamentalmente establecer nuevas filiaciones entre su literatura y una heterogénea y fabulosa biblioteca: Gombrowicz, Hudson, Darío, Lugones, Sarmiento, Bon Head, Ebelot, Colón, por nombrar sólo algunos. Esta lista, en parte invisibilizada por el estribillo de nombres que el mismo Saer siempre se encargaba de repetir, hizo posible a su vez incorporarlo a una serie de problemas culturales y literarios con los que no había sido estrictamente vinculado: su participación en los debates sobre el exilio de los escritores, la recuperación apátrida de la clásica tensión entre lengua nacional y lenguas extranjeras, y su inscripción problemática en la serie del "regreso". Advertir el interés temprano que Saer experimentó por el viaje y la literatura decimonónica permitió volver a calibrar las etapas de su escritura, sopesar las productivas consecuencias de ese "otro comienzo" que había abierto "La ocasión" y revisar el parcial redescubrimiento de la "zona" que se opera a partir de la escritura documental y viajera de las libretas.

Por último, leer a Saer en esta clave permitió examinar costados más inusuales, extravagantes y problemáticos de escritores nacionales y extranjeros que ya forman parte de la literatura argentina, algo así como un "efecto Saer" sobre sus precursores que habilitó pensar "en serie" las más disímiles distorsiones visuales y políticas que antiguos y nuevos viajeros operaron sobre el desierto, el río y las islas, y por supuesto, sobre sus habitantes. Si como apuntaba Borges en su conocido ensayo sobre Kafka, "la 
labor [de cada escritor] modifica nuestra concepción del pasado, como ha de modificar el futuro" ("Kafka y sus precursores" 86-7) la obra viajera de Saer permite descubrir, también, a los escritores contemporáneos que siguen interrogando en el presente las potentes sedimentaciones de la tradición, o hacen de la extranjería, la casa de la escritura. 


\section{BIBLIOGRAFÍA}

\section{Fuentes primarias:}

Saer, Juan José. En la zona. Santa Fe: Castellvi, 1960. Edición citada: Cuentos completos. Buenos Aires: Seix Barral, 2004.

Responso. Buenos Aires: Jorge Álvarez editor, 1964. Edición citada: Buenos Aires: Seix Barral, 1998.

Palo y hueso. Buenos Aires: Camarda-Junior Editores, 1965. Edición citada: Cuentos completos. Buenos Aires: Seix Barral, 2004.

La vuelta completa. Rosario: Ed. Biblioteca popular Constancio C. Vigil, 1966. Edición citada: Buenos Aires: Seix Barral, 2001.

Unidad de lugar. Buenos Aires: Galerna, 1967. Edición citada: Cuentos completos. Buenos Aires: Seix Barral, 2004.

Cicatrices. Buenos Aires, Sudamericana, 1969. Edición citada: Buenos Aires: Planeta, 2001.

El limonero real. Barcelona: Planeta, 1974. Edición citada: Buenos Aires: Seix Barral, 2015.

La mayor. Barcelona: Planeta, 1976. Edición citada: Cuentos completos. Buenos Aires: Seix Barral, 2004.

El arte de narrar. Caracas, Fundarte, 1977. Edición citada: Buenos Aires: Seix Barral, 2000.

Nadie nada nunca. México DF: Siglo Veintiuno Editores, 1980. Edición citada: Buenos Aires: Seix Barral, 2009.

El entenado. Buenos Aires: Folios, 1983. Edición citada: Buenos Aires: Seix Barral, 2008.

Glosa. Buenos Aires: Alianza, 1986. Edición citada: Buenos Aires: Seix Barral, 2006.

“Razones”. Lafforgue, Jorge (ed.). Juan José Saer por Juan José Saer. Buenos Aires: Celtia, 1986.

La ocasión. Buenos Aires: Alianza, 1987. Edición citada: Buenos Aires: Seix Barral, 2010.

El río sin orillas: tratado imaginario. Buenos Aires: Alianza, 1991. Edición citada: Buenos Aires: Seix Barral, 2003.

Lo imborrable. Buenos Aires: Alianza, 1992. Edición citada: Buenos Aires: Seix Barral, 2013.

La pesquisa. Buenos Aires: Seix Barral, 1994. Edición citada: Buenos Aires: Seix Barral, 2003.

"s/t" en AA.VV. "Los que se van". Página/12. Domingo 8 de septiembre de 1996, p. 6.

Las nubes. Buenos Aires: Seix Barral, 1997.

El concepto de ficción. Buenos Aires: Ariel, 1997. Edición citada: Buenos Aires: Seix Barral, 2004.

La narración-objeto. Buenos Aires: Seix Barral, 1999.

- "Una deuda en el tiempo". Gola, Hugo; Saer, J. J.; Padeletti, Hugo; Espino, F. La trama bajo las apariencias. La pintura de Fernando Espino. México: Artes de México, 2000, pp. 27-49. 
Esquina de febrero. Buenos Aires: Seix Barral, 2001. Edición citada: Cuentos completos. Buenos Aires: Seix Barral, 2004.

Lugar. Buenos Aires: Seix Barral, 2000. Edición citada: Cuentos completos. Buenos Aires: Seix Barral, 2004.

Trabajos. Buenos Aires: Seix Barral, 2005. Edición citada: Buenos Aires: Seix Barral, 2006.

La grande. Buenos Aires: Seix Barral, 2005.

Papeles de trabajo. Borradores inéditos. Buenos Aires: Seix Barral, 2012.

Papeles de trabajo II. Borradores inéditos. Buenos Aires: Seix Barral, 2013.

Poemas. Borradores inéditos III. Buenos Aires: Seix Barral, 2014.

Ensayos. Borradores inéditos. Buenos Aires: Seix Barral, 2015.

\section{Fuentes secundarias}

Amaro Villanueva et al. Islote municipal: antología de textos. Paraná: Universidad Nacional de Entre Ríos, UNER, 2014.

Arlt, Roberto. "El idioma de los argentinos". Aguafuertes porteñas. Buenos Aires: Losada, 2007, pp. 141-144.

Asís, San Francisco de. Las florecillas de San Francisco; El Cántico del sol. Disponible en http://www.cervantesvirtual.com/obra-visor/las-florecillas-de-san-franciscoel-cantico-del-sol--0/html/ff7b777a-82b1-11df-acc7-002185ce6064_6.html

Bon Head, Francis. Apuntes tomados durante algunos viajes rápidos por las Pampas y entre los Andes (estudio preliminar de Patricio Fontana y Claudia Román). Buenos Aires: Santiago Arcos Editor, 2007.

Borges, Jorge Luis. "El idioma de los argentinos". El idioma de los argentinos. Buenos Aires: Seix Barral, 1994, pp. 135-150.

“Argumentum ornithologicum”. El Hacedor. Obras completas (Tomo 2). Buenos Aires: Círculo de lectores-Emecé, 1984, p. 162.

"Los dos reyes y los dos laberintos". El Aleph. Obras completas (Tomo 1). Buenos Aires: Círculo de lectores-Emecé, 1984, pp. 588-598.

"Las calles". Fervor de Buenos Aires. Obras completas (Tomo 1). Buenos Aires: Círculo de lectores-Emecé, 1984, p. 15.

"Fundación mítica de Buenos Aires". Cuaderno San Martín. Obras completas (Tomo 1). Buenos Aires: Círculo de lectores-Emecé, 1984, pp.83-4.

Colón, Cristóbal. Diario, cartas y relaciones y otros textos. Antología Esencial; edición literaria a cargo de Vanina M. Teglia y Valeria Añón. Buenos Aires: Corregidor, 2012.

Cortázar, Julio. "Viaje alrededor de una mesa". Buenos Aires: Editorial Rayuela, 1970.

Darío, Rubén. Autobiografía. Madrid: Mundo Latino, 1918.

Cantos de vida y esperanza. Los cisnes y Otros poemas. Buenos Aires: Losada, 2015.

Darwin, Charles. Viaje de un naturalista por América del Sur. Buenos Aires: Terramar, 2013

Ebelot, Alfred. La zanja de Alsina y La Pampa: relatos de la frontera del desierto. Buenos Aires: Distribuidora Quevedo de Ediciones, 2015.

Gauguin, Paul. Escritos de un salvaje. Madrid: Akal, 2008.

Gombrowicz, Witold. Diario argentino. Buenos Aires: Adriana Hidalgo, 2006. 
Guimarães Rosa, João. “Mi tío el jaguareté”. Campo general y otros relatos (selección y prólogo Valquiria Wey). México: Fondo de Cultura Económica, 2001, pp. 411-455.

Gutiérrez, Eduardo. Juan Moreira (prólogo de Alejandra Laera). Buenos Aires: Eudeba, 2012.

Hudson, William H. El naturalista en el Plata. Buenos Aires: El Elefante Blanco, 2010. Allá lejos y hace tiempo. Buenos Aires: Terramar, 2007.

Khayyam, Omar. Rubáiyát. (Versión española de Felix E. Etchegoyen. Según traducción francesa de Franz Toussaint). Buenos Aires: Guillermo Kraft Limitada, 1956.

Lugones, Leopoldo. Las fuerzas extrañas. Buenos Aires: Agebe, 2012.

Mansilla, Lucio V. Una excursión a los indios ranqueles. Buenos Aires: Edicol, 2006.

Martínez Estrada, Ezequiel. Radiografía de la pampa. Buenos Aires: Losada, 2011.

Ortiz, Juan L. El junco y la corriente (prólogo y comentarios de Francisco Bitar). Paraná: Universidad Nacional de Entre Ríos, UNER; Santa Fe: Universidad Nacional del Litoral, UNL, 2013.

Pavese, Cesare. Cesare Pavese (antología). Selección, traducción y nota de Guillermo Fernández. Universidad Nacional Autónoma de México. Coordinación de difusión cultural. Dirección de literatura, México, 2008. Disponible en http://www.materialdelectura.unam.mx/images/stories/pdf5/cesare-pavese.1$1 . \mathrm{pdf}$

Pedroni, José. "Palabras a mi padre y a su digna herramienta". Disponible en https://josepedroni.es.tl/Otros-d--Palabras-a-mi-padre-y-a-su-dignaherramienta.htm

"El entierro de mi abuelo". Disponible en https://josepedroni.es.t1/Otros-d--Elentierro-de-mi-abuelo.htm

Prado, Manuel. Guerra al malón. Buenos Aires: Editorial Universitaria de Buenos Aires, 1960.

Quevedo, Francisco de. Vida de Marco Bruto.Edición digital basada en la de Buenos Aires, Espasa-Calpe, 1950. Alicante: Biblioteca Virtual Miguel de Cervantes, 2002. Disponible en http://www.cervantesvirtual.com/obra/vida-de-marco-bruto$-0 /$

Sarmiento, Domingo F. Viaje a Francia. Caracas: Biblioteca Ayacucho, 2004. Facundo o civilización y barbarie en las pampas argentinas. Buenos Aires: Centro Editor de Cultura, 2005.

El Carapachay: imágenes de las islas del Delta del Paraná (con prólogo de Liborio Justo y Marta Susana Ramírez). Buenos Aires: Eudeba, 2011.

Sastre, Marco. El tempe argentino: impresiones y cuadros del Paraná. Buenos Aires: Imprenta de Mayo, $1858 . \quad$ Disponible en http://trapalanda.bn.gov.ar/jspui/handle/123456789/2925 .

Schmidl, Ulrico (Utz). Derrotero y viaje a España y las Indias (traducido por Edmundo Wernicke; prologado y comentado por Loreley El Jaber; coordinado por Guillermo Mondejar). Paraná: Universidad Nacional de Entre Ríos, UNER, [1567] 2016.

\section{Bibliografía general}

AA.VV. "Literatura, viajeros e historia del paisaje en la Argentina". Dossier de Prismas. Revista de Historia Intelectual, vol. 4, n. ${ }^{\circ}$ 4, Buenos Aires, 2000. 
Adams, Percy G. Travel literature and the evolution of the novel. Lexington: The University Press of Kentucky, 1983.

Adorno, Rolena. "El sujeto colonial y la construcción cultural de la alteridad". Revista de Crítica Literaria, vol. XIV, n. ${ }^{\circ} 28$, Lima, 1988, pp. 55-68.

Adorno, Theodor. "El ensayo como forma". Notas de literatura. Barcelona: Ariel, 1962, pp. 12-36.

Agamben, Giorgio. "Política del exilio". Archipiélago. Cuadernos de crítica de la cultura. Barcelona, n. ${ }^{\circ}$ 26-27, 1996, pp. 41-52.

“¿Qué es lo contemporáneo?”. Desnudez. Buenos Aires: Adriana Hidalgo, 2011, pp. 17-29

Aira, César. "La intimidad", Boletín/13-14 del Centro de Estudios de Teoría y Crítica Literaria. Rosario, 2007-2008, pp. 6-12. Disponible en http://www.celarg.org/int/arch publi/aira 13 14.pdf.

"Exotismo". Boletín/3 del Centro de Estudios de Teoría y Crítica Literaria. Rosario, 1993, pp. 73-79.

Aliata, Fernando y Graciela Silvestri. El paisaje en el arte y las ciencias humanas, Buenos Aires: Centro Editor de América Latina, 1994.

Alpers, Svetlana. El arte de describir. El arte holandés en el siglo XVII. Madrid: Hermann Blume, 1987.

Amante, Adriana. Poéticas y políticas del destierro: Argentinos en Brasil en la época de Rosas. Buenos Aires: FCE, 2010.

Andermann, Jens. Mapas de poder. Una arqueología literaria del espacio argentino. Rosario: Beatriz Viterbo, 2000.

Añón, Valeria. "Figuraciones y usos del viaje en cartas de la conquista de América". Colombi, Beatriz et al. Viajes, desplazamientos e interacciones culturales en la literatura latinoamericana: de la conquista a la modernidad. Ciudad Autónoma de Buenos Aires: Biblos, 2016, pp. 19-35.

Añón Valeria y Vanina Teglia. "Introducción general”. Colón, Cristóbal. Diario, cartas $y$ relaciones y otros textos. Antología Esencial; edición literaria a cargo de Vanina M. Teglia y Valeria Añón. Buenos Aires: Corregidor, 2012, pp. 9-85.

Auerbach, Erich. Mímesis. La representación de la realidad en la literatura occidental. Buenos Aires: FCE, 1979.

Augé, Marc. El viaje imposible. El turismo y sus imágenes. Barcelona: Gedisa, 1997. El tiempo en ruinas. Barcelona: Gedisa, 2003.

Aumont, Jacques. La imagen. Barcelona: Paidós, 1992.

Bachelard, Gastón. La poética del espacio. Buenos Aires: FCE, 2000.

Baldasarre, María Isabel y Silvia Dolinko (eds.). Travesías de la imagen. Historias del arte en la Argentina. Buenos Aires: Centro Argentino de Investigadores de Arte/ EDUNTREF, Archivos del CAIA IV, Tomo II, 2012.

Barthes, Roland. Lo obvio y lo obtuso. Imágenes, gestos, voces. Barcelona: Paidós, 1986.

La preparación de la novela: notas de cursos y seminarios en el College de France: 1978-1979 y 1979-1980. Buenos Aires: Siglo XXI Editores Argentina, 2005.

"Las láminas de la enciclopedia". El grado cero de la escritura seguido de Nuevos Ensayos críticos. Buenos Aires: Siglo XXI, 2006, pp. 123-147.

Benjamin, Walter. Iluminaciones II. Baudelaire: Un poeta en el esplendor del capitalismo. Madrid: Taurus, 1972.

"El narrador". Para una crítica de la violencia y otros ensayos: Iluminaciones $I V$. Madrid: Taurus, 1998. 
Conceptos de filosofía de la historia. La Plata: Terramar, 2007.

Bergel, Martín. El oriente desplazado: los intelectuales y los orígenes del tercermundismo en la Argentina. Bernal: Universidad Nacional de Quilmes, 2015.

Bernabé, Mónica. "Rubén Darío y las reglas del arte americano". Vidas de artista: Bohemia y dandismo en Mariátegui, Valdelomar y Eguren (Lima, 1911-1922). Rosario: Beatriz Viterbo; Perú: Instituto de Estudios Peruanos, 2006, pp. 33-62.

Bérodot, Solène y María Isabel Pozzo. "La inmigración sirio-libanesa en la ciudad de Rosario, Argentina: continuidades, desvanecencias e intercambios socioculturales". Amerika, n. ${ }^{\circ}$ 5, 2011, disponible en http://journals.openedition.org/amerika/2746\#quotation

Bestene, Jorge e Ignacio Klich. "La inmigración siriolibanesa en la Argentina. Introducción”. Estudios migratorios latinoamericanos, vol. 9, n. ${ }^{\circ}$ 26, 1994, pp. 3-6.

Bocchino, Adriana et al. Escrituras y exilios en América latina. Mar del Plata: Estanislao Balder, 2008.

Borges, Jorge Luis. "Kafka y sus precursores". Otras inquisiciones. Obras completas (Tomo 2). Buenos Aires: Círculo de lectores-Emecé, 1984, pp. 85-87.

"El último viaje de Ulises". Nueva ensayos dantescos. Obras completas, Tomo III. Buenos Aires: Emecé, 2007, pp. 386-389.

Bourdieu, Pierre. "Introducción”. La distinción. Crítica social del juicio. París: Minuit, 1979.

"Campo intelectual y proyecto creador". AA.VV. Problemas del estructuralismo, México: Siglo XXI, 1967.

Las reglas del arte. Génesis y estructura del campo literario. Barcelona: Anagrama, 1995.

Boym, Svetlana. The future of Nostalgia. New York: Basic Books, 2001.

Brizuela, Natalia. "Capítulo II: O som da natureza, ou escrevendo com luz nos trópicos: Hercule Florence". Fotografia e império. Paisagens para um Brasil moderno. San Pablo: Companhia das Letras, 2012, pp. 63-105.

Bürger, Peter. Teoría de la vanguardia. Barcelona: Península, 1987.

Campra, Rosalba. "La ciudad en el discurso literario". SyC, n. ${ }^{\circ}$ 5, Buenos Aires, 1994, pp. 19-40.

Cassin, Barbara. La nostalgia. ¿Cuándo es que, por fin, uno está en su hogar? Ulises, Eneas, Arendt. Ciudad Autónoma de Buenos Aires: Nueva Visión, 2014.

Catelli, Nora. En la era de la intimidad: seguido de El espacio autobiográfico. Rosario: Beatriz Viterbo Editora, 2007.

Cella, Susana, "Introducción". Historia crítica de la literatura argentina (dir. Noé Jitrik), Tomo 10, La irrupción de la crítica (dir. Susana Cella). Buenos Aires: Emecé, 1999, pp. 7-16.

Cirlot, Lourdes. Primeras vanguardias artísticas. Barcelona: Labor, 1995.

Colombi, Beatriz. Viaje intelectual, migraciones y desplazamientos en América Latina (1880-1920). Rosario: Beatriz Viterbo, 2004.

"Camino a la meca: escritores hispanoamericanos en París (1900-1920)". Altamirano, Carlos (dir.). Historia de los intelectuales en América Latina. Buenos Aires: Katz Editores, 2008, pp. 544-566.

"El viaje letrado y su escritura". Quimera. Revista de Literatura, n. ${ }^{\circ} 304$, Barcelona, marzo de 2009, pp. 22-26. 
"El viaje, de la práctica al género". Marinone, Mónica y Gabriela Tineo (eds.). Viaje y relato en Latinoamérica. Buenos Aires: Katatay, 2010, pp. 287308.

Cosmópolis. Del flâneur al globe trotter. Buenos Aires: Eterna Cadencia, 2010.

Collot, Michel. "De l'horizon du paysage à l'horizon des poètes [Del horizonte del paisaje al horizonte de los poetas]". Ferreira Alves, Ida y Marcia Manir Miguel Feitosa (org.) Literatura e paisagem. Perspectivas e diálogo. Nitéroi: Editora da UFF, 2010, p. 191-203.

Contreras, Sandra. "En torno al realismo". Confines, n. ${ }^{\circ}$ 17, diciembre de 2005, pp. 1931.

Crary, Jonathan. Las técnicas del observador. Visión y modernidad en el siglo XIX. Murcia: Cendeac, 2008.

Dalmaroni, Miguel. "El imperativo y sus destiempos". Anclajes. Revista del Instituto de Análisis Semiótico del Discurso, vol. VI, n. ${ }^{\circ}$ 6, 2002, pp. 441-468.

Una república de las letras: Lugones, Rojas, Payró: Escritores argentinos y Estado. Rosario: Beatriz Viterbo Editora, 2006.

(dir.) La investigación literaria: Problemas iniciales de una práctica. Santa Fe: Universidad Nacional del Litoral, 2009.

“El juicio del siglo: Leopoldo Lugones revisitado”. Castilla. Estudios de Literatura, n. ${ }^{\circ} \quad 1, \quad 2010, \quad$ pp. 408-419. Disponible en https://revistas.uva.es/index.php/castilla/article/view/38

De Certeau. M. La invención de lo cotidiano I, Arte de hacer. México: Universidad Iberoamericana, 1996.

"La operación historiográfica". La escritura de la historia. México: Universidad Iberoamericana Tlaquepaque: Instituto Tecnológico y de Estudios, 2006.

De Diego, José Luis. "Relatos atravesados por exilios". Historia crítica de la literatura argentina (dir. Noé Jitrik), Tomo 11, La narración gana la partida (dir. Elsa Drucaroff). Buenos Aires: Emecé, 2002, pp. 431-459.

¿Quién de nosotros escribirá el Facundo?: Intelectuales y escritores en Argentina [1970-1986]. La Plata: Al Margen, 2003.

Delgado, Sergio. "El personaje y su sombra. Rerealismos y desrealismos en el escritor argentino actual". Boletín/12 del Centro de Estudios de Teoría y Crítica Literaria. Rosario, 2005, pp. 1-22.

Deleuze, Giles. "Lo que dicen los niños". Crítica y clínica. Barcelona: Anagrama, 1996, pp. 89-97.

Devoto, Fernando. Historia de la inmigración en la Argentina. Buenos Aires: Editorial Sudamericana, 2002.

Didi-Huberman, Georges. Ante el tiempo. Buenos Aires: Adriana Hidalgo editora, 2006. La imagen mariposa. Barcelona: Mudito \& Co, 2007.

Ante la imagen. Pregunta formulada a los fines de una historia del arte. Murcia: Cendeac, 2010.

Drucaroff, Elsa (dir.). Historia crítica de la literatura argentina (dir. Noé Jitrik), Tomo 11, La narración gana la partida (dir. Elsa Drucaroff). Buenos Aires: Emecé, 2002.

El Jaber, Loreley. "Introducción" en Schmidl, Ulrico (Utz). Derrotero y viaje a España y las Indias (prologado y comentado por Loreley El Jaber). Paraná: Universidad Nacional de Entre Ríos, UNER, [1567] 2016, pp. XIII-XXXV.

Fantoni, Guillermo. Instantáneas sobre el arte de la ciudad de Santa Fe. Una antología desde el siglo XIX hasta el presente. Rosario: Fundación Osde, 2007. 
Fernández Bravo, Álvaro. Literatura y frontera: Procesos de territorialización en las culturas argentina y chilena del siglo XIX. Buenos Aires: Editorial Sudamericana, 1999.

"Juan L. Ortiz y la poesía china: Un episodio de cosmopolitismo provinciano". Actas del IV Congreso Internacional Cuestiones Críticas, Rosario, 2015. Disponible en http://www.celarg.org/int/arch publi/fernandezbravocc2015.pdf

Fombona, Jacinto. La Europa necesaria. Textos de viaje de la época modernista. Rosario Beatriz Viterbo: 2005.

Fondebrider, Jorge. La París de los argentinos. Buenos Aires: Bajo la luna, 2010.

Fontana, Patricio y Claudia Román. "Estudio preliminar. La leyenda de la cabeza galopante. Correrías sudamericanas del capitán Francis Bon Head (1825-1826)". Bon Head, Francis. Apuntes tomados durante algunos viajes rápidos por las Pampas y entre los Andes. Buenos Aires: Santiago Arcos Editor, 2007, pp. 5-31.

Foster, Hal: El retorno de lo real. La vanguardia a finales de siglo. Madrid: Akal, 2001. Foucault, Michel. Las palabras y las cosas. Una arqueología de las ciencias humanas. Buenos Aires: Siglo XXI Editores, 2013.

Franken, Clemens K. "Arthur Conan Doyle y su detective científico”. Lit. lingüíst., n. ${ }^{\circ}$ 31, Santiago, 2015 pp.105-128. Disponible en: http://www.scielo.cl/scielo.php?script=sci arttext\&pid=S071658112015000100007

Frisby, David. Paisajes urbanos de la modernidad. Quilmes: Universidad Nacional de Quilmes, 2007.

Gabrieloni, Ana Lía. "Interpretaciones teóricas y poéticas sobre la relación entre poesía y pintura. Breve esbozo desde el Renacimiento hasta la Modernidad". Saltana. Revista de literatura y traducción, 16 de noviembre de 2006. Disponible en http://www.saltana.org/1/docar/0010.html

"La literatura y artes". Miguel Dalmaroni (coord.). La investigación literaria: problemas iniciales de una práctica. Santa Fe: Universidad Nacional del Litoral, 2009.

Gaignard, Romain. La pampa argentina. Ocupación, poblamiento, explotación. De la Conquista a la crisis mundial (1550-1930). Buenos Aires: Solar, 1989.

Gamerro, Carlos. "Cuatro versiones de Moreira". Cuadernos LIRICO n. ${ }^{\circ}$ 10, 2014. Disponible en http://lirico.revues.org/1704

Facundo o Martín Fierro. Los libros que inventaron la Argentina. Buenos Aires: Sudamericana, 2015.

"Para una reformulación del género policial argentino". El nacimiento de la literatura argentina. Ciudad Autónoma de Buenos Aires: Excursiones, 2015, pp. 56-65.

García, Germán. "Leer a Gombrowicz”. Los libros, agosto de 1969, p. 12.

García Canclini, Néstor. Imaginarios urbanos. Buenos Aires: EUDEBA, 2005.

Garramuño, Florencia. Genealogías culturales. Argentina, Brasil y Uruguay en la novela contemporánea (1981-1991). Rosario: Beatriz Viterbo editora, 1997.

Gasparini, Pablo. El exilio procaz: Gombrowicz por la Argentina. Rosario: Beatriz Viterbo Editora, 2006.

Gasquet, Axel. "El orientalismo argentino (1900-1940). De la revista Nosotros al grupo Sur". Working Paper 28, The University of Maryland - College Park, 2008. Disponible en file:///D:/Downloads/2404-1-7021-1-10-20140218.pdf

Gilman, Claudia. Entre la pluma y el fusil: debates y dilemas sobre el escritor revolucionario en América Latina. Buenos Aires: Siglo XXI, 2003. 
Giordano, Alberto. Modos del ensayo. De Borges a Piglia. Rosario: Beatriz Viterbo Editora, 2005.

Una posibilidad de vida: Escrituras intimas. Rosario: Beatriz Viterbo Editora, 2006.

La contraseña de los solitarios: Diarios de escritores. Rosario: Beatriz Viterbo Editora, 2011.

Vida y obra: Otra vuelta al giro autobiográfico. Rosario: Beatriz Viterbo Editora, 2011.

(ed.). El discurso sobre el ensayo en la cultura argentina desde los 80. Ciudad Autónoma de Buenos Aires: Santiago Arcos editor, 2015.

Giunta, Andrea. Vanguardia, internacionalismo y política. Arte argentino en los años sesenta. Buenos Aires: Siglo XXI Editores Argentina, 2008.

Escribir las imágenes. Ensayos sobre arte argentino y latinoamericano. Buenos Aires: Siglo XXI Editores, 2011.

González Echevarría, Roberto. "Humanismo, retórica y las crónicas de la conquista". Historia y ficción en la narrativa hispanoamericana. Caracas: Monte Ávila, 1984.

Gorelik, Adrián. La grilla y el parque. Espacio público y cultura urbana en Buenos Aires, 1887-1936. Universidad Nacional de Quilmes, 1998.

Gramuglio, María Teresa. "La construcción de la imagen". Tizón, Héctor et al. La escritura argentina. Santa Fe, UNL-Ediciones de la Cortada, 1992, pp. 35-64. (dir.). Historia crítica de la literatura argentina, (dir. Noé Jitrik), Tomo 6, El imperio realista (dir. María Teresa Gramuglio). Buenos Aires: Emecé, 2002.

"Leopoldo Lugones: La construcción de imágenes de escritor". Nacionalismo y cosmopolitismo en la literatura argentina. Rosario: Municipal de Rosario, 2013, pp. 98-116.

Grimal, Pierre. Diccionario de la mitología griega y romana. Barcelona: Paidós, 1994.

Halperín Donghi, Tulio. Una nación para el desierto argentino. Buenos Aires: Centro Editor de América Latina, 1982.

Heinich, Nathalie. Etre écrivain. Création et identité. París: La Découverte, 2000.

Horkheimer, Max y Adorno, Theodor. "La industria cultural. Iluminismo como mistificación de masas". Dialéctica del Iluminismo. Buenos Aires: Sudamericana, 1988.

Iglesia Cristina. La violencia del azar: Ensayos sobre literatura argentina. Buenos Aires: FCE, 2003.

James, Jamie. Rimbaud en Java. El viaje perdido. Buenos Aires: La Bestia Equilátera, 2013.

Joseph, Isaac. El transeúnte y el espacio urbano. Buenos Aires: Gedisa, 1988.

Justo, Liborio. "Introducción a la primera edición". Sarmiento, D. Faustino. El Carapachay: imágenes de las islas del Delta del Paraná (con prólogo de Liborio Justo y Marta Susana Ramírez). Buenos Aires: Eudeba, 2011, pp. 19-47.

Klich, Ignacio. "Árabes, judíos y árabes judíos en la Argentina de la primera mitad del novecientos". Estudios interdisciplinarios de América Latina y el Caribe, vol. 6 n. ${ }^{\circ}$ 2. Disponible en http://eial.tau.ac.il/index.php/eial/issue/view/82

Kohan, Martín. "Significación actual del realismo crítico". Boletín/12 del Centro de Estudios de Teoría y Crítica Literaria, Rosario, diciembre de 2005, pp. 1-13.

Kristeva, Julia. Strangers to ourselves. New York: Columbia University Press, 1991.

Laera, Alejandra. El tiempo vacio de la ficción: Las novelas argentinas de Eduardo Gutiérrez y Eugenio Cambaceres. Buenos Aires: FCE, 2003. 
"Prólogo. Metamorfosis de un héroe popular argentino: las mil caras de Juan Moreira". Gutiérrez, Eduardo. Juan Moreira. Buenos Aires: Eudeba, 2012, pp. 5-10.

Laera, Alejandra et al. "Aventura y relato. Apuntes para una historia literaria de la frontera". Fronteras escritas: límites, desvíos y pasajes en la literatura argentina. (Alejandra Laera; Graciela Batticuore; Loreley El jaber comps.). Rosario: Beatriz Viterbo Editora, 2008, pp. 7-21.

Lafforgue, Jorge. "Repensar el policial hoy en la Argentina". Setton, Román y Gerardo Pignatiello (comps.). Crimen y pesquisa: el género policial en la Argentina (1870-2015): literatura, cine, televisión, historieta y testimonio. Buenos Aires: Título, 2016, pp. 45-56.

Livon-Grosman, Ernesto. Geografias imaginarias. El relato de viaje y la construcción del espacio patagónico. Rosario: Beatriz Viterbo Editora, 2003.

López, María Pía y Juan Bautista Duizeide. Desierto y nación 1: lenguas (prólogo de Gustavo Míguez y José Hage). Ciudad Autónoma de Buenos Aires: Caterva Editorial, 2017.

Ludmer, Josefina. "Los Moreira". El cuerpo del delito: Un manual. Buenos Aires: Perfil, 1999, pp. 225-300.

El género gauchesco: un tratado sobre la patria. Buenos Aires: Eterna Cadencia, 2012.

Malosetti Costa, Laura. Los primeros modernos: Arte y sociedad en Buenos Aires a fines del siglo XIX. Buenos Aires: Fondo de cultura económica, 2003.

"La cuestión del público en la gestación de un arte nacional. El caso de Juan

Manuel Blanes". Disponible en http://www.caia.org.ar/docs/24-Malosetti\%20Costa.pdf (org.). Pampa, ciudad y suburbio. Buenos Aires: Fundación Osde, 2007.

Malosetti Costa, Laura y Marta Penhos. "Imágenes para el desierto argentino. Apuntes para una iconografía de la pampa", III Jornadas de Teoría e Historia de las Artes, Ciudad/campo en las Artes en Argentina y Latinoamérica, Buenos Aires, CAIA, 1991, pp. 195-204.

Manzi, Joaquín. "1939 y después: el largo invierno austral de Gombrowicz". Historia crítica de la literatura argentina (dir. Noé Jitrik), Tomo 7, Rupturas (dir. Celina Manzoni). Buenos Aires: Emecé, 2009, pp. 411-436.

Manzoni, Celina (dir.). Historia crítica de la literatura argentina (dir. Noé Jitrik), Tomo 7, Rupturas (dir. Celina Manzoni). Buenos Aires: Emecé, 2009.

Martínez Peláez, Agustín y Justo Romero Torres. "El vino en la poesía musulmana de al-Andalus". DOURO Estudos \& Documentos, vol. VI, n. ${ }^{\circ} 12,2001\left(2^{\circ}\right)$, pp. 922. Disponible en http://ler.letras.up.pt/uploads/ficheiros/9544.pdf

Masiello, Francine. El cuerpo de la voz (poesía, ética y cultura). Buenos Aires: Beatriz Viterbo; UNR Editora. Editorial de la Universidad Nacional de Rosario, 2013.

Mignolo, Walter. "Cartas, crónicas y relaciones del descubrimiento y la conquista". Madrigal, Luis I. (ed.) Historia de la literatura hispanoamericana. Madrid: Cátedra, 1986, pp. 57-116.

Molloy, Sylvia. "Desde lejos: la escritura a la intemperie". Disponible en http://www.enriquevilamatas.com/escritores/escrmolloys1.html Acto de presencia: La escritura autobiográfica en Hispanoamérica. México: FCE, 1996.

"Dislocación e intemperie: el viaje de vuelta". Caracol. Revista do programa de pós-graduação da Área de Língua Espanhola e Literaturas Espanhola e Hispano-Americana do Departamento de Letras Modernas, n. ${ }^{\circ}$ 10, Universidad 
de San Pablo, Brasil, 2015. Disponible en http://www.revistas.usp.br/caracol/article/view/114538 (última consulta 29/04/2017).

Vivir entre lenguas. Ciudad autónoma de Buenos Aires: Eterna Cadencia Editora, 2015.

Montaldo, Graciela. De pronto, el campo: Literatura argentina y tradición rural. Rosario: Beatriz Viterbo, 1993.

Ficciones culturales y fábulas de identidad en América Latina. Rosario: Beatriz Viterbo Editora, 2004.

Monteleone, Jorge. El relato de viaje. De Sarmiento a Umberto Eco. Buenos Aires: El Ateneo, 1998.

"La hora de los tristes corazones. El sujeto imaginario en la poesía romántica argentina". Historia crítica de la literatura argentina (dir. Noé Jitrik), Tomo 2. La lucha de los lenguajes (dir. Julio Schvartzman). Buenos Aires: Emecé, 2003, pp. 119-159.

"Prólogo". Benjamin, Walter. Infancia en Berlín hacia 1900 (edición, prólogo y notas de Jorge Monteleone). Buenos Aires: El Cuenco de Plata, 2016, pp. 5-32.

Moretti, Franco. Atlas de la novela europea: 1800-1900. Madrid: Trama, 2001.

Müller, Luis. "Santa Fe en la segunda mitad del siglo XX". En Bertuzzi Ma. Laura (comp.). Ciudad y urbanización. Problemas y potencialidades. Santa Fe: Editorial UNL, 2005.

Nancy, Jean-Luc. "La existencia exiliada". Archipiélago. Cuadernos de crítica de la cultura, n. ${ }^{\circ}$ 26-27, 1996, pp. 34-40. Disponible en http://www.redalyc.org/pdf/815/81500813.pdf

La ciudad a lo lejos. Buenos Aires: Manantial, 2013.

Negroni, María. La noche tiene mil ojos (Museo Negro, Galería fantástica y Film Noir). Ciudad Autónoma de Buenos Aires: Caja Negra, 2015.

"El Gótico es una grieta en el mundo de la luz y la razón" (entrevista realizada por Alejandro Alonso). Revista Axxón. Ciencia ficción en Bits, diciembre de 2009. Disponible en http://axxon.com.ar/rev/2009/12/maria-negroni-el-gotico-es-unagrieta-en-el-mundo-de-la-luz-y-la-razon-por-alejandro-alonso/

Olea Franco, Rafael. El otro Borges, el primer Borges, México-Buenos Aires: El Colegio de México-Fondo de Cultura Económica, 1993.

Olivares Briones, Edmundo. Pablo Neruda, los caminos de Oriente: tras las huellas del poeta itinerante (1927-1933). Santiago: LOM, 2000.

Ortiz, Mario. "El don valioso de sus poemas. Acerca de la correspondencia René Char / Raúl Gustavo Aguirre". El jardín de los poetas. Revista de teoría y crítica de poesía latinoamericana. Año III, n. ${ }^{\circ} 4$, 2017, pp. 130-142. Disponible en http://www.cajaderesonancia.com/archivos/10\%20Ortiz_Eljard\%C3\%ADn_4.pd $\underline{f}$

Oubiña, David. El silencio y sus bordes. Modos de lo extremo en la literatura y el cine. Buenos Aires: FCE, 2011.

Pagni, Andrea. "Ser o no ser turista. Relatos de viajes a Europa". Historia crítica de la literatura argentina, (dir. Noé Jitrik), Tomo 3, El brote de los géneros (dir. Alejandra Laera). Buenos Aires: Emecé, 2010, pp. 39-60.

Pastormerlo, Sergio. Borges crítico. Buenos Aires: FCE, 2007. 
"Besos bárbaros: pretensión y privación cultural". Orbis Tertius. Revista de Teoría y Crítica Literaria, vol. 4, n. ${ }^{\circ}$ 7, La Plata, 2000, pp.73-88. Disponible en http://www.memoria.fahce.unlp.edu.ar/art revistas/pr.2836/pr.2836.pdf

Pauls, Alan. "El fondo de los fondos". Revista Dossier 10/Punto Seguido, Universidad Diego Portales, Facultad de Comunicación y Letras. Disponible en http://www.revistadossier.cl/el-fondo-de-los-fondos/

Pavese, Cesare. La literatura norteamericana y otros ensayos. Barcelona: Lumen, 2008.

Penhos, Marta. Ver, dominar, conocer. Imágenes de Sudamérica a fines del siglo XVIII. Buenos Aires: Siglo XXI, 2005.

"Viajes, viajeros e imágenes: una relación necesaria". Baldasarre, María Isabel y Silvia Dolinko (eds.), Travesías de la imagen. Historias del arte en la Argentina, Tomo II. Buenos Aires: Centro Argentino de Investigadores de Arte/ EDUNTREF, Archivos del CAIA IV, 2012.

Pera, Cristóbal. "De viajeros y turistas: reflexiones sobre el turismo en la literatura hispanoamericana". Revista Iberoamericana, vol. LXIV, n. ${ }^{\circ} 184-185$, JulioDiciembre 1998, pp. 507-528.

Piglia, Ricardo. "Ideología y ficción en Borges". Punto de Vista, Año II, n. 5, 1979, pp. 3-6.

“¿Existe la novela argentina?”. Crítica y ficción. Buenos Aires: Siglo XX, 1990, pp. 49-57.

Crítica y ficción. Buenos Aires: Anagrama, 2006.

Pierini, Margarita. "La mirada y el discurso: la literatura de viajes". Pizarro, Ana. América Latina: palavra, literatura e cultura. Sao Paulo: Unicamp, 1994.

Pimentel, Juan. Testigos del mundo. Ciencia, literatura y viajes en la Ilustración. Madrid: Marcial Pons, Ediciones de Historia, 2003.

Plante, Isabel. Argentinos en París. Arte y viajes culturales durante los años sesenta. Buenos Aires: Edhasa, 2013.

Podlubne, Judith. "Setecientosmonos y la modernización de la crítica literaria argentina". Cuadernos de Literatura vol. 20, n. ${ }^{\circ} 39$, 2016, pp 270- 295. Disponible en http://dx.doi.org/10.11144/Javeriana.cl20-39.smcl

Podlubne, Judith y Alberto Giordano. "Exilio y extraterritorialidad: Juan Rodolfo Wilcock y Héctor Bianciotti". Historia crítica de la literatura argentina (dir. Noé Jitrik), Tomo 11, La narración gana la partida (dir. Elsa Drucaroff). Buenos Aires: Emecé, 2002, pp. 381-403.

Porrúa, Ana. Caligrafía tonal. Ensayos sobre poesía. Buenos Aires: Entropía, 2011.

Portantiero, Juan Carlos. Realismo y realidad en la narrativa argentina. Buenos Aires: Editorial Lautaro, 1961.

Pratt, Mary Louise. Ojos imperiales. Literatura y transculturación. Buenos Aires: Fondo de Cultura Económica, 2011.

Prieto, Adolfo. Los viajeros ingleses y la emergencia de la literatura argentina. Buenos Aires: Sudamericana, 1996.

Prieto, Martín. "Archivo de desapariciones" (entrevista con David Viñas). Clarín, Buenos Aires, 26 de abril de 2003. Disponible en http://edant.clarin.com/suplementos/cultura/2003/04/26/u-00601.htm

Breve historia de la literatura argentina. Buenos Aires: Taurus, 2006.

Quereilhac, Soledad. Cuando la ciencia despertaba fantasías: prensa, literatura y ocultismo en la argentina de entresiglos. Buenos Aires: Siglo XXI, 2016.

Rama, Ángel. "La modernización literaria latinoamericana (1870-1910). Hispamérica. Revista de literatura, n. $^{\circ} 36,1983$, pp. 3-19. 
"El poeta frente a la modernidad". Literatura y clase social. México: Folios Ediciones, 1983, pp. 78-143.

Ramos, Julio. Desencuentros de la modernidad en América Latina. Literatura y política en el siglo XIX. México: FCE, 1989.

"Migratorias". Ludmer, Josefina (comp.). Las culturas de fin de siglo en América Latina. Buenos Aires: Beatriz Viterbo, 1994, pp. 52-61.

Renzi, Juan Pablo. "Autobiografía Juan Pablo Renzi” en Constantin, María Teresa. II Juan Pablo Renzi (1940-1992): la razón compleja / María Teresa Constantin y Xil Buffone. Buenos Aires: Fundación OSDE, 2009. pp. 96-101.

Retamoso, Roberto. "Reescrituras del Moreira". La trama de la comunicación, vol. 10. Anuario del Departamento de Ciencias de la Comunicación. Facultad de Ciencia Política y Relaciones Internacionales, Universidad Nacional de Rosario, 2005. Disponible http://www.latrama.fcpolit.unr.edu.ar/index.php/trama/article/view/123

Rodríguez, Fermín. Un desierto para la nación. La escritura del vacío. Buenos Aires: Eterna Cadencia, 2010.

Rodríguez Pérsico, Adriana. "Viajes alrededor del modelo: para una política estética de las identidades". Dispositio, vol. XVII, n. ${ }^{\circ}$ 42-43, 1992, pp. 285-304.

Roger, Alain. Breve tratado del paisaje. Madrid: Biblioteca Nueva, 2007.

Romero, José Luis. Latinoamérica: Las ciudades y las ideas. Buenos Aires: Siglo XXI, 2010.

Rosa, Nicolás (ed.). Historia del ensayo argentino. Intervenciones, coaliciones, interferencias. Buenos Aires: Alianza, 2002.

Said, Edward. Orientalismo. Madrid: Libertarias, 1990. Cultura e imperialismo. Barcelona: Anagrama, 1993.

"Exilio intelectual: expatriados y marginales". Representaciones del intelectual. Buenos Aires: Paidós, 1996.

Saítta, Sylvia (dir.). Historia crítica de la literatura argentina, (dir. Noé Jitrik), Tomo 9, El oficio se afirma, (dir. Sylvia Saítta). Buenos Aires: Emecé, 2004.

Salabert, Pere. Figuras del viaje. Tiempo, arte, identidad. Rosario: Facultad de Humanidades y Artes, Universidad Nacional de Rosario, 1995.

Sarlo, Beatriz. "Oralidad y lenguas extranjeras: El conflicto en la literatura argentina durante el primer tercio del siglo XX”. Orbis Tertius. Revista de Teoría y Crítica Literaria, vol. 1, n. ${ }^{\circ}$ 1, La Plata, 1996, pp. 167-178. Disponible en: http://www.fuentesmemoria.fahce.unlp.edu.ar/art_revistas/pr.2475/p r.2475.pdf

La ciudad vista. Mercancías y cultura urbana. Buenos Aires: Siglo XXI, 2009.

"Del otro lado del horizonte", en Boletín/9 del Centro de Estudios de Teoría y Crítica Literaria, Rosario, diciembre, 2001.

Escritos sobre literatura argentina. Buenos Aires: Siglo XXI, 2007.

"La crítica: entre la literatura y el público". Giordano, Alberto. (ed.). El discurso sobre el ensayo en la cultura argentina desde los 80. Ciudad Autónoma de Buenos Aires: Santiago Arcos editor, 2015, pp. 43-58.

Sbarra, Noel H. Historia del alambrado en la Argentina. Buenos Aires: Eudeba, 1964.

Schvartzman, Julio. Letras gauchas. Buenos Aires: Eterna Cadencia, 2013.

Segalen, Victor. Ensayo sobre el exotismo. Una estética de lo diverso (y textos sobre Gauguin y Oceanía). México: FCE, 1989.

Sennett, Richard. El extranjero. Dos ensayos sobre el exilio. Barcelona: Anagrama, 2014. 
Schamun, Alejandro. La colectividad Siria en la República Argentina. Buenos Aires: Santa Fe, 1910.

Scott, Edgardo. Caminantes. Ciudad Autónoma de Buenos Aires: Ediciones Godot, 2017.

Silvestri, Graciela. El color del río Historia cultural del paisaje del Riachuelo. Buenos Aires: Editorial de la Universidad Nacional de Quilmes/Prometeo, 2003.

"Cuadros de la naturaleza. La retórica del viaje en el fin de siglo argentino [18781904]". Historia crítica de la literatura argentina, (dir. Noé Jitrik), Tomo 3, El brote de los géneros (dir. Alejandra Laera). Buenos Aires: Emecé, 2010, pp. 467-498.

El lugar común: Una historia de las figuras de paisaje en el Río de la Plata. Buenos Aires: Edhasa, 2011.

Silvestri Graciela y Aliata Fernando. El paisaje como cifra de armonía. Buenos Aires: Ediciones Nueva Visión, 2001.

Simmel, George. Sobre la aventura. Ensayos filosóficos. Barcelona: Península, 1988.

Sinclair, Iain. Los ríos perdidos de Londres. El sublime topográfico. (Prólogo y traducción de Edgardo Scott). Ciudad Autónoma de Buenos Aires: Fiordo, 2016.

Speranza, Graciela. Atlas portátil de América Latina. Arte y ficciones errantes. Barcelona: Anagrama, 2012.

Spiller, Roland (ed.). La novela argentina de los años 80. Frankfurt-am-Main, Vervuert Verlg, 1991.

Starobinsky, Jean. “¿Es posible definir el ensayo?”. Cuadernos Hispanoamericanos, n. ${ }^{\circ}$ 575, mayo de 1998, pp. 31-40.

Steiner, George. Extraterritorial. Ensayos sobre literatura y la revolución del lenguaje. Buenos Aires: Adriana Hidalgo, 2000.

Stewart, Susan. On longing: Narratives of the Miniature, the Gigantic, the Souvenir, the Collection. Durham; London: Duke University Press, 1993.

Subirats, Eduardo. El continente vacio. La conquista del Nuevo Mundo y la conciencia moderna. Madrid: Maya y Mario Muchnik, 1994.

Todorov, Tzvetan "Retratos de viajeros". Nosotros y los otros. México: Siglo XXI, 1991, pp. 386-398.

"El viaje y su relato". Las morales de la historia. Barcelona: Paidós, 1993, pp. 91102.

La Conquista de América. El problema del otro. México: Siglo Veintiuno, 1998.

Torre, Claudia. Literatura en tránsito. La narrativa expedicionaria de la Conquista del Desierto. Buenos Aires: Prometeo, 2010.

"Estudio preliminar. Las narraciones del desierto". El otro desierto de la nación argentina. Antología de narrativa expedicionaria. Bernal: Universidad Nacional de Quilmes, 2011.

Van den Abbeele, Georges. Travel as metaphor. From Montaigne to Rousseau. Minneapolis: University of Minnesota, 1992.

Villanueva, Graciela. “Avatares de Moreira”. Revista Iberoamericana, vol. LXXI, n. ${ }^{\circ}$ 213, Octubre-Diciembre 2005, pp. 1167-1178.

"Inmigrantes y extranjeros en las leyes y en la ficción". Historia crítica de la literatura argentina, (dir. Noé Jitrik), Tomo 3, El brote de los géneros (dir. Alejandra Laera). Buenos Aires: Emecé, 2010, pp. 501-33.

Viñas, David, "La mirada a Europa: del viaje colonial al viaje estético". Literatura Argentina y política. Buenos Aires: Sudamericana, 1964, pp. 3-80.

Indios, ejército y frontera. Ciudad autónoma de Buenos Aires: Galerna; Buenos Aires: Santiago Arcos editor, 2013. 
Williams, Raymond. El campo y la ciudad. Buenos Aires: Paidós, 2001.

Palabras Clave: Un vocabulario de la cultura y la sociedad. Buenos Aires: Nueva Visión, 2003.

Zanetti, Susana. "El modernismo y el intelectual como artista: Rubén Darío". Altamirano, Carlos (dir.). Historia de los intelectuales en América Latina. Buenos Aires: Katz Editores, 2008, pp. 523-543.

Zanín, Marcela. "El don de Verlaine". Zanetti, Susana y otros. Las cenizas de la huella. Linajes y figuras de artista en torno al modernismo. Rosario: Beatriz Viterbo, 1997, pp. 39-61.

\section{Bibliografía crítica sobre Juan José Saer}

AA.VV. Dossier con textos de Miguel Dalmaroni, Beatriz Sarlo, Mario Goloboff y Milagros Ezquerro. Orbis Tertius. Revista de Teoría y Crítica Literaria, vol. 10, n. ${ }^{\circ}$ 11, La Plata, 2005, pp.19-35.

AA.VV. Una forma más real que la del mundo. Conversaciones con Juan José Saer (compilación y prólogo de Martín Prieto). Buenos Aires: Mansalva, 2016.

Abbate, Florencia. El espesor del presente. Tiempo e historia en las novelas de Juan José Saer. Villa María: Eduvim, 2014.

"La posición estética de Saer". Crítica Cultural, vol. 5, n. 2, 2010, pp. 75-85.

Aira, César. "Zona peligrosa". El Porteño, no 64, 1987, pp. 66-68.

Albornoz, María Victoria. "Caníbales a la carta: mecanismos de incorporación y digestión del 'otro' en El entenado de Juan José Saer”. Chasqui, vol. 32, n. ${ }^{\circ}$, 2003, pp. 56-73.

Arce, Rafael. "El escritor no es nada, nadie: Saer contra una estética latinoamericana". Florianópolis: Boletim de Pesquisa Nelic, 2009, pp. 184-197.

“Juan José Saer: La genealogía del relato". Actas del VII Congreso Internacional Orbis Tertius de Teoría y Crítica Literaria, 18, 19 y 20 de mayo de 2009, La Plata. Disponible en: http://www.memoria.fahce.unlp.edu.ar/trab eventos/ev.3508/ev.3508.pdf

"Un realismo de lo irreal: la imaginación material en la obra de Juan José Saer". Anclajes, vol. 13, n. ${ }^{\circ}$ 1, Santa Rosa, 2009, pp. 9-25.

"Un enigma familiar: los últimos relatos de Juan José Saer". Revista de crítica literaria latinoamericana, año 37, n. ${ }^{\circ}$ 74, Lima-Boston, 2012, pp. 111-129.

"Violencia metonímica: la historia y la política en la narrativa de Juan José Saer", Helix, vol. 5, Heidelberg, 2012, pp. 44-61.

"Algo más sobre La grande de Saer: experimentación y programa novelescos". Orbis Tertius. Revista de Teoría y Crítica Literaria, vol. 17, n. ${ }^{\circ}$ 18, La Plata, 2012, pp.1-7.

"La destrucción del estatuto antropomorfo del narrador novelesco en la obra de Juan José Saer". Iberoamericana, vol. 13, n. 52. Madrid: Ibero-Amerikanisches Institut PK, diciembre 2013, pp. 47-64. Disponible en https://journals.iai.spkberlin.de/index.php/iberoamericana/article/view/165/72

Juan José Saer: la felicidad de la novela. Santa Fe: Ediciones UNL, 2015.

Balderston, Daniel. "Saer, Juan José". Encyclopedia of Latin American Literature. Londres: Fitzroy Dearborn, 1997, pp. 742-743.

“El entenado. Del recuerdo a la voz”. Ricci, Paulo (comp.). Zona de prólogos. Buenos Aires: Seix Barral, 2011.

Beceyro, Raúl. "Sobre Saer y el cine”. Punto de Vista, Año XV, n. ${ }^{\circ} 43,1992$, pp. 26-30. 
Benítez Pezzolano, Hebert. "Encrucijadas de la objetividad". Historia crítica de la literatura argentina (dir. Noé Jitrik), Tomo 11, La narración gana la partida (dir. Elsa Drucaroff). Buenos Aires: Emecé, 2002, pp. 143-159.

Berg, Edgardo. "Juan José Saer: una música imborrable". Poéticas en suspenso: migraciones narrativas en Ricardo Piglia, Andrés Rivera y Juan José Saer. Bs.As.: Biblos, 2002, pp.137 a 181.

Bermúdez Martínez, María. La incertidumbre de lo real: bases de la narrativa de Juan José Saer. Tesis de Doctorado, España, Universidad de Oviedo, 2001.

"Recuperaciones del pasado colonial en algunos relatos de Juan José Saer". América sin nombre. Boletín de la Unidad de Investigación de la Universidad de Alicante: Recuperaciones del mundo precolombino y colonial en el siglo XX hispanoamericano, n. ${ }^{\circ}$ 5-6, diciembre 2004, pp. 53-59. Disponible en https://rua.ua.es/dspace/bitstream/10045/5944/1/ASN_05-06_08.pdf

Bernabei, Verónica. "De la potencia de la imagen a la potencia escrituraria: El haiku de Juan José Saer". Actas del IX Congreso Internacional Orbis Tertius de Teoría y Crítica Literaria, 3 al 5 de junio de 2015, Ensenada, Argentina. Disponible en: http://www.memoria.fahce.unlp.edu.ar/trab eventos/ev.8615/ev.8615.pdf

Boldori, Rosa. "Experimentación y Apocalipsis en Cicatrices de Saer". AA.VV. Narrativa argentina del litoral. Santa Fe: Cuadernos Aletheia, pp. 157-200.

Brando, Oscar. La escritura de Juan José Saer: la tercera orilla del río. Ciudad Autónoma de Buenos Aires: Corregidor, 2015.

Castro, Pilar de. "Juan José Saer: el perfil propio de un proyecto estético". Abaco, vol. 2, n. ${ }^{\circ}$ 2, 1993, pp. 93-99.

Catelli, Nora. "Desplazamientos necesarios". Ricci, Paulo (comp.). Zona de prólogos. Buenos Aires: Seix Barral, 2011, pp.217-230.

Chejfec, Sergio. "La organización de las apariencias". Hispamérica, n. ${ }^{\circ}$ 67, Maryland, 1994, pp. 114-115.

“Aventura y especulación”. Saer, Juan José, El entenado - Glosa. Edición crítica (Julio Premat coordinador). Poitiers: CRLA; Córdoba: Alción Editora (Colección Archivos), 2010, pp. 802-807.

Colautti, Sergio. "Saer: la escritura en expansión". Letralia, Año XIII, n. ${ }^{\circ} 297$ (abril), Cagua-Venezuela, 2009. Disponible en https://letralia.com/207/articulo08.html

Contreras, Sandra. "Saer en dos tiempos". Boletín/16 del Centro de Estudios de Teoría y Crítica Literaria, Rosario, 2011. Disponible en http://www.lectorcomun.com/sandra-contreras/ensayos/165/saer-en-dostiempos/

Copertari, Gabriela. "La invención de la identidad en El entenado de J.J. Saer". Latin American Literary Review XXVI, n. ${ }^{\circ}$ 52, Jul-Dec 1998, pp. 225-240.

Corbatta, Jorgelina. "En la zona: germen de la praxis poética de Juan José Saer". Revista Iberoamericana, n. ${ }^{\circ}$ 155-156, Pittsburgh, abril-sep 1991, pp. 557-568. Juan José Saer: arte poética y práctica literaria. Buenos Aires: Corregidor, 2005.

Corral, Rose (ed.). Entre ficción y reflexión: Juan José Saer y Ricardo Piglia. México: El Colegio de México, ed. Estudios Lingüísticos y Literarios, 2007.

Corral, Wilfrido. "El canibalismo de la crónica colonial en la novela contemporánea: un ejemplo argentino". El texto latinoamericano. Madrid: Université de PoitiersFundamentos, 1994, pp. 245-251.

Corradini, Luisa. "Argentino de mate y asado". La Nación, sábado 8 de diciembre de 2007. Disponible en http://www.lanacion.com.ar/968402-argentino-de-mate-yasado 
Dalmaroni, Miguel y Margarita Merbilhaá. "Un azar convertido en don. Juan José Saer y el relato de la percepción”. Historia crítica de la literatura argentina (dir. Noé Jitrik), Tomo 11, La narración gana la partida (dir. Elsa Drucaroff). Buenos Aires: Emecé, 2002, pp. 321-343.

Dalmaroni, Miguel. "La vuelta incompleta (una pintura)". bazaramericano.com, Buenos Aires, 2005, pp. 1-5.

"Notas de un profano en pintura". Otra parte. Revista de letras y artes, n. ${ }^{\circ} 10$, 2006-2007, pp. 6-9.

"Lo real sin identidades. Violencia política y memoria en Nadie nada nunca, Glosa y Lo imborrable de Juan José Saer”, en Miguel Dalmaroni; Alvaro F. Bolaños et al. (eds.). Literatura, política y sociedad: construcciones de sentido en la Hispanoamérica contemporánea. Pittsburg, 2008, pp. 126 - 141.

" 'Una certidumbre sensorial de permanencia'. Narración y pintura en Juan José Saer". Coloquio Internacional "Ut pictura poesis. Las palabras y las imágenes en la literatura y el arte". Centro Interdisciplinario de Estudios Europeos en Humanidades, UNR, 4 y 5 de noviembre de 2008, Museo Municipal de Arte Decorativo "Firma y Odilo Estévez". Disponible en: http://notgood.com.ar/lector/descarga/144/una-certidumbre-sensorial-depermanencia-narracion-y-pintura-en-juan-jose-saer.pdf

"Lo incalculable. Saer en la escuela argentina". Otra Parte. Revista de artes y letras, $.^{\circ} 18,2009$, pp. 46-50.

"Iracundo, asceta, profesional. Juan José Saer en las editoriales argentinas". Páginas de guarda. Revista de lenguaje, edición y cultura escrita, n. ${ }^{\circ}$ 7, 2009, pp. 99-115.

“El largo camino del 'silencio' al 'consenso'. La recepción de Saer en la Argentina (1964-1987)”. Saer, Juan José, El entenado - Glosa. Edición crítica (Julio Premat coordinador). Poitiers: CRLA; Córdoba: Alción Editora (Colección Archivos), 2010, pp. 607-663.

"El empaste y el grumo. Narración y pintura en Juan José Saer, Crítica cultural, vol. 5, n. ${ }^{\circ} \quad 2, \quad 2010 . \quad$ Disponible en http://www.portaldeperiodicos.unisul.br/index.php/Critica_Cultural/article/view/ 701.

"El grafismo visible de la voz de lo real. La lección del poema en Juan José Saer". Estudios. Revista de Investigaciones Literarias y Culturales, vol. 18, n. ${ }^{\circ} 36$, enejunio 2011, pp. 81-101.

“Cinco razones sobre Saer". Boletín/16 del Centro de Estudios de Teoría y Crítica Literaria, Rosario, 2011, pp. 1-15.

Dalmaroni, Miguel et al. Dossier Juan José Saer. Zama, año 3, n. ${ }^{\circ} 3$. UBA, Instituto de Literatura Hispanoamericana, Facultad de Filosofía y Letras, 2011.

Dámaso Martínez, Carlos. "El ensayo y las estrategias de un narrador". Espacios, n. ${ }^{\circ}$ 12, Buenos Aires, jun-jul 1993, pp. 77-78.

Delgado, Sergio. "Paisaje desde el andén". Cuadernos LIRICO, $n .^{\circ}$ 6, 2011. Disponible en http://lirico.revues.org/179

"Presentación". Saer, Juan José. Papeles de trabajo II. Borradores inéditos. Buenos Aires: Seix Barral, 2013, pp. 275-280.

Díaz-Quiñones, Arcadio. "El entenado: Las palabras de la tribu". Hispamérica XXI, n. ${ }^{\circ}$ 63, Diciembre 1992, pp. 3-14.

Di Ció, Mariana. "Juan José Saer, a medio escribir”. Cuadernos LIRICO, n. ${ }^{\circ}$ 6, 2011, pp. 159-172. 
Dobry, Edgardo. "Apuntes sobre la poesía de Juan José Saer". Orfeo en el quiosco de diarios: ensayos sobre poesía. Buenos Aires: Adriana Hidalgo, 2007, pp. 178186.

Ehrlicher, Hanno. "Funciones de la antropofagia en la Verdadera historia de Hans Staden y en El entenado de Juan José Saer". Orbis Tertius, vol. XIX, n. ${ }^{\circ} 20$, 2014, pp.

85-94.

Disponible

en http://www.orbistertius.unlp.edu.ar/article/viewFile/OTv19n20a10/6259

Fernández, Nancy. Narraciones viajeras: César Aira y Juan José Saer. Buenos Aires: Biblos, 2000.

Ferrari, Silvia E. "La problemática del espacio en la novelística de Juan José Saer, a la luz de la modernidad". Río de la Plata, n. ${ }^{\circ} 23-24$. Los múltiples desafios de la modernidad en el Río de la Plata, Göeteborg, 2001, pp. 419-428.

Foffani, Enrique y Mancini, Adriana. "Más allá del regionalismo: la transformación del paisaje". Historia crítica de la literatura argentina (dir. Noé Jitrik), Tomo 11, La narración gana la partida (dir. Elsa Drucaroff). Buenos Aires: Emecé, 2002, pp. 261-291.

Frassoni Fernando y Adriana Schettini. "Las claves múltiples". Página/12, jueves 8 de septiembre de 1988, p. 13.

Gamerro, Carlos. "La orgía indígena de Echeverría a Saer"; "Juan José Saer, policial y dictadura". Facundo o Martín Fierro. Los libros que inventaron la Argentina. Buenos Aires: Sudamericana, 2015, pp. 108-132 y pp. 426-440.

Gandolfi, Laura. "La ocasión de Juan José Saer: hacia una tensión entre espíritu y materia”. The Colorado Review of Hispanic Studies, n. ${ }^{\circ}$ 8-9, 2010-2011, pp. 287-298.

Giordano Alberto. “A medio borrar”. Discusión, año 1, n. ${ }^{\circ}$ 1, Rosario, 1989, pp. 65-69. "El efecto de irreal". La experiencia narrativa. Juan José Saer - Felisberto Hernández - Manuel Puig. Rosario: Beatriz Viterbo, 1992, pp. 11-33.

"Saer como problema". Ricci, Paulo (comp.). Zona de prólogos. Buenos Aires: Seix Barral, 2011, pp. 243-260.

Gnutzmann, Rita. "Repetición y variación en Lo imborrable de Juan José Saer". Iris, Montpellier, 1995, pp. 107-121.

“El entenado o la respuesta de Saer a las crónicas", Iris, 1992, pp. 107-121.

Gramuglio, María Teresa. "Juan José Saer: el arte de narrar". Punto de Vista, año VII, n. ${ }^{\circ} 6,1979$, pp. 3-8.

"La filosofía y el relato". Punto de Vista, año VII, n. ${ }^{\circ}$ 20, 1984, pp. 35-36.

"El lugar de Saer". Juan José Saer por Juan José Saer. Buenos Aires: Celtia, 1986, 261-307.

"Una imagen obstinada del mundo". Saer, Juan José, El entenado - Glosa. Edición crítica (Julio Premat coordinador). Poitiers: CRLA; Córdoba: Alción Editora (Colección Archivos), 2010, pp.729-741.

"La expansión de los límites". Ricci, Paulo (comp.). Zona de prólogos. Buenos Aires: Seix Barral, 2011, pp. 261-274.

"El Cónsul". Podlubne, Judith y Martín Prieto. María Teresa Gramuglio: La exigencia crítica: quince ensayos y una entrevista. Rosario: Beatriz Viterbo Editora, Universidad Nacional de Rosario, 2014, pp. 229-232.

El lugar de Saer: sobre una poética de la narración: 1969-2004. Rosario: Espacio Santafesino Ediciones; Rosario: Editorial Municipal de Rosario, 2017.

Gramuglio, María Teresa, et al. "Literatura, mercado y crítica. Un debate". Punto de Vista, año XXIII, n. ${ }^{\circ} 66,2000$, pp. 1-9. 
Grandis, Rita de. "El entenado de Juan José Saer y la idea de historia". Revista Canadiense de Estudios Hispánicos, vol. XVIII, n. ${ }^{\circ}$ 3, 1994, pp. 417-426. Disponible en https://www.jstor.org/stable/27763136

"The First Colonial Encounter in El entenado by Juan José Saer: Paratextuality and History in Postmodern Fiction". Latin American Literary Review, vol. 21, n. ${ }^{\circ} 41,1993$, pp. 30-38. Disponible en https://www.jstor.org/stable/20119648

Iglesia Cristina. "Cautivos en la zona. Sobre El entenado de Juan José Saer". La violencia del azar: Ensayos sobre literatura argentina. Buenos Aires: FCE, 2003, pp.109-116.

Jitrik, Noé. "Entre el corte y la continuidad. Hacia una escritura crítica". Revista Iberoamericana, . $^{\circ}$ 102-103, 1978, pp. 99-109.

Kohan, Martín. "Saer, Walsh: una discusión política en la literatura". Nuevo Texto Crítico, año VI, n. ${ }^{\circ} 12-13$, julio de 1993-junio de 1994, pp. 121-130.

"Historia y literatura: la verdad de la narración". Historia crítica de la literatura argentina (dir. Noé Jitrik), Tomo 11, La narración gana la partida (dir. Elsa Drucaroff). Buenos Aires: Emecé, 2002, pp. 254-256.

Kramer, Nicholas Michael. "Outlaws of the Pampa: representations of the gaucho and the indigenous in Las nubes (1997) and La ocasión (1988) by Juan José Saer". Latin American Literary Review, vol. 40, n. ${ }^{\circ}$ 79, enero-junio 2012, pp. 88-114.

Link, Daniel. "Saer en B.A.”. Página/12, 14 de noviembre de 1999. Disponible en https://www.pagina12.com.ar/1999/suple/libros/99-11/99-11-14/nota1.htm

Litvan, Valentina. "“A medio borrar' en el origen: de Saer a Saer”. Cuadernos LIRICO, n. ${ }^{\circ}$ 6, 2011. Disponible en http://lirico.revues.org/219

Lucero, Nicolás. "El ensayo como forma en El río sin orillas". Revista Iberoamericana, vol. LXXVIII, n. ${ }^{\circ} 240$, Julio-Septiembre 2012, pp. 681-694.

La vuelta incompleta: Saer y la novela. Ciudad Autónoma de Buenos Aires: Santiago Arcos Editor, 2017.

Lucero, Nicolás y Daniel Balderston. "Diálogos, risas y tropiezos en Glosa". Saer, Juan José, El entenado - Glosa. Edición crítica (Julio Premat coordinador). Poitiers: CRLA; Córdoba: Alción Editora (Colección Archivos), 2010, pp. 683-696.

Luzzani, Telma. "Una estética del desamparo: ficción e historia durante la dictadura militar". Río de la Plata, n. ${ }^{\circ}$ 11-12, 1991, pp. 341-350.

Manzi, Joaquín. "Formas de lo visible y lo invisible en Borges, Calvino y Saer". Actas del Coloquio Internacional: Borges, Calvino, la literatura, vol. II. Madrid/Poitiers, Fundamentos/Université de Poitiers, 1996, pp. 263-275.

"Novela y crónica del descubrimiento en el Río de la Plata". Maryse Renaud y Fernando Moreno (eds.). Historia y novela. La ficcionalización de la historia en la narrativa latinoamericana, URA 2007-CNRS, Poitiers, 1996, pp. 53-70.

Maranguello, Carolina. "Una geografía pintada: paisaje y abstracción en ficciones y ensayos de Juan José Saer". Anclajes. Revista del Instituto de Investigaciones Literarias y Discursivas, vol. 21, n. ${ }^{\circ}$ 1, 2017, pp. 43-58. Disponible en http://cerac.unlpam.edu.ar/index.php/anclajes/article/view/1136

Merbilhaá, Margarita. "Elogio saeriano de la razón caprichosa: El río sin orillas". ALP Cuadernos Angers-La Plata, n. ${ }^{\circ}$ 4, Angers, 2001, pp. 133-145.

"Del testimonio a la experiencia minimalista: lo político en las primeras narraciones de Juan José Saer”. Vázquez, María Celia y Sergio Pastormerlo (eds.) Literatura argentina. Perspectivas de Fin de Siglo. Buenos Aires: Eudeba, 2001, pp. 28-37. 
“Entrevista a Juan José Saer". Orbis Tertius. Revista de Teoría y Crítica Literaria, vol. 9, n. ${ }^{\circ}$ 10, La Plata, 2004, pp. 1-11.

"Hacia una 'memoria del lugar': entre pasados imaginados y presentes leídos". Ricci, Paulo (comp.). Zona de prólogos. Buenos Aires: Seix Barral, 2011, pp. 231-242.

Mondragón, Juan Carlos. “A propósito de Lugar". Crítica Cultural (Critic), v. 5, n. ${ }^{\circ}$, 2010, pp. 411-420.

Montaldo, Graciela. Juan José Saer: El limonero real. Buenos Aires: Hachette, 1986.

Monteleone, Jorge. "Eclipse de sentido: de Nadie nada nunca a El entenado". Roland Spiller (ed.). La novela argentina de los años 80. Frankfurt-am-Main, Vervuert Verlg, 1991, pp. 152-175.

Oubiña, David. "Lo irrecuperable: la distante región de la memoria en Juan José Saer". Dalmaroni, Miguel y Rogers, Geraldine (ed.). Contratiempos de la memoria en la literatura argentina. La Plata: EDULP, 2009, pp. 153 - 171.

"Cronofotografías literarias". El silencio y sus bordes. Modos de lo extremo en la literatura y el cine. Buenos Aires: FCE, 2011, pp. 63-122.

Páez, Natalia. "Saer, el persistente. La vigencia del escritor que creó su propio paisaje". La Nación, Domingo 26 de Junio, 2016. Disponible en http://www.lanacion.com.ar/1911857-pagina-3pensamiento-libros-arte

Panesi, Jorge. "Cicatrices de Juan José Saer: El peligroso juego de la literatura". Boletín/16 del Centro de Estudios de Teoría y Crítica Literaria, Rosario, 2011, pp. 1-5. Disponible en http://www.celarg.org/int/arch_publi/panesi_dossierrescates.pdf

Patruno, Luigi. Relatos de regreso. Ensayos sobre la obra de Juan José Saer. Rosario: Beatriz Viterbo Editora, 2015.

Piglia, Ricardo. "La amistad en Saer". Saer, Juan José, El entenado - Glosa. Edición crítica (Julio Premat coordinador). Poitiers: CRLA; Córdoba: Alción Editora (Colección Archivos), 2010, pp.. XVII-XX.

Las tres vanguardias: Saer, Puig, Walsh. Buenos Aires: Eterna Cadencia, 2016.

Plotnik, Viviana. 'Colonialismo y aculturación en 'El informe de Brodie' de Jorge Luis Borges y El entenado de Juan José Saer". Monographic Review/Revista Monográfica, n. ${ }^{\circ}$ XII, 1996, pp. 345-354.

Pons, María Cristina. Memorias del olvido. Del Paso, García Márquez, Saer y la novela histórica del siglo XX. México: Siglo XXI, 1996.

Premat, Julio. "El eslabón perdido. El entenado en la obra de Saer". Caravelle, n. ${ }^{\circ} 66$, 1996, pp. 75-93.

"La imagen de los desaparecidos. Psicoanálisis, historia y literatura en $L a$ pesquisa de Juan José Saer". Jacqueline Covo, (ed.). Creación e historia: los poderes de la imagen. Lille, Presses Universitaires du Septentrion, 1998, pp. 323-330.

"Juan José Saer y el relato regresivo. Una lectura de Cicatrices". Revista Iberoamericana, vol. LXVI, n. ${ }^{\circ}$ 192, Julio-Septiembre 2000, 501-509.

La dicha de Saturno. Escritura y melancolía en la obra de Juan José Saer. Rosario: Beatriz Viterbo, 2002.

"Saer fin de siglo y el concepto de lugar". Geneviève Fabry e Ilse Logie (dir.)

Foro Hispánico: revista hispánica de Flandes y Holanda. La literatura Argentina de los años 90, n. ${ }^{\circ}$ 24, 2003, pp. 43-52.

"Saer: un escritor del lugar". Héroes sin atributos. Buenos Aires: Fondo de Cultura Económica, 2009, pp. 167-202. 
“Introducción del coordinador". Saer, Juan José, El entenado - Glosa. Edición crítica (Julio Premat coordinador). Poitiers: CRLA; Córdoba: Alción Editora (Colección Archivos), 2010, pp. XII-XLIII.

"Notas críticas". Glosa. Saer, Juan José, El entenado - Glosa. Edición crítica (Julio Premat coordinador). Poitiers: CRLA; Córdoba: Alción Editora (Colección Archivos), 2010, pp.179-204.

"Estando empezando". Ricci, Paulo (comp.). Zona de prólogos. Buenos Aires: Seix Barral, 2011, pp. 19-35.

Prieto, Martín. "Introducción. En el aura del sauce en el centro de la historia de la poesía argentina". Ortiz, Juan L. Obra completa. Santa Fé: Universidad Nacional del Litoral, 1996, pp. 111-125.

"El arte de narrar de Juan José Saer en la tradición modernista". Fin(es) de siglo y Modernismo: Congreso Internacional Buenos Aires-La Plata, coord. por María Payeras Grau y Luis M. Fernández Ripoll, vol. 2, 1996, pp. 767-771.

"Escrituras de la 'zona'". Historia crítica de la literatura argentina (dir. Noé Jitrik), Tomo 10, La irrupción de la crítica (dir. Susana Cella). Buenos Aires: Emecé, 1999, pp. 343-357.

"El canto de las estrellas". Ricci, Paulo (comp.). Zona de prólogos. Buenos Aires: Seix Barral, 2011, pp. 107-116.

Prieto, Martín y Constantin, María Teresa. Catálogo Conexión Saer. Santa Fe Cultura; Fundación Osde, 2018.

Quintana, Isabel. Figuras de la experiencia en el fin de siglo. Cristina Peri Rossi, Ricardo Piglia, Juan José Saer, Silviano Santiago. Rosario: Beatriz Viterbo, 2001.

Reati, Fernando. "Posse, Saer, Di Benedetto y Brailovsky: deseo y paraíso en la novela argentina sobre la Conquista". Revista de Estudios Hispánicos vol. 1, n. ${ }^{\circ}$ 29, enero de 1995, pp. 121-136.

"Las nubes de Juan José Saer: un viaje por la pampa hacia otra metafísica de lo real". Inti: Revista de literatura hispánica: $\mathrm{n} .^{\circ}$ 52, Otoño-Primavera 2000. Disponible en http://digitalcommons.providence.edu/inti/voll/iss52/19

Ricci, Paulo (comp.). Zona de prólogos. Buenos Aires: Seix Barral, 2011.

Riera, Gabriel. "Fidelidad al acontecimiento: De la narración en Saer (Historia, memoria y trauma en Glosa)". Revista de crítica literaria latinoamericana, ${ }^{\circ}{ }^{\circ}$ 57, Lima/Berkeley, 2003, pp. 107-124.

Littotal of the Letter. Saer's Art of Narration. Lewisburg: Bucknell University Presses, 2010.

Rogers, Geraldine. "Desfases a la luz del día. Lecturas de Fogwill, Saer y Ocampo en torno al pasado reciente argentino". Rogers, Geraldine y Miguel Dalmaroni (eds.). Contratiempos de la memoria en la literatura argentina. La Plata: EDULP, 2009, pp. 171 - 185.

Romano Thuesen, Evelia. "El entenado: relación contemporánea de las memorias de Francisco del Puerto". Latin American Literary Review, vol. XXIII, n. ${ }^{\circ} 45$, Enero-Junio 1995, pp. 43-63.

Russo, Miguel. "Lo imborrable". Página/12, 19 de febrero de 2017. Disponible en https://www.pagina12.com.ar/20832-lo-imborrable

Sager, Valeria. El punto en el tiempo: Realismo y gran obra en Juan José Saer y César Aira. Tesis de doctorado, Universidad Nacional de La Plata. Facultad de Humanidades y Ciencias de la Educación, 2014. Disponible en: http://www.memoria.fahce.unlp.edu.ar/tesis/te.1079/te.1079.pdf 
Sarlo, Beatriz. "3 novelas argentinas Saer-Tizón-Conti (sobre El limonero real de Juan José Saer; Sota de bastos, caballo de espadas de Héctor Tizón; y Mascaró, el cazador americano de Haroldo Conti)". Los libros, n. ${ }^{\circ} 44$, enero-febrero de 1976, p.3-6.

"La condición mortal”. Punto de Vista, Año XVI, n. ${ }^{46}$, 1993, pp. 28-31.

"Aventuras de un médico filósofo. Sobre Las nubes de Juan José Saer". Punto de Vista, Año XX, n. ${ }^{\circ}$ 59, 1997, pp. 35-38.

“El mejor. Juan José Saer (1937-2005)”. Punto de Vista, Año XXVIII, n. ${ }^{\circ} 82$, 2005, p. 1.

"La duda y el pentimento", "Narrar la percepción"; "Política, ideología y figuración literaria"; "El tiempo inagotable". Escritos sobre literatura argentina. Buenos Aires: Siglo Veintiuno, 2007, pp. 269-277; 281-285; 327-355 y 317-320. Zona Saer. Santiago de Chile: Ediciones Universidad Diego Portales, 2016.

Scavino, Dardo. Saer y los nombres. Buenos Aires: El cielo por asalto, 2004.

Stern, Mirta. "Juan José Saer y la construcción de una teoría del relato". Historia de la literatura argentina. Buenos Aires: CEAL, 1982, pp. 656-660.

"El espacio intertextual en la narrativa de Juan José Saer: instancia productiva, referente y campo de teorización de la escritura". Revista Iberoamericana, vol. 49, n. $^{\circ} 125$, pp. $965-981$.

"Prólogo" en Juan José Saer. El limonero real. Buenos Aires: Centro Editor de América Latina, 1992, pp. I-XI.

Sztrum, Marcelo. "Variación y fronteras lingüísticas en El entenado de Juan José Saer", América n. ${ }^{\circ}$ 8, Frontiéeres culturelles en Amérique Latine. París: Presses de la Sorbonne Nouvelle, pp. 259-278.

Torre, María Elena. "Juan José Saer en la zona crítica". Giordano Alberto y María Celia Vázquez (comps.). Las operaciones de la crítica. Rosario: Beatriz Viterbo, 1998, pp. 123-132.

Vezetti, Hugo. "La nave de los locos de Juan José Saer". Punto de Vista, Año XX, n. ${ }^{\circ}$ 59, 1997, pp. 39-41.

Villanueva, Graciela. "De Tebas a la zona: derroteros policiales del mito de Edipo". Alicante: Biblioteca Virtual Miguel de Cervantes, 2008. Edición digital a partir de Perla Petrich, Julio Premat, Maria Llombart. Les sujets contemporains et leurs mythes en Espagne et en Amérique latine, Alacant: Université Paris 8, Universitat d'Alacant, Grup d'Estudis transversals: literatura i altres arts en les cultures mediterrànies; Paris: Universite de Paris 8, Vincenne-Saint-Denis, pp.112, (Traverses (E.A). Études catalanes) Disponible en http://www.cervantesvirtual.com/nd/ark:/59851/bmcvh623

“ 'En un lugar arcaico y sin orillas'. Imágenes del río en la obra de Juan José Saer”. Delgado, Sergio et al. (ed.). El horizonte fluvial. Coloquio en el país del sauce. Paraná: Universidad Nacional de Entre Ríos, UNER, 2017, pp. 129-166. 